\title{
ICPP WASTE CALCINING FACILITY SAFETY ANALYSIS REPORT
}
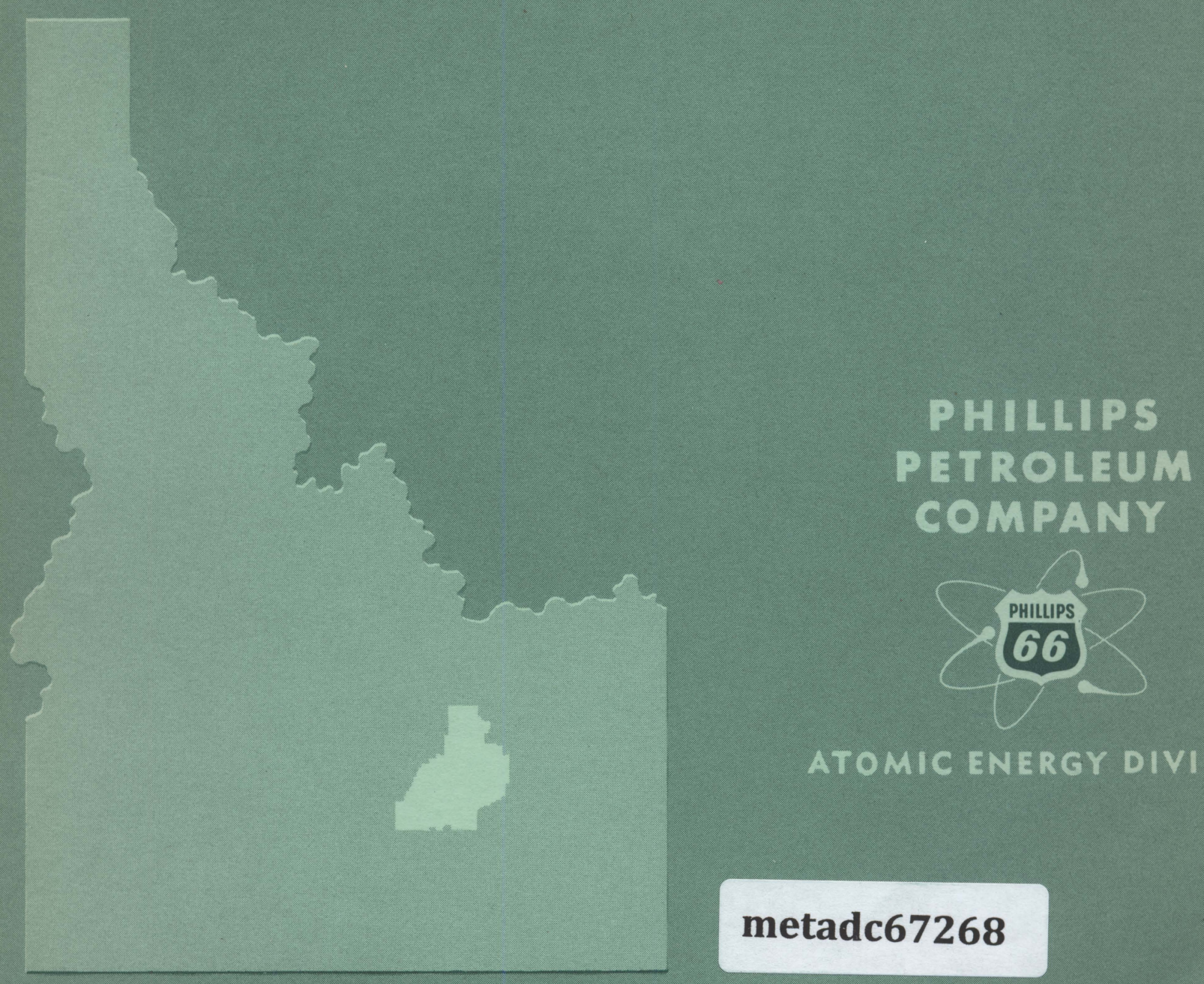

ATOMIC ENERGY DIVISION

\section{metadc67268}

NATIONAL REACTOR TESTING STATION US ATOMIC ENERGY COMMISSION 
PRICE $\$ 5.00$

AVAILABLE FROM THE

OFFICE OF TECHNICAL SERVICES

U. S. DEPARTMENT GF COMMERCE

WASHINGTON 25, D. C.

\section{LEGAL NOTICE}

This report was prepared as an account of Government sponsored work. Neither the United States, nor the Commission, nor any person acting on behalf of the Commission:

A. Makes any warranty or representation, express or implied, with respect to the accuracy, completeness, or usefulness. of the information contained in this report, or that the use of any information, apparatus, method, or process disclosed in this report may not infringe privately owned rights; or

B. Assumes any liabilities with respect to the use of, or for damages resulting from the use of any information, apparatus, method, or process disclosed in this report.

As used in the above, "person acting on behalf of the Commission" includes any employee or contractor of the Commission, or employee of such contractor, to the extent that such employee or contractor of the Commission, or employee of such contractor prepares, disseminates, or provides access to, any information pursuant to his employment or contract with the Commission, or his employment with such contractor.

PRINTED IN USA 


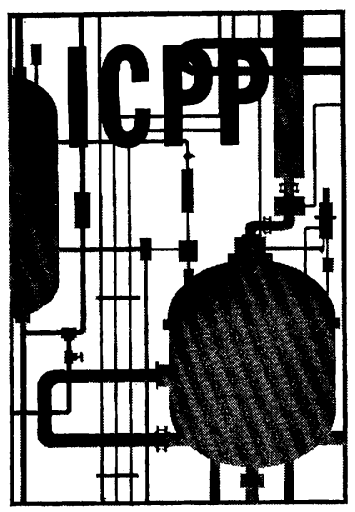

\author{
IDO-14620-Rornet \\ AEC Research \& Development Report \\ Waste Disposal and Processing \\ TID-4500 (25th Ed.) \\ Issued: December 1, 1963
}

\title{
ICPP WASTE CALCINING FACILITY
}

\section{SAFETY ANALYSIS REPORT}

L. T. Lakey, J. R. Bower EDITORS

J. A. McBride

DIRECTOR, CHEMICAL TECHNOLOGY
J. A. Buckham

MANAGER, ICPP TECHNICAL

J. R. Huffman

ASSISTANT MANAGER, TECHNICAL

\section{PHILLIPS}

PETROLEUM

COMPANY

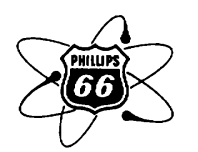

Atomic Energy Division

Contract AT(10-1)-205

Idaho Operations Office

U. S. ATOMIC ENERGY COMMISSION 


\section{ACKNOWLEDGMENT}

The following persons from the CPP Operations, CPP Technical, AED Analytical and AED Health and Safety Branches made significant contributions to the text material appearing in this report:
D. E. Black
R. L. Mail
R. E. Commander
R. D. Modrow
E. D. Cooper
L. F. Morrow
I. L. Doggett
G. F. Offutt
R. W. Edson
W. P. Palica
M. P. Hales
L. G. Pearson
N. Kormanik
A. S. Rangitsch
G. E. Lohse
B. R. Wheeler
S. M. Maag
C. L。Willis

The drawings and graphs were prepared by D. Steel and others of the CPP Design Engineering Section, with help from L. P. Mickelson and H. A. Rayburn of the CPP Operations Branch. Credit for the final typing and assembly of the report belongs to the AED Technical Editing Section, headed by T. J. Wadsworth. 


\begin{abstract}
A detailed study has been made of the radiological hazards associated with operation of the ICPP Waste Calcining Facility. In addition to the normal release of small amounts of radioactivity with the process off--gas, possible accidental releases of larger amounts of radioactivity through operational error or equipment failure have been examined. Bypassing of off--gas cleaning elements, uncontrolled chemical reactions, overheating by fission product heat, corrosion, abrasion, vibration, overpressure, utility failures, and major catastrophes have been studied as possible causes of accidental radioactivity releases. No major safety deficiencies have been found, and the facility appears satisfactory for processing of high-level radioactive wastes. Details of the safety analysis and extensive information on the process, equipment, and operation procedures are furnished in the report.
\end{abstract}



ICPP WASTE CALCINING FACIL.ITY

SAFETY ANALYSIS REPORT

\section{CONTENTS}

ACKNOWLEDGMENT $\ldots \ldots \ldots \ldots \ldots \ldots \ldots \ldots \ldots \ldots \ldots \ldots \ldots \ldots$

ABSTRACT ........................... i iii

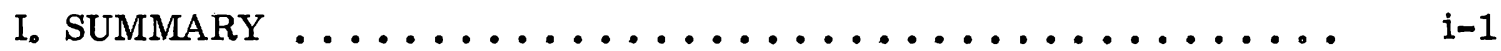

II. INTRODUCTION .......................... . .

1. HISTORY ....................................

2. PROCESS DESCRIPTION $\ldots \ldots \ldots \ldots \ldots \ldots \ldots \ldots \ldots$ ii-2

3. SITE AND FACILITY DESCRIPTION $\ldots \ldots \ldots \ldots \ldots \ldots \ldots$ ii-3

4. OPERATION ......................... ii 4

5. SAFETY ANALYSIS ..................... i i . . .

6. REFERENCES ........................ ii-6

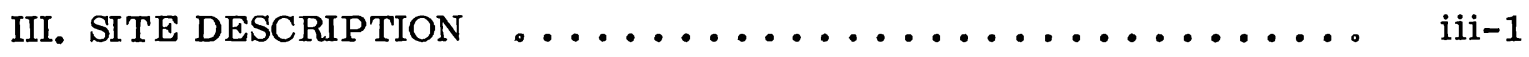

1. DESCRIPTION OF SITE AND ADJACENT AREAS ........ i ii-1

2. POPULATION DISTRIBUTION $\ldots \ldots \ldots \ldots \ldots \ldots \ldots \ldots \ldots$ iii-1

3. METEOROLOGY ........................ i iii-2

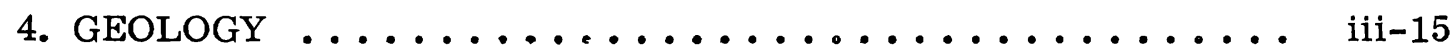

5. SEISMOLOGY ............................. iii-16

6. HYDROLOGY ............................. ili-16

7. BIBLIOGRAPHY .....................

IV. FACILITY DESCRIPTION ..................... . .

1. WCF AREA LAYOUT ...................... iv

2. PROCESS BUILDING, ICPP-633 ................ iv-1

2.1 General ....................................

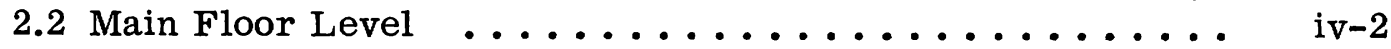

2.3 Operating Corridor Level ................. i ... iv-5

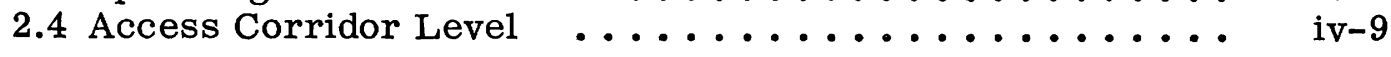


3. SOLIDS STORAGE FACILITY ................ . . iv-13

3.1 Solids Storage Vault (ICPP-729) . . . . . . . . . . . iv-13

3.2 Solids Cooling Blower Building (ICPP-639) . . . . . . . . iv-14

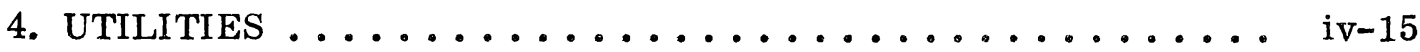

4.1 Electrical System ................... iv 15

4.2 Raw Water System .................... iv

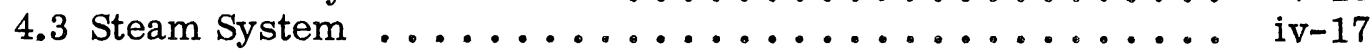

4.4 Compressed Air System ..................... iv -18

4.5 Service Waste System ........................... iv-18

4.6 Heating and Ventilation System ............... . . iv-19

4.7 Fuel Oil System ...................... . . iv-21

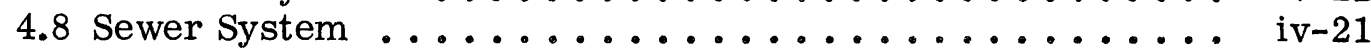

4.9 Fire Protection System ................. iv

V. PROCESS DESCRIPTION ...................... . .

1. FEED COMPOSITION $\ldots \ldots \ldots \ldots \ldots \ldots \ldots \ldots \ldots \ldots$ v -1

2. CALCINATION REACTIONS ................. v v-6

3. PROCESS FLOWSHEET ................... v v

4. PRODUCT PROPERTIES ..................... $v-11$

4.1 General Product Description . ................ v v-11

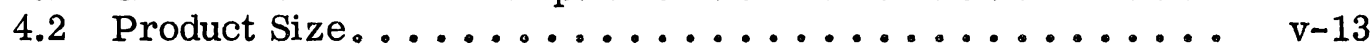

4.3 Structure of Alumina .................... v $v-14$

4.4 Product Densities ...................... v v -15

4.5 Nitrate and Water .......................... v $\mathrm{v}-17$

4.6 Ruthenium and Fission Products in Solids .......... v $\mathrm{v}-18$

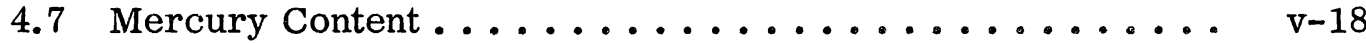

4.8 Thermal Conductivity........................... v-19

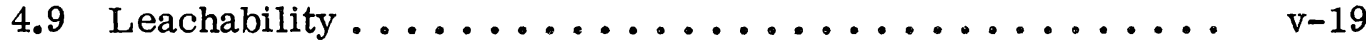

4.10 Attrition Resistance $\ldots \ldots \ldots \ldots \ldots \ldots . \ldots \ldots$ v $-20 . \ldots \ldots$

5. ACTIVITY OF AND HEAT GENERATION

BY FISSION PRODUCTS IN WCF PRODUCT ........... v-21

6. RADIOACTIVITY LEVELS IN WCF PROCESSING CELLS $\ldots \ldots$ v-26

7. RADIOACTIVITY LEVELS IN WCF OPERATING AREAS $\ldots \ldots \quad$ v-26

8. TEMPERATURE DISTRIBUTION OF STORED SOLIDS $\ldots \ldots \ldots \quad \mathrm{v}-28$

9. REFERENCES ......................... v $v$. . . .

VI. EQUIPMENT DESCRIPTION ..................... vi-1

1. GENERAL DESIGN CONSIDERATIONS ............. vi-1

1.1 Materials of Construction ................ vi-1

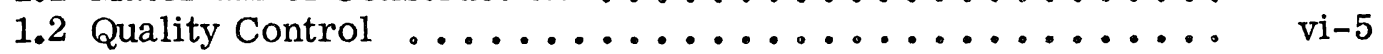

1.3 Special Equipment Features . . . . . . . . . . . . . . vi-5 
2. FEED SYSTEM $\ldots \ldots \ldots \ldots \ldots \ldots \ldots \ldots \ldots \ldots \ldots \ldots$ vi-6

2.1 General Description . ................ vi-6

2.2 Waste Hold Tanks $\ldots \ldots \ldots \ldots \ldots \ldots \ldots \ldots \ldots$ vi-8

2.3 Airlifts $\ldots \ldots \ldots \ldots \ldots \ldots \ldots \ldots \ldots \ldots \ldots \ldots$ vi-9

2.4 Feed Tank ...................... vi-9

2.5 Magnetic Flowmeters ................ vi-11

2.6 Feed Control Valves $\ldots \ldots \ldots \ldots \ldots \ldots \ldots \ldots \ldots$ vi-13

2.7 Feed Nozzles . . . . . . . . . . . . . . . . vi-14

3. CALCINER VESSEL AND CYCLONE ............ vi-16

3.1 General Description . . . . . . . . . . . . . vi-16

3.2 Calciner Vessel $\ldots \ldots \ldots \ldots \ldots \ldots \ldots \ldots \ldots \ldots$ vi-16

3.3 Calciner Cyclone $\ldots \ldots \ldots \ldots \ldots \ldots \ldots \ldots \ldots \ldots$ vi-24

4. FLUIDIZING AND OFF-GAS SYSTEMS $\ldots \ldots \ldots \ldots \ldots \ldots$ vi-26

4.1 General Description ................ vi-26

4.2 Fluidizing Air Blowers $\ldots \ldots \ldots \ldots \ldots \ldots \ldots \ldots \ldots$ vi-28

4.3 Quench Tower .................... vi-29

4.4 Venturi Scrubber and De-entrainment Cyclones ...... vi-29

4.5 Scrubbing Solution Surge Tank $\ldots \ldots \ldots \ldots \ldots \ldots \ldots$ vi-31

4.6 Scrubbing Solution Pumps $\ldots \ldots \ldots \ldots \ldots \ldots \ldots \ldots$ vi-35

4.7 Scrubbing Solution Cooler $\ldots \ldots \ldots \ldots \ldots \ldots \ldots$ vi-35

4.8 Off-Gas Heater $\ldots \ldots \ldots \ldots \ldots \ldots \ldots \ldots \ldots$ vi-37

4.9 Ruthenium Adsorbers $\ldots \ldots \ldots \ldots \ldots \ldots \ldots \ldots$ vi-37

4.10 Regeneration Solution Surge Tank $\ldots \ldots \ldots \ldots \ldots \ldots$ vi-42

4.11 Off-Gas Knock-Out Pot ............... vi-44

4.12 Off-Gas Reheater . . . . . . . . . . . ..... vi-44

4.13 Off-Gas Filters $\ldots \ldots \ldots \ldots \ldots \ldots \ldots \ldots \ldots$ vi-44

4.14 Off-Gas Blowers $\ldots \ldots \ldots \ldots \ldots \ldots \ldots \ldots \ldots \ldots$ vi-45

5. SOLIDS TRANSPORT SYSTEM $\ldots \ldots \ldots \ldots \ldots \ldots \ldots$ vi-48

5.1 General Description . . . . . . . . . . ... vi-48

5.2 Transport Air Heater . . . . . . . . . . . . . vi-51

5.3 Cyclone Fines Jet $\ldots \ldots \ldots \ldots \ldots \ldots \ldots \ldots \ldots$ vi $\ldots \ldots 1$

5.4 Air Distributor Plate and Cone Drain Lines . . . . . . . vi-51

5.5 Product Takeoff Lines $\ldots \ldots \ldots \ldots \ldots \ldots \ldots \ldots$ vi-54

5.6 Silica Gel Transfer $\ldots \ldots \ldots \ldots \ldots \ldots \ldots \ldots \ldots \ldots$ vi-55

5.7 Solids Storage Cyclone $\ldots \ldots \ldots \ldots \ldots \ldots \ldots \ldots$ vi-55

5.8 Transport Air Jet $\ldots \ldots \ldots \ldots \ldots \ldots \ldots \ldots \ldots \ldots$ vi-58

6. SOLIDS STORAGE $\ldots \ldots \ldots \ldots \ldots \ldots \ldots \ldots \ldots \ldots$ vi-58

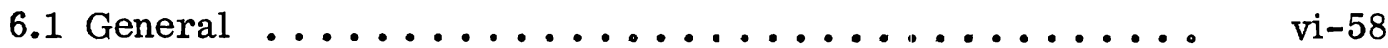

6.2 Solids Storage Bins, wC-115-1, 2, 3, and $4 \ldots \ldots \ldots \ldots$ vi-59

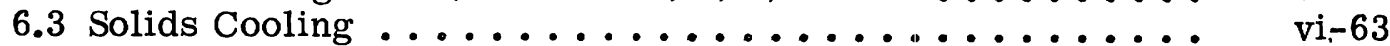

6.4 Solids Storage Off-Gas $\ldots \ldots \ldots \ldots \ldots \ldots \ldots \ldots$ vi-64

7. NaK HEATING SYSTEM $\ldots \ldots \ldots \ldots \ldots \ldots \ldots \ldots$ vi-68

7.1 General Description ................. vi-68

7.2 Electromagnetic Pump and Flowmeter .......... vi-68

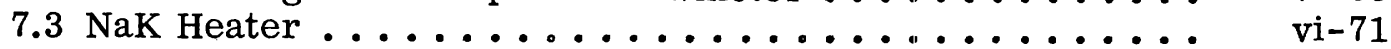

7.4 NaK Expansion Tanks $\ldots \ldots \ldots \ldots \ldots \ldots \ldots$ vi-71 
7.5 Fluidized Bed Heater .................. vi-74

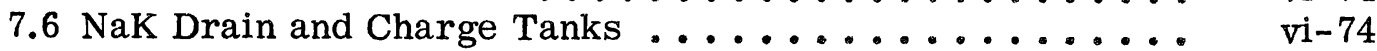

7.7 Oxide Detection and Removal System ............ vi . . . . . . .

8. INSTRUMENTATION AND CONTROL ............. vi-80

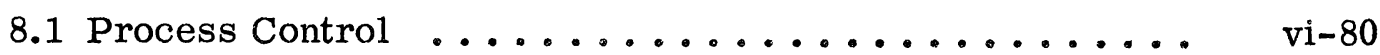

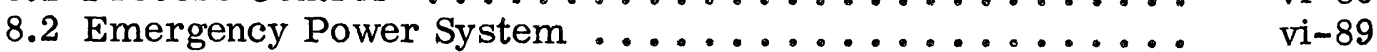

8.3 Emergency Shutdown System ................ v. vi-89

8.4 Automatic Motor Starting ................ v. vi-90

8.5 Temperature and Pressure Monitoring . . . . . . . . . vi-92

8.6 Alarms ................................ vi

9. SAMPLING AND ANALYTICAL EQUIPMENT .......... . vi-92

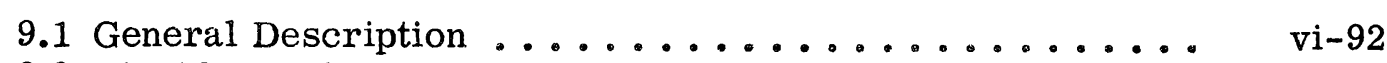

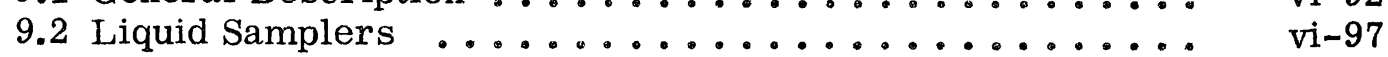

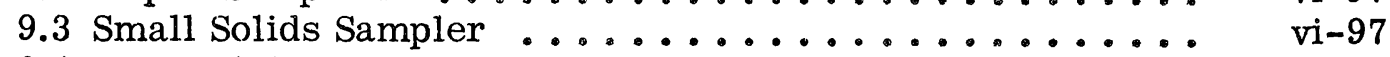

9.4 Bulk Solids Sampler ... . . . . . . . . . . . . . . . . . . . . . . . . . . . . . . . . . . . . . .

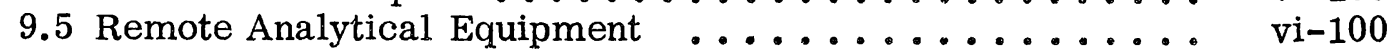

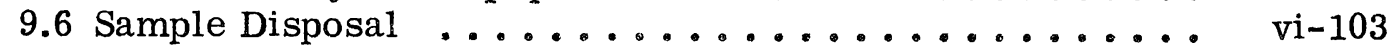

10. DECONTAMINATION AND HOT WASTE DISPOSAL ..... vi-105

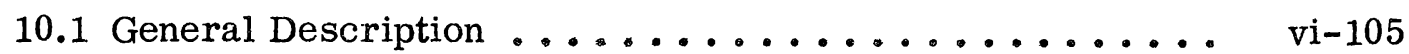

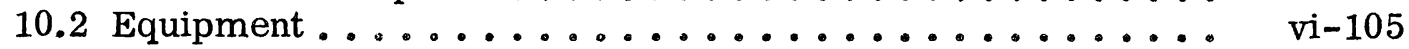

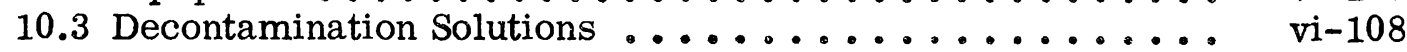

10.4 Hot Sump WC-119 and Waste Transfer Lines ....... v. vi-109

10.5 Equipment Vent System ......................... vi-109

11. RADIATION MONITORING EQUIPMENT . . . . . . . . . . v vi-114

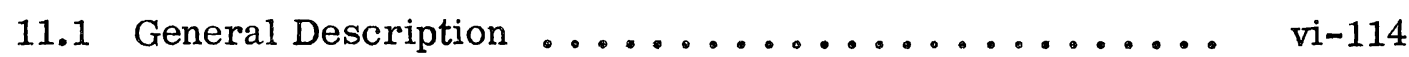

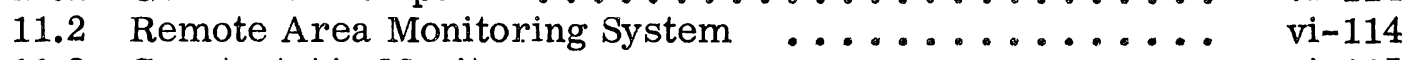

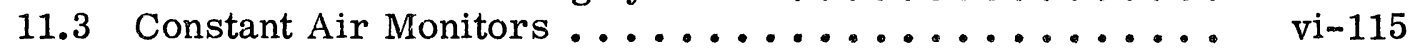

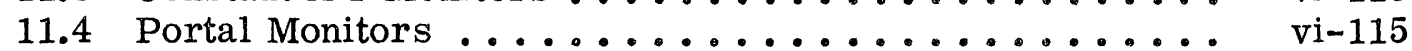

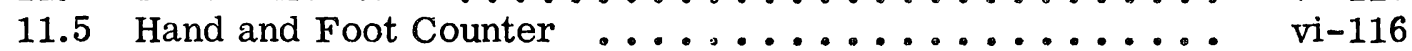

11.6 Portable and Mobile Instrumentation and Equipment . . . vi-116

11.7 Routine Area Survey Equipment ............. vi-116

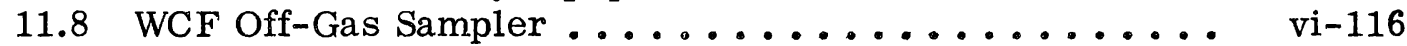

11.9 ICPP Stack Sampler and Monitor ............. vi-118

11.10 Service Waste Monitoring System ... . . . . . . . vi

12. REFERENCES ................................ vi-120

VII. PROCESS ENGINEERING AND DEVELOPMENT . . . . . . . v vii-1

1. THE EFFECTS OF OPERATING

VARIABLES ON THE CALCINATION PROCESS ........ vii-1

1.1 Introduction $\ldots \ldots \ldots \ldots \ldots \ldots \ldots \ldots$ vii-1 . . . . . . . . . . . .

1.2 Independent Operating Variables .............. vii-1

1.3 Dependent Operating Variables .............. vii-7

2. REMOVAL OF PARTICULATE SOLIDS FROM OFF-GAS ... vii-10

2.1 Determination of Off-Gas System Performance ...... vii-11

2.2 Off-Gas System Performance .............. vii-12 
3. REMOVAL OF RUTHENIUM FROM WCF OFF-GAS . . . . v vii-14

3.1 Ruthenium Volatility ................... vii-15

3.2 Removal of Ruthenium from Off-Gas . . . . . . . . . v vii-17

3.3 Anticipated Adsorber Regeneration Frequency ...... vii-20

4. NaK TUBE VIBRATION STUDY ............... vii-22

5. REFERENCES ................................ vii-24

VIII. OPERATING ORGANIZATION AND PROCEDURES . . . . . . viii-1

1. ATOMIC ENERGY DIVISION OPERATING ORGANIZATION . • viii-1

2. ICPP OPERATING ORGANIZATION ............. v. viii-4

2.1 Training and Qualification of Personnel ......... viii-6

2.2 Service Assistance ................... viii-7

2.3 ICPP Engineering - Safeguard Committee ........ viii-8

3. OPERATING POLICIES AND PROCEDURES ........ viii-9

3.1 Standard Practices Manual ............... viii-9

3.2 Safe Work Permits ..................... v. viii-9

3.3 WCF Emergency Evacuation Procedure .......... vili-10

IX. HAZARD AND ACCIDENT ANALYSIS .............. ix-1

1. ACTIVITY RELEASE DURING NORMAL OPERATION .... i ix-1

1.1 Release of Process Off-Gas to the ICPP Stack . . . . . . ix-2

1.2 Release of Off-Gas from Stored Solids to the ICPP Stack . ix-6

1.3 Release During Sample Handling Operations ........ ix-6

2. ACTIVITY RELEASE FROM BYPASS

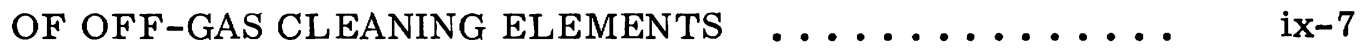

2.1 Bypass of Calciner Cyclone ............... ix -9

2.2 Failure of Scrubbing Solution Recirculation System .... ix-10

2.3 Bypass of Adsorbers .................. ix

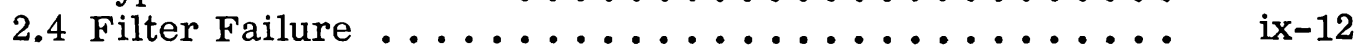

2.5 Bypass or Failure of Equipment Vent Filters ....... ix-12

3. ACTIVITY RELEASE FROM SYSTEM RUPTURE BY

CHEMICAL REACTION OR FISSION PRODUC'T DECAY HEAT ix-13

3.1 Release of NaK Into the Calciner Vessel ......... . . ix-13

3.2 Organic-Air or Organic-Nitric Acid Reactions ...... . ix 19

3.3 Decomposition of Ammonium Nitrate Present in the Feed ix-21

3.4 Overheating of the Calciner

Vessel by Fission Product Heat .............. ix-22

3.5 Loss of Cooling Air at Solids Storage Bins ........ . ix -24

4. ACTIVITY RELEASE FROM SYSTEM

FAILURE BY CORROSION, ABRASION, OR VIBRATION ... ix-24

4.1 Off-Gas Piping or Vessels ............... ix-25 
4.2 Vessels or Piping Containing Dry Solids. . . . . . . . . . . ix-25

4.3 Vessels or Piping Containing Liquids. . . . . . . . . . . . ix-26

4.4 Solids Storage Bins ................... ix-26

5. ACTIVITY RELEASE IN THE WCF

FROM OVERPRESSURE OF EQUTPMENT . . . . . . . . . . . . ix-29

5.1 Loss of Off-Gas Blower or Equipment Vent Fan ........ ix-30

5.2 Accidental Valve Closure .................. ix . . $\ldots .31$

5.3 Line Plugging .......................... . . ix

6. EFFECT OF UTILITY FAILURE . . . . . . . . . . . . . . ix-32

6.1 Simultaneous Failure of 'Both

Normal and Emergency Electrical Systems ... . . . . . . ix-33

6.2 Failure of Compressed Air System ... . . . . . . . . . . ix -34

6.3 Failure of Steam System ................ . . ix-35

6.4 Failure of the Water System .............. . . . ix-35

7. ACTIVITY RELEASE FROM MAJOR CATASTROPHES . . . . . . ix-36

7.1 Floods . . . . . . . . . . . . . . . . . . . . ix -37

7.2 Earthquakes ...............................

7.3 Nuclear Bomb Hit . . . . . . . . . . . . . . . . . ix -38

8. RADIOLOGICAL HAZ ARDS OF ACTIVITY RELEASES FROM

WCF ACCIDENTS .......................... ix -39

8.1 Direct Radiation from the Stack Plume ........... ix -40

8.2 Radiation from Ground Contamination ........... . . ix -41

8.3 Ingestion or Inhalation of Activity ............ ix -42

9. NON-RADIOLOGICAL SAFETY PROBLEMS $\ldots \ldots \ldots \ldots \ldots$ ix -45

9.1 Handling of $\mathrm{NaK} \ldots \ldots \ldots \ldots \ldots \ldots \ldots$ ix $-4 \ldots \ldots \ldots \ldots$

9.2 Emission of Nitrogen Oxides ............... ix 4.45

9.3 Emission of Mercury .................. ix -46

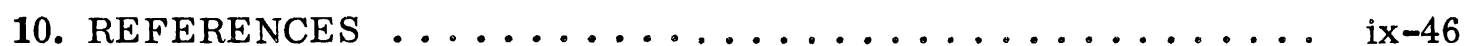

APPENDIX A - DETERMINATION OF FISSION PRODUCT

DISTRIBUTION IN AND TOTAL ACTIVITY OF WASTE

RESULTING FROM REPROCESSING MTR-TYPE FUEL ELEMEN'TS

$\mathrm{A}-1$

1. REACTOR DATA AND ASSUMPTIONS $\ldots \ldots \ldots \ldots \ldots \ldots \ldots$ A $\ldots \ldots$

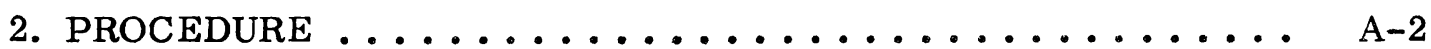

3. REFERENCES .................................. A-6

APPENDIX B - ESTIMATION OF RATE OF HEAT GENERATION RESULTING FROM FISSION PRODUCT DECAY IN SOLIDS FROM THE CALCINATION OF MTR-TYPE FUEL ELEMENT REPROCESSING WASTES ........................ B-1

1. BASES AND ASSUMPTIONS ...................... B-1 


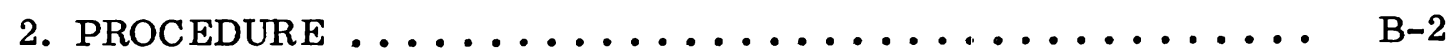

3. REFERENCES $\ldots \ldots \ldots \ldots \ldots \ldots \ldots \ldots \ldots \ldots \ldots$ B-9

APPENDIX C - ESTIMATION OF TEMPERATURE

PROFILES IN THE WCF SOLIDS STORAGE BINS $\ldots \ldots \ldots \ldots \ldots$ C-1

1. FORCED CONVECTION ................. C-5

1.1 Cooling Air Outlet Temperature .............. C-5

1.2 Cooling Air Channel Wall Temperatures ............ C-8

1.3 Solids Temperature Profile . . . . . . . . . . . . . . C-10

2. NATURAL CONVECTION $\ldots \ldots \ldots \ldots \ldots \ldots \ldots \ldots \ldots$ C-13

2.1 Cooling Air Outlet Temperature $\ldots \ldots \ldots \ldots \ldots \ldots \ldots$ C-13

2.2 Cooling Air Channel Wall Temperatures ........... C-14

2.3 Solids Temperature Profile $\ldots \ldots \ldots \ldots \ldots \ldots \ldots \ldots . \ldots . \ldots . \ldots$

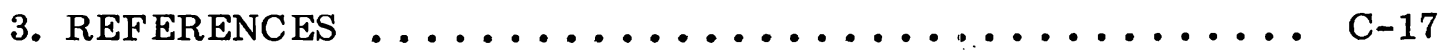

APPENDIX D - ESTIMATED EQUILIBRIUM TEMPERATURES IN

CALCINER BED AFTER SHUTDOWN AND WTH NO INTERNAL

COOLING

D-1

1. ESTIMATION OF BULK CELL AIR TEMPERATURE AND INSULATION OUTER SURFACE TEMPERATURE $\ldots \ldots \ldots \ldots$ D-2

2. ESTIMATION OF TEMPERATURE DROP ACROSS INSULATION • D-4

3. ESTIMATION OF TEMPERATURE PROFILE IN BED $\ldots \ldots \ldots$ D-5

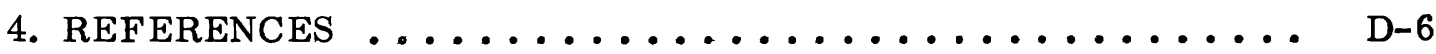

APPENDIX E - SUMMARY OF EXPERIENCE WITH MATERIALS

OF CONSTRUCTION USED IN NaK HEATING SYSTEMS $\ldots \ldots \ldots$ E-1

APPENDIX F - CALCULATION OF TEMPERATURE T'RANSIENT

FOR THE CALCINER IN EVENT OF A NaK LEAK . . . . . . . F-1

1. OXIDIZER INPUT RATES AT NORMAL

CALCINER OPERATING CONDITIONS $\ldots \ldots \ldots \ldots \ldots \ldots \ldots$ F-3

2. REACTIONS OF NaK WITH OXIDIZ ER IN THE CALCINER VESSEL F-3

3. DETERMINATION OF MAXIMUM LEAK RATE $\ldots \ldots \ldots \ldots$ F-4

4. CONSTANTS USED IN THE CALCUlations $\ldots \ldots \ldots \ldots \ldots$ F-5

5. CALCULATIONS OF TEMPERA TURE TRANSIENTS $\ldots \ldots \ldots$ F-6

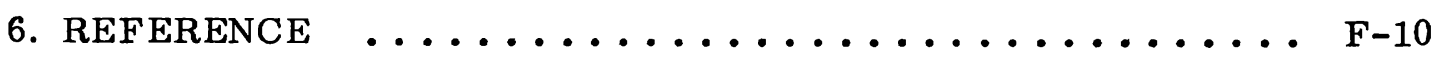


APPENDIX G - THE EFFECT OF NORMAL PARTICULATE DEPOSITION FROM WCF OFF-GAS ON SOIL ACTIVITY

AT THE ICPP AND SURROUNDING AREAS ............. G-1

1. ESTIMATION OF PARTICULATE DEPOSITION RATE FROM STACK PLUME BY GROUND CONTACT ONLY . . . . . G G-2

2. ADDITIONAL DEPOSITION ON SOIL DUE TO PLUME WASHOUT BY RAIN AND SNOW .......... G-2

3. NET DEPOSITION RATE FROM CONTACT OF PLUME WITH GROUND AND WASHOUT . . . . . . . . . G-5

4. ESTIMATION OF EQUILIBRIUM RADIOACTIVITY BUILDUP IN SOIL FROM NET DEPOSITION RATE

G-5

5. ESTIMATION OF THE DOSE RATE RESULTING FROM THE EQUILIBRIUM ACTIVITY DEPOSITED ON THE SOIL . . . G-8

6. REFERENCES ................................ G-12

APPENDIX H - SUMMARY OF CORROSION/ABRASION EXPERIENCE WITH WCF EQUIPMENT DURING TESTING PROGRAM ........ H-1

1. ULTRASONIC THICKNESS TESTER .............. . . H-1

2. VISUAL INSPECTION OF EQUIPMENT . . . . . . . . . . . . H H-4

2.1 Calciner Cyclone, WC-131, and Connecting Lines ....... H-4

2.2 Solids Storage Cyclone .................. H-4

2.3 Product Takeoff Line ..................... . . H-4

2.4 Feed and Scrubbing Solution Control Valves .......... H-5

2.5 Slide Valves ............................... H-5

2.6 Scrubbing Solution Pumps ..................... H-6

2.7 Calciner Interior $\ldots \ldots \ldots \ldots \ldots . \ldots \ldots$ H

3. REFERENCES ................................ H-6

APPENDIX I - CALCULATED RADIATION LEVELS AT

CRITICAL EXTERNAL WALL SURFACES IN THE WCF $\ldots . . .$. I-1

1. METHOD AND ASSUMPTIONS ................. I-1

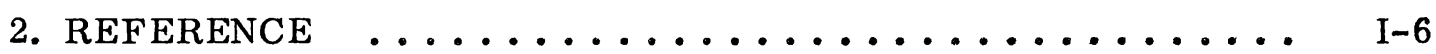

APPENDIX J - SUMMARY OF WCF NON-RADIOACTIVE

TESTING OPERATIONS ........................... J-1

APPENDIX K - CALCULATED TOTAL PERSONAL LIFETIME

RADIATION DOSES FROM INHALATION OR INGESTION OF

RADIOACTIVE MATERIAL FOLLOWING ACCIDENTAL

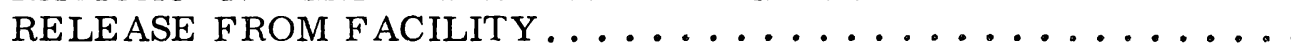

$\mathrm{K}-1$ 


\section{FIGURES}

ii-1. Fluidized bed waste calcining facility ............. i . . . .

iii-1. Facilities at the National Reactor Testing Station . . . . . . . . iii-3

iii-2. National Reactor Testing Station and vicinity $\ldots . . . .$. iii-4

iii-3. 250-ft-level wind roses for period July 1951 through May 1962 . . iii-6

iii-4. 250-ft-level lapse wind roses July 1951 through May 1962 . . . . iii-6

iii-5. 250-ft-level inversion wind roses July 1951 through May 1962 — iii-8

iii-6. 20-ft-level wind roses January 1950 through May 1962 . . . . . iii-9

iii-7. 20-ft-level lapse wind roses January 1950 through May 1962 . . iii-10

iii-8. 20-ft-level inversion wind roses January 1950 through May 1962 . iii-11

iv-1. Plot plan of ICPP area ... . . . . . . . . . . . . . . iv -24

iv-2. Plan view WCF, main floor level ... . . . . . . . . . . iv-25

iv-3. Plan view WCF, operating corridor level ........... iv-26

iv-4. Plan view WCF, access corridor (high level) . . . . . . . . iv-27

iv-5. Plan view WCF, access corridor (low level) . . . . . . . . . iv-28

iv-6. Elevation view WCF, looking west (Section DD, Fig. IV-3) . . . . iv-29

iv-7. Elevation view WCF, looking west (Section CC, Fig. IV-3) . . . . iv-30

iv-8. Elevation view WCF, looking north (Section AA, Fig. IV-3) . . . iv-31

iv-9. Elevation view WCF, looking north (Section BB, Fig. IV-3) . . . iv-32

iv-10. Elevation view WCF, looking east (Section EE, Fig. IV-4) . . . . iv-33

iv-11. WCF solids storage upper plan and section . . . . . . . . iv-34

iv-12. WCF solids storage, elevation view looking east . . . . . . . iv-35

iv-13. WCF solids storage, lower plans and view . . . . . . . . . iv-36

iv-14. WCF electrical diagram ................... . . iv-37

iv-15. WCF water supply system ................. . . iv-38

iv-16. WCF 120-psi steam system .................. . iv-39

iv-17. WCF air supply system .................... . iv 40

iv-18. WCF fuel oil system ..................... iv 4 . 41 
v-1. Activity of ICPP first cycle waste ................

v-2. Calculated individual fission product activities and total activity

of liquid waste from reprocessing of MTR-type fuel elements .. . v-5

v-3. Process flowsheet - ICPP Waste Calcining Facility ...... . v-8

v-4. Size distribution data of calcined material $\ldots \ldots \ldots \ldots . . . . \quad$ v-14

$\mathrm{v}-5$. Relationship of particle and bulk densities of calcined material a v-16

$\mathrm{v}-6$. Variation of calcine porosity with

calcination temperature and feed concentration ........ v $\mathrm{v}-17$

$\mathrm{v}-7$. Variation of calcine nitrate content with calcination temperature $\mathrm{v}-18$

$\mathrm{v}-8$. Variation of calcine thermal conductivity with temperature $\ldots \quad \mathrm{v}-19$

v-9. Activity of calcined solids from existing ICPP first cycle wastes $\quad \mathrm{v}-22$

$\mathrm{v}-10$. Activity of calcined solids from theoretical MTR-type waste $\ldots \quad \mathrm{v}-23$

$\mathrm{v}-11$. Heat generation of calcined solids from existing ICPP

first cycle wastes .......................... $v-24$

$\mathrm{v}-12$. Heat generation of calcined solids from

theoretical MTR-type waste ................. v $\mathrm{v}-25$

v-13. Estimated activity levels in WCF process cells $\ldots \ldots \ldots \ldots \ldots$ v-27

$\mathrm{v}-14$. Temperature profiles in stored calcine with forced air circulation $\mathrm{v}-29$

$\mathrm{v}-15$. Temperature profiles in stored calcine

with natural convection cooling ............... v-30

vi-1. Enclosed bellows seal valve ................... v. vi-4

vi-2. Calciner feed system flow diagram ............. v. vi-7

vi-3. Waste hold tank and fitting schedule .............. vi-10

vi-4. Feed air lift and associated piping ............... . . vi-11

vi-5. Feed tank and fitting schedule ... . . . . . . . . . . . . vi-12

vi-6. Magnetic flowmeter ...................... vi vi-14

vi-7. Feed nozzle ......................... vi-15

vi-8. Calciner vessel ........................ vi . . . . . . . . .

vi-9. Calciner vessel plan and sections ............... vi-18

vi-10. Calciner distributor plate and cap detail $\ldots \ldots \ldots \ldots \ldots$ vi-19 
vi-11. Slide valve ......................... vi-23

vi-12. Calciner cyclone (Multiclone) ................. vi-25

vi-13. Off-gas system flow diagram ................. vi . . . .

vi-14. Fluidizing air blower ..................... . . vi-28

vi-15. Quench tower ....................... vi-30

vi-16. Venturi scrubber $\ldots \ldots \ldots \ldots \ldots \ldots \ldots \ldots . \ldots \ldots$ vi-32

vi-17. Secondary de-entrainment cyclone ............... . . vi-33

vi-18. Scrubbing solution surge tank ... . . . . . . . . . . . vi-34

vi-19. Scrubbing solution pump ..................... . . vi-36

vi-20. Scrubbing solution cooler ................... vi-38

vi-21. Off-gas heater .......................... . . vi-39

vi-22. Ruthenium adsorber . . . . . . . . . . . . . . . . . vi vi

vi-23. Regeneration solution surge tank ... . . . . . . . . . vi-43

vi-24. Off-gas filter facility ..................... . . vi-46

vi-25. Off-gas blower ...................... . vi-47

vi-26. Transport air system ... . . . . . . . . . . . . . . vi-50

vi-27. Transport air heater ...................... . . vi . . . . . . .

vi-28. Cyclone fines jet system ................... vi-53

vi-29. Cyclone fines jet construction ................. . . vi-54

vi-30. Product takeoff system .................... . . vi-56

vi-31. Solids storage cyclone .................... . . vi-57

vi-32. Solids storage system flow diagram .............. vi-60

vi-33. Individual solids storage bin .................. vi-61

vi-34. Storage bin plan . . . . . . . . . . . . . . . . . . . vi-62

vi-35. Solids storage off-gas trap .................. . . vi-66

vi-36. Solids storage off-gas condensate receiver . . . . . . . . . vi-67

vi-37. NaK system flow diagram ................... . . . vi-69 
vi-38. NaK electromagnetic pump ................... . vi-70

vi-39. NaK heater ........................... . . vi-72

vi-40. NaK expansion tank ...................... vi . . . . . . . . . .

vi-41. Fluidized bed NaK heat exchanger . . . . . . . . . . . . vi-75

vi-42. NaK heat exchanger details . . . . . . . . . . . . . vi-76

vi-43. NaK drain and charge tanks .................. vi-77

vi-44. NaK oxide removal system ... . . . . . . . . . . . . . vi-79

vi-45. WCF liquid sampling circuit ................. . . vi-98

vi-46. Detail of liquid sampling station . . . . . . . . . . . . . vi-99

vi-47. Small solids sampler ... . . . . . . . . . . . . . . vi-101

vi-48. Bulk solids sampler . . . . . . . . . . . . . . . . . . . vi-102

vi-49. Analytical apparatus for particle size distribution . . . . . . vi-104

vi-50. Decontamination system flow diagram . . . . . . . . . . vi-106

vi-51. Hot sump system flow diagram ... . . . . . . . . . . vi-107

vi-52. Hot sump tank ........................ . . vi-110

vi-53. Equipment vent system .................... . vi-112

vi-54. Equipment vent condenser ... . . . . . . . . . . . . . vi-113

vi-55. Off-gas sampler ...................... vi-117

vi-56. ICPP stack monitoring system ................ . vi-119

vii-1. Capacity (throughput) of a fluidized bed
calciner as a function of temperature $\ldots \ldots \ldots \ldots \ldots$ vii-8

vii-2. Location of sample stations for WCF off-gas system ..... vii-12

vii-3. Particulate matter flow rates and

decontamination factors for the WCF off-gas system ..... vii-13

vii-4. Effect of dust accumulation on

pressure drop through a silica gel bed ............ vii-21

viii-1. Organizational framework of the AED $\ldots \ldots \ldots \ldots \ldots$ viii-2

viii-2. Relationship of the ICPP production branch with

other branches of the Atomic Energy Division (AED) . . . . . viii-5 
ix-1. Calculated temperature transients for NaK leakage ....... ix-17

ix-2. Cooling air system and proposed closed-loop cooling system . . ix-28

C-1. WCF solids storage bin .................... C-3

C-2. Storage bin dimensions and heat fluxes ........... C-6

C-3. Bin temperature profiles for forced circulation $\ldots \ldots \ldots . . . . . . .13$

C-4. Bin temperature profiles for natural circulation $\ldots \ldots \ldots . . . \quad \mathrm{C}-17$

D-1. Sectional view of calciner .......................... D-3

D-2. Estimated equilibrium temperatures in calciner bed after shutdown with no internal cooling ........... D-7

G-1. Net weight deposition rates at varying distances from the ICPP stack for various meteorological conditions ..... G-7

G-2. Maximum radioactivity dose rates as

a function of distance from the ICPP stack ........... G-11

TABLES

III-1. Population Distribution Around NRTS ............. . . iii-2

III-2. Diffusion Parameters at the NRTS for 30 Minutes or Longer ... iii-12

III-3. Location of Population Centers from WCF . . . . . . . . . . iii-14

III-4. Radioactivity Transport Time from the WCF to NRTS Sites ... iii-14

III-5. WCF Downwind Meteorological Parameters . . . . . . . . . iii-15

V-1. Analyses of First Cycle Waste Tanks

at the Idaho Chemical Processing Plant ............. v v-2

V-2. Waste Tank WM-182 Sampling Results ..............

V-3. Range of Property Values for Alumina Calciner

Product Generated in WCF and Pilot Plant Calciners ...... v v-12

V-4. Analytical Techniques for Identification of Product Properties . v -13

V-5. Leachability of Gamma Emitters from

Calciner Product by Various Solutions .............. v $\mathrm{v}-20$

V-6. Shielding and Calculated Radiation

Levels at Critical Locations in WCF ............... v $v$-28 
VI-1. WC-102 - WC-302 Fitting Schedule ............. vi-20

VI-2. WCF Equipment on Emergency Power Circuit ......... vi-89

VI-3. Summary of the Temperature Alarms in the WCF Process .... vi-93

VI-4. Summary of the Pressure Alarms in the WCF Process ..... vi-94

VI-5. Summary of the Liquid Level Alarms in the WCF Process ... vi-96

VI-6. Summary of the Flow Alarms in the WCF Process ....... vi-97

VI-7. Radiation Detector Stations in the

Remote Area Monitoring System ... . . . . . . . . . . vi-115

VII-1. Range of Operating Variable Values Employed

With the WCF and ICPP Pilot Plant Calciner ........... vii-2

VII-2. General Effect of Operating Variables on Calcination Process . . vii-3

VII-3. Effect of Calcination Temperature on Ruthenium Volatilization . vii-16

VII-4. Effect of Carbon Monoxide Gas on Ruthenium Volatilization . . . vii-16

VII-5. Ruthenium Volatility from ICPP Laboratory Studies . . . . . . vii-17

VII-6. Decontamination Factors Obtained in Waste

Calcination Tests with Diluted ICPP Waste Soltuion ....... vii-18

IX-1. Estimated Radioactivity Release Rate From ICPP

Stack and Diffusion Parameters Required to Meet the

$\mathrm{RCG}_{\mathrm{a}}$ of Radioactive Nuclides in the Atmosphere ........ ix-4

IX-2. Wind Distribution Frequency ................. ix-5

IX-3. Activity Release to Atmosphere with Portions of

Off-Gas System Bypassed .................... ix-8

IX-4. Probable Ammonium Nitrate Decomposition Reactions ...... ix-21

IX-5. Heat Dissipation Systems Normally

Available for Calciner Cooling During Shutdown . . . . . . . . ix-23

IX-6. Estimated Lifetime Bone Dose from Strontium -90

Inhaled After WCF Accidents ................... ix . . . .

A-1. $\mathrm{N}_{\mathrm{S}}$ and $\mathrm{N}_{\mathrm{T}}=$ Grams of Fission Product $/ \mathrm{kg} \mathrm{U-235}$ at

Saturation and at Irradiation Time $\mathrm{T}$, Respectively ....... A A

A-2. $\mathrm{N}_{\mathrm{T}}$ and $\mathrm{N}_{\mathrm{t}}=$ Grams of Fission Product $/ \mathrm{kg} \mathrm{U-235}$ at

Irradiation Time $\mathrm{T}$ and After Decay Time $\mathrm{t}$, Respectively .... A A

A-3. Activity in Curies/Gallon of Waste $\left[=\mathrm{N}_{\mathrm{t}}(\mathrm{K} \lambda 1 / 2)\right] \ldots \ldots \ldots \ldots$ 
B-1. Estimation of Energy Resulting from Decay of Fission Products . B-3

B-2. Heat Generation from Theoretical MTR-Type Waste ... . . . B B-4

B-3. Heat Generation from ICPP WM-180 Waste . . . . . . . . . . B-5

B-4. Heat Generation from ICPP WM-182 Waste .......... . . B-6

B-5. Heat Generation from ICPP WM-183 Waste . . . . . . . . . . B-7

B-6. Heat Generation from ICPP WM-185 Waste ........... . . B-8

F-1. Input Rates of Oxidizing Materials into the Calciner . . . . . . F F

F-2. Energy Balance for Three NaK Leak Rates into the Calciner . . F F-7

G-1. Estimated Particulate Deposition Rate from Contact of Plume with Ground ............... G-3

G-2. Estimated Particulate Deposition Rate from Washout . . . . . G G-5

G-3. Estimated Net Deposition Rates from ICPP Stack Plume _... G G-6

G-4. Estimated Equilibrium Soil Radioactivity ............ G G-9

G-5. Conversion from Radioactivity Deposition

Rate to Radioactivity Dose Rate .............. G-10

G-6. Radioactivity Dose Rates as a Function of Distance from ICPP Stack ................. G-11

H-1. WCF Process Piping Location for Wall Thickness Measurements H-2

H-2. Sonizon Thickness Measurements of Waste Calcination Facility Process Pipes ........... H-3

H-3. Wall Thickness Measurements on Process Piping Accessible for Inspection ........... . H H

I-1. Dimensions, Activity Levels, and Estimated Linear Absorption Coefficients for WCF Process Vessels ........ I-2

$\mathrm{K}-1$. Lifetime Doses from Inhalation of Stack Plume for Fifteen Minutes after $\mathrm{H}_{2}-\mathrm{O}_{2}$ Explosion in WCF ............... K-3

K-2. Estimated Lifetime Bone Doses from Strontium-90 Inhaled After WCF Accidents ......................... K-3 



\section{SUMMARY}

The ICPP Waste Calcining Facility (WCF) is scheduled to begin processing existing ICPP high-level radioactive wastes in late 1963. In preparation for this operation, an analysis of the radiological hazards associated with operation of the facility has been made. No major safety problems, only the need for several minor equipment and procedure changes to minimize possible hazards, were uncovered during the course of the analysis. All of these changes are being made and will be in effect when the processing of radioactive waste begins. This report presents a description of the facility, including the process, equipment, and operating procedures, and describes the analysis of the safety aspects of operating the facility. A summary of the radiological problems considered and safety aspects of the facility is given in the following paragraphs.

The calcination process possesses considerable inherent safety in that the primary decomposition reactions are not exothermic and process changes develop slowly. No organic materials, which could lead to explosions similar to those experienced at Oak Ridge and Savannah River, are normally used in the process, nor is the process itself such as to be susceptible to catastrophic results from inadvertent introduction of organic material into the process system. Ammonium nitrate, present in small quantities in the ICPP first cycle wastes, decomposes irreversibly in the calciner, releasing but a small fraction of the heat required for the calcination reactions. Criticality is not a problern. Significant measures of safety are provided by the use of many design features already thoroughly tested in nuclear fuel reprocessing plants and by the use of operating crews, health physicists, and supervisors who have had previous experience operating the Idaho fuel reprocessing facilities. These personnel have already gained experience at the WCF through approximately 4000 hours of test operation prior to the start of radioactive operation.

Several process operations, ie, the cleanup of large volumes of contaminated off-gas, the use of a highly reactive liquid metal ( $\mathrm{NaK}$ ) as a heat transfer medium in the fluidized bed, and the handling and storage of large quantities of contaminated particulate solids, are unusual, and as such have been the subject of the major safety questions posed in connection with the facility. A careful study has revealed no extreme hazard or undue risk connected with these operations. 
Estimates of the atmospheric concentrations of all fission products released during the calcination of existing waste tank contents in the WCF are below the allowable limits set by NBS HANDBOOK 69 under all historical weather conditions. These estimates are based upon the particulate release rate determined through the WCF test program and upon ruthenium decontamination factors achieved in ICPP and ANL laboratory and pilot plant testing. The estimated maximum instantaneous atmospheric concentrations of ruthenium when calcining 200-day cooled waste $(\approx 800$ curies/gal), exceed the continuous exposure limits (by factors no greater than eleven) for weather conditions which occur approximately 20 percent of the time at the NRTS, and are within the limits during the remaining 80 percent of the time. More accurate data on ruthenium emission will be obtained during initial operation of the WCF with present wastes (five years old) having a relatively low radioactive ruthenium content. Increase in the ground activity surrounding the ICPP as a result of the off-gas release is expected to be very little. The activity release to the atmosphere will be monitored by stack-gas activity detection equipment and through site radiation surveys continuously conducted in the area by the AEC Health and Safety Division.

An examination of the consequences of failures in the off-gas cleanup system shows that the adsorbers are the most critical cleanup element, primarily because of the large ruthenium decontamination factor $\left(10^{3}\right)$ attributed to the silica gel. Failure of the off-gas scrubbing system would not result in a major release because most of the radioactivity passing the scrubbing system would be trapped in the silica gel beds and off-gas filters.

NaK released into the calciner as a result of a tube failure in the fluidized bed heater would reactimmediately with the oxygen, water, and nitrogen oxides present. The rate of heat release is limited by the amount of oxidizer and water available. In a hypothetical worst situation where the NaK leaks at a rate (14.8 gpm) just sufficient to react with all the water and oxidizer present in the fluidizing air, purge air, and feed - and in which no heat losses are considered - the calciner vessel walls would reach the design temperature limit in 13 minutes but would never reach the melting temperature. Using the emergency shutdown circuitry provided, the NaK can be dumped from the system in 90 seconds, well before the time these conservative estimates indicate the integrity of the calciner vessel would be threatened. Both lower and higher leak rates would result in lower maximum calciner temperatures and in longer times to attain any given temperature. At higher leak rates, excess NaK 
accumulating in the bed would begin vaporizing in approximately nine minutes and would be carried into the off-gas scrubbing system where the reaction with the scrubbing solution would evolve considerable steam and hydrogen. A hydrogenoxygen explosion occurring in the scrubbing system would not release large amounts of radioactivity because of the lowinventory of contaminated particulate material in the equipment likely to be ruptured. NaK leak rates of $14.8 \mathrm{gpm}$ and greater require simultaneous small leaks in several tubes or a sudden, complete break of a single tube - both highly unlikely occurrences.

Overheating of the calciner vessel by fission product decay heat during a shutdown will not occur with waste of the activities to be processed in the WCF. During shutdowns, the decay heat can be removed easily by passing purge air through the bed or by circulating cold NaK through the fluidized bed heater. In the unlikely event that neither of these cooling modes can be used, the temperature of the walls of the calciner will still not exceed their melting temperature.

Overheating of the solids storage bins also is impossible, except in the event of a major catastrophe which could disrupt the cooling air ducting; no mechanical equipment is required in the solids storage cooling system for the waste solids scheduled for storage in the present bins; natural circulation of the cooling air will provide sufficient cooling. A filter is provided to remove radioactive particulates released into the cooling air in the event of a small fracture in the walls of the bins. A closed loop cooling system is being designed as an alternative measure if a bin failure occurs and filter replacement costs become excessive. Such a system can be installed after radioactive operation begins.

All of the equipment at the WCF is ordinarily under only a small fraction of the allowable material stress limits. Breaks in equipment occurring from corrosion, erosion, or vibration, therefore, should be slow and progressive and have a high probability of detection before any activity release becomes serious. No failure in any of the utility systems would create an immediate crises in the facility. Valves in the off-gas lines to the stack would remain in the open position on loss of either air or electricity, allowing the process and vessel off-gas to continue flowing to the ICPP stack. Operating personnel then have time to take remedial measures to prevent equipment damage (primarily off-gas filter wetting) which might eventually occur if these measures were not taken. 
Major catastrophes such as bombings and earthquakes could result in significant release of activity, but the magnitude of and hazard from such a release is no worse if the WCF is operated than if it is not.

Several accidents that would result in a release of radioactivity were postulated for the facility. The chance of any of these accidents, especially those resulting in the greatest activity release, is so remote their "credibility" is questionable. In all such accidents, except major catastrophes, the radioactivity would be released through the 250 -foot high ICPP stack. The greatest hazards accompanying a release are inhalation of the radioactive dust and ground contamination. Radiation from the stack plume is a lesser problem. Of the fission products, strontium-90 presents the greatest hazard because of its solubility and long retention in the body.

The worst postulated accident from the standpoint of release of radioactive solids is a hydrogen-explosion in the scrubbing system following an unchecked gross failure of the liquid metal heating coil in the fluidized bed. Following such an accident, some ICPP personnel could inhale sufficient strontium-90 that the maximum weekly dosage from the material retained by the bone would be approximately 10 percent of the Radiation Concentration Guide limit of $0.56 \mathrm{rem} /$ week. Persons in surrounding communities would receive far smaller doses. Deposition by fallout or washout from the plume also could contaminate some areas, but these areas could be isolated to prevent hazardous exposure of personnel. Considering the severe assumptions made in postulating this accident and in the dose calculations, the figure quoted is believed to represent the maximum exposure possible from operation of the WCF. Furthermore, a series of highly unlikely events must take place for such an accident to occur. Therefore, operation of the WCF does not appear to present any undue hazard, and through its operation, large quantities of high-level radioactive waste solutions will be converted to a safer, solid form. 


\section{I . I NTRODUCTION}

The ICPP Waste Calcining Facility (WCF), for which this safety analysis report has been prepared, is the world's first plant--scale facility built in an effort to achieve safe, efficient disposal of high-activity radioactive wastes resulting from reprocessing of nuclear fuels. This disposal problem is receiving wide attention by atomic energy agencies throughout the world [1]; none of the techniques suggested as yet, however, offers the high degree of safety with low overall cost necessary to the optimum solution. The greater portion of the effort on this problem, particularly in the United States, is being directed toward the conversion or incorporation of the wastes (generally liquid) into stable, solid media. Many processes for accomplishing this, eg, fluidized bed calcination, pot calcination, spray calcination, fusion in glass, have been studied and a few have reached the pilot plant or demonstration stage [2]. The fluidized bed technique is employed in the WCF, and it is the most advanced of these processes. Because of the uniqueness of this application of fluidized bed technology, and the potential problems in dealing with large volumes of radioactivity contaminated gas, a quite detailed safety analysis of the process and the WCF equipment has been made.

\section{HISTORY}

The fluidized-bed calcination process was conceived at the Argonne National Laboratory [3, 4], and has been under development by the Atomic Energy Division of Phillips Petroleum Co. since 1955 [5-9] [13] [15-17] as a means of converting to solids the high-level aluminum nitrate wastes stored at the Idaho Chemical Processing Plant (ICPP). Additional contributions to fluidized bed technology were made by the Hanford Laboratories in $1959^{[10,11]}$. Because of the encouraging results obtained in the early work, a proposal to demonstrate the fluidized bed process on a relatively large scale was accepted by the U.S. AEC in 1956. The Fluor Corporation of Los Angeles, California, designed and constructed the WCF at an approximate cost of $\$ 6,000,000$. Construction, started in 1958 at a location adjacent to the ICPP, was completed in 1961. "Cold" testing with simulated wastes was started by the operator, Phillips Petroleum Co., in 1961. Process problems and equipment deficiencies encountered during the test program were overcome or defined by the conclusion of the final "cold" test 
in 1962, and operational control of the process has been shown to be reliable ${ }^{[14]}$. Final modifications to correct deficiencies are presently underway and processing of radioactive wastes is scheduled to begin in the fall of 1963.

\section{PROCESS DESCRIPTION}

The WCF is designed to process $60 \mathrm{gph}$ of the high activity wastes resulting from the reprocessing of aluminum-uranium fuel elements [12]. The primary reaction taking place in the calcination process, aside from the evaporation of liquids, is the thermal decomposition of aluminum nitrate (29 percent of the waste solution) into aluminum oxide. This is accomplished by spraying the waste solution into a bed of alumina particles which have been fluidized with air and heated to $400^{\circ} \mathrm{C}$ by liquid metal (NaK) flowing through a heat exchanger immersed in the bed (Figure II-1). The aluminum oxide, together with chemically stable forms of the fission products and other elements in the waste solution, builds up on the outside surfaces of the bed particles. Product is removed continuously and transported pneumatically to solids storage bins.

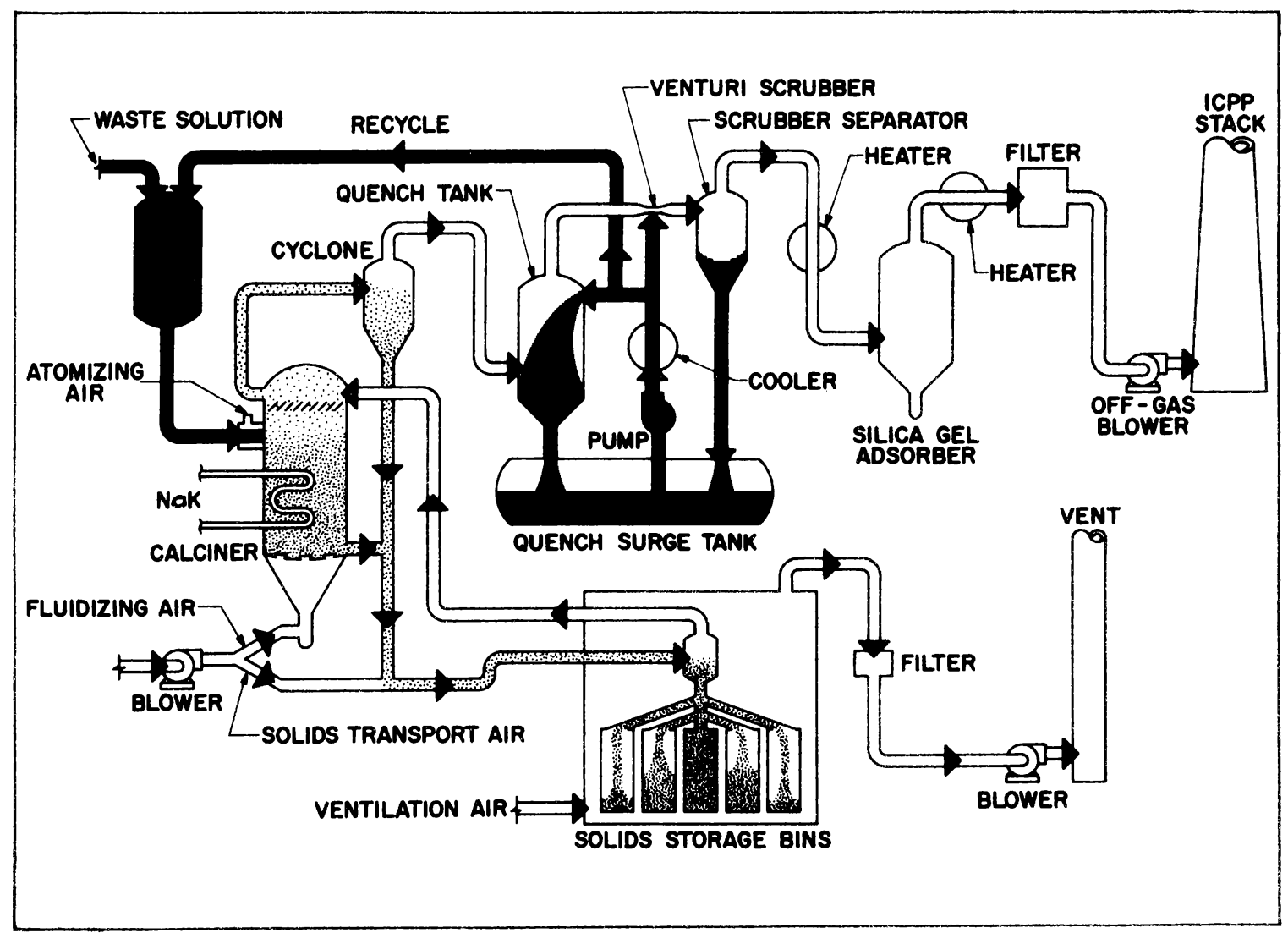

FIG. II-I FLUIDIZED BED WASTE CALCINING FACILITY. 
Entrained dust in the fluidizing and reaction gases leaving the calciner is removed in a series of cleaning elements, ie, cyclone, venturi scrubber, silica-gel beds, and high-efficiency filters, in the off-gas system. Radioactive ruthenium, which presents a special problem because of the volatility of ruthenium tetroxide at the calcination temperature, is removed by adsorption upon the silica gel beds. Water, which constitutes 67 percent of the waste solution, is discharged to the atmosphere as a vapor along with the clean process off-gas.

Four stainless steel bins, located in an underground concrete vault, provide storage for approximately $7800 \mathrm{ft}^{3}$ of solid wastes (roughly equivalent to 580,000 gallons of liquid wastes). Heat generated in the stored solids by fission product decay is removed by passing air over the metal bin surfaces. Because of uncertainties at the time of design regarding the migration of fission products at higher temperatures, the bins and the cooling system are sized to prevent temperatures from rising above the calcination temperature of $400^{\circ} \mathrm{C}$ anywhere in the bins.

\section{SITE AND FACILITY DESCRIPTION}

The Waste Calcining Facility (WCF) is located adjacent to the Idaho Chemical Processing Plant at the National Reactor Testing Station in Idaho. The area surrounding the Site is flat and arid; the ground structure underlying the area consists of porous lava flows. The depth of the water table under the NRTS varies from 200 to 500 feet, and the ground waters are believed to drain under sparsely populated territory to the Thousand Springs area approximately 150 miles southwest. Principal centers of population near the site are Arco (population of 1700,25 miles west of the site), Blackfoot (population of 7500, 40 miles southeast of the site), and Idaho Falls (population of 33,000, 50 miles east of the site).

The facility is a concrete structure similar to the ICPJ itself. The processing cells lie underground in two banks with the service corridors lying between them. Non-radioactive service areas for the facility are located in a concrete block structure above the processing cells.

As is the case with the ICPP reprocessing facilities [18], the WCF is designed for direct maintenance of equipment during periodic shutclowns. Insurance against unexpected shutdowns in plants of this type is gained by elaborate testing and inspection of equipment before "hot" operation begins. Critical equipment 
items are either installed in duplicate or placed in lead shielded cubicles outside the process cells. Sprays and piping are provided so that both equipment and process cells can be decontaminated remotely; ladders and platforms facilitate access to equipment for maintenance. With few exceptions, process equipment items are fabricated from stainless steel because of the corrosiveness of the acidic process and decontaminating solutions.

Shielding at the WCF is provided by the concrete cell walls, or, in a few cases, by lead or steel housings where process equipment lies outside the cell walls. The processing part of the WCF has been designed to handle wastes having an activity as high as 1400 curies per gallon (120-day to 200-day cooled waste). The solids storage area, on the other hand, was designed with lighter shielding to accommodate material aged a minimum of two years, since older materials will be processed first. Future storage bins, for use after the present ones have been filled, may be built with shielding to accommodate higher-activity wastes.

\section{OPERATION}

The responsibility for operation of the WCF has been assigned to the Atomic Energy Division of Phillips Petroleum Co. The plant will be operated by the existing operating group of the ICPP, with the necessary support from ICPP Special Maintenance, ICPP Technical, ICPP Design Engineering, ICPP Analytical, and ICPP Health Physics. The total work forcepresently assigned at the ICPP is approximately 250. A minimum of 20 men per shift, including two technically trained supervisory employees, will be engaged in operating the WCF and supporting facilities on each shift.

Safety will play an important part in the operation of the WCF as it does in operation of the ICPP itself; no safety precautions will be bypassed in order to meet production commitments. Enforced compliance with standard approved procedures and development of skilled personnel are the primary means used to promote safety. All procedures, as well as the initial design of a process

installation, are reviewed for nuclear safety problems by the ICPP Engineering Safeguard Committee, composed of five experienced Operations and Technical personnel. Assistance and/or guidance on non-nuclear safety problems is provided by a safety engineer assigned to the ICPP. Radiation monitoring is provided by a Health Physics group on a round-the-clock basis. Training of personnel is 
accomplished both through close supervision on the job and through periodic training programs.

\section{SAFETY ANALYSIS}

Since it is the first large-scale plant of its kind and incorporates a process new to the nuclear field, the WCF poses many safety problems that cannot be analyzed in the light of previous experience. The handling and containment of large quantities of radioactive particulate matter will be demonstrated for the first time in the WCF. Of special interest also is the decontamination of the process off-gas to the very low activity levels required for safe release to the atmosphere. Other safety questions that are raised from time to time regarding this particular facility concern the probable consequences of a NaK tube rupture in the calciner vessel and the possibility of overheating the calciner bed (from fission product heat) after a shutdown when the bed cannot be unloaded. These questions and many others are discussed in detail in Section IX, "Hazard and Accident Analysis”.

Safety was given prime consideration during development of the process and design of the WCF; however, many changes have been made in the equipment and process as a result of subsequent non-radioactive testing, It is the purpose of this safety analysis to review all aspects of the process and facility in the light of current knowledge to make certain that no unsafe radiological hazards exist and that the WCF is ready to operate. The proposed AEC guide for reactor hazards summary reports was followed to a great extent in establishing the report outline.

Examination of the radiological hazards was made for two types of wastes -that presently in WM-185 waste tank at the ICPP and a theoretical waste resulting from reprocessing of 200-day cooled MTR-type fuel elements. The activity of tank WM-185 waste has been determined by radiochemical means; the activity of the theoretical waste was estimated by conventional nuclear formulae. The original design calculations for the facility also used a theoretical waste composition and a calculated activity as design bases. Readers familiar with the original design work will note differences in activities quoted for wastes aged the same period of time. The values used in this report are believed more accurate because of the more accurate nuclear data now available.

During the safety analysis of the WCF, no major oversights were found, but the need for several minor equipment changes was uncovered. All of these 
changes will be made prior to start of radioactive operation. The analysis also proved valuable in that it established guides for emergency operating procedures at the facility and served to focus attention on the more critical equipment items and procedures.

\section{REFERENCES}

1. The Treatment and Storage of High-Level Radioactive Wastes. Papers presented at the International Atomic Energy Agency Symposium held at Vienna, Austria, October 8-13, 1962.

2. W. H. Regan, Report of the Third Working Meeting on Calcination and/or Fixation of High-Level Wastes in Stable, Solid Media at Washington D. C., February 1-2, 1962, TID-7646 (January 1963).

3. A. A. Jonke, et a1, "The Use of Fluidized Beds for the Continuous Drying and Calcination of Dissolved Nitrate Salts," Nuclear Science and Engineering, 2, pp 303-319 (May 1957).

4. J. W. Loeding, et al, The Fluid-Bed Calcination of Radioactive Waste, ANL6322 (May 1961).

5. E. S. Grimmett, Calcination of Aluminum-Type Reactor Fuel Wastes in a Fluidized Bed, IDO-14416 (August 1, 1957).

6. D. R. Evans, Pilot Plant Studies with a Six-Inch Diameter Fluidized Bed Calciner, IDO-14539 (April 20, 1961).

7. B. P. Brown, et al, Development of a Fluidized Bed Calcination Process for Aluminum Nitrate Wastes in a Two-Foot-Square Pilot Plant Calciner. Part I. Equipment Development and Initial Process Studies, IDO-14586 (June 20, 1962).

8. B. R. Wheeler, et al, Development of a Fluidized Bed Calcination Process for Aluminum Nitrate Wastes in a Two-Foot-Square Pilot Plant Calciner. Part II. Factors Affecting the Intra-Particle Porosity of Alumina, IDO-14587 (July 25, 1962).

9. B. P. Brown, et al, Development of a Fluidized Bed Calcination Process for Aluminum Nitrate Wastes in a Two-Foot-Square Pilot Plant Calciner. Part III. Intermediate Process Studies - Runs 11-22, IDO-14618 (to be published).

10. K. J. Schneider, Fluidized Bed Calcination Studies with Simulated ICPP Waste Solution, HW-65838-RD (June 6, 1960). 
11. M. D. Alford, Fluidized Bed Calcination of Simulated Purex High-Activity Level Wastes, HW-66384-RD (September 1, 1960).

12. D. K. MacQueen, J. I. Stevens, Design Bases for ICPP Waste Calcination Facility, IDO-14462 (April 22, 1959).

13. E. J. Bailey, Testing of Pumps for Use in Nitric Acid - Alumina Slurry Service, IDO-14612 (May 20, 1963).

14. J. R. Bower, Ed., Chemical Processing Technology Quarterly Progress Report, 4th Qtr 1962, IDO-14611 (June 7, 1963).

15. M. E. McLain, D. W. Rhodes, Leaching of Fission Products from Calcined Process Waste, IDO-14440 (April 30, 1958).

16. D. W. Rhodes, D. R. Anderson, Capacity Test Data for the Adsorption of Volatile Ruthenium on Silica Gel, IDO-14510 (June 17, 1960).

17. D. A. Hanson, et al, The Adsorption of Ruthenium from Nitric Acid-Air Mixtures, IDO-14458 (June 8, 1959).

18. Chemical Processing and Equipment. Selected Reference Material. United States Atomic Energy Program, TID-5276 (1955). 



\section{SITE DESCRIPTION}

\section{DESCRIPTION OF SITE AND ADJACENT AREAS}

The Waste Calcining Facility (WCF) is located at the National Reactor Testing Station (NRTS) near Arco, Idaho. The NRTS covers about 894 square miles of the central-northern edge of the semiarid Snake River Plain, and consists of portions of the counties of Jefferson, Bingham, Bonneville, Butte, and Clark in southwestern Idaho. The terrain is predominantly flat with a one percent slope from southwest to northeast. The average elevation is 5000 feet above sea level. Three large volcanic buttes are prominent land marks. The highest, Big Southern Butte, is three miles south of the NRTS boundary at an elevation of 7576 feet. The other two, Middle Butte (elevation $6394 \mathrm{feet}$ ) and East Butte (elevation 6605 feet), lie within the southern boundary.

The WCF is constructed at the installation known as the Idaho Chemical Processing Plant (ICPP). The ICPP is an exclusion area of approximately 95 acres within which are located facilities for storage and reprocessing of reactor fuel elements, and for treatment and storage of liquid and gaseous radioactive wastes. Research and technical assistance groups also are located at the ICPP.

\section{POPULATION DISTRIBUTION}

The working forces at each NRTS installation are variable, depending upon the status of the various programs. For the month of February 1963 there were 241 employees assigned to the ICPP area. Operation of the WCF will not change this work force. The Materials Testing Reactor Area (MTR-ETR), the closest facility to the WCF (two miles), had 705 persons permanently assigned for the same month. The number of employees at the Central Facilities Area (CFA), which is approximately three miles from the WCF, was 618 for the same period. The total NRTS working force is approximately 5000.

The area around the NRTS includes a few small towns and villages. The closest large towns and cities are located along the Snake River which is approximately 40 miles southeast of the WCF site. The distance from the WCF and the population of towns within a 50-mile radius of the NRTS are listed 
in Table III-1. Figure III-1 shows the location of the ICPP and WCF site with respect to other sites at the NRTS. The area surrounding NRTS is shown on Figure III-2.

TABIE III-I

POPULATION DISTRIBUTION AROUND NRTS

\begin{tabular}{|c|c|c|c|}
\hline Location & Distance from WCF (mi) & Population & Direction from WCF \\
\hline Atomic City & 10 to 15 & 141 & $\mathrm{SE}$ \\
\hline Howe & 15 to 20 & 20 & NNW \\
\hline Arco-Butte City & 20 to 30 & 1,670 & W \\
\hline Taber & 30 to 40 & 5 & $\mathrm{SE}$ \\
\hline Darlington & 30 to 40 & 10 & NW \\
\hline Mud Iake & 30 to 40 & 187 & $N E$ \\
\hline Mackay & 30 to 40 & 650 & NW \\
\hline MonteView & 30 to 40 & 10 & $\mathrm{NE}$ \\
\hline Moore & 30 to 40 & 358 & WNW \\
\hline Terreton & 30 to 40 & 10 & $\mathrm{NE}$ \\
\hline Idaho Falls & 40 to 50 & 33,100 & $\mathrm{E}$ \\
\hline Blackfoot & 40 to 50 & 7,378 & $\mathrm{SE}$ \\
\hline Shelley & 40 to 50 & 2,612 & ESE \\
\hline Roberts & 40 to 50 & 422 & ENE \\
\hline Firth & 40 to 50 & 322 & ESE \\
\hline Basalt & 40 to 50 & 275 & ESE \\
\hline
\end{tabular}

A considerable fraction of the ground in the area within and around the NRTS is covered with lava flows. This makes the area unsuitable for agriculture and there appears to be no other reason for a change in the population density.

\section{METEOROLOGY}

Topographic features which affect the meteorology at the NRTS are the northeast-southwest orientation of the plain, and the continental divide to the north and east. The predominant surface winds are either southwesterly or northeasterly. All air masses that enter the plain must first cross a mountain barrier, regardless of the direction from which they enter. Being subjected to lifting, these masses usually precipitate moisture over the mountains and enter the plain sufficiently dry to give the region its desert-like characteristics.

The average annual precipitation at the NRTS has been 7.57 inches per year over an adjusted 30-year period. May is the wettest month, averaging 1.30 


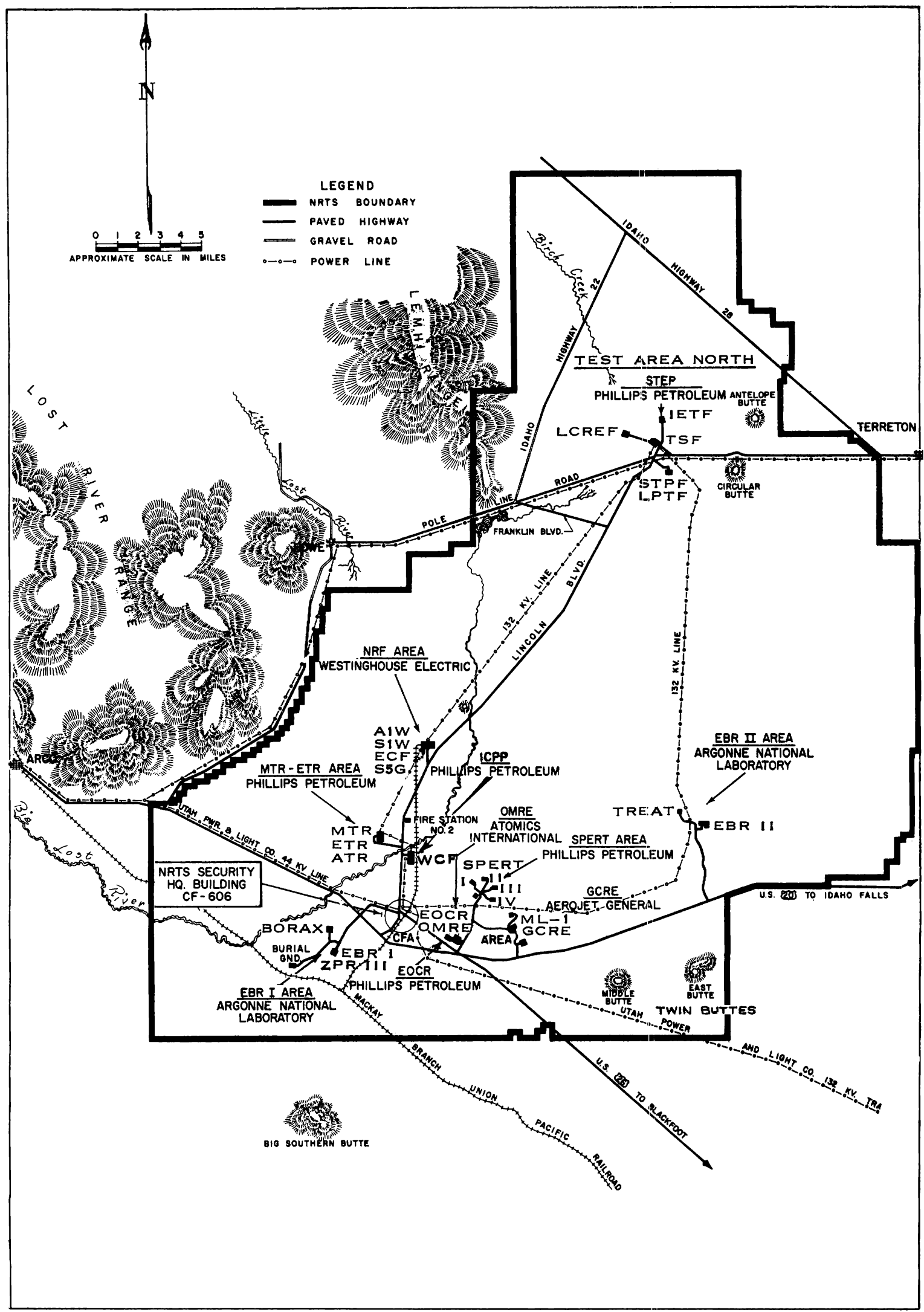

FIG. III-I FACILITIES AT THE NATIONAL REACTOR TESTING STATION. 


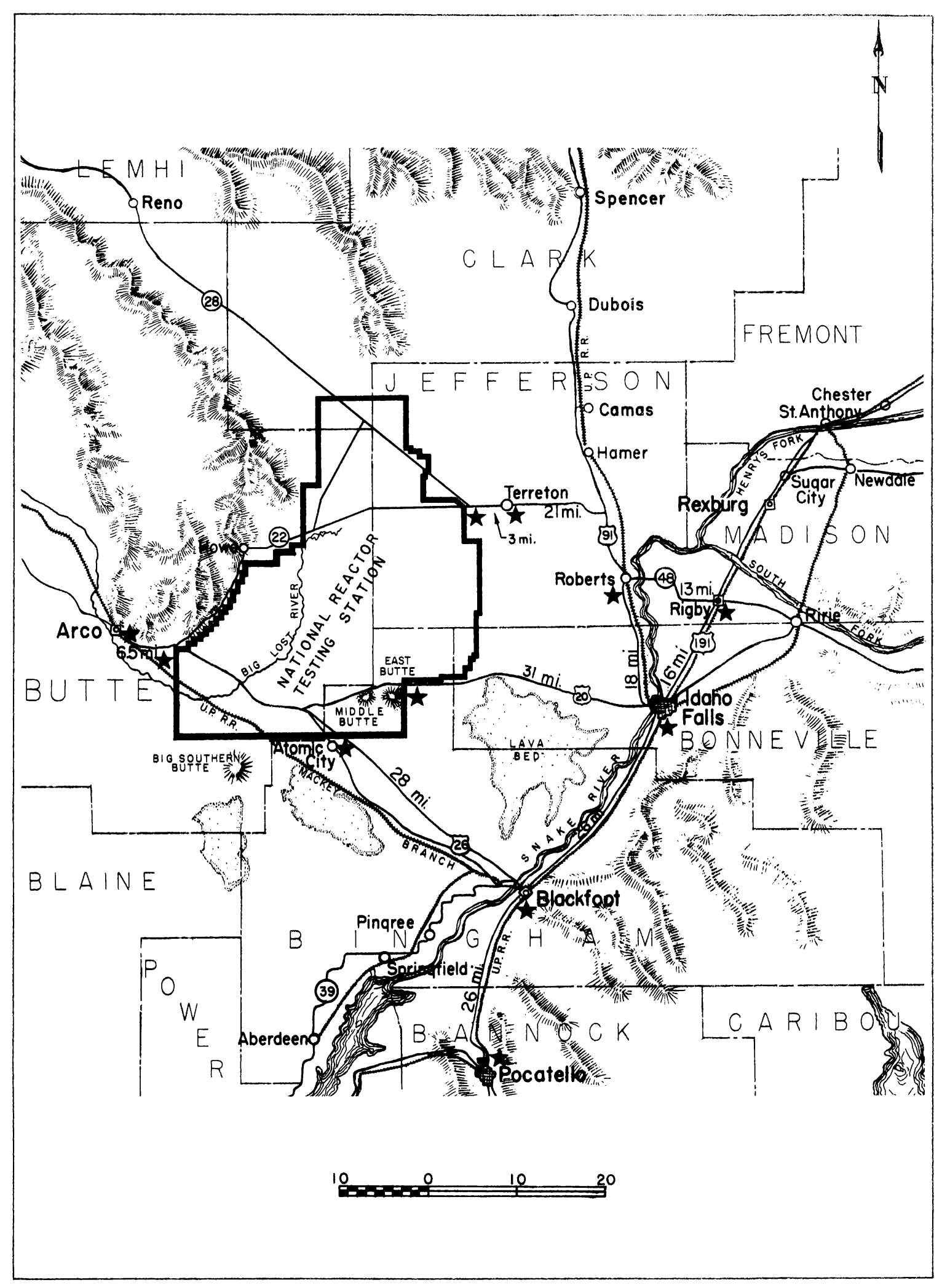

FIG. III-2 NATIONAL REACTOR TESTING STATION AND VICINITY. 
inches, while November is the driest, averaging 0.37 inch. The maximum expectable rate of precipitation is approximately 1 inch per hour and about 2 inches in a 24-hour period; this would normally occur as summer rain. The greatest recorded rainfall in 24 hours was 1.73 inches in June 1954, and the greatest recorded 24-hour snowfall was 8.5 inches, occurring in January 1957.

A very wide range of daily temperatures can be expected. The average range is greatest (about $37^{\circ} \mathrm{F}$ ) in the summer and the least (about $23^{\circ} \mathrm{F}$ ) in the winter. The maximum recorded temperature is $102^{\circ} \mathrm{F}$ in July 1951 , and the minimum recorded temperature is $-42^{\circ} \mathrm{F}$ in January 1962 . The annual mean temperature is $42.2^{\circ} \mathrm{F}$.

The NRTS is in the belt of prevailing westerly winds which are channeled before reaching the station. This channeling causes a southwest wind to predominate at the south end of the NRTS while a south-southwest wind occurs most frequently at the north end. However, the winds generally rotate around the compass every day with northerly winds occurring most frequently at night during inversions while southerly winds occur most frequently during the day. The wind frequency patterns for the NRTS, as determined by the U. S. Weather Bureau Office at CFA, are shown in Figures III-3 through III-8.

It has long been recognized that the ability of the atmosphere to disperse pollutants, such as the discharge of fission products from a stack, covers a wide range. It varies not only with the time of day, but with geographical location. Several relationships have been developed which describe the atmospheric dispersion of material; perhaps the best known is O. G. Sutton's [9], which defines the diffusion parameter $\frac{X}{Q}=\left(\frac{\text { curies per cubic meter at ground level }}{\text { curies released per second }}\right)$ as a function of the weather conditions. As the result of many tests, Sutton's equations generally have been found applicable at the NRTS. Table III-2 presents the values of wind speed $(\bar{u})$, stability index $(n)$, and lateral $\left(C_{y}\right)$ and vertical $\left(C_{z}\right)$ diffusion coefficients to be used in the Sutton equations for four conditions that constitute approximately 80 percent of the weather at the NRTS. Except near the stack, the strong inversion generally represents the worst of these cases; the strong lapse generally represents the bestdispersion case. The neutral lapse and slight inversion cases fall within these extremes. Two special conditions, fumigation and looping, account for the remaining 20 percent of the weather at the NRTS. Poorer diffusion, especially near the stack, accompanies both of these weather conditions. 


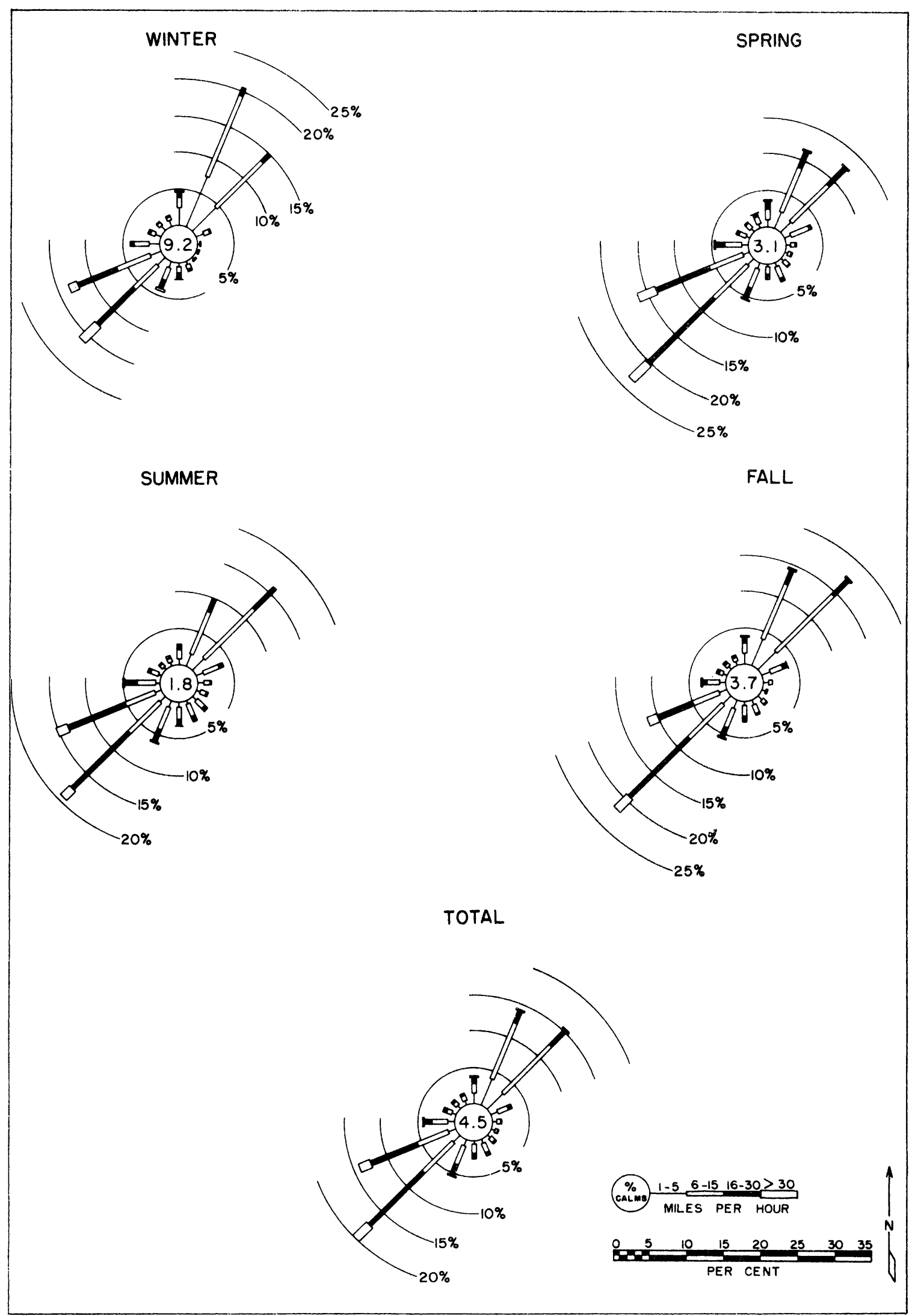

FIG III-3 250-FT-LEVEL WIND ROSES FOR PERIOD JULY 1951 THROUGH MAY 1962. 


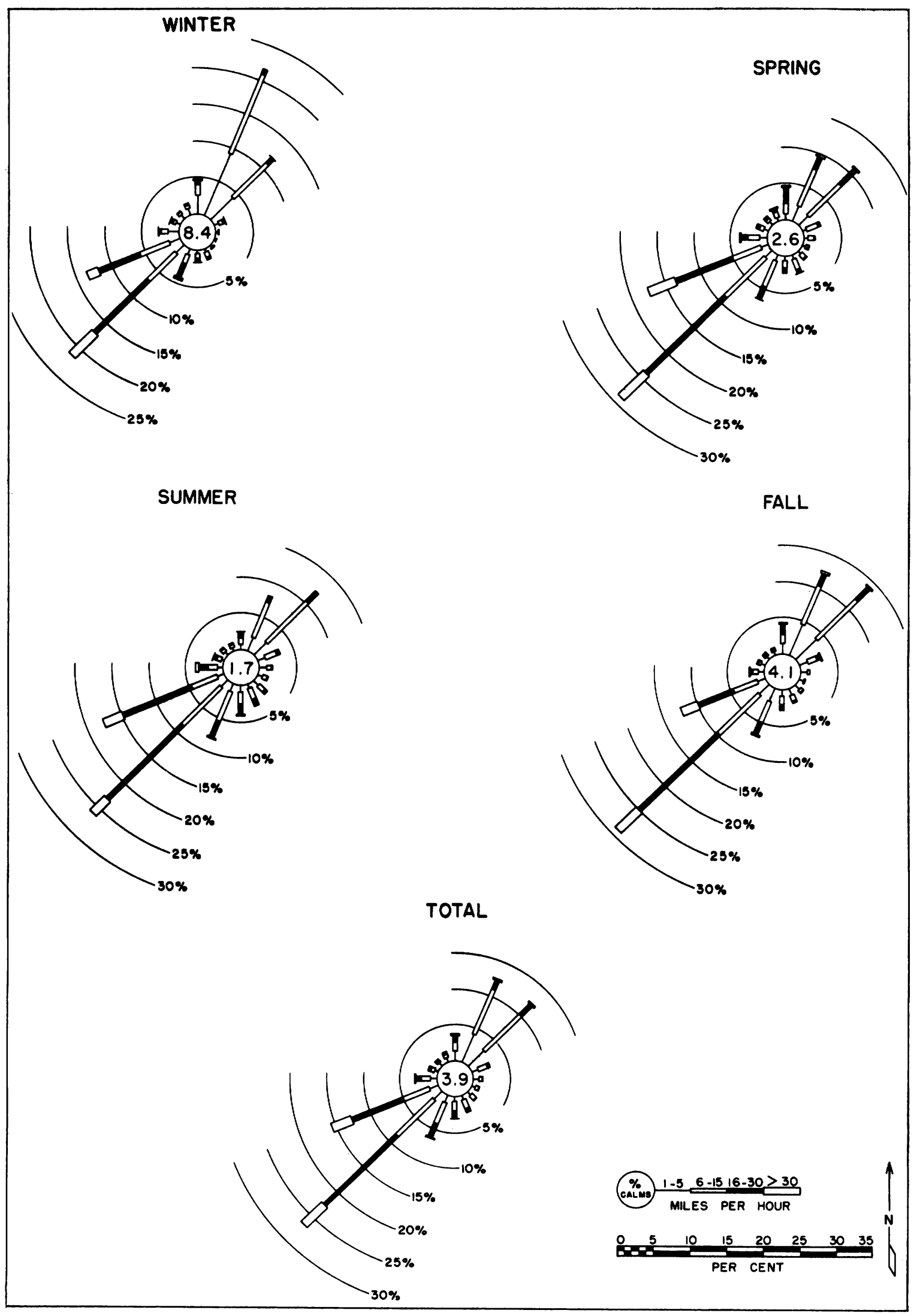

FIG. III-4 250-FT-LEVEL LAPSE WIND ROSES JULY 1951 THROUGH MAY 1962. 


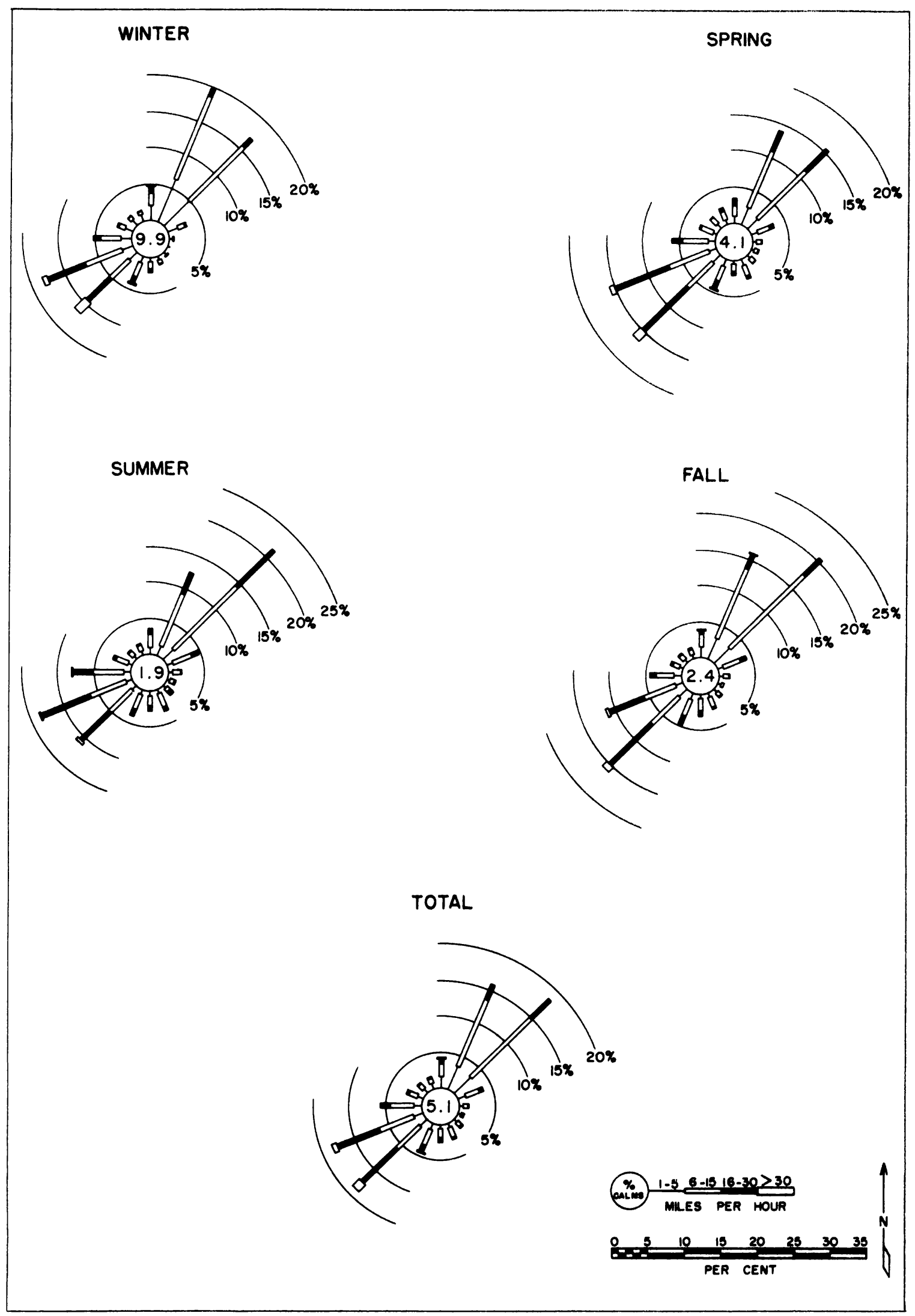

FIG. III-5 250-FT-LEVEL INVERSION WIND ROSES JULY 1951 THROUGH MAY 1962 


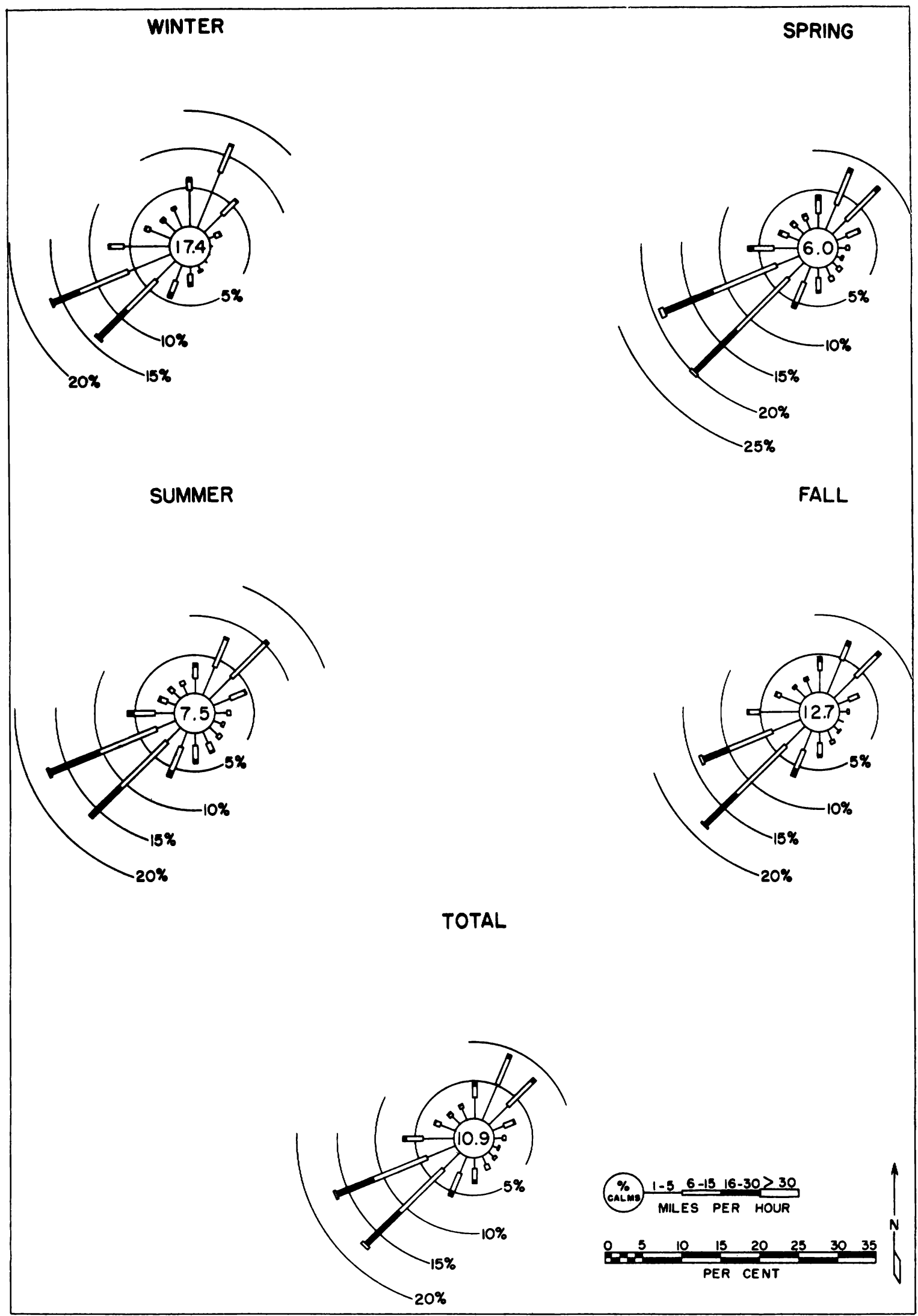

FIG. III-6 20-FT-LEVEL WIND ROSES. JANUARY 1950 THROUGH MAY 1962. 


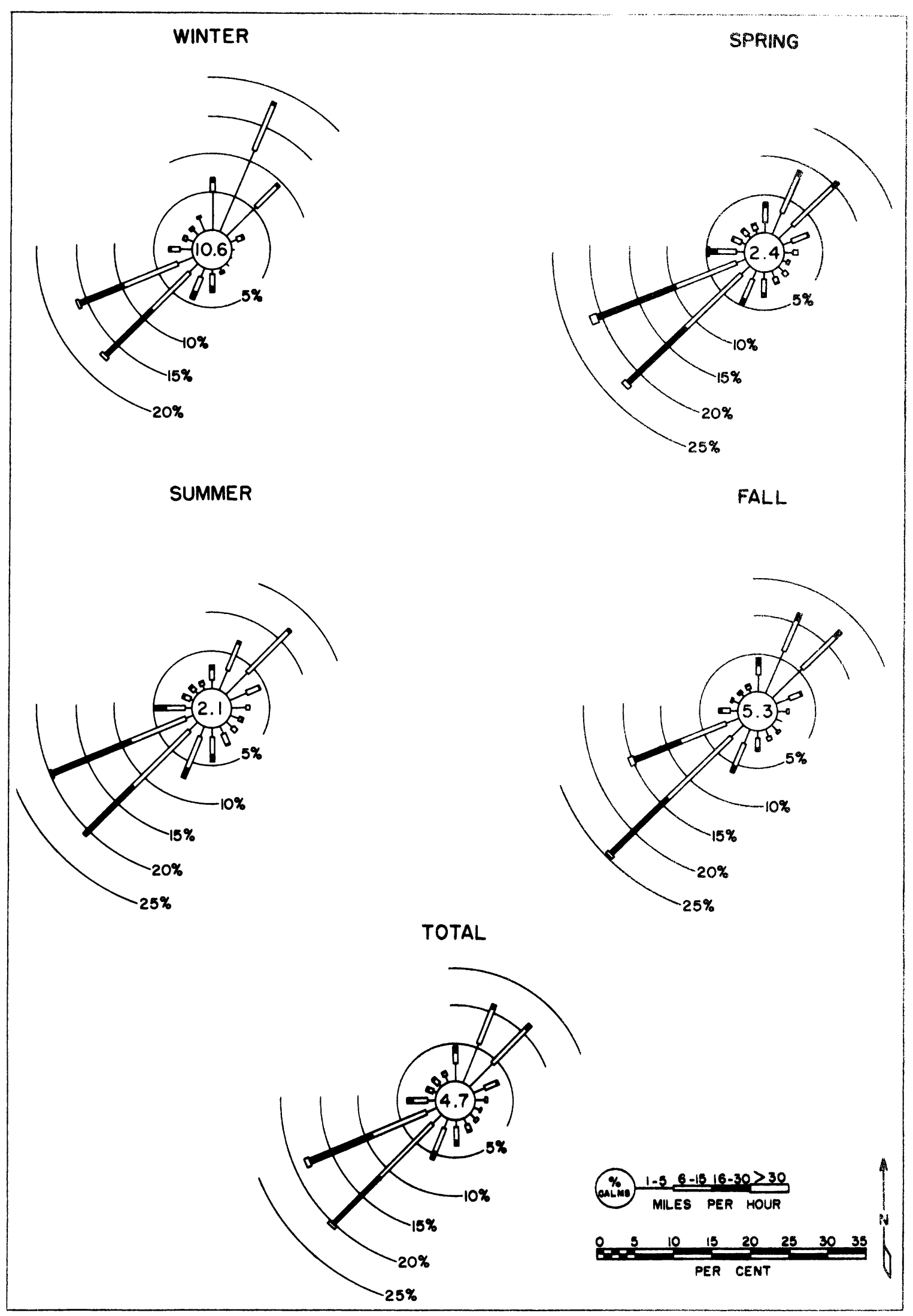

F1G. III-7 20-FT-LEVEL LAPSE WIND ROSES JANUARY 1950 THROUGH MAY 1962. 


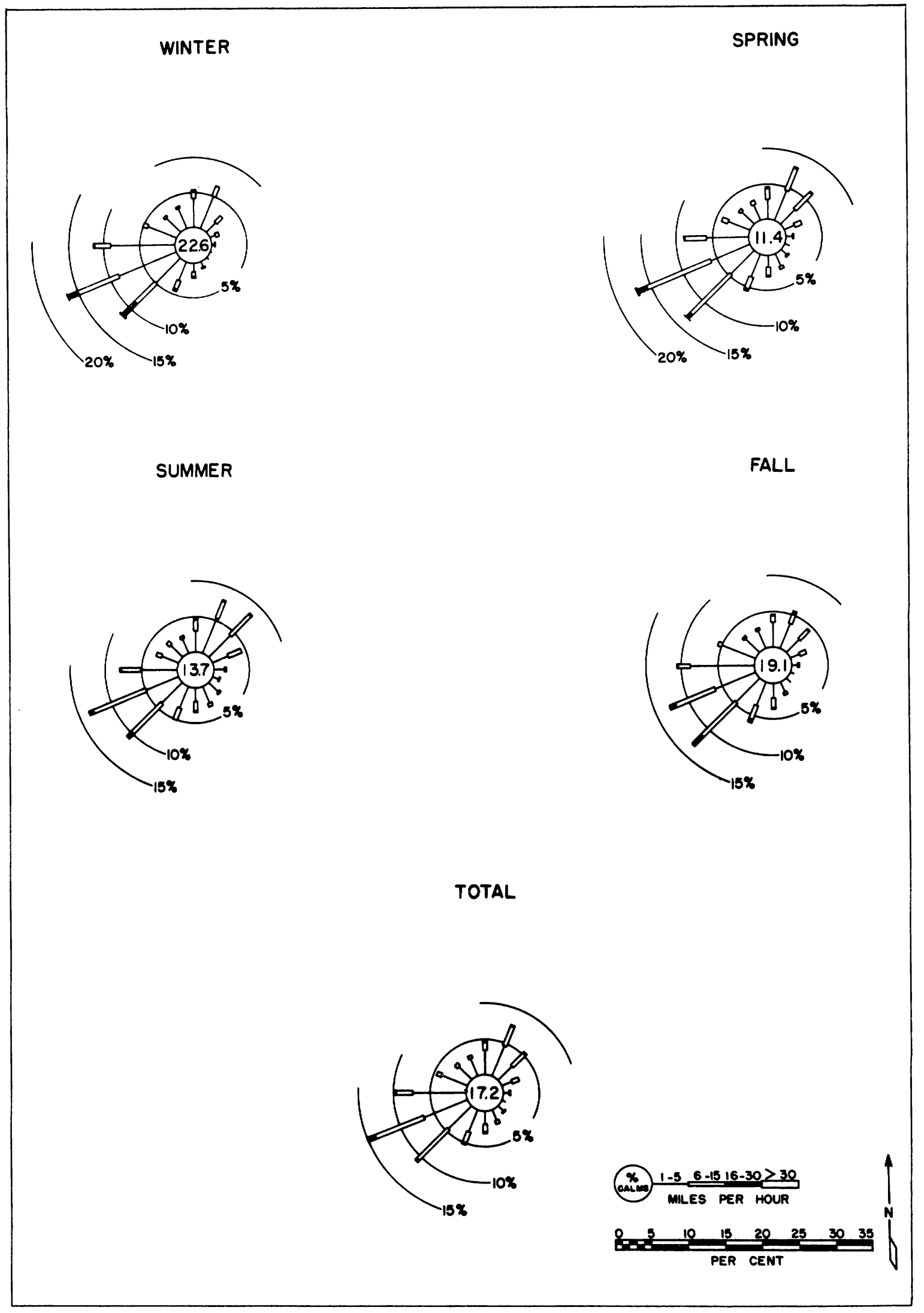

FIG. III-8 20-FT-LEVEL INVERSION WIND ROSES JANUARY 1950 THROUGH MAY 1962. 
DIFFUSION PARAMETERS AT THE NRTS FOR 30 MINUIES OR LONGER ${ }^{[a]}$

\begin{tabular}{|c|c|c|c|c|c|}
\hline $\begin{array}{l}\text { Weather } \\
\text { Condition }\end{array}$ & $\begin{array}{c}\text { Mean Wind Speed } \\
(\mathrm{m} / \mathrm{s})\end{array}$ & $\begin{array}{l}\text { Stability } \\
\text { Index }\end{array}$ & $\begin{array}{c}\text { "Effective" } \\
\text { Stack Height } \\
\text { (h) }\end{array}$ & $\begin{array}{l}\text { Lateral } \\
\text { Diffusion } \\
\text { Coefficient } \\
\quad\left(\mathrm{Cy}_{\mathrm{y}}\right)\end{array}$ & $\begin{array}{l}\text { Vertical } \\
\text { Diffusion } \\
\text { Coefficient } \\
\quad\left(\mathrm{C}_{\mathrm{z}}\right)\end{array}$ \\
\hline Strong Lapse & $\bar{u}=7.0$ & $\mathrm{n}=0.20$ & $\begin{array}{r}2 \text { meters } \\
45 \text { meters } \\
75 \text { meters } \\
100 \text { meters }\end{array}$ & $\begin{array}{l}0.350 \\
0.273 \\
0.251 \\
0.236\end{array}$ & $\begin{array}{l}0.350 \\
0.273 \\
0.251 \\
0.236\end{array}$ \\
\hline Neutral Lapse & $\overline{\mathrm{u}}=5.0$ & $\mathrm{n}=0.25$ & $\begin{array}{r}2 \text { meters } \\
45 \text { meters } \\
75 \text { meters } \\
100 \text { meters }\end{array}$ & $\begin{array}{l}0.193 \\
0.129 \\
0.119 \\
0.115\end{array}$ & $\begin{array}{l}0.193 \\
0.129 \\
0.119 \\
0.115\end{array}$ \\
\hline Slight Inversion & $\overline{\mathrm{u}}=3.0$ & $\mathrm{n}=0.33$ & $\begin{array}{r}2 \text { meters } \\
45 \text { meters } \\
75 \text { meters } \\
100 \text { meters }\end{array}$ & $\begin{array}{l}0.292 \\
0.264 \\
0.244 \\
0.232\end{array}$ & $\begin{array}{l}0.073 \\
0.066 \\
0.062 \\
0.058\end{array}$ \\
\hline Strong Inversion & $\bar{u}=2.0$ & $n=0.50$ & $\begin{array}{r}2 \text { meters } \\
45 \text { meters } \\
75 \text { meters } \\
100 \text { meters }\end{array}$ & $\begin{array}{l}0.280 \\
0.264 \\
0.248 \\
0.232\end{array}$ & $\begin{array}{l}0.035 \\
0.033 \\
0.031 \\
0.029\end{array}$ \\
\hline
\end{tabular}

[a] For releases occurring over periods less than 30 minutes, $C_{y}$ should be set equal to $\mathrm{C}_{Z}$.

The rate of decrease of temperature with elevation is usually referred to as its lapse rate; the normal rate of temperature decrease with height is $5.4^{\circ} \mathrm{F} / 1000 \mathrm{ft}$. During a strong lapse, the temperature decreases at a rate greater than $5.4^{\circ} \mathrm{F} / 1000 \mathrm{ft}$. Looping occurs with a strong lapse condition and is characterized by very strong but localized concentrations from the plume occurring momentarily at the ground near the stack. A weak lapse signifies that the rate of temperature decrease with height is between the normal lapse rate and isothermal, where no change of temperature occurs with altitude. Weather conditions of strong and weak lapses, where the air turbulence ranges from high to average, are indicative of good to fair atmospheric dispersion of contaminants, respectively. The surface wind speed is correlated somewhat with the lapse rate, following a fairly regular pattern regardless of the season. At the NRTS, the wind speeds usually attain their maximum during the afternoon when the most intense lapse conditions exist, and then generally decrease gradually to a minimum at the time when inversions reach their greatest intensity - usually in the early morning, just before sunrise ${ }^{[6]}$. 
A condition involving a layer of air with a negative lapse rate is called an inversion. The stratification is stable, and turbulence is at a minimum under these conditions since warm air lies over the denser, relatively cold air. From the standpoint of air pollution, stable surface layers are undesirable because they minimize the rate of dilution of contaminants in the atmosphere. Generally, an inversion forms shortly before sunset and breaks an hour or two after sunrise. The usual duration of an inversion is about one hour longer than the number of hours between sunset and sunrise.

At the NRTS, inversion conditions exist for some length of time during 92 to 98 percent of the days in a year. These inversions last at least 10 hours on 61 percent of the nights. Long periods of inversion ( $>15$ hours) have only a 0.2 percent probability of occurrence during summer months. The probability increases for the spring, fall, and winter seasons with the winter probability being 50 percent. An inversion lasting 20 hours has a five percent probability in the winter but has never been recorded in the summer. When an inversion breaks, there is a period called fumigation. It involves a lapse below and an inversion aloft that might limit the dispersion of a stack effluent and create strong concentrations at ground level. Measurements of this period indicate that it is always of short duration, lasting usually less than one to two hours. The approximate locations of various population centers are given in Table III-3. Radioactivity transport times from the WCF to various sites are given in Table III-4. Values of the diffusion parameter, calculated by Sutton's equation, for both strong lapse and strong inversion weather conditions, are given in Table III-5. The strong lapse and strong inversion together comprise about 60 percent of the prevailing weather at the NRTS. During a period of fumigation, lasting for a short period (one to two hours) each day, the point of maximum concentration would be near the stack (approximately 150 meters). The parameter $(X / Q)$ for this condition is $2.5 \times 10^{-4}$ and decreases with distance $\left(\mathrm{MTR}=1.6 \times 10^{-5}, \mathrm{CFA}=1.1 \times 10^{-5}\right.$, Arco $=2.2 \times 10^{-6}$, and Idaho Falls = $9.9 \times 10^{-7}$ ). For periods of looping, which occur on the average about 15 percent of the time, the entire stack effluent may touch the ground momentarily within approximately 75 meters of the stack. The parameter $(x / Q)$ at this distance is $1.6 \times 10^{-3}$ and decreases rapidly with distance $\left(\mathrm{MTR}=4.2 \times 10^{-6}\right.$ ).

A more comprehensive study of meteorology at the NRTS can be found in Reference 6 , listed in the bibliography at the end of this section. 
TABLE III-3

IOCATION OF POPULATION CENTERS FROM WCF

\begin{tabular}{|c|c|c|c|}
\hline Center & $\begin{array}{l}\text { Approximate } \\
\text { (feet) }\end{array}$ & $\begin{array}{l}\text { Distance } \\
\text { (meters) } \\
\end{array}$ & Approximate Direction \\
\hline$N R F$ & 29,000 & 8,800 & N \\
\hline TAN & 118,000 & 35,000 & NNE \\
\hline Terreton & 150,000 & 45,600 & $\mathrm{NE}$ \\
\hline EBR II & 73,500 & 22,400 & $\mathrm{E}$ \\
\hline Idaho Falls & 225,000 & 68,500 & E \\
\hline Atomic City & 57,000 & 17,300 & $\mathrm{SE}$ \\
\hline CFA & 16,000 & 4,800 & $\mathrm{~S}$ \\
\hline EBR I & 29,000 & 8,800 & SW \\
\hline Arco & 108,000 & 32,800 & WNW \\
\hline MTR & 10,000 & 3,050 & NW \\
\hline
\end{tabular}

TABIE III-4

RADIOACTIVITY TRANSPORT TIME FROM THE WCF TO NRTS SITES

\begin{tabular}{lcc}
\hline & \multicolumn{3}{c}{$\begin{array}{c}\text { Approximate Arrival Time } \\
\text { (minutes) }\end{array}$} \\
\cline { 2 - 3 } Site & Inversion Conditions [a] & Lapse Conditions [b] \\
\cline { 2 - 3 } NRF & 22 & 13 \\
TAN & 91 & 33 \\
EBR II & 56 & 7 \\
CFA & 12 & 13 \\
EBR I & 22 & 4 \\
MTR & 7 & \\
\hline & & \\
[a] 15 mph wind speed assumed for inverse conditions \\
[b] 25 mph wind speed assumed for lapse conditions \\
\hline
\end{tabular}


WCF DOWNWIND METEOROLOGICAL PARAMETERS[a]

\begin{tabular}{|c|c|c|}
\hline Location & $\begin{array}{c}\text { Strong Inversion }[\mathrm{b}] \\
\text { Diffusion Parameter } \\
(\mathrm{x} / \mathrm{Q}) \text { [a] }\end{array}$ & $\begin{array}{c}\text { Strong Lapse [c] } \\
\text { Diffusion Parameter } \\
(x / Q) \text { [d] }\end{array}$ \\
\hline $\begin{array}{l}\text { MTR } \\
\text { CFA } \\
\text { EBR I } \\
\text { NRF } \\
\text { Atomic City } \\
\text { EBR II } \\
\text { Arco } \\
\text { TAN } \\
\text { Terreton } \\
\text { Idaho Falls } \\
\text { Maximum Concentration }\end{array}$ & $\begin{array}{l}3.44 \times 10^{-21} \\
4.76 \times 10^{-13} \\
2.96 \times 10^{-8} \\
2.96 \times 10^{-8} \\
1.27 \times 10^{-6} \\
1.97 \times 10^{-6} \\
2.60 \times 10^{-6} \\
2.61 \times 10^{-6} \\
2.38 \times 10^{-6} \\
1.80 \times 10^{-6} \\
2.62 \times 10^{-6}(22 \mathrm{mi})\end{array}$ & $\begin{array}{l}1.17 \times 10^{-6} \\
4.90 \times 10^{-7} \\
1.49 \times 10^{-7} \\
1.49 \times 10^{-7} \\
5.13 \times 10^{-8} \\
3.38 \times 10^{-8} \\
1.62 \times 10^{-8} \\
1.31 \times 10^{-8} \\
8.76 \times 10^{-9} \\
4.21 \times 10^{-9} \\
9.30 \times 10^{-6}(1 / 3 \mathrm{mi})\end{array}$ \\
\hline \multicolumn{3}{|c|}{$\begin{array}{l}\text { [a] Release height } 75 \text { meters (no momentum or thermal rise considered) } \\
\text { [b] Strong inversion: } \frac{n}{u}=0.50 ; C_{y}=0.240 ; C_{z}=0.03 \\
\text { [c] Strong lapse: } \quad \frac{n}{u}=0.20 ; C_{y}=0.260 ; C_{z}=0.260 \\
\text { [d] Sutton's continuous point source equation }\end{array}$} \\
\hline
\end{tabular}

\section{GEOLOGY}

The Snake River Plain was formed by the eruption and emplacement of great masses of volcanic rock. Successive flows of basalt underlie the entire NRTS but this is mantled by sediments in large areas. The depth of the basalt is unknown, the greatest depth penetrated by drilling being 1500 feet. A complex network of communicating voids, formed by contacts between individual lava flows, exists in the basalt. The principal types of geologic materials that occur at the surface in the NRTS are basalt, alluvial lake beds, slope wash sediments and talus, silicic volcanic rocks, and ancient sedimentary rocks.

Windblown sediments cover much of the basalt and some of the older sediments. The two principal types of windblown material present are loess and wind-drifted sand and silt. The thickness of these sediments varies in depth from a few inches to over 100 feet.

Relatively recent volcanism (within the past 2000 years) has occurred in Craters of the Moon National Monument, 20 miles to the southwest, and at other locations in the Snake River Plain. There is no way of determining 
whether the present period is a cessation of activity or merely a period of quiescence. The inactivity has endured for some hundreds of years at least, longer than is ordinary for areas of active volcanism, and renewed activity seems remote ${ }^{[4]}$.

\section{SEISMOLOGY}

The seismic record of the Snake River Plain is short, with the first earthquake being recorded in 1884. Since this time there have been 21 quakes with sufficient epicenter intensity to be classed in category $V$, ie, of sufficient intensity to be noticed by nearly everyone within the area. The chief epicenters have been more than 100 miles from the NRTS. The strongest recorded quake occurred in August 1959, with an epicenter estimated to be near the northwestern part of Yellowstone Park approximately 100 airline miles from the NRTS. This quake produced shocks of 7.5 to 7.8 on the Richter Scale but did not damage any structures at the NRTS. The earthquake classification of the NRTS is listed as zone 2 (area subject to moderately damaging earthquakes) by the U. S. Coast and Geodetic Survey.

\section{HYDROLOGY}

Very little water enters the NRTS by surface inflow and no water leaves the NRTS by surface outflow except for minor local slope runoff. The named drainage ways into the NRTS are the Big Lost River, Little Lost River, and Birch Creek. Most of the water in these drainages has been diverted for irrigation purposes and only the Big Lost River flows into the NRTS occasionally during the winter months. This flow disappears into a number of sinks within the NRTS area. Flood hazard on the NRTS is relatively small, although a local cloudburst might produce heavy flash runoff. Flooding hazard from the Big Lost River has been largely eliminated by providing an alternate path for the water to a holding basin at the south end of the station. The WCF is located approximately $1 / 2$ mile from the river and is approximately 11 feet above the river bed.

The depth of the ground water table ranges from about 200 feet in the northern NRTS to more than 800 feet in the southeastern part near Twin Buttes. This water occurs in individual aquifers formed by voids between 
basaltic flows. The water table gradient is about five feet per mile toward the southwest. Crude estimates place average velocities in the range of 5 to 30 feet per day. A rough approximation establishes water flow southward to southwestward through the station at a flow of not less than 300 million gallons per day.

The two wells which supply water to the WCF and the ICPP Area are located several hundred yards north of the nearest ICPP facility. Well ICPP-1

is 585 feet deep and has delivered $1500 \mathrm{gpm}$ through a 16-inch casing. Well ICPP-2 is 605 feet deep and has delivered 1940 gpm through a 16-inch casing.

\section{BIBLIOGRAPHY}

1. Site Survey Report, Fort Peck, Montana and Pocatello, Idaho, Sites, prepared for the U. S. Atomic Energy Commission by Smith, Hinchman, and Grylls, Inc., Architects and Engineers (Detroit, Michigan), under contract No. AT-(49-1)-311 (March 1949).

2. G. A. De Marrais, The Climatology of the National Reactor Testing Station, Weather Bureau, Idaho Falls, Idaho, IDO-12003 (June 1958).

3. R. L. Nace, Geography, Geology, and Water Resources of the National Reactor Testing Station, Idaho. Part I. Purpose, History, and Scope of Investigations, U. S. Department of the Interior, Geological Survey, Water Resources Division, Ground Water Branch, (Boise, Idaho) IDO-22033-1USGS (1956).

4. R. L. Nace, et al, Geography, Geology, and Water Resources of the National Reactor Testing Station, Idaho. Part 2. Geography and Geology, U. S. Department of the Interior, Geological Survey, Water Resources Division, Ground Water Branch, (Boise, Idaho), IDO-22033-2-USGS (1956).

5. R. L. Nace, et al, Geography, Geology, and Water Resources of the National Reactor Testing Station, Idaho. Part 3. Hydrology and Water Resources, U. S. Department of the Interior, Geological Survey, Water Resources Division, Ground Water Branch, (Boise, Idaho), IDO-22034-3-USGS (1959).

6. G. A. De Marrais and N. F. Islitzer, Diffusion Climatology of the National Reactor Testing Station, Weather Bureau, Idaho Falls, Idaho, IDO-12015 (April 1960).

7. G. A. De Marrais, The Engineering Climatology of the National Reactor 
Testing Station, Weather Bureau, Idaho Falls, Idaho, IDO-12004 (November 1958).

8. Local Climatological Data, U. S. Department of Commerce Weather Bureau, Idaho Falls, Idaho (1961).

9. Meteorology in Atomic Energy, Weather Bureau, Washington, D. C., AECU3066 (1955). 


\section{FACILITY DESCRIPTION}

\section{WCF AREA LAYOUT}

Figure IV-1 shows the location of the WCF and associated facilities in relation to the other buildings within the confines of the Idaho Chemical Processing Plant complex. The major source of electrical power is the NRTS distribution loop. Steam, air, water, and emergency electrical power are supplied from the ICPP powerhouse, ICPP-606. Fuel oil is supplied from two storage tanks located at ICPP-702.

\section{PROCESS BUILDING, ICPP-633}

\subsection{General}

The process building is a single unit 110 feet long and 70 feet wide. This building houses all components of the WCF system with the exception of two fuel oil storage tanks and the solids storage vault. The building design follows the basic concepts used in existing ICPP processing structures. Since the waste material to be processed is highly radioactive, all waste processing equipment is located below grade level in underground cells. Radiation shielding is provided by the thick reinforced-concrete walls of the "hot" process cells. The thickness of individual walls, floors, and cellings is based on a design assumption that the feed material would be 200-day cooled and would contain 1400 curies/gallon of liquid or 1580 curies/pound of calcined solid material (Section V-6).

Processing equipment and utilities not in radioactive service are housed above grade level in a steel-framed, hollow pumice-block structure lying above the process cells.

Several types of covering are used to protect the interior walls in the WCF from chemical attack and radioactive contamination. The criteria for determining which covering to use were radiation levels, severity of the decontamination methods to be used, and the type of chemicals used in decontamination operations. The coverings used include stainless steel sheet, acidand radiation-resistant paint, asphalt tiles, high-temperature paint, flat wall paint, and hardened cement surfaces. 
The building has six levels: the main floor, the operating corridor floor, and the access corridor floor; plus three intermediate access levels designated as the pipe room level, the adsorber cell level, and hot sump level. These six floors, or levels, provide access to all rooms and cells in the WCF process building.

\subsection{Main Floor Level}

The main floor level lies four feet above grade level at a reference elevation of $0^{t}-0^{\prime \prime}$ (Figures IV-2 and IV -6 ) and provides access to the following rooms: Health and Safety field office, switch gear room, decontamination room, locker room, heating and ventilating room, the $\mathrm{NaK}$ equipment room (furnace room), and the filter removal room.

These rooms overlay the various "hot" cells. Shielding is provided between the rooms and the lower cells by concretefloors of sufficient thickness to reduce the radiation to insignificant levels. The walls and room dividers are of structural steel and pumice-block construction. The roof is a "built-up" aggregate-type cover.

2.21 Health and Safety Field Office. This room is $16-1 / 2$ feet wide, $21-1 / 2$ feet long, and 11-1/2 feet high. It is located directly over the off-gas blower cell and is shielded from it by a three-foot-thick concrete floor (Figures IV -2 and IV -7 ).

In addition to providing work space for the Health Physics activity, this room also houses an off-gas sampling station in a shielded cubicle, an off-gas flow recorder, and an off-gas temperature recorder.

Heating and ventilation air is supplied through a branch duct from the main heating and ventilation duct system. A thermostatic controller in this room regulates the air temperature in the branch duct.

The floor is covered with a grade $\mathrm{C}$ asphalt tile. The walls and ceiling are covered with two coats of flat wall paint.

2.22 Switch Gear Room. The switch gear room is a small room 6 feet wide, 21-1/2 feet long, and 11-1/2 feet high, located adjacent to the Health and Safety field office (Figures IV-2 and IV-7). All the calciner switch gear, with the exception of the switch gear for WC-251A and WC-251B off-gas blowers, are located in this room.

Heating and ventilation air is furnished through a branch duct from the Health and Safety field office ventilation ducting.

A three-foot-thick concrete floor separates this room from the off-gas blower cell below. The floor is bare concrete and the walls are covered with two 
coats of flat wall paint.

2.23 Locker Room. This room is 15 feet wide, 22 feet long, and 11-1/2 feet high and is located adjacent to the north stairwell "A" (Figure IV-2). These facilities provide the locker and sanitary requirements for building personnel and also can serve as a temporary personnel decontamination room, should the need arise. Space is provided for a hand and foot counter.

Heating air is supplied through a branch duct from the main Health and Safety field office ventilation ducting. A ceiling fan exhausts the air to the outside.

Since the room is not adjacent to any "hot" process cells, no radiation shielding is necessary. The floors are covered with grade $\mathrm{C}$ asphalt tile, and the walls and ceiling are finished with two coats of flat wall paint.

2.24 Decontamination Room. The decontamination room occupies the south half of the main floor level and is oriented directly over the operating corridor (Figures IV-2 and IV-9). The room is $26-1 / 2$ feet wide, $43-3 / 4$ feet long, and 27 feet high.

The calciner start-up hopper (WC-106), two decontamination solution tanks (WC-117 and WC-118), a compressed air surge tank (WC-120), an adsorber-regeneration air-heater (WC-351), steam and decontamination manifolds, two decontamination-solution transfer-pumps (WC-217 and WC-218), and air manifolds for operations involving the silica gel adsorbers are housed in this room.

Heat to the room is supplied by four steam space heaters; a twospeed roof exhaust fan provides ventilation.

A stainless steel drip pan, 12 feet wide $\mathrm{x} 18-1 / 2$ feet long $\mathrm{x} 4$ inches high, covers the floor area under the chemical makeup area. The rest of the floor area is exposed concrete. The floor drains in this room drain to the hot sump tank (WC-119) through a 40-inch seal loop.

The east floor, overlaying the calciner and off-gas cells, is of four-footthick reinforced concrete to provide radiation shielding from the cells below. The floor over the operating corridor is of nine-inch-thick reinforced concrete.

The walls, ceiling, and exposed carbon steel surfaces are coated with three coats of acid-resistant paint.

2.25 Heating and Ventilation Room. This room houses the main building heating and ventilation system. Outside air enters the supply unit and is filtered, heated, washed, and reheated. The conditioned air is then distributed to three areas: 
the main floor, the operating corridor, and the access corridor. From these areas, the air flows to the process cells and from these cells through cell exhaust ducts to the cell exhaust blower (WC-G-3302) and on to the ICPP stack.

The heating and ventilation room is 15 feet wide, 26-1/2 feet long, and 27 feet high and is located adjacent to the north end of the decontamination room (Figures IV-2 and IV-6).

The east part of the room overlays the calciner cell and is shielded from it by a four-foot-thick concrete floor. The floor is uncovered and the walls are finished with two coats of flat wall paint.

2.26 NaK Equipment Room (Furnace Room). The NaK equipment room is located just above grade level, but $3-1 / 2$ feet lower than the main floor level. Because of this elevation difference, the floor constitutes a pit lower than any room or cell entry in the upper part of the WCF building. The entrance to the NaK pipe chase, which extends from the NaK room floor to the calciner cell, is surrounded by a 5-1/2-inch-thick concrete curbing. The low floor level plus the concrete curbing prevents $\mathrm{NaK}$ from entering any other room or cell in the building should a leak occur in this room. Further isolation of this room is provided in that the room is actually a separate building connected to the main level by a hallway, sealed by two doors (Figures IV-2 and IV-6).

The room is 20 feet wide, 21-1/2 feet long, and 30 feet high, and houses the NaK furnace (WC-304), two NaK expansion tanks (WC-103 and WC-103-A), two fluidizing air blowers (WC-250A and WC-250B), an electromagnetic pump (WC-204), a NaK plugging indicator (WC-903), a NaK cold trap (WC-904), and the helium manifold system.

Ventilation and combustion air enters the room through three adjustable louvered windows. Hot room air is exhausted through the roof by means of an $8700-c$ fm fan. Heat is supplied by two steam space heater units.

Radiation shielding is not provided since this room is separate from the main process areas.

The floor is uncovered concrete and the walls and equipment are painted with three coats of heat-resistant paint.

2.27 Filter Removal Room. This room is located directly over the three off-gas filter cells. It is provided with a 20-ton bridge crane for lifting the offgas filter-cell hatch covers, removing the spent filter units in a shielding cask, and installing new filter units. The crane extends 20 feet beyond the building so the shielding cask containing the spent filter elements can be loaded on a 
truck for removal to the NRTS burial ground. A stainless steel decontamination pan is provided in the room so the cask may be washed prior to loading on the truck. The decontamination pan drains to the hot sump tank (WC-119) through a valved manifold system.

The room is 20 feet wide, 21-1/2 feet long, and 17-1/2 feet high. Entrance to the room is made through an exterior roll-up door on the west side of the room (Figures IV-2 and IV-8).

The filter-cell hatch covers are 3-3/4 feet thick and provide radiation shields for the operating area above the filter cells.

The entire room, with the exception of the decontamination pan, is painted with three coats of acid- and radiation-resistant paint to facilitate decontamination.

Heat is supplied by one steam space heater.

\subsection{Operating Corridor Level}

The operating corridor (Figures IV-3 and IV-8) lies over the access corridor, and the floor is 12 feet, 3-1/4 inches below the main floor level (elevation= $\left.0^{\prime}-0^{\prime \prime}\right)$. This corridor is oriented adjacent to and between process cells on the east and west sides. The operating corridor is 15 feet wide, 77-1/4 feet long, and 11 feet high. A 9-1/2- x 8-foot glass-partitioned office is provided at the south end of the corridor. The main instrument control panel, 28 feet long $x 2$ feet, 2 inches wide, is centered in the corridor. Much of the service piping for the cells is located on both sides of the corridor, conveniently combining the piping and controls in a central area. Two floor drains in the corridor are connected to the hot sump tank (WC-110) through a 40-inch water loop seal.

The operating corridor provides access to the off-gas blower cell, the transport air jet cell, the sample room, the filter removal access corridor, and the pipe room and vent air duct. The off-gas filter cells and cell ventilation blower pit are located at the operating corridor level, but access can be gained only through exterior building entryways and hatches.

Thick reinforced-concrete walls on each side and on the north end of the operating corridor will reduce radiation levels to less than $1.0 \mathrm{mr} / \mathrm{hr}$ in the corridor.

The operating corridor floor is covered with grade $C$ asphalt tile; the walls, ceiling, and equipment are painted with three coats of acid-and radiationresistant paint. 
2.31 Sample Room. The sample room is 9 feet wide, 24-1/2 feet long, and 11 feet high, and is located between the transport air jet cell and the calciner cell, and above the waste hold tank cell (Figures IV-3 and IV-6).

This room houses one sample blister (which contains five liquid-sample stations and one solid-sample station), a sample elevator for transporting lead sample "pigs" from the sample room level to ground level, and a stainless steel "hot" sink. Three electromagnetic flowmeters, which control the feed rate to the three calciner feed nozzles, are located in a shielded cubicle in the sample room.

The floor drain and the sample blister drain discharge to the hot sump tank through a 40-inch water seal loop.

This room is shielded from radiation from the adjacent "hot" cells by reinforced concrete walls of the following thicknesses: transport air jet cell, 4 feet; calciner cell, 4-1/2 feet; waste hold tank cell, 4-1/2 feet. The outer wall, which is below grade level, is two feet thick.

Entry to this room is normally made through a door from the operating corridor. Two concrete hatches are located in the ceiling directly above identical hatches in the sample room floor. These provide access for heavy objects from the outside ground level to this cell or to the waste hold cell below.

The floor is covered with grade $C$ asphalt tile. The walls, ceiling, and equipment are covered with three coats of acid- and radiation-resistant paint.

2.32 Transport Air Jet Cell. This cell is located adjacent to the sample room at an elevation 2 feet, 7 inches below the operating corridor level. This cell originally was designed to house two transport air blowers (WC-202A and (WC-202B). The cell now contains piping for returning transport air to the calciner vessel, and the transport air jet (WC-521), which will be used to provide additional motivating force for transporting the calciner bed to solids storage whenever the bed is to be completely removed from the calciner vessel.

The cell is 12 feet wide, 21 feet long, and 10-1/2 feet high. Access to the cell is made from the north end of the operating corridor through an " $L$ "-shaped labyrinth. Access also may be gained through a removable concrete hatch 3 feet wide $\times$ 4-1/2 feet long $\times 4-1 / 2$ feet thick in the cell roof (Figures IV-3 and IV-6).

The cell ventilation system pulls air from the operating corridor through the cell to a 24-inch exhaust duct in the cell wall. Air enters the cell from the operating corridor through louvers in the cell door. 
Access and working areas around this cell are shielded with reinforced concrete as follows: roof, 4 feet; wall common to sample room, 4 feet; "L"shaped laby rinth, 2 and $2-1 / 4$ feet. The outer walls and the floor are two feet thick.

The cell floor is covered with a stainless steel liner which extends up the walls for six inches. The ceiling and the remaining part of the walls are covered with three coats of acid-and radiation-resistant paint. The floor drain discharges to the hot sump tank (WC-119) through a manual valve operated from the access corridor.

2.33 Off-Gas Blower Cell. This room is 24 feet wide, 26 feet long, and 8-3/4 feet high and is located north of the filter removal corridor (Figures IV-3 and IV-7). This room contains two off-gas blowers (WC-251-A and WC-251-B), the equipment vent blower (WC-252), the equipment vent filter (WC-F-2722), and the equipment vent heater (WC-356).

Entry to the cell is made from the north end of the operating corridor through a labyrinth and a door. Two concrete ceiling hatches, one 4-1/2 feet wide $\times 8$ feet long $\times 3$ feet thick and one $3 \times 3 \times 3$ feet, are provided for equipment removal and filter changing. Radiation shielding between this cell and other operating areas is provided by concrete walls of the following thicknesses: roof, 3 feet; labyrinth, 2-3/4 feet; filter removal corridor, 2-1/2 feet. The outer walls and the floor are two feet thick.

Two openings are provided from this cell to the cell exhaust duct system. A louvered door permits air to enter the cell from the operation corridor.

To facilitate decontamination, the cell floor is covered with a stainless steel liner extending six inches up each wall. The walls and ceiling are painted with three coats of acid-and radiation-resistant paint. The floor drain discharges to the hot sump tank (WC-119) through a manually operated valve.

2.34 Filter Removal Corridor. The filter removal corridor is $3-1 / 2$ feet wide, 24 feet long, and 9 feet high. It is located adjacent to the three off-gas filter cells (Figures IV-3 and IV-7). Access to this room is made from the north end of the operating corridor.

This room provides a shielded observation and control point for remotely removing and replacing the off-gas filter units. The room has three lead-glass windows (18 inches square on the hot side, 12 inches square on the cold side, and 40 inches thick), each providing a viewing port for one cell. A control console for the 20-ton crane located in the filter removal room, extension 
handles for coupling or uncoupling the filter boxes, and handles for opening the valves on the inlet and outlet lines on the filter housings also are located in this corridor.

This room is shielded from the final filter cells by a 3-1/2-foot-thick concrete wall and from the off-gas blower cell by a 2-1/2-foot-thick concrete wall. The floor, which is over the pipe room and ventilation air duct, and the outer wall are two feet thick.

Asphalt tile covers the floor. The walls and ceiling are painted with three coats of acid- and radiation-resistant paint.

2.35 Off-Gas Filter Cells. Each of the three off-gas filter cells is $9-2 / 3$ feet wide, $18-1 / 2$ feet long, and 8-1/2 feet high and one filter unit is located in each cell (Figures IV-3 and IV-8). Access to these cells is made from the filter removal room. Each cell is covered by a concrete hatch cover 6 feet wide, 11 feet long, and 3-3/4 feet thick. These can be removed by the 20 -ton overhead bridge crane.

During operation, the three cells are heated to $\approx 60-70^{\circ} \mathrm{C}$ so that condensation will not occur in the piping orfilter units. Air from the access corridor is pulled through a steam space heater into the pipe room and then through 3-inch ventilation ducts into each cell. Air from the cells is exhausted to the 18-inch cell ventilation duct system on the west side of the WCF building, thus maintaining a positive air flow from the access corridor through the cells and out the ICPP stack.

These cells are shielded from the operating areas by concrete walls and ceilings of the following thicknesses: filter removal room, 3-3/4 feet; filter removal corridor, 3-1/4 feet; operating corridor, 7 feet. The divider walls between filter cells are constructed of one-foot-thick steel plate. Other wall and floor thicknesses are: north adsorber cell, 2-1/2 feet; pipe room and ventilation air duct, 2 feet; and outer wall, 2 feet. The cell floors and walls are completely lined with stainless steel sheet. The cell ceilings (bottom of cell hatch covers) are coated with three layers of acid-and radiation-resistant paint. The floor drain in each cell discharges to the hot sump tank (WC-119) through a manually operated valve located in the access corridor.

2.36 Blower Pit. The blower pit is located at the north end of the WCF process building (Figures IV -3 and IV -7). This pit is $7-1 / 4$ feet wide, 11-1/2 feet long, and 8-1/2 feet high, and houses the main cell exhaust blower (WC-G3302). This blower is connected to the process cells by a buried tile ducting system lying outside the building. A positiveflow of air from the non-radioactive 
corridors to the "hot" cells, which are individually connected to the duct, and thence to the ICPP stack is maintained by this cell exhaust system.

A two-foot-thick concrete wall provides radiation shielding between this pit and the off-gas blower cell. The outer walls and floor are six-inch-thick concrete for structural purposes only. A 3/8-inch steel plate covers the pit for protection from the weather. The concrete surfaces are uncovered.

\subsection{Access Corridor Level}

The access corridor is located directly below the operating corridor (Figures IV-5 and IV-10). This corridor is 15 feet wide, 59 feet long, and 21 feet high, and is oriented between hot process cells on either side. This corridor provides direct access to the calciner cell and the off-gas cell through a labyrinth at each cell entry. The adsorber manifold cell can be entered through a labyrinth located between the operating and access corridor levels. Special access openings to the north and south adsorber cells (from the adsorber manifold cell), the waste hold tank cell (from the access corridor), and the filter piping tunnel were left open for the cold test program; these will be sealed prior to "hot" processing. Entry to the hot sump cell, located below the access corridor, is made through a hatch, $2-1 / 4$ feet square $x 4$ feet thick, in the floor at the north end of the access corridor.

Equipment housed in this corridor includes the NaK system dump valve, two NaK tanks (WC-104A and WC-104B), extension handles for manual valves in the drain lines to the hot sump (WC-119), a condensate collection tank, and two condensate pumps.

The concrete walls and labyrinth, which furnish radiation shielding between the adjacent cells and the access corridor, are described under the individual cell descriptions. Three pipe tunnels, fabricated from surplus 16-inch Navy gun barrels, provide radiation shielding for process lines which cross the access corridor between the off-gas scrubbing cell and the adsorber manifold cell.

Grade $\mathrm{C}$ asphalt tile covers the access corridorfloor. All walls and surfaces have been covered with three coats of acid-and radiation-resistant paint. Two floor drains discharge to the hot sump tank (WC-119) through a manual valve.

2.41 Waste Hold Tank Cell. The waste hold tank cell is located on the east side of the access corridor directly below the sample room (Figures IV -5 and IV -6). This cell is 12 feet wide, 21 feet long, and 17-1/2 feet high, and houses the two waste hold tanks (WC-100 and WC-101). A sump 3 feet wide, 4 feet long, and 5-1/2 feet deep, containing the two feed air lifts (WC-500-4 and 
WC-501-4) is located in the cell floor.

Access to this cell is provided by two ceiling hatches 2 feet square $\times 5-1 / 2$ feet thick located directly below the two access hatches in the sample room ceiling. A manway provided at the access corridor level will be sealed before "hot" operations begin.

The following thicknesses of concrete radiation shielding are provided between the cell and the adjacent areas: "A" stairwell and access corridor, 4-1/2 feet; calciner cell, 4-1/2 feet; sample room, 4-1/2 feet. The outer walls and cell floor are two feet thick.

A stainless steel liner covers the floor and extends seven inches up the wall. The walls and ceiling are covered with three coats of acid-and radiation-resistant paint. The air lift pit drains to the hot sump tank (WC-119) through a manual valve operated from the access corridor.

2.42 Calciner Cell. The calciner cell is located adjacent to the waste hold tank cell (Figures IV -5 and IV -6 ) and contains the following major equipment items: the calciner vessel (WC-102), the NaK heat exchanger (WC-302), the calciner cyclone (WC-131), the feed metering pot (WC-105), and the equipment vent condenser (WC-130). The cell is 15-1/4 feet wide, 21 feet long, and 29-1/2 feet high.

Direct maintenance of equipment located in this cell is facilitated by direct entry via an "L"-shaped labyrinth at the access corridor level and a hatch 7 feet wide $\times 10$ feet long $\times 4-1 / 2$ feet thick located in the cell ceiling.

Adjacent areas are shielded from the high-radiation sources in this cell by concrete walls and ceilings of the following thicknesses: access corridor, 4-1/2 feet; labyrinth, $3-1 / 2$ feet and 4 feet; operating corridor, $4-1 / 2$ feet; sample room, 4-1/2 feet; waste hold tank cell, 3-1/2 feet; off-gas cell, 3-1/4 feet; and the ceiling, 4-1/2 feet. The outer wall and the floor are two-foot-thick concrete.

Air is exhausted from the cell through an opening to the 24-inch cell exhaust duct on the east side of the WCF building. Air flows from the access corridor through door louvers into the cell.

The cell floor and walls are completely lined with stainless steel sheet. The ceiling is covered with three coats of acid-and radiation-resistant paint. The floor drain discharges to the hot sump tank through a manual valve. 2.43 Off-Gas Cell. This cell houses all equipment in the off-gas quenching and scrubbing systems plus a hold tank for solutions used in regenerating the 
silica gel adsorbers. The main equipment items in the cell are the quench tower (WC-107), the scrubbing solution surge tank (WC-108), two scrubbing solution pumps (WC-208A and WC-208B), the regeneration solution surge tank (WC-114), and off-gas heater (WC-305), a scrubbing solution cooler (WC-307), the venturi scrubber (WC-907), and two liquid-entrainment separators (WC-908 and WC-910).

The cell is located on the east side of the process building adjacent to the calciner cell (Figures IV -5 and IV-6). It is 21 feet wide, 35 feet long, and 30 feet high. A cell equipment-removal hatch (8-1/2 feet wide $\times 11$ feet long $\times 4$ feet thick) in the ceiling, and an entryway shielded by an "L"-shaped labyrinth at the access corridor level permit access for direct maintenance on the pumps and valves.

Air is exhausted from the cell through two openings to the 18-inch cell exhaust duct on the east side of the WCF process building. Air from the access corridor flows into the cell through louvers in the cell door.

Concrete walls and ceilings of the following thicknesses provide radiation shielding between the cell and the following adjacent areas: access corridor and "B" stairwell, 4 feet; operating corridor, 4 feet; calciner cell, 3-1/4 feet; ceiling, 4 feet. The outer walls and the cell floor are two-foot-thick concrete.

The cell floor is lined with stainless steel sheeting which extends seven inches up the wall. The walls and ceiling are painted with three coats of acidand radiation-resistant paint. A cell floor drain discharges to the hot sump tank (WC-119) through a manual valve.

2.44 Hot Sump Tank Cell. This cell is located below the north end of the access corridor (Figures IV -6 and IV -8). The cell is $9-1 / 2$ feet wide, 25 feet long, and 20-3/4 feet high, and contains the hot sump tank (WC-119). All floor and process drains discharge to this tank. Solution in the tank can be jetted either to the liquid-waste evaporation system at ICPP-604, or to the waste hold tanks (WC-100 or WC-101) for recycle to the process. A floor sump and sump jet are supplied to return liquid from the floor of this cell to the hot sump tank. This cell is normally isolated, but access can be made by removing a 2-1/4foot-square $x$ 4-foot-thick hatch cover in the access corridor floor. A fourfoot-thick concrete ceiling provides radiation shielding between the cell and the access corridor. The walls and floor are two-foot-thick structural concrete. The floor is lined with stainless steel sheeting which extends six inches up the walls. The walls and ceiling are protected with three coats of acid- and radiation-resistant paint. 
2.45 Adsorber Manifold Cell. This cell is located on the west side of the process building between the north and south ruthenium adsorber cells (Figures IV -4 and IV -7). The cell houses all the valves on lines entering and leaving the adsorber vessels, the off-gas reheater (WC-354), and the off-gas knock-out pot (WC-133).

The cell is 17 feet wide, 22-1/3 feet long, and 20-3/4 feet high. Entry is provided at the $-24-$ feet, 6-1/2-inch level through a shielded concrete labyrinth.

This cell is connected to the 18 -inch cell exhaust duct system indirectly. The adsorber cells on both sides of the manifold cell are connected to the 18-inch cell ventilation duct. One opening is provided to each ruthenium adsorber cell from the manifold cell. Heated air from a steam space heater enters the adsorber manifold cell through a 12-inch duct from the access corridor. During operation, this cell and the adsorber cells are heated to $\approx 60-70^{\circ} \mathrm{C}$ to prevent condensation in the vessels and piping.

Concrete shielding walls of the following thicknesses are provided to shield the adjacent areas: access corridor and " $B$ " stairwell, 3-3/4 feet; operating corridor, 3-3/4 feet; north and south adsorber cells, 3-1/4 feet; ceiling, 3-3/4 feet; labyrinth, 3 and $2-1 / 2$ feet. The outer wall and the floor are two-foot-thick concrete.

The cell floor and walls are protected as follows: floor and lower seven inches of the walls, stainless steel sheeting; walls and ceiling, three coats of acid- and radiation-resistant paint. The cell floor drain discharges to the hot sump tank (WC-119) through a manual valve.

2.46 Adsorber Cells. A ruthenium adsorber cell is located on each side of the adsorber manifold cell(Figures IV-4 and IV-7). Each cell is 11 feet wide, 21 feet long, and 20-3/4 feet high and houses two adsorber vessels. The north adsorber cell contains adsorbers WC-110 and WC-111. The south cell contains adsorbers WC-112 and WC-113. Two-feet-square x 2-1/4-feet-thick concrete manway openings provided between the adsorber manifold cell and each adsorber cell for "cold" testing will be sealed prior to "hot" operation. Access to these cells can then be made only by removing an 11-foot-wide x 12-foot-long x 4-1/2-foot-thick concrete access hatch above each adsorber.

Radiation shielding is provided by the following thicknesses of concrete between these cells and the surrounding areas: adsorber manifold cell, 3-1/4 feet; access corridor, 5 feet; operating corridor, 5 feet; final filter cell, 3-1/4 feet; roof top, 4-1/2 feet. The outer walls and the floors are two-foot-thick concrete. 
A stainless steel liner covers the floor and extends seven inches up the walls. The walls and ceiling are covered with three coats of acid-and radiationresistant paint. The cell floor drain in each cell discharges to the hot sump tank (WC-119) through a manual valve.

2.47 Filter Piping Tunnel. This room is located directly below the off-gas filter cells (Figures IV -4 and IV-8). The room is $6-1 / 2$ feet wide, $23-1 / 2$ feet long, and 3-3/4 feet high and is accessible only through a 2-foot-square $\times 2-1 / 2$ foot-thick hatchway located in the filter removal corridor. No equipment is housed in the tunnel. Heated airfrom the vent duct heater enters this chamber and is distributed to each of the off-gas filter cells and then exhausted to the exhaust duct system.

Shielding walls and ceilings of the following thicknesses are provided: access corridor, 2-1/2 feet; final filter cell and filter removal corridor, 2 feet; north adsorber cell, 2-1/3 feet. The outer wall is two-foot-thick concrete and the floor is one-foot-thick concrete. The concrete surfaces are finished with three coats of acid- and radiation-resistant paint. No drains are provided in the room.

\section{SOLIDS STORAGE FACILITY}

The WCF solids storage area is located 75 to 100 feet east of the main WCF process building (ICPP-633). The facilities in this area are the solids storage vault (ICPP-729), the solids cooling blower building (ICPP-639), and the solids cooling air stack (ICPP-732). The overall layout of the solids storage area is shown in Figure IV -1 .

\subsection{Solids Storage Vault (ICPP-729)}

The solids storage vault is a reinforced concrete structure which houses four 3-bin units for storage of solids, the solids separation cyclone and distribution piping to the bins, and the solids off-gas cleanup equipment. The structure is divided into two main sections, a lower section which houses the storage units and an upper section which houses the balance of the equipment (Figures IV-11, IV-12, and IV-13).

The lower section is $25-1 / 2$ feet square $x$ $41-1 / 3$ feet high (inside dimensions). The walls are $2-1 / 2$ feet thick, the bottom is 2 feet thick, and the ceiling (partition between upper and lower sections) is $1-3 / 4$ feet thick. The top of the 
ceiling slab is approximately at ground level.

The upper section, which houses the off-gas equipment, is $16-3 / 4$ feet long $x 10$ feet wide $x 8$ feet high (inside dimensions). The walls are 1-3/4 feet thick; the bottom (partition between upper and lower sections) is 1-3/4 feet thick, and the ceiling is $1-3 / 4$ feet thick.

Cooling air inlet ducts run outside of the north and south walls of the upper level of the vault. The ducts then continue down inside the walls of the lower level of the vault to the vault floor. Each duct (a 24-inch-diameter spiralwound carbon steel pipe) then connects to an 18-inch-square distribution duct on the vault floor which distributes cooling air to the bottom of the concentric solids storage bins. The air rises through annuli between the bin sections.

Located directly beneath a central solids distribution stand pipe, in a sump in the vault floor, is a steam syphon jet. This unit is provided for removing liquid matter that enters the vault from wall seepage or the condensing water vapor. The jet has a one-inch suction line, a one-inch discharge line, and a one-inch steam inlet line. It is rated for $10 \mathrm{gpm}$ at $100^{\circ} \mathrm{F}$ using $110-\mathrm{psig}$ steam. The jet is constructed of type 304L stainless steel.

The sump is equipped with a liquid-level-indicating alarm instrument to indicate the presence of condensate in the sump. This instrument is located on the panel board in the solids storage control room.

\subsection{Solids Cooling Blower Building (ICPP-639)}

The main solids cooling blower building is 12 feet, 10 inches wide $\mathrm{x} 13$ feet, 2 inches long $\times 9$ feet high. This room houses the cooling air blower and the instrument panel for solids storage instrumentation. An addition, 5-1/2 feet wide $\times 6-1 / 2$ feet long $\times 9$ feet high, was constructed on the north side of the building to house a 40-point rotary-switch temperature indicator. The control room is located directly above the process equipment level of the storage vault.

The wall and roof framing are of structural steel. The wall and roof covering consists of corrugated asbestos cement sheathing. Internal and external wall angles are flashed or covered to provide watertight joints. The floor slab of the control room is constructed of reinforced concrete $1-3 / 4$ feet thick. 
The local control panel is 6-1/2 feet high $\times 3$ feet wide; has a 50-pound air supply manifold for supplying air to the instruments, purge rotameters, etc; and holds pressure indicators, pressure alarms, pressure difference indicators, liquid-level indicator alarms, and purge rotameters.

Heating of the solids-storage control room is provided by two 3-kw Electromode Model AN-30-A unit heaters with a heat capacity of 10,245 Btu/hr/heater.

Louvers in the door permit entrance of air required for ventilation.

\section{UTILITIES}

\subsection{Electrical System}

Electrical power for the WCF can be supplied from either the NRTS power system or the ICPP emergency power generator located in the emergency power building (ICPP-644). Normally, electrical power is taken from the NRTS power system. This power enters the area at the ICPP substation building (ICPP613). From there, 2400-volt power is supplied by underground lines to a substation adjacent to the WCF process building (ICPP-633). The distribution network is shown in Figure IV-14.

The normal power feeder connects to a 2400 -volt automatic transfer switch in the ICPP-633 substation. The load side of the transfer switch is connected to a 2400-volt motor control center supplying the two off-gas blowers and a 300-kva transformer. A 480-volt motor control center located inside building ICPP-633 is supplied from the 300-kva transformer. The 480-volt motor control center is split for normal and emergency service, the two sections being connected through a contactor. This contactor is held closed when the system is on normal service and will open automatically when a transfer is made to emergency power, dropping off services supplied with normal power only. All essential motors, emergency lighting, instrumentation, and alarms are connected to the emergency section of the motor control center.

A 2400-volt emergency-power feeder originates at the emergency power building (ICPP-644) and runs underground to the substation adjacent to building ICPP-633. The emergency feeder connects to a 2400-volt automatic transfer switch which, on loss of normal service, transfers automatically to the emergency service line and also starts the emergency generator located in building ICPP644. Upon restoration of normal power, the transfer switch must be returned to 
normal service manually by a remote pushbutton located on the main instrument board in the WCF operating corridor. After the return to normal power, motors connected only to normal power must be restarted manually.

Electrical power to the emergency power bus is obtained from a diese1driven generator. The diesel unit is an in-line, cylinder-type engine manufactured by Fairbanks-Morse Motor Co. This unit is rated for 2400-volt, 3-phase, 60 -cycle operation. The generator is capable of delivering 1200 to $1250 \mathrm{kw}$ continuously at 80 percent power factor at an altitude of 4900 feet. In the event of a commercial power failure, the load will be transferred automatically to emergency power in approximately 11 seconds. The emergency-power system is tested once a week.

\subsection{Raw Water System}

All water used at the WCF is supplied from the ICPP area raw water system. A six-inch raw water line for the WCF originates from the underground fire water loop at fire hydrant 5 near building ICPP-702. This six-inch line runs underground eastward some 250 to 260 feet from the hydrant at which point a three-inch line tees off and runs south to the calciner building (ICPP633). The six-inch line then turns to the north for seven feet before continuing another 80 to 90 feet to where it reduces to a 1-1/2-inch line which continues on to the solids storage blower building (ICPP-639). A fire hydrant located northeast of building ICPP-633 connects to the six-inch water line before it reduces to $1-1 / 2$ inches. A block valve is located in the water line at a point about 28-1/2 feet east of ICPP-702. The valve is operated by a handwheel extension from the valve located below the ground. This valve is always kept open during operation of the calciner.

The three-inch raw water line which supplies ICPP-633 enters the building at the north wall of the NaK pipe tunnel and runs through the pipe tunnel to the access corridor. The line passes through the ceiling of the access corridor to the operating corridor where it connects to a pressure-control valve. From the control valve the water line drops through the floor back to the access corridor where it splits for distribution to various parts of the building. Figure IV-15 shows a schematic layout of the water supply system and the main distribution headers.

Normally, water is supplied to the fire water loop by one or more of three parallel-connected water pumps located in the ICPP service building (ICPP606). Each pump has a rated capacity of $1000 \mathrm{gpm}$ at $90 \mathrm{psig}$. In addition, two fire pumps (one for normal service and one for emergency service) are avail- 
able for use if needed. Each of these pumps has a capacity of $2000 \mathrm{gpm}$ at 125 psig. Pressure on the fire water loop is normally maintained at 80 to 90 psig. This pressure could be boosted during tests or for a fire.

\subsection{Steam System}

Steam is required for ejectors, process heating units, decontamination of process equipment, and for space heating throughout the WCF. The average steam usage is about $6800 \mathrm{lbs} / \mathrm{hr}$ and the maximum usage during cold weather is about $10,900 \mathrm{lb} / \mathrm{hr}$. The line which supplies steam to the WCF was designed for a capacity of $40,000 \mathrm{lb} / \mathrm{hr}$.

Steam for the WCF is supplied from independent facilities located in the ICPP service building (ICPP-606). The facilities consist of four existing boilers with a combined rating of $112,500 \mathrm{lb} / \mathrm{hr}$ steam at $250 \mathrm{psig}$. Individual units are operated at about 145 psig. Normally, two boilers will supply sufficient steam for the ICPP area.

An eight-inch steam line for the WCF and other plant facilities originates in the service building (ICPP-606) from an existing 10-inch steam header. The main block valve for the WCF and the other facilities is located in this 10inch line on the north side of building ICPP-606. The eight-inch line runs through the service building some 40 to 50 feet to a point on the south side of the building where it drops underground. It then runs eastward some 100 to 150 feet at which point a four-inch line tees off and continues eastward to supply existing equipment in ICPP-619,-628,-634, and-635. A block valve is located in the four-inch line at a point near the control house (ICPP-619). The eightinch line turns southward at the tee and runs approximately 10 feet to a valve box, located near the laboratory building ramp of building ICPP-602. A block valve at this point permits steam shutoff to the calciner without disrupting the supply to other areas. The eight-inch line continues south and then turns east to a point opposite building ICPP-604 where it is reduced to a sixinch line that continues on to the calciner building (ICPP-633). The steam line is buried approximately six-feet below ground, and is covered with six inches of Gilsulate insulation.

The calciner steam line enters building ICPP-633 at the north wall of the NaK pipe tunnel and continues to the access corridor where a chain-operated block valve is located. Downstream of the block valve the line splits to distribute steam to various parts of the building as shown in Figure IV-16. 
There are several pressure-reducing stations on the steam line throughout the calciner building where lower pressure steam is required.

\subsection{Compressed Air System}

Air at 100 psig is supplied to the WCF from existing facilities at the ICPP service building (ICPP-606). This system furnishes clean, dry compressed air for the utility, process, and instrument needs. Normal WCF requirements range from 400 to $600 \mathrm{scfm}$.

The facilities at the service building (ICPP-606) for supplying compressed air to the entire ICPP a rea consists of two compressors, each rate at $950 \mathrm{scfm}$ at 125 psig, and an air dryer with a rated capacity of $1000 \mathrm{scfm}$ at an exit dew point of $-20^{\circ} \mathrm{F}$. Both of the air compressors are connected to emergency power but must be manually switched to emergency power when a power failure occurs.

A four-inch line, originating from air receiver D-609 in building ICPP-606, carries compressed air to the WCF. The main block valve in the air supply line is located in the service building.

The compressed air piping is buried approximately six feet below ground and is covered with six inches of Gilsulate insulation. This line follows the same route as the steam line from building ICPP-606 to WCF.

Figure IV-17 shows the main air distribution network in the WCF. The supply line enters the calciner building through the NaK pipe tunnel and continues into the access corridor. The air line is split with a portion of the air distributed as 100-psig plant air to serve various process requirements. Plant air (100 psig) is reduced to 5 psig at the off-gas filter cells for use in clearing contaminated dust from the off-gas piping, the filter housing, and block valves, prior to filter replacement. The other portion is sent through an instrument air receiver (WC-120) located in the decontamination room. Air downstream of the instrument air receiver is reduced to $50 \mathrm{psig}$ for high-pressure instrument air. A portion of the 50-psig instrument air is in turn reduced to $20 \mathrm{psig}$ for low-pressure instrument air used for pneumatic instruments on the control boards.

\subsection{Service Waste System}

Condensate, from the heating and ventilating system and steam traps located in the access corridor, drains to a condensate collection tank (E-3310) located under the stairwell at the southeast corner of the access corridor in building ICPP-633. The condensate collection receiver consists of a 40-gallon tank, 20 inches ID x 30 inches long, mounted on a common base with two centrifugal pumps. Each pump has a capacity of $30 \mathrm{gpm}$ at a discharge pressure of 30 to 35 
psig and is driven by a 440-volt, 3-phase, 60-cycle electric motor. The pumps operate from two float switches of the automatic alternating type that alternate the operation of the two pumps on successive cycles. The float switches also will bring the second pump into service if, under peak load conditions, one pump is not capable of handling the condensate.

The condensate received in the collection tank is pumped directly to the main service waste header in building ICPP-633. Cooling water from process equipment, and condensate from steam traps located in the operating corridor and decontamination room, also discharge directly into the main service waste header. The header, a three-inch line, runs the length of the building and leaves the building underground on the north side of the building. A 1-1/2-inch service waste line from building ICPP-639 connects into the threeinch line at the north side of building ICPP-633. The three-inch line is then routed to manhole ICPP-309 east of building ICPP-709. The water passes into the monitoring station (ICPP-709) where it is monitored prior to its discharge to the ground via the service waste disposal well, (ICPP-304).

\subsection{Heating and Ventilation System}

Under the general arrangement of the heating and ventilating equipment in the WCF, air flows from the occupied operating areas toward the process cells. Air flow in this direction reduces the possibility of exposing personnel to radiation should active material be released in a cell. Motivation for the ventilating air is provided by a forced-draft blower in the ventilating unit on the main floor level and by an induced-draft blower in a pit outside the process building. With this arrangement, a positive pressure of 0.25 inch of water is maintained in the operating corridor while a negative pressure of 0.75 inch of water is maintained in the process cells. All doors in the process building a re normally kept closed, and the flow distribution to the cells is determined by the position of louvers in the cell doors.

The outside air entering the process building passes through a central supply unit on the main floor level and is distributed through duct work to areas requiring ventilation. In addition to the forced draft blower (WC-G-3301), the unit contains a preheat coil, a spray coil, and a reheat coil. The blower is a two-wheel unit rated to deliver $13,200 \mathrm{cfm}$ at two-inch water pressure. It is driven by a standard enclosure motor with a $\mathrm{V}$-belt drive. The motor is rated for 440-volt, 3-phase, 60-cycle operation. The preheat, spray, and reheat coils 
are large-face-area types designed for a flow of $13,200 \mathrm{cfm}$ at a $600-\mathrm{fpm}$ face velocity and entering and leaving air temperatures of $-20^{\circ} \mathrm{F}$ and $90^{\circ} \mathrm{F}, 90^{\circ} \mathrm{F}$ and $112^{\circ} \mathrm{F}$, and $112^{\circ} \mathrm{F}$ and $135^{\circ} \mathrm{F}$, respectively. An air washer, complete with spray unit, spray eliminators, sump, and recirculating pump also is provided. The spray coil and washer unit have been found unnecessary and are not being used. The air enters the supply unit through a heavy-duty filter box with removable, cleanable, permanent viscous filters. Air entering the duct work from the central supply unit is routed to the upper level of the building (except for the NaK furnace room and the decontamination room), the operating corridor, and the access corridor via the south stairwell. Air passes from the operating and access corridors into the process cells and is exhaustedfrom the cells by the main cell exhaust fan. The main cell exhaust blower (WC-G-3302) has a rated capacity of $11,000 \mathrm{cfm}$ at seven inches of water pressure. The exhaust blower discharges through an underground vitrified clay pipe to the main ICPP stack.

Air enters the adsorber manifold cell and the filter pipe tunnel from the access corridor through steam heaters and pipe ducts. The heater for the adsorber manifold cell air (WC-E-3301) is designed for an air flow of 1440 cfm with air entering at $80^{\circ} \mathrm{F}$ and leaving at $230^{\circ} \mathrm{F}$. The heater for the air to the pipe tunnel (WC-E-3304) is designed for an air flow of $170 \mathrm{cfm}$ and air entering at $80^{\circ} \mathrm{F}$ and leaving at $190^{\circ} \mathrm{F}$. The air circulated through these areas is heated to maintain the ambient temperature above the dew point of the gas passing through the process lines and equipment, and thus prevents moisture condensation due to loss of heat to the environment. The air is exhausted from the adsorber cells and pipe tunnel through louvered outlet ports which connect to the common suction line of the main cell exhaust blower.

A steam space heater with fan (WC-E-3309), designed for an air flow of $13,200 \mathrm{cfm}$ with entering air at $112^{\circ} \mathrm{F}$ and leaving air at $135^{\circ} \mathrm{F}$, provides heat in the filter removal room directly above the off-gas filter cells.

The NaK and decontamination equipment rooms are ventilated by outside air and heated by recirculation-type steam space heaters. The space heaters will maintain these rooms at $70^{\circ} \mathrm{F}$ or higher. The decontamination room is equipped with a two-speed, roof exhaust fan rated at $16,200 / 8100 \mathrm{cfm}$ for rapid removal of chemical fumes. There also are four fan-circulating steam space heaters (located in the decontamination room) with a total rated output of 203,000 Btu/hr. The NaK room is equipped with a similar but less powerful exhaust fan rated at $8700 \mathrm{cfm}$ and two fan-circulating steam space heaters with a total rating of 
$125,000 \mathrm{Btu} / \mathrm{hr}$.

\subsection{Fuel Oil System}

No. 2 fuel oil, brought in by tank truck, is used in the WCF to fire the NaK heater (WC-304). Two tanks, located in a separate earth-dike enclosure directly south of the fuel oil pump house (ICPP-702), provide storage capacity for 26,400 gallons. A transfer pump unloads the fuel oil from a tank truck to the appropriate storage tank. This pump is a cast iron, rotary pump, driven by a 7-1/2-horsepower, 440-volt, 3-phase, 60-cycle motor. It unloads tank truck shipments at a rate of $100 \mathrm{gpm}$.

Each fuel oil storage tank contains a set of steam heating coils located at the bottom of the tank to facilitate pumping oil in cold weather. Fuel oil is drawn from either tank through a suction header by one of two rotary pumps (WC-3305A or WC-3305B). WC-3305A is a screw-type pump driven by a 5-horsepower, 440-volt induction motor. WC-3305B is a gear-type pump driven by a 1-horsepower, 440-volt induction motor. Both pumps are cast iron. WC-3305A and WC-3305B deliver fuel oil at 7 and $2 \mathrm{gpm}$, respectively, to a recirculating oil loop as shown in Figure IV-18. Start-stop buttons in either the fuel oil pump house or on the NaK heater control board in ICPP-633 can be used to operate the pumps. A pressure control valve in the NaK furnace room maintains the fuel feed line pressure at $30 \mathrm{psig}$ and returns the excess flow to the storage tank.

\subsection{Sewer System}

All sanitary waste from the WCF is disposed of in a leaching cesspool. Effluent from the service sink, rest room, water cooler, and floor sink flow by gravity in a four-inch cast iron line to two septic tanks located north of building ICPP-633. The two concrete tanks, each having 1000-gallon capacity, are connected in series and are located about 12 feet below ground level. From these septic tanks, the effluent goes directly to the leaching cesspool.

The leaching cesspool is a 10-foot-diameter vault, 17 feet high, with a capacity of 5000 gallons. The walls are constructed of eight-inch pumice blocks. The walls above the effluent entrance are blocks laid in a mortar bed, while below the effluent entrance the blocks are laid flat with no mortared joints. Gravel one foot thick surrounds the sides and bottom of the vault to permit filtered seepage. A four-inch cast iron line connects the septic tanks to the cesspool.

Four vent lines are provided in the sanitary waste system and vent through the roof of building ICPP-633. Also, all facilities on the waste system are 
equipped with cleanout traps.

\subsection{Fire Protection System}

The ICPP fire water distribution system services the WCF and consists of a water loop which supplies nine fire hydrants throughout the plant area. Water pressure is normally maintained at 90 psig by the raw water pumps. Should the fire water system pressure decrease to 75 psig, automatic switchgear will start the electric fire water pump. This is a centrifugal pump which will deliver $2000 \mathrm{gpm}$ at $125 \mathrm{psig}$ and is driven by a 200-horsepower motor. The switchgear for this pump is located in the service building (ICPP-606).

The electric fire water pump is backed up by a diesel fire water pump which will deliver $2000 \mathrm{gpm}$ at $125 \mathrm{psig}$ and is driven by an 1875-rpm, General Motors diesel engine. Fuel for the diesel-driven pump is supplied from a 1000-gallon steel storage vessel.

Both the electric and diesel fire water pumps are test-operated weekly to insure their readiness at all times.

4.91 Fire Hydrants and Hose Stations. The WCF may be reached from two fire hydrants, one located by the northeast corner of building ICPP-633, and one located west of building ICPP-633 by the hose house (ICPP-702). In addition, there is one hose station located on the west wall of the heating and ventilating room.

4.92 Fire Alarm System. The WCF fire alarm system is a manual system. The alarm can be actuated at any of four pull-lever fire boxes located throughout the facility. The fire alarm boxes are the coded, shunt, non-interfering type capable of transmitting at least four rounds of signals. Code alarms are transmitted to the ICPP guardhouse, thence to the CFA fire station and the CF A communications room.

The evacuation alarm system is not a spectfic part of the fire alarm system; however, it can be utilized in case of extreme emergency resulting from a fire.

4.93 Fire Extinguishers. In addition to the fire protection facilities described above, there are several portable fire extinguishers, listed on the following page, which are strategically located throughout the WCF building. Not listed is a stationary Met-L-X system which is actuated from the operating corridor and which provides protection against NaK leakage from the drain and charge tanks (WC-104A and WC-104B). 
WCF FIRE EXTINGUISHERS LOCATED IN ICPP-633

\begin{tabular}{|c|c|c|c|}
\hline Number & Location & Capacity & Type \\
\hline 203 & NaK Furnace Room & $30 \mathrm{lb}$ & Met-L-X \\
\hline 204 & NaK Furnace Room & $30 \mathrm{lb}$ & Met-L-X \\
\hline 205 & NaK Furnace Room & $30 \mathrm{lb}$ & Met-L-X \\
\hline 206 & North Entrance & $2-1 / 2 \mathrm{gal}$ & Water \\
\hline 207 & North Entrance & $15 \mathrm{lb}$ & $\mathrm{CO}_{2}$ \\
\hline 208 & Heater Room & $15 \mathrm{lb}$ & $\mathrm{CO}_{2}$ \\
\hline 209 & Decontamination Room & $2-1 / 2$ gal & Water \\
\hline 210 & Decontamination Room & $15 \mathrm{lb}$ & $\mathrm{CO}_{2}$ \\
\hline 211 & Operating Corridor, South & $2-1 / 2$ gal & Water \\
\hline 212 & Operating Corridor, South & $15 \mathrm{lb}$ & $\mathrm{CO}_{2}$ \\
\hline 213 & Operating Corridor, North & $2-1 / 2$ gal & Water \\
\hline 214 & Operating Corridor, North & $15 \mathrm{lb}$ & $\mathrm{CO}_{2}$ \\
\hline 215 & Access Corridor & $30 \mathrm{lb}$ & Met-L-X \\
\hline 216 & Switch Gear Room & $15 \mathrm{lb}$ & $\mathrm{CO}_{2}$ \\
\hline 217 & Crane Room & $15 \mathrm{lb}$ & $\mathrm{CO}_{2}$ \\
\hline
\end{tabular}




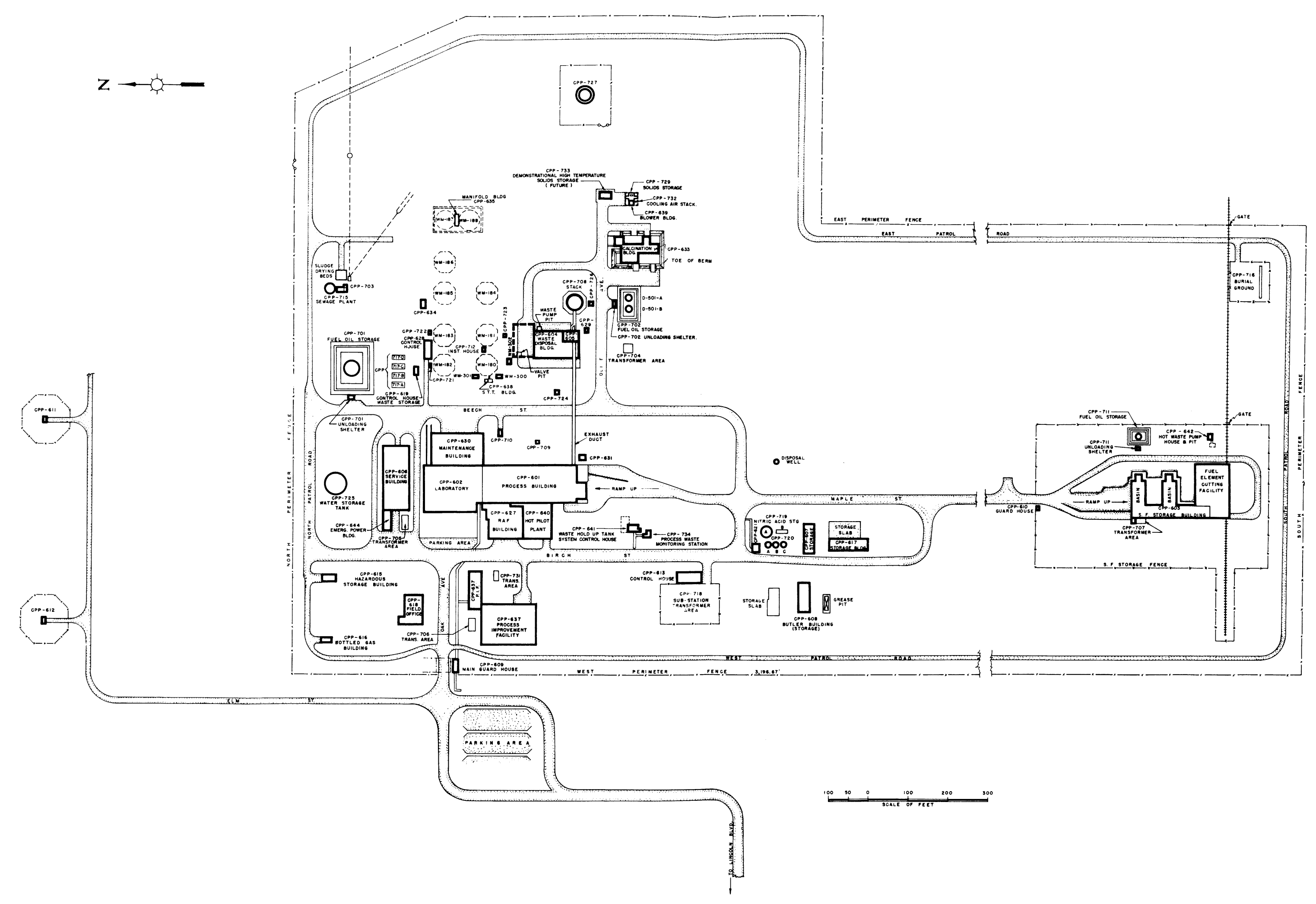

FIG. IV-I PLOT PLAN OF ICPP AREA. 


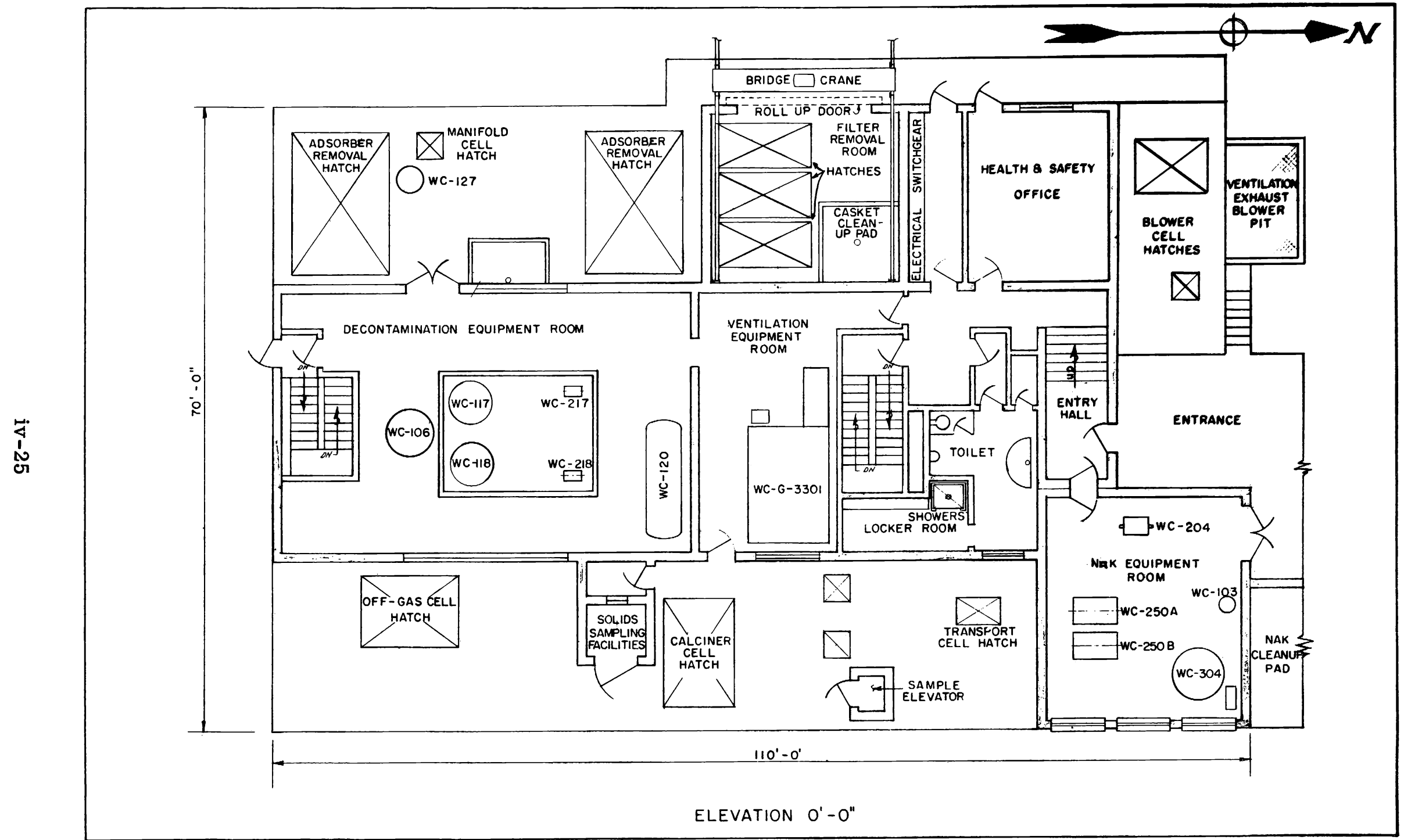

FIG. IV-2 PLAN VIEW WCF, MAIN FLOOR LEVEL. 


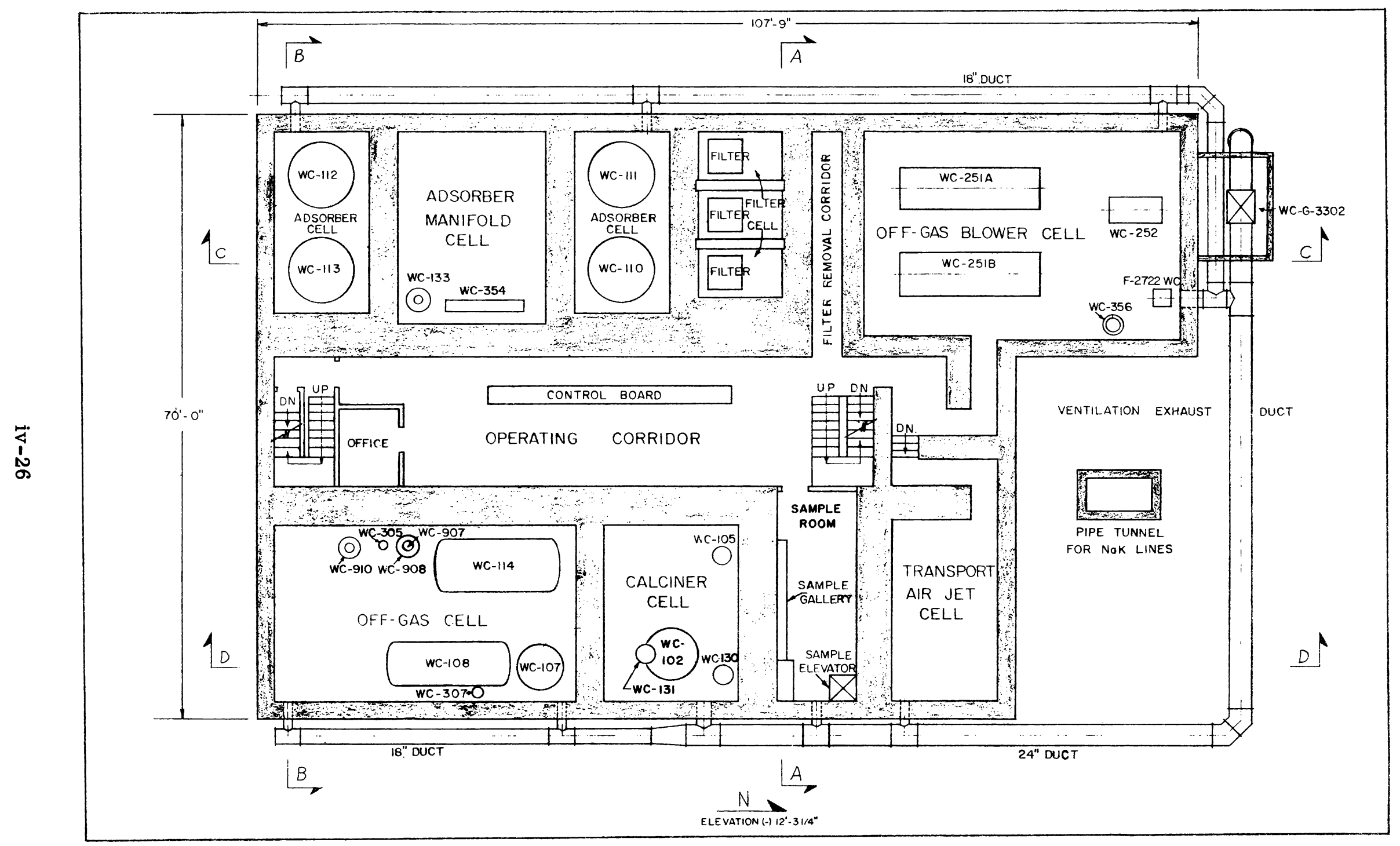

FIG. IV-3 PLAN VIEW WCF, OPERATING CORRIDOR LEVEL 


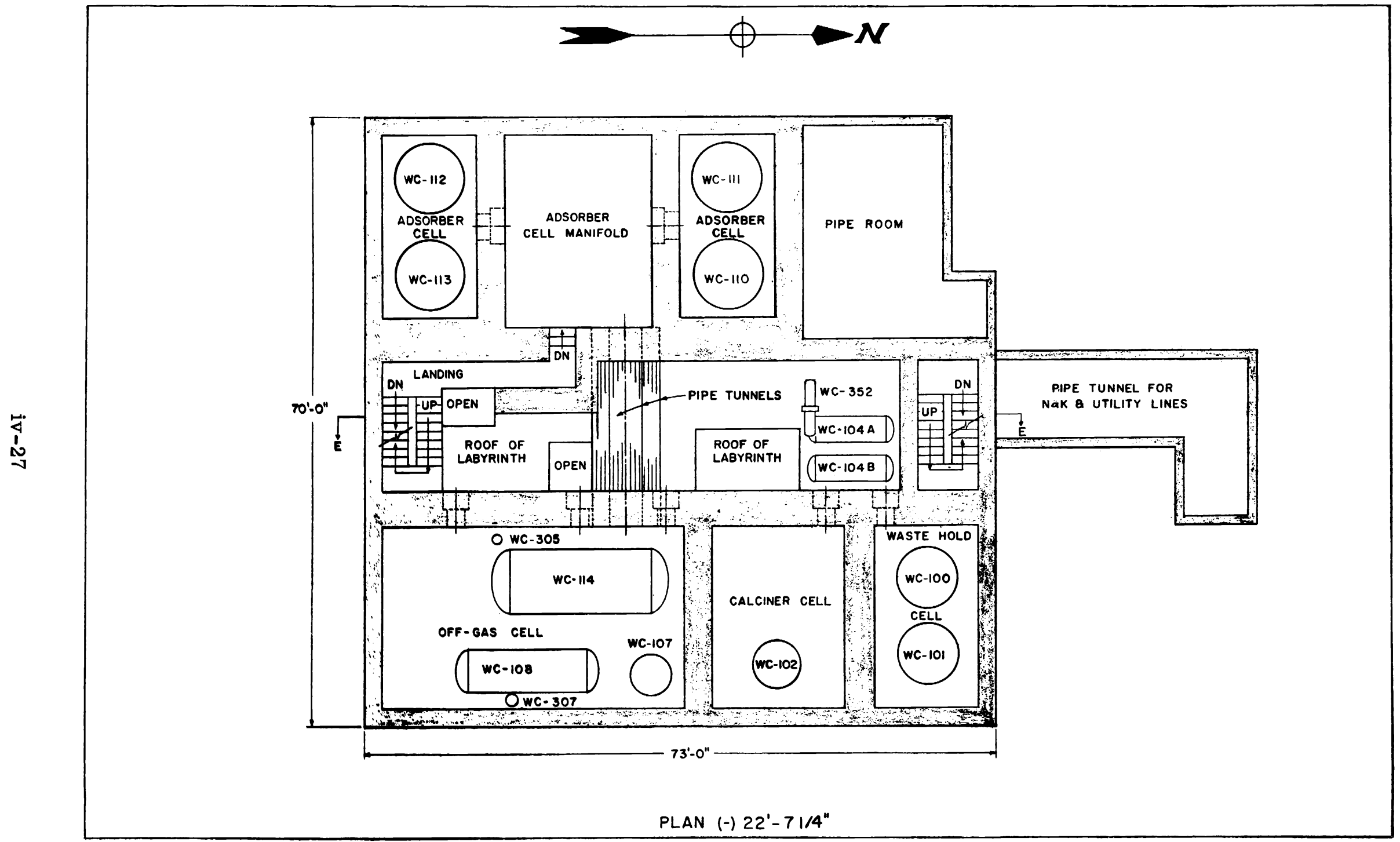

FIG. IV-4 PLAN VIEW WCF, ACCESS CORRIDOR (HIGH LEVEL). 


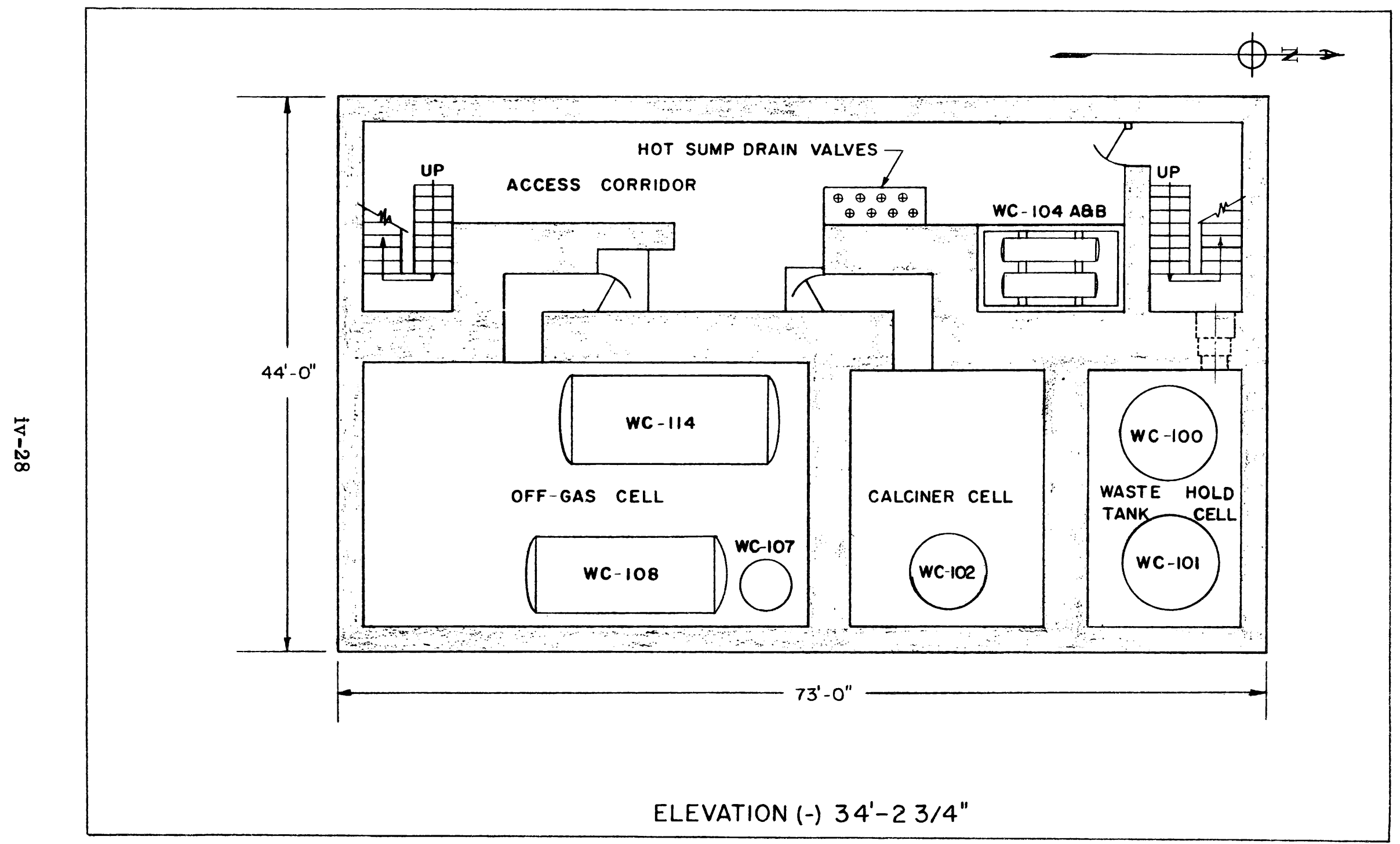

FIG. IV-5 PLAN VIEW WCF, ACCESS CORRIDOR (LOW LEVEL) 


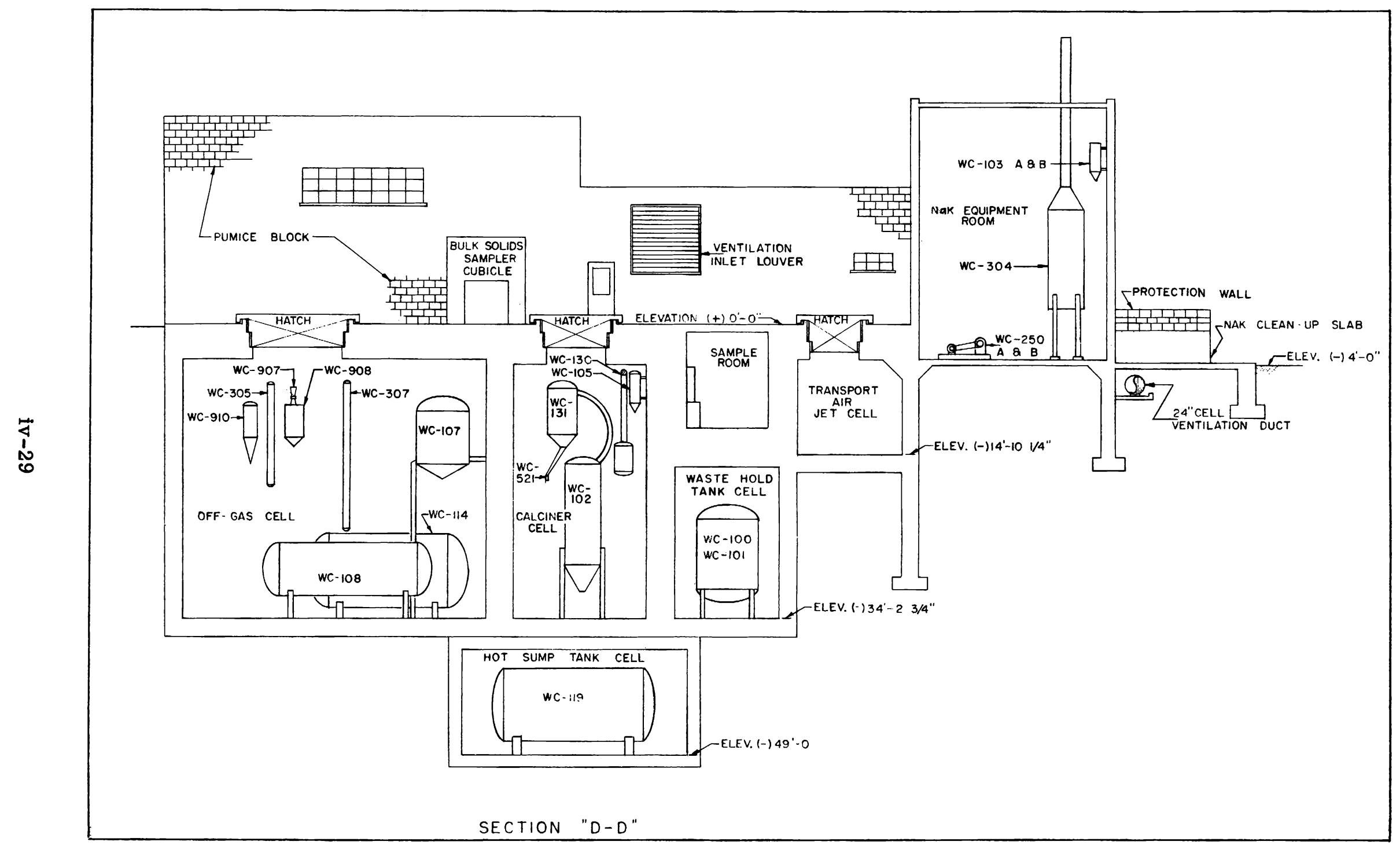

FIG. IV-6 ELEVATION VIEW WCF, LOOKING WEST (SECTION DD, FIG. IV-3). 


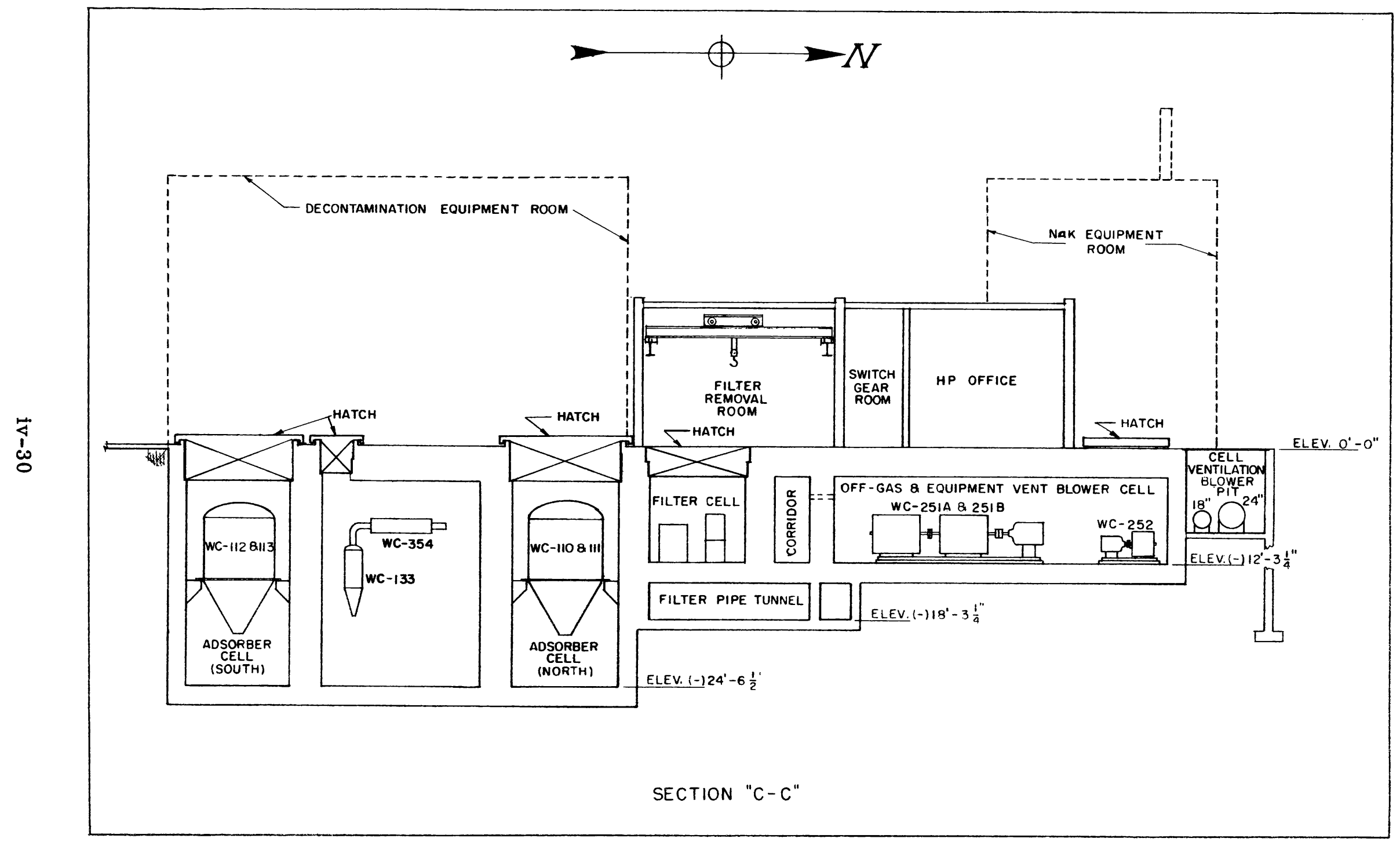

FIG. IVT7 ELEVATION VIEW WCF, LOOKING WEST (SECTION CC, FIG, IV-3), 


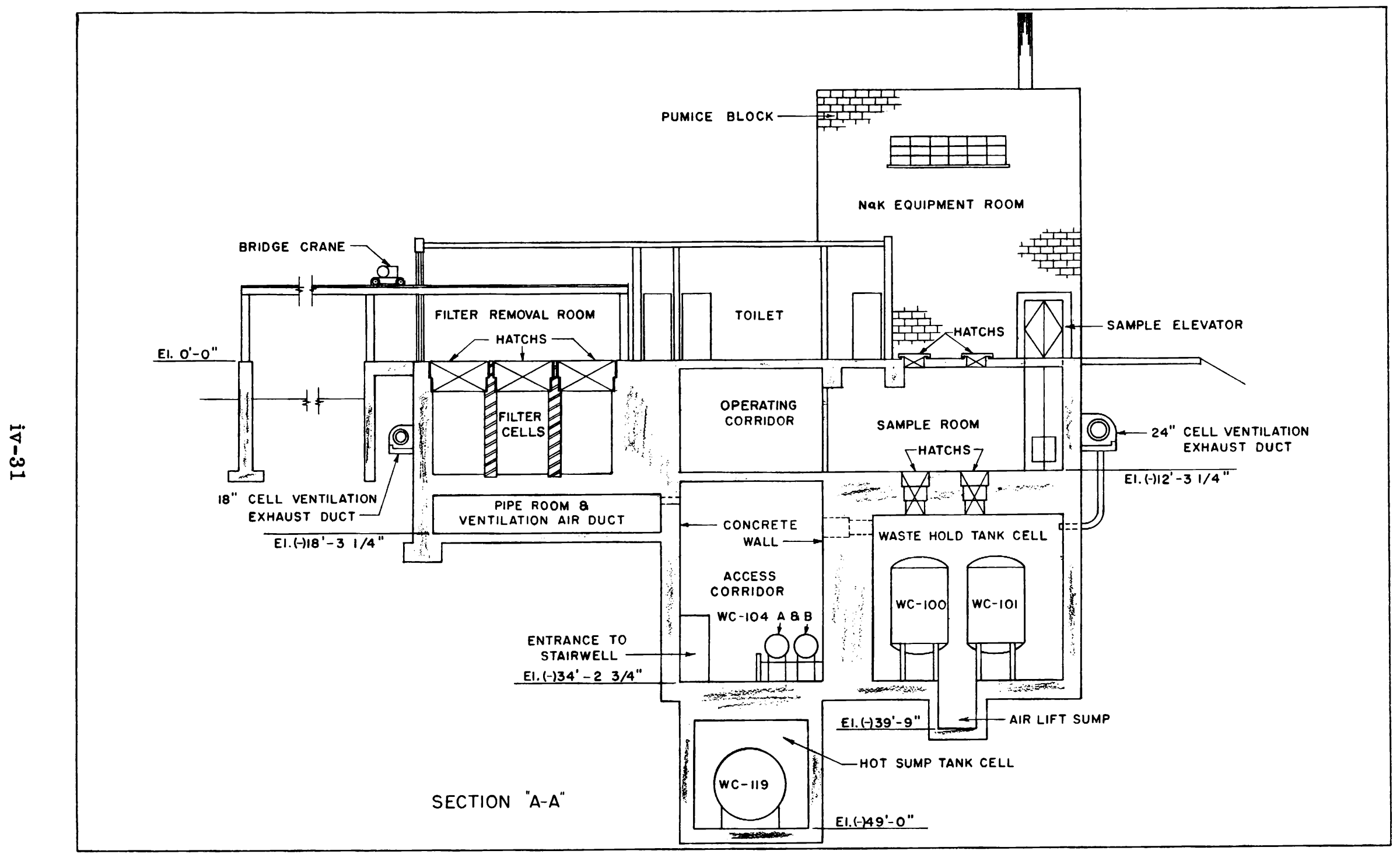

Fig. IV-8 ELEVATION VIEW WCF, LOOKING NORTH (SECTION AA, FIG. IV-3). 


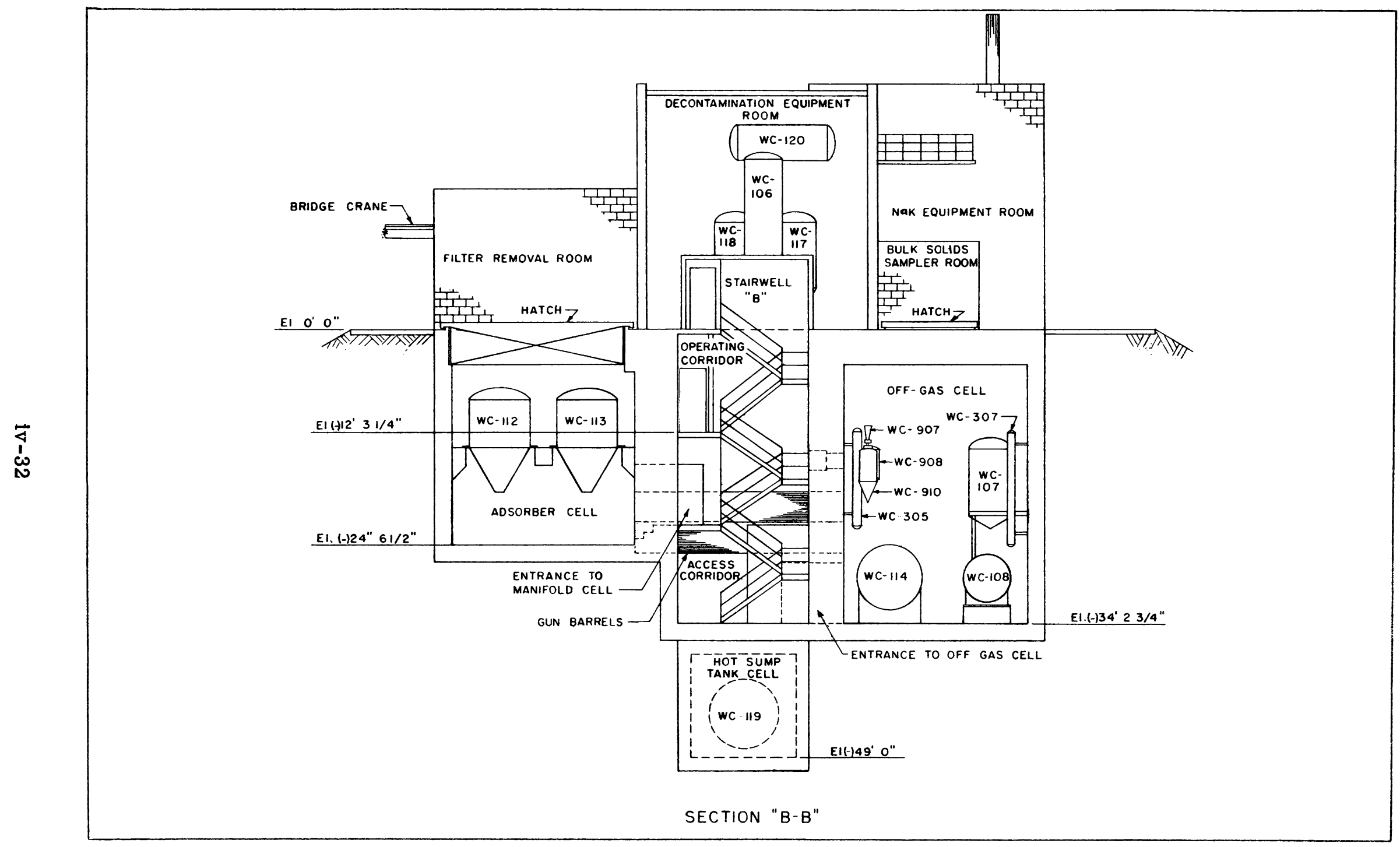

Fig. IV-9 ELEVATION VIEW WCF, LOOKING NORTH (SECTION BB, FIG. IV-3). 


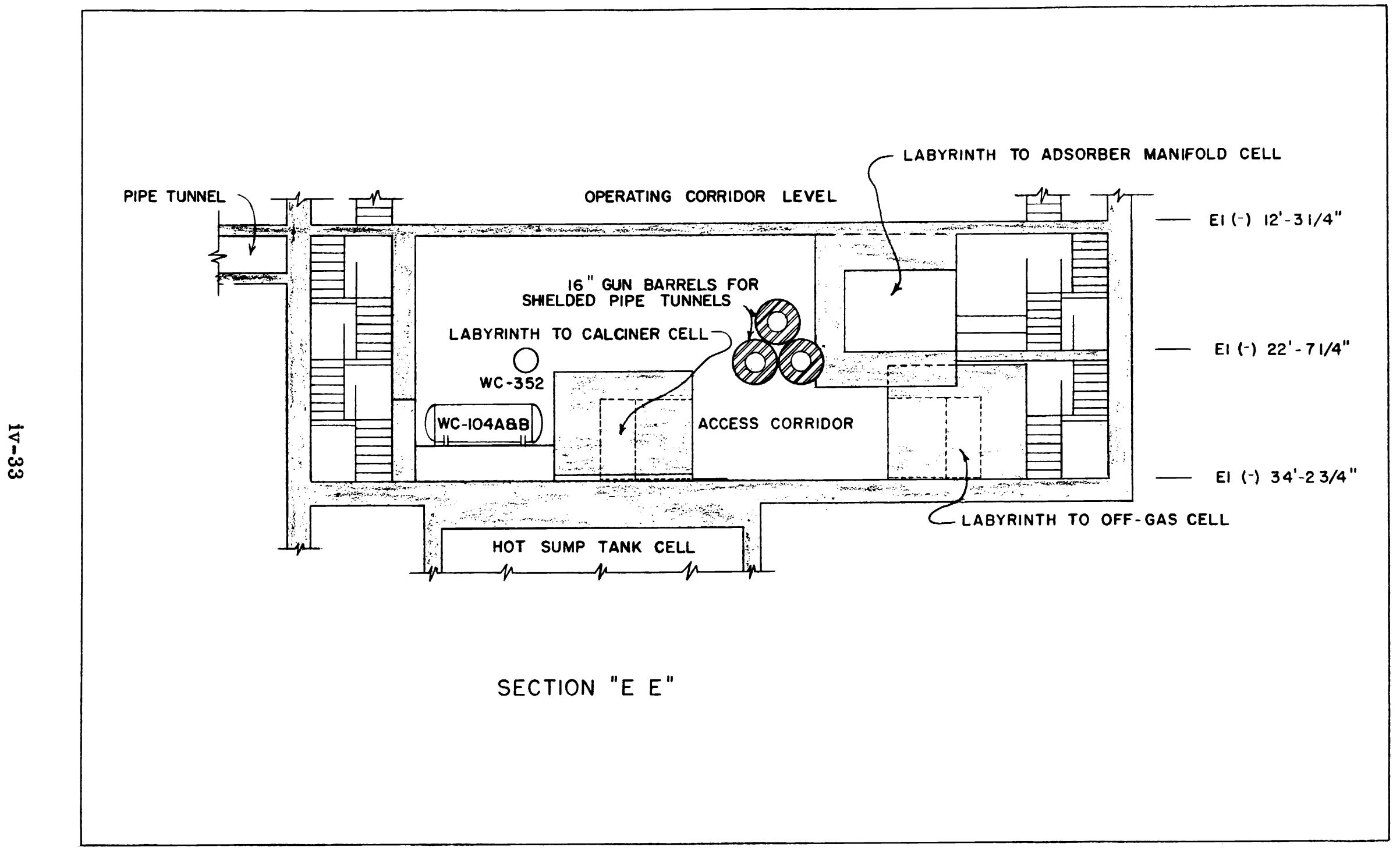

Fig. IV-10 ELEVATION VIEW WCF, LOOKING EAST SECTION EE, FIG, IV-4) 


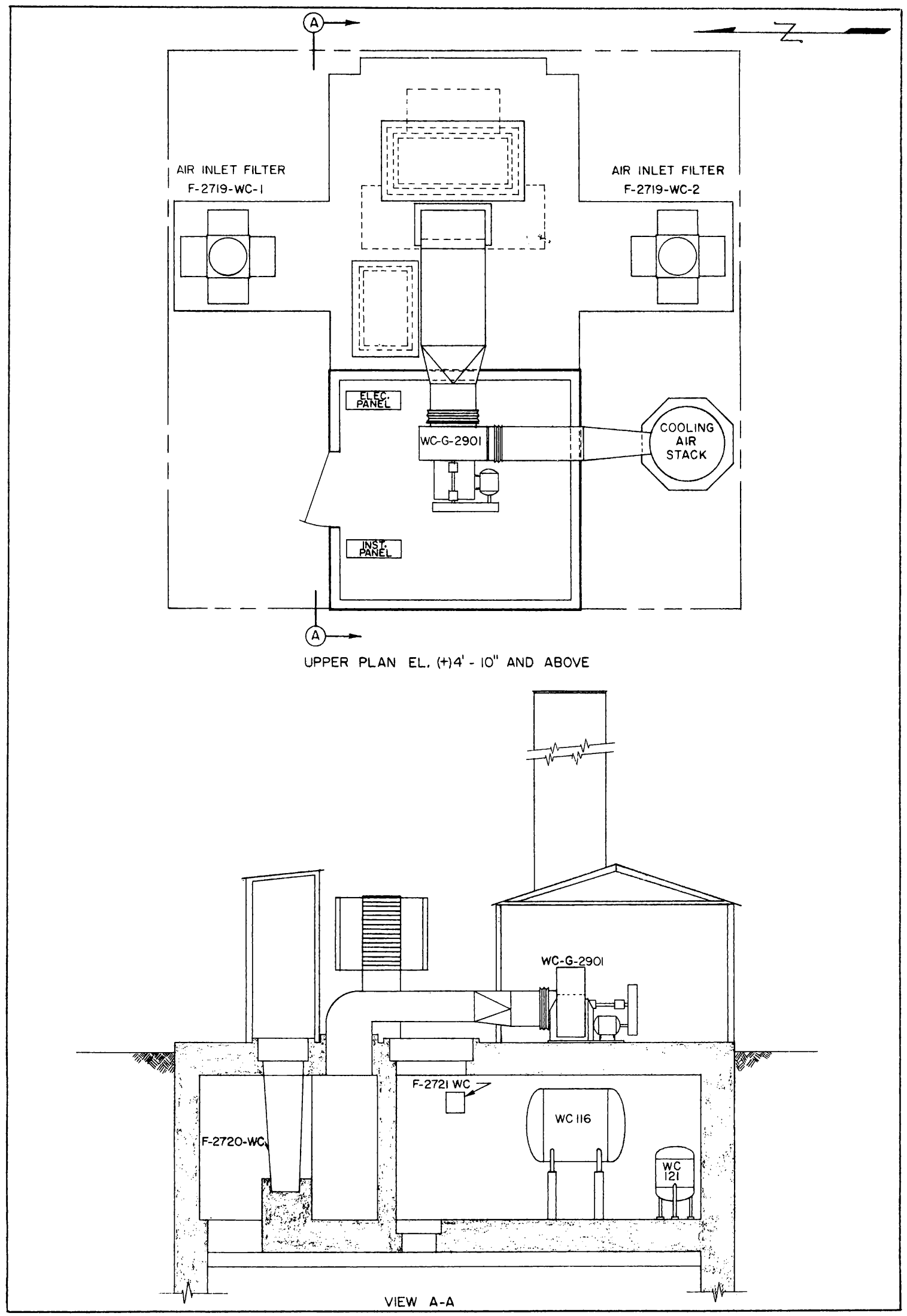

FIG. IV-11 WCF SOLIDS STORAGE UPPER PLAN AND SECTION. 


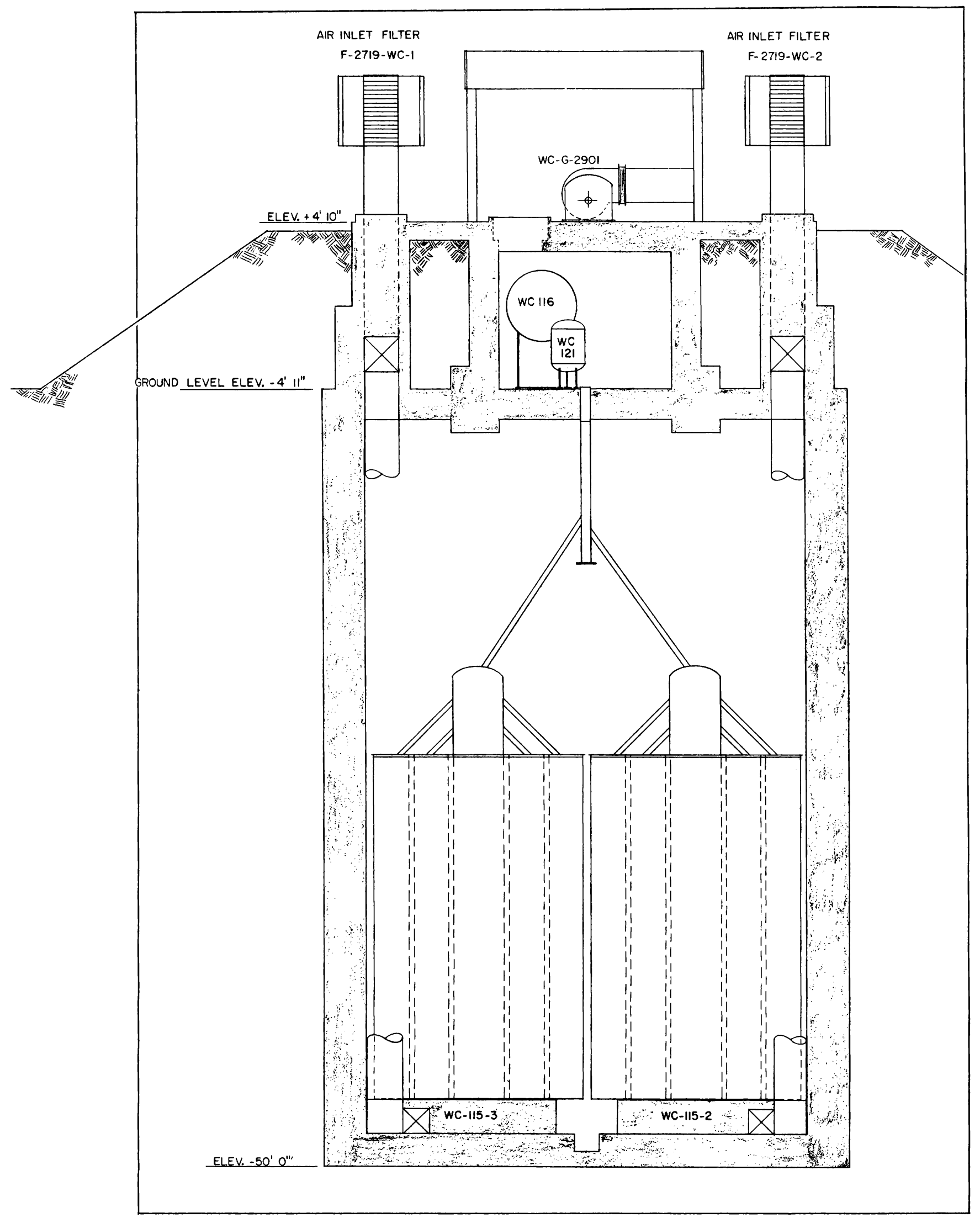

FIG. IV-12 WCF SOLIDS STORAGE, ELEVATION VIEW LOOKING EAST. 


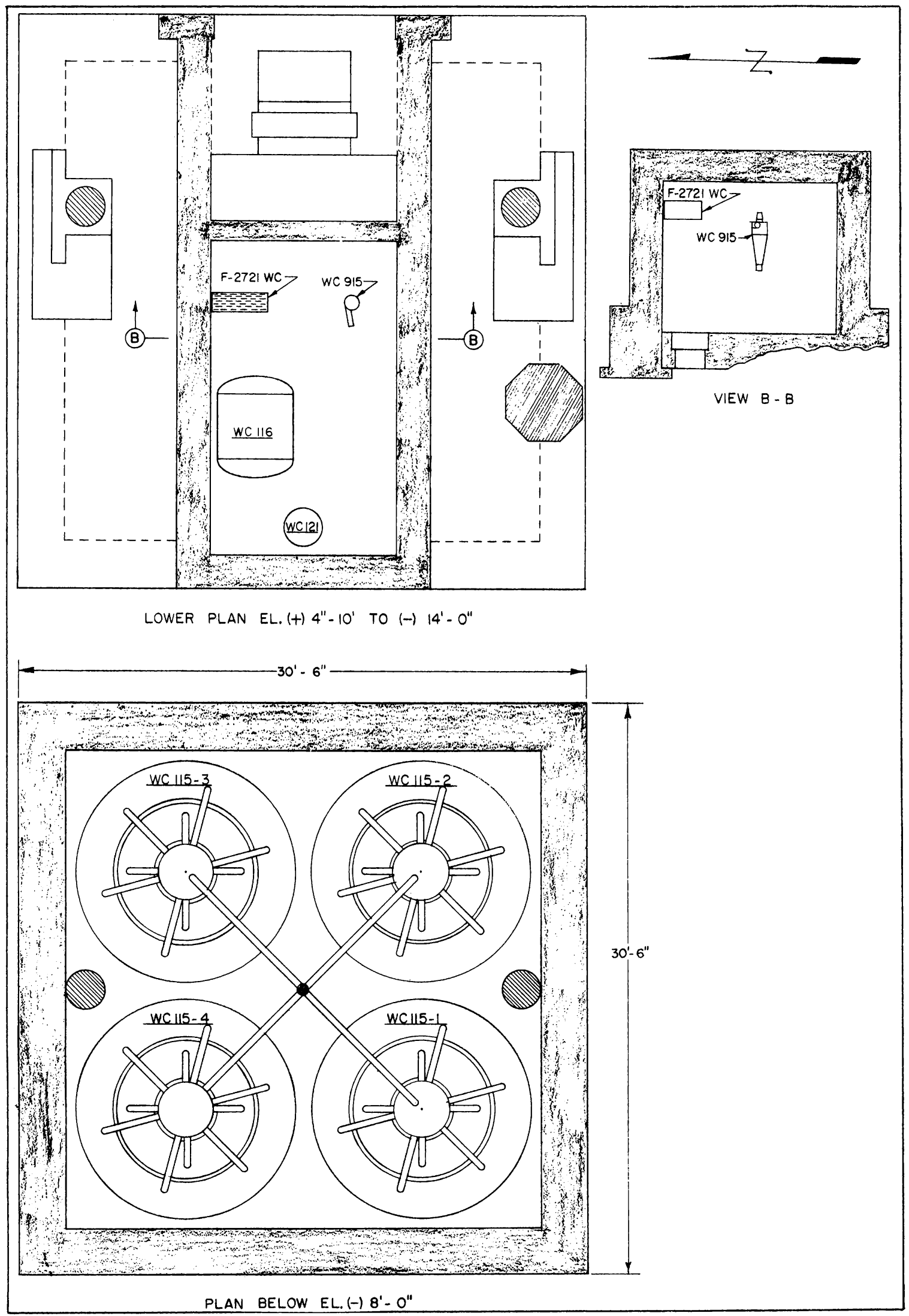

FIG. IV-13 WCF SOLIDS STORAGE, LOWER PLANS AND VIEW. 


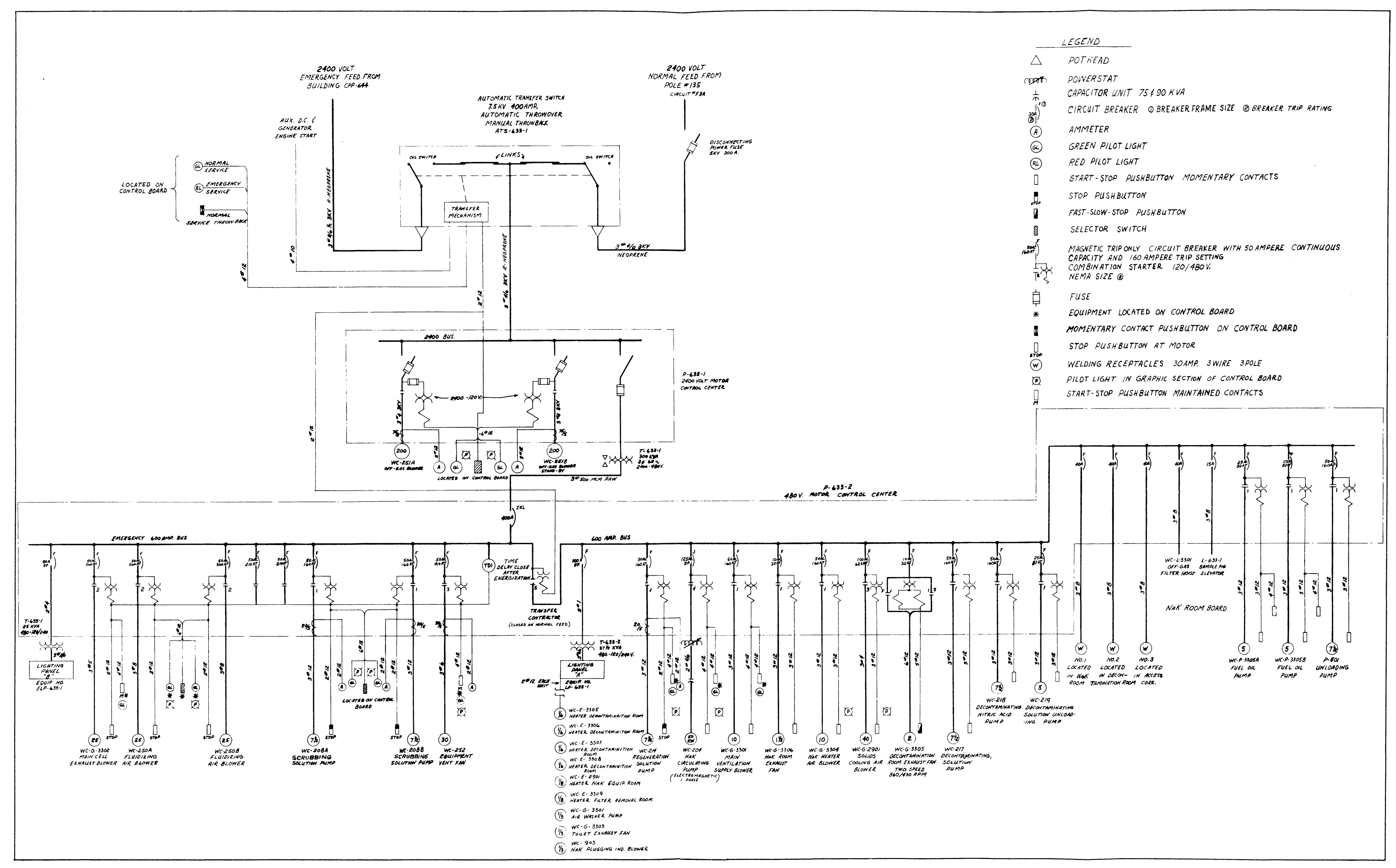

Fig. IV-14 WCF ELECTRICAL DIAGRAM. 


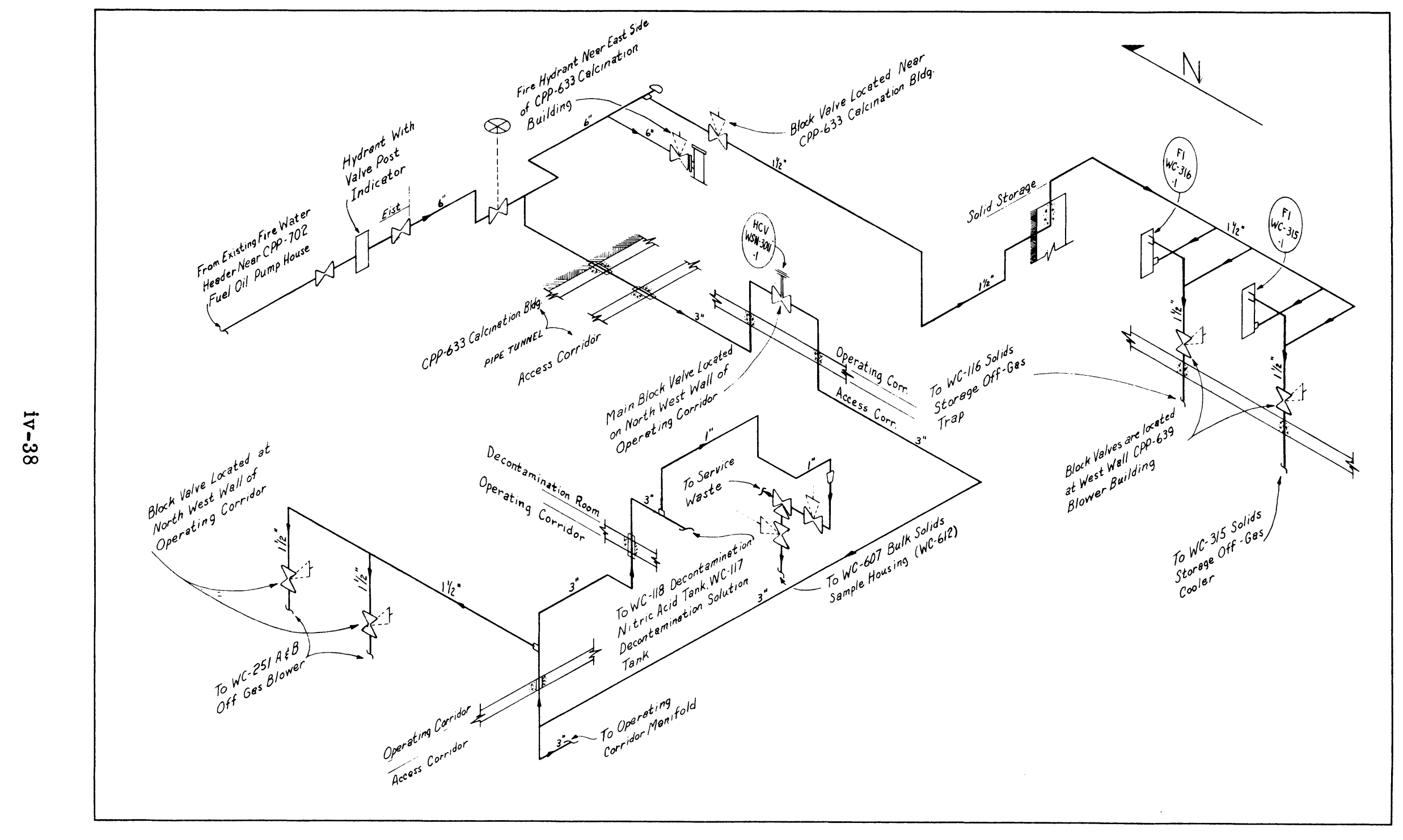

FIG. IV-15 WCF WATER SUPPLY SYSTEM. 


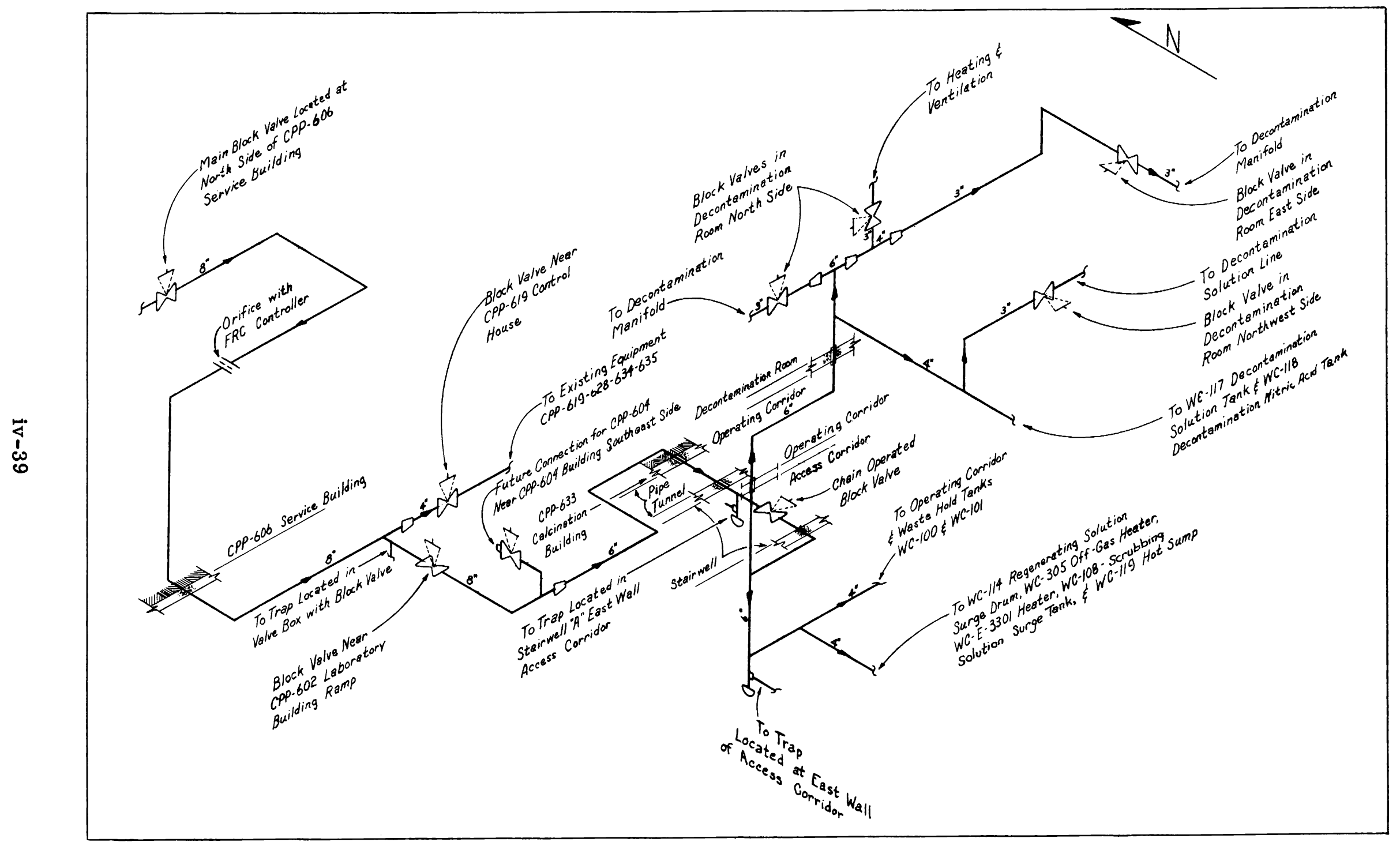

FIG. IV-16 WCF 120-PSI STEAM SYSTEM. 


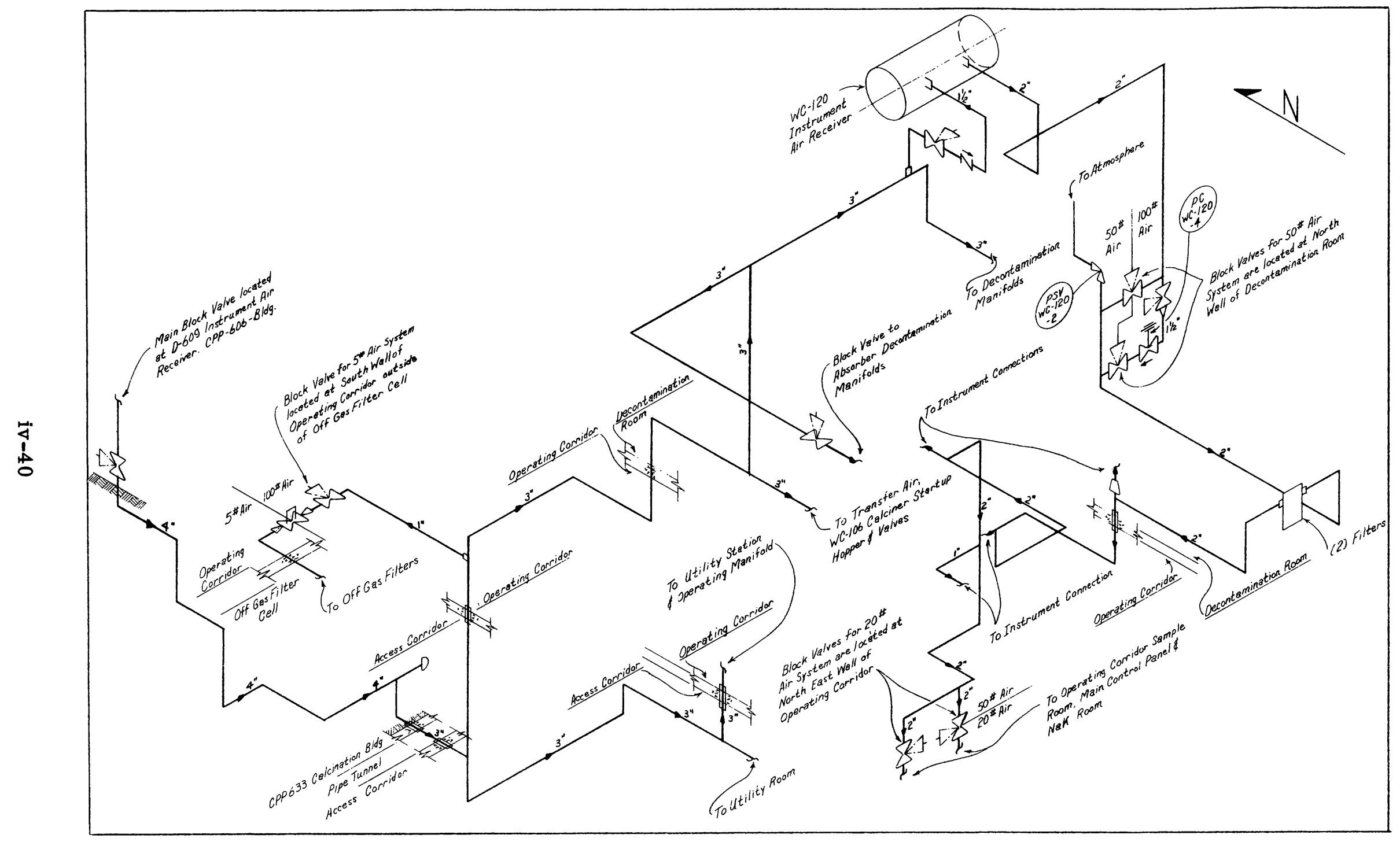

FIG. IV-I7 WCF AIR SUPPLY SYSTEM. 


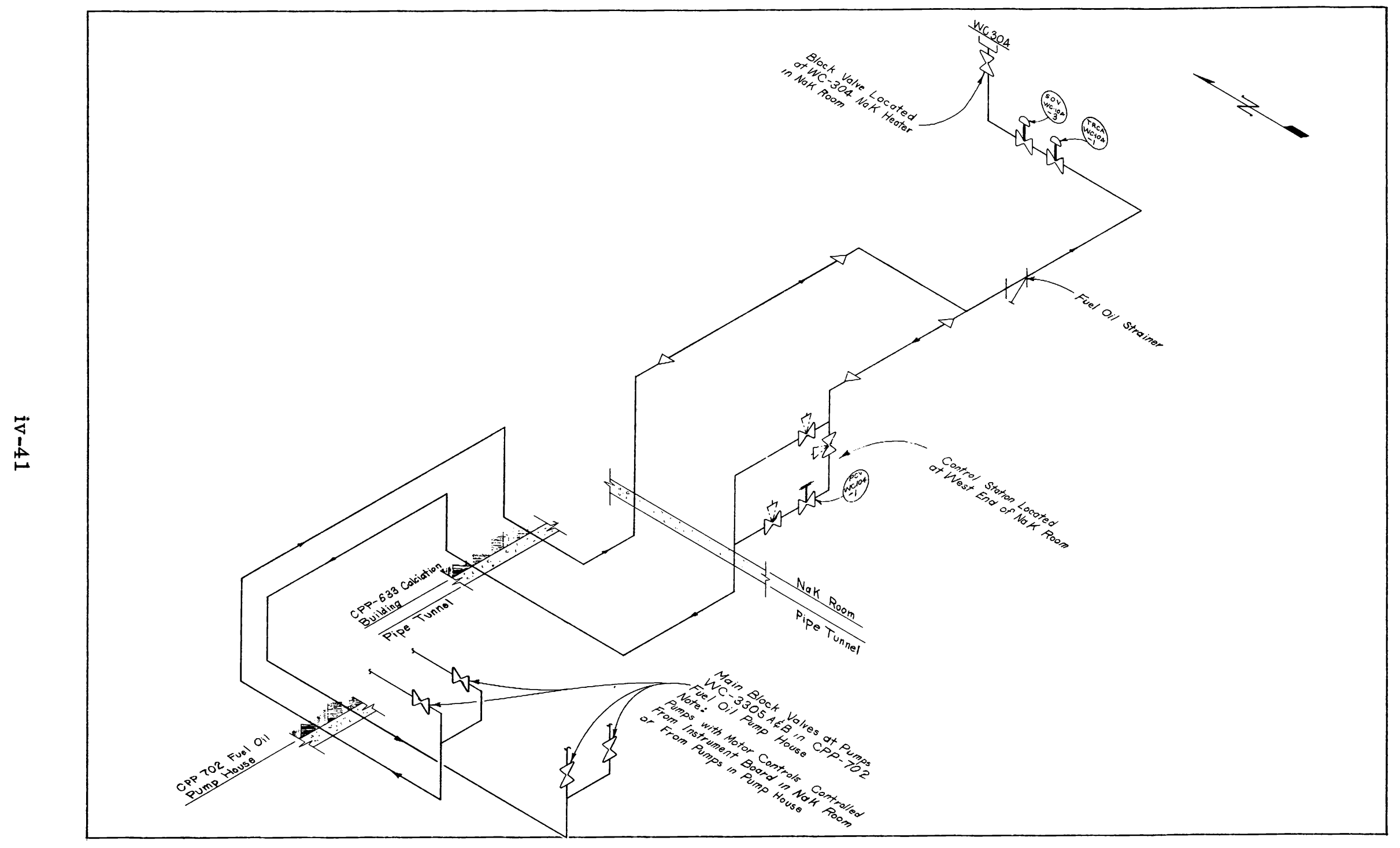

FIG. IV-18 WCF FUEL OIL SYSTEM. 



\section{PROCESS DESCRIPTION}

\section{FEED COMPOSITION}

The radioactive waste solutions to be processed initially through the WCF are produced during the reprocessing of aluminum-type fuel elements at the Idaho Chemical Processing Plant. The reprocessing ${ }^{[1,2]}$ consists of three steps: (a) dissolution of the uranium-aluminum elements in nitric acid, (b) adjustment of the dissolver solution to a composition suitable for solvent extraction of the uranium, and (c) separation of the uranium from the aluminum, fission products, and transuranic elements with which it is associated in the fuel elements. The separation is done by continuous liquid-liquid extraction employing a suitable solvent. Three extraction cycles are normally used; however, the bulk of the fission products is accumulated in the first-cycle waste solutions which constitute feed material for the WCF. Aluminum nitrate, water, and nitric acid are the major components of the first-cycle waste-solutions. Other components, in addition to the fission products, include: (a) mercury, added in the process to catalyze the aluminum dissolution, (b) iron, added as ferrous sulphamate to aid separation of transuranics, (c) ammonia, added to control acidity, and (d) sodium, added as sodium carbonate to aid in removing solvent decomposition products. The first extraction process installed at the ICPP employed methyl isobutyl ketone (hexone) as the solvent. The high ammonia and low acid concentrations in WM-180 waste tank resulted from the use of ammonia to maintain low acidity in the process. In 1955, the first cycle solvent was changed to tributyl phosphate (TBP) and the acid level of the process was raised; this accounts for the low ammonia and high acid concentrations in the remaining first-cycle waste tanks, WM-182, WM-183, WM-185, and WM-187. Similar high acid wastes will be stored in two new tanks, currently being installed.

The chemical and radiochemical analyses made on samples taken from the first-cycle waste-tanks are given in Table V-1. The wastes presently in storage are considerably older - varying from three to eight years in age - than the wastes for which the WCF was designed. The processing portion of the facility was designed for wastes containing fission products aged for only 200 days. In anticipation of the lack of fresh wastes at the time of the facility start-up, a fission product activity after a two-year aging period was used as a basis for 


\section{TABLE V-1}

ANALYSES OF FIRST CYCLE WASTE TANKS AT THE IDAHO CHEMICAL PROCESSING PLANT

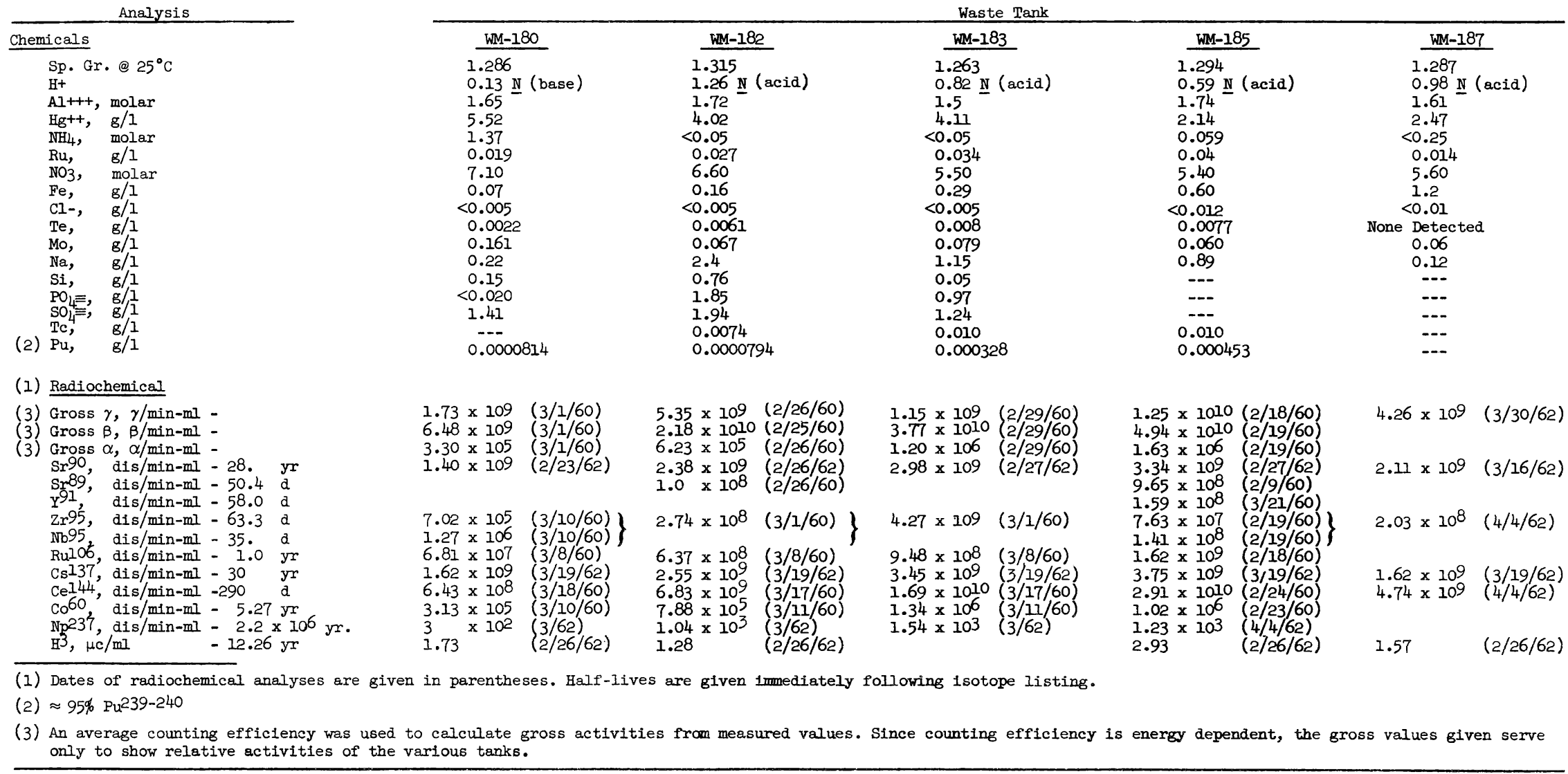


designing the shielding and cooling system for the first storage bins. The first tank destined to be processed through the WCF is WM-185, having an estimated age of five years by September 1963.

Samples taken at various levels in WM-182 (Table V-2) show little variation in specific gravity or the major constituents, indicating no stratification. No visual evidence of a sludge layer on the tank bottom or a hydrocarbon layer on the liquid surface was obtained while taking any of the tank samples. Foaming, which would be expected if hydrocarbons were present, was not observed when a sample of waste solution from tank WM-185 was boiled for one hour ${ }^{[3]}$.

TABIE V-2

WASTE TANK WM-182 SAMPLING RESULTS

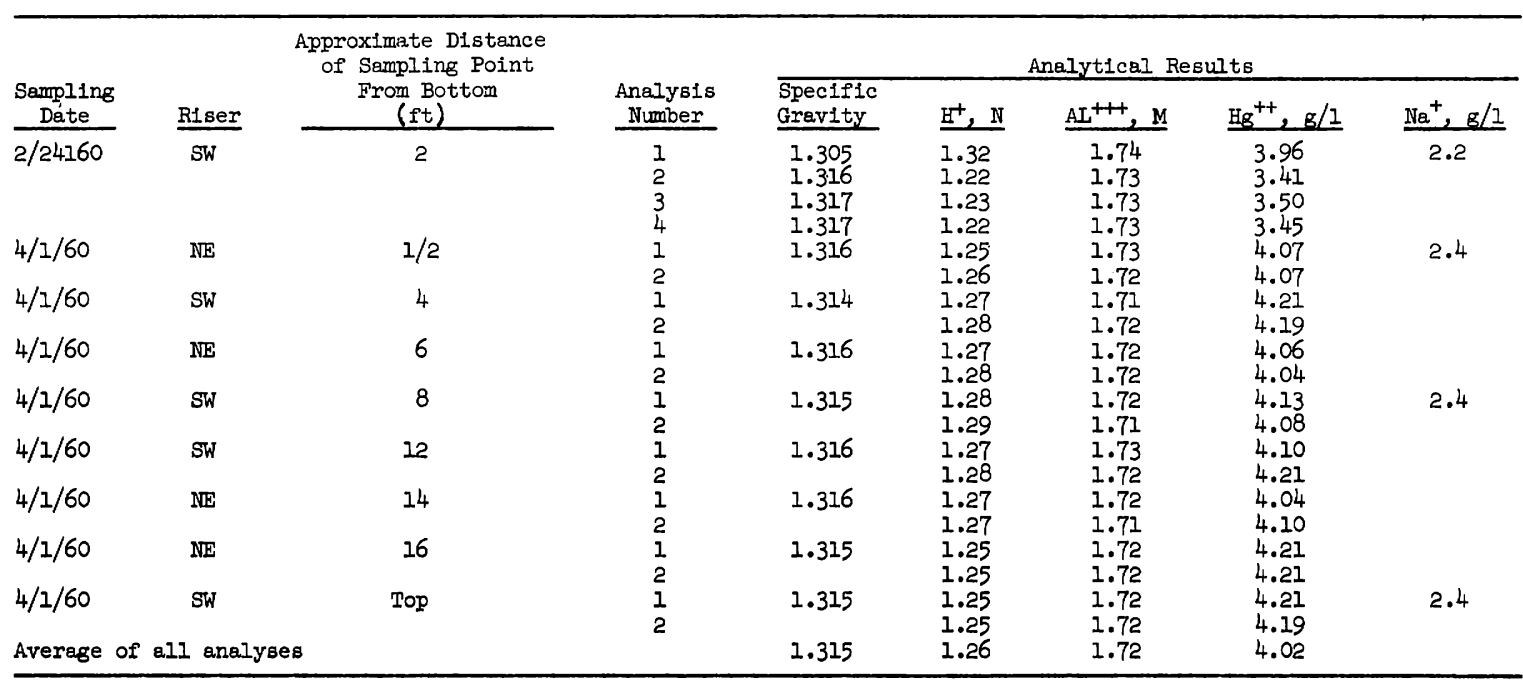

The total activities in curies per gallon as determined from the analyses of tanks WM-180, WM-182, WM-183, and WM-185 are shown in Figure $\mathrm{V}-1$. No activities are presented for tank WM-187 as this tank is not full and will receive additional waste from the processing plant before being processed through the WCF.

The activity and fission product distribution of more recent waste solutions can be estimated from Figure V-2. The data for this plot were calculated by the method of Blomeke and Todd ${ }^{[4]}$ for an MTR-type fuel having an aluminum to uranium ratio of 21. A burnup period of 20 days at a flux level of $2.6 \times \frac{1014 \mathrm{n}}{\mathrm{cm}^{2} \mathrm{sec}}$ and an aluminum dilution of five percent in the reprocessing were assumed for the 


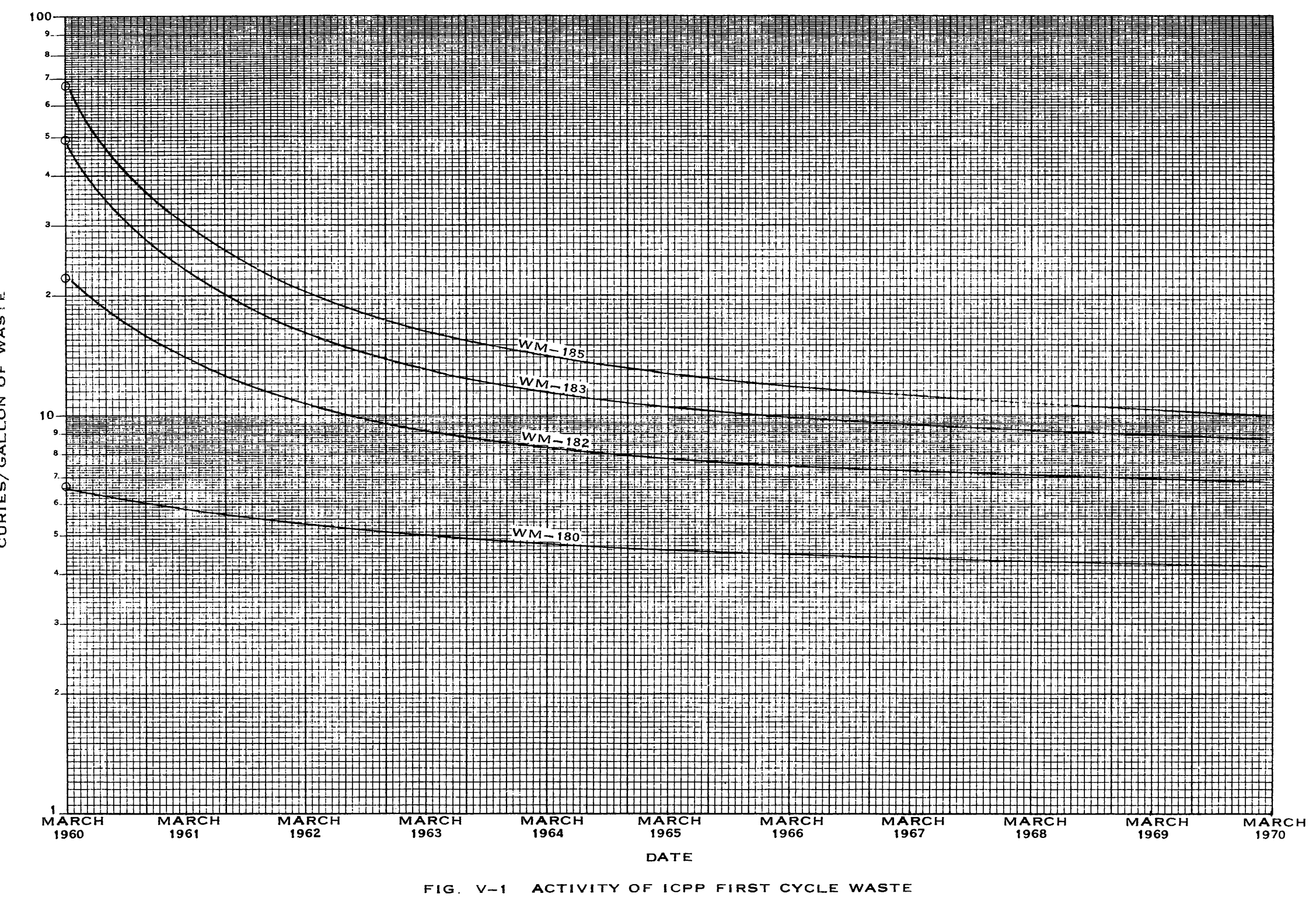




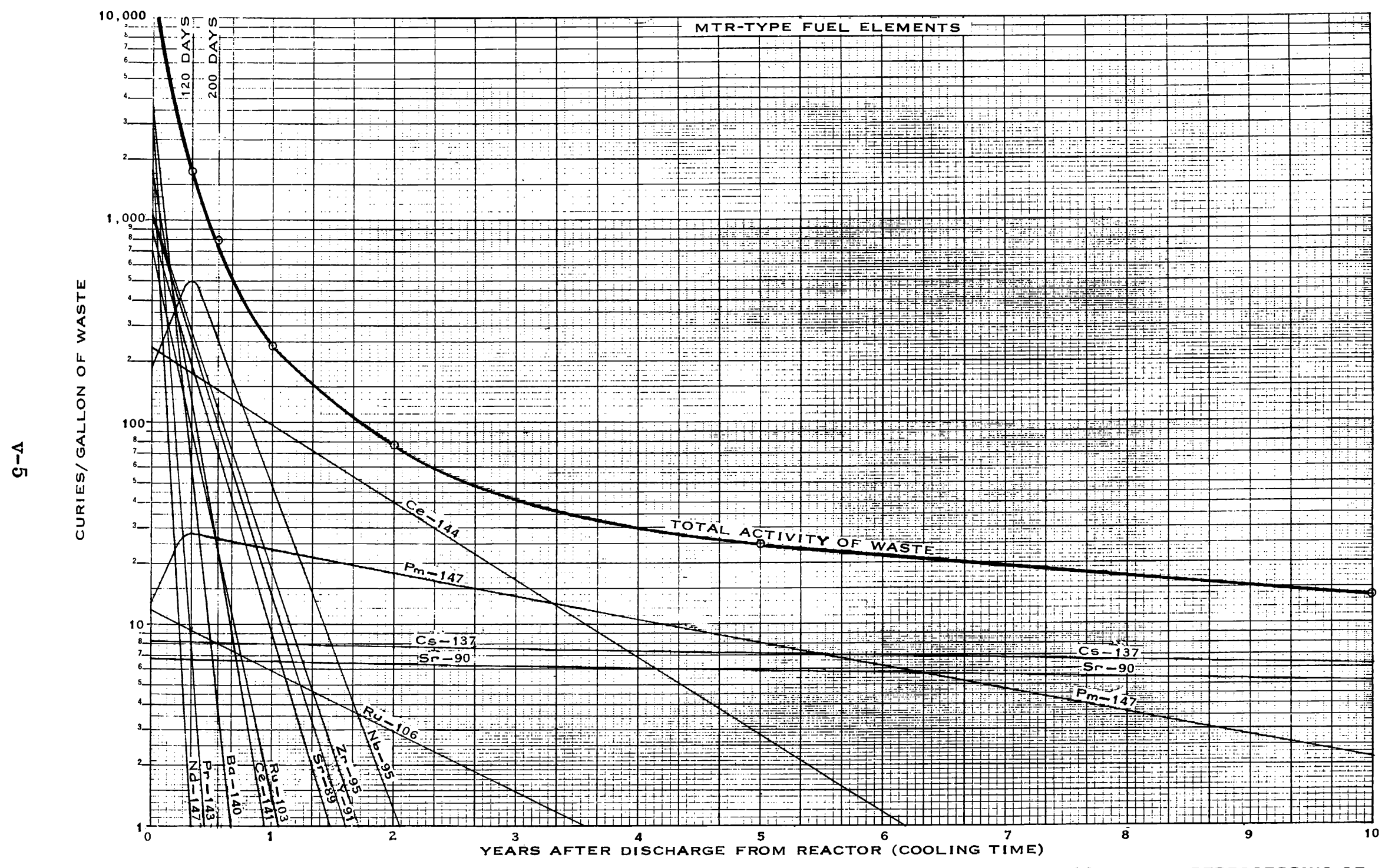
FIG. V-2 CALCULATED INDIVIDUAL FISSION PRODUCT ACTIVITIES AND TOTAL ACTIVITY OF LIQUID WASTE FROM REPROCESSING OF 
calculations. A comparison of the measured and calculated activities at the apparent ages of the ICPP waste tanks indicates that the assumptions used in the calculations are conservative; the measured activities are considerably lower than the calculated activities. The calculations are summarized in Appendix A.

\section{CALCINATION REACTIONS}

The primary reactions taking place in the calcination process are the decomposition of nitric acid, the evaporation of water, and the conversion of the aluminum nitrate portion of the waste solution to aluminum oxide. At the same time, the remaining elements present in the waste solutions, including the fission products, are converted into an oxide form if the nitrate is unstable at the calcination temperature. The final form sodium takes in the product is uncertain; sodium nitrate begins to decompose at $380^{\circ} \mathrm{C}^{[5]}$, but does not decompose completely in the calcination process as it has been detected in the product from both pilot plant and WCF tests ${ }^{[6,7]}$. Mercuric nitrate decomposes into mercuric oxide upon heating, and into mercury and oxygen upon further heating. Experiments ${ }^{[8]}$ indicate that 20 percent of the mercury volatilizes and is carried as a vapor from the system by the fluidizing gas. The chemical reactions taking place in the calcination process are:

$$
\begin{aligned}
& 2 \mathrm{Al}\left(\mathrm{NO}_{3}\right)_{3} \cdot \mathrm{nH}_{2} \mathrm{O} \longrightarrow \mathrm{Al}_{2} \mathrm{O}_{3}+6 \mathrm{NO}_{2}+3 / 2 \mathrm{O}_{2}+2 \mathrm{n} \mathrm{H}_{2} \mathrm{O} \\
& 2 \mathrm{HNO}_{3} \longrightarrow 2 \mathrm{NO}_{2}+1 / 2 \mathrm{O}_{2}+\mathrm{H}_{2} \mathrm{O} \\
& \mathrm{NO}_{2} \rightleftharpoons \mathrm{NO}+1 / 2 \mathrm{O}_{2} \\
& \mathrm{Hg}\left(\mathrm{NO}_{3}\right)_{2} \longrightarrow \mathrm{HgO}+2 \mathrm{NO}_{2}+1 / 2 \mathrm{O}_{2} \\
& \mathrm{HgO} \longrightarrow \mathrm{Hg}+1 / 2 \mathrm{O}_{2} \\
& \mathrm{NaNO}_{3} \longrightarrow \mathrm{NaNO}_{3} / \mathrm{Na}_{2} \mathrm{O} \\
& \text { Fission Product Nitrates } \longrightarrow \text { Fission Product Nitrates/Oxides } \\
& 2 \mathrm{H}_{3} \mathrm{BO}_{3} \longrightarrow \mathrm{B}_{2} \mathrm{O}_{3}+3 \mathrm{H}_{2} \mathrm{O}
\end{aligned}
$$




\section{PROCESS FLOWSHEET}

The process operating conditions and a material balance are shown on the flowsheet, Figure V-3, for a processing rate of $60 \mathrm{gph}$ of waste solution. The operating conditions shown are those anticipated for radioactive operation and which were found most satisfactory during the test runs (Section VII-1). The degree of off-gas cleanup shown is that achieved in the final test run (Section VII-2). The process flowsheet, Figure V-3, also identifies equipment mentioned in the following discussion.

Waste solution to be processed in the WCF is transferred by steam jet from the 300,000 gallon underground storage tanks into the two holding tanks (Waste Hold Tank, WC-100 or WC-101) where it is blended with scrubbing solution recycled from the scrubbing system; boric acid is added to prevent the formation of alpha alumina (Section VII-1). An air lift raises the combined waste-scrubbing solution to an overhead tank (Feed Tank, WC-105) from which the mixture drains by gravity to the feed nozzles in the calciner vessel (Calciner Vessel, WC-102).

The calcination is done by spraying the waste solution into a bed of alumina particles fluidized with air in the calciner vessel. The solid reaction products from the thermal decomposition of the waste solution build up in layers on the bed particles, while the gaseous products are swept from the vessel with the fluidizing air. A stable bed height of approximately 72 inches is maintained by adjusting the product drawoff rate. The average size of the bed particles is controlled within the range of $0.4-0.6 \mathrm{~mm}$ by adjusting the air rates to the feed nozzles. Raising the nozzle air rate increases the particle breakup and reduces the average particle size in the bed.

Bed temperatures from 300 to $600^{\circ} \mathrm{C}$ have been used in pilot plant tests (see Section VII for effect of temperature); $400^{\circ} \mathrm{C}$ was used through the WCF cold tests and will be used for the initial stages of operation. When operating at this temperature, the product will contain approximately seven percent residual volatiles (nitrate and water). The heat necessary for the decomposition and calcination reactions is supplied by heated $\mathrm{NaK}$ flowing through a heat exchanger (Fluidized Bed Heater, WC-302) in the fluidized bed. The NaK is heated in an oil fired furnace (NaK Furnace, WC-304) and pumped through the exchanger with an electromagnetic pump (NaK Circulating Pump, WC-204). 


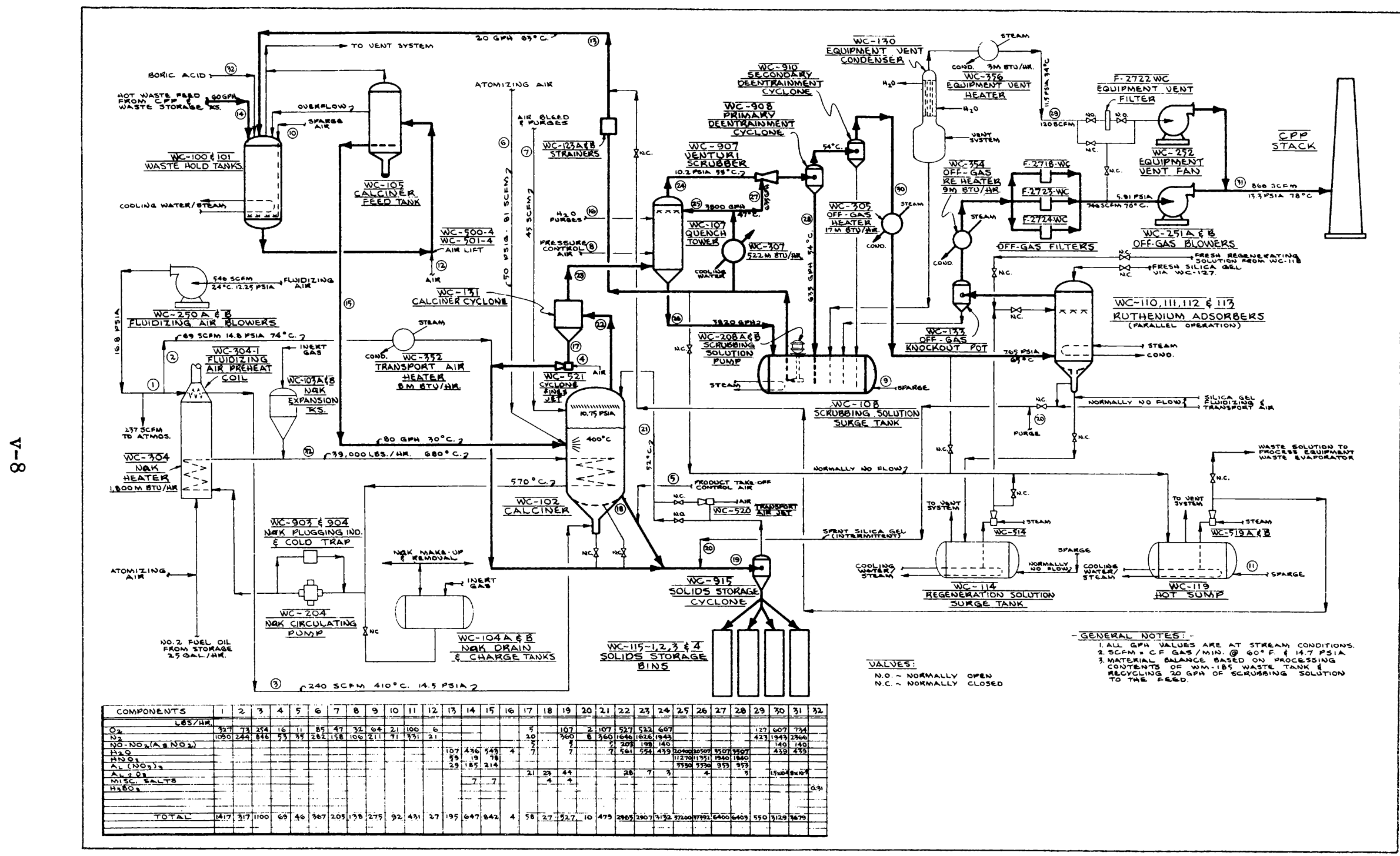

FIG. V-3 PROCESS FLOWSHEET - ICPP WASTE CALCINING FACILITY 
The fluidizing air, which is supplied by a positive displacement blower (Fluidizing Air Blower, WC-250A or WC-250B), is preheated to $400^{\circ} \mathrm{C}$ in the convection section of the oil fired $\mathrm{NaK}$ furnance prior to introduction into the calciner vessel. A fluidizing velocity ${ }^{[*]}$ of one $\mathrm{ft} / \mathrm{sec}$ has been selected as optimum from experience gained in the test runs. A vacuum is maintained in the calciner vessel and in the off-gas system by a centrifugal blower (OffGas Blower, WC-251A or WC-251B) discharging to the main ICPP stack.

The alumina withdrawn from the bed, together with the fine solids collected in the scalping cyclone (Calciner Cyclone, WC-131), is transported pneumatically to the solids storage bins. A jet (Cyclone Fines Jet, WC-521) provides sufficient differential pressure to discharge solids from the cyclone into the solids transport line. Since the jet also introduces saturated process gas into the solids transport line, the transport air is preheated in a steam heater (Transport Air Heater, WC-352) to prevent condensation in the transport lines. The solids are removed from the transport air at the storage bins by a cyclone (Solids Storage Cyclone, WC-915) and the transport air is returned to the calciner vessel where it mixes with the fluidizing and reaction gases.

The initial product storage vault furnished with the WCF contains four bins, having a total storage capacity of $\approx 7800 \mathrm{ft}^{3}$. This capacity is adequate for approximately 400 days of operation at flowsheet conditions and is approximately equivalent to the contents of two 300,000 gallon liquid waste tanks. Heat, generated in the product by decay of the fission products, is removed by passing air over the bin surfaces. The bins and the cooling system have been designed to prevent the temperature anywhere in the bins from exceeding the calcination temperature $\left(400^{\circ} \mathrm{C}\right)$.

Five elements; ie, a scalping cyclone, a spray cooling tower, a venturi scrubber, silica gel beds, and high efficiency filters, have been installed at the WCF to clean up the calciner off-gas before being discharged to the atmosphere. The calciner cyclone, located above the calciner vessel, removes dust particles larger than 20 to 40 microns in size. After leaving the cyclone, the gases are cooled to near $60^{\circ} \mathrm{C}$ in a countercurrent spray tower (Quench Tower, WC-107) and cleaned further in a venturi scrubber (Venturi Scrubber, WC-907). The

[*] The fluidizing velocity is the linear velocity that would be attained by the fluidizing gas in the empty calciner vessel at the operating temperature and vapor space pressure. The fluidizing gas includes only the fresh air passing through the distributor plate. 
scrubbing solution is continuously recirculated by a pump (Scrubbing Solution Pump, WC-208A or WC-208B) to both the quench tower and venturi scrubber from a surge tank (Scrubbing Solution Surge Tank, WC-108). The absorption of nitrogen oxides and dissolution of the alumina results in an acidic aluminum-nitrate scrubbing solution. The aluminum nitrate concentration in the scrubbing solution is controlled by adjusting the amount of scrubbing solution pumped back to the waste hold tanks to be mixed with each batch of waste feed solution. The liquid level in the scrubbing solution surge tank is controlled by adjusting the gas temperature at the outlet of the venturi scrubber; increasing this temperature raises the water content of the gas stream and lowers the level of the scrubbing solution in the surge tank. Two separators (Primary De-entrainment Cyclone, WC-908, and Secondary De-entrainment Cyclone, WC-910) have been provided after the venturi scrubber to minimize liquid entrainment into the following heater (Off-Gas Heater, WC-305). This heater adds 5 to $10^{\circ} \mathrm{C}$ superheat to the gas stream to prevent condensation in the downstream piping and vessels.

The only fission product found in the volatile form (Section VII-3) at the temperatures of the calcination process was ruthenium whose tetroxide has a normal boiling point of $135^{\circ} \mathrm{C}$. To remove the volatile ruthenium from the off-gas, four silica gel beds (Ruthenium Adsorbers, WC-110, WC-111, WC-112, and WC-113) have been provided. The volatile ruthenium tetroxide is adsorbed on the surface of the silica gel. The absorbers also remove a considerable portion of the fine solids escaping the entrainment separators following the venturi scrubber. Periodically, the silica gel is cleaned and regenerated by flooding with water, agitating with air, draining, and drying with heated air. The wash liquid, which is accumulated in a holding tank (Regeneration Solution Tank, WC-114) can be returned to the waste hold tanks or transferred to the main plant for evaporation and subsequent storage as low activity level waste.

Three filter units (Off-Gas Filters, F-2718, F-2723, and F-2724), each consisting of a prefilter and an AEC-type high efficiency filter housed in a stainless steel case, have been installed for final cleanup of the process offgas. Protection against filter damage by liquid carryover from the adsorbers during regeneration or condensation in the lines ahead of the filters is provided by a liquid separator (Off-Gas Knockout Pot, WC-133) and a steam heater (Off-Gas Reheater, WC-354) downstream of the adsorbers. Both the adsorber regeneration and filter replacement operations are carried out remotely while 
the plant is operating. From experience gained during the cold testing, it is anticipated that each adsorber will be regenerated about every 120 days while the filters will be replaced every 2500 hours. Pressure drop and activity buildup will be used as guides for determining the adsorber regeneration and filter replacement frequency.

All process vessels and cells drain into a common tank (Hot Sump, WC-119) in the WCF. The contents of this tank can be returned to the waste hold tanks or transferred to the main plant for evaporation and storage as low level activity waste. The hot sump, along with other vessels and equipment not connected directly to the process off-gas system; ie, waste hold tanks, feed tank. regenerating solution tank, and sampling cubicles, are vented to the ICPP stack through a centrifugal blower (Equipment Vent Fan, WC-252) which maintains a vacuum on the system. A condenser, liquid separator, superheater, and high efficiency filter have been provided in this system to clean up the gases before they are discharged to the stack.

Remote sampling stations have been provided for sampling the waste hold tanks, the scrubbing solution surge tank, the regeneration solution tank, and the hot sump tank. Samples of the calciner bed can be obtained with the small solids sampler $(15 \mathrm{cc})$ or the brlk solids sampler (one quart). A permanent gas sampling station has been installed to sample the off-gas going to the ICPP stack; another is installed at the ninety-foot level in the main stack.

\section{PRODUCT PROPERTIES}

\subsection{General Product Description}

Typical product expected to resuit from calcination of first cycle waste from WM-185 tank will contain approximately 91 percent $\mathrm{Al}_{2} \mathrm{O}_{3}$; volatiles and chemically stable forms of the fission products and other elements in the waste make up the remaining nine percent.

Properties of the radioactive product are expected to be similar to those of the non-active product generated in pilot plant calciners and in the WCF to date. Ranges of these product properties measured during pilot plant and WCF testing are shown in Table V-3; values anticipated for radioactive operation of the WCF also are shown. The granular product of this process consists of spheroidal particles varying in size, mostly from 0.1 to $1.5 \mathrm{~mm}$; it is free flowing and is readily conveyed pneumatically through long pipe lines. Product 
RANGE OF PROPERTY VALUES FOR ALUMINA CALCINER PRODUCT GENERATID IN WCF AND PILOT PLANT CALCINERS

\begin{tabular}{|c|c|c|c|}
\hline PRODUCT PROPERTY & PILOT PLANT TESTING $[10,13,14,15]$ & WCF TESTING [9] & $\begin{array}{l}\text { ANPICIPATED } \\
\text { FOR WCF } \\
\text { OPERATION }\end{array}$ \\
\hline Mass Median Particle Diameter, millimeters & $0.25-1.35$ & $0.2-0.7$ & 0.55 \\
\hline Alpha Alumina Content, percent & $0-85$ & $0-80$ & 0 \\
\hline Bulk Density, $\mathrm{g} / \mathrm{cc}$ & $0.54-1.6$ & $0.9-1.6$ & 0.95 \\
\hline Particle Density, $\mathrm{g} / \mathrm{cc}$ & $0.9-2.7$ & $1.5-2.7$ & 1.5 \\
\hline Absolute Density, g/cc & $2.6-3.8$ & $2.5-3.8$ & 2.6 \\
\hline Intra-Particle Porosity, percent voids & $5-60$ & $25-55$ & 41 \\
\hline \multicolumn{4}{|l|}{ Nitrate Content, percent } \\
\hline $300^{\circ} \mathrm{C}$ & $9-13$ & & \\
\hline $400^{\circ} \mathrm{C}$ & $4-8$ & $2-5$ & 5 \\
\hline $500^{\circ} \mathrm{C}$ & $3-6$ & & \\
\hline Water Content, percent & & $1-2$ & $1-2$ \\
\hline \multicolumn{4}{|l|}{$\begin{array}{l}\text { Mercury Content, percent of feed mercury re- } \\
\text { tained in product }\end{array}$} \\
\hline $400^{\circ} \mathrm{C}$ & $60-70$ & & $60-70$ \\
\hline $500^{\circ} \mathrm{C}$ & less than 15 & & \\
\hline $\begin{array}{l}\text { Ruthenium Content, percent of feed ruthenium re- } \\
\text { tained in } 400^{\circ} \mathrm{C} \text { product }\end{array}$ & nil to 67 & & $50-75$ \\
\hline \multicolumn{4}{|l|}{$\begin{array}{l}\text { Thermal Conductivity, (amorphous alumina) } \\
\operatorname{BTU} /(\mathrm{hr})(\mathrm{ft})\left({ }^{\circ} \mathrm{F}\right)\end{array}$} \\
\hline (e) $40^{\circ} \mathrm{C}$ & 0.08 & & \\
\hline$@ 800^{\circ} \mathrm{C}$ & 0.25 & & \\
\hline Attrition Resistance Index, percent & $5-98$ & $40-95$ & 95 \\
\hline
\end{tabular}

bulk density is in the range 40 to 95 percent of actual material density, and both amorphous and crystalline forms of alumina can be produced. The volume of the stored granular product of the WCF is expected to be in a range $1 / 10$ to $1 / 20$ that of the original waste solutions. The analytical methods used to determine properties of non-radioactive product from the pilot plant calciners and the WCF, including those which will be used for radioactive product from the WCF are listed in Table V-4. Specific information on the various product properties follows. 
ANALYTICAL TECHNIQUES FOR IDENTIFICATION OF PRODUCT PROPERTIES

\begin{tabular}{|c|c|c|}
\hline \multirow[b]{2}{*}{ Product Property } & \multicolumn{2}{|c|}{ Anelytical Technique } \\
\hline & Used For Non-Radioactive Product & To Be Used For Radioactive Product \\
\hline Product Size & Tyler Sieve [24] & $\begin{array}{l}\text { Remote Elutriation Pevice Similar } \\
\text { to Roller Analyzer [25] }\end{array}$ \\
\hline Alumina Structure & X-Ray Diffraction & Remote X-Ray D1ffraction \\
\hline Bulk Dens1ty & Untapped Bulk Density Techn1ques[6] & Remote Welghing \\
\hline Particle Density & Mercury Displacement & Will Not Be Determined \\
\hline Absolute Density & $\begin{array}{l}\text { Carbon Tetrachloride Displacement, Later } \\
\text { Replaced By Modifled Beckman Air Pycnometer }\end{array}$ & W1II Not Be Determined \\
\hline Porosity & Colculation & W1ll Not Be Determined \\
\hline Volatile Material & Weight Ioss on Heating to $1000^{\circ} \mathrm{C}$ & Will Not Be Determined \\
\hline N1trate Content & KJeldahl[24] & Remote Kjeldahl [24] \\
\hline Sodium Nitrate & $\mathrm{X}$-Ray Diffraction & W1ll Not Be Determined \\
\hline Sodium & Flame & W11l Not Be Determined \\
\hline Thermal Conductivity & Experimental Apparatus $[15]$ & Will Not Be Determined \\
\hline Leachability & Experimental Apparatus [19] & $\begin{array}{l}\text { Will Not Be Determined Except } \\
\text { During Special Studies }\end{array}$ \\
\hline
\end{tabular}

\subsection{Product Size}

The mass median particle diameter of calciner product has been found controllable within the desirable range of 0.25 to 0.60 millimeters ${ }^{[9]}$, although product with an average size up to 1.35 millimeters has been produced ${ }^{[10]}$. The average particle size of product is influenced by a complex mechanism of particle growth and attrition as discussed in Section VII-1.

When the mass median particle diameter of product in a bed becomes significantly greater than 0.6 millimeters, the resulting decrease in the overall heat transfer coefficient causes a reduction in the calciner throughput capacity. A mass median particle diameter less than 0.25 millimeters results in excessive elutriation of bed material, which in turn, can deplete the bed and expose the feed nozzles. At the WCF, fines elutriated from the calcination vessel and captured by the calciner cyclone will be combined with product on its way to solids storage to result in a stored material somewhat finer than the bed material. Typical size distribution data for the bed and stored material are presented on Figure V-4. 


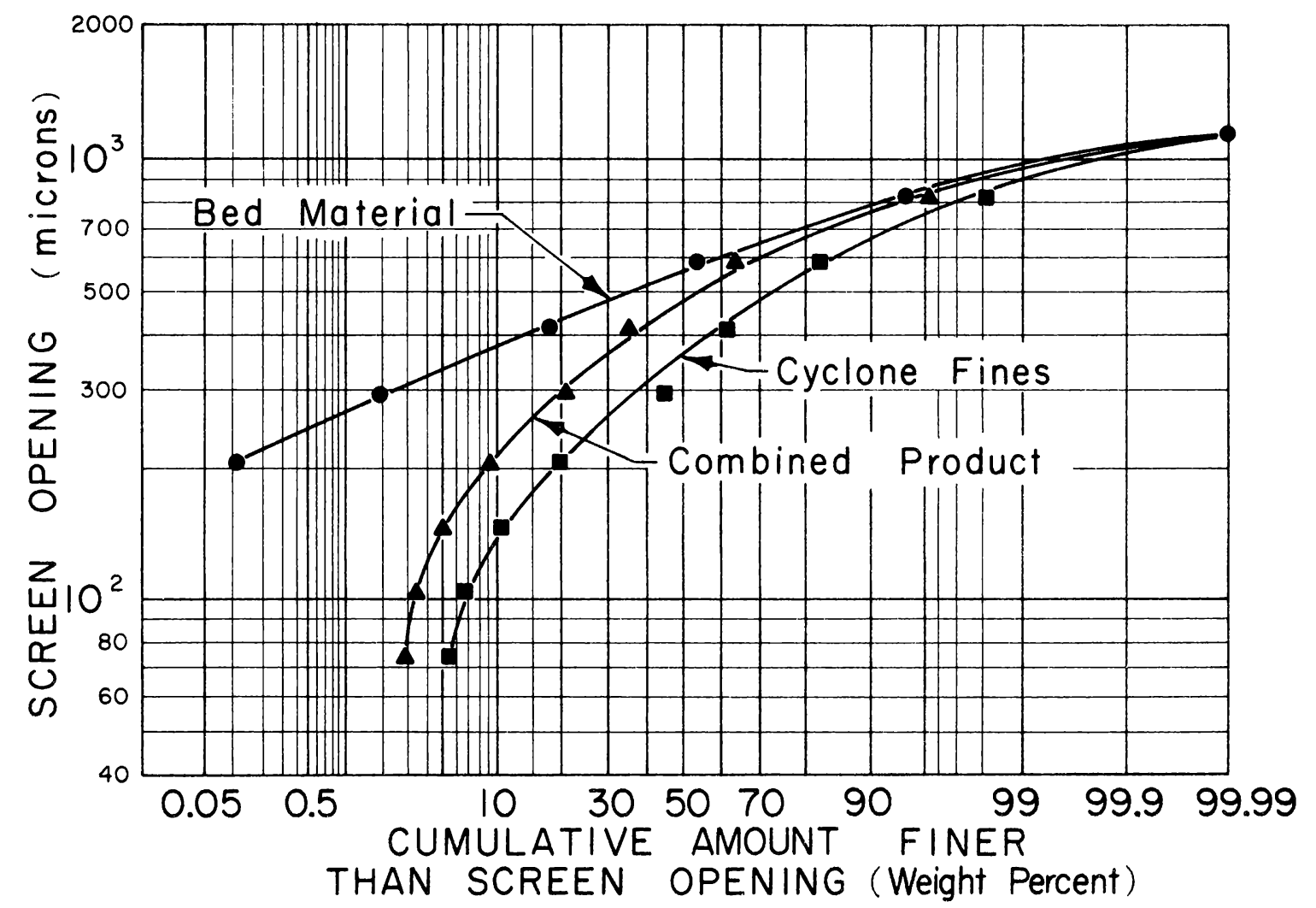

FIG, V-A SIZE DISTRIBUTION DATA OF CALCINED MATERIAL.

\subsection{Structure of Alumina}

The principal constituent of calciner product, alumina, has been produced as a mixture of varying proportions of amorphous and alpha crystalline forms, up to 85 percent alpha alumina ${ }^{[6]}$. The gamma and iota crystalline forms also have been produced on rare occasions in very small amounts.

Although less dense, the amorphous form of alumina is favored because it is soluble in dilute nitric acid - alpha alumina is not - and because the amorphous alumina is less frangible than the alpha form ${ }^{[10]}$. During all development work to date, formation of alpha alumina in a calciner has been accompanied by a reduction in the mass median particle diameter of particles in a fluidized bed and an increase in the elutriation rate of fines from the calcination vessel. High concentrations of alpha alumina fines in the off-gas scrubbing solution on early WCF runs [9] resulted in significant equipment erosion.

Although the extent and rate of formation of the alpha form is a complex function of temperature, product residence time, and probably other factors, satisfactory promotion and inhibition of the formation of alpha alumina have 
been found possible by addition of nominal quantities of inexpensive chemicals, eg, sodium nitrate or boric acid, to the feed (Section VII-1). The formation of alpha alumina with respect to fluidized bed calcination has been studied in detail at the ICPP as well as at the Stanford Research Institute ${ }^{[11,12]}$.

\subsection{Product Densities}

Bulk density is perhaps the most important factor affecting the economics of calciner product storage and, as applied in this work, is defined as the weight, in grams, of a cubic centimeter of poured, unpacked solid product. It is dependent on the inter-particle voids (essentially a constant for fluidizedcalciner bed product), the absolute material density, and the intra-particle porosity ${ }^{[10]}$. For material in a bed, bulk density is independent of product size over the size ranges normally encountered ${ }^{[6]}$. Some samples of bed material when combined with elutriated fines from the WCF occasionally have had bulk densities as high as 10 percent greater than the bed material; this indicates an optimum product size distribution does exist. However, because it would not be practical to attempt to control the exact size distriubtion of product transferred to storage, product bulk density can be optimized best by generating a material having a high absolute density with a minimum intraparticle porosity.

The inter-particle void fraction, or that volume not occupied by particles of "as-poured" granular alumina product, has been remarkably constant at a value of about 41 percent. This fact has been established by relating particle density values to those of bulk density, as shown in Figure V-5, for hundreds of samples of calcined alumina product of widely varying size ranges which were produced under widely varying operating conditions.

Apparent particle density is defined as the density, in $\mathrm{g} / \mathrm{cc}$, of the material which would be observed if the particles were covered with a weightless, dimensionless, impermeable membrane which would follow the surface contour, including the surface cracks and pores. The volume of intra-particle pores would thus be included in the volume used to compute this density value. Particle densities are obtained by measuring the volume of mercury forced into a volumetric container of product. The high interfacial tension between the mercury and the alumina minimizes penetration into the intra-particle voids; hence, the volume of mercury used in a test is actually a measure of the interparticle void fraction. From this volume and the weight of the sample, particle density can be calculated. 


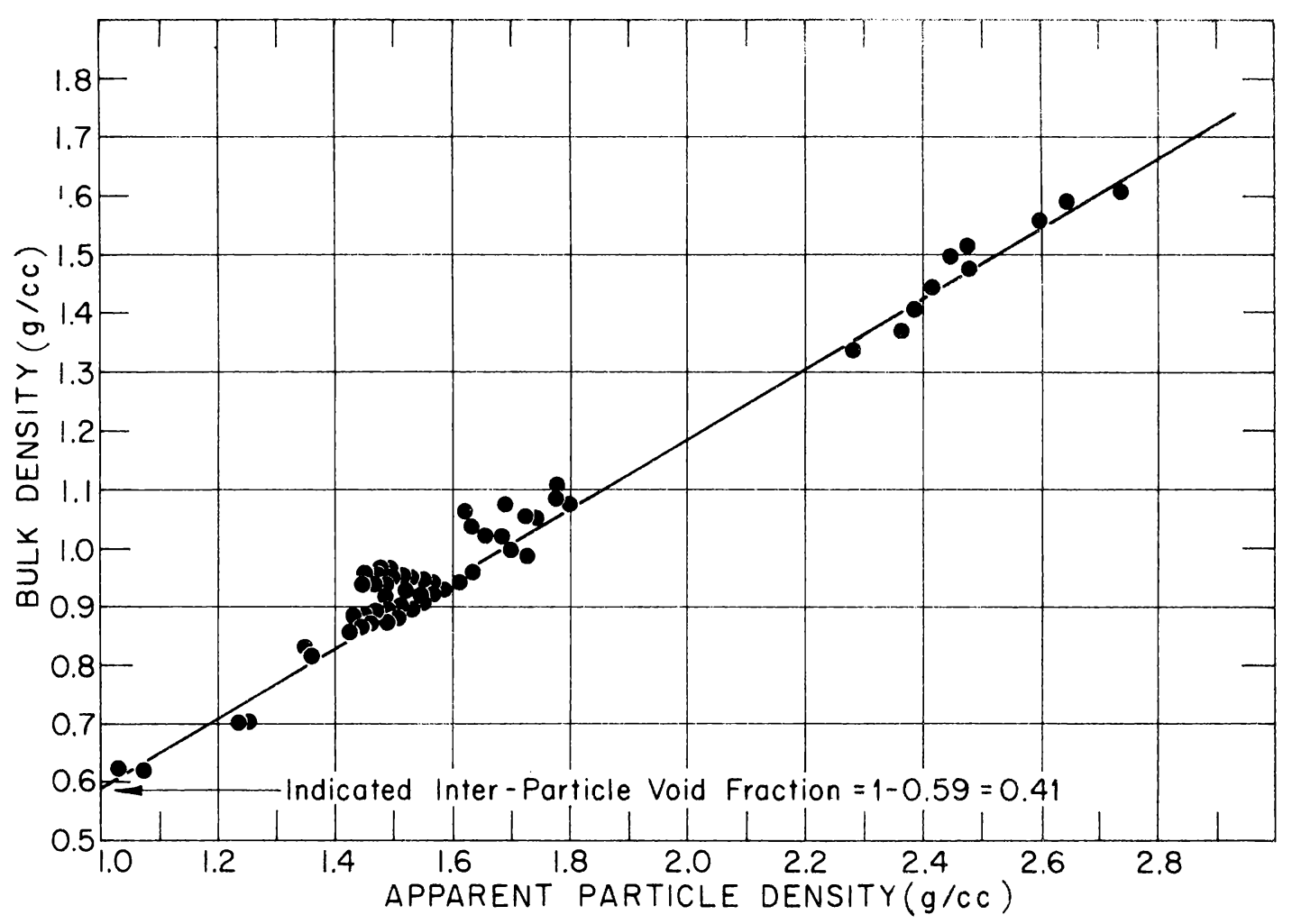

FIG, V-5 RELATIONSHIP OF PARTICLE AND BULK DENSITIES OF CALCINED MATERIAL.

The absolute density - that density of the basic material from which a product particle is formed, excluding all particle voids - of pure alpha alumina is $3.95 \mathrm{~g} / \mathrm{cc}$, while that of the amorphous alumina generated during development studies has been about $2.60 \mathrm{~g} / \mathrm{cc}$. The absolute density of the two forms of alumina has been found to vary essentially in a linear manner with the alpha alumina content ${ }^{[10]}$. Bulk density of the product, therefore, is significantly affected by its alpha alumina content. Absolute densities are determined currently by measuring the total void space, both inter andintra, of the product by a Beckman Air Pycnometer modified to use a helium purge.

Intra-particle porosity, the third factor affecting bulk density, was found during an extensive study to range from 5 to 60 percent depending on bed temperature and feed aluminum concentration ${ }^{[13]}$; although values in the range of 40 to 55 percent can be expected when calcining ICPP wastes in the WCF. Low porosity alumina results through use of an appropriate combination of low bed temperature and dilute aluminum concentration in accordance with the quantitative relationship shown on Figure V-6. Intra-particle porosities are calculated from values of particle and absolute densities ${ }^{[13]}$. 


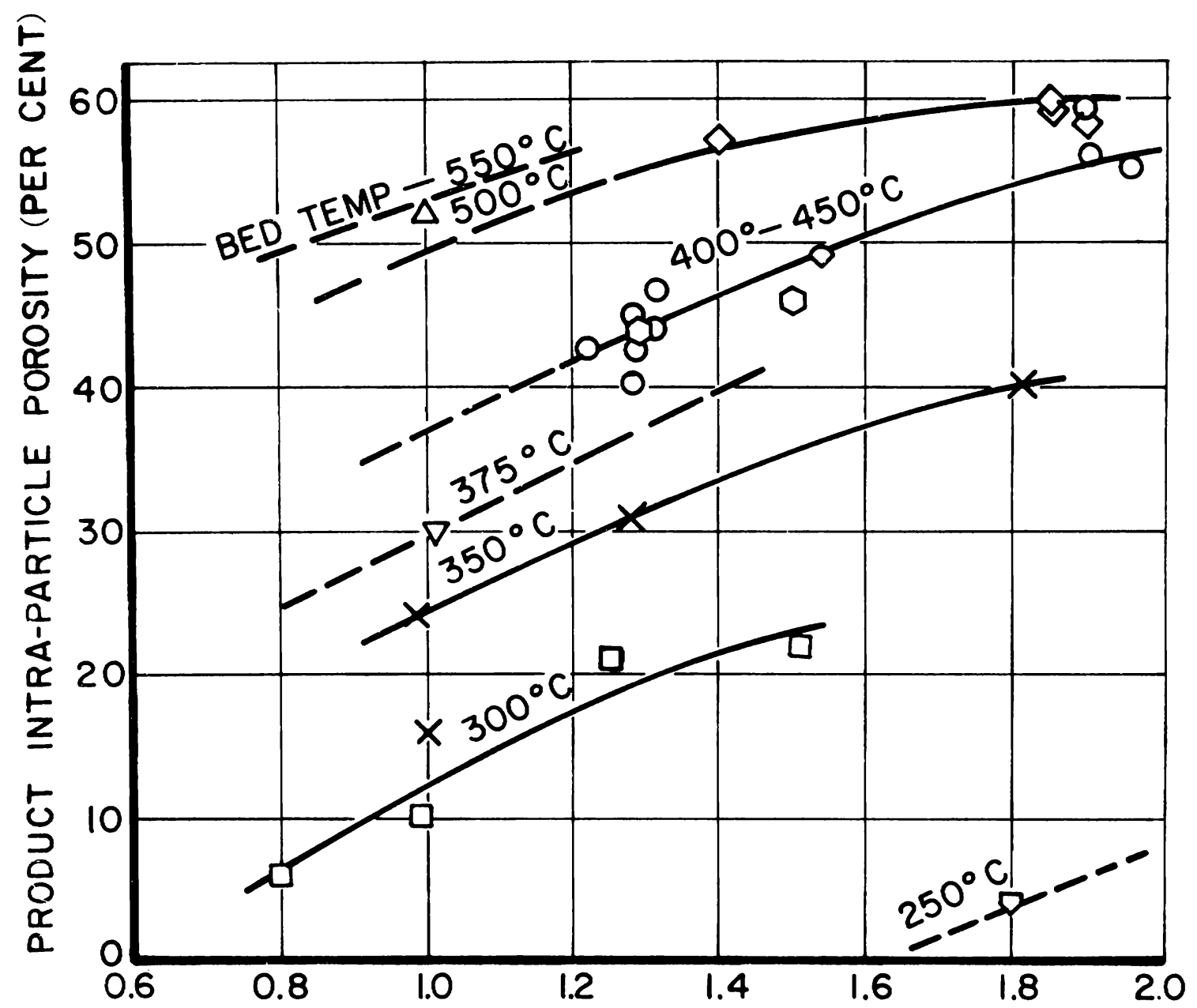

FEED ALUMINUM NITRATE CONCENTRATION (MOLARITY)

$\begin{array}{lll}\Delta-550^{\circ} \mathrm{C} & 0-\frac{\mathrm{KEY}}{425^{\circ} \mathrm{C}} & \mathrm{C}-350^{\circ} \mathrm{C} \\ \diamond-500^{\circ} \mathrm{C} & 0-400^{\circ} \mathrm{C} & \square-300^{\circ} \mathrm{C} \\ 0-450^{\circ} \mathrm{C} & \nabla-375^{\circ} \mathrm{C} & \nabla-250^{\circ} \mathrm{C}\end{array}$

(FEED SODIUM CONTENT-0.08-0.09M)

FIG. V-6 VARIATION OF CALCINE POROSITY WITH CALCINATION TEMPERATURE AND FEED CONCENTRATION.

\subsection{Nitrate and Water}

The nitrate plus water content (determined by weight loss upon heating to $1000^{\circ} \mathrm{C}$ ) of calciner product is affected both by the calcination temperature and by the crystalline form of the alumina. The relative amounts of nitrateto-water in calciner product are about two to one. Figure V-7 shows the variation of nitrate content with calcination temperature and crystalline form.

In addition, scanty data indicate a slight but noticeable effect of residence time in a calciner and sodium content of the feed on the nitrate content of a product. The relative magnitude of these effects has not been established. 


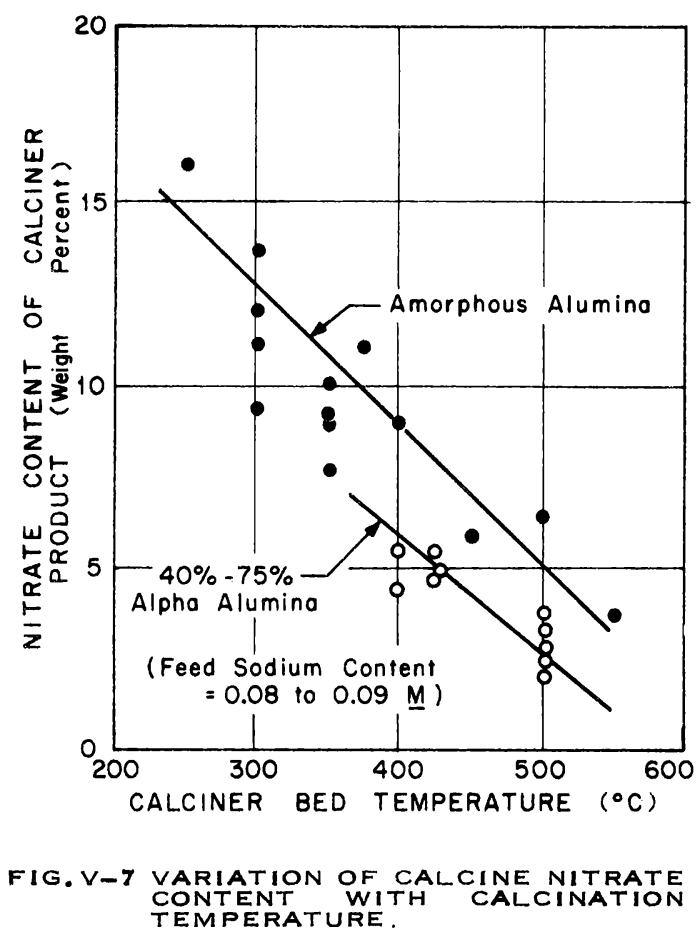

Solids produced from synthetic wastes, one sodium-free and the other containing 0.89 M sodium, had comparable amounts of nitrate ${ }^{[10]}$. During later runs, when the feed sodium concentration was $0.2 \mathrm{M}$, the nitrate content of the corresponding product was 75 percent higher than that created from a feed containing $0.078 \mathrm{M}$ of sodium.

Crystalline sodium nitrate has been detected at times (but not routinely) by $\mathrm{X}$-ray diffraction analysis of calciner product. It is believed that nitrate is usually present in a non-cry stalline form.

\subsection{Ruthenium and Fission Products in Solids}

The ruthenium content of calciner product is highly dependent on the operating conditions employed. Experimental studies show that retention of ruthenium in the product is significantly affected by both the calcination temperature and calcining atmosphere (Section VII-3). In the WCF, between 50 and 75 percent of the ruthenium is expected to remain in the product and be retained in the storage bins at the planned operating conditions.

Fission products other than ruthenium are expected to remain entirely with the product at WCF calcination and product storage temperatures. Ignition tests of alumina produced from high-level wastes at Argonne ${ }^{[14]}$ show no loss in gross gamma activity when heated to $700^{\circ} \mathrm{C}$; when heated to $1000^{\circ} \mathrm{C}$, depending on the original bed temperature and time of ignition, gamma losses between 1 and 11 percent were observed. When heated to $1200^{\circ} \mathrm{C}$, the calciner product showed a loss of up to 86 percent in gross gamma activity.

\subsection{Mercury Content}

Experimental data obtained at the ICPP ${ }^{[21]}$ indicate that between 60 and 70 percent of the feed mercury is retained by calciner product created at $400^{\circ} \mathrm{C}$; at $500^{\circ} \mathrm{C}$, less than 15 percent is retained by the product. The mercury content of calciner product appears to be independent of the feed mercury 
concentration and is believed, therefore, to be solely temperature dependent. No effect on calciner product or operating conditions have been linked to mercury in feed solutions.

\subsection{Thermal Conductivity}

Thermal conductivity is a property of considerable importance with respect to solids storage because the product must be maintained below some maximum temperature to prevent the volatilization of fission products and maintain the integrity of the bins. This temperature is a function of the specific activity and thermal conductivity of the solids, the configuration of the storage vessel, and the rate of heat dissipation from the vessel. The thermal conductivity of bulk amorphous alumina having a high intra-particle porosity has been found to vary linearly from $0.08 \mathrm{Btu} /(\mathrm{hr})(\mathrm{ft})\left({ }^{\circ} \mathrm{F}\right)$ at $40^{\circ} \mathrm{C}$ to approximately $0.25 \mathrm{Btu} /(\mathrm{hr})$ $(\mathrm{ft})\left({ }^{\circ} \mathrm{F}\right)$ at $800^{\circ} \mathrm{C}{ }^{[15]}$ as shown by Figure $\mathrm{V}-8^{[15]}$. Studies to establish quantitatively the thermal conductivity of alpha alumina and of low porosity amorphous alumina have not been completed for the temperatures encountered in the WCF. However, based on typical conductivities of other materials as reported by various investigators $[16,17,18]$, it is believed that their conductivities will be higher than that of porous amorphous alumina.

\subsection{Leachability}

In general, it is possible to leach

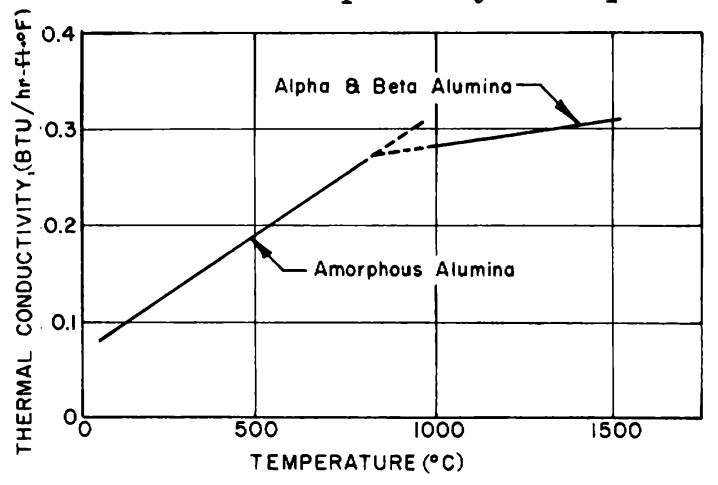
FIG. V-8 VARIATION OF CALCINE THERMAL CONDUCT

certaiis fission products from calciner product. It may be desirable to do so, at some future time, in order to minimize the possibility of contamination of ground water, to reduce heat generation in the stored product, or to utilize the fission products for commercial or experimental purposes.

Substantiating earlier work by McLain and Rhodes [19], Grimmett and Brown ${ }^{[22,23]}$ report that up to 60 percent of the cesium-137 and up to 80 percent of the strontium-90 in WCF calciner product can be leached with $0.5 \mathrm{M}$ nitric acid in a single stage of a countercurrent leaching process. McLain and Rhodes worked with spiked product having less than one percent of the cesium and strontium that will be in WCF calciner product while Grimmett and Brown used concentrations corresponding to the waste in WM-182. Grimmett and Brown show 
that removal of up to 99.9 percent of the cesium and strontium can be effected by using 7.6 and 2.8 theoretical contact stages, respectively. The leachability of fission products in various solutions with respect to water was determined by McLain and Rhodes, and is summarized in Table V-5.

\section{$\underline{\text { TABLE V }-5}$}

\section{IEACHABILITY OF GAMMA EMITTERS FROM CALCINER} PRODUCT BY VARIOUS SOLUTIONS [13]

\begin{tabular}{|c|c|c|}
\hline $\begin{array}{l}\text { Leaching }[a] \\
\quad \text { Solution }\end{array}$ & Molarity & $\begin{array}{c}\text { Leachability of Gross Gamma Emitters } \\
\text { Relative to Water }\end{array}$ \\
\hline Water & & 1.00 \\
\hline Hydrochloric Acid & 0.5 & 1.23 \\
\hline Nitric Acid & 0.5 & 1.19 \\
\hline Ammonium Acetate & 1.0 & 1.16 \\
\hline Ammonium Acetate & 8.0 & 1.15 \\
\hline Sulfuric Acid & 0.5 & 1.12 \\
\hline Hydrofluoric Acid & 0.5 & 1.07 \\
\hline Versene & 0.001 & 1.04 \\
\hline Versene & 0.01 & 0.97 \\
\hline Cyquest-40 & $1 \%$ by Volume & 0.92 \\
\hline \multicolumn{3}{|c|}{$\begin{array}{l}\text { [a] Calciner product produced at } 400^{\circ} \mathrm{C} \text {, contacted by leaching solution } \\
\text { at } 250^{\circ} \mathrm{C} \text { for one hour. }\end{array}$} \\
\hline
\end{tabular}

\subsection{Attrition Resistance}

Product attrition occurs mostly as a breaking off of small irregularly shaped particles from the outer portion of granules in the fluidized bed ${ }^{[10]}$. In order to compare the relative attrition resistance of various calciner products generated under different conditions, a standard empirical test for attrition resistance index was developed, based on a method advanced by Forsythe and Hertwig ${ }^{[20]}$. The attrition resistance index is the percent original material that remains unchanged in size after the test. Although there is significant scatter in the data, the attrition resistance index for a high-alpha content alumina is much lower than for a low alpha content alumina, indicating a greater breakup of particles. Typical index values for amorphous alumina produced from feed solutions containing boric acid have been in a range 92 to 
98 percent unchanged in size; material with less than 10 percent alpha has an index in the 80 to 96 percent range, and material having an alpha content greater than 30 percent has an index in the 5 to 75 percent range.

\section{ACTIVITY OF AND HEAT GENERATION}

BY FISSION PRODUCTS IN WCF PRODUCT

Except for ruthenium, which is volatile in the calciner, the fission products will appear in the WCF product at the same ratio of aluminum to fission products that exists in the waste being processed. Using this basis and an estimated alumina content in the solids of 91 percent, the fission product activities of the present ICPP wastes and a theoretical fresh waste (Section V-1) have been converted to curies per pound of solids in Appendix A. The total activities of solids produced from existing first-cycle wastes are presented on Figure V-9; the total activity and individual fission product activities in solids produced from the theoretical fresh waste are presented on Figure V-10. In these calculations, it was assumed that 100 percent of the ruthenium would appear in the product. The actual activities of the solids would be lower than the calculated activities, the extent depending upon the degree of ruthenium volatilization (Section VII-3).

The rate of heat generation by the decay of fission products in the solids is an important factor determining the design of the solids storage bins, and also is of interest when analyzing the hazards of shutting the calciner down without unloading the bed. The heat generation rates for the solids have been calculated in Appendix B using fission product decay energies taken from the literature and assuming that all the radiation is dissipated within the solids. The heat generation rates calculated on this basis would be higher than actually experienced; the error decreases as the bulk of solids increases. The assumption that 100 percent of the ruthenium appears in the solids would also contribute to the difference between the calculated rate and actual rates. The heat generation rates for solids produced from the existing first cycle waste solutions are shown on Figure V-11; the same data for the theoretical fresh waste are shown on Figure V-12. 


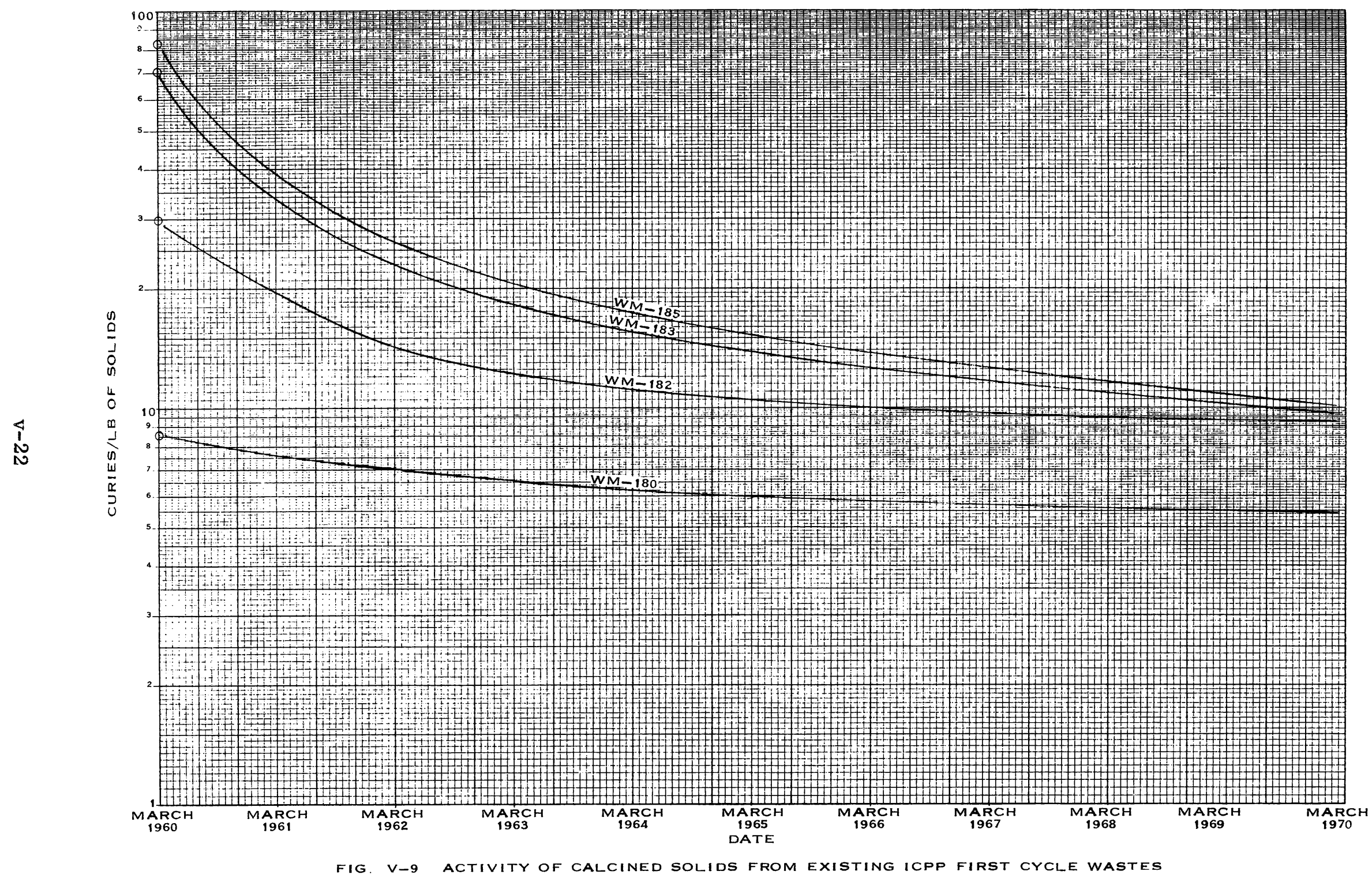




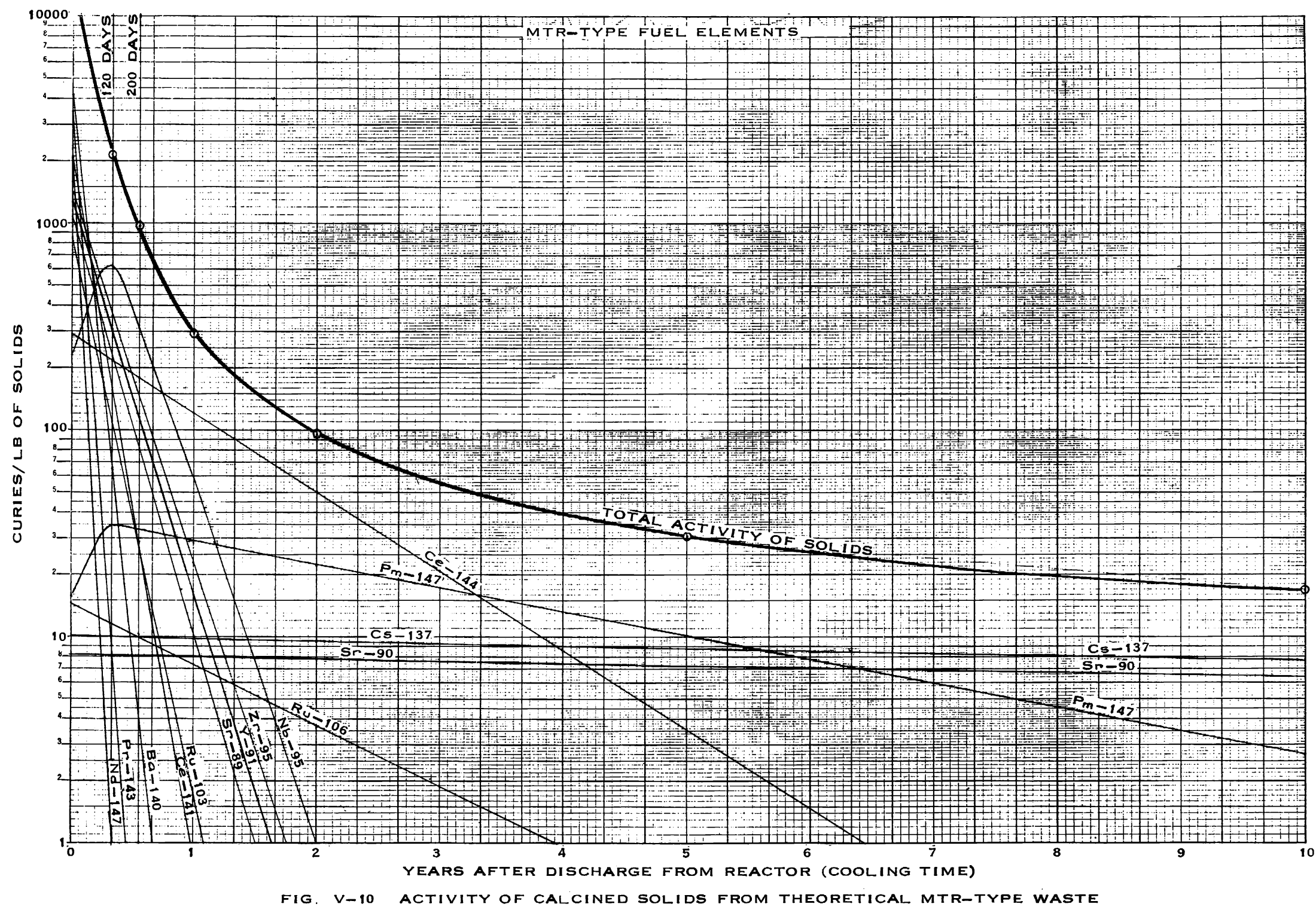




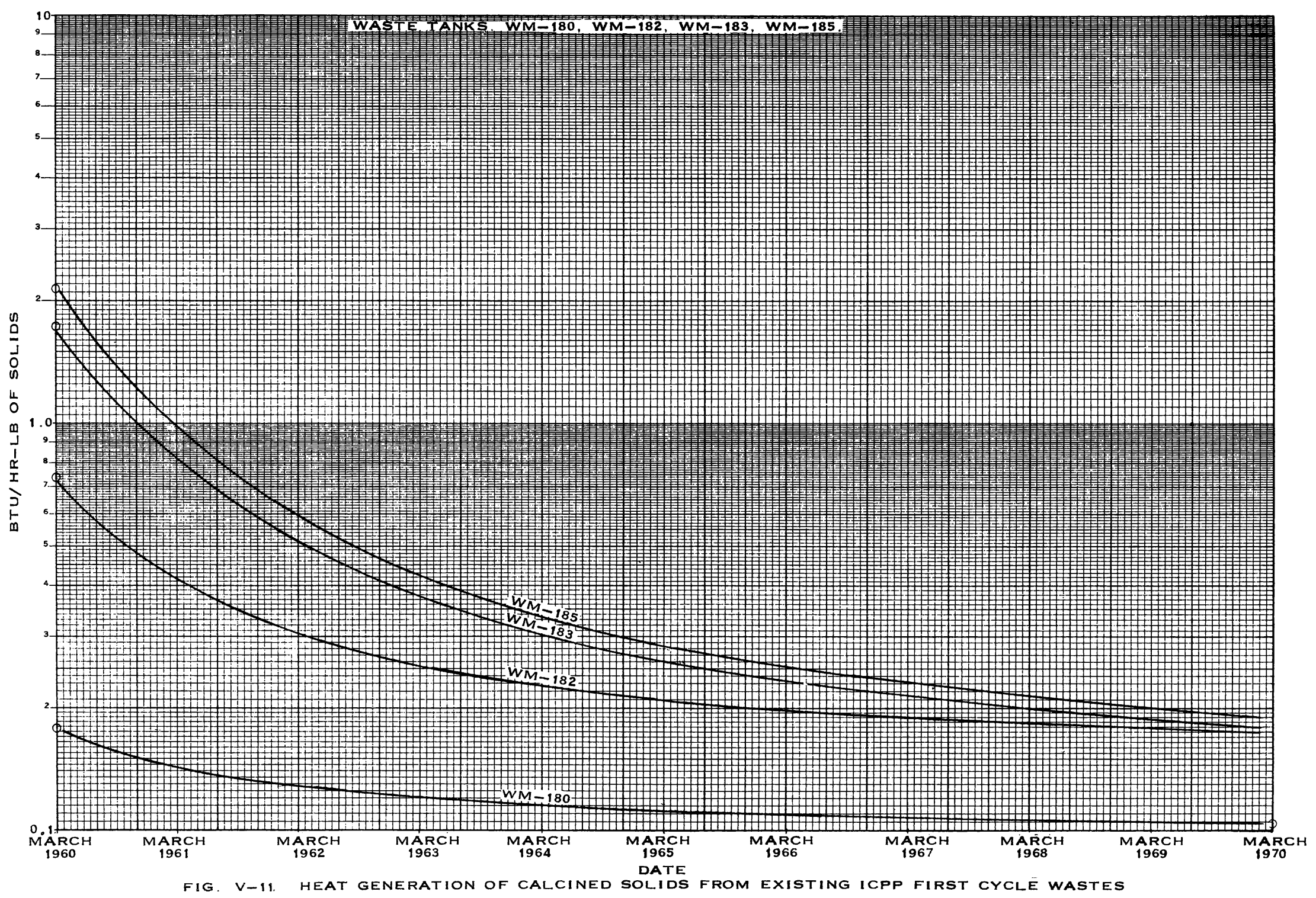




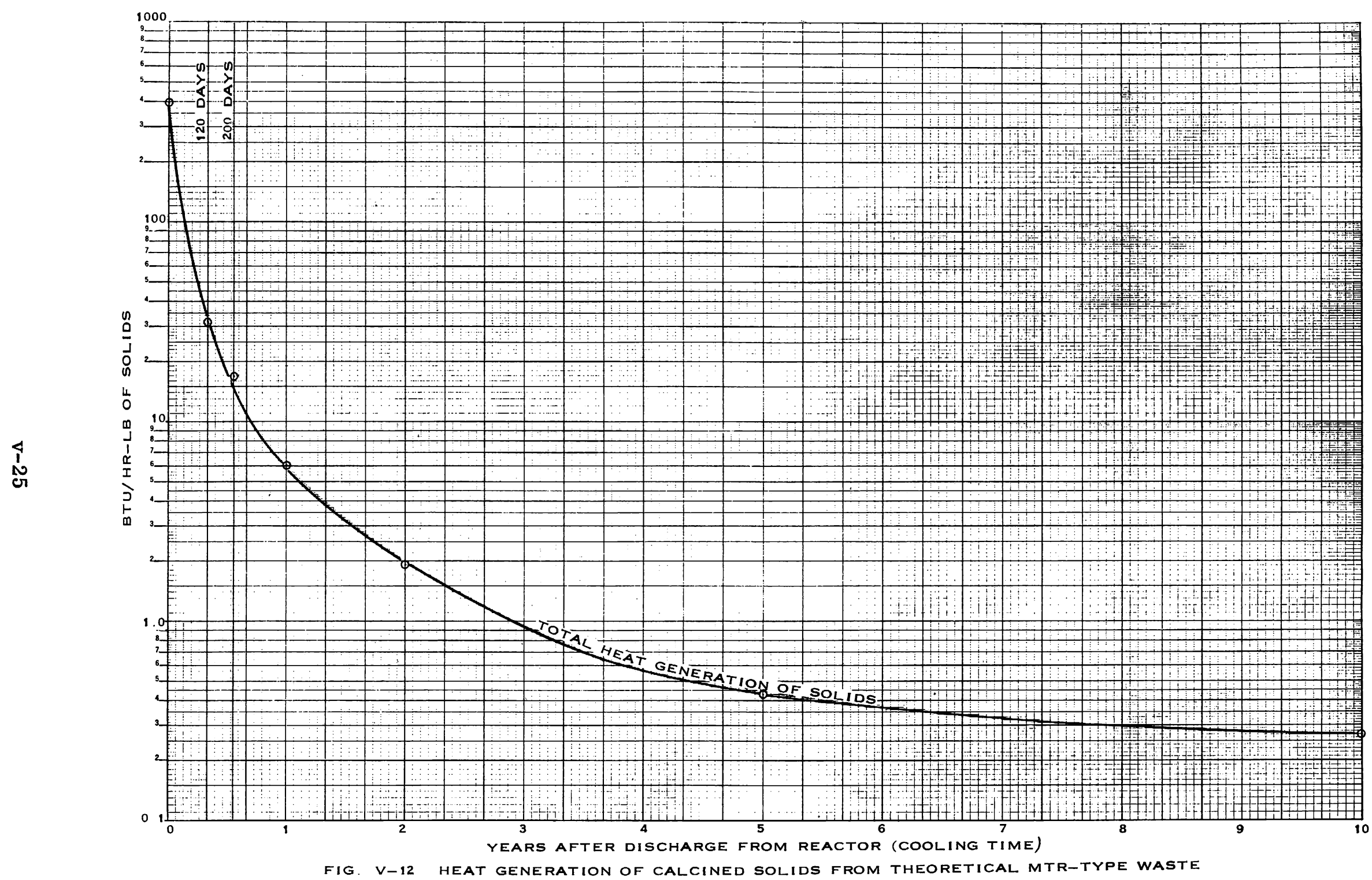




\section{RADIOACTIVITY LEVELS IN WCF PROCESSING CELLS}

The estimated amounts of activity that will be present in each of the WCF process cells during radioactive processing are shown in Figure V-13. Three cases were considered: (a) processing WM-185 waste tank, (b) processing an MTR-type waste containing fission products two years out of the reactor, and (c) processing an MTR-type waste containing fission products 200 days out of the reactor. The processing portion of the facility is designed to handle a 200day cooled waste while the first storage bins were designed for a two-year cooled waste.

The activity levels shown in the solids storage vault were determined for the completely full bins. The activity levels in the adsorber cells were calculated for an adsorber solids and ruthenium loading corresponding to a 150 day interval between adsorber regenerations. The activity levels in the filter cells are based upon a filter loading of $0.6 \mathrm{lb}$ of solids on each filter (50 percent of an estimated maximum of $1.2 \mathrm{lb}$ per filter).

The activity levels in the other cells are based upon the maximum solids or liquid levels expected in the process vessels during normal operation.

\section{RADIOACTIVITY LEVELS IN WCF OPERATING AREAS}

A tabulation of the radiation levels expected at the critical external surfaces of the cells is given in Table V-6 for three types of waste solutions: 200-day cooled, two-year cooled, and tank WM-185 on October 1963. The shielding calculations are presented in Appendix I.

Radiation shielding at the WCF is furnished primarily by the process cell walls. All cells containing radioactivity are located underground and are enclosed by concrete walls varying from two to five feet thick. A Type C 3000 pound concrete was used in the walls. Direct radiation beams from the cells to personnel areas are prevented by the use of labyrinth-type doorways, off-set pipe sleeves through the process walls, and stepped hatches (Section IV). In a few instances where radioactivity-containing equipment lies outside a regular process cell, special shielding means have been employed. Lead is used around the sample gallery, around the electromagnetic feed meters, and in the access holes into the waste hold cell and the filter pipe tunnel. Surplus 16-inch naval gun barrels provide shielding for process lines between the off-gas scrubbing 


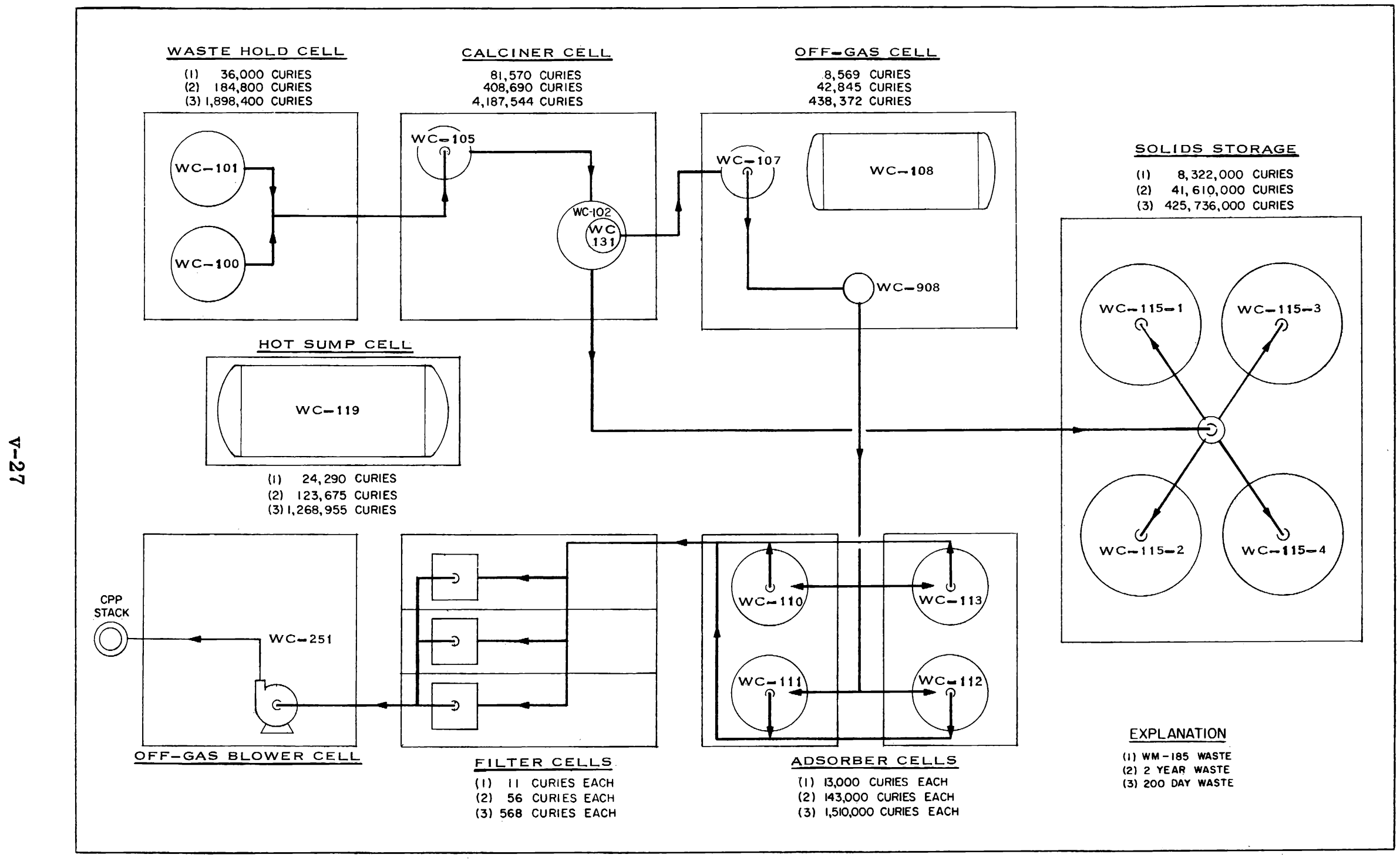

Fig. V-13 ESTIMATED ACTIVITY LEVELS IN WCF PROCESS CELLS 
SHIELDING AND CALCULATED RADIATION LEVELS AT CRITICAI LOCATIONS IN WCF

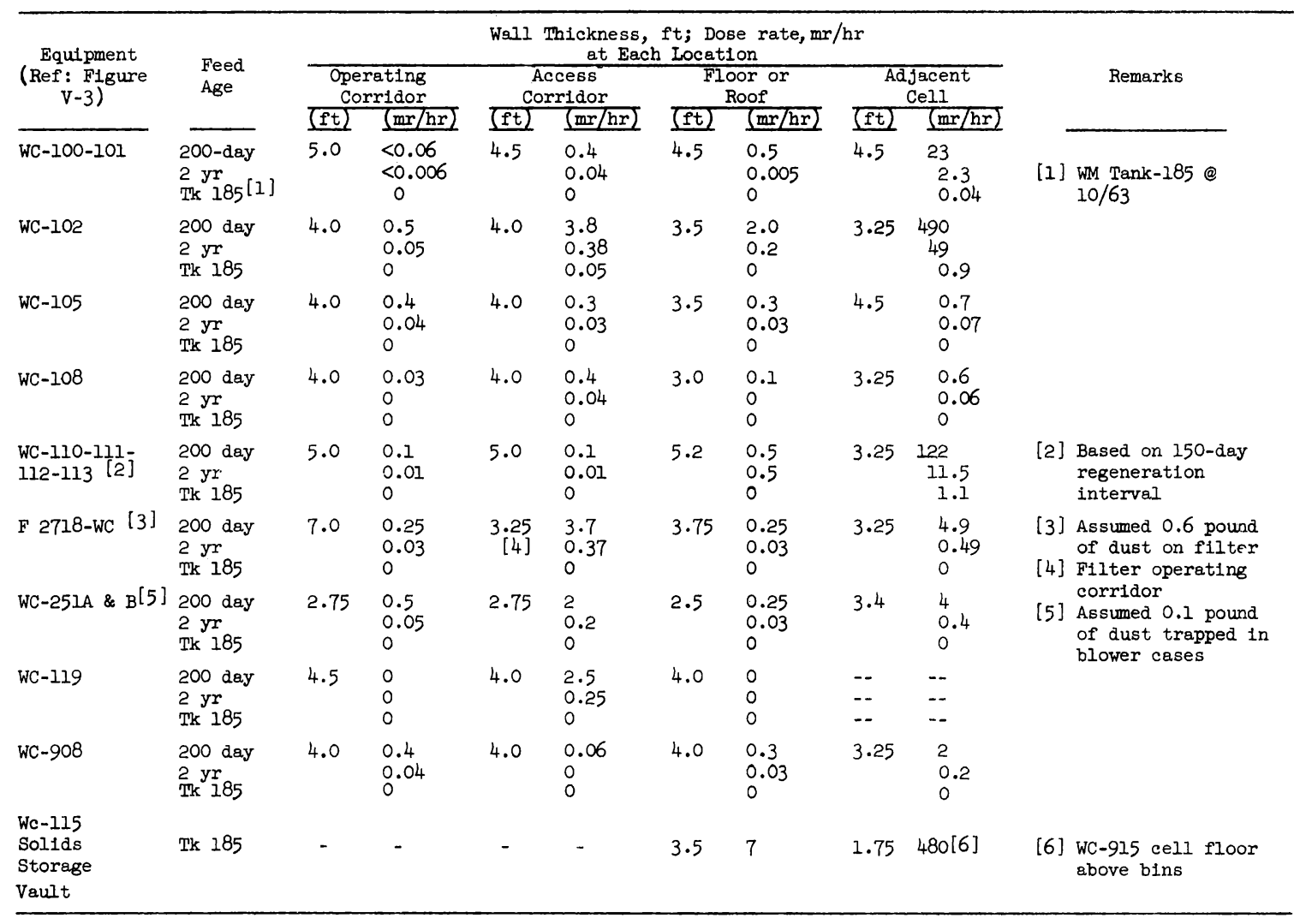

cell and the adsorber manifold cell. The only viewing ports provided at the WCF are three in the off-gas filter cells. The windows in these ports are of conventional design for radioactive service; ie, stepped construction, nonbrowning leaded glass. Outside walls of the processing cells and of the solids storage vault, which face the earth, are two-feet thick.

\section{TEMPERATURE DISTRIBUTION OF STORED SOLIDS}

The primary factor determining the shape of the storage bins for the WCF product is the need for removing heat generated by the attenuation of beta and gamma radiation resulting from the decay of fission products. The WCF bins (see Section VI for description of bins) have been designed to maintain all stored material, two-year cooled and older, below the calcination temperature $\left(\approx 400^{\circ} \mathrm{C}\right)$; this was done because of the uncertainty regarding the behavior of fission products at higher temperatures. Subsequent pilot plant data indicate that the 
solids can be raised to $700^{\circ} \mathrm{C}$ before any fission products begin to volatilize. The maximum temperature will occur in the center of a bin and depends upon the heat generation rate, the thermal conductivity of the alumina, the bin thickness, and the heat removal rate from the bin wall. Each of the four WCF bins consists of a 36-inch-diameter standpipe nested in two concentric 24-inchwide bins. Heat is removed from the bin surfaces by air flowing in the cooling air channels between the bins. Either natural convection or forced circulation can be used to move the cooling air; a $9000 \mathrm{scfm}$ blower is installed to provide the forced circulation. It is anticipated that forced circulation will be necessary to hold centerline temperatures below $400^{\circ} \mathrm{C}$ in the case of wastes less than about three years out of the reactor; natural convection will provide sufficient cooling for older wastes.

The temperature distribution of the stored solids has been calculated in Appendix C. To simplify the complex calculations, heat losses from the bin ends and radiation losses from the bins were ignored; therefore, the calculated temperatures would be somewhat higher than the actual temperatures.

Calculated temperature profiles with forced air circulation are shown in Figure V-14 for both two-year cooled solids and solids from WM-185 tank

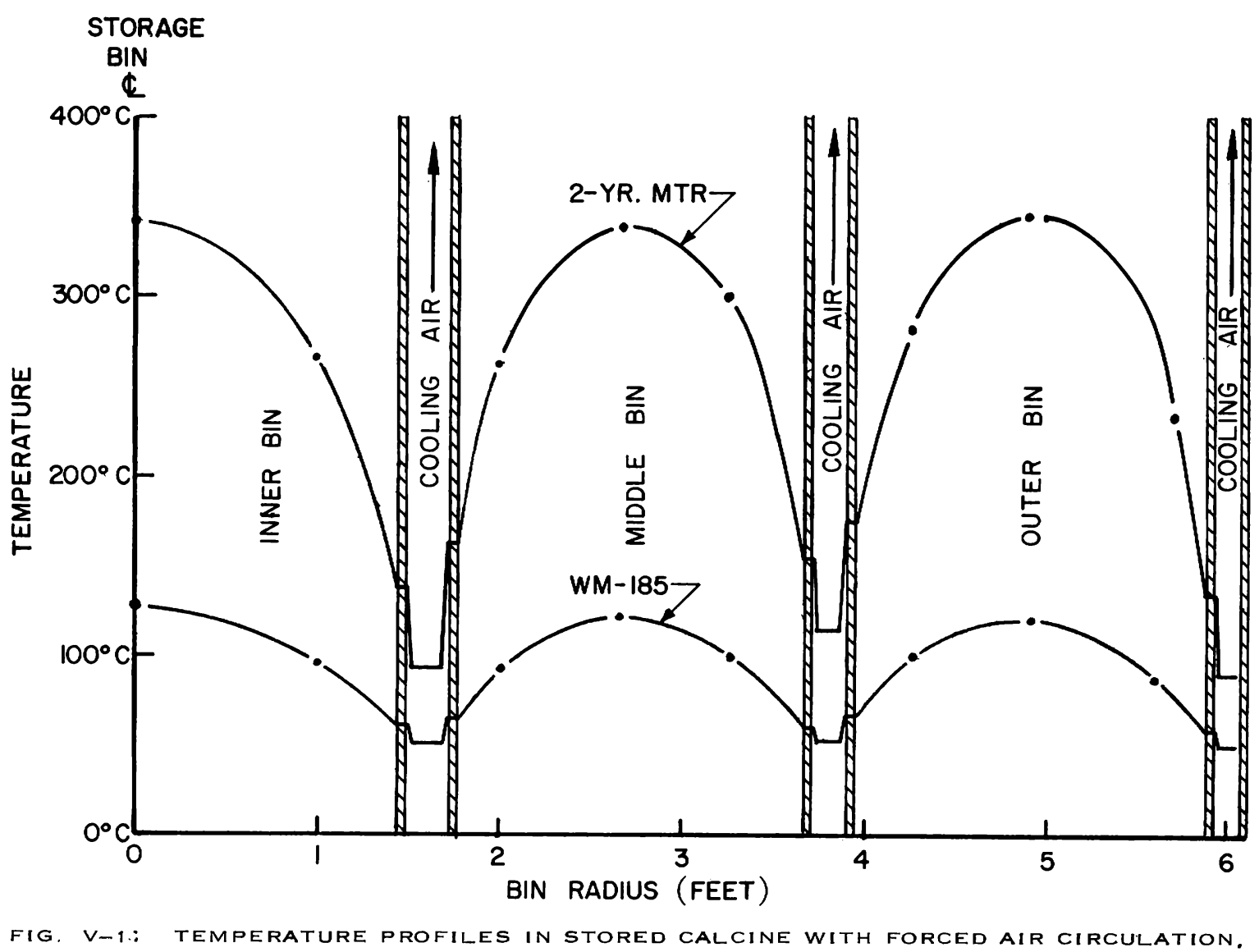


wastes - the first to be processed through the WCF. The maximum temperature obtained for a two-year cooled waste is $345^{\circ} \mathrm{C}$; that of wastes from $\mathrm{WM}-185$ tank is $128^{\circ} \mathrm{C}$. These values are higher than those actually expected because of the conservative assumptions made to simplify the calculations.

Calculated temperature profiles with natural convection cooling are shown in Figure V-15 for both two-year cooled solids and solids from WM-185 tank wastes. The maximum temperature obtained with two-year cooled solids is $459^{\circ} \mathrm{C}$; that of wastes from $\mathrm{WM}-185$ is $176^{\circ} \mathrm{C}$.

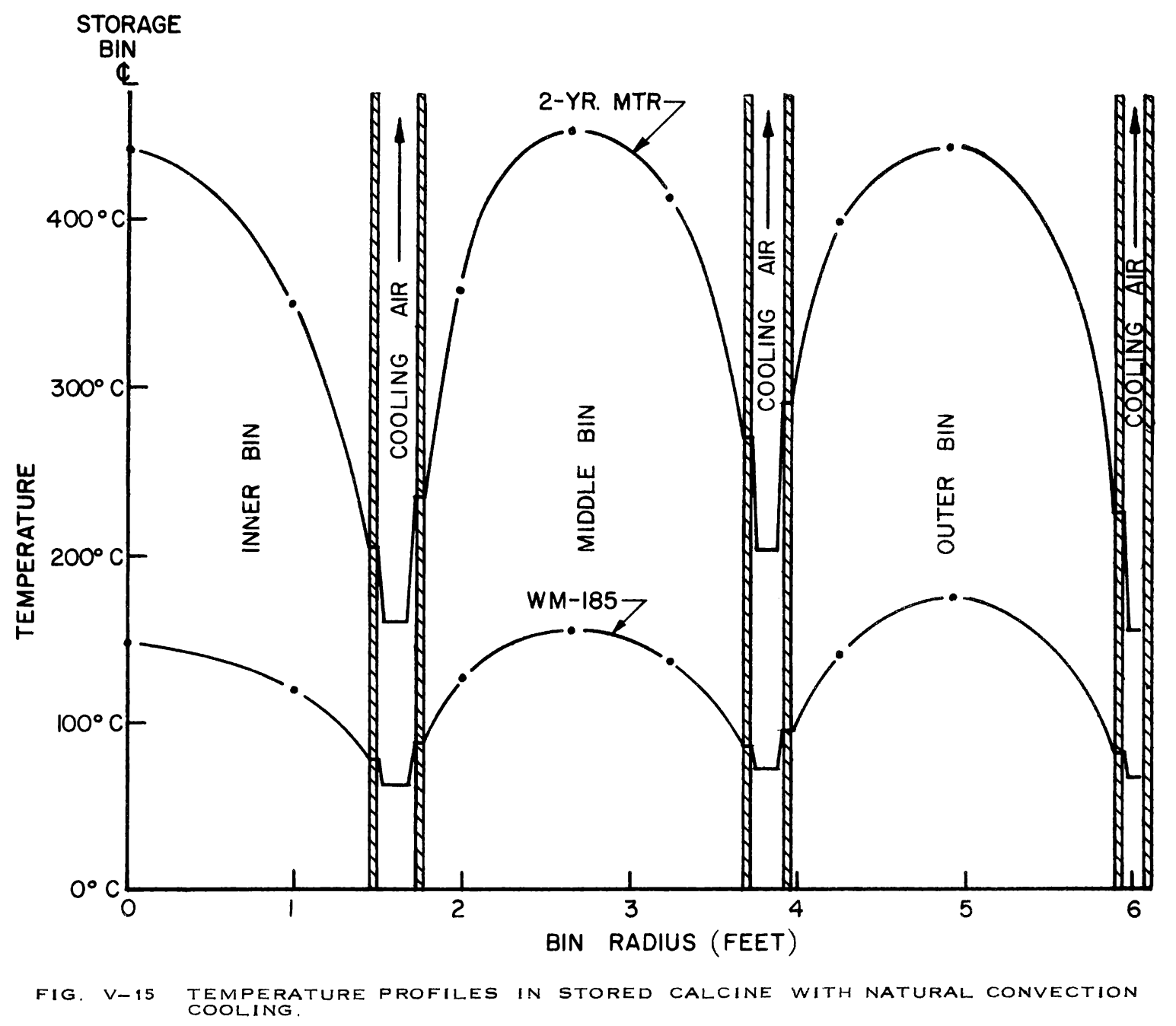

\section{REFERENCES}

1. V. W. Irvine, IDO-14277 (June 1954) (Secret).

2. Blaw-Knox Co. IDO-18003, September 15, 1955 (Secret). 
3. B. R. Wheeler, J. A. Buckham, Design of a Pilot Plant Facility for Radioactive Demonstration of the Pot Calcination Process, IDO-14596, p 34 (December 14, 1962).

4. J. O. Blomeke, M. F. Todd, Uranium-235 Fission Product Production as a Function of Thermal Neutron Flux, Irradiation Time, and Decay Time, Part 1. - Atomic Concentrations and Gross Totals, ORNL-2127, Pt. 1 Vol. 1 and 2 (August 19, 1957).

5. J. H. Perry, Chemical Engineers' Handbook, 3rd Edition, p 125, McGraw Hill (1950).

6. B. P. Brown, et al, Development of a Fluidized Bed Calcination Process for Aluminum Nitrate Wastes in a Two-Foot-Square Pilot Plant Calciner. Part 1. Equipment Development and Initial Process Studies, IDO-14586 (June 20, 1962).

7. J. R. Bower, Ed, Chemical Processing Technology Quarterly Progress Report, 4th Qtr 1961, IDO-14583, p 26 (March 28, 1962).

8. J. R. Bower, Ed., Chemical Processing Technology Quarterly Progress Report 2nd Qtr 1963, IDO-14621 (to be published).

9. W. P. Palica, L. T. Lakey, Development of Fluidized Bed Calcination of Aluminum Nitrate Wastes in the Waste Calcining Facility, IDO-14608 (to be published).

10. J. A. Buckham, et al, Development of the Fluidized Bed Waste Calcination Process, Paper presented at the Fiftieth National Meeting of American Institute of Chemical Engineers, Buffalo, New York, May 5-8, 1963.

11. R. F. Murray, D. W. Rhodes, Low Temperature Polymorphic Transformations of Calcined Alumina, IDO-14581 (September 28, 1962).

12. H. J. Eding, et al, Phase Transformations in Alumina, IDO-14580 (December 5, 1962).

13. B. R. Wheeler, et al, Development of a Fluidized Bed Calcination Process for Aluminum Nitrate Wastes in a Two-Foot-Square Pilot Plant Calciner. Part II. Factors Affecting the Intra-Particle Porosity of Alumina, IDO-14587 (July 25, 1962).

14. J. W. Loeding, et al, The Fluid-Bed Calcination of Radioactive Waste, ANL-6322 (May 1961).

15. P. N. Kelly, Thermal Conductivity of Alumina Produced by the Fluidized Bed Process, IDO-14592 (September 4, 1962). 
16. H. W. Russell, "Principles of Heat Flow in Porous Insulators", J. Am. Ceram. Soc., 18 (1935).

17. W. D. Kingery, M. C. McQuarrie, "Thermal Conductivity: I. Concepts of Measurement and Factors Affecting Thermal Conductivity of Ceramic Materials", J. Am. Ceram. Soc., 37, pp 67-72 (February 1954).

18. J. Francl, W. D. Kingery,"Thermal Conductivity; IX. Experimental Investigation of Effect of Porosity on Thermal Conductivity", J. Am. Ceram. Soc., 37 (February 1954).

19. M. E. McLain, D. W. Rhodes, Leaching of Fission Products from Calcined Process Waste, IDO-14440 (May 1958).

20. W. L. Forsythe, Jr., W. R. Hertwig, "Attrition Characteristics of Fluid Cracking Catalysts - Laboratory Studies". Ind. \& Engr. Chem., 41, Pt. 1, pp 1200-1206 (June 1949).

21. J. R. Bower, Ed, Chemical Processing Technology Quarterly Progress Report, 2nd Qtr 1963, IDO-14621 (1963).

22. J. R. Bower, Ed, Chemical Processing Technology Quarterly Progress Report, 1st Qtr 1960, IDO-14520 (September 1960).

23. J. R. Bower, Ed, Chemical Processing Technology Quarterly Progress Report, 2nd Qtr 1960, IDO-14534 (December 1960).

24. M. J. Shepherd, Jr., J. E. Rein, Manual of Analytical Methods Used by the Control Laboratory at the Chemical Processing Plant, IDO-14316 (January, 1955).

25. Subsieve Analysis of Granular Metal Powders by Air Classification, ASTM Designation B293-60. 


\section{EQUIPMENT DESCRIPTION}

\section{GENERAL DESIGN CONSIDERATIONS}

Maintenance, corrosion, and radiation are the major factors dictating the selection of construction materials and design features for the processing equipment used at the WCF. A "direct maintenance" concept is employed at the WCF, much the same as in the Idaho fuel reprocessing facility. This means that access must be provided so that maintenance personnel can work in the process cells. Exposure limitations on personnel greatly increase the cost of maintenance work performed under these conditions; therefore, all equipment must be as trouble-free as possible. Extensive quality control measures during fabrication, and the installation of duplicate systems are employed to achieve this high reliability.

Corrosion resistance is an important design consideration as the materials used must withstand not only the nitric acid atmosphere of the process but also the corrosive solutions used to decontaminate equipment. In the WCF, solids introduce a special problem of abrasion in a number of locations. The selection of materials for corrosion resistance at the WCF was made primarily from previous experience at the ICPP and other sites. Materials selected for both corrosion and abrasion resistance were selected generally upon experience gained during pilot plant or WCF testing of the calcination process. A summary of this experience at the WCF is given in Appendices $\mathrm{H}$ and $\mathrm{J}$.

Radiation protection at the WCF is provided primarily by the thick, concrete walls of the processing cells. Many other features of the facility and equipment also have been added for radiation safety. Welded construction with few flanges and operation of the process under a vacuum are two features that minimize opportunities for radioactive materials to leak into the cells. More equipment features and the general design considerations are presented in the following paragraphs.

\subsection{Materials of Construction}

Stainless steel is used extensively in the WCF process cells as a material of construction because of the corrosive nature of the acidic process and decontamination solutions. Compositions of the process solutions are shown on the process flowsheet (Figure V-3). While the problem to be met in decontaminating equipment containing large amounts of radioactive particulate 
matter remains undefined, experiences at the ICPP processing facility indicate that any of the following solutions [1] may be used for decontamination at some time: (a) 10 percent nitric acid, (b) 10 percent citric acid, (c) 10 percent oxalic acid, (d) 10 percent sodium hydroxide-2.5 percent tartaric acid, (e) 0.003 molar periodic acid, and (f) 20 percent nitric acid-3 percent sodium fluoride. Most of the process vessels and piping are fabricated of a low carbon stainless steel (type 304L) which has demonstrated satisfactory corrosion resistance and favorable economics in use in the Idaho reprocessing facility. In-cell valves are fabricated of either type 304L or type 347 stainless steel. Floor and wall liners, where used, also are made of type 304L stainless steel. Cell walls not covered by stainless steel have been covered with three coats ( 10 mils total thickness) of a modified phenolic paint, also used in the fuel reprocessing facility under similar service conditions.

The calciner vessel and cyclone, which are exposed to high temperatures over long periods of time, are fabricated of type 347 stainless steel. The presence of small amounts of columbium and tantalum in this type of stainless steel prevents carbide precipitation at high temperatures and the subsequent intergranular corrosion to which the type 304 stainless steel is subject. Type 316 stainless steel was selected for use in contact with liquid metal (NaK), primarily upon the experience and recommendations of other companies using such systems (Appendix E). Those surfaces of the NaK heat exchanger in contact with the fluidized bed are made of type 347 stainless steel or type 316 stainless steel also stabilized against carbide precipitation by the addition of columbium and tantalum. A cold trap is provided at the WCF to maintain the oxygen content in the $\mathrm{NaK}$ between 30 and 50 parts per million. If the oxygen content is maintained below 100 parts per million, no intergranular attack will occur and surface corrosion rates will be less than 10 milligrams per square decimeter per month (less than 0.65 mil per year) [5]. Thus unlimited life of the NaK piping system, from the corrosion standpoint, is expected. A NaK heating system containing several alloys, types 304 and 316 stainless steel and Carpenter 20, has been operated over 13,000 hours in a pilot plant calciner at the ICPP Chemical Engineering Laboratory with no evidence of corrosion. Two leaks that have occurred have been attributed to stress cracking [2].

In several locations throughout the processing cells, special materials are used in equipment subjected to abrasion. These include: 
(1) Type 440-C stainless steel - Early tests of a WCF feed nozzle in a pilot plant calciner indicated that abrasion of the feed nozzle cap (Figure VI-7) would be a problem. In WCF service, however, caps fabricated of titanium, type 347 stainless steel, and hardened 440-C stainless steel endured approximately 2000 hours of service with little abrasion taking place. Even so, caps of hardened 440-C stainless steel (Rockwell $\mathrm{C}=60$ ) have been installed for "hot" operation.

(2) ARMCO 17-4 PH and 17-7 PH stainless steels - Although not used anywhere in the facility as originally built, these hardened stainless steels were the best materials found for most applications requiring both abrasion and corrosion resistance, and have been used in a number of critical locations, eg, air distributor plate caps, valve trim. These applications are discussed in detail in Appendix H. (3) Boron carbide - During cold testing of the WCF, it was found desirable to transfer fines removed from the off-gas by the primary cyclone directly to solids storage, rather than returning the fines to the bed [4]. A jet (Figure VI-29) was subsequently designed to effect this transfer. Parts of the jet which are subjected to the severe abrasive action of the fines have been lined with boron carbide. The jet operated satisfactorily for 700 hours in the tenth WCF test run, experiencing no abrasion of the boron carbide [3]. (4) Silicon carbide - During the cold runs in the WCF, periodic inspections of the off-gas quench tower revealed that the type 347 stainless steel spray nozzles were worn severely by abrasion from solids carried in the off-gas scrubbing solution. These nozzles were replaced with nozzles having the same design but fabricated of silicon carbide. Inspection of the silicon carbide spray nozzles after 700 hours of use in the tenth WCF test run revealed no evidence of abrasion or other deterioration.

As an economy measure, the operator housings for all remotely operated valves have been fabricated of carbon steel or cast iron. These have been protected, however, by completely enclosing the housings in type 304 stainless steel cans as shown in Figure VI-1. Vessels and piping located in non-radioactive areas and not used in corrosive service also are fabricated of carbon steel. A straight chrome stainless steel, type 405, was selected over the austenitic 


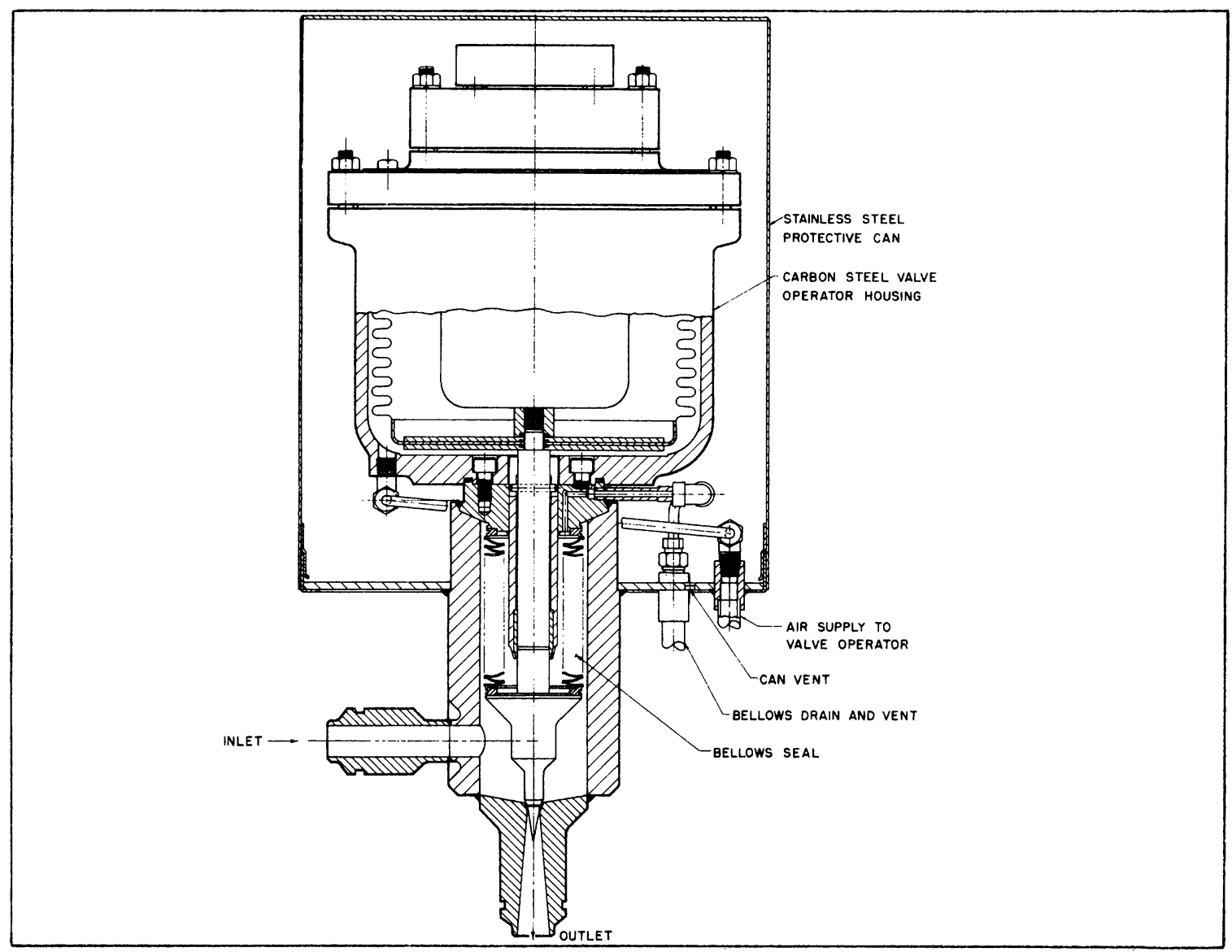

FIG. VI-I ENCLOSED BELLOWS SEAL VALVE

18-8 alloys for the storage bins because of the lower corrosion rates anticipated under the dry storage conditions.

Several types of gasket material are used in the WCF. In the most critical process location, the flanges on the scrubbing solution pumps, spiral-wound stainless steel gaskets using a Marlex [*] filler material will be installed. Flanges on the waste hold tanks, the quench tower, and the hot sump tank, also use a gasket of this type. In less critical locations with lower radiation exposure, eg, check valve bonnets, and off-gas blower piping, gaskets fabricated of calcium fluoride filled Teflon are employed. Unplasticised polyvinyl chloride gaskets are used on the flanges for the off-gas filter housings and the solids storage off-gas filter. Many factors - ease of decontamination, corrosion resistance, radiation resistance, effectiveness as a seal - were considered

[*] A trade name of Phillips Petroleum Company for its family of polyolefin plastics. 
when selecting the gasket materials for WCF service. Because of the limited data available on gasket decontamination and radiation deterioration, the gasket materials being used cannot be considered fully proved until actual service has shown them to be satisfactory.

\subsection{Quality Control}

During construction of the WCF and during the subsequent equipment modifications, extensive quality control measures were followed to minimize equipment failures which could lead to costly shutdowns and hazardous activity releases. These include:

(1) Specifications - All fabrication and material acquisitions were covered by specifications written by the construction contractor and approved by appropriate engineering-construction personnel of both the USAEC and the operating contractor. The requirements in the specifications, for the most part, conform to industrial standards, eg, ASME Boiler Code, Uniform Building Code, National Electrical Code. Requirements peculiar to the WCF were originated during the design phases by a special committee composed of technical representatives from the AEC, the operator, and the contractor. Inspection personnel, supplied by the construction contractor, checked for adherence to the specifications during the construction work. Included among these checks were the 100\% radiographing of process vessel welds and the dye penetrant tests on the welds in the process piping.

(2) Pressure Testing - All process vessels conform to the ASME Code for unfired pressure vessels, which includes a pressure test requirement, generally at one and one-half times the vessel design pressure. In addition, all piping systems in contact with radioactive material underwent a pressure test after the piping installation had been completed. Hydrostatic or air tests were made at pressures between 20 and 200 psi depending on limitations of equipment connected to the line. These were followed by halogen snifter tests in which Freon-12 with air was used for checking leaks.

\subsection{Special Equipment Features}

Certain features, common to most processing operations where radiation is a problem, have been utilized in the WCF. These include: 
(1) All valves located in a processing cell, or directly connected to equipment containing radioactive material, use a bellows seal over the stem packing to prevent leakage (Figure VI-1).

(2) Each line entering a process cell is provided with a bellowssealed block valve on the non-radioactive side of the cell wall. (3) All piping sleeves through a cell wall are installed with an off-set within the wall so a direct radiation path is not formed by the pipe.

\section{FEED SYSTEM}

\subsection{General Description}

The feed system receives waste from the underground storage tanks, blends this liquid with recycle solution generated in the off-gas scrubbing system, and meters the blended feed to the fluidized bed in the calciner vessel through atomizing feed nozzles. The system includes the following equipment (Figure VI-2) described later in more detail:

(1) Two waste hold tanks to receive and blend waste, recycle solutions, and to serve as a starting point in the feed loop.

(2) Two air lifts, one for each waste tank, transfer feed from the waste hold tank to a constant head gravity feed tank.

(3) A feed tank which provides a continuous source of feed at a constant head. The feed tank allows switching of the waste hold tanks without disrupting feed operations and acts as a disengaging pot for the airlifts.

(4) Three feed flow meters which measure and provide means of controlling the feed rate to each nozzle.

(5) Three feed control valves, one to control feed rate to each nozzle.

(6) Three feed nozzles which atomize the feed as it enters the calciner vessel.

A two-inch steam jet at each 300,000-gallon underground waste tank is used to transfer the waste through a three-inch underground line to an empty waste hold tank. The transfer rate is approximately $40 \mathrm{gal} / \mathrm{min}$. Recycle from the WCF scrubbing solution tank is pumped into the waste hold tank and mixed with waste feed in a ratio of about three parts waste to one part recycled scrubbing solution. 


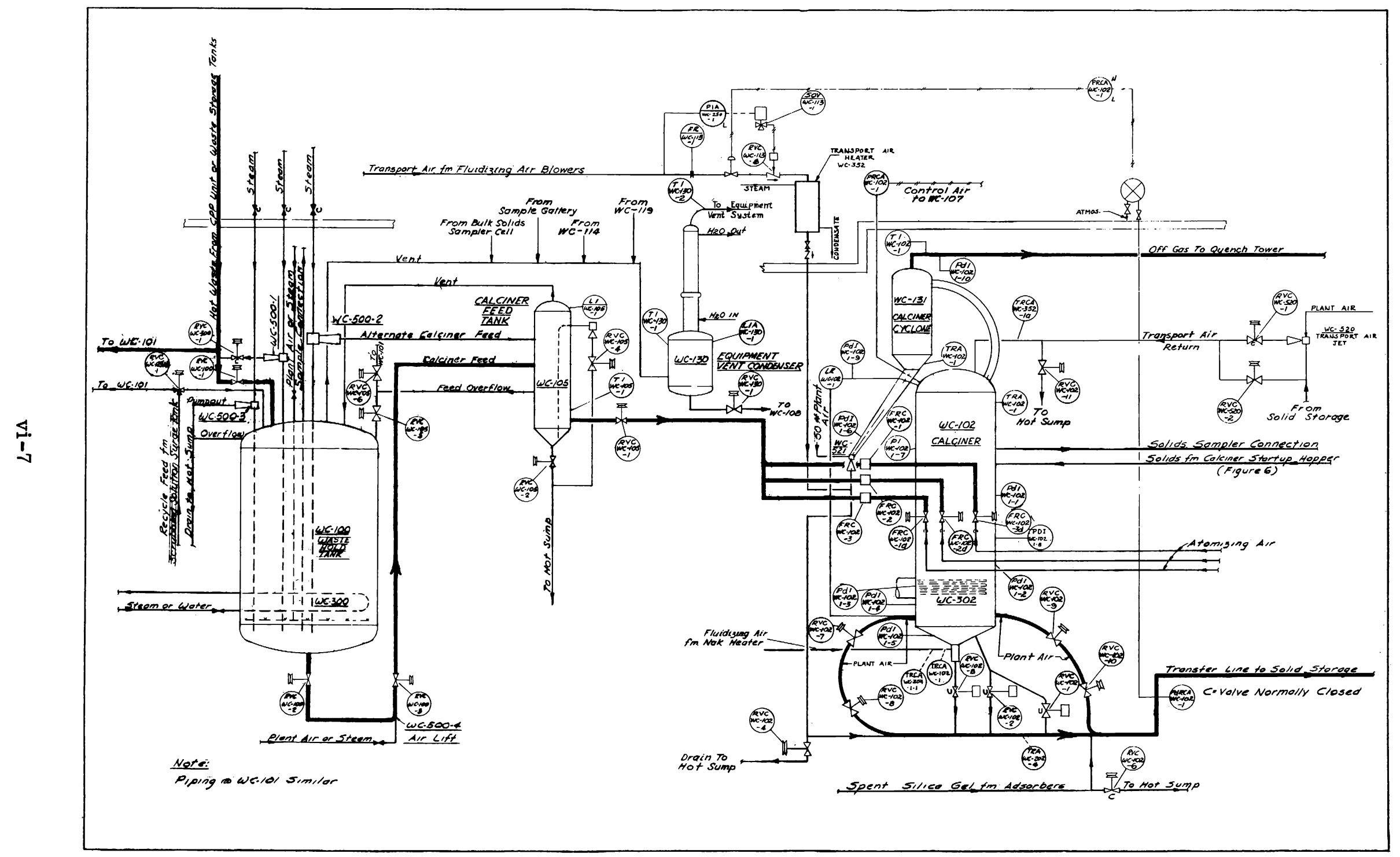

FIG. VI-2 CALCINER FEED SYSTEM FLOW DIAGRAM. 
Mixing is accomplished by sparging the tank with air. The feed solution is sampled and, unless further adjustment is needed, is ready for transfer to the feed tank. A tank of blended feed is sufficient for about 20 hours of operation.

Feed is transferred from a waste hold tank to the feed tank by an air lift. A constant head is maintained in the feed tank by an overflow; excess feed overflows back to the appropriate waste tank. Continuous operation is maintained by blending in one waste hold tank while the other is being emptied.

Solution leaves the feed tank through a single side outlet. The outlet line splits into three individual lines, in which the feed flows by gravity, at up to $40 \mathrm{gal} / \mathrm{hr}$ per line, through a magnetic flowmeter, through a control valve, and finally through a feed nozzle into the fluidized bed. Air, introduced at the feed nozzle, atomizes the feed in the calciner vessel.

\subsection{Waste Hold Tanks}

Two waste hold tanks, WC-100 and WC-101, permit blending feeds of different history, provide a point for sampling the calciner feed, and function as surge tanks to insure continuous operation of the calciner. The tanks are located in the waste hold tank cell and are mounted in a vertical position with the bottom tangent line approximately $3-1 / 2$ feet above the floor.

The waste hold tanks are vertical, cylindrical vessels, eight feet tangent to tangent, and 72 inches in diameter, equipped with standard flanged and dished heads. The tanks are constructed from 3/16-inch-thick type 304L stainless steel plate. All welds were radiographed and the tanks were hydrostatically tested at 122 psig. Design volume is 2090 gallons and operating volume is 1672 gallons, which is enough for 20 hours operation. The tanks are designed for pressures between -1.5 and +30 psig at $175^{\circ} \mathrm{C}$. The normal operating pressure is about -0.5 psig. Each tank is equipped with a cooling coil having a capacity of $43,000 \mathrm{Btu} / \mathrm{hr}$ to remove any heat generated by steam jets or fission product decay. Steam also can be supplied to the coil to heat the vessel contents. Each vessel has an air-steam sparger in the lower section and a decontamination sparger in the upper section. The tanks are vented to the equipment vent system which maintains the operating vacuum.

Sampling lines from the tanks to sample stations in the sample corridor permit samples to be drawn from either tank. Each tank is equipped with dip tubes for measuring liquid level and specific gravity and a thermocouple for measuring solution temperature. WC-100 also is equipped with a pressure 
indicator. The recording and indicating instruments are located on the main instrument panel in the operating corridor.

Each waste hold tank can be emptied by a steam jet to the hot sump tank. An overflow line also drains to the hot sump tank. By proper valving, the solution can be returned to the waste storage tanks or circulated within or between the hold tanks by steam jets. Each tank has a valve in the inlet line from the waste storage tanks which automatically closes at a high liquid level to prevent overfilling the tank.

A drawing of the waste hold tanks is shown in Figure VI-3.

\subsection{Airlifts}

Two air lifts, WC-500-4, and WC-501-4, one for each tank, are used to transfer feed from the waste hold tanks to the feed tank. The air lifts are in a pit about five feet below the floor level in the waste hold tank cell. The low level of the pit provides enough submergence for good operation of the air lifts. A remotely operated block valve is located on the inlet and outlet of each air lift to permit the lines from the waste hold tank or to the feed tank to be flushed. Air flow to the air lift is regulated through a rotameter in the operating corridor.

The air lifts and associated feed piping are fabricated of type 304L stainless steel. The feed line is two inches in diameter from the waste hold tank to the upward bend from the pit. A 2- $x$ 1-1/2-inch reducer is welded in the line at this point. A 3/4-inch air supply line reduces to $1 / 2$ inch about 4 inches before entering near the bottom of the 2-inch feed line. The air line extends about 4 inches upward in the feed line to direct air flow in that direction.

A sketch of an air lift and its associated piping is shown in Figure VI-4.

\subsection{Feed Tank}

Feed is normally transferred from the waste hold tanks to the feed tank, WC-105, by the air lifts through a 1-1/2-inch line. A steam jet on each waste hold tank serves as an alternate feed transfer device. The feed tank provides a constant head of liquid feed at the calciner feed nozzle control valves. This is accomplished by overflowing excess feed back to the waste hold tanks.

The feed tank is located in the northwest corner of the calciner cell. The elevation of the feed inlet line is about 33 feet above the air lifts from the waste hold tanks. The feed tank is a vertical, cylindrical tank with a semielliptical head and a conical bottom. The straight sides are 3-1/2 feet tangent to tangent, and the inside diameter is 18 inches. It is constructed of $3 / 16$ inch type 304L stainless steel. The volume at overflow to the waste hold tanks is 


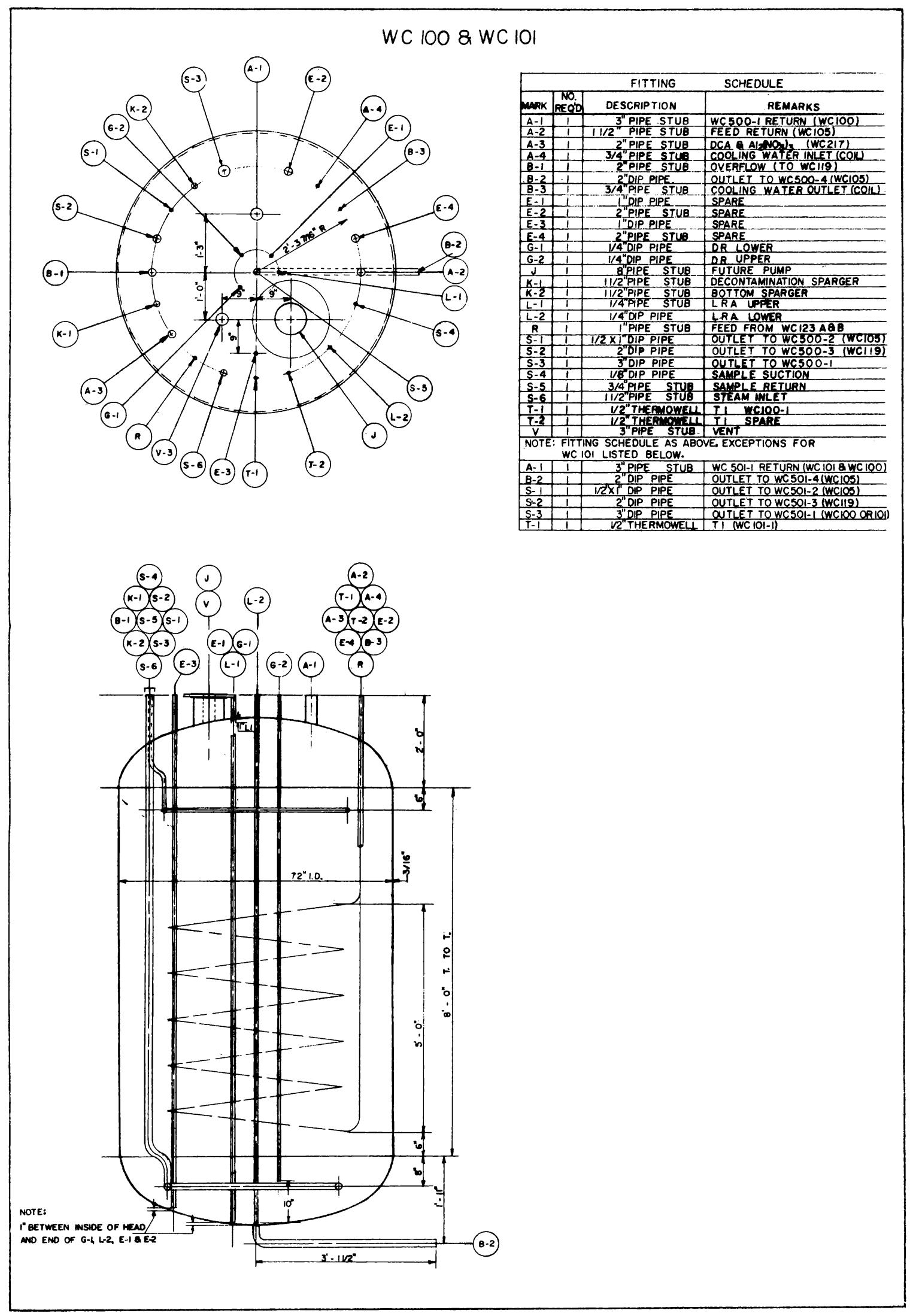

FIG. VI-3 WASTE HOLD TANK AND FITTING SCHEDULE, 


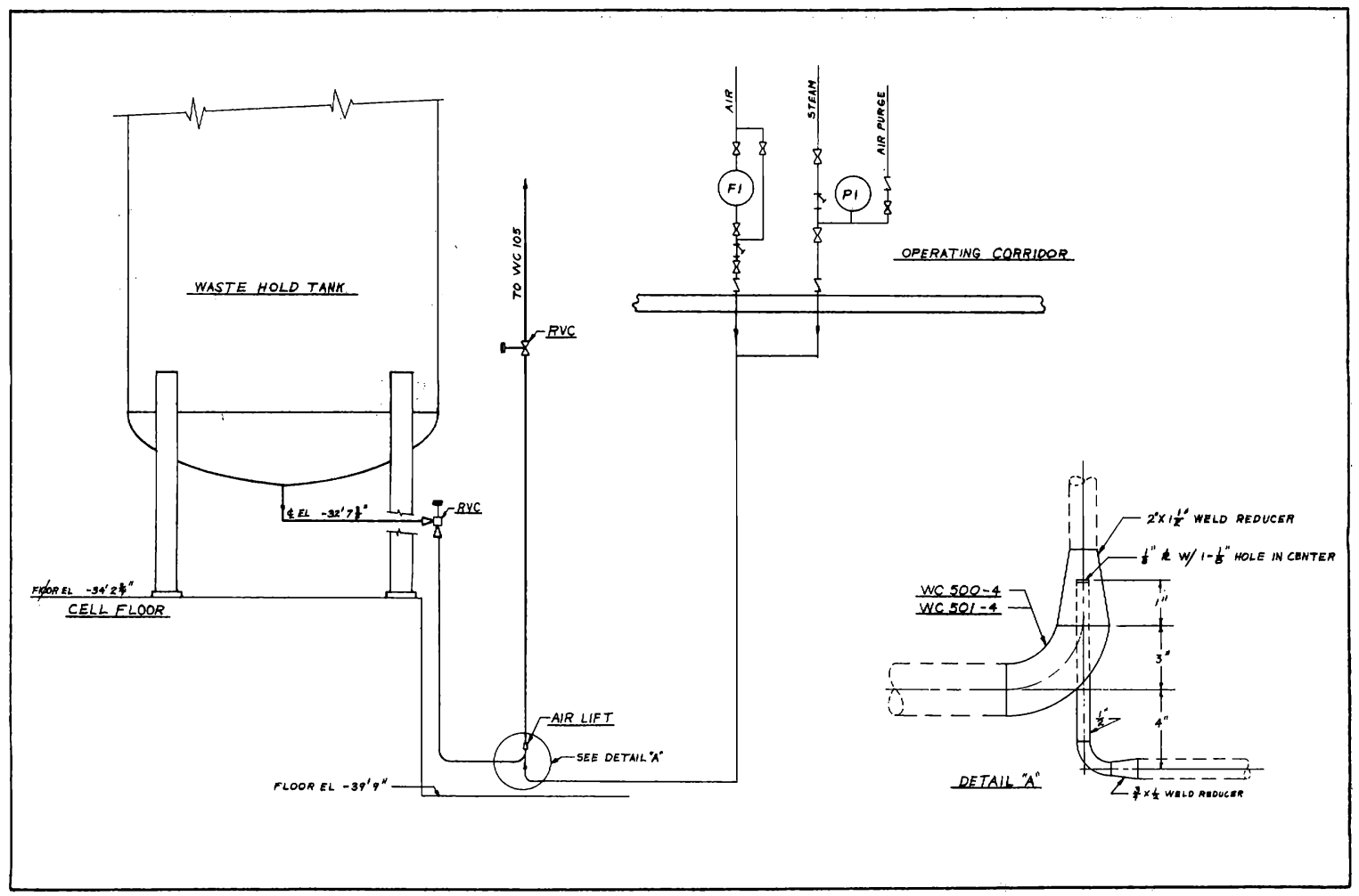

FIG. VI-4 FEED AIR LIFT AND ASSOCIATED PIPING.

about 39 gallons. It was designed for a pressure range of -1.5 to +30 psig and for temperatures up to $175^{\circ} \mathrm{C}$. The normal operating pressure is about -0.5 psig. There are steam and decontamination spargers in the top section of the vessel.

The air lifts discharge into the feed tank about six inches above the overflow level and six inches below the top tangent line. The outlet from the feed tank is located about six inches above the bottom tangent line of the tank to permit solids present to settle in the bottom of the vessel. The outlet line extends 15 inches inside the feed tank and is perforated with $7 / 32$-inch holes on a 3/8-inch triangular pitch to strain out any large particles which might otherwise plug the atomizing feed nozzles. A steam jet having a dip tube at the bottom of the feed tank is operated periodically to remove solids to the hot sump tank. The feed tank has a level indicator alarm and a temperature indicator. The indicating and alarm instruments are located on the operating corridor panel board. The tank is vented to the equipment vent system through waste hold tank WC-100.

The feed tank is shown in Figure VI-5.

\subsection{Magnetic Flowmeters}

Three Fischer Porter Model 10D1415A magnetic flowmeters are used for feed rate measurements. The flowmeter is a volumetric fluid flow rate device 


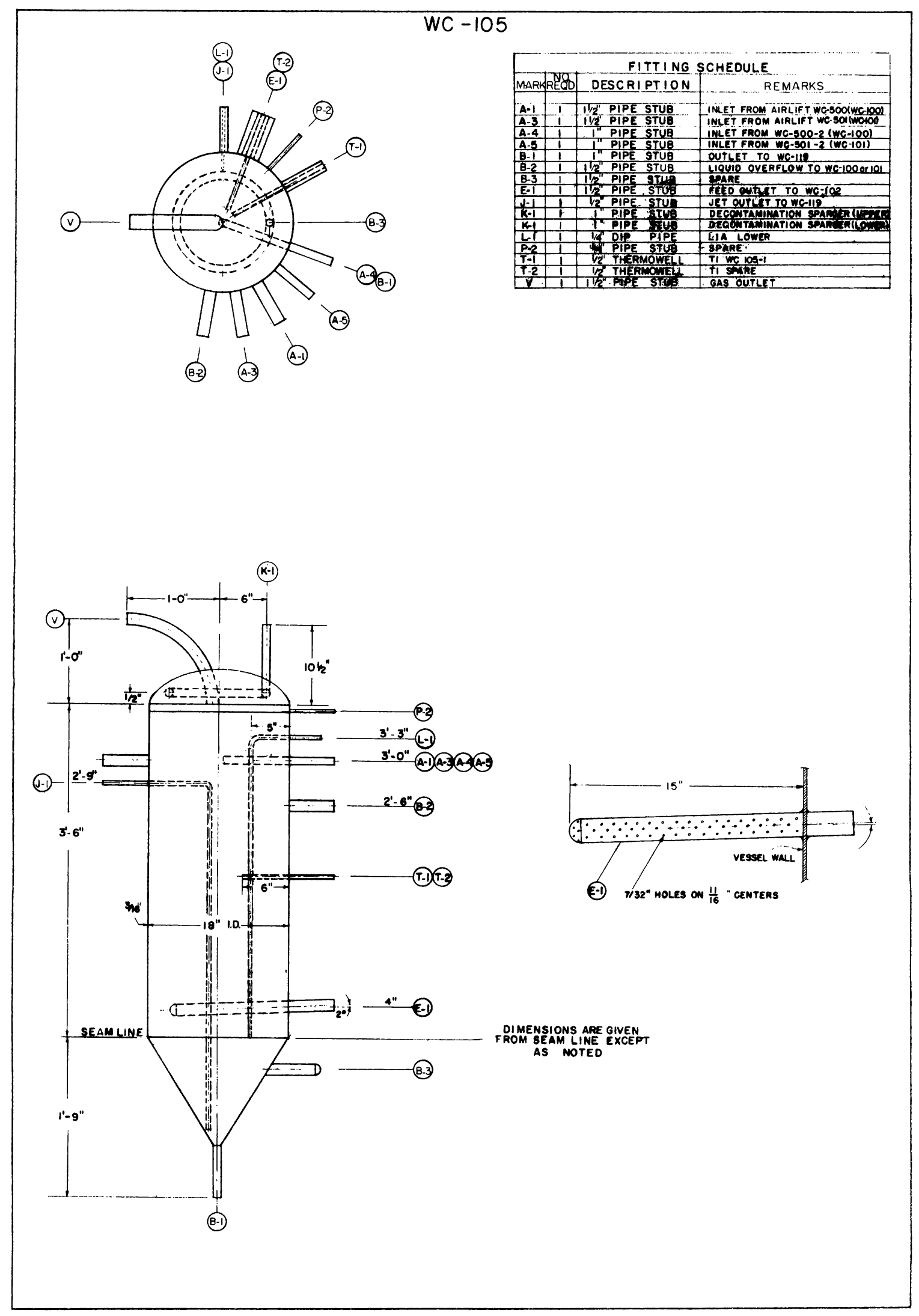

FIG. VI-5 FEED TANK AND FITTING SCHEDULE. 
which utilizes the characteristics of the metered fluid to produce an individual voltage when flowing through a magnetic field. The operating principle is based upon Faraday's Law of Induction which states the "the voltage induced across any conductor as it moves at right angles to a magnetic field is proportional to the velocity of the conductor." Essentially the magnetic flowmeter constitutes a modified form of an AC generator. The amplitude of the voltage generated is directly proportional to the flow rate of the metered fluid.

The flowmeter consists basically of an unobstructed pipe section. The inner pipe (inconel) surface is lined with a vitreous enamel insulator. Two platinum cylindrical electrodes are mounted, diametrically opposed, in the central portion of the pipe section and are completely insulated from the pipe. The end surfaces of the electrodes are flush with the inner surface of the insulating liner and come in contact with the fluid to be metered. A field coil assembly, consisting of two square magnet coils which surround the central arms of two E-shaped laminated iron cores, completely encompasses the central portion of the pipe section. The field coil assembly is designed to produce a linear and uniform magnetic field through the metering section of the flowmeter.

The flowmeter assembly is about $8-1 / 8 \times 8-1 / 8 \times 9-5 / 16$ inches, exclusive of the terminal boxes. The meters are limited to operation at temperatures below $180^{\circ} \mathrm{C}$ and to pressures below 275 psig at $40^{\circ} \mathrm{C}$ or 190 psi at $180^{\circ} \mathrm{C}$.

The signal from the flowmeter is transmitted to a flow recorder controller which controls a throttling valve downstream of the flowmeter.

The flowmeters are located in a shielded cubicle in the sample corridor so that only the flowmeters need be decontaminated before maintenance can be performed on them.

A cut-away view of the magnetic flowmeter is shown in Figure VI-6.

\subsection{Feed Control Valves}

A pneumatically operated throttling valve is installed in each of the three feed lines to regulate flow to the calciner nozzles. The valve has an angle type body with a percentage parabolic plug and a single seat. The valve plug is bellows sealed and is connected to an air operator driven by 3-15 psig air from a controller in the operating corridor. The signal from the magnetic flowmeter determines the amount of air to the operator which regulates the plug position. The operator is covered with a stainless steel housing and a drain is provided in the housing to prevent line fluid from entering the valve operator in case of a seal-bellows failure. 


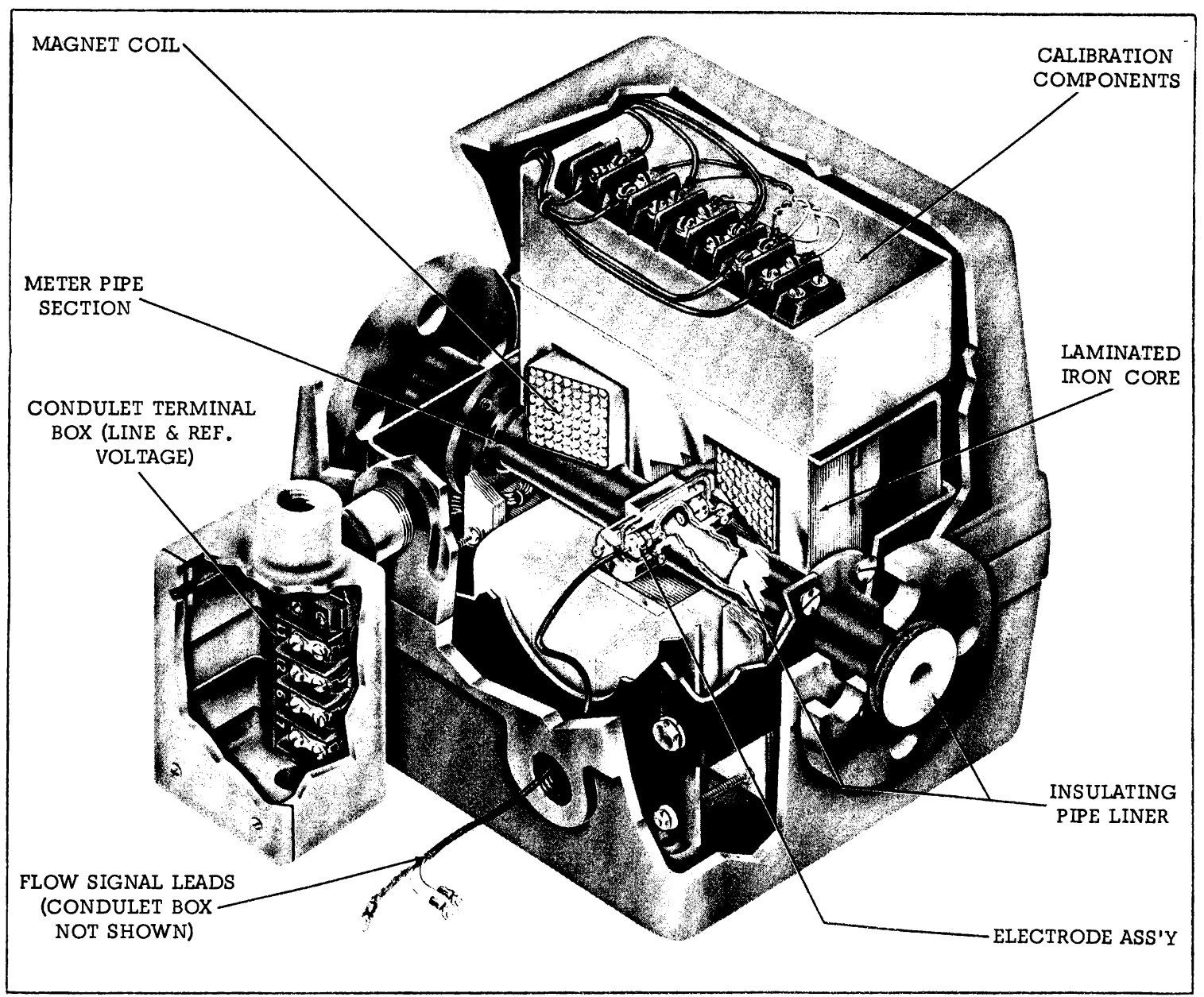

FIG. VI-6 MAGNETIC FLOWMETER.

Feed enters a 1/2-inch inlet and flows around the plug through a 0.20inch seat orifice to the $1 / 2$-inch outlet. Flow is reduced as the plug approaches the seat. The valve body and seat are type 347 stainless steel and the plug is ARMCO 17-4 PH stainless steel.

Design pressure of the valve is 150 psigat $260^{\circ} \mathrm{C}$, while operating conditions are $5.8 \mathrm{psig}$ and $25^{\circ} \mathrm{C}$. Normal flow is $0.45 \mathrm{gpm}$ and maximum flow is $1.3 \mathrm{gpm}$.

The valves are located in the calciner cell about three feet upstream of the feed nozzles. Overall length of the valve and operator housing is $23-5 / 8$ inches. The housing is $12-1 / 32$ inches in diameter. The valve is $4-3 / 8$ inches in diameter and about 11-5/8 inches long.

\subsection{Feed Nozzles}

The radioactive liquid feed is atomized with air at each feed nozzle and sprayed into the calciner vessel. The feed nozzles are Spraying Systems Company type $1 / 2 \mathrm{JN}$ with $1 / 2$-inch feed and air inlets. The nozzles, WC-902-1A, $1 \mathrm{~B}$, and $1 \mathrm{C}$, have a 1/4-inch fluid orifice. The nozzle bodies are made of type 347 
stainless steel and the liquid orifice is fabricated of type 303 stainless steel. The nozzle caps are fabricated of hardened type 440-C stainless steel. Atomizing air is metered to the feed nozzles through rotameters FI-WC-102-1, 2, 3 and the air pressure to the rotameters is controlled at about $50 \mathrm{psig}$. The volumetric ratio of nozzle air to nozzle liquid may be varied from about 300 to 1 to over 600 to 1.

Remotely operated needles are provided to clean out plugs in the liquid nozzle. An air driven cylinder is connected to the cleaning needle with a bellows. In case of nozzle plugging, the cylinder can be remotely activated from the operating corridor. The cleanout cylinder has a $1 / 2$-inch piston rod with a 7/16-inch stroke and a maximum striking force of $500 \mathrm{lbs}$. The design pressure of the cylinder is $100 \mathrm{psig}$ at $260^{\circ} \mathrm{C}$. Normal operating pressure is $20 \mathrm{psig}$ at $150^{\circ} \mathrm{C}$. Flushing water may be added to the feed lines downstream of the control valves to aid in cleaning the nozzles. The flushing water is normally regulated by manual valves from the operating corridor, but is automatically added as part of the emergency feed shutdown system. A typical feed nozzle is shown in Figure VI-7.

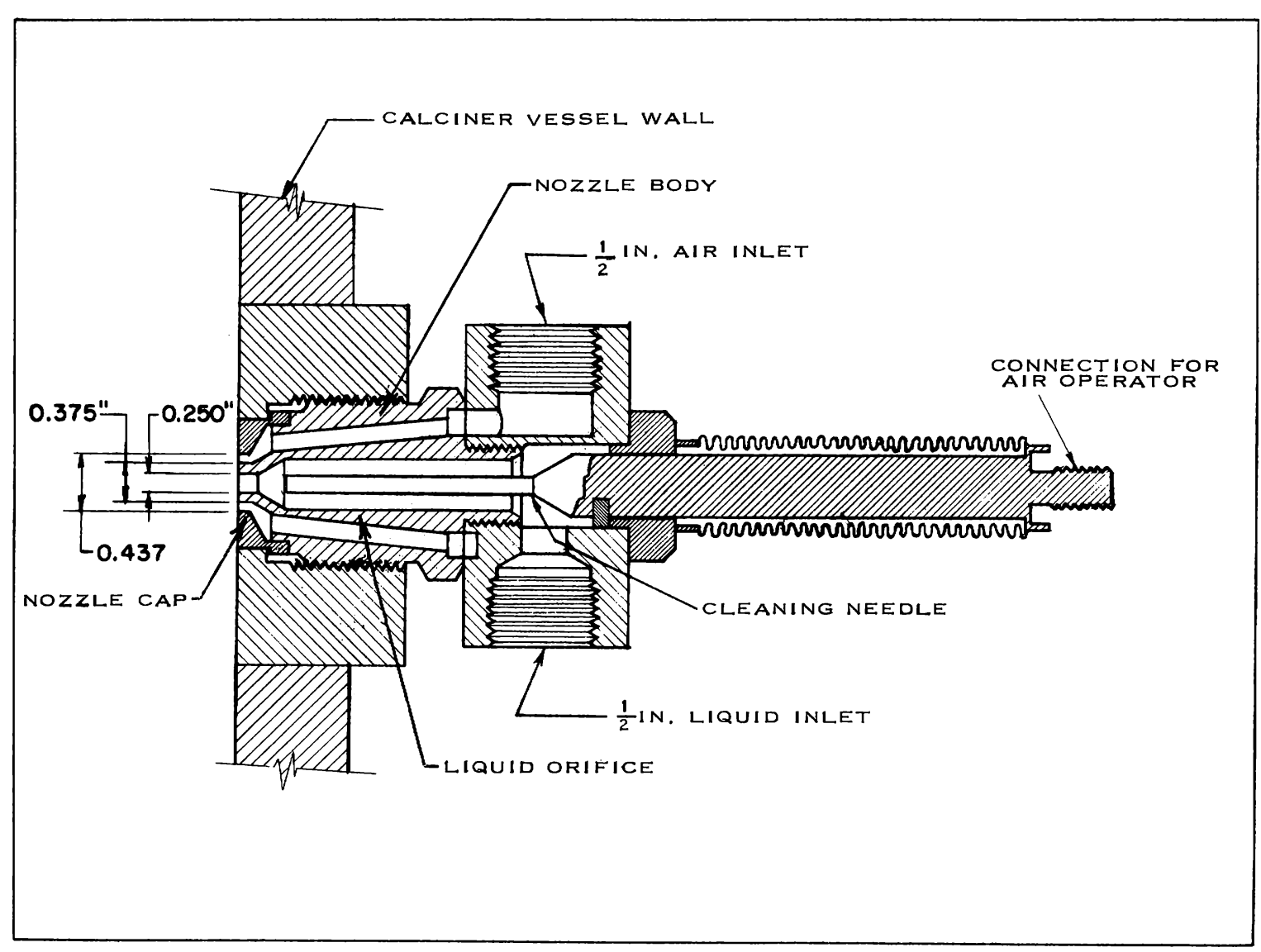

FIG. VI-7 FEED NOZZLE 


\section{CALCINER VESSEL AND CYCLONE}

\subsection{General Description}

Calcination of the waste liquid is accomplished by introducing a fine spray of the liquid into a heated, fluidized bed of alumina 6 to 10 inches below the bed surface. Approximately 5000 pounds of bed material are contained in the fourfoot-diameter calciner vessel during normal operation. Heat is supplied to the bed by hot NaK circulated through a heat exchanger located in the bed below the point of feed introduction. Particles elutriated by the off-gas leaving the calciner are largely removed by a cyclone located above the calciner; the particles separated by the cyclone are ejected into the transport line. Product solids are withdrawn from the calciner and combined with the cyclone bottoms to maintain a constant bed height of approximately 72 inches and are pneumatically conveyed to solids storage.

\subsection{Calciner Vessel}

The calciner vessel, WC-102, is a vertical cylinder with a hemispherical head and conical bottom. Details of this vessel are shown in Figures VI- 8 and VI-9. Table VI-1 is a fitting schedule for WC-102 and WC-302. It is designed for a maximum temperature of $600^{\circ} \mathrm{C}$, and an internal pressure of $30 \mathrm{psig}$ to a full vacuum. Normal operating conditions are $400^{\circ} \mathrm{C}$ and -1.5 to +4.0 psig (from the vapor space above the bed to below the fluidizing air distributor plate). The maximum allowable pressure for the new vessel at room temperature is 245 psig and is limited by the conical bottom. Previous to installation, the vessel was hydrostatically tested at 368 psig. All thicknesses include a nominal corrosion allowance of $1 / 8$ inch. During fabrication, the calciner vessel was stress relieved for two hours at $730^{\circ} \mathrm{C}$. Type 347 stainless steel was used in the construction of the vesseland all piping attachments, and welds in the vessel were 100 percent radiographed.

A curved 3/8-inch-thick plate, located at the bottom tangent line of the calciner vessel, distributes the fluidizing air to the calciner bed. This plate contains fourteen 3/4-inch-diameter holes, lined with a 1/8-inch-thick hard facing alloy (Colmonoy No. 70), to minimize erosion. In the initial test runs of the WCF, fluidizing air was distributed solely by the holes in the grid plate. In later test runs a bubble cap was installed over each hole to increase the plate pressure drop and to minimize bed attrition resulting from the direct impingement of the fluidizing gas on the bed material. The cap design is shown in Figure VI-10. 


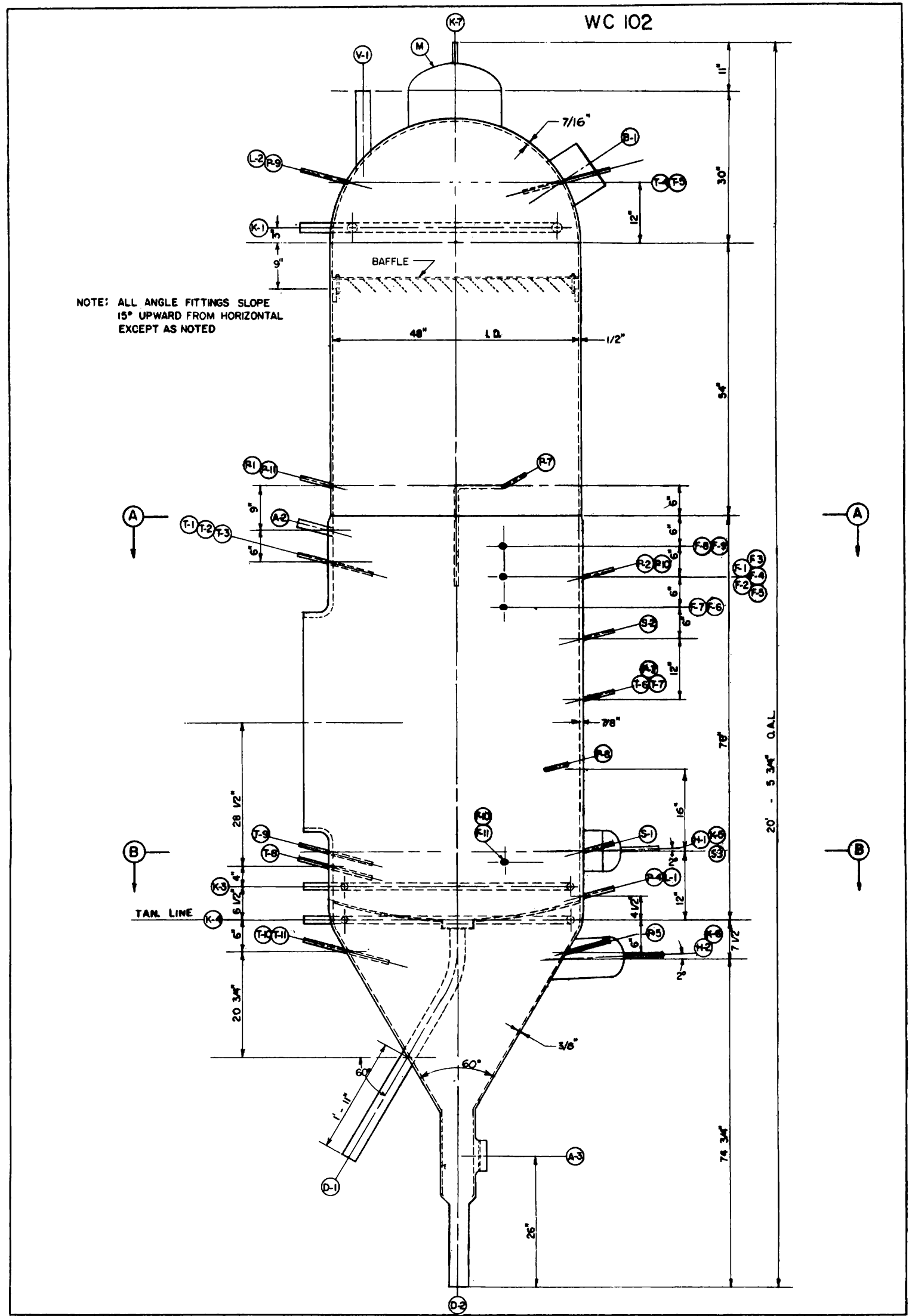

FIG. VI-8 CALCINER VESSEL. 


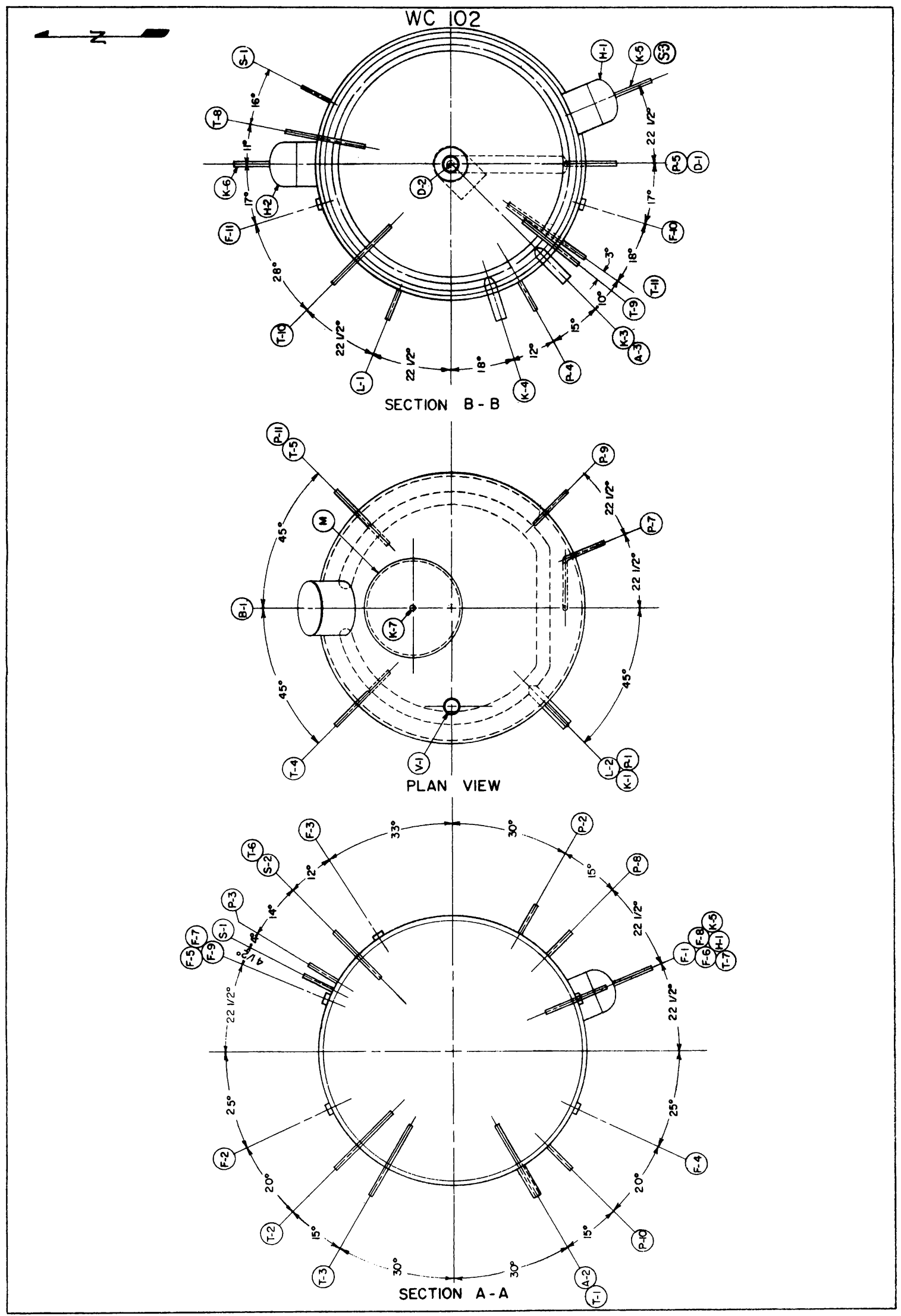

FIG. VI-9 CALCINER VESSEL PLAN AND SECTIONS. 


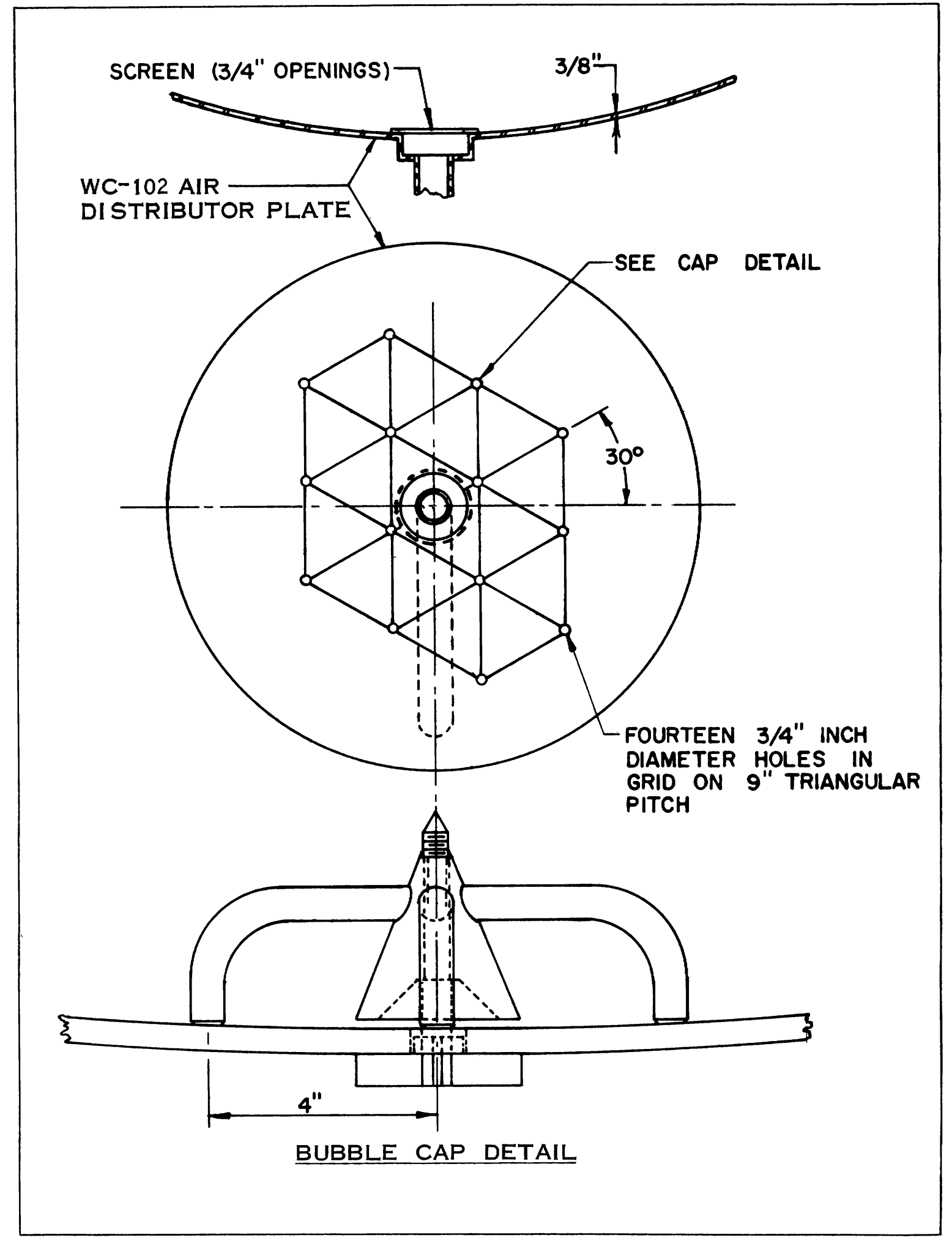

FIG. VI-10 CALCINER DISTRIBUTOR PLATE AND CAP DETAIL.

A baffle is located in the upper section of the calciner vessel to reduce the carryover of large particles into the calciner cyclone. The baffle consists of 
TABLE VI-I

WC-102 - WC-302 FITTING SCHEDULE

\begin{tabular}{|c|c|c|c|}
\hline Mark & $\underline{\operatorname{Req}} \mathbf{d}$ & Description & $\underline{\text { Remarks }}$ \\
\hline$A-2$ & 1 & $1-1 / 2-i n \cdot$ pipe stub & Solids inlet from WC-106 \\
\hline$A-3$ & 1 & 6-in. pipe stub & Fluidizing air inlet from $\mathrm{WC}-250 \mathrm{~A}$ and $\mathrm{B}$ \\
\hline$A-4$ & 1 & 3-in. pipe stub & $\mathrm{NaK}$ inlet \\
\hline$A-5$ & 1 & 1/2-in. pipe stub & Helium inlet \\
\hline$B-1$ & 1 & 10-in. pipe stub & Off-gas outlet \\
\hline$B-3$ & 1 & 3-in. pipe stub & NaK outlet \\
\hline$D-1$ & 1 & 3-in. internal & Calcine drain to solids storage \\
\hline$D-2$ & 1 & 3-in. pipe stub & Drain to WC-119 \\
\hline$D-3$ & 1 & $1-1 / 2-i n \cdot$ pipe stub & NaK drain to $W C-104 A$ and $B$ \\
\hline$F-1,3,6,7,8$ & 5 & Special & Spare openings for feed nozzles (blanked off) \\
\hline$F-2$ & 1 & Special & C nozzle feed from WC-105 \\
\hline$F-4$ & 1 & Special & B nozzle feed from WC-105 \\
\hline $\mathrm{F}-5$ & 1 & Special & A nozzle feed from WC-105 \\
\hline$F-9$ & 1 & Special & Bulk solids return \\
\hline F-10 & 1 & 1/2-in. pipe stub & Product takeoff \\
\hline$F-11$ & 1 & Special & Solids takeoff for gallery sampler \\
\hline $\mathrm{H}-\mathrm{I}$ & 1 & 8-in. pipe stub & Hand hole with welded cap \\
\hline $\mathrm{H}-2$ & 1 & 8-in. pipe stub & Hand hole with welded cap \\
\hline$K-2$ and 8 & 2 & 1 I/2-in. internal pipe & Decontamination nozzles on tube bundle \\
\hline $\mathrm{K}-1,3$, and 4 & 3 & 2-in. internal pipe & Ring decontamination spargers \\
\hline
\end{tabular}




\begin{tabular}{|c|c|c|c|}
\hline Mark & $\underline{\text { Req'd }}$ & Description & $\underline{\text { Remarks }}$ \\
\hline $\mathrm{K}-5-7$ & 3 & 1-in. dip pipe & Hand hole and manway decontamination sparger \\
\hline$L-1$ & 1 & 3/4-in. pipe stub & Level recorder-lower \\
\hline$L-2$ & 1 & 3/4-in. pipe stub & Level recorder-upper \\
\hline M & 1 & 18-in. pipe stub & Manway \\
\hline$P-1-5$ & 5 & 3/4-in. pipe stub & PdI on calciner \\
\hline$P-7$ & 1 & 3/4-in. pipe stub & Probe to 66-in. level \\
\hline$P-8-11$ & 4 & 3/4-in. pipe stub & Spare PaI \\
\hline T-1 & 1 & 3/4-in. thermowell & TRCA \\
\hline $\mathrm{T}-2,5$, and 7 & 3 & 3/4-in. thermowell & Spare thermocouple points \\
\hline T-9 and 11 & 2 & 3/4-in. thermowell & Spare thermocouple points \\
\hline $\mathrm{T}-3,6$, and 8 & 3 & 3/4-in. thermowell & TRA \\
\hline T- 4 and 10 & 2 & 3/4-in. thermowell & $\mathrm{TI}$ \\
\hline V-1 & 1 & 3-in. pipe stub & Transport air return \\
\hline $\mathrm{V}-2$ & 1 & I/2-in. pipe stub & Vent from jacket \\
\hline S-1 & 1 & 1/2-in. pipe stub & Product takeofi \\
\hline$S-2$ & 1 & 3/4-in. pipe stub & Solids sampler return \\
\hline$S-3$ & 1 & 1/2-in. pipe stub & Bulk solids takeoff \\
\hline
\end{tabular}


thirteen $1 / 8$-inch-thick by 6 -inch-wide plates positioned at a $45^{\circ}$ angle to the vertical center line of the calciner, with their upper edge about 6 inches below the top vessel tangent line. All material in the baffle is type 347 stainless steel.

The lower portion of the calciner vessel is covered with four-inch-thick insulation, which in turn is covered with a thin stainless steel sheet to protect the insulation from decontamination solutions that may be sprayed onto exterior equipment surfaces. All fittings protruding through the insulation jacket have stainless steel expansion joints welded to the nozzle and to the stainless steel jacket. The upper section of the calciner has not been insulated since heat conservation in this area is not critical.

Decontamination lines (for decontamination solutions or steam) connect to a ring sparger in the top head, a ring sparger below the air distributor plate, to the two handholes, and to three spray nozzles in the tube bundle recess. A ring sparger, located just above the air distributor plate, may be supplied through a single line with either air or steam. All decontamination lines and vessel sparge rings are continuously purged with air during operation to prevent solids from entering the lines and forming plugs.

Fluidizing air, heated by the NaK heater, enters the calciner vessel via a nozzle on a 6-inch tee below the distributor grid. This nozzle incorporates a drip ring over its top half to prevent calcined solids from entering the nozzle. Additional fluidization can be accomplished by the introduction of air into the calciner bed through the lower sparge ring located immediately above the air distributor plate. A 3-inch drain line at the center of the grid plate is provided to dump the calciner bed to solids storage; this line splits outside the calciner shell to provide two connections into the solids transport line. The bottom of the conical section also is provided with a 3-inch drain line to dump any solids that have accumulated below the air distributor plate. Both plate drain lines and the cone drain line discharge solids into the transport air system; the solids are then pneumatically conveyed to solids storage.

The flow of solids through the plate drain lines and cone drain line is controlled by slide valves in each line at the bottom of the calciner (RVC-WC$102-1,2$, and 3 ). The valve operators are springless, double-acting cylinders and the position of the valve is controlled by adjusting the top and bottom air loading from manual loading stations on the main control panel. An indicator connected to the operator shows the position of the valve at any time. The valves have bonnet and seat air purges to keep dust and small particles from the sliding surfaces. Details of the slide valves are shown in Figure VI-11. 


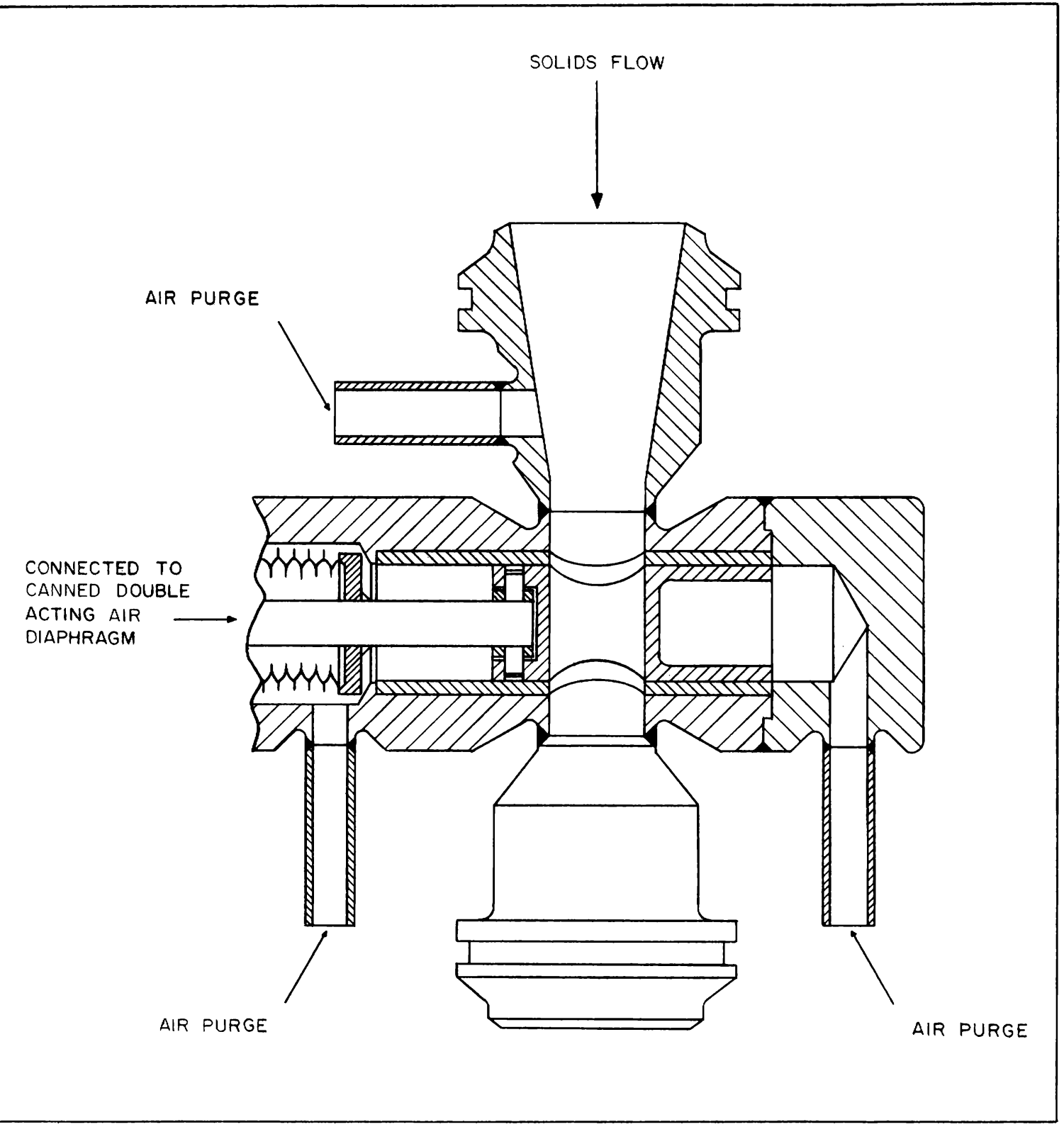

FIG. VI-II SLIDE VALVE

Probes for level and pressure measurements are provided at the following elevations with respect to the calciner bottom tangent line:

$\mathrm{P}_{5} \ldots \ldots . . . .6$ inches (below support plate)

$\mathrm{P}_{4}$ and $\mathrm{L}_{2} \ldots \ldots \ldots+4-1 / 2$ inches (just above the support plate)

$\mathrm{P}_{8} \ldots \ldots \ldots \ldots+28$ inches

$\mathrm{P}_{3} \ldots \ldots \ldots \ldots+42$ inches

$\mathrm{P}_{2}$ and $\mathrm{P}_{7} \ldots \ldots \ldots+66$ inches (about 6 inches below top of bed)

$\mathrm{P}_{1} \ldots \ldots \ldots \ldots+84$ inches

$\mathrm{L}_{1}$ and $\mathrm{P}_{9} \ldots \ldots \ldots+144$ inches (located in top head) 
All pressure instruments are located on the main control panel in the operating corridor. The total bed level is recorded as the difference in pressure between $\mathrm{L}_{2}$ and $\mathrm{L}_{1}$. The level of bed above $\mathrm{P}_{2}$ is recorded as the difference in pressure between $\mathrm{P}_{2}$ and $\mathrm{P}_{9}$. In addition, the pressures at $\mathrm{P}_{3}, \mathrm{P}_{4}$, and $\mathrm{P}_{5}$ are recorded, and the difference in pressure between any of the points $\mathrm{P}_{1}$ through $\mathrm{P}_{5}$ can be obtained on a pressure differential indicator by suitable manifolding. The calciner vacuum is controlled by a pressure recorder controller alarm instrument that senses the pressure at $\mathrm{P}_{9}$. Normal operating pressure in the vapor space above the bed is 42 inches of $\mathrm{H}_{2} \mathrm{O}$ vacuum.

Thermocouple wells are provided at the following elevations with respect to the bottom tangent line:

$$
\begin{aligned}
& \mathrm{T}_{10} \text { and } \mathrm{T}_{11} \text { (spare) ....-6 inches } \\
& \mathrm{T}_{8} \ldots \ldots \ldots \ldots . . . . . . .10-1 / 2 \text { inches } \\
& \mathrm{T}_{9} \text { (spare) ........... 13-1/2 inches } \\
& \mathrm{T}_{6} \text { and } \mathrm{T}_{7} \text { (spare) ....... } 42 \text { inches } \\
& \mathrm{T}_{1}, \mathrm{~T}_{2} \text { (spare), and } \mathrm{T}_{3} \ldots+69 \text { inches } \\
& \mathrm{T}_{4} \text { and } \mathrm{T}_{5} \text { (spare) ...... } 144 \text { inches (in top head) }
\end{aligned}
$$

These temperatures are measured by iron-constantan thermocouples. Temperatures at $\mathrm{T}_{3}, \mathrm{~T}_{4}, \mathrm{~T}_{6}, \mathrm{~T}_{8}$, and $\mathrm{T}_{10}$ are recorded on a multipoint recorder on the main instrument panel. The thermocouple at $\mathrm{T}_{1}$ provides the signal to a TRCA instrument which controls the temperature of the fluidized bed.

Eleven openings for feed nozzles were provided in the calciner shell, nine above the tube bundle and two below. The two openings below the tube bundle are currently being used for other purposes. The three openings which will be used for feed introduction are located 66 inches above the bottom tangent line; the remaining openings are plugged. The top of the fluidized bed will be maintained about 72 inches above the tangent line. Feed will be introduced about 6 inches below the top of the bed.

Calcined alumina for the initial fluidized bed is introduced into the calciner vessel at the start of processing. This material is transported pneumatically from the start-up hopper (WC-106), located in the decontamination room, to the calciner after the calciner vacuum has been established.

\subsection{Calciner Cyclone}

The off-gas stream leaving the top of the calciner vessel is made up of oxygen, nitrogen, water vapor, nitrogen oxides, and entrained solids. This gas flows through the calciner cyclone where most of the entrained solids are 
removed. Solids collected in the cyclone hopper are removed and injected into the transport air line by the cyclone fines jet (WC-521), and pneumatically conveyed to solids storage.

Details of the cyclone (or Multiclone) are shown in Figure VI-12. It was designed for pressures ranging from full vacuum to $30 \mathrm{psig}$ at a temperature of $590^{\circ} \mathrm{C}$, and was hydrostatically tested at $50 \mathrm{psig}$. All welds were dye penetrant tested and radiographed. The cyclone is normally operated at a temperature of $390^{\circ} \mathrm{C}$ and a pressure of 10.70 psia. The off-gas inlet and outlet lines are 10-inch schedule 40 pipe. The vessel was fabricated from 1/4-inch type 347

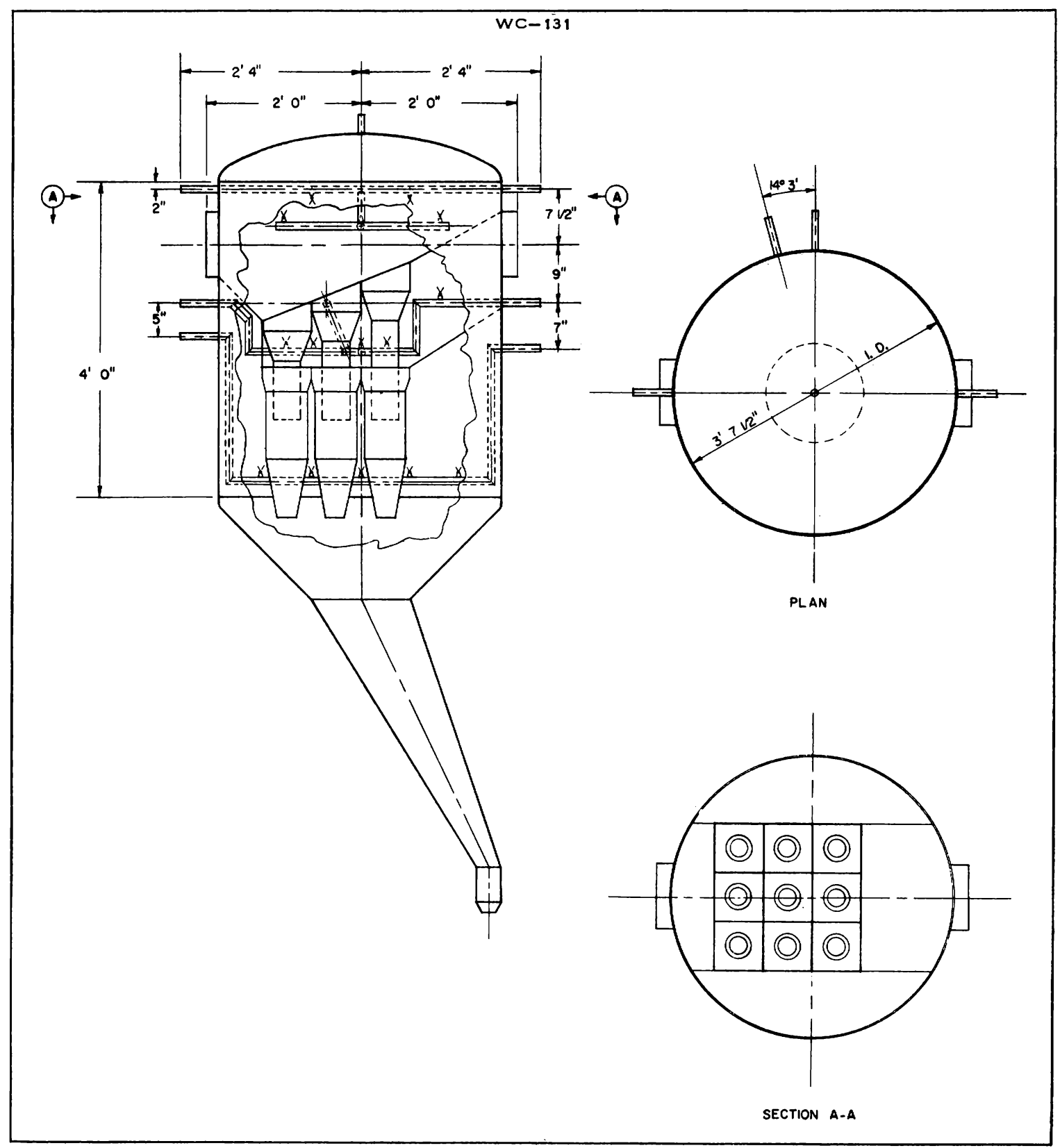

FIG. VI-12 CALCINER CYCLONE (MULTICLONE). 
stainless steel and has a minimum allowance of $1 / 16$ inch on surfaces subjected to erosion. The cyclone is equipped with a blast air connection to blow dust from the top plenum, three internal spray decontamination manifolds to flush internal surfaces, and pressure taps to measure pressure drop across the cyclone. A temperature indicator at the bottom of the cyclone measures the temperature of gas leaving the bottom of the cyclone hopper and serves to indicate backflow from the transport air system into the bottom of the cyclone.

\section{FLUIDIZING AND OFF-GAS SYSTEMS}

\subsection{General Description}

The fluidized bed calcination of ICPP radioactive liquid waste produces a large quantity $(\approx 800-900 \mathrm{scfm})$ of contaminated off-gas. The off-gas is composed primarily of the fluidizing air delivered to the calciner by a positive displacement blower, WC-250A or B; also included are: decomposition gases (water vapor, nitrogen oxides), the feed nozzle air, the solids transport air, and air introduced at numerous purge locations. The off-gas system is designed to remove the contaminants from the off-gas to the degree necessary to permit discharge of this gas through the ICPP stack to the environs. A flow diagram of the off-gas system is shown in Figure VI-13. The flow path of the fluidizing air to the calciner is shown in the NaK system flow diagram, Figure VI-37.

There are two sources of contamination in the off-gas: entrained radioactive dust and volatile radioactive ruthenium. Dust removal from the off-gas leaving the calciner cyclone, WC-131, is largely achieved in the scrubbing system quench tower, WC-107, and the venturi scrubber, WC-907. The primary purpose of the quench tower, however, is to cool the off-gas to a temperature suitable for efficient operation of the venturi scrubber. Intimate contact between the dust escaping the quench tower and the scrubbing solution is achieved in the venturi scrubber. The liquid droplets containing the captured dust particles are removed from the off-gas by two de-entrainment cyclones, WC-908 and WC-910, placed in series downstream of the venturi scrubber. The dust thus removed from the off-gas is collected in the scrubbing solution that drains continuously from the quench tower and the de-entrainment cyclones to the scrubbing solution surge tank, WC-108. Scrubbing solution is continuously recirculated from this tank to the scrubbing system by a pump WC-208A or B. The heat removed from the off-gas and gained by the scrubbing solution is removed from the scrubbing 


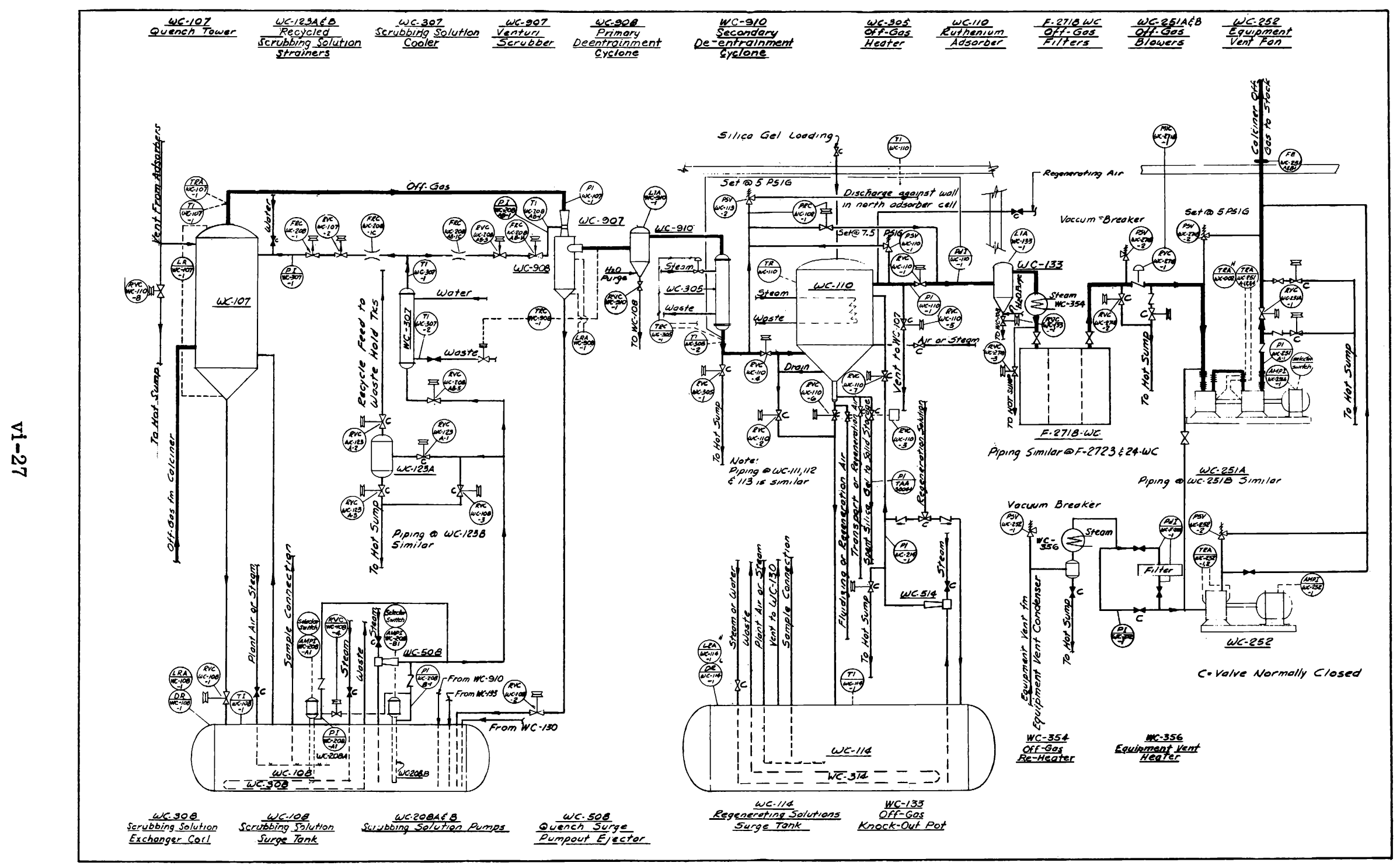

FIG. VI-13 OFF-GAS SYSTEM FLOW DIAGRAM. 
system via the scrubbing solution cooler, WC-307. Ruthenium vapors are adsorbed from the off-gas on the silica gel beds in adsorbers WC-110, 111, 112, and 113. Final dust removal is accomplished by dry filtration in the ruthenium adsorbers and in the off-gas filters, F-2718, F-2723, and F-2724 WC. Cleaned off-gas is delivered to the ICPP stack by one of the off-gas blowers, WC-251A or WC251B.

\subsection{Fluidizing Air Blowers}

The single stage positive displacement blowers, WC-250A and WC-250B, shown in Figure VI-14, supply the air for fluidizing the bed and transporting the solids in the calcination process. The blowers are driven by $25-\mathrm{hp}, 220 / 440-$ volt, squirrel cage induction motors which are equipped with automatic starters. These starters energize the spare blower when the discharge pressure drops

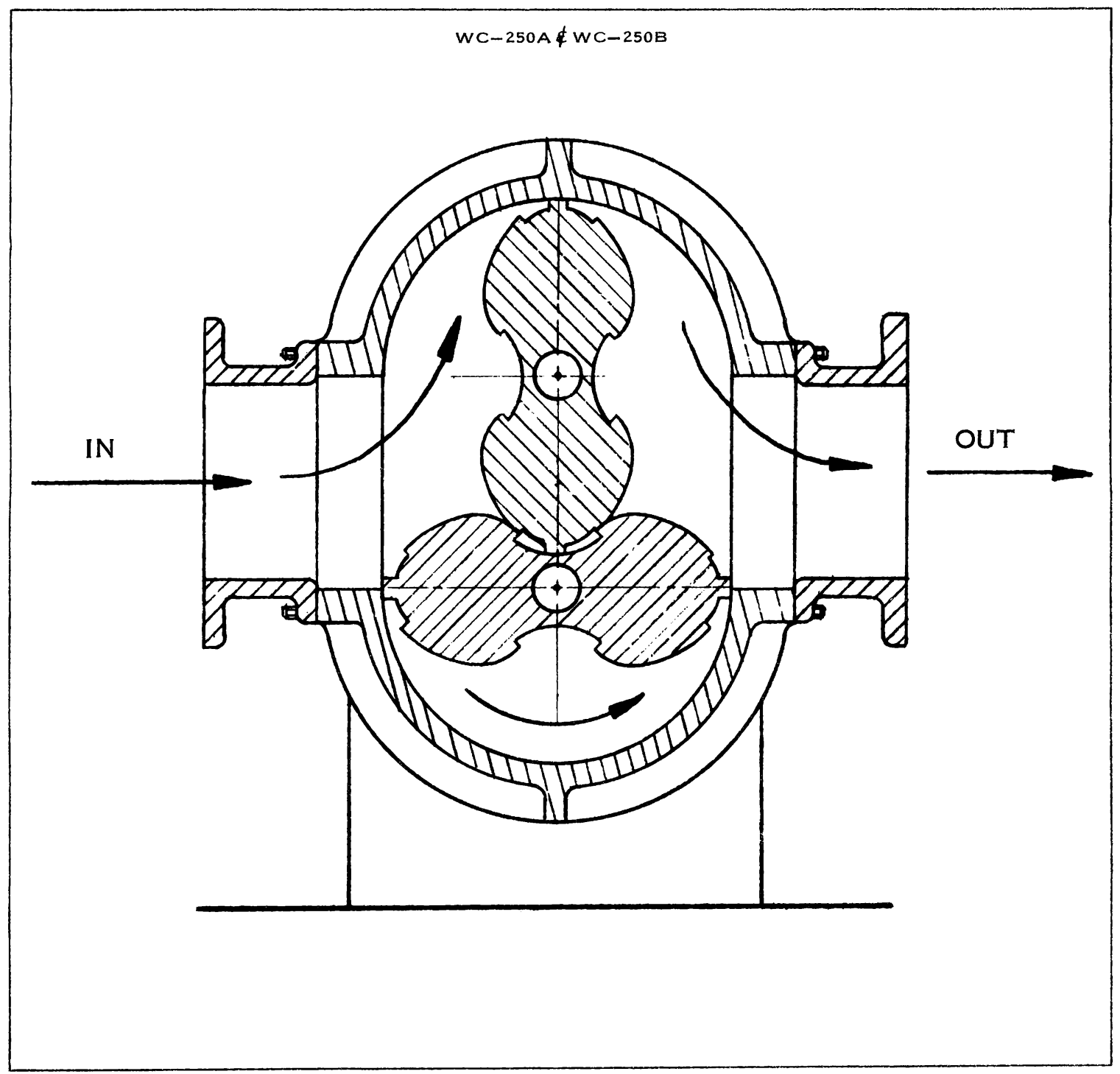

FIG. VI-14 FLUIDIZING AIR BLOWER 
below 3.75 psia or when a blower in service fails. A blower will deliver $546 \mathrm{scfm}$ of air at 5.5 psig. The normal fluidizing and transport flows are approximately $240 \mathrm{scfm}$ and $69 \mathrm{scfm}$, respectively. Excess air from the blower is vented to the atmosphere.

Blower operation is controlled from the main instrument panel board; start and stop switches with locking devices also are provided near the blowers. A discussion on the flow and temperature controls in the fluidizing air and the transport air systems is given in Section VI-8.

A reverse current check valve, RVC-WC-304-1-1, is provided in the blower discharge line upstream of the calciner vessel. This valve closes when the fluidizing air pressure falls below 2.0 psig (14.2 psia) and prevents backflow of activity from the calciner during pressure surges or blower failures. Further precautions against backflow are provided by check valves in the fluidizing air line at the calciner cell wall and at the blower discharge.

\subsection{Quench Tower}

The quench tower, shown in Figure VI-15, cools the off-gas stream by contacting the hot off-gas from the calciner cyclone with a scrubbing solution that is sprayed countercurrent to the gas flowing up the tower. In the tower, coarse solids are captured by the liquid and removed from the off-gas.

The vessel is constructed of type 347 stainless steel. It is designed to withstand pressures from -15 to $30 \mathrm{psig}$ at $500^{\circ} \mathrm{C}$. The normal operating conditions are -2 psig $(10.2 \mathrm{psia})$ at 50 to $350^{\circ} \mathrm{C}$. The welds on the vessel were 100 percent radiographed, a 1/16-inch wall thickness was added to the vessel for corrosion allowances, and the vessel was hydrostatically tested at 150 psig.

Control of the scrubbing solution to the tower and the temperature of off-gas leaving the tower are discussed in Section VI-8. Liquid level instrumentation is provided to indicate tower flooding resulting from a plugged drain line. A water line is connected to the drain line to aid in removing plugs if they occur. Two spray headers, one near the top and one near the bottom, are provided for decontaminating the vessel.

\subsection{Venturi Scrubber and De-entrainment Cyclones}

Most of the entrained dust and water vapors escaping the quench tower are removed from the off-gas in the venturi scrubber and de-entrainment cyclones. This is achieved by spraying scrubbing solution into the off-gas passing through the venturi throat. The liquid containing the captured dust and water is passed 


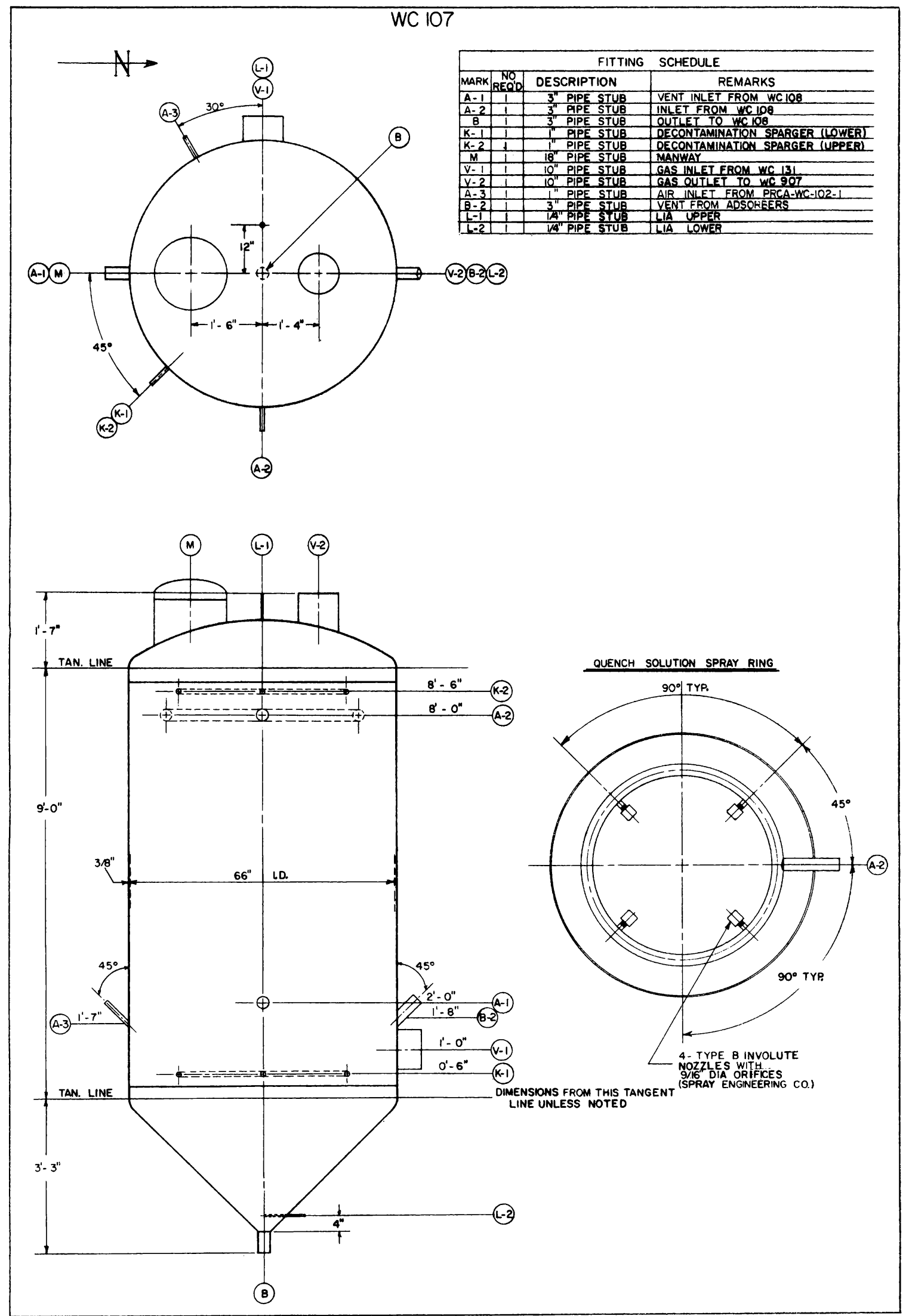

FIG. VI-15 QUENCH TOWER. 
through cyclones where it is separated from the gas and is drained into the quench surge tank.

The venturi scrubber and primary de-entrainment cyclone, WC-907 and WC-908, shown in Figure VI-16, form an integral unit that is constructed of type 304L stainless steel. The unit is designed for pressures from a full vacuum to 30 psig at $425^{\circ} \mathrm{C}$. The normal operating pressure is $-2.2 \mathrm{psig}$ (10.0 psia) at $59^{\circ} \mathrm{C}$. The welds on the unit were 100 percent radiographed, and a 1/16inch wall thickness was added to the equipment structure for corrosion allowance. A liquid-level recorder-alarm, LRA-WC-908, is provided with the vessel to indicate if, or when flooding occurs. Decontamination sprays are provided in the vessel and water is connected to the drain to aid in removing plugs.

A secondary de-entrainment cyclone, WC-910, shown in Figure VI-17, was installed downstream of the primary unit as additional insurance against scrubbing solution carry-over into the off-gas heater. As with the primary deentrainment cyclone, this unit has been provided with a level recorder alarm, decontamination sprays, and a water connection to the drain line. This unit was hydrostatically tested at $50 \mathrm{psi}$ and the welds in the structure were 100 percent radiographed. A corrosion allowance of $1 / 16$-inch thickness was added to the vessel wall.

\subsection{Scrubbing Solution Surge Tank}

The scrubbing solution for quenching the off-gas and removing the solids from the decomposition gases is contained in the scrubbing solution surge tank, WC-108. The vessel, shown in Figure VI-18, is fabricated from type 304L stainless steel and is designed to withstand pressures from -15 to $30 \mathrm{psig}$ at $175^{\circ} \mathrm{C}$. The normal operating pressure is $-2.0 \mathrm{psig}(10.2 \mathrm{psia})$ at $63^{\circ} \mathrm{C}$. The welds on the vessel were 100 percent radiographed. A 1/16-inch wall thickness was added to the shell and heads for corrosion allowance, and the vessel was hydrostatically tested at 217 psig.

The vessel is provided with a steam coil for heating the liquid during start-up operations. It also is provided with a liquid density and level recorder. A remote sampler, connected to the sampling gallery, provides a means for analyzing the tank composition. To maintain the solids and liquid in a homogeneous mixture, an air sparger is installed near the bottom of the vessel. A decontamination sparger is available for flushing and cleaning.

The dust removed from the calciner off-gas is collected in the scrubbing solution. It is necessary to return a portion of this dust-laden solution to the 


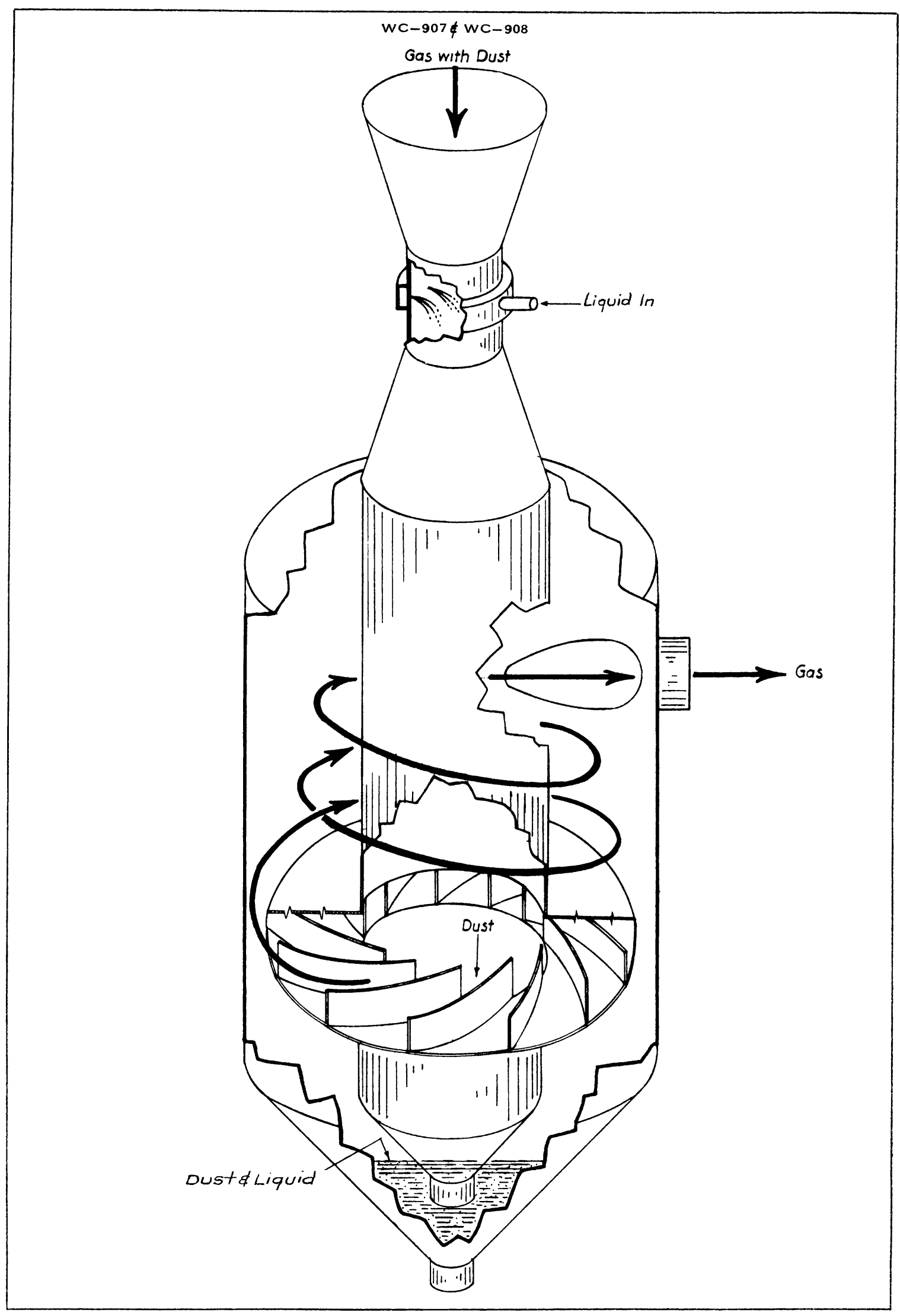

FIG. VI-16 VENTURI SCRUBBER 


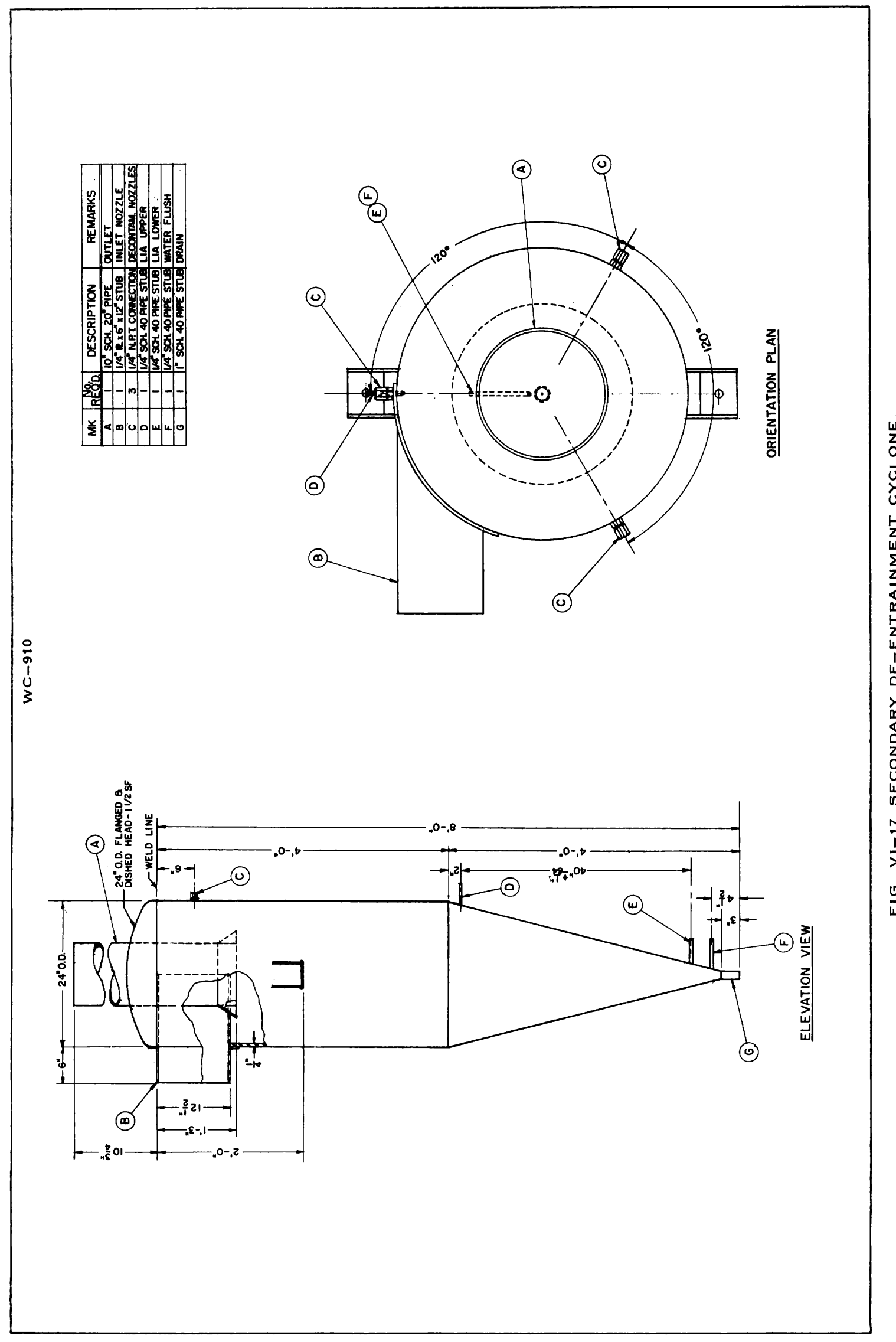




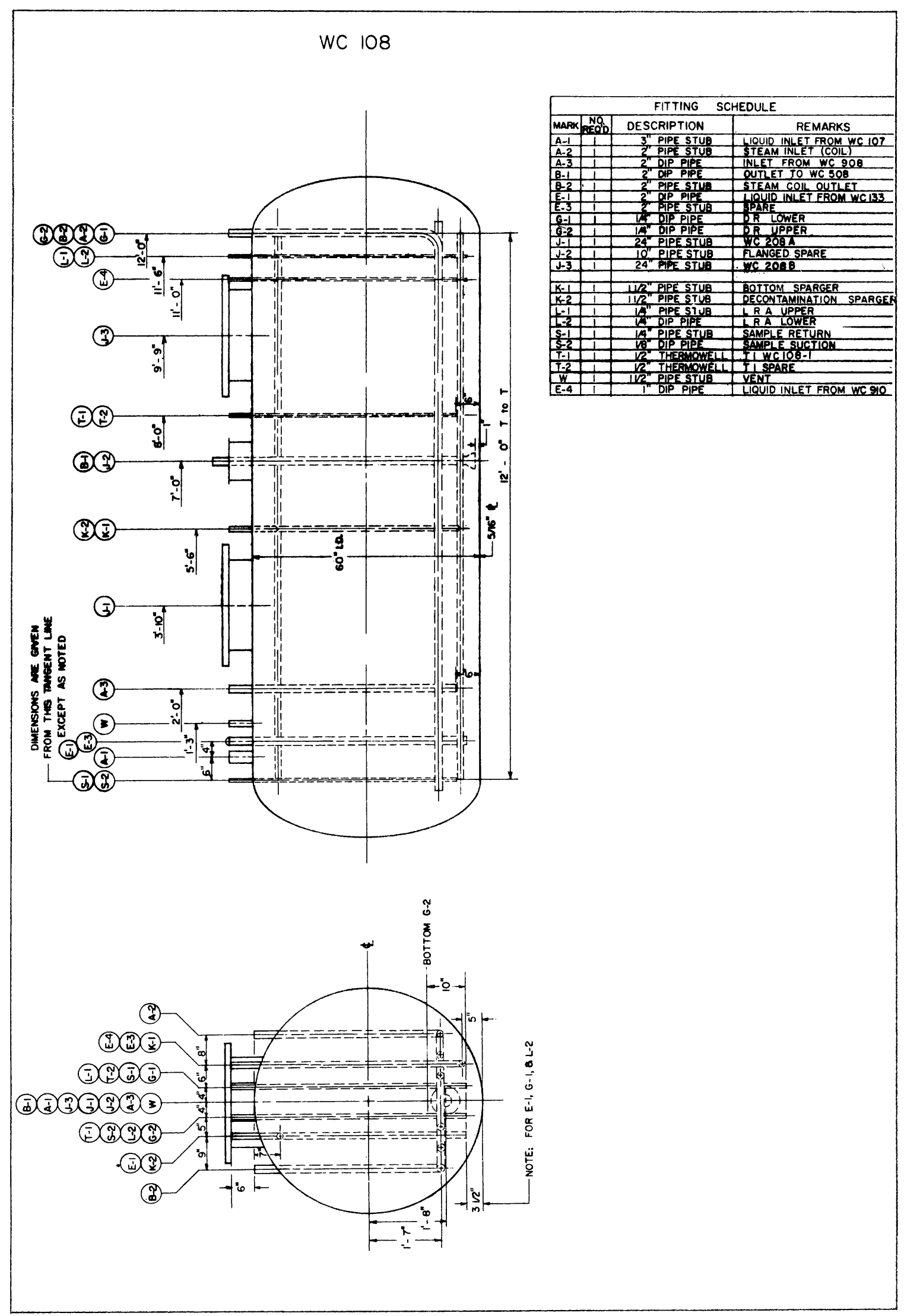

FIG. VI-18 SCRUBBING SOLUTION SURGE TANK, 
calciner waste hold tanks for reprocessing in order to maintain a reasonable aluminum and undissolved solids concentration in the surge tank. This return flow is expected to be small, ie, about 10 to 20 gallons per hour calculated on a continuous basis. Because this flow rate is difficult to meter continuously, the solution is periodically transferred to the waste hold tanks. As a result, the level in the scrubbing solution surge tankfluctuates from 800 to 1300 gallons to provide for the periodic transfers. The scrubbing solution thus recycled is replenished by condensing water and acid from the off-gas.

\subsection{Scrubbing Solution Pumps}

Scrubbing solution pumps, WC-208A and WC-208B, circulate scrubbing solution to the quench tower and the venturi scrubber, and periodically transfer dust-laden scrubbing solution to the waste hold tanks. The two pumps are installed in the tank and spare each other in operations to insure continuous scrubbing solution circulation.

The scrubbing solution pumps are vertical, submerged, centrifugal types without any submerged bearings or packing boxes (Figure VI-19). The pump bodies are type 304 stainless steel. The impellers and pump shafts are fabricated of type 304L stainless steel. Each pump has a capacity of $120 \mathrm{gpm}$ at $62^{\circ} \mathrm{C}$ when operating at a discharge pressure of 48 psig and a suction pressure of -2 psig. The pump bearings, which are located in the housings above the tank, are lubricated remotely from oil reservoirs located in the operating corridor. Oil overflowing the bearings is collected by a shaft slinger ring housing assembly and drains to collection pots located in the off-gas cell entrance labyrinth. Individual oil reservoirs and collection pots and thermocouples at each bearing provide a continuous indication of oil consumption and the bearing condition.

Each pump is driven at $1760 \mathrm{rpm}$ by a 10-hp induction motor which is connected to the emergency power circuit. Stop-start switches for the motors are provided on the main operating panel. Also, stop and lockout switches are provided outside the door of the calciner off-gas cell in which the pumps are located.

\subsection{Scrubbing Solution Cooler}

Heat picked up by the scrubbing solution is removed by the scrubbing solution cooler (WC-307), located in the discharge line from the scrubbing solution pumps. The cooler indirectly controls the temperature of the off-gas leaving the venturi scrubber and de-entrainment separator by adjusting the 


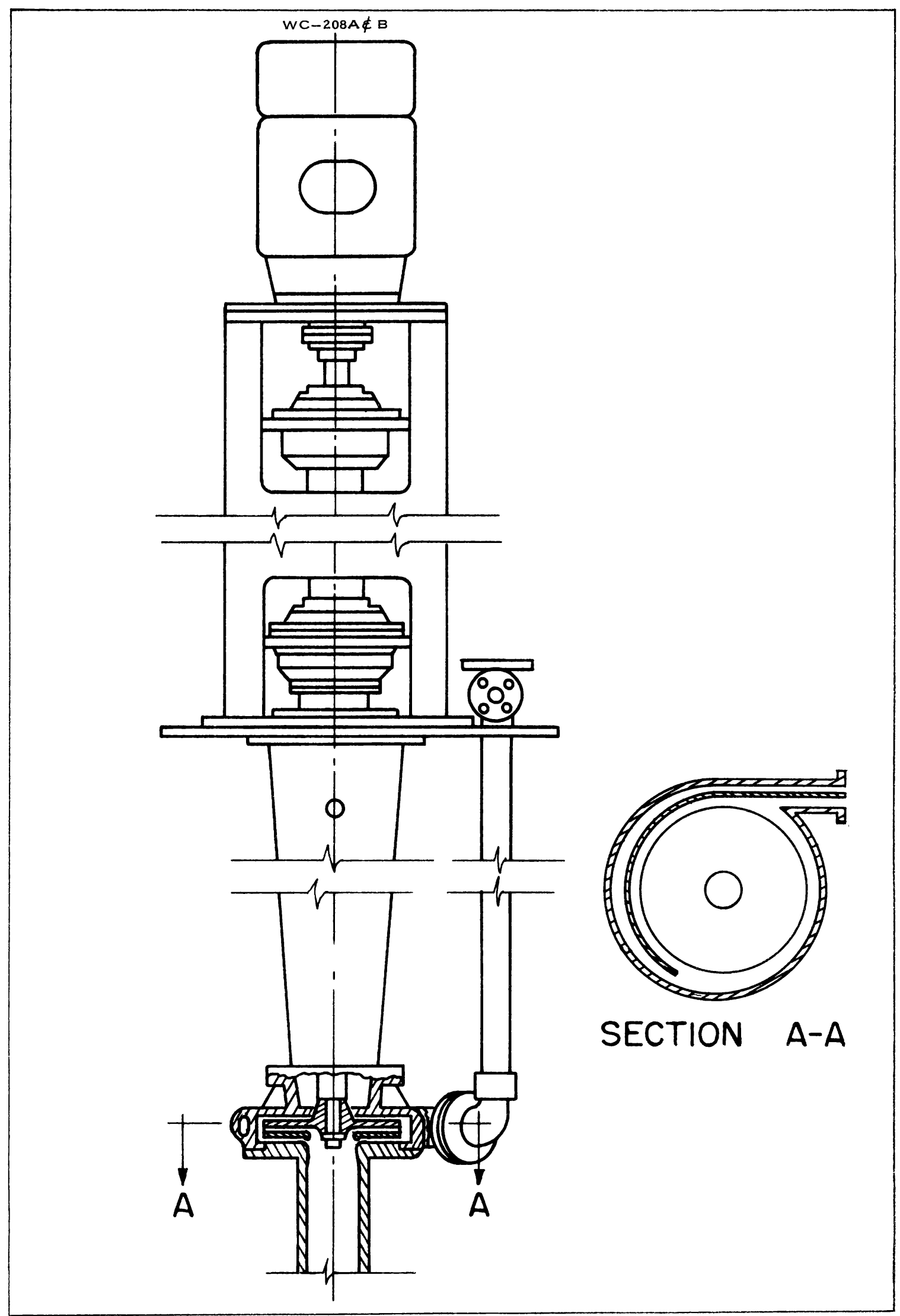

FIG. VI-19 SCRUBBING SOLUTION PUMP 
temperature of the scrubbing solution. The temperature of the scrubbing solution is, in turn, controlled by adjusting the flow of water to the cooler.

The scrubbing solution cooler is a vertical, cylindrical shell-and-tube heat exchanger as shown in Figure VI-20. Cooling water is circulated through the type 304L stainless steel shell, and the scrubbing solution passes through stainless steel tubes. The cooler was designed for $75 \mathrm{psig}$ at $65^{\circ} \mathrm{C}$ in the shell, and $75 \mathrm{psig}$ at $93^{\circ} \mathrm{C}$ in the tubes; the entire unit was hydrostatically tested at 280 psig. Operating conditions are $45 \mathrm{psig}$ at $38^{\circ} \mathrm{C}$ on the shell side and $48 \mathrm{psig}$ at $46^{\circ} \mathrm{C}$ in the tube side. The cooler design duty is $856,000 \mathrm{Btu} / \mathrm{hr}$ at operating conditions.

\subsection{Off-Gas Heater}

The saturated off-gas from the secondary de-entrainment cyclone is superheated in the off-gas heater, WC-305, before entering the ruthenium adsorbers. The purpose of this heater is to add sufficient heat to the saturated off-gas to prevent condensation of water in the ruthenium adsorbers and downstream piping.

The off-gas heater is a vertical, cylindrical shell-and-tube heat exchanger (Figure VI-21) fabricated entirely of type 304L stainless steel. Steam circulates through the shell, and off-gas flows through the tubes. The heater was designed for $150 \mathrm{psig}$ at $168^{\circ} \mathrm{C}$ on the shell side, $30 \mathrm{psig}$ to full vacuum at $150^{\circ} \mathrm{C}$ on the tube side. The heater design duty is $175,000 \mathrm{Btu} / \mathrm{hr}$ at operating conditions. Both the shell and tube sides were pressure tested at 200 psig. The operating pressures are 35 psig for the shell and -3.9 psig in the tubes.

Steam flow to the off-gas heater is adjusted by a controller which senses the temperature of the off-gas at the inlet of the ruthenium adsorbers and regulates the steam accordingly. The controller is normally set to maintain the gas temperature $10^{\circ} \mathrm{C}$ higher than the off-gas dewpoint. The maximum gas temperature that can be attained by this exchanger at design gas flow rate is $150^{\circ} \mathrm{C}$.

\subsection{Ruthenium Adsorbers}

The ruthenium adsorbers remove ruthenium vapors and some residual dust from the off-gas after it has passed the heater, WC-305. The ruthenium and dust can be removed from the adsorbers by contacting the silica gel with water. The spent regenerating or washing solution, containing the ruthenium and dust, can be transferred to either the ICPP waste evaporator or to the waste hold tanks by way of the hot sump tank, WC-119. 


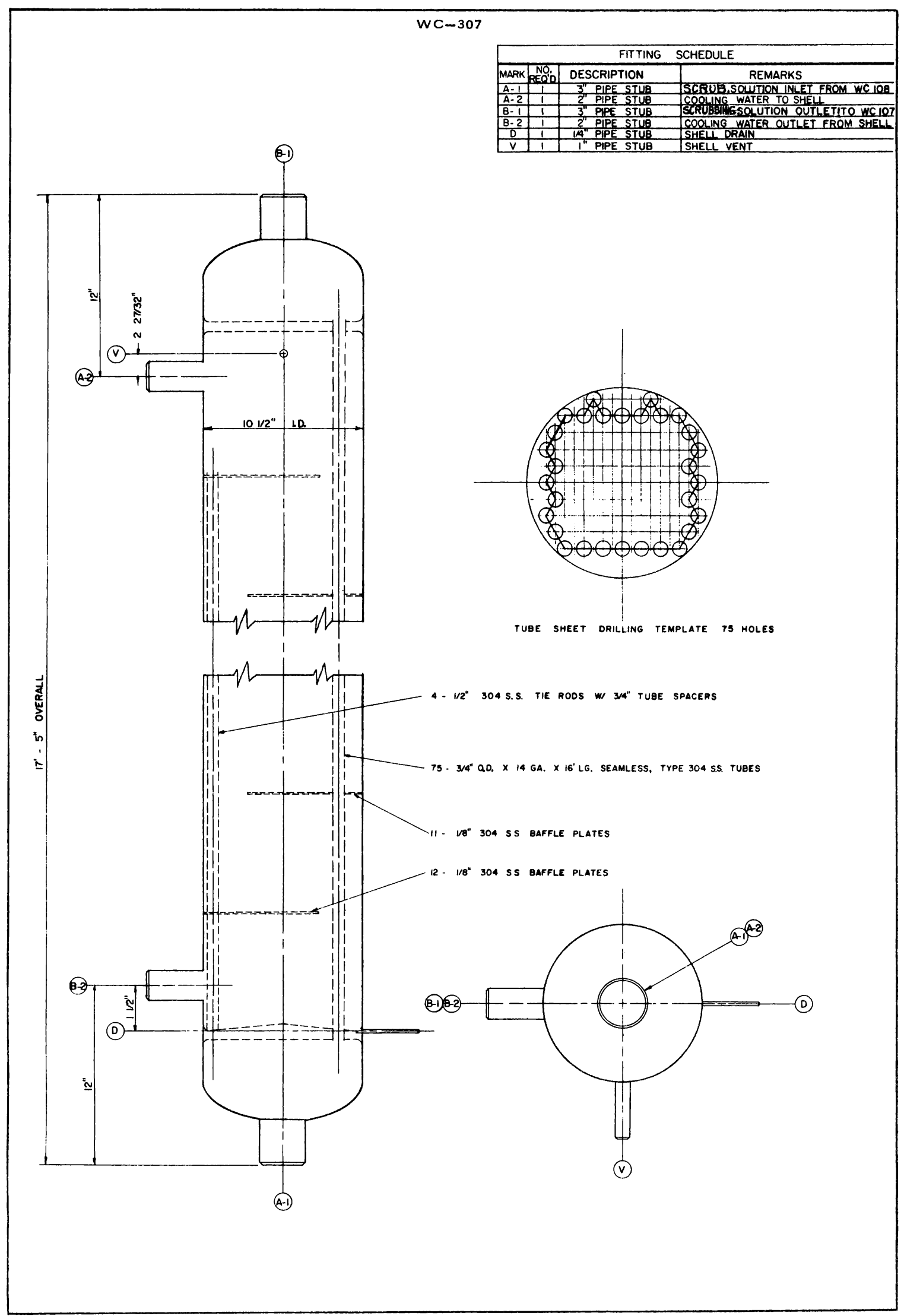

FIG. VI-20 SCRUBBING SOLUTION COOLER. 


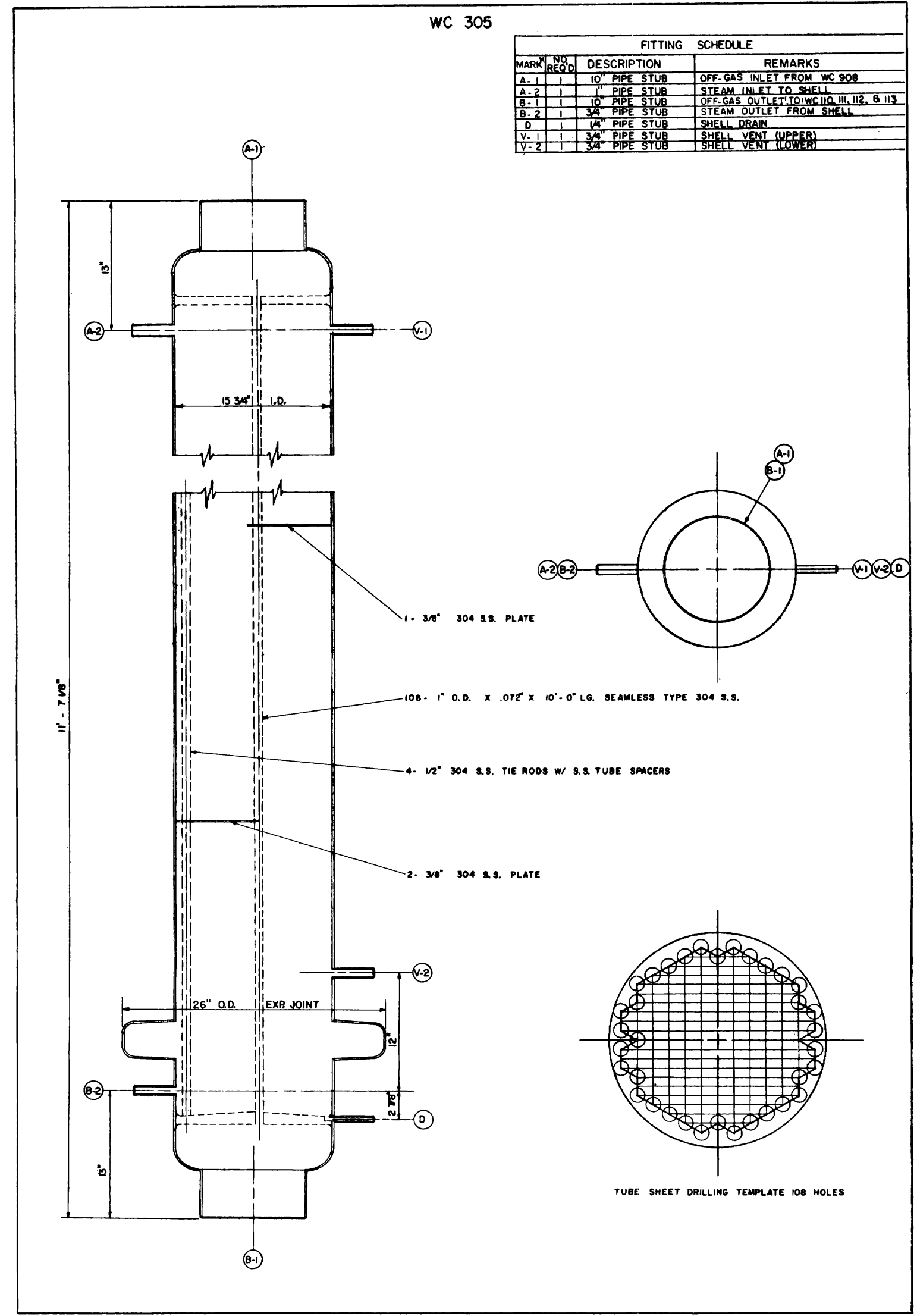

FIG. VI-2I OFF-GAS HEATER. 
The ruthenium adsorbers, WC-110, 111, 112, and 113, (Figure VI-22) are fabricated from type 304L stainless steel. The vessels were designed for pressure from 13.6 to $14 \mathrm{psi}$ at $350^{\circ} \mathrm{F}$. Normal operating pressure is $7.6 \mathrm{psia}$ at $65^{\circ} \mathrm{C}$. The welds in the vessels were 100 percent radiographed, and the vessel was hydrostatically tested at $150 \mathrm{psi}$. Each adsorber contains approximately 6000 pounds (138 $\mathrm{ft}^{3}$ ) of $6-12$ mesh silica gel. The bed is supported on a conical grid plate sloped $30^{\circ}$ toward a center drain line through which the silica gel can be unloaded. Uniform distribution of the off-gas through the bed, which varies in height because of the sloped grid plate, is achieved by varying the plate orifice spacing, ie, less orifice area is provided in the shallower portion of the bed.

Off-gas, upstream of the adsorbers, is routed from the off-gas cell into the adsorber manifold cell through the access corridor in a line shielded by a surplus 16-inch US Navy gun barrel. The adsorber manifold cell contains all of the remote valving associated with the ruthenium adsorbers and is shielded from the adsorbers to facilitate direct maintenance on these valves. The manifold cell is placed between the north adsorber cell, containing adsorbers WC-110 and 111, and the south adsorber cell, containing adsorbers WC-112 and 113. The manifold and adsorber cells are heated to $60^{\circ} \mathrm{C}$ to prevent condensation in the piping and adsorbers. Heat to these cells is provided by a steam space-heater, WC-E-3301, located in the ventilation duct between the access corridor and the manifold cell. The heated ventilation air is drawn from the manifold cell, through the adsorber cells, and into the ventilation duct outside the building (Section IV-4). Off-gas from the adsorber manifold cell can be valved to any combination of the four ruthenium adsorbers. Normally, three adsorbers are on stream in parallel at one time while the fourth is being regenerated or held on standby. The off-gas, which flows upward in the adsorbers, deposits the bulk of the ruthenium and dust in the first foot or so of the bed. The amount of dust deposit is determined by a pressure differential indicator provided on the adsorbers.

The beds are frequently regenerated to remove the accumulated ruthenium and dust from the adsorbers. This is accomplished by agitating the silica gel in water. However, since unsaturated silica gel is subject to decrepitation upon contact with liquid water, it is necessary to pretreat or saturate the silica gel before adding liquid water. In the regeneration operation, the adsorber is removed from service by closing a block valve in the outlet line. Moist regeneration air of controlled water content is heated to $65^{\circ} \mathrm{C}$ by the adsorber air heater, WC-351 


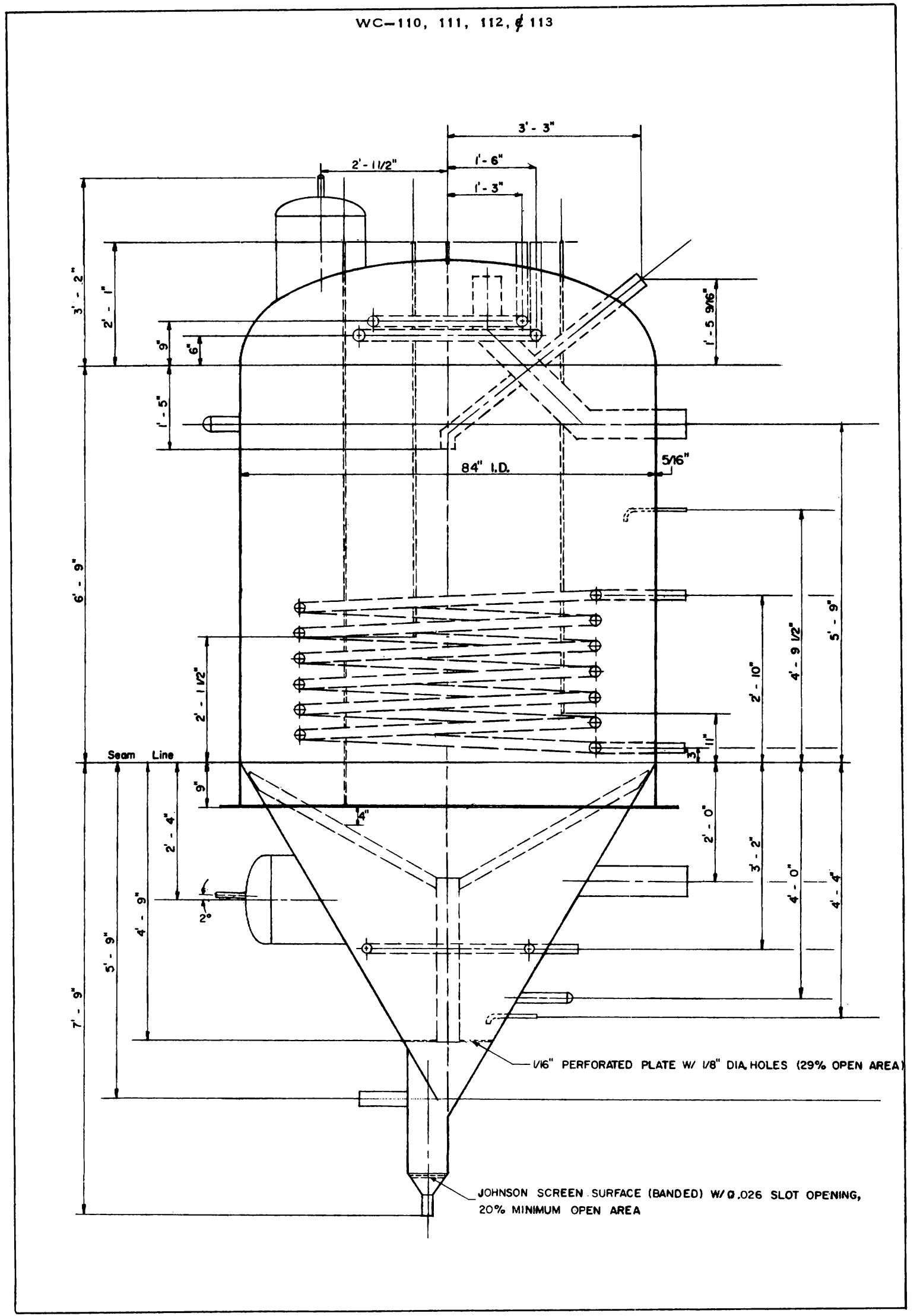

FIG. VI-22 RUTHENIUM ADSORBER. 
(rated duty $47,000 \mathrm{Btu} / \mathrm{hr}$ ). This air is introduced to the top of the bed, and is removed from the bottom by a reverse flow through the off-gas inlet line. The air then combines with the off-gas and passes on through the other three adsorbers still on stream. After a flow of $65^{\circ} \mathrm{C}$ air is established through the adsorber, live steam is gradually added to the air until the silica gel is completely saturated. Once the bed is saturated, the adsorber is flooded with about 1500 gallons of water - this water is heated to 65 to $70^{\circ} \mathrm{C}$ in decontamination nitric acid tank WC-118 and added to the adsorber through the upper decontamination sparger. While the adsorber vessel is being filled with water, the vent line of that adsorber is opened to displace contaminated gases to the quench tower. After the silica gel in the adsorber is flooded, air is introduced below the bed to provide mild agitation. This treatment breaks the bond between ruthenium and silica gel and disengages the dust held between bed granules. The ruthenium goes into solution while the dust settles to the bottom of the adsorber. When agitation is complete, the water is drained to the regeneration surge tank, WC-114. The wash water collected in WC-114 is sampled for analysis and then is transferred to the hot water sump tank, WC-119.

After the silica gel in the adsorber is drained of surface water, the bed must be dried before it can be placed back in service. Drying air, heated to $150^{\circ} \mathrm{C}$ by WC-351, is introduced into the bed in the same manner in which the silica gel is saturated. Additional heat is provided by the imbedded steam coils. Sufficient drying is indicated when the temperatures at the bottom, midpoint, and top of the bed reach the temperature of the drying air. The adsorber is then ready to replace one of the other adsorbers which are on stream.

\subsection{Regeneration Solution Surge Tank}

The regeneration solution surge tank, WC-114, receives the warm water washes from the ruthenium adsorber regeneration. This water, containing radioactive ruthenium and undissolved dust, can be remotely sampled. The solution can then be transferred to either the hot waste tank, WC-119, (from where it is transferred to the ICPP waste evaporator) or to the waste hold tanks.

The regeneration solution surge tank (Figure VI-23) is a horizontally mounted, cylindrical vessel with semi-elliptical heads and is constructed of type $304 \mathrm{~L}$ stainless steel. The vessel is designed for pressures from -1.5 to $5.0 \mathrm{psi}$ at $105^{\circ} \mathrm{C}$. All the welds were 100 percent radiographed and the vessel was hydrostatically tested at 146 psig. The operating pressure on the vessel is 


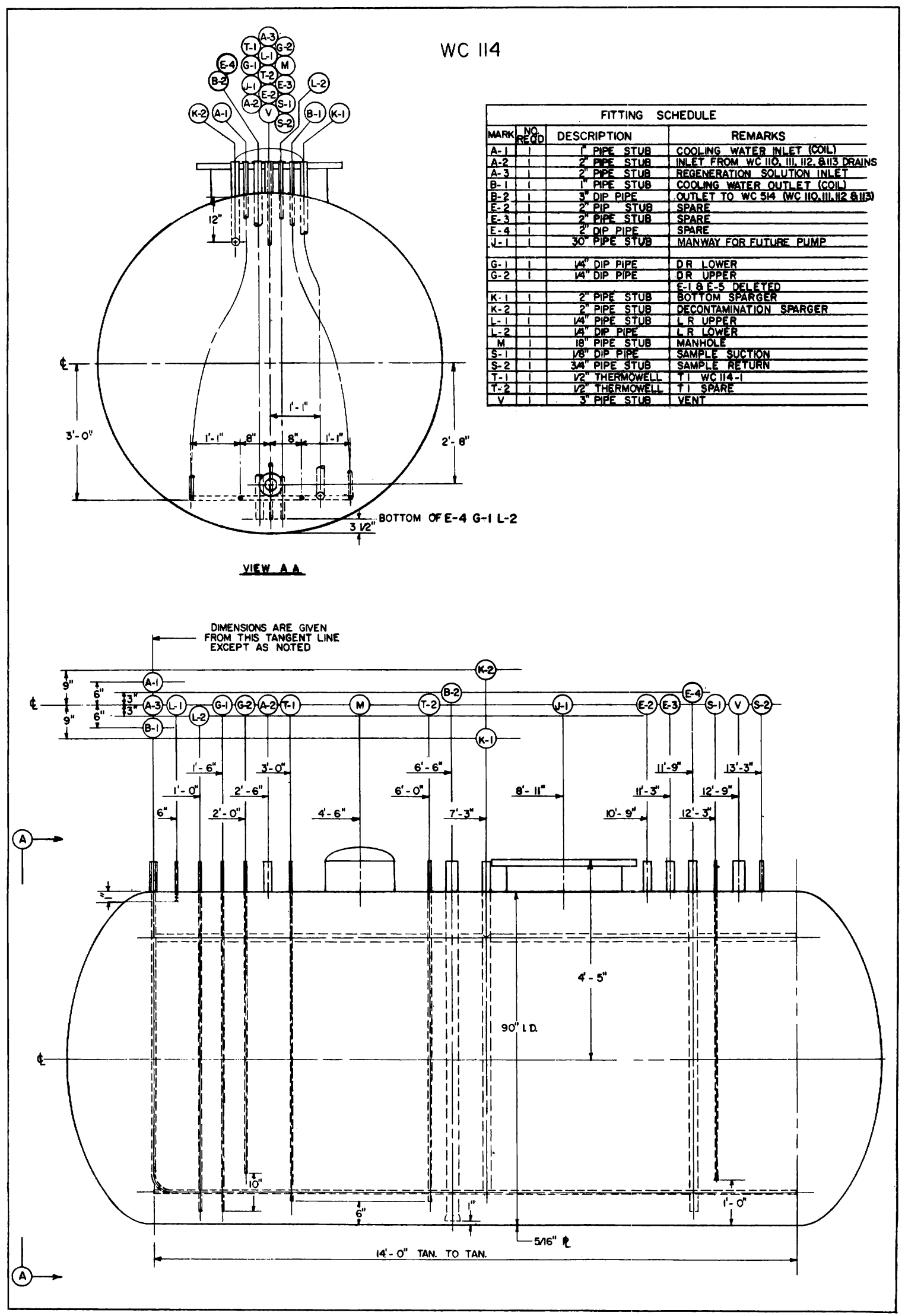

FIG. VI-23 REGENERATION SOLUTION SURGE TANK. 
12.0 psia. A steam jet ejector, WC-514, is provided for transferring the liquid from the tank to the adsorbers and waste hold tank. The vessel is vented to the equipment vent system by a three-inch connecting line. Instrumentation for temperature indicators and liquid level and density recorders are provided on the main instrument board.

\subsection{Off-Gas Knock-Out Pot}

The off-gas knock-out pot, WC-133, removes any entrained water which has entered the off-gas through various vent lines or decontamination lines downstream of the adsorbers. This unit is similar to the secondary de-entrainment separator, WC-910, shown in Figure VI-17. Liquids collected in this pot are drained into the scrubbing solution surge tank, WC-108, through a one-inch line normally kept open. The drain line is submerged in WC-108, forming a liquid seal so that off-gas cannot bypass the adsorbers through the drain line. The pot is provided with a liquid level indicator-alarm to indicate flooding. A continuous water purge is added to keep the drain line open.

This unit is constructed of type 304L stainless steel and is designed for pressures from a full vacuum to $30 \mathrm{psi}$ at $425^{\circ} \mathrm{C}$. The normal operating pressure is $-5.5 \mathrm{psi}(6.8 \mathrm{psia})$ at $65^{\circ} \mathrm{C}$. The vessel was hydrostatically tested at $50 \mathrm{psi}$. The weld in the structure was 100 percent radiographed and a $1 / 16$-inch thickness was added to the walls for corrosion allowances.

\subsection{Off-Gas Reheater}

The off-gas is heated to $70^{\circ} \mathrm{C}$ in the off-gas reheater, WC-354, to insure that all the moisture is vaporized before it enters the off-gas filters, F-2718, F-2723, and F-2724-WC.

The off-gas reheater is a jacketed pipe heat exchanger fabricated from type $304 \mathrm{~L}$ stainless steel. The off-gas flows inside a 10-inch line which is jacketed by a section of 12-inch pipe through which steam circulates. The unit was designed for pressures from a full vacuum to $30 \mathrm{psi}$ at $188^{\circ} \mathrm{C}$ on the gas side, and $150 \mathrm{psig}$ at $188^{\circ} \mathrm{C}$ on the steam side. This unit was hydrostatically tested at 225 psi. A thickness of $1 / 16$ inch was added to the vessel wall for corrosion allowance; the welds were all radiographed. Operating conditions are -5.8 psi $\left(6.5\right.$ psia) at $70^{\circ} \mathrm{C}$ on the gas side, and $146^{\circ} \mathrm{C}$ on the steam side. The heater will provide a heater duty of $17,500 \mathrm{Btu} / \mathrm{hr}$ at the operating conditions.

\subsection{Off-Gas Filters}

Final cleanup of the calciner off-gas is accomplished in three remotely removable filter units, F-2718-WC, F-2723-WC, and F-2724-WC, in parallel

$$
\text { vi }-44
$$


service. Each filter unit consists of a Fiberglas prefilter in series with an AEC-type glass-asbestos final filter. These are inside a stainless steel housing which has internal inlet and outlet valves.

The prefilter and AEC-type final filter media are fireproof and are designed to operate in an atmosphere of nitric acid vapors at temperatures up to $350^{\circ} \mathrm{F}$. Prior to arriving at the NRTS, the AEC-type final filters are visually inspected and must pass a standard filter DOP efficiency test (99.97 percent removal of 0.3 micron particles) at both the vendor's plant and Hanford. Prior to installation in the WCF, each complete filter unit (filters installed in case) will be tested and must show an efficiency greater than 99.97 percent with 0.9 micron, DOP smoke.

The filter housings are fabricated of type 304 stainless steel and are designed for pressure from -6.75 psig to $+6.75 \mathrm{psig}$ at $177^{\circ} \mathrm{C}$. The normal operating pressure is $-6.4 \mathrm{psi}(5.9 \mathrm{psia})$ at $70^{\circ} \mathrm{C}$. The housings were air tested with soap solution at 6.75 psi. The off-gas enters the filter housing at the bottom, passes through the prefilter and the AEC-type final filter, and leaves the housing near the top. A pressure differential indicator with alarm is provided across all three filters.

Normally, all three filter units are operated together; however, two units can handle the total off-gas flow during filter changes. Filter replacement is conducted remotely from the filter operating corridor because of the high radiation intensity of the accumulated dust. For this purpose, a shielded window in each filter cell (Figure VI-24) is provided for observing the operation. When a filter unit must be replaced, the unit is isolated from the off-gas system by closing the remote valves on the filter inlet and discharge lines. Next, the remote internal valves in the housing are closed before the housing flanges are remotely disconnected from the off-gas line. Then, the individual cell hatch cover over the cell is removed by a 20 -ton filter removal crane, WC-L3301. This crane can be operated directly from the access area above the filter cells or remotely from the filter operating corridor. The filter housing is placed in a shielding cask for removal to the AEC burial ground. The filter shielding cask is provided with a hinged bottom that can be opened remotely so the filter case can be easily dropped out at the burial ground.

\subsection{Off-Gas Blowers}

A vacuum is maintained on the calciner and off-gas system by one of the two off-gas blowers, WC-251A or WC-251B. These blowers deliver 


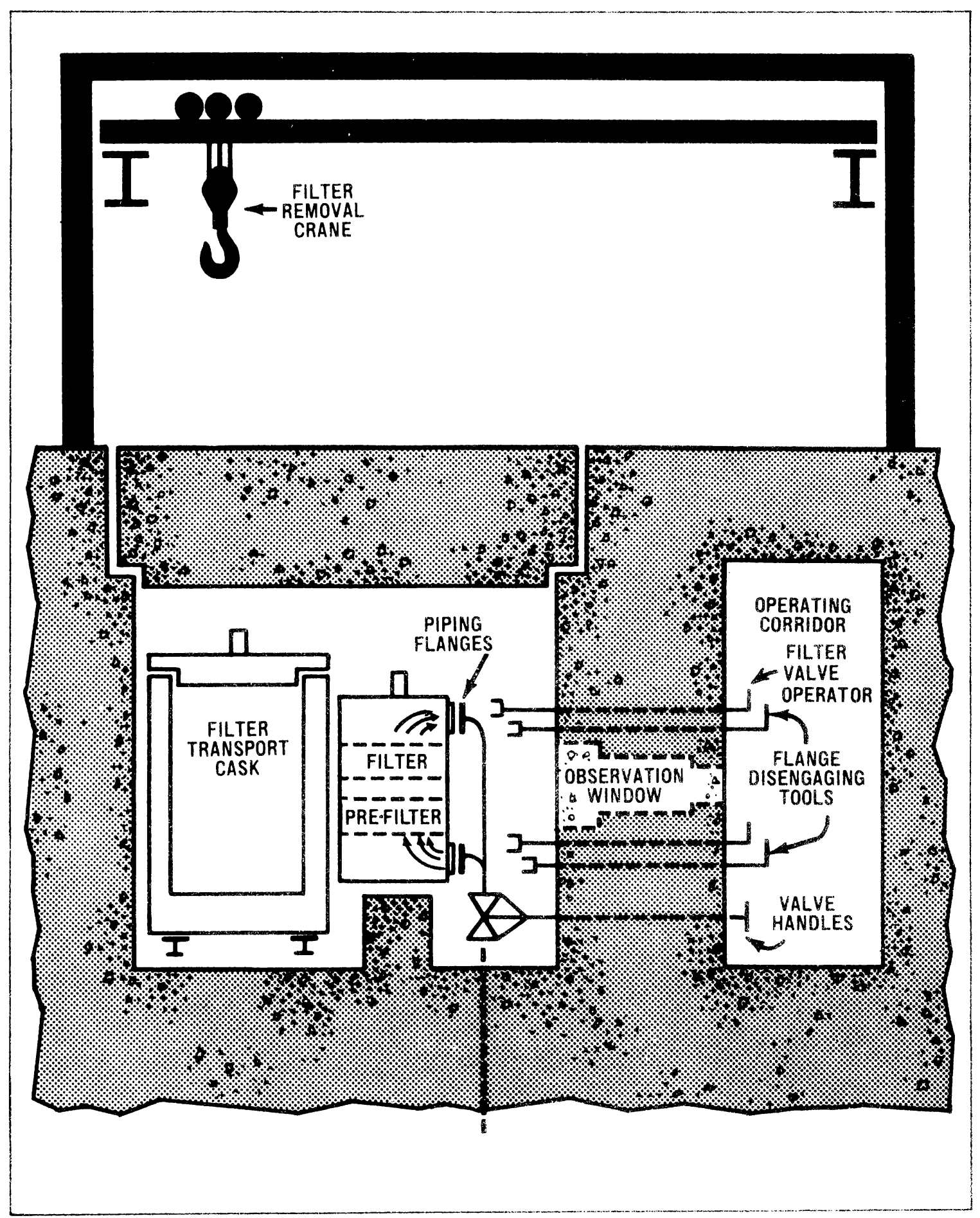

FIG. VI-24 OFF-GAS FILTER FACHLITY

off-gas, cleaned of dust and radioactive contaminants, to the ICPP stack where it is discharged to the atmosphere.

The off-gas blowers (Figure VI-25) are two case units with eight stages per case that are mounted in tandem to a $200-\mathrm{hp}$ squirrel-cage induction motor. 


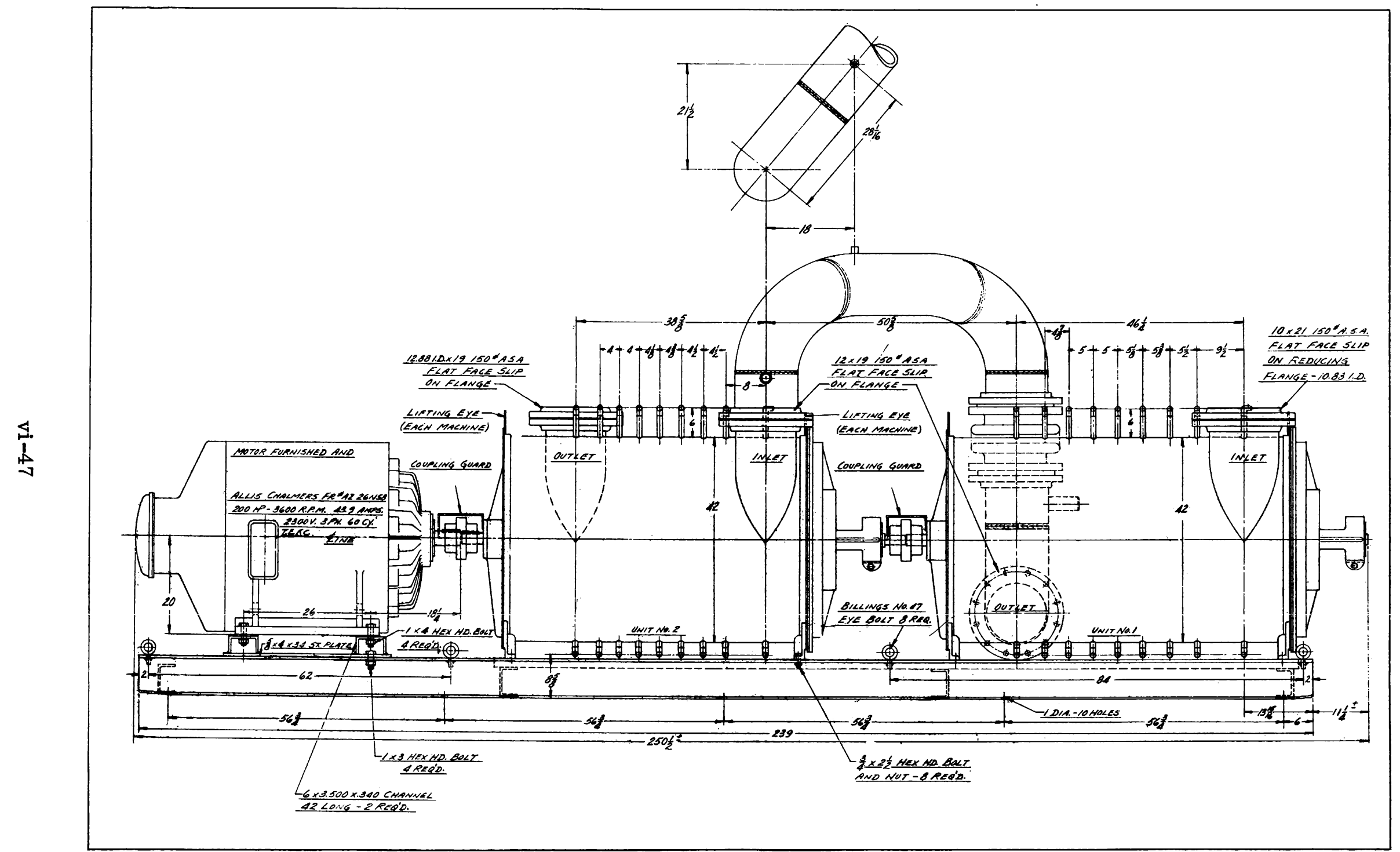

FIG. VI-25 OFF-GAS BLOWER. 
They are constructed of type 304L stainless steel and are provided with automatic starters that will start the spare blower when the suction pressure rises above 8.5 psia or the blower in service fails. The blower will deliver $1166 \mathrm{cfm}$ (0.9 gravity air) at a suction pressure of 6.5 psia. The operating pressure is 5.9 psia at a blower load of $746 \mathrm{scfm}$ of gas.

Off-gas enters the blower from a 10-inch inlet line, passes between cases in a 12-inch line, and discharges into an 8-inch stack header. All the off-gas lines connected to the blowers are provided with suitable expansion joints in order to prevent blower case distortion from thermal expansion of the piping. Expansion joints have been included in the decontamination lines connected to the blowers for the same purpose.

The blowers are oil lubricated by a remote lubricating system that is located in the filter removal corridor adjacent to the off-gas blower cell. The oil from this reservoir is controlled and metered by individual needle valves which have sight glass attachments in the stainless steel lines to the respective off-gas blower bearings. Surplus oil is collected in a receiver manifold below each bearing and drains to a second reservoir also located in the filter removal corridor. Two alternate service oil pumps, WC-228A and WC-228B, return the oil to the feed supply reservoir. These pumps are rotary displacement type and are constructed of type 316 stainless steel with hypalon impellers. They are driven by $1 / 3-\mathrm{hp}$ motors, operating on 115/230-volt, 3-phase, 60-cycle commercial power. The feed supply reservoir is provided with a water coil for cooling, the oil before returning it to the off-gas blower bearings.

The individual blower cases are provided with decontamination lines to the turbines, and are equipped with a check valve to prevent radioactivity from backing up into the decontamination system.

An emergency power supply (2300-volt generator) is available and connected to the off-gas blowers to insure uninterrupted operation during loss of commercial power.

\section{SOLIDS TRANSPORT SYSTEM}

\subsection{General Description}

The alumina produced in the calcining process is conveyed pneumatically from the calciner vessel to the storage bins through a buried and concreteencased three-inch line connecting the calciner cell with the storage vault. 
Approximately $69 \mathrm{scfm}$ of air are supplied to this line in the calciner cell by the fluidizing air blower (WC-250A or B). In the calciner cell, solids from the calciner vessel are normally discharged into the transport line from the cyclone fines jet and a product takeoff line. Occasionally, solids also may be discharged into the transport line through the calciner cone drain line, the air distributor plate drain lines, spare product takeoff line, and the adsorber unloading line. At the storage bins, alumina (or silica gel) is removed from the transport air by a cyclone (WC-915) and drops by gravity into the storage bins. The transport air, cleaned of solids, is returned to the top of the calciner through a 3-inch line contained in the same concrete encasement as the transport line to the storage bins. The solids transport system is shown schematically in Figure VI-26.

All components of the transport air system upstream of the calciner cellwall block valve are located in non-radioactive areas, and the normal material of construction is carbon steel. Air from the discharge manifold of the fluidizing air blowers travels in a 3-inch line from the NaK furnace room to the access corridor. In the access corridor the air passes through an orifice meter, a flow control valve, a reverse current check valve, a shell and tube heat exchanger, a block valve, a conventional check valve, and through the wall into the calciner cell. The remainder of the transport system lies in radioactive areas; the block valve and all components downstream are fabricated of stainless steel except as noted.

An orifice meter measures the flow of air through the transport air line. Air flow is not volume controlled and will vary considerably with the solids loading of the transport air line; thus a knowledge of the air flow is vital to prevent overloading the system with solids. The flow measured by the orifice is recorded on the operating corridor control panel. A flow control valve regulates the air flow into the transport air line to maintain a constant pressure in the transport air line at the point just upstream of where product from the calciner enters the line. The control loop is described more fully under instrumentation and control in Section VI-8.

A reverse current check valve gives positive assurance against backflow of air from the active section of the transport air line to the non-active section in the event of blower failure. The valve is automatically tripped if the pressure immediately upstream of the control valve drops below a predetermined pressure. When tripped, the valve partially closes immediately, but does not close 


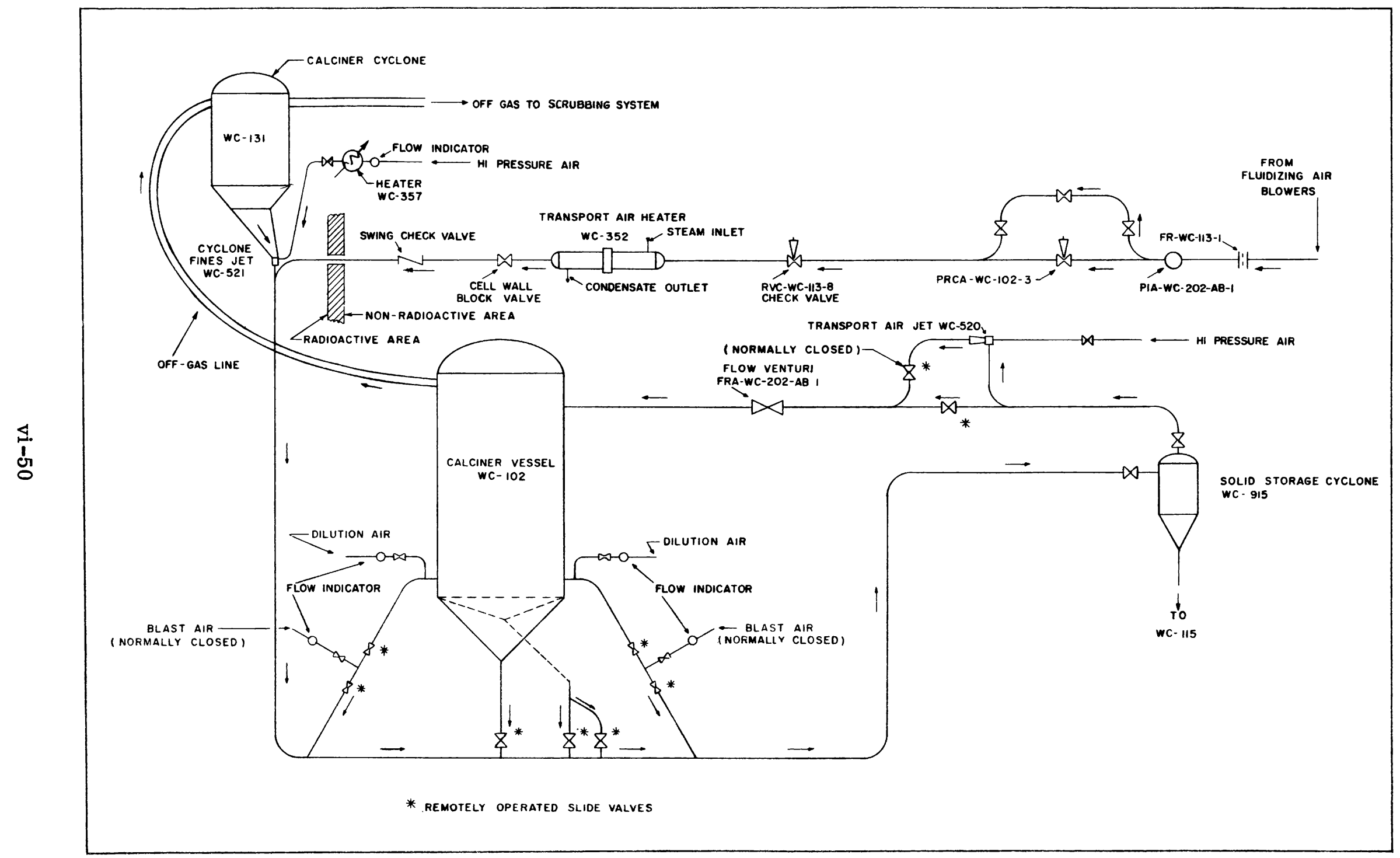

FIG. VI-26 TRANSPORT AIR SYSTEM. 
completely until all air flow in the normal direction ceases. The valve reopens automatically when normal pressure upstream on the control valve is restored.

\subsection{Transport Air Heater}

The transport air must be heated to prevent condensation of moisture introduced from the calciner cyclone by the cyclone fines jet. This is accomplished by passing the transport air through the transport air heater, WC-352, located in the access corridor. Sufficient heat is added with this steam heater to maintain the transport air temperature above $125^{\circ} \mathrm{F}$ everywhere in the transport system. The estimated maximum dew-point of the transport air is near $100^{\circ} \mathrm{F}$. Design pressures are 110 psig for the shell and 15 psig for the tubes; the heater is fabricated of type 347 stainless steel. Details are shown in Figure VI-27.

\subsection{Cyclone Fines Jet}

After entering the calciner cell the 3-inch transport air line rises above the calciner vessel and passes beneath the cyclone dust hopper. Cyclone fines and some off-gas from the calciner are injected into the transport air line by the cyclone fines jet, WC-521. The jet is located at the junction of the conical section of the cyclone and the transport air line and discharges solids to the transport air line as shown in Figure VI-28. In addition to discharging solids into the transport line, the jet also prevents backflow from the transport line to the cyclone. Backflow from the transport air line into the cyclone disrupts the gas-solid flow patterns and thus reduces the cyclone collection efficiency. The amount of gas pulled from the bottom outlet of the cyclone is determined by the amount of motive air to the jet. The higher the flow rate of primary (or motive) air to the jet, the greater the flow rate of secondary gases from the cyclone. Motive air to the jet is controlled by a rotameter located in the operating corridor, and is heated to approximately $200^{\circ} \mathrm{C}$ by a $7250 \mathrm{Btu} / \mathrm{hr}$ electric heater (located in the operating corridor) to preclude any possibility of condensation in the area of the jet. To minimize wear in the jet mixing chamber, a boron carbide liner is employed as shown in Figure VI-29.

\subsection{Air Distributor Plate and Cone Drain Lines}

After picking up fines from the cyclone, the transport air line drops below the calciner vessel where the cone and air-distributor-plate drain lines connect to it. Each of these lines connects to the transport air line through a slide valve (section VI-3.2) which is remotely operated from the operating corridor control panel. A screen is placed over the inlet to the distributor 


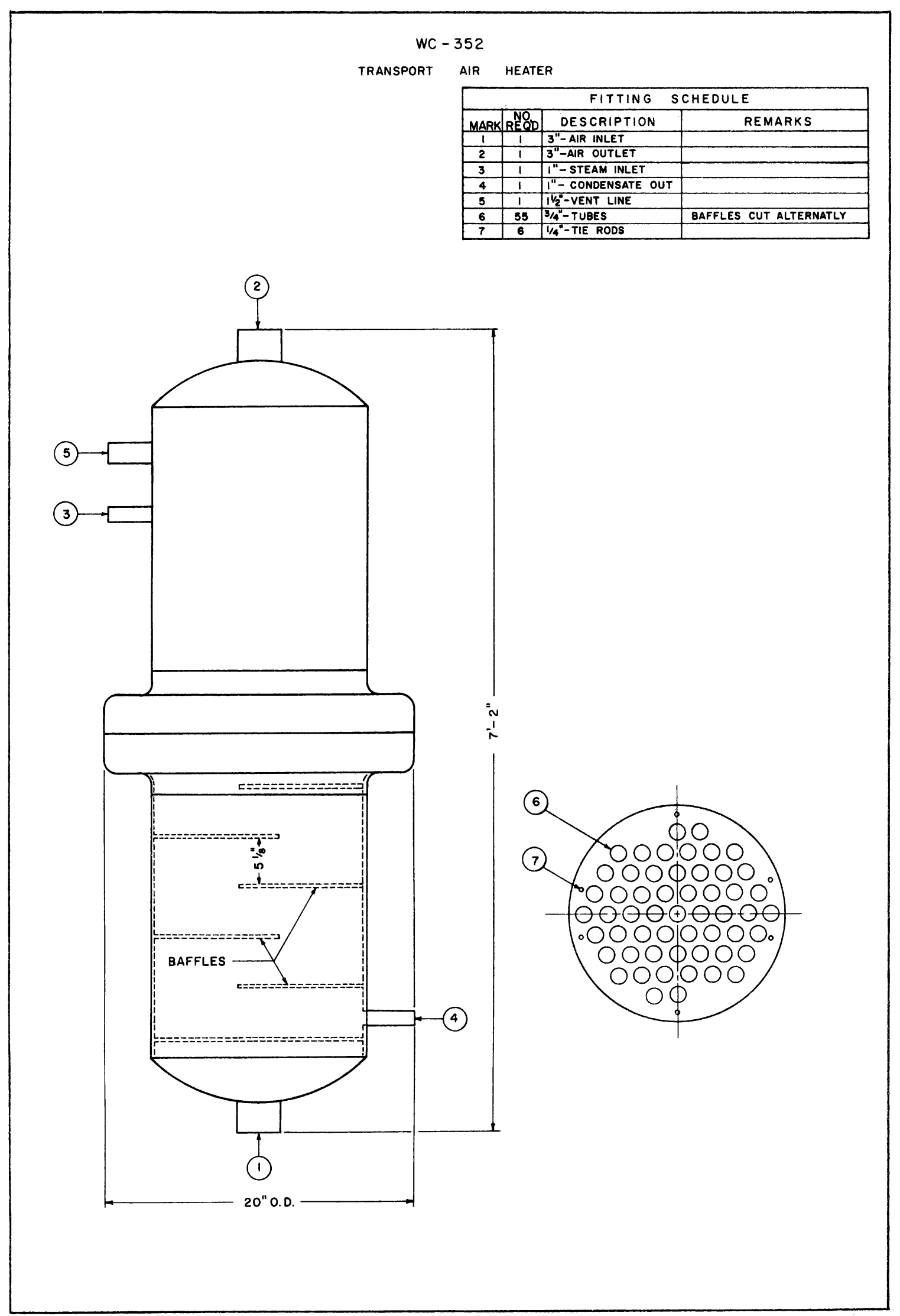

FIG. VI-27 TRANSPORT AIR HEATER,

vi -52 


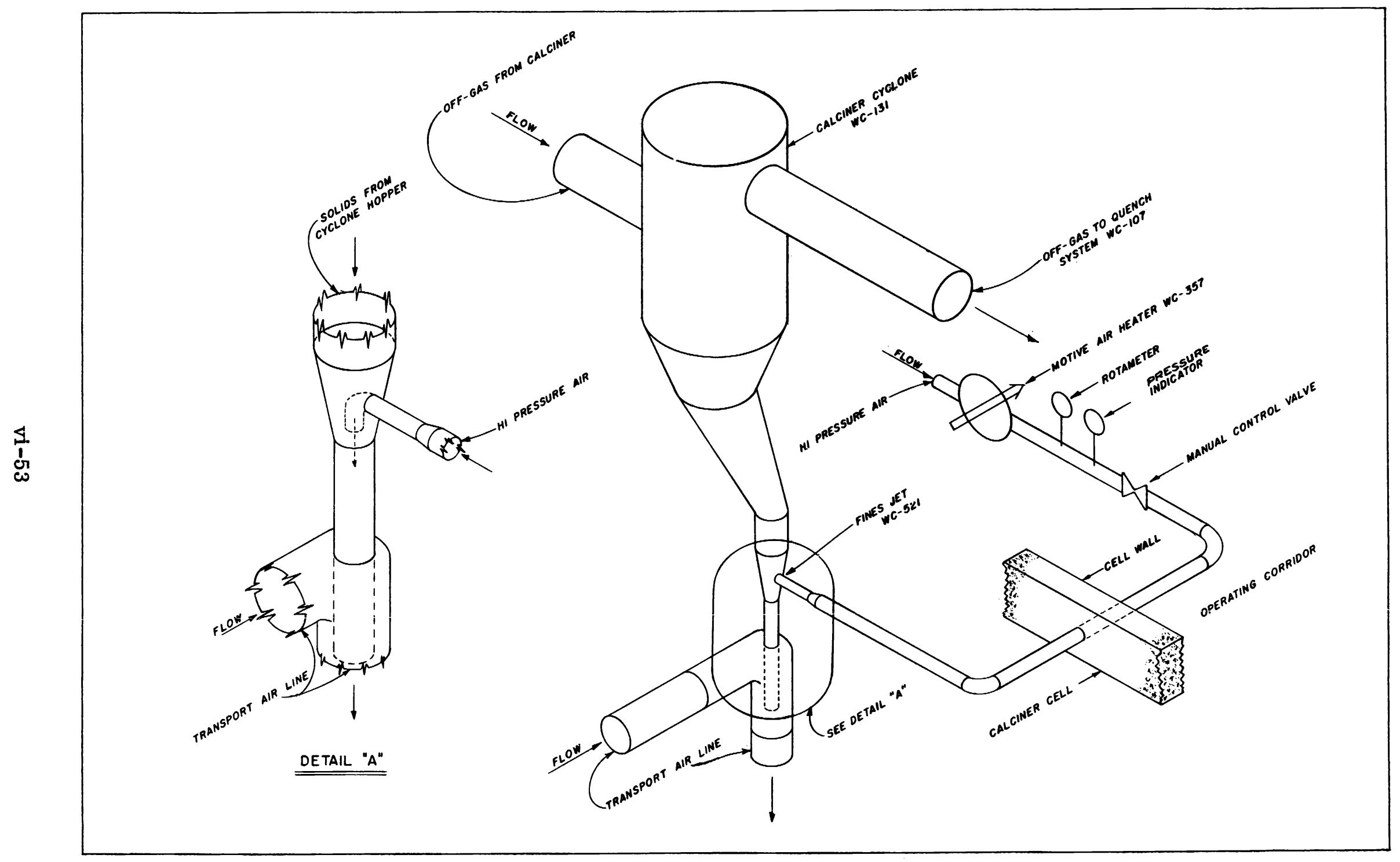

FIG. VI-28 CYCLONE FINES JET SYSTEM. 


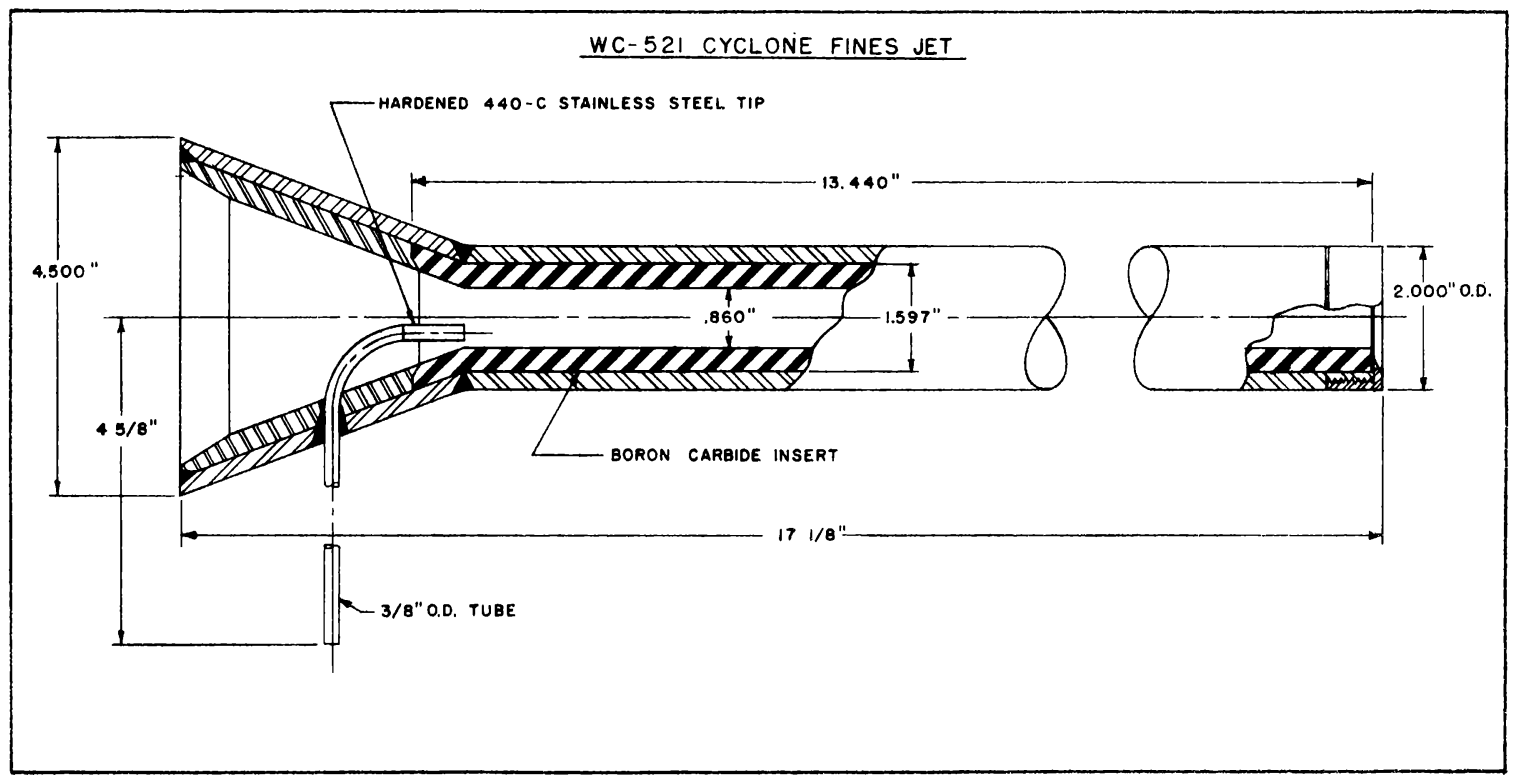

FIG. VI-29 CYCLONE FINES JET CONSTRUCTION.

plate drain line to prevent cakes or large foreign material from entering and plugging the line. During normal operation the valves remain closed. During shutdown the slide valve in one of the air-distributor-plate drain lines is positioned to control the flow of the bed material into the transport air line. After the material above the distributor plate has been transferred to storage, the cone drain valve is opened to transfer solids which have dropped below the support plate. At the start of the bed dumping operation, the pressure above the distributor plate is greater than the pressure in the transport air line causing solids to overflow freely into the transport air line. As the bed level decreases however, the pressure above the distributor plate decreases (the vacuum above the bed is maintained constant) and the driving force for solids flow to the transport line could eventually become zero. To prevent this from happening and also to create a greater driving force for the flow of transport air during the bed dumping operation, the pressure in the transport line is reduced by use of the transport air jet, located in the transport line after it has returned from solids storage. This jet is used during bed unloading and silica gel transfer only.

\subsection{Product Takeoff Lines}

Two 1/2-inch product takeoff lines enter horizontal sections of the transport line from opposite sides of the calciner. One of the takeoff lines is operated while the other is available as a spare. Each line connects to the calciner vessel near the bottom of the bed and slopes downward until it enters the 3-inch transport air line. Two remotely-operated slide-valves are located in each line, and an 
air purge line (Blast Air) connects to the takeoff line between the two valves (Figure VI-30). With this arrangement the line can be blown out in either direction. When not in service, the line is continuously purged back to the calciner vessel to prevent the line from plugging. The air purge rate is indicated by a rotameter and controlled by a manual valve, both located in the operating corridor.

A second air line connects to each product takeoff line close to the junction of the line with the calciner vessel. Air introduced at this point controls the rate of product flow through the line. The solids product flow varies inversely to the air flow rate. This air stream is designated as dilution air, and the flow rate is measured and controlled from the operating corridor in the same manner as the purge air.

To prevent large lumps of calcine from entering the product takeoff lines and possibly plugging them, screens are welded over the product takeoff lines inside the calciner vessel to limit the size of particles which can enter the takeoff line to $3 / 16$ inches in diameter.

\subsection{Silica Gel Transfer}

Spent silica gel from the adsorbers is pneumatically transported through a 3-inch line from the adsorbers to the main transport air line. This line joins the transport air line downstream of the product takeoff points. The silica gel is transported from the adsorbers to the calciner cell by high pressure air introduced to the transport line at the adsorber. Because this additional air would overload the transport air system during normal operation, the transport air jet must be used during silica gel transfer operations. In addition, product transfer from the calciner vessel would be discontinued.

\subsection{Solids Storage Cyclone}

From the calciner cell the transport air travels underground to the solids storage area, passes through the solids storage cyclone and returns underground to the calciner building. Most of the solids are separated in the solids storage cyclone, WC-915, and drop through distributor lines to the storage bins. This cyclone is shown in Figure VI-31.

The cyclone is constructed of 3/16-inch type 304L stainless steel and all connections are 3 -inch schedule 40 pipe. It was designed for full vacuum and 30 psig at $345^{\circ} \mathrm{C}$, and for a maximum allowable pressure drop of 4 inches of water at $106 \mathrm{scfm}$ and a solids loading of $50 \mathrm{lbs} / \mathrm{hr}$. A minimum removal efficiency of 98 percent was specified for a solids size distribution of 99.8 percent greater 


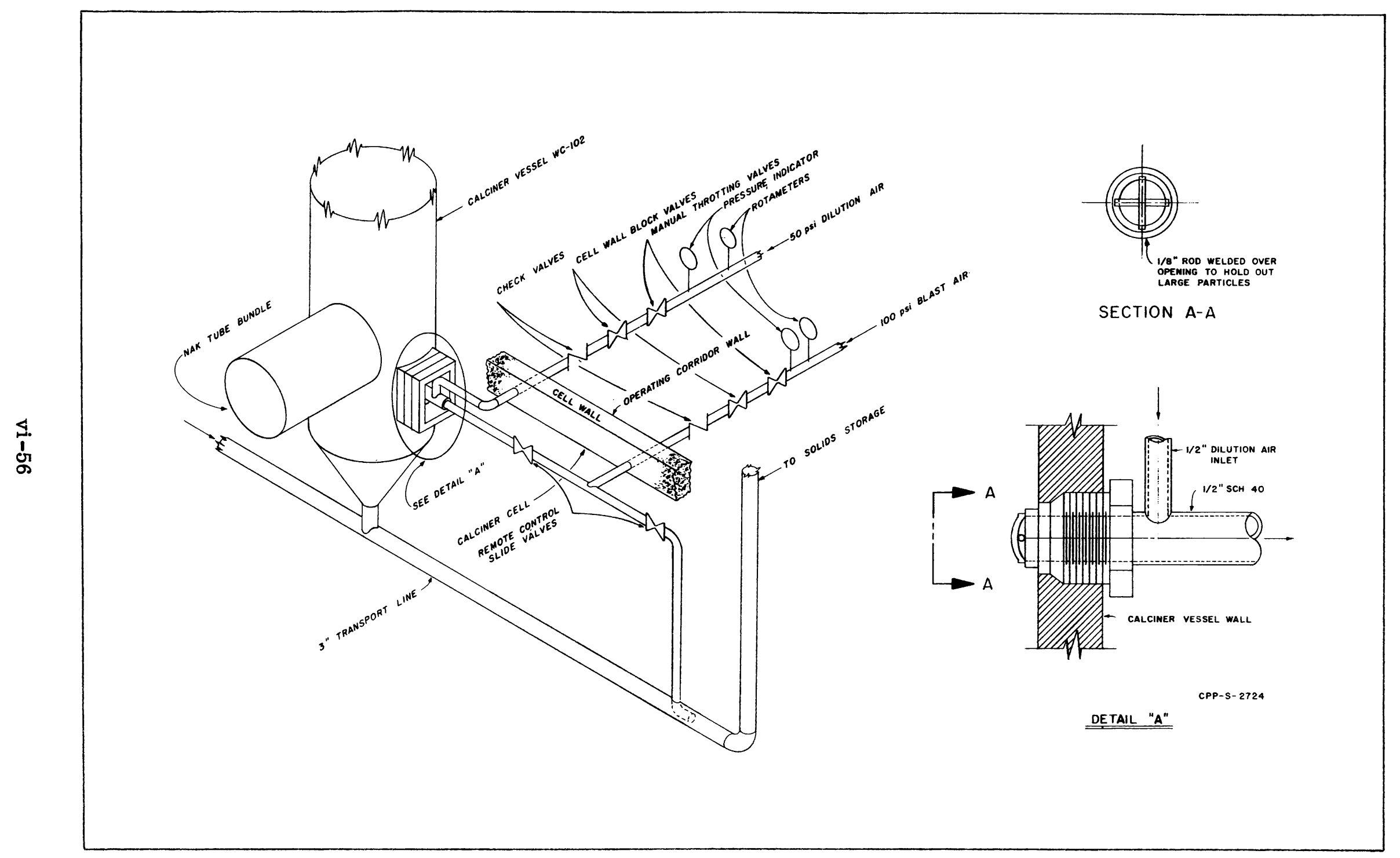

FIG. VI-3O PRODUCT TAKE OFF SYSTEM. 


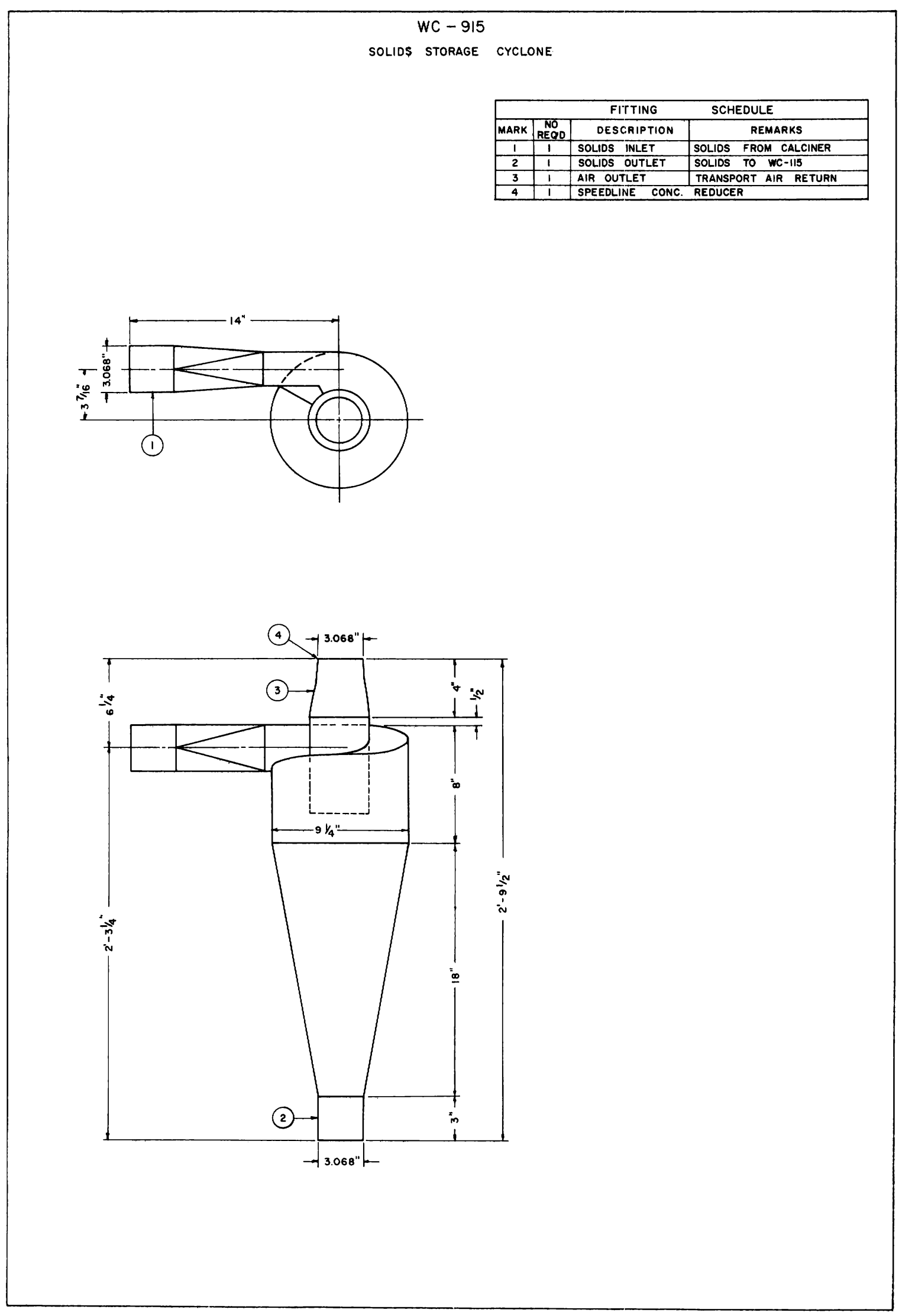

FIG. VI-31 SOLIDS STORAGE CYCLONE 
than 100 Tyler mesh screen. The concentration of particles less than 100 Tyler mesh in the solids actually handled by the cyclone is considerably greater than the design figure, so that in practice the efficiency of the cyclone is less than 98 percent. The root pass of all butt welds and the finished surface of all welds were dye penetrant inspected. All butt welds were 100 percent radiographed and fillet welds were spot radiographed at a minimum of two places per seam.

\subsection{Transport Air Jet}

An air operated jet is located in the transport air return line to the calciner. This jet, WC-520, is normally blocked out of the process by a remotely operated valve located on the jet discharge line. A remotely operated block valve also is located in the bypass line around the jet. The jet is normally used only when dumping the calciner bed or when transferring silica gel. At such times the jet must be operated to alter the pressure balance on the system and to overcome the added resistance created by high solids loading. The jet is operated by high pressure air controlled from the decontaminating room. Downstream of the transport air jet the transport air passes through a venturi tube flow meter. The flow rate is recorded on the operating corridor panel.

\section{SOLIDS STORAGE}

\subsection{General}

The existing (and first) solids storage unit provided with the WCF was designed to maintain all of the stored material below the calcination temperature $\left(400^{\circ} \mathrm{C}\right)$ and to prevent, if possible, the evolution of radioactive fission products. At temperatures above $400^{\circ} \mathrm{C}$, unconverted aluminum nitrate and mercuric oxide in the stored product could decompose with the evolution of oxides of nitrogen, oxygen, and mercury. These gases might entrain active dust in passing through the stored solids. At still higher temperatures, radioactive fission products may volatilize.

Storage of the WCF solids product is complicated by the poor heat transfer characteristics of the granular calcine formed by fluidized bed calcination(see Section V-4.8, Thermal Conductivity). Attenuation of gamma and beta radiation from the decay of the contained fission products generates heat within the stored particles of alumina. In the narrow bin type storage developed, excessive solids temperatures are avoided by limiting the distance between cooling surfaces to 24 inches with the exception of the central cylinder which has a diameter of 
36 inches (see Section V-8, Temperature Distribution in Stored Solids). Heat is removed from the cooling surfaces by air flowing through annuli between the concentric bins. Cooling air is circulated either by a blower or by natural convective circulation.

While being filled, the storage bins are vented to the calciner off-gas system through the solids transport line; after filling is complete or during process shutdown, the bins are vented to the ICPP stack through a separate off-gas cleanup system located above the bins. A flow diagram of the solids storage equipment is shown in Figure VI-32.

\subsection{Solids Storage Bins, WC-115-1, 2, 3, and 4}

Storage for calcined waste is provided by four units located underground in a concrete vault. Each unit, as shown in Figures VI-33 and VI-34, is made up of a central cylinder and two progressively larger concentric bins with annular spaces between each section. The outermost bin is enclosed by a carbon steel shell which leaves a 1-1/2-inch-wide annular space between the bin and the shell. The capacity of each unit is 1950 cubic feet and the total capacity for the four units is 7800 cubic feet. This is equivalent to approximately 570,000 gallons of liquid waste. The design pressure range for each unit is from $\mathbf{- 3 . 7 5}$ psig to +3.75 psig at a design temperature of $343^{\circ} \mathrm{C}$. These units were designed in accordance with the ASME code for Unfired Pressure Vessels and were fabricated from Type 405 stainless steel.

Temperature data will be used to determine the level of solids in the bins and to monitor heat generation from fission product decay. The solids storage bins are equipped with 202 thermocouples located at various points on the four units as shown in Figure VI-34. A 48-point temperature indicator with five 40point rotary switches is located in the solids storage control room to monitor the temperatures. Connected to this temperature indicator are 186 of the 202 thermocouples located on the four units. The other 16, which are located in the last bin to be filled, are connected to a temperature indicator located on the main control board in the operating corridor of building ICPP-633 for close monitoring of the bin level.

The solids storage vessels are protected by three pressure relief valves. One valve is set at two psig to take care of over-pressure which might result from operator error in accidentally closing all three block valves to the solids storage cyclone. It bypasses the valves and vents the vessel off-gas to the off-gas cooler, WC-316. The second valve bypasses the off-gas cleanup equipment as 


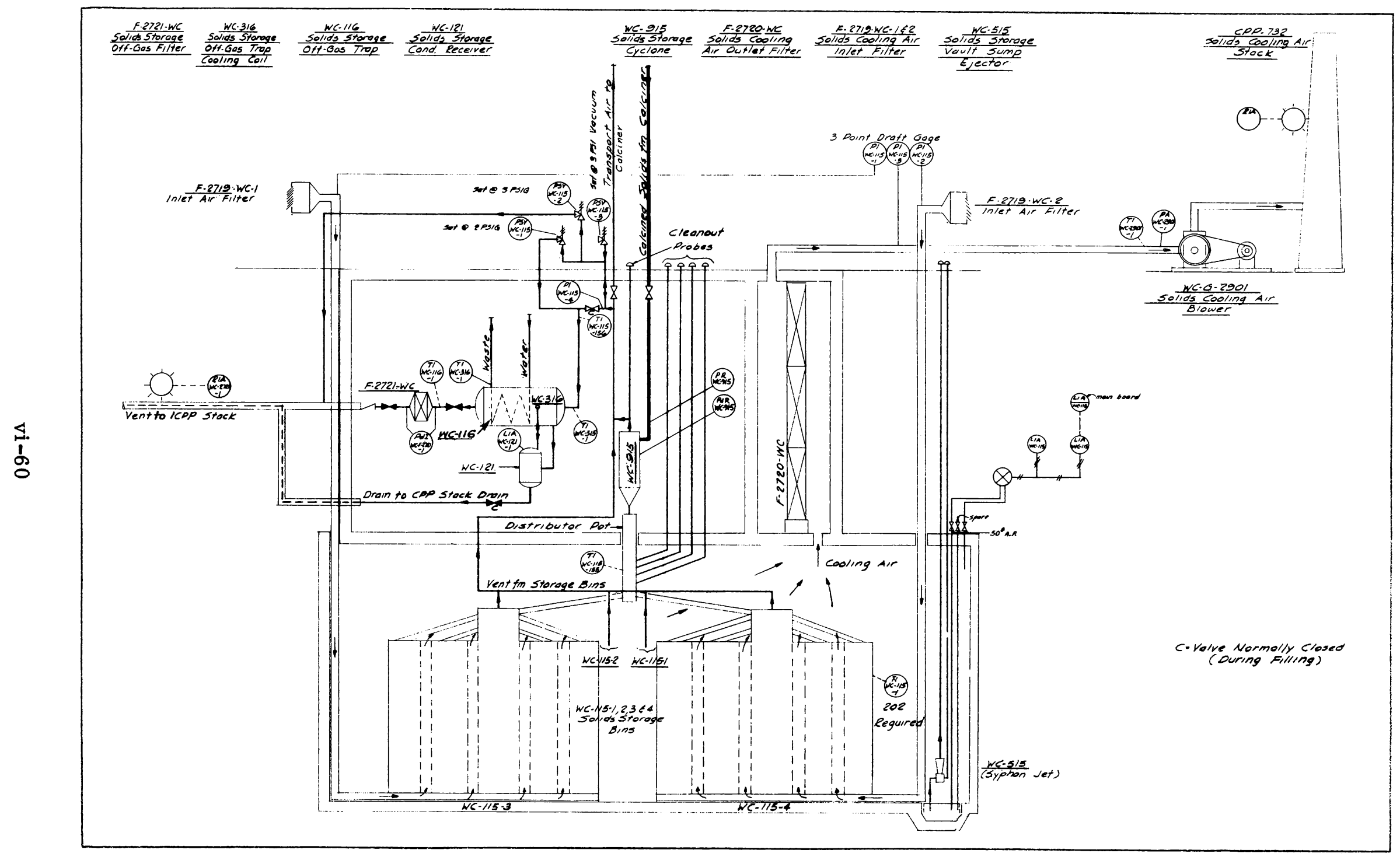

FIG. VI-32 SOLIDS STORAGE SYSTEM FLOW DIAGRAM. 


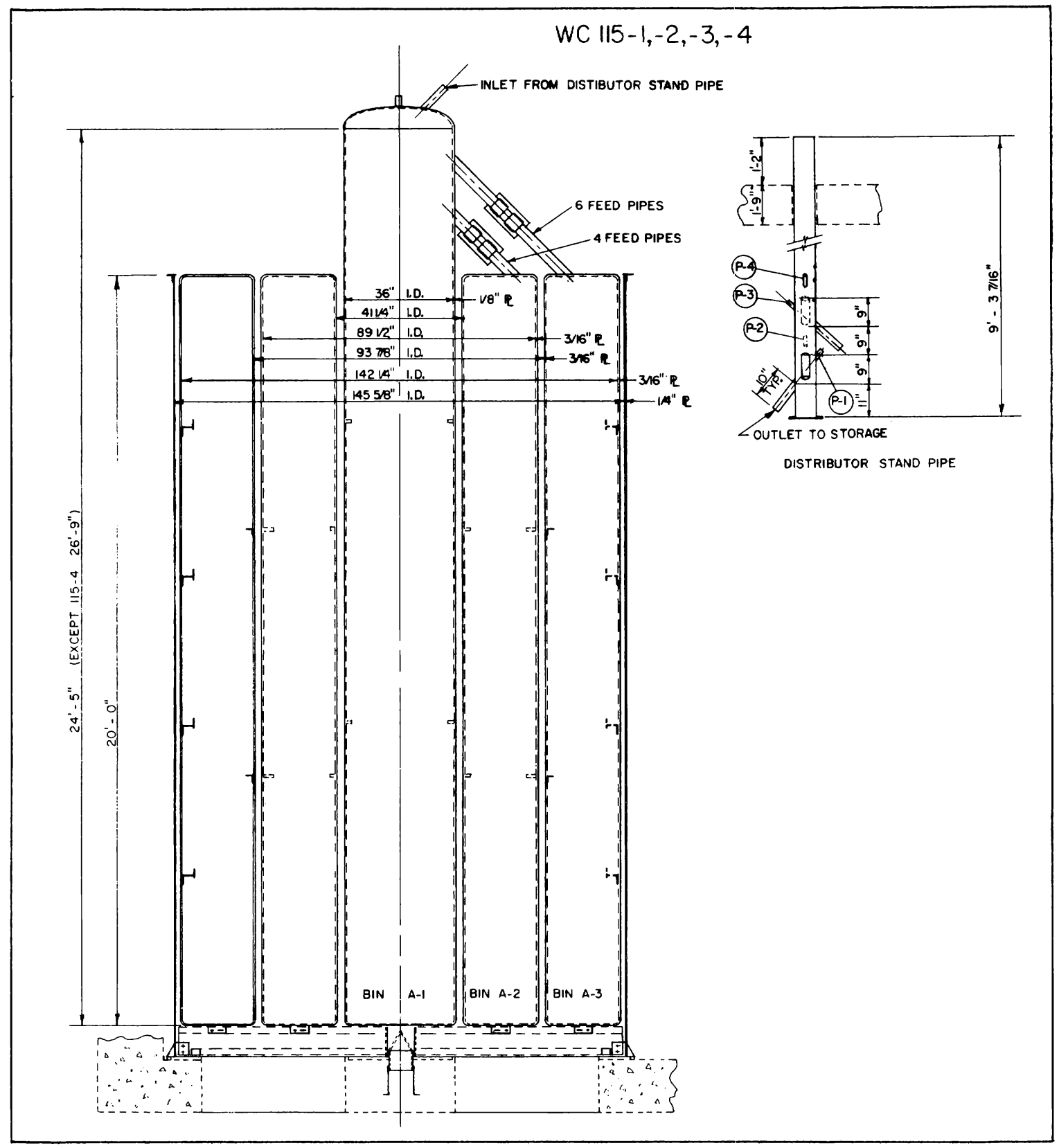

FIG. VI-33 INDIVIDUAL SOLIDS STORAGE: BIN.

protection against over-pressure resulting from restrictions. It opens at 3 psig and discharges directly to the line leading to the ICPP stack. The third valve protects the vessels against a vacuum in excess of 3 psig. During operation of the calciner, any gases generated in the solids storage bins vent through the transport air line to the calciner vessel.

Calcined solids which are pneumatically conveyed from the calciner vessel drop from a cyclone, WC-915, into a central distributor stand pipe which is 6 inches in diameter and approximately 10 feet high (Figure VI-33). Four lines, 


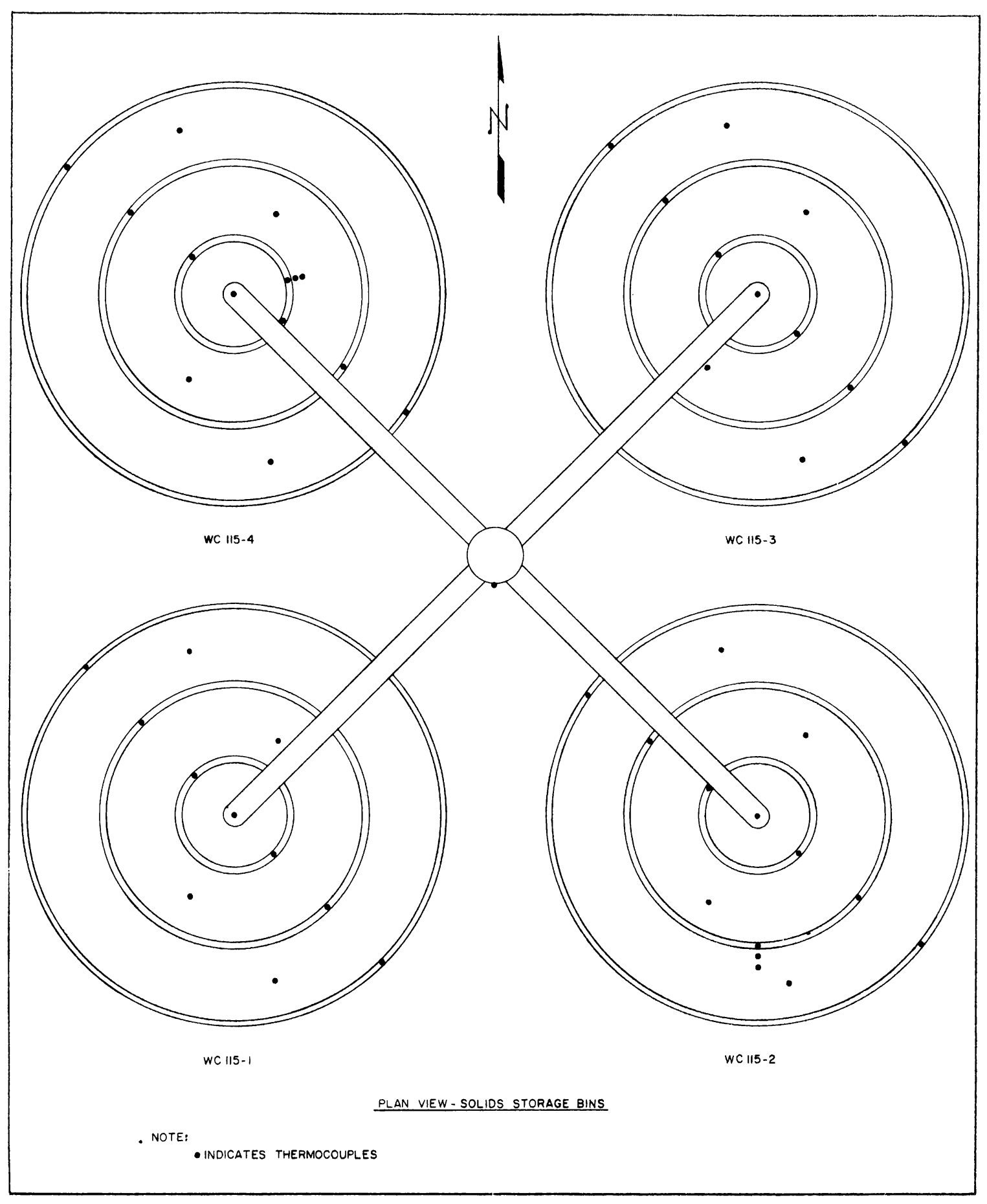

FIG. VI-34 STORAGE BIN PLAN.

located at different elevations, conduct solids from the distributor stand pipe to the storage bins. These pipes are inclined at 45 degrees, whereas the static angle of repose of the solids is about 33 degrees. The solids fill the central cylinder of a bin until the level of the first set of distributor pipes is reached. When the center cylinder is filled to this level the solids flow to the first annular 
ring of the storage bin; similarly, when the first ring is filled, the level rises in the standpipe until the second ring starts filling. When the entire unit is full, the solids level in the central distributor stand pipe then rises until the next higher distributor pipe is reached, whereupon, flow into the second cylindrical bin begins. The process will continue until all four storage units are filled. The entire filling operation is automatic and requires no motive equipment or maintenance.

Five cleanout stubs are available for use in unplugging the solids gravity flow lines leaving the cyclone and the distributor stand pipe. Four of these enter the distributor stand pipe, one placed opposite each of the gravity flow lines to the four central cylinders in the solid storage bins $(\mathrm{P} 1,2,3,4$, on Figure VI-33). One enters the top of the cyclone. These stubs extend outside of the vault where they are equipped with neoprene diaphragms and blind flanges. In the event cleanout is necessary, the blind flanges can be removed and the neoprene diaphragms punctured with the probe being used for unplugging. The flexible diaphragm forms a seal between the probe and the stub piping.

A number of expansion joints have been installed to protect the bins and piping from the effects of thermal expansion. Special sleeved type expansion joints have been installed in the solids gravity flow lines from the distributor pot and central stand pipes. Expansion joints also are provided in the cleanout stubs and individual bin vent lines.

\subsection{Solids Cooling}

Heat generated by attentuation of radioactive fission products is removed by air circulating in the annular spaces between the circular bins and in the annular space between the outer bin and the shell. Atmospheric air, induced by the solids-cooling air blower, WC-G-2901, enters through two inlet air filters, F-2719-WC-1 and 2, into a radial circumferential distribution duct system which distributes the air to the annular cooling spaces between bins (Figure VI-32).

The solids-cooling air blower, WC-G-2901, has a capacity of $30,450 \mathrm{cfm}$ at $220^{\circ} \mathrm{F}$ inlet temperature with a discharge pressure of $12.3 \mathrm{psig}$. It is driven by a $40-\mathrm{hp}, 1800-\mathrm{rpm}$ electric motor. Operating conditions for two-year cooled wastes require forced air circulation at a rate of $9000 \mathrm{acfm}$ to provide adequate bin cooling; WM-185 wastes require only natural convection air flow (5000 acfm). More details on bin cooling are given in Appendix $\mathbf{C}$.

Two inlet air filter assemblies, F-2719-WC-1 and 2, keep large atmospheric dust particles and other foreign matter from entering the vault with the cooling 
air. Each filter assembly contains eight $24 \times 24 \times 2$ inch viscous filter elements and eight high-efficiency prefilters.

A remotely-operated flapper valve is provided in each cooling air intake duct. Should a bin rupture or begin leaking, those valves automatically close on a signal from a radiation detector installed to monitor the cooling air leaving the bins. After the cooling air is stopped in this manner, the outlet filter (F-2720-WC) can be installed and the cooling air flow restored.

The cooling air outlet filter, F-2720-WC, consists of an assembly of 6 AEC high-efficiency filters, 30 inches wide $\times 24$ inches high, with an efficiency of 99.97 percent on 0.3 micron dioctylphthalate smoke particles. Each filter is constructed of a continuous sheet of glass-asbestos medium folded into closely spaced pleats, separated by aluminum inserts. The design conditions of the filter unit correspond to an air flow rate of $14,000 \mathrm{cfm}$ at $600^{\circ} \mathrm{F}$ with an allowable "clean" pressure drop of 2 inches of water. The normal operating conditions of the filter unit are for an air flow rate of $14,000 \mathrm{cfm}$ at $120^{\circ} \mathrm{F}$ with an allowable "dirty" pressure drop of 4 inches of water.

As the activity of the stored solids decreases, it is possible to stop and bypass the blower and initiate natural convection air cooling. Natural convective circulation is established by replacing the solids cooling air blower with a transition piece provided for connecting the blower suction and discharge lines. Since filtration is required for maximum safety, a 50-foot stack, ICPP-732, has been provided to give sufficient draft to permit use of the cooling air filters.

\subsection{Solids Storage Off-Gas}

The purpose of the solids storage off-gas sytem is to effect sufficient decontamination to permit disposal to the main ICPP stack of any evolved gases, such as water vapor and oxides of nitrogen, which might be contaminated by entrained particles and/or volatile fission products. During filling of the solids storage unit, the off-gas system is blocked off, and any gases generated during this period are returned to the calciner with the spent transport air. After filling, the transport air lines are blocked off, and a valve is opened to place the solids storage off-gas system in service. Switching of these lines is accomplished by manual operation of extension handle block valves located in the solids storage control room. If the solids storage off-gas system is ineffective in decontaminating such gases as may be generated by the stored product, it is possible to use the transport air return line to convey these gases to building ICPP-633 for decontamination in the calciner off-gas system. 
The solids storage off-gas passes at a very low velocity into the off-gas trap, WC-116, and on through an AEC-type final filter to the ICPP stack as shown in Figure VI-32. The solids storage off-gas trap, WC-116, is a cylindrical, horizontal vessel with dished heads as shown in Figure VI-35, and contains a stainless steel wire mesh demister for removing large particulate solids carried in the storage bin off-gas. A water cooling coil, consisting of five $1 / 2$-inch schedule 80 pipe coils with $3 / 4$-inch schedule 80 pipe headers, is imbedded in the stainless steel mesh to remove heat which would be generated by fission products trapped in the mesh. The stainless steel mesh demister consists of four 6-inch layers of style \#421 Yorkmesh fitted between the cooling coils. The design capacity of the vessel is 480 gallons, with a pressure range of -3.75 to +3.75 psig at a temperature of $250^{\circ} \mathrm{F}$. The normal operating conditions are from -3.3 to +3.3 psig. The cooling coil will dissipate heat at the rate of $1200 \mathrm{Btu} / \mathrm{hr}$ at a water inlet temperature of $50^{\circ} \mathrm{F}$ and an outlet temperature of $80^{\circ} \mathrm{F}$. Temperature probes are located on the vent line downstream of the trap. These temperatures can be monitored on the temperature indicator in the solids storage control room. This unit is equipped with a fluwmeter to meter the water rate to the internal cooling coils.

Any particulate matter which passes through the off-gas trap will be removed in the off-gas filter, F-2721-WC. This is a 12- x 12- x 12-inch, high-temperature, fireproof, AEC-type final filter with stainless steel separators, mounted in a stainless steel frame with a one-piece gasket. This filter has an efficiency of greater than 99.97 percent when tested with 0.3 micron dioctylphthalate smoke. It is rated for $190 \mathrm{cfm}$ at $100^{\circ} \mathrm{F}$ with a pressure drop of one inch of water when clean. A gamma ray detecting radiation monitor measures the radioactivity being carried to the ICPP stack in the filtered off-gas. If replacement is necessary, mobile lifting equipment, and possibly temporary shielding, will be required to remove the hatch plug and filter from the filter housing.

If it becomes necessary to store spent silica gel in the solids storage bins, water vapor may be driven from this material and condensed in the solids storage off-gas trap. Piping is arranged so that any condensate formed in the off-gas trap drains to the solids storage condensate receiver, WC-121. This unit is a vertical, cylindrical vessel with semi-elliptical heads constructed of type $304 \mathrm{~L}$ stainless steel, as shown in Figure VI-36. The capacity is 60 gallons at $200^{\circ} \mathrm{F}$ with a pressure range of -3.75 to $+3.75 \mathrm{psig}$. The vessel is normally operated 


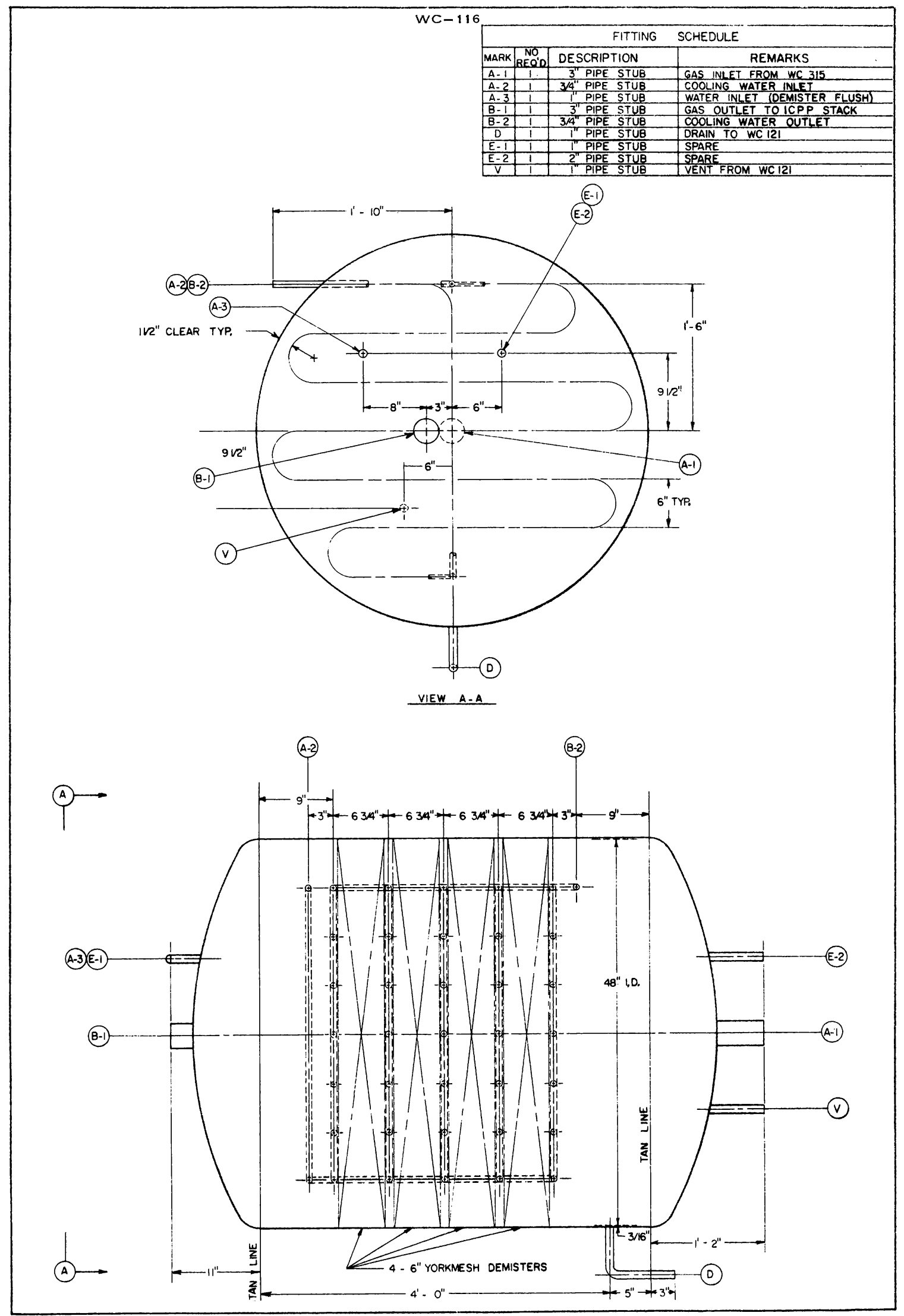

FIG. VI-35 SOLIDS STORAGE OFF-GAS TRAP. 


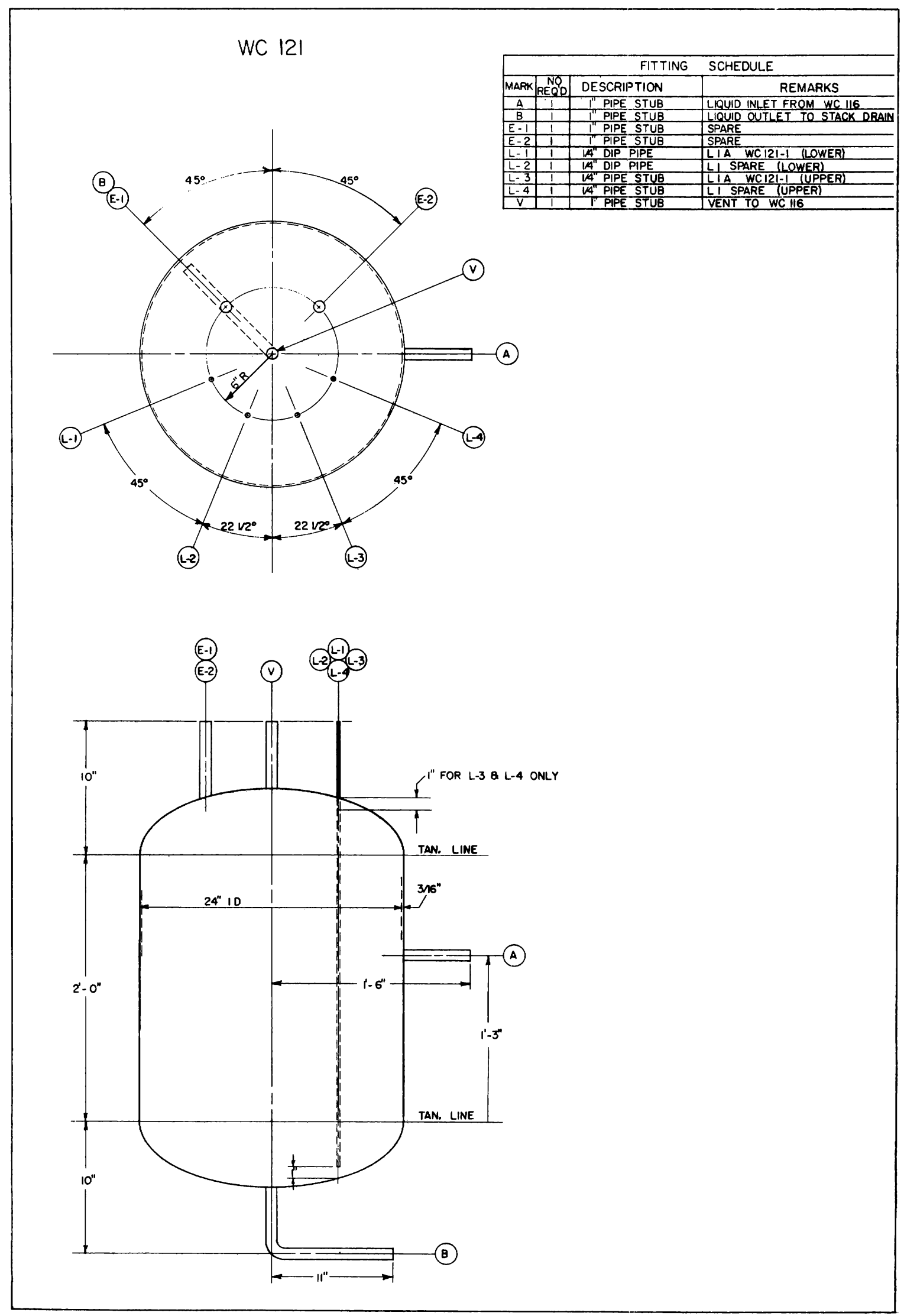

FIG. VI-36 SOLIDS STORAGE OFF-GAS CONDENSATE RECEIVER. 
at $100^{\circ} \mathrm{F}$ with a pressure range of -3.3 to $+3.3 \mathrm{psig}$. This vessel is equipped with a liquid level indicating alarm for detecting condensate formation. The condensate receiver drains through a 3/4-inch line inside the 3-inch solids storage off-gas vent line to the main ICPP stack drain system.

\section{NaK HEATING SYSTEM}

\subsection{General Description}

The heat required for the decomposition of the calciner feed is supplied through an indirect heat transfer system. An eutectic liquid metal (NaK) is pumped through a three-inch stainless steel pipe to an oil-fired radiant heater where the temperature is raised to a maximum of $760^{\circ} \mathrm{C}$, past expansion tanks which allow for an increase of 25 percent of the cold volume, to the fluidized bed heater where it is cooled approximately $110^{\circ} \mathrm{C}$, then back to the pump. The system differs from conventional heat transfer systems in that the design of certain components is peculiar to liquid metal systems. These include the NaK pump, flowmeters, and oxide removal system. In addition, the fluidized bed heater is constructed with specially designed "duplex tubes" in order to provide additional safety features for that part of the NaK loop in contact with radioactivity.

The NaK system flow diagram is shown in Figure VI-37. The NaK pump is normally operated at a constant flow of 39,000 pounds per hour. The NaK temperature, and hence the calciner bed temperature, is controlled by automatic adjustment of the $\mathrm{NaK}$ heater firing rate. Details of the bed temperature control system are given in Section VI-8. Helium is used as a blanket gas over the alkali metal surfaces, and monitors are provided to indicate insufficient helium pressure. The entire loop is of welded construction with either type 316 or stablized type 316 stainless steels; the latter steel is used where components will be subjected to decontamination with nitric acid. All piping used in the system is schedule 40 .

\subsection{Electromagnetic Pump and Flowmeter}

The NaK pump, WC-204, is an alternating-current electromagnetic conduction-type pump (Figure VI-38). It is completely sealed and has no moving parts. Operation is on the "motor principle" ie, a conductor carrying a current 


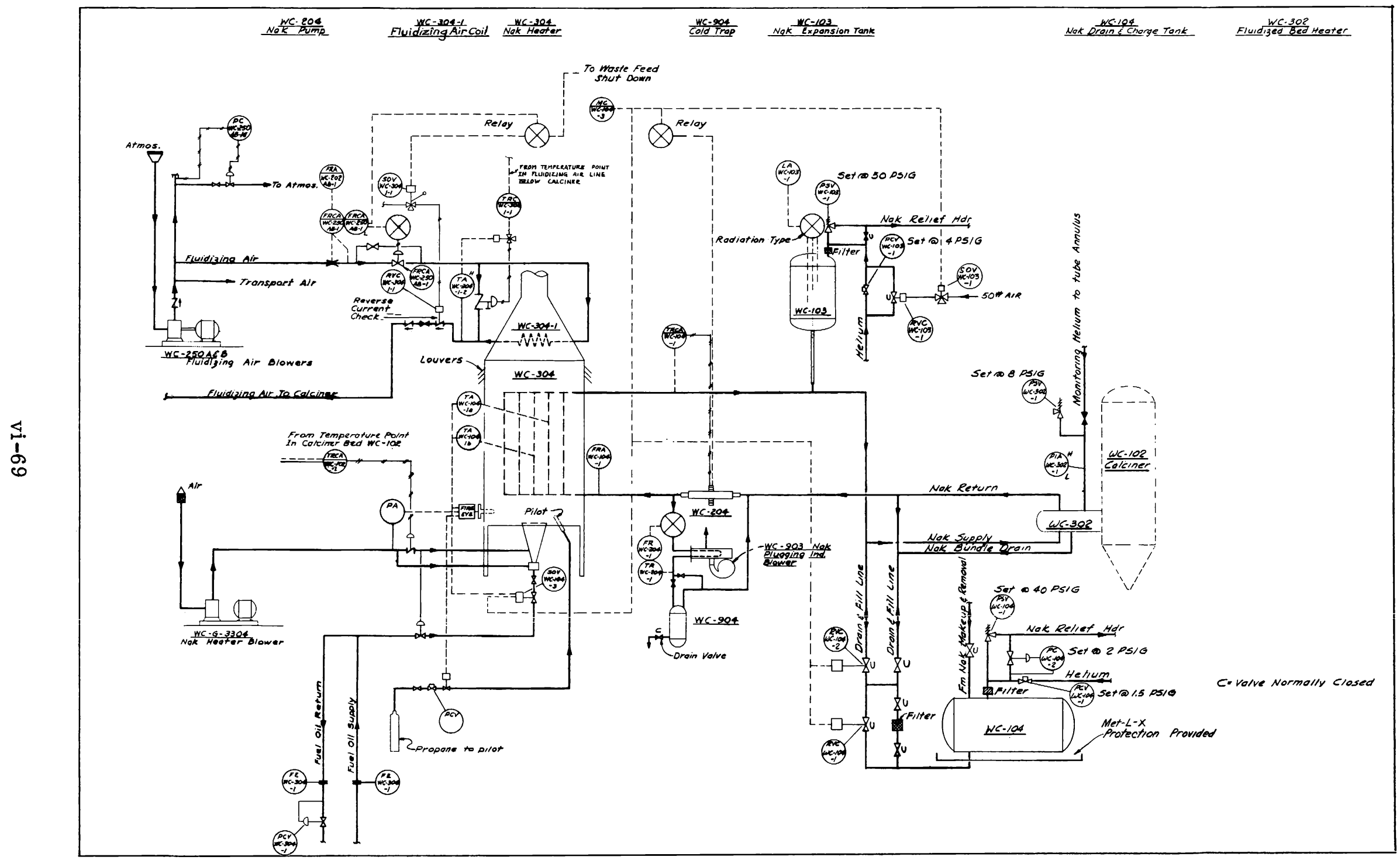

FIG. VI-37 NAK SYSTEM FLOW DIAGRAM 


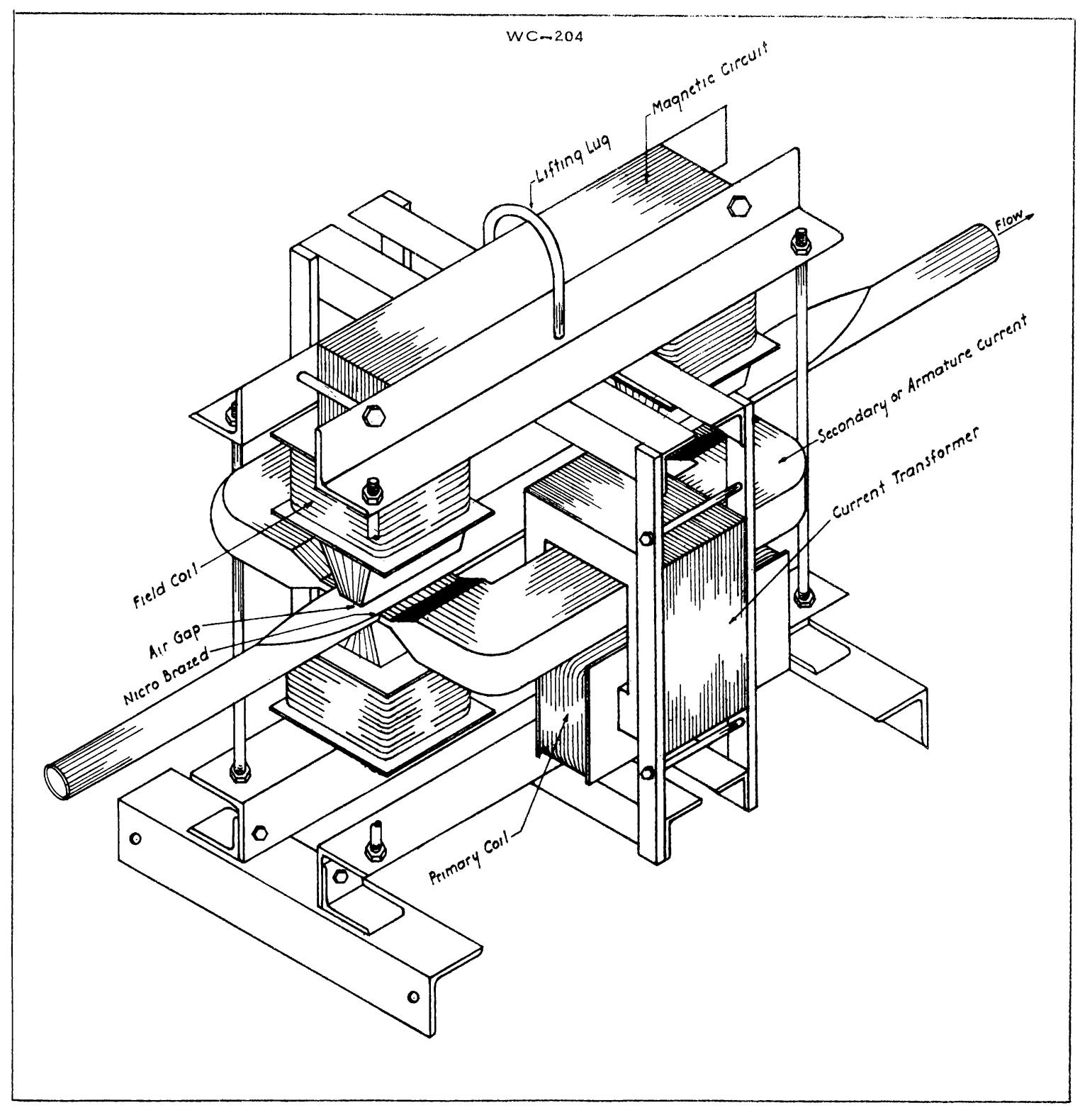

FIG, VI-38 NaK ELECTROMAGNETIC PUMP

in a magnetic field experiences a force which imparts motion to the conductor. In this case, the NaK stream itself is the conductor. The pump rate is controlled by adjustment of an auto-transformer in the power supply to the pump. The pump was designed for a maximum temperature of $815^{\circ} \mathrm{C}$, but its operating temperature rarely exceeds $600^{\circ} \mathrm{C}$.

The NaK flow rate is measured with an electromagnetic flowmeter, FRAWC-104-1. The flowmeter operates in a manner similar to that of the pump. The NaK flowing through a magnetic field produced by a permanent magnet generates a low dc voltage proportional to the flow. Because of the output of 
the flowmeter varies with temperature, the instrument is used only as an indicator of flow and not for direct control.

Both the pump and the flowmeter have the disadvantage of thin stainless steel walls which are necessary to minimize current loss to the piping. Consequently, the tubes in the flowmeter and pump are structurally the weakest points in the circulation system. However, corrosion should be controlled by the $\mathrm{NaK}$ oxide removal system (Section VI-7.7) and provision has been made to accommodate thermal expansion so troubles from these sources are not anticipated.

\subsection{NaK Heater}

The NaK heater, WC-304, is an oil-fired liquid metal heater (Figure VI-39). It contains $62-1 / 2-i n c h$ schedule 40 vertical pipes welded on two-inch centers to horizontal inlet and outlet manifolds. In addition, the upper section contains a 4-1/2-inch OD coil for heating the fluidizing air to the calciner. The furnace has an interrupted propane pilot which burns long enough to ignite the oil. The pilot is shut off when a solenoid valve in the propane supply line closes automatically upon oil ignition. The oil flame is surveyed by a "flame eye" which will automatically stop improper combustion by closing a solenoid valve in the oil supply line.

Conventional controls are provided to prevent overheating of the furnace or explosion of fuel mixtures. These include two indicating pyrometer controllers and a pressure switch, which is actuated by the furnace blower pressure. When actuated, these controls disrupt the electrical power to the furnace panel and close solenoid valves in the fuel supply lines.

\subsection{NaK Expansion Tanks}

The NaK expansion tanks, WC-103A and B (Figure VI-40), are vertical, cylindrical, type 316 stainless steel vessels. They are located at the high point of the loop to provide surge capacity for thermal expansion of the NaK. These tanks have an operating capacity of 78 gallons each and have been pressure tested at 60 psig and $820^{\circ} \mathrm{C}$.

Three gamma radiation level detectors are installed on WC-103A to indicate point levels of $\mathrm{NaK}$ in the expansion tanks. Radiation from cesium-137 sources is measured by three GM tubes mounted opposite the sources. Presence of the NaK in the tank greatly reduces the radiation intensity measured by the GM tube; therefore, the NaK level can be determined at the upper, middle, and lower portions of the tank. Three thermocouples are inserted into wells near the radiation detectors and are excellent backups for confirming the NaK level. Two pressure 


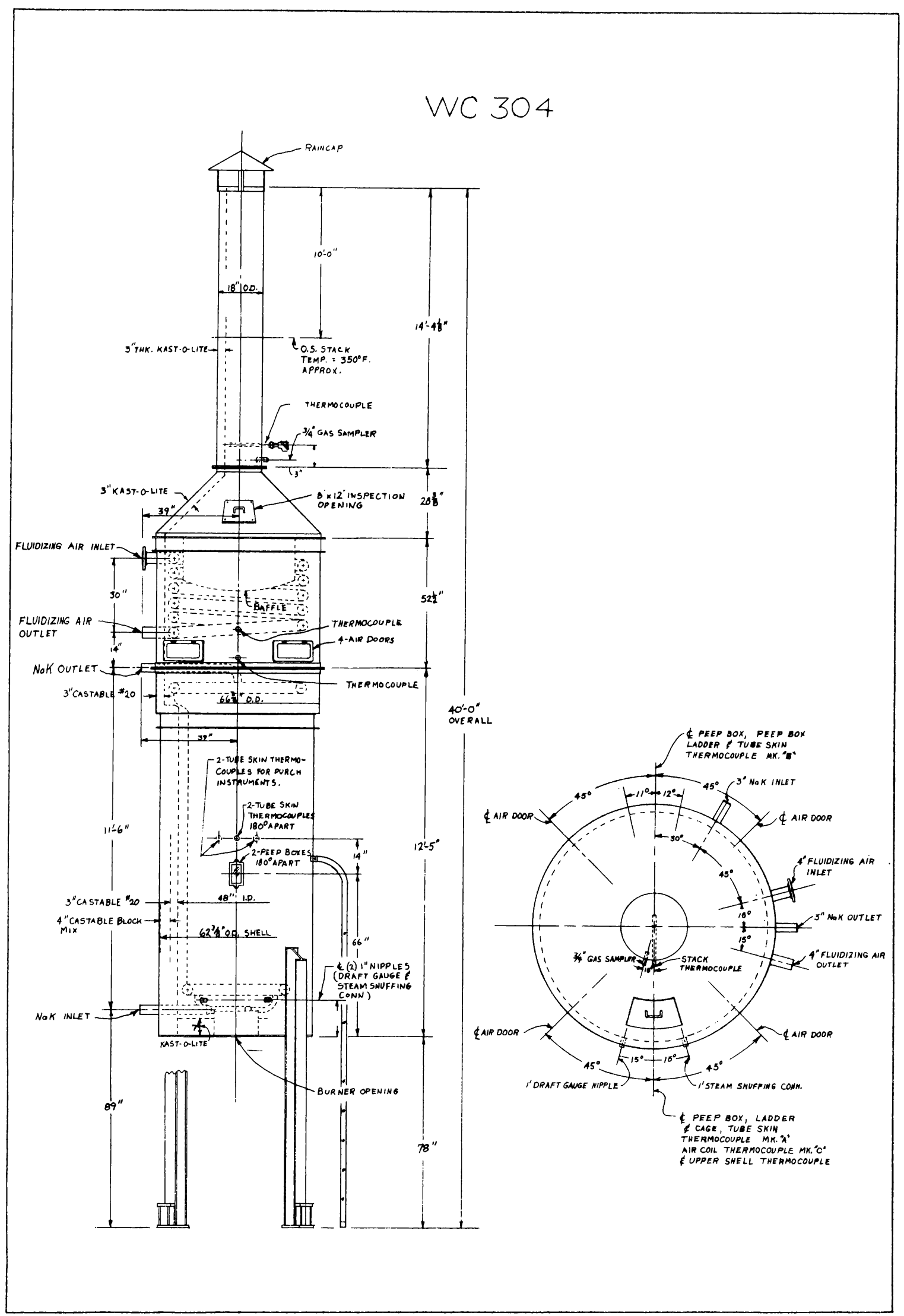

FIG. VI-39 NaK HEATER 


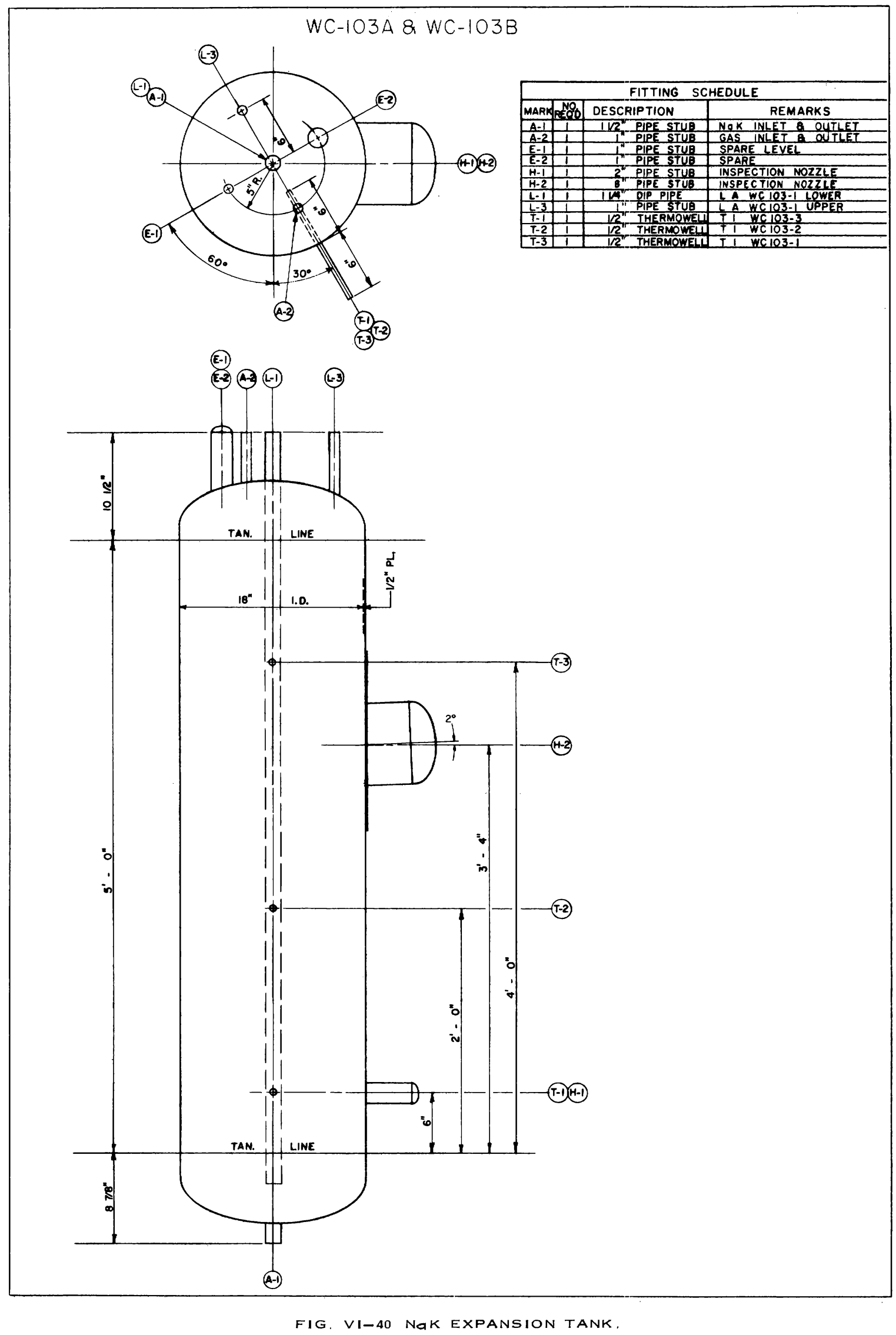

vi -73 
transmitters are installed upstream and downstream of the NaK heater; these also can be used to determine the NaK level in the expansion tanks.

\subsection{Fluidized Bed Heater}

The most probable location for thermal stresses in an indirect heat transfer system is the heat exchanger. Because of the high temperature expected in the NaK system, a special design developed for sodium power reactors has been chosen for the fluidized bed heater, WC-302. The design of this unit is shown in Figure VI-41. The exchanger has 42 bayonet-type tubes, each consisting of a core tube and two outside "duplex" tubes (Figure VI-42). The core tube is a sandwich-type tube with an argon atmosphere between tubes to reduce heat loss from the hot NaK entering the core tube, to the cooler NaK exiting through the annulus between the core and inner duplex tube. The outer surface of the inner duplex tube is knurled with approximately 66 grooves and is roller expanded into the outer tube. Helium gas under pressure is contained within the space between the two tubes to serve as a leak indicator. A decrease in helium pressure below specified limits will indicate a failure of an outer tube and subsequent helium leak into the calciner. An increase in pressure above specified limits will indicate a failure of the inner tube and NaK leak through the tube to the helium chamber.

The heat exchanger was designed for 100,000 hours of operation at $760^{\circ} \mathrm{C}$ and 40 psig pressure. The outer tubes were constructed with stabilized type 316 stainless steel and vary from $51-3 / 8$ to 58 inches in length. The average tube length is 56 inches and the approximate outside surface area of the tube bundle is 81.25 square feet.

During cold runs, vibration measurements on the unsupported tubes indicated strain as high as 620 microinches per inch were caused by the fluidizing action of the bed. The support shown on Figure VI-41 was installed, and thereafter, measurements indicated about 62 microinches per inch strain. Unlimited tube life is anticipated for the exchanger as a result of the support installation. Further details on the vibration problem and solution are given in Section VII-4.

\subsection{NaK Drain and Charge Tanks}

The NaK drain and charge tanks, WC-104A and B, shown in Figure VI-43 have sufficient volume to contain the complete inventory of $\mathrm{NaK}$ in the system. The design volume is 328 gallons per tank, and the design pressure is 40 psig at a temperature of $820^{\circ} \mathrm{C}$. The tanks are isolated from the circulating system by dump valves which can be either remotely or manually operated. A NaK 


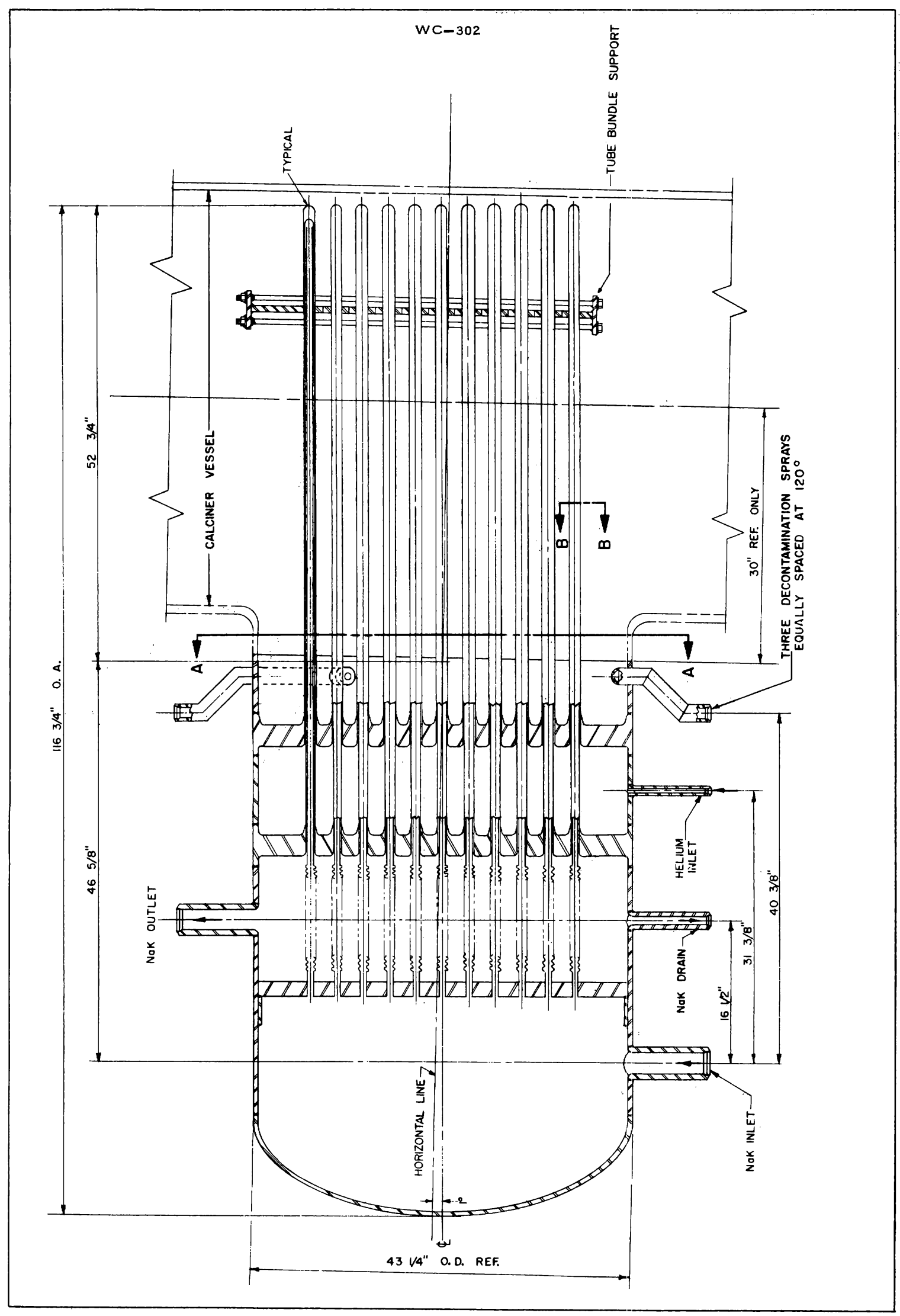

FIG, VI-4I FLUIDIZED BED NAK HEAT EXCHANGER. 


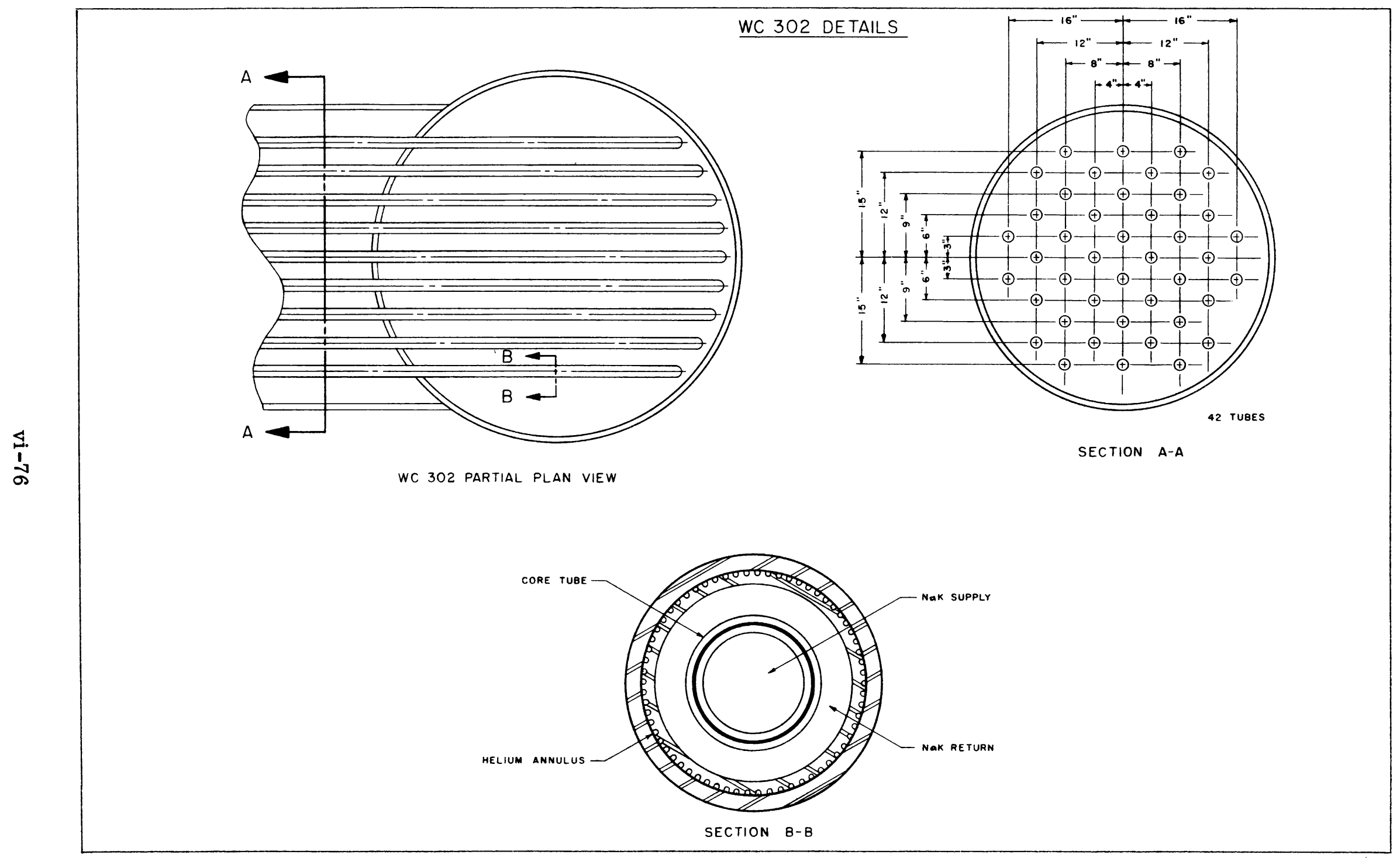

FIG. VI-42 NAK HEAT EXCHANGER DETAILS. 
WC 104A \& $104 B$
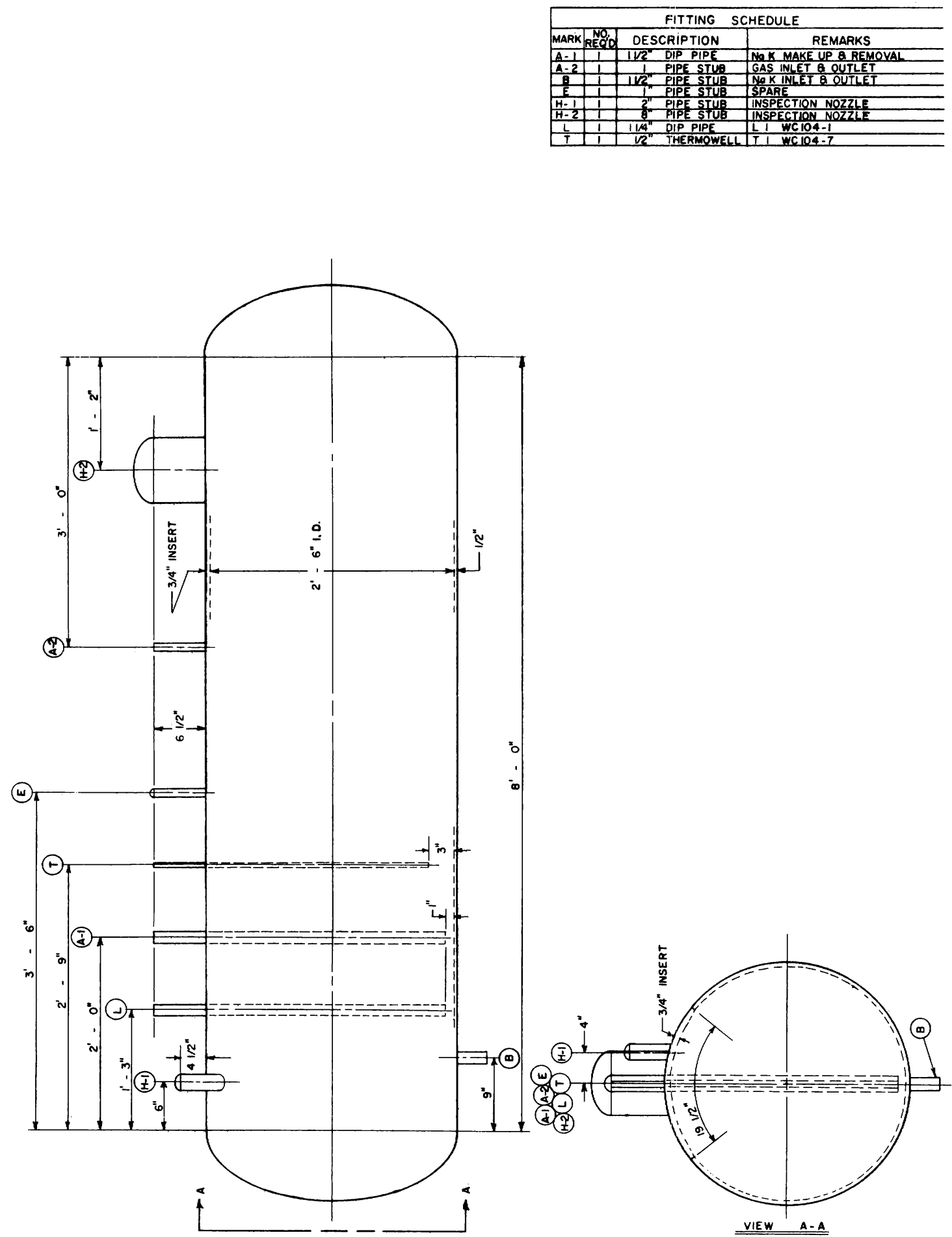

FIG, VI-43 NaK DRAIN AND CHARGE TANKS. 
heel, equal to 30 percent of the circulating volume ( 400 gallons) will remain in the tank to absorb some of the thermal shock which will result if hot $\mathrm{NaK}$ is dumped in the normally cold vessels.

A stainless steel-lined basin is installed under WC-104A and B to contain $\mathrm{NaK}$ in the event of tank rupture. A smoke alarm is provided above the tanks to detect smoke from NaK fires, and a Met-L-X spray system is installed for extinguishing $\mathrm{NaK}$ fires in the basin. This system is manually actuated from the operating corridor.

\subsection{Oxide Detection and Removal System}

In order that corrosion may be eliminated, or at least reduced to tolerable levels, an oxide removal system, shown schematically on Figure VI-44, has been provided. The presence of sodium oxide in the NaK can accelerate the corrosion of stainless steel, though the attack of pure alkali metal, other than lithium, on stainless steel is negligible. Additionally, the oxide removal system will prevent plugs which can occur in cold zones because of the crystallization of sodium monoxide. Oxygen in the system reacts with the sodium at the liquid-gas interface causing an oxide scum on the NaK surface. When the metal temperature increases, the surface oxide dissolves in the sodium. The oxide then migrates throughout the loop and causes increased corrosion rates, or crystallizes in zones of lowest temperature where plugs are possible. When the $\mathrm{NaK}$ is intentionally routed to a cold zone, controlled removal of the sodium monoxide can be effected. If the oxide level in NaK is reduced to 10 parts per million, corrosion is reduced to a tolerable level and oxide-plug formation is eliminated. Oxide concentration is determined through the use of a plugging indicator valve, WC-903, and the oxide is removed in a cold trap, WC-904.

The plugging indicator consists of a globe valve with small holes drilled around the periphery of the plug. Hot NaK will pass through the small holes when the valve is closed. When contaminated NaK cools, oxide deposits in the small holes and the flow is gradually reduced until a plug forms. An electromagnetic flowmeter measures the NaK flow. Relationship of the flow reduction with temperature indicates the oxide concentration.

The cold trap is packed with stainless steel wire mesh which provides a large area for oxide filtration, oxide crystallization, and crystal growth.

The oxide removal system is operated during start-up of the NaK loop until the oxide concentration is reduced to less than 10 parts per million. Thereafter, the system is operated intermittently to check the oxide content and to actuate removal if necessary. 


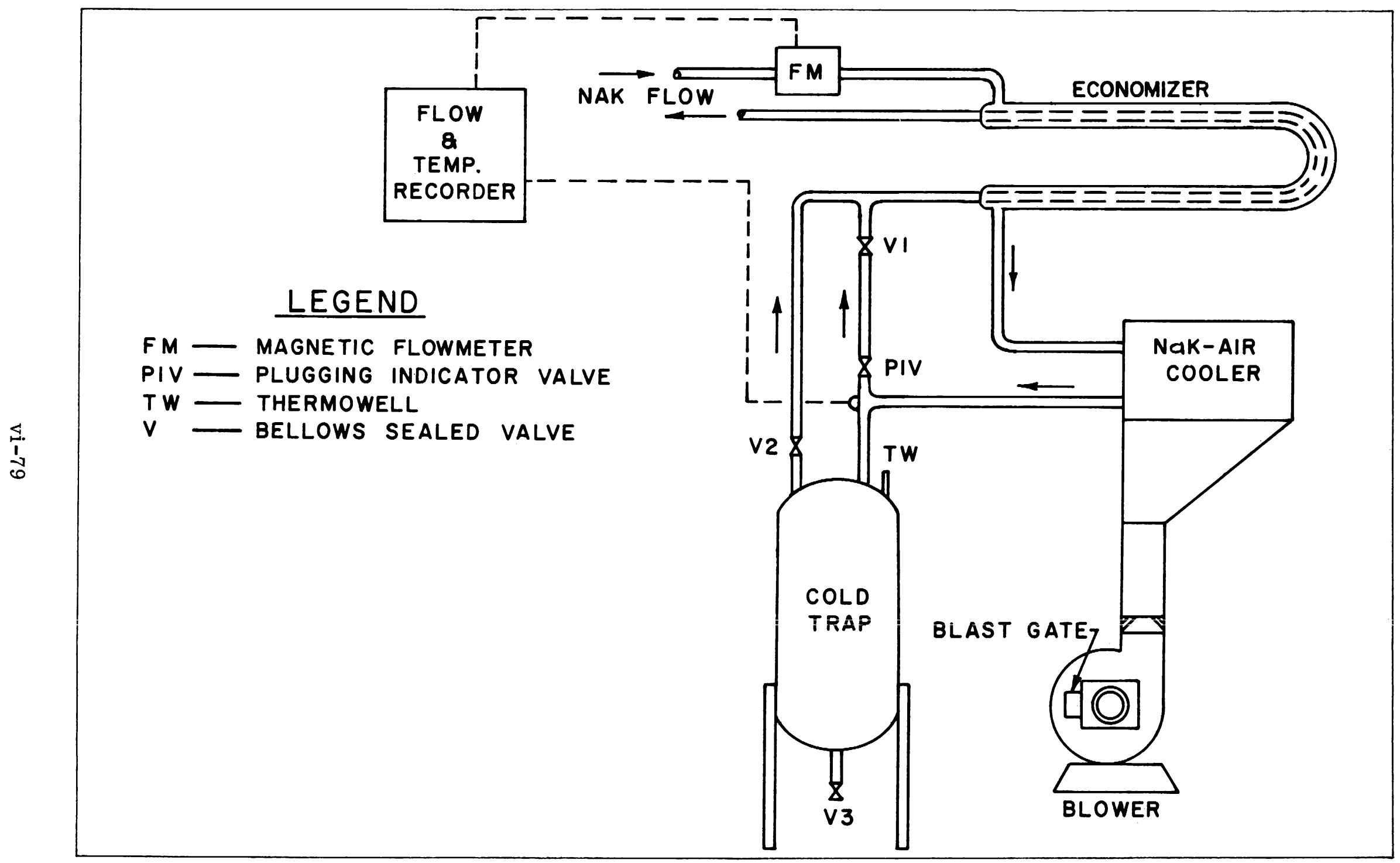

FIG. VI-44 NaK OXIDE REMOVAL SYSTEM 


\section{INSTRUMENTATION AND CONTROL}

\subsection{Process Control}

Electronic, pneumatic, and electropneumatic modes of instrumentation are used in process control of the WCF. Controllers are installed on a centrally located panel board in the operating corridor. Temperatures are measured by thermocouples connected to electronic receivers and controllers, and pressures are measured with standard pneumatic instruments. Flow rates are measured by pneumatic differential pressure instruments or, in the case of the calciner feed and NaK flows, by electromagnetic flowmeters. Electronic controllers are normally of the electropneumatic type, although some are completely electronic and operate electric valves or electropneumatic relays at remote stations.

8.11 Feed Rate Control. Feed flows to the calciner through three separate feed lines, three pneumatic controlvalves, and three feed nozzles. Each flow rate is measured by an electromagnetic flowmeter which determines the voltage induced between electrodes as the conducting liquid flows through a magnetic field. Each flowmeter has a calibrated flow range of 0 to 60 gallons per hour which is indicated by an electropneumatic converter with a 3 to 15 psig output. A pneumatic controller regulates a throttling valve in a feed line.

The flowmeters are located in a shielded cubicle in the sample gallery in order to provide easy accessibility with a minimum of decontamination in the event of failure of the meters. The throttling valves, however, are located in the calciner cell and complete shutdown and decontamination is mandatory before corrective maintenance is possible.

Emergency shutdown for feed is described in Section VI-8.3.

8.12 Fluidizing Air Control. A line diagram showing the basic connections and control elements for the fluidizing air system is shown in Figure VI-37. The fluidizing air for the calciner is supplied by either of two positive displacement blowers, one of which is a spare. It passes through an orifice and throttling valve to a heating coil in the top section of the NaK heater, then to the calciner. The pressure, flow, and temperature are each separately controlled. The descriptions of these systems are as follows:

(1) Fluidizing Air Pressure Control. A constant flow rate of a fluid through a metering orifice is obviously dependent upon the maintenance of a constant pressure upstream of the orifice. Therefore, 
a control valve has been installed, which is actuated by a proportional-action pressure controller, to regulate the pressure upstream of the flow orifice at 4.5 psig; this is done by venting to atmosphere the air in excess of that required by the process. The control valve is of parabolic design and is capable of throttling from $1200 \mathrm{scfh}$ to full blower capacity $(46,000 \mathrm{scfh})$. A valve positioner is used for fast response of the valve. A manualvalve in series with the control valve would be used if the controller fails.

(2) Fluidizing AirFlow Control. The fluidizing air rate is controlled by a temperature-compensated flow recorder-controller which receives its signal from an electropneumatic transmitter measuring the differential pressure across an orifice. The controller operates a throttling valve which regulates the fluidizing air flow.

The recorder-controller is equipped with a low flow alarm which actuates at $3500 \mathrm{scfh}$. If the flow drops to $2000 \mathrm{scfh}$, a microswitch actuates a relay which closes a piston-operated check valve in the fluidizing air line outside the calciner cell. The check valve will allow a small volume of fluidizing air to enter the calciner, but will close completely upon total air failure to prevent backflow of airborne radioactive dust into operating areas. The relay also activates the emergency feed shutdown circuit on low fluidizing air flow. In case of instrument failure, manual adjustment of the throttling valve, or regulation of a manual bypass valve can be used.

(3) Fluidizing Air Temperature Control. The temperature of the fluidizing air to the calciner is maintained at $400^{\circ} \mathrm{C}$ by blending cold air with the air heated in the furnace fluidizing air coil. The amount of cold air bypassing the heater is controlled by a pneumatic valve actuated by an electronic temperature recorder-controller. The controller receives its input signal from a thermocouple located in the fluidizing air line immediately upstream of the calciner. Also installed on the fluidizing air line is a temperature-actuated electrical switch which serves as an "override" for the temperature recorder-controller. If the fluidizing air temperature reaches $510^{\circ} \mathrm{C}$ (as a result of controller malfunctions) the switch activates 
an alarm in the operating corridor. If the temperature rises to $537^{\circ} \mathrm{C}$, the switch activates a solenoid valve to vent the controller air from the air-to-close bypass valve, thus allowing the valve to open to full cold air flow. Excessive temperature and, hence, high oxidation rates on the fluidizing air piping are thereby avoided. (4) Fluidizing Air Blower Autostart. The fluidizing air blower system is equipped with alarm and automatic start circuitry. The normal operating pressure on a blower discharge is $4.5 \mathrm{psig}$. If the pressure drops to 2.0 psig, a pressure switch activates a low pressure alarm. If the pressure drops to 0.5 psig, a second pressure switch activates the automatic start circuit for the spare blower. Thus, complete stoppage of the fluidizing air is prevented unless the spare blower fails to operate.

8.13 Transport Air Control. Line diagrams of the basic connections and control elements for the transport air system are shown in Figures VI-2 and -26. Most of the transport air is furnished by the fluidizing air blowers, but approximately 30 percent is introduced by the motivating and driven air from the cyclone fines ejector. The transport air carries moist gas, cyclone fines, and solids from the bed to the solids storage bins before returning to the calciner off-gas system. Both pressure and temperature control are employed for the transport air system.

(1) Transport Air Pressure Control. Normally, air flow rates are controlled by pneumatic-actuated systems including orifices or venturi meters. Though an orifice and venturi meter are both installed in the WCF transport air system, the transport air rate from the blower is controlled from a pressure control system. As mentioned above, the cyclone fines ejector contributes some 30 percent to the total flow. Because the ejector adds to the performance of the calciner cyclone, and because the ejector performance is dependent upon the pressure downstream, the transport air rate from the blower is regulated by a pressure-actuated controller in order that the line pressure remain constant. Also, the removal of product through the takeoff lines is stable only if the line pressure is constant. When the pressure in the line rises, the throttling valve closes slightly and allows for a vacuum increase as the air flow drops. When the pressure decreases, the air flow increases, 
thus tending to reduce the vacuum. Obviously, if plugs occur in the system, pressure will rise because of the 4.5 psig pressure on the discharge of the fluidizing air blowers. This pressure is sufficient to prevent the diffusion of radioactive dust back to the operating areas, but it probably will cause backflow up the cyclone downcomer until the plugs are removed. The pressure controller is equipped with high and low alarms set at 12.0 psia and 10.75 psia, respectively. A malfunction of the system will be quickly detected, and remedial action (stopping the solj.ds flow) initiated so that any upset will be only momentary. The scrubbing system is capable of handling momentary surges of high solids loading which would occur in the event of backup flow up the cyclone downcomer. Momentary upsets have indeed occurred in WCF cold tests, but these did not prove detrimental with regard to off-gas cleanup. These upsets were traced primarily to condensation of moist gas discharging into the transport air line from the calciner cyclone. The transport air line contains a reverse current check valve similar to that in the fluidizing air line. Operated by a pneumatic pressure switch, the check valve closes on loss of blower discharge pressure. (2) Transport Air Temperature Control. The introduction of moisture-laden gas from the cyclone into the transport air system requires that the air be heated above the gas dew point to avoid condensation and plugging. Material balances indicate that even under the worst possible operating conditions, the dew point of the transport air will not exceed $38^{\circ} \mathrm{C}$. After the completion of cold tests, a heat exchanger was installed to maintain the air temperature above $50^{\circ} \mathrm{C}$ throughout the system. A low temperature alarm is installed on the controller, which will activate if the air drops to this temperature.

The gas temperature is contolled by metering steam to the transport air heater with a pneumatic control valve. The signal for the controller is received from a thermocouple located in the transport air line immediately upstream of its entry into the calciner vessel. On instrument failure, the steam valve opens to assure steam supply to the heater. 
8.14 Calciner Control. A system flow diagram for the calciner is shown on Figure VI-2. The control systems are simple and involve only pressure, temperature, and solids level.

(1) Calciner Pressure Control. The calciner is maintained at 42 inches of water vacuum by adjusting a combination of manual and automatic controls. The amount of adjustment necessary depends upon the off-gas rate and the pressure drop in the equipment between the calciner and the off-gas blower. Coarse control is accomplished by regulating a butterfly valve in the suction of the off-gas blower from a manual control located on the panel board. Fine control is achieved by bleeding plant air into the quench tower downstream of the calciner through a control valve actuated from a pressure controller which monitors the vacuum above the calciner bed.

(2) Calciner Temperature Control. The temperature of the calciner bed is dependent upon the rate at which heated NaK is pumped through the fluidized bed heater, and upon the NaK temperature. A comprehensive discussion is presented later in the $\mathrm{NaK}$ control system (Section VI-8.15).

(3) Bed Level Control. The level of the calciner bed is determined by measuring the differential pressure between a pneumatic probe located in the vapor space above the bed and a probe located at the same elevation as the feed nozzles (66 inches above the bottom tangent line of the vessel). Several additional probes are available and can be used for bed level determination if necessary. The bed level is maintained within six to ten inches above the nozzles by adjusting the rate of product removal from the calciner. Solids from the bed are removed via one of two takeoff lines located approximately ten inches above the bed support plate.

The rate of product removal is controlled manually by adjusting the flow of air metered into the product takeoff line which is approximately two inches from the calciner vessel wall. This air, called dilution air, tends to balance the pressure difference $(1.40 \mathrm{psi})$ between the calciner and the transport air line. The air also serves to provide dilute phase solids transfer to the transport line. Though automatic control of the dilution air (and hence the bed level) is 
possible, it was considered unnecessary because of the relatively large range of bed height which is tolerable in the fluidized bed calciner.

8.15 NaK System Controls. Components in the NaK system have been described previously in Section VI-7. The line diagram and basic control schemes are shown on Figure VI-37. Control instrumentation includes temperature, flow, and pressure components.

(1) NaK Temperature Control. The temperature and heat required for decomposition of the feed sprayed into the calciner are provided by a closed-cycle liquid metal system. NaK is heated in an oilfired furnace controlled by an electronic temperature recordercontroller which receives its signal from a thermocouple in the top of the calciner bed. The electronic controller actuates a power relay which operates a pneumatic butterfly valve in the combustion air line to the NaK furnace. The combustion air pressure downstream of the butterfly valve regulates an oil valve in the furnace oil line. The controller is equipped with thermocouple break protection. On failure of instrument components, the controller output will normally stay constant. On electrical failure, the controller will give maximum output, and full furnace fire.

Two indicating pyrometer controllers are installed in conjunction with thermocouples on the furnace tubes to provide furnace overheat protection, and to prevent boiling the NaK. On failure of the instruments or thermocouples, the furnace fire will be shut off. Similarly, if furnace temperatures reach the set points of the controllers, the furnace fire is stopped.

(2) NaK Flow Control. NaK flow is measured with an electromagnetic flowmeter and is controlled manually or automatically by an electronic temperature recorder-controller which receives its signal from a thermocouple in the NaK line out of the heater. The temperature is attained by adjustment of a pneumatic-driven auto-transformer in the power supply of the NaK pump which regulates the NaK flow. Though automatic control is possible, better performance of the system was obtained in cold testing of the WCF when the NaK flow was held constant. The controller is equipped 
with thermocouple break protection, and on electrical failure, the controller will provide maximum NaK flow.

(3) NaK System Pressure Control. Helium cover gas for the NaK system is controlled by self-actuating pressure controllers which maintain at least 4 psig on the main NaK loop, and 1.5 psig on the NaK drain tanks.

Pressure relief valves are installed to relieve excess gas from the main loop if the pressure exceeds $50 \mathrm{psig}$, and to relieve excess gas from the drain tanks if the pressure exceeds two psig. (4) NaK Furnace Flame Safeguard. The NaK heater is equipped with automatic purge and shutdown devices to prevent explosive mixtures from accumulating in the furnace.

The furnace is a propane-pilot oil-fired heater. Both fuels are automatically turned on in sequence by a timed flame control. The furnace control system is powered through a mercury switch activated from the furnace blower discharge pressure. When the furnace start button is depressed, the timer system allows 30 seconds for purging the furnace. Then a solenoid valve in the propane line opens and the propane is ignited by an electric spark. If a flame eye detects the propane flame, the voltage generated activates a relay which opens an oil solenoid valve. When the oil ignites, the propane solenoid valve closes and interrupts the pilot flame. The flame detector supervises the main oil flame and deactivates the circuit on flame failure. The oil solenoid valve closes and the complete timing sequence must be energized before the furnace can be reignited.

8.16 Equipment Vent System. Instrument and sparge air from WCF vessels is discharged to atmosphere through a condenser, demister, steam heater, filter, and equipment vent blower. Vacuum on the system is maintained by manually regulating a valve on the blower suction. The vacuum is monitored by a pressure indicating alarm on the hot sump tank. The alarm sounds if the vacuum drops to five inches of water. (The normal vacuum is 10 inches of water.)

The only automatic control instrumentation in the equipment vent system is for controlling the gas temperature from the heater. The vent gas is heated above its dew point to prevent mist from collecting on and ruining the filter. An electronic controller receives a signal from a thermocouple installed between 
the heater and filter, and positions an electric-operated valve in the steam supply to the heater to obtain approximately 10 degrees of superheat in the gas. The controller has a low alarm at $50^{\circ} \mathrm{C}$ and a high alarm at $65^{\circ} \mathrm{C}$. The high alarm was included to prevent excessive heating in the turbine-blower, which would raise the operating temperature and decrease the life of the blower bearings.

8.17 Off-Gas System Control. The off-gas system performs three main functions in the WCF process. First, the off-gas blowers maintain a vacuum on the process and discharge fluidizing air, purge and sparge air, and decomposition gases to the atmosphere. Second, the scrubbing system, ruthenium adsorbers, and absolute filters remove radioactive materials from the off-gas so that it can be discharged to the atmosphere. Third, the scrubbing system controls the humidity of the off-gas so that water content of the feed and water introduced as purges, etc, can be evaporated from the process. A line diagram showing the basic control schemes for the off-gas system is shown in Figure VI-13.

The off-gas vacuum control was discussed in Section VI-8.14. The second function, cleanup of the off-gas, contains control instrumentation for metering the scrubbing solution to the venturi scrubber. In addition, flow and temperature controls are used during regeneration of a ruthenium adsorber. The latter controls will not be discussed becaused there is no process significance (except air flow rate increase) involved during adsorber regeneration. The second and third functions are interrelated and will be discussed simultaneously below.

(1) Scrubbing Solution Flow Control. The primary purpose of the venturi scrubber is the removal of fine dust, the average diameter of which is larger than 0.1 micron. This performance is possible if the scrubbing liquid is metered to the scrubber at a rate ranging from 11 to 17 gallons per 1000 actual cubic feet of off-gas. A venturi meter, a control valve, and a pneumatic controller constitute the control instrumentation for this system.

Flow rate of scrubbing solution to the quench tower is metered by a control system identical to that for the venturi scrubber except for the size of the meter and valve. The prime purpose of the quench tower is the cooling of the off-gas from 400 to $54^{\circ} \mathrm{C}$. The design volume of solution is 63 gallons per minute at $47^{\circ} \mathrm{C}$. Obviously, the required volume depends on the solution temperature, and on the gas rate and temperature. Normally, the flow rate 
to the quench tower is established and the temperature is then the dependent variable in the control scheme. It is to be noted that the venturi scrubber also acts as a heat exchanger and humidifier and hence affects the off-gas temperature.

On failure of the pneumatic controllers, operation can be continued merely by switching to manual control. On instrument air failure, valves to the quench tower will open and valves to the venturi scrubber will close. Spare venturi meters and valves are installed for both streams.

(2) Off-Gas Temperature Control. After flow rates to the quench tower and venturi scrubber are established, the off-gas temperature downstream of the scrubbing system is adjusted by controlling the scrubbing solution temperature. An electronic controller receives a signal from a thermocouple downstream of the venturi scrubber entrainment separator, and adjusts the rate of cooling water to the scrubbing solution cooler. By reducing the cooling water rate, the off-gas temperature increases, and the water evaporation rate increases. If the cooling water rate increases, both the off-gas temperature and water evaporation rate decrease. The rate of solution buildup in the scrubbing solution surge tank is used to indicate abnormal operation, or a change in the water input to the system. (3) Off-Gas Reheat Control. In order to prevent condensation of mositure from the saturated gas leaving the venturi scrubber, the off-gas is reheated to $5^{\circ} \mathrm{C}$ above the scrubber outlet temperature. This is accomplished by regulating the steam rate to a heat exchanger by means of an electronic temperature recorder controller and pneumatic throttling valve. This controller, as well as that for adjusting the scrubber outlet temperature, is similar to those for the NaK system. Manual operation is possible on instrument failure, and both controllers are set up to "fail safe" on electrical failure.

A second off-gas reheater is installed downstream of the ruthenium adsorbers. Control for this system is similar to that for the first reheater, except that the throttling valve is electricdriven. On electrical failure, a manual bypass around the valve can be used for adjusting the off-gas temperature. 


\subsection{Emergency Power System}

The WCF emergency electrical power system, as described in Section IV, will supply electrical power to all equipment listed in Table VI-2. In the event of commercial power failure, the emergency system is activated and the emergency diesel generator located in building ICPP-644 starts within 15 seconds. After normal electrical power is restored, a transfer switch located on the WCF operating corridor panel board must be energized. The generator will continue to operate for five minutes following activation of the transfer switch. All items on emergency power are equipped with automatic restarting. Equipment on normal power only must be restarted manually after normal service is restored. TABLE VI-2

WCF EQUIPMENT ON EMERGENCY POWER CIRCUIT

\begin{tabular}{|c|c|c|}
\hline EQUIPMENTT & POWER PANEL & POWER PANEL LOCATION \\
\hline $\begin{array}{l}\text { WC-250A, fluidizing air } \\
\text { blower }\end{array}$ & $P-633-2$ & Switch gear room in ICPP-633 \\
\hline $\begin{array}{l}\text { WC-250B, fluidizing air } \\
\text { blower }\end{array}$ & $P-633-2$ & Switch gear room in ICPP-633 \\
\hline $\begin{array}{l}\text { WC-208A, scrubbing } \\
\text { solution pump }\end{array}$ & $P-633-2$ & Switch gear room in ICPP-633 \\
\hline $\begin{array}{l}\text { WC- } 208 \mathrm{~B} \text {, scrubbing } \\
\text { solution pump }\end{array}$ & $P-633-2$ & Sritch gear room in ICPP-633 \\
\hline $\begin{array}{l}\text { WC-G-3302, cell exhaust } \\
\text { blower }\end{array}$ & $P-633-2$ & Switch gear room in ICPP-633 \\
\hline WC-252, equipment vent fan & $P-633-2$ & Switch gear room in ICPP-633 \\
\hline WC-251A, off-gas blower & $P-633-1$ & $\begin{array}{l}\text { West of the calciner decon- } \\
\text { tamination room and directly } \\
\text { south of oil storage tanks }\end{array}$ \\
\hline WC-251B, off-gas blower & $P-633-1$ & $\begin{array}{l}\text { West of the calciner decon- } \\
\text { tamination room and directly } \\
\text { south of oil storage tanks }\end{array}$ \\
\hline $\begin{array}{l}\text { ELP-633-1, light panel } \\
\text { (Contains all instrument } \\
\text { power) }\end{array}$ & ELP-633-1 & $\mathrm{H}$ and $\mathrm{V}$ room, ICPP -633 \\
\hline
\end{tabular}

\subsection{Emergency Shutdown System}

There are two emergency shutdown systems in the WCF. These include feed shutdown and NaK system shutdown. As noted in Table VI-2, Section 8.2 above, all instruments on the panel board are on the emergency electrical system. Both these systems will remain operable unless a total electrical failure occurs. 
8.31 Emergency Feed Shutdown System. The calciner feed system can be shut down and flushed with water by depressing the emergency feed shutdown button located on the operating corridor panel board. The shutdown button energizes a relay which opens solenoid valves in the three air lines to the valve operators, allowing the valves to close. The relay energizes a timing delay which activates solenoids in the flushing water lines to the nozzles. Flushing continues for 30 seconds, after which the timing delay deactivates the solenoids. The relay, however, remains energized and prevents opening of the feed valves until the feed shutdown button is reset.

8.32 Emergency NaK System Shutdown. In the event of an emergency which requires an immediate removal of $\mathrm{NaK}$ from the circulating loop, the NaK dump system can be placed in operation by depressing a shutdown button located on the control panel board in the operating corridor. This button energizes a relay which shuts down the furnace, turns off the NaK pump and drains the NaK to two drain and charge tanks.

When the NaK shutdown button is pressed, the following events are initiated:

(1) A solenoid valve is de-energized and shuts off the fuel oil to the furnace.

(2) A contact in the motor control circuit is opened which shuts down the NaK pump.

(3) Solenoid valves which control air to the NaK dump valves are energized, and the NaK is allowed to drain freely from the system. (4) A solenoid-operated valve opens a pneumatic valve which supplies helium at about 35 psig to the top of the NaK expansion tanks. The added pressure increases the NaK drain rate from the system. The NaK dump system has been tested three times and will dump the $\mathrm{NaK}$ in about 90 seconds.

The drain and charge tanks are vented through a pressure relief valve (set at about 2 psig) which prevents pressure from building up as the tanks are filled with NaK. The fill line enters the tanks from the bottom.

\subsection{Automatic Motor Starting}

In the event of a blower, pump or motor failure, automatic starters have been provided on the spare fluidizing air blower, WC-250, the spare scrubbing solution pump, WC-208, and the spare off-gas blowers, WC-251. The automatic starters are arranged so that either unit may be used as the spare. 
8.41 Automatic Start-up of the Spare Fluidizing Air Blower. This sytem will automatically start the spare blower, WC-250A or $\mathrm{B}$, in the event of low pressure of the fluidizing air. If the pressure drops to $2.0 \mathrm{psig}$, a contact will open and sound an alarm. If the pressure continues to drop to $0.5 \mathrm{psig}$, a contact will close energizing a relay in the motor control circuit, and start the spare blower. Simultaneously, a contact closes, locking the above relay in the energized position. This prevents the blower from stopping when air pressure returns to normal. All of these devices will remain in the energized position until manually reset from the control board.

8.42 Automatic Start-up of the Spare Scrubbing Solution Pump. Because adequate scrubbing solution circulation is an extremely important step in the off-gas cleanup system, a spare pump and automatic starting system are installed for emergencies.

If the pump discharge pressure drops to $30 \mathrm{psig}$, a low pressure alarm sounds in the operating corridor. If the pressure continues to drop to $25 \mathrm{psig}$, a relay closes and starts the spare pump. The relay is self-locking and must be manually reset from the control board. This prevents the standby pump from being cut off when the scrubbing solution pressure returns to normal.

Either pump may be used as the primary or standby pump with the alarm and autostart system working in the same manner. A selector switch on the panel board in the operating corridor determines which pump is acting as the primary pump.

8.43 Automatic Start-up of the Spare Off-Gas Blower. The off-gas system is equipped with an automatic relay system which actuates an alarm when the pressure rises to 8.0 psia at the blower suction, and starts the spare off-gas blower when the pressure reaches 8.5 psia.

For the automatic start-up, the emergency high pressure switch actuates a relay which closes a contact in the motor control circuit and starts the spare blower. It also de-energizes a solenoid valve which bleeds air off the discharge valve for the spare blower, allowing it to open. When the high pressure relay is energized, it automatically locks itself in the energized position. If the off-gas pressure is below 7.58 psia, the spare blower may be stopped by depressing the reset button located on the control board.

The desired blower for operation can be selected with a selector switch located on the panel board. When the position of this switch corresponds with the operating blower, the discharge valve on the spare blower remains closed 
and prevents off-gas from recycling through the blower. The off-gas blowers are wired so that the blower that is in service will continue to run when the plant is switched to emergency power, but the spare blower will not start automatically. In the event of a blower failure during this time, the spare blower must be started manually with the selector switch on the control board.

\subsection{Temperature and Pressure Monitoring}

There are numerous temperature and pressure instruments for monitoring process conditions through the WCF. Relative positions of these instruments are shown in Figures VI-2, 13, 32, 37, 50, and 51. Temperatures are measured with thermocouples and indicated, or recorded, on multipoint instruments. Pressures are measured with absolute or differential pressure transmitters and are indicated on dial gauges.

\subsection{Alarms}

Tables VI-3, VI-4, VI-5, and VI-6 summarize the temperature, pressure, liquid level, and flow alarm systems in the WCF process.

\section{SAMPLING AND ANALYTICAL EQUIPMENT}

\subsection{General Description}

Process operation at the WCF is monitored routinely by sampling and analyzing the contents of all major vessels as well as by observing the available instrumentation. Five liquid sampling units are installed to sample the contents of the two waste hold tanks, the scrubbing solution surge tank, the regeneration solution tank, and the hot sump tank. Two solids sampling stations are installed for sampling the calciner bed. The five liquid sampling stations and one solids sampling station (small solids sampler) are located in a lead shielded gallery in the WCF sample room; the other solids sampler (bulk solids sampler) is located in a shielded cubicle above the calciner and off-gas cells. The liquid sampling units are identical to those already in use at the fuel processing facility [1]. The solids sampling units, though similar in principle to the liquid sampling units, were designed expressly for the WCF.

Samples taken in the sample gallery are transported in a shielded cask to the remote analytical facility (RAF) in building ICPP-627, where the analyses are conducted. This facility contains remote handling equipment for receiving, storing, and analyzing radioactive samples, and has been used for eight years to analyze radioactive samples from the fuel reprocessing operations. Samples 
TABLE VI-3

SUMMARY OF THE TEMPERATURE ALARMS IN THE WCF PROCESS

\begin{tabular}{|c|c|c|c|}
\hline \multirow[b]{2}{*}{ INSTRUMENT NUMBER } & \multirow[b]{2}{*}{ PURPOSE OF ALARM } & \multicolumn{2}{|c|}{ ATARM POINTS } \\
\hline & & $\underline{\mathrm{HIGH}}$ & LOW \\
\hline \multirow[t]{2}{*}{ TA-WC-104-1-A \& B } & $\begin{array}{l}\text { Temperature alarm for } \mathrm{NaK} \text { tube in NaK heater } \\
\text { (WC-304) }\end{array}$ & $800^{\circ} \mathrm{C}$ & \\
\hline & Shutdown heater at the alarm point & & \\
\hline TA-WC-304-1-1 & $\begin{array}{l}\text { Temperature alarm for air tube temperature } \\
\text { in fluidizing air preheat coil (WC-304-1) }\end{array}$ & $825^{\circ} \mathrm{C}$ & \\
\hline \multirow[t]{2}{*}{ TA-WC-3O4-1-2 } & Alarm for fluidizing air temperature & $510^{\circ} \mathrm{C}$ & \\
\hline & $\begin{array}{l}\text { Overrides TRC-WC-304-1-1 at high temperal- } \\
\text { tures to protect RVC-WC-304-1-1 }\end{array}$ & $537^{\circ} \mathrm{C}$ & \\
\hline TRCA-WC-352-1 & Recorder and alarm for transport air & & $50^{\circ} \mathrm{C}$ \\
\hline TRCA-WC-354-1 & Recorder and alarm for off-gas temperature & $85^{\circ} \mathrm{C}$ & $65^{\circ} \mathrm{C}$ \\
\hline TRCA-WC-356-1 & $\begin{array}{l}\text { Recorder and alarm for equipment vent gas } \\
\text { temperature }\end{array}$ & $65^{\circ} \mathrm{C}$ & $50^{\circ} \mathrm{C}$ \\
\hline TRA-WC-002 & $\begin{array}{l}\text { Temperature recorder and alarm for blowers } \\
\text { and scrubbing pump bearings }\end{array}$ & $94^{\circ} \mathrm{C}$ & \\
\hline TRA-WC-003-1 & $\begin{array}{l}\text { Temperature recorder and alarm for off-gas } \\
\text { system }\end{array}$ & $825^{\circ} \mathrm{C}$ & \\
\hline TRA-WC-102-1, 2 & $\begin{array}{l}\text { Temperature recorders and alarms below and } \\
\text { above grid temperature, respectively (WC-102) }\end{array}$ & $410^{\circ} \mathrm{C}$ & $390^{\circ} \mathrm{C}$ \\
\hline TRA-WC-102-3, 4,5 & $\begin{array}{l}\text { Temperature recorders and alarms at center } \\
\text { of bed, top of bed, and at top of calciner, } \\
\text { respectively (WC-102 TRA-102-1,2,3,5, have } \\
\text { spares) }\end{array}$ & $410^{\circ} \mathrm{C}$ & $390^{\circ} \mathrm{C}$ \\
\hline TRA-WC-107-1 & $\begin{array}{l}\text { Temperature recorder and alarm for off-gas } \\
\text { from quench tower (WC-107); Point \#17 of } \\
\text { TRA-WC-003-1 }\end{array}$ & $65^{\circ} \mathrm{C}$ & \\
\hline TRA-WC-202-4 & $\begin{array}{l}\text { Temperature recorder and alarm for transport } \\
\text { air line (has a spare); point \#19 on } \\
\text { TRA-WC-003-1 }\end{array}$ & $170^{\circ} \mathrm{C}$ & \\
\hline TRCA-WC-102-1 & $\begin{array}{l}\text { Temperature recorder, controller, and alarm } \\
\text { for calciner bed; Controls NaK furnace }\end{array}$ & $410^{\circ} \mathrm{C}$ & $300^{\circ} \mathrm{C}$ \\
\hline TRCA-WC-104-1 & $\begin{array}{l}\text { Temperature recorder and alarm for } \mathrm{NaK} \text { at } \\
\text { heater outlet; Controls NaK pump rate } \\
\text { (wC-204) }\end{array}$ & $760^{\circ} \mathrm{C}$ & \\
\hline
\end{tabular}


TABIE VI-4

SUMMARY OF THE PRESSURE ALARMS IN THE WCF PROCESS

\begin{tabular}{|c|c|c|c|}
\hline \multirow[b]{2}{*}{ INSTRUMENT NUMBER } & \multirow[b]{2}{*}{ PURPOSE OF ALARM } & \multicolumn{2}{|c|}{ AIARM POINTS } \\
\hline & & HIGH & LOW \\
\hline PA-WC-120-I & Alarm for 10O\# air supply & & 80 psig \\
\hline$P A-W C-208 A B-1$ & $\begin{array}{l}\text { Alarm for discharge pressure at scrubbing } \\
\text { solution pumps }\end{array}$ & & $30 \mathrm{psi}$ \\
\hline & Autostart of spare pump & & 25 psi \\
\hline$P A-W C-250 A B-I A$ & $\begin{array}{l}\text { Alarm for discharge pressure at fluidizing } \\
\text { air blowers }\end{array}$ & & $2.0 \mathrm{psi}$ \\
\hline$P A-W C-250 A B-1 B$ & $\begin{array}{l}\text { Pressure switch for energizing the automatic } \\
\text { start circuit of the spare fluidizing air } \\
\text { blower }\end{array}$ & & $0.5 \mathrm{psi}$ \\
\hline PA-WC-2901-1 & $\begin{array}{l}\text { Alarm for solids cooling air pressure } \\
\text { (WC-G-2901) }\end{array}$ & $\begin{array}{l}3.0 \text { in. } \\
\text { Vaculum }\end{array}$ & \\
\hline PRCA-Wi-102-3 & $\begin{array}{l}\text { Alarm and recorder for pressure in transport } \\
\text { system }\end{array}$ & 12.0 psia & 10.75 psia \\
\hline PRCA-WC-IOP-I & $\begin{array}{l}\text { Alarm and recorder of vacuum in calciner } \\
\text { (WC-102) }\end{array}$ & $\begin{array}{l}6.95 \text { in } \\
\mathrm{H}_{2} \mathrm{O} \text { Vacuum }\end{array}$ & \\
\hline PRCA-WC-102-2 & $\begin{array}{l}\text { Alarm and recorder of pressure in atomizing } \\
\text { air lines to feed nozzles }\end{array}$ & & 50 psig \\
\hline PIA-WC-103-I & $\begin{array}{l}\text { Alarm and indicator for pressure in } \mathrm{NaK} \\
\text { expansion tank (WC-103) }\end{array}$ & & $3.5 \mathrm{psig}$ \\
\hline
\end{tabular}




\section{ATARM POINTS}

\section{INSTRUMENT NUMBER}

\section{PURPOSE OF ALARM}

Alarm and indicator for pressure in $\mathrm{NaK}$ drain tanks (WC-104A \& B)

$1.0 \mathrm{psig}$

Alarm and indicator for pressure in

$20 \mathrm{Ib}$ instrument air line

17.0 psig

Alarm and indicator for pressure in $50 \mathrm{lb}$ instrument air lins

Alarm for air supply to transport system

Close reverse flow check valve

Alarm and indicator for off-gas blower (WC-25]A \&B)

Autostart of spare blower

Alarm and indicator for pressure in fluidized bed heater jacket (WC-302)

PIA-WC-304-I

Alarm and indicator for pressure in fuel oil line to $\mathrm{NaK}$ heater (WC-304)
27 psig

8.65 in.

Hg Vacuum

7.62 in.

Hg Vacuum

$$
27 \text { psig }
$$

5.0 in.

$\mathrm{H}_{2} \mathrm{O}$ Vacuum

TABLE VI-4 (Continued) 
TABLE VI-5

SUMMARY OF THE LIQUID LEVEL ALARMS IN THE WCF PROCESS

INSTRUMENT NUMBER

LIA-WC-105-1

LIA-WC-I19-I

LIA-WC-121-I

IRA-WC-100-1 or

$-101-1$

IRA-WC-108-I

IRA-WC-114-I

IRA-WC-117-1 or

$-118-1$

LRA-WC-119-1

LRA-WC-908-I

LIA-WC-130-1

IIA-WC-I33-1 and LIA-WC-910-1

PIA-WSN-300I-1

PIA-HSN-300I-I
PIURPOSE OF ATARM

Alarm and indicator for calciner feed tank

Alarm for floor sump in hot sump cell

Solids storage condensate receiver

Alarm and recorder for waste hold tank

Close transfer valve into tanks

Alarm and recorder for scrubbing solution tank

Alarm and recorder for regeneration solution surge tank

Alarm and recorder of decontaminating solution tank

Alarm and recorder for hot sump tank

Alarm and recorder for de-entrainment separator

Alarm and indicator for equipment vent condenser

Alarm and indicator of off-gas knock-out pot

Alarm and indicator for water supply pressure

Alarm and indicator for steam supply pressure
AIARM POINTS

HIGH

LOW

37.2 in

$2.4 \mathrm{in}$.

2 in.

133 in.

149 in.

$40.5 \mathrm{in.} \quad 3.37 \mathrm{in}$

81.2 in. 7.64 in.

75.5 in. $8.4 \mathrm{in.}$

$70.0 \mathrm{in.} \quad 10.0 \mathrm{in.}$

10 in.

$13.3 \mathrm{in}$.

10 in.
22 psig

38 psig 
TABIE VI-6

SUMMARY OF THE FLOW ALARMS IN THE WCF PROCESS

\begin{tabular}{|c|c|c|c|}
\hline & & ALARM & POINTS \\
\hline INSTRUMENT NUIMBER & PURPOSE OF ALARM & $\underline{\mathrm{HIGH}}$ & LOW \\
\hline FRA-WC-10!-1 & $\mathrm{NaK}$ flow rate & & $50 \mathrm{gpm}$ \\
\hline \multirow[t]{2}{*}{ FRCA-WC-25OAB-IA } & $\begin{array}{l}\text { Fluidizing and transport } \\
\text { air flow }\end{array}$ & & 8000 scfh \\
\hline & $\begin{array}{l}\text { Close fluidizing air re- } \\
\text { verse flow check valve and. } \\
\text { feed shutdown }\end{array}$ & & $6000 \mathrm{scth}$ \\
\hline
\end{tabular}

are disposed of by burial at the NRTS burial ground or may, if high in activity, be returned to the WCF and dropped into a solids storage bin.

\subsection{Liquid Samplers}

Air-jet type samplers are used to sample liquids in the WCF. The hot sump tank sampler requires a two-stage jet to lift the liquid to the sample corridor level. All five liquid samplers are provided with an air bleed into the suction leg of the sampler just above the tank nozzle to assist the vacuum jet in raising the process solutions to the sample gallery level. The air bleed forms bubbles in the process solution, decreasing the solution density and reducing the suction lift required. The liquid sampling circuit is schematically shown in Figure VI-45. Sample bottles (both $5 \mathrm{ml}$ and $25 \mathrm{ml}$ sizes) are fitted with a screw cap with a plastic diaphragm in the cap top. The sample bottle is connected to the sampling circuit with remote handling tongs by piercing the diaphragm on the sample bottle top with a hypodermic needle sampler assembly. One needle of the sampler assembly is the sample supply line. The other needle is the sample return line. The diaphragm provides a bottle seal, both during sampling and after sampling.

Each sample station is equipped with a sample blowdown assembly which can be positioned over the hypodermic needles individually, and air or steam can be applied to the sample lines to clear obstructions. Details of a liquid sampling station are shown in Figure VI-46.

\subsection{Small Solids Sampler}

The small solids sampler removes 15 cc solids samples from the lower section of the calciner vessel. Sampling is accomplished by lifting the calcined solids material from the calciner vessel to a small cyclone sample station 


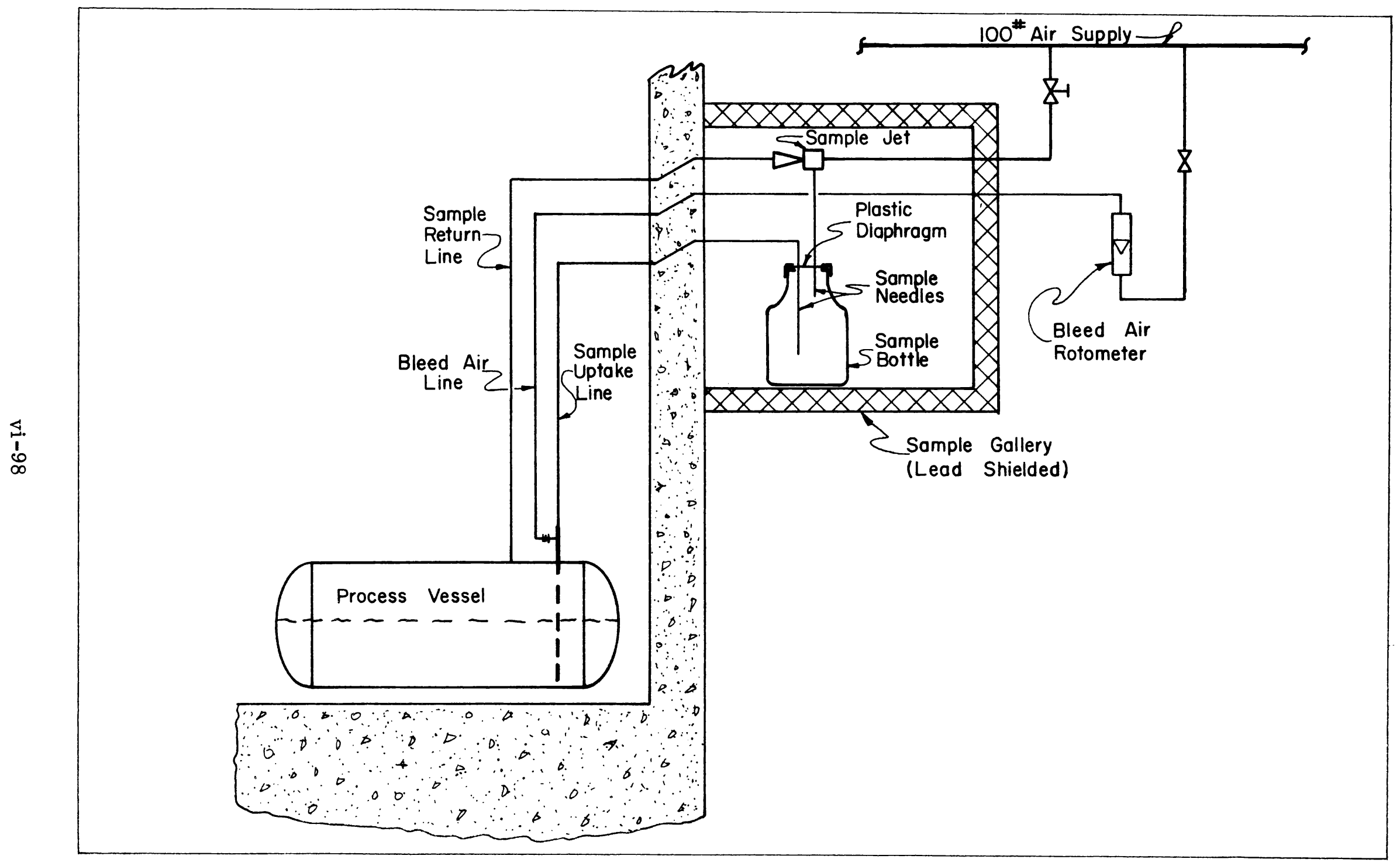

FIG. VI-45 WCF LIQUID SAMPLING CIRCUIT 


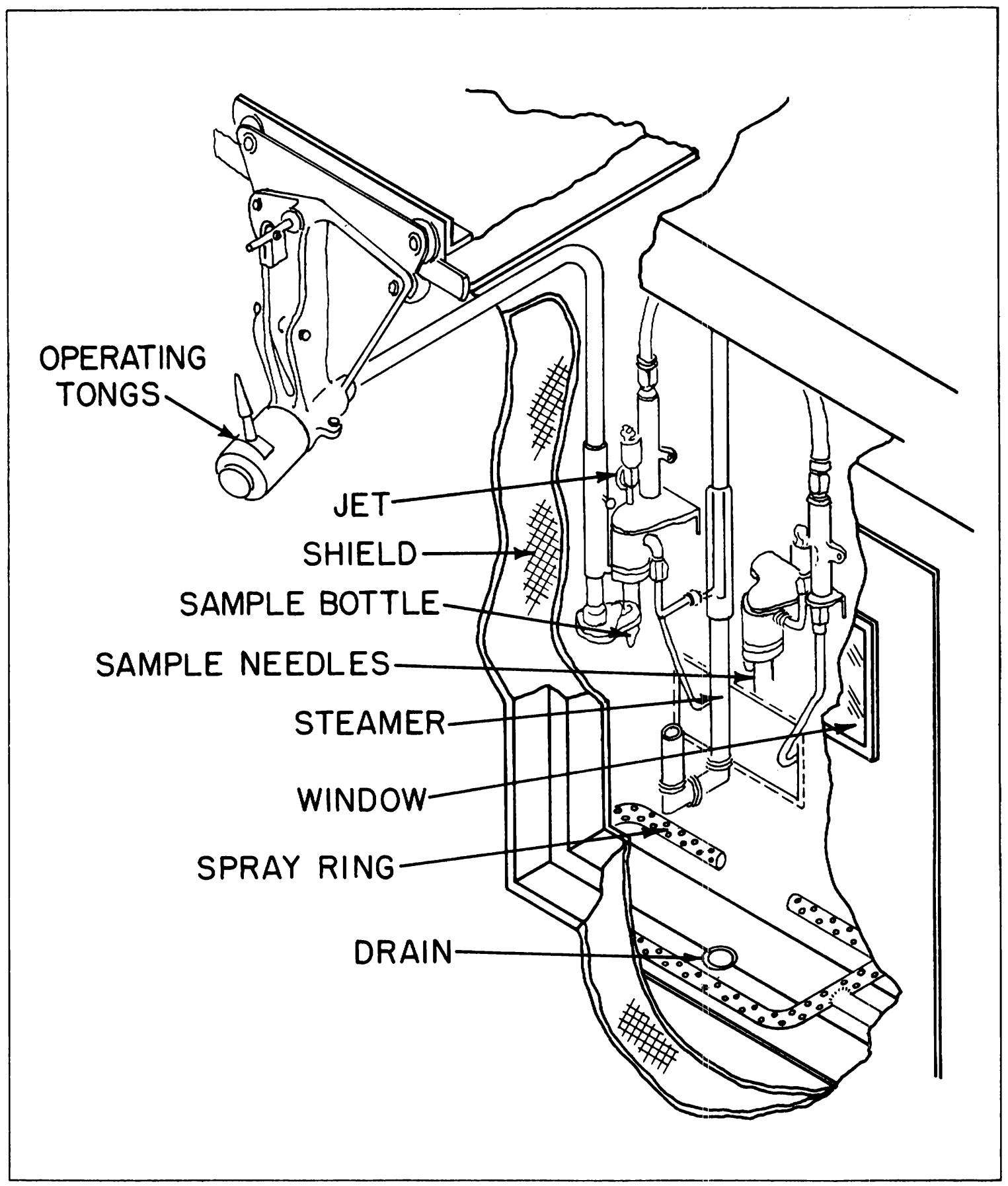

FIG. VI-46 DETAIL OF LIQUID SAMPLING STATION.

through a 1/2-inch stainless steel line by applying vacuum to the sample station and sample supply line with an air operated vacuum jet. Dilution air added at the sample supply line inlet assists the transfer operation by keeping the calcined solids in a fluidized state. Solids collected in the sample station cyclone are transferred to a sample bottle by a sliding gate mechanism. A 5 cc sample of solids is collected from the cyclone into a perforation in the sliding gate. 
The perforation on the slide is then positioned over the sample bottle and the sample drops into the bottle. During the sampling operation, the slide seals the sample bottle from the high vacuum sampling circuit. Excess solids in the sample cyclone are returned to the calcine vessel through the sample jet and sample return line. The samples are removed remotely by means of handling tongs to a lead sample cask. The small solids sampling circuit is shown schematically in Figure VI-47.

\subsection{Bulk Solids Sampler}

The bulk solids sampler is designed to remove remotely one-quart samples of calcined material from the calciner vessel to a sample can contained in a shielding cask. The bulk solids sampling equipment is shown schematically in Figure VI-48.

The sample can, into which the sample is to be drawn, is placed in a sample shielding cask mounted on a wheeled dolly. The cask is then placed in the shielded sample cubicle where the sample cask plug is removed by lifting it out with a hydraulically operated magnetic chuck. The cask is then positioned under the sample needles and lifted into sampling position.

Transfer of solids from the calciner vessel to the sample can is accomplished by applying a vacuum to the sample can and the sample supply line with an air operated sample jet. Dilution air added at the sample supply line inlet assists the material transfer by keeping the calcine sample in a fluidized state. Excess sample is returned to the calciner vessel through the sample jet and sample return line.

When the sample can is filled, the suction on the jet will increase and the jet can be turned off. The sample cask is lowered on the hydraulic mechanism to floor level and the cask plug is inserted into the top, sealing the sample in position. The sample cask is then moved from the shielded cubicle, removed from the wheeled dolly by a mobile crane, and placed on a truck for shipment to a predetermined destination.

\subsection{Remote Analytical Equipment}

The remote analytical facility (RAF) in ICPP building 627 contains 16 removable, shielded, analytical boxes. These boxes hold the remote handling equipment for receiving samples, storing samples, diluting samples, dissolving solid samples, and for performing various liquid analyses. Detailed information on this equipment can be found in Reference 6 . This facility has been used for eight years in the analysis of radioactive liquids from the fuel reprocessing operation. 


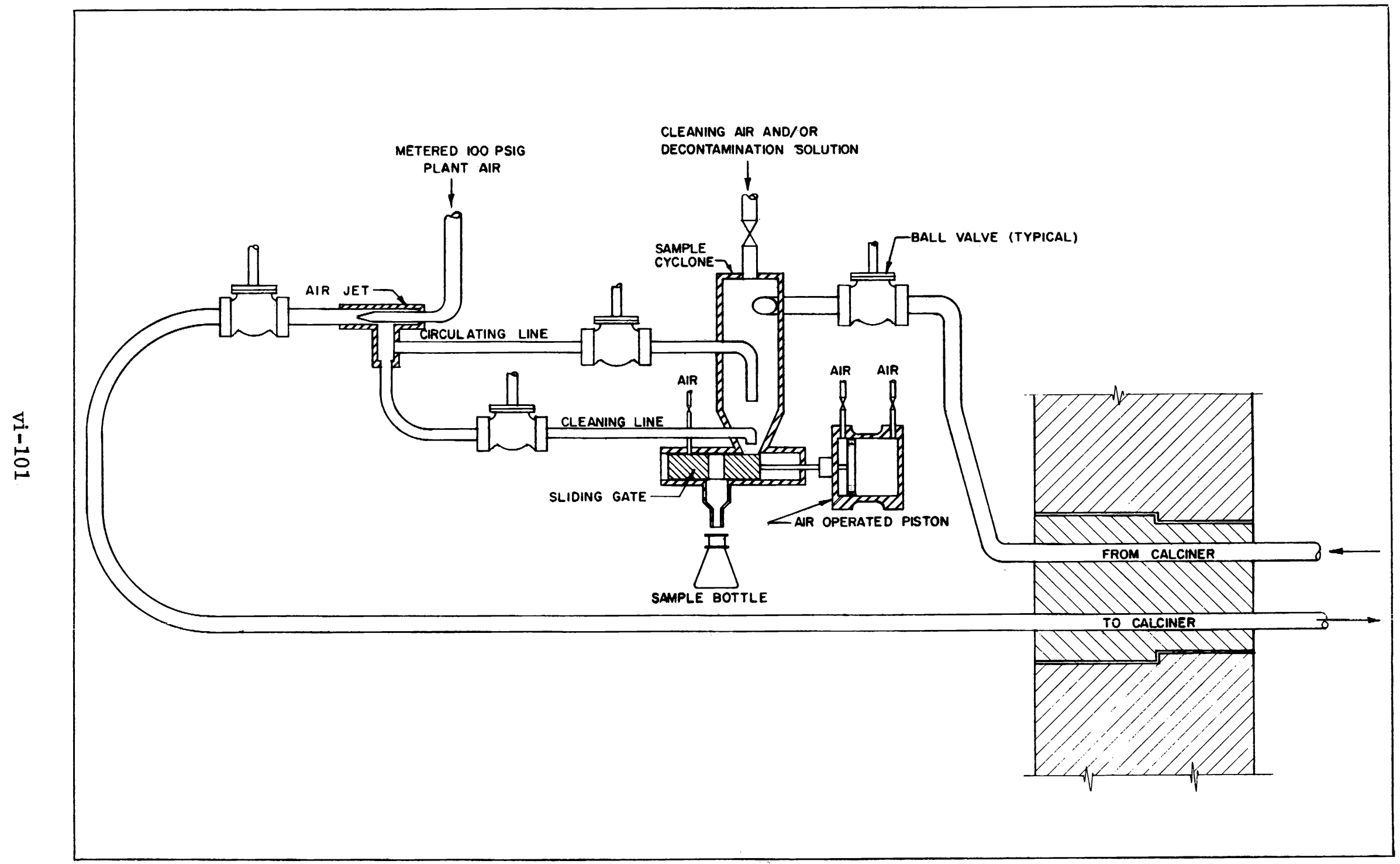

FIG. VI-47 SMALL SOLIDS SAMPLER 


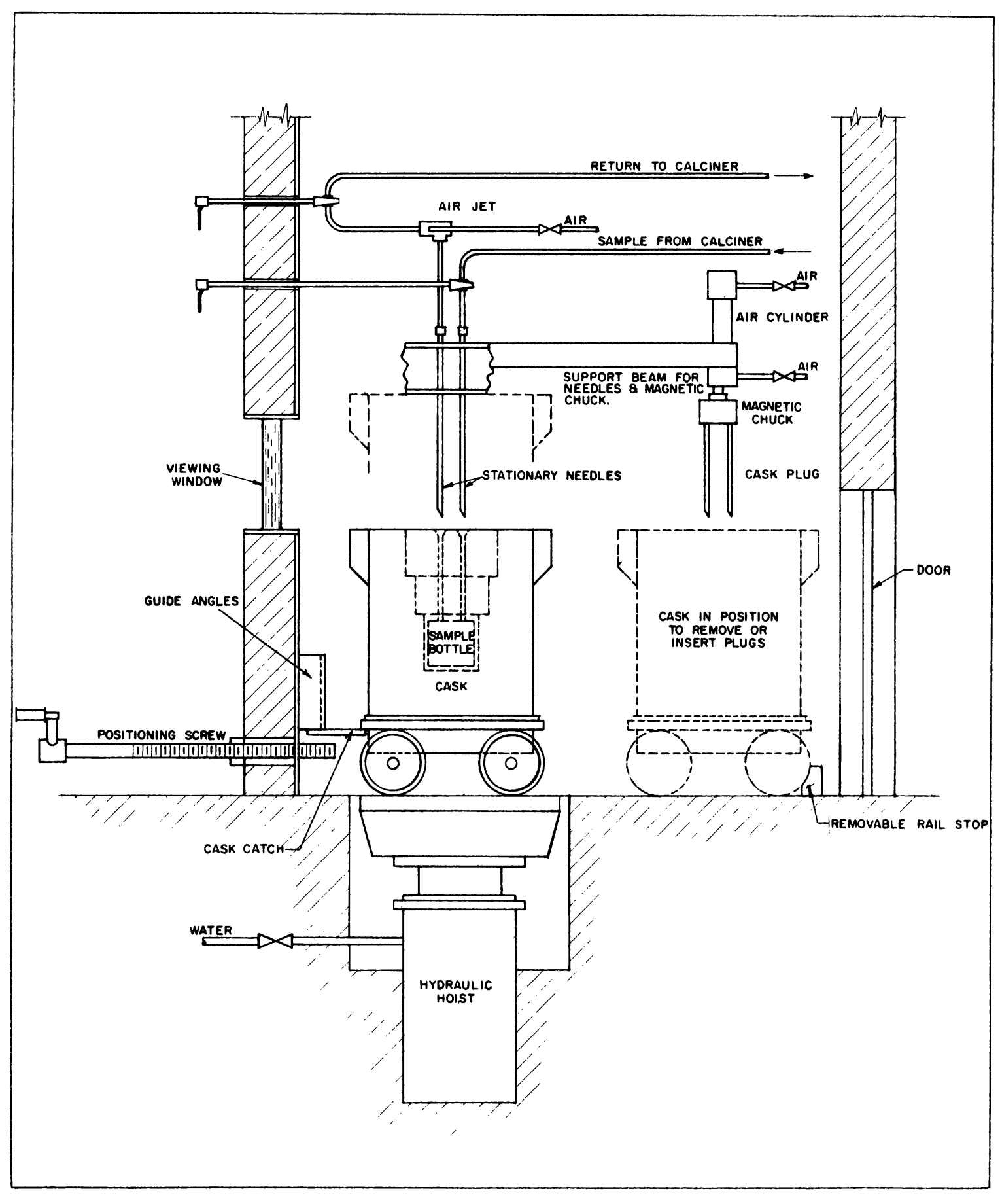

FIG. VI-48 BULK SOLIDS SAMPLER.

9.51 Liquid Samples. Liquid samples from the WCF will be analyzed for aluminum, acidity, specific gravity, nitrate, gross activity, ruthenium activity, and solids content. Of these, only the nitrate analysis requires equipment in addition to that used in the past. This additional equipment will be a $250 \mathrm{ml}$ capacity Kjeldahl distillation apparatus. 
9.52 Solid Samples. Sample measurements on the WCF solids will be new to the RAF and will require equipment in addition to that used in the past. Equipment has been installed to conduct routine analyses for alpha alumina nitrate, bulk density, and size distribution.

(1) Alpha Alumina. The sample is ground in a mixer mill and a slurry formed by adding methanol. A portion of this slurry is then air dried on a plastic plate and the plate transferred to the $\mathrm{X}$-ray laboratory where the alpha alumina content is determined by X-ray diffraction.

(2) Nitrate. A sample is weighed on an analytical balance adapted for remote weighing. The balance is a standard single pan balance with the pan extended through the balance cabinet floor and through four inches of lead shielding. This positions the balance in the open and shields the weighing pan. After weighing, the sample is heated in a $250 \mathrm{ml} \mathrm{Kjeldahl} \mathrm{apparatus;} \mathrm{the} \mathrm{distillate} \mathrm{obtained} \mathrm{from} \mathrm{the}$ heating is transferred to a "cold" laboratory for titration and determination of the nitrogen.

(3) Bulk Density. The volume of a sample is measured in a tared graduated cylinder and weighed. The bulk density is reported as $\mathrm{g} / \mathrm{cc}$.

(4) Size Distribution. A special analytical apparatus has been fabricated for remote determinations of the particle size distribution (see Figure VI-49). This apparatus consists of a sample tube, a cyclone, and a rotameter. A 5 cc sample of the solids is placed in the fluidizing tube and air is blown through the sample at several velocities, each progressively higher than the previous. The volume of solids entrained in the gas at each fluidizing rate is collected in the graduated cylinder and recorded. Previous correlations between data of this type and screen analyses provide a means of estimating the actual size distribution of the sample.

\subsection{Sample Disposal}

Liquid samples may be disposed of through the box drains as has been done routinely for years. All solid waste will be sealed in No. 2 tall form cans by a canning device. Cans containing low amounts of radioactivity will be buried at the NRTS burial ground. Waste cans with radiation levels too high for direct handling will be returned to the calciner facility, using a cask designed for this 


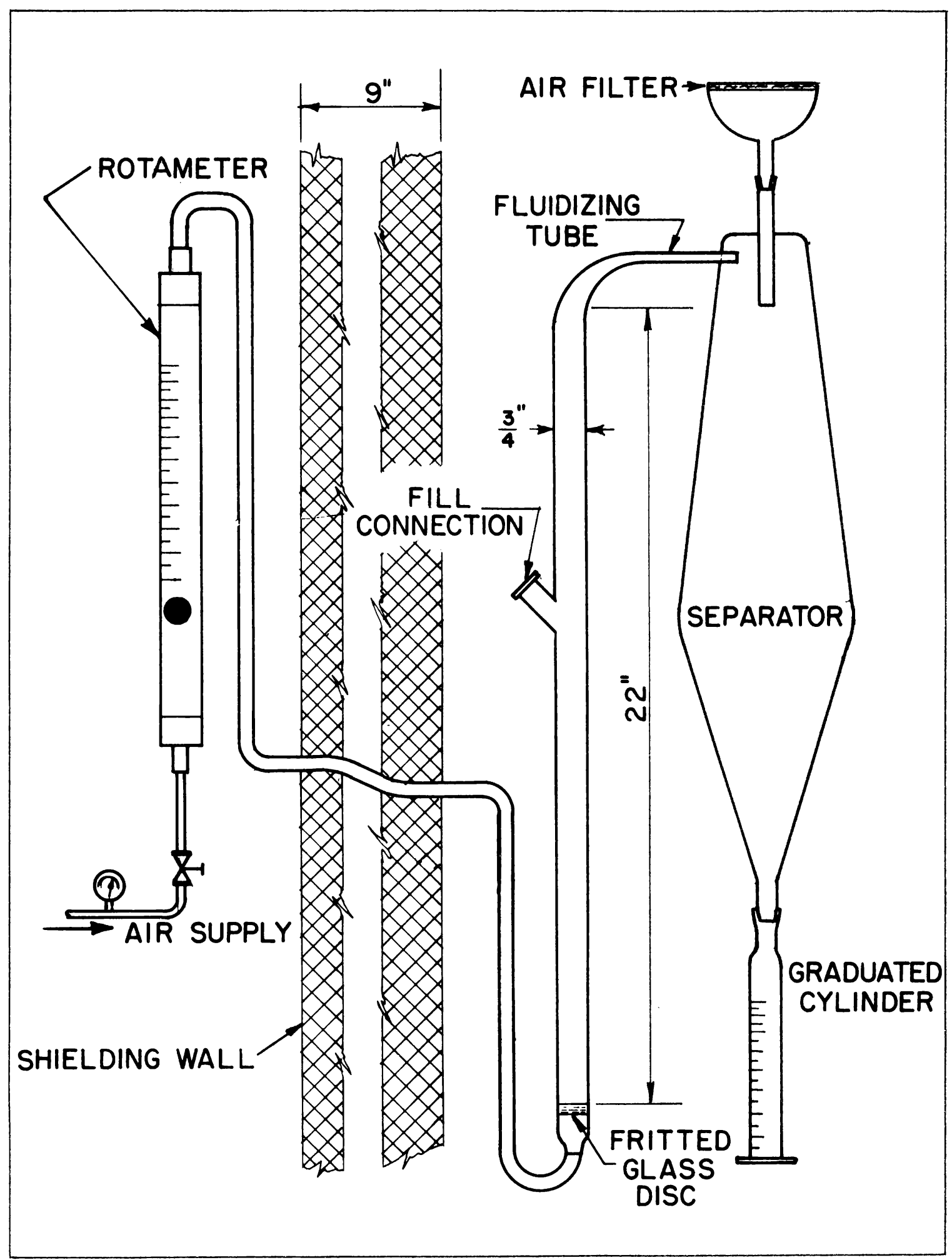

FIG. VI-49 ANALYTICAL APPARATUS FOR PARTICLE SIZE DISTRIBUTION.

purpose. At the WCF, the cans are dropped from the cask into one of the product storage bins through a 4-inch line and double-valve air-lock assembly. 


\section{DECONTAMINATION AND HOT WASTE DISPOSAL}

\subsection{General Description}

The Idaho Chemical Processing Plant philosophy of direct maintenance was incorporated in the design of the Waste Calcining Facility. Provisions were made for remote decontamination of equipment and piping normally contacted by radioactive materials. Permanently installed decontamination lines and sprays are provided to all equipment and piping. Air, steam, and decontaminating solutions can be supplied for removing residual radioactive deposits adhering to metal walls, crevices, and inaccessible places on the equipment. A hot sump, WC-119, is provided for receiving the decontamination waste and other wastes from the process. This vessel is located at the lowest elevation in the WCF building and receives wastes by gravity flow from the equipment. Final disposition of these wastes is made either to the ICPP waste evaporators for processing before storage or to the WCF hold tanks for reprocessing to solids. The hot sump, like the main process equipment, is maintained under vacuum through a connection to the equipment vent system. Flow diagrams of the decontamination system and hot sump are shown in Figures VI-50 and 51, respectively.

\subsection{Equipment}

The decontamination equipment is located above the process cells in a cold area of the WCF building. Tanks and pumps are connected to two manifold headers that lead to the sprays and spargers on all equipment in the hot areas. The system is protected from backflow of radioactive materials from the hot areas, by check and block valves that are provided in all lines, and by the elevated position of the cold area.

10.21 Decontaminating Solution Tanks WC-117 and WC-118. The decontamination solutions are stored in two tanks (WC-117 and WC-118) that have top-mounted quick-opening manways for adding chemicals. Each tank has a storage capacity of 1200 gallons and is constructed of Type 304L stainless steel. The tanks are designed for atmospheric pressure at a temperature of $275^{\circ} \mathrm{C}$. No hydrostatic pressure tests were made on the vessels due to the cold nature of service; however, the vessels were filled with water for leak tests and the vessel welds were spot radiographed. Steam coils, with a maximum heating duty of $1,200,000 \mathrm{Btu} / \mathrm{hr}$, are provided in each tank. These coils were hydrostatically tested at 180 psi and can be used for cooling as well as heating the vessel contents. Level recorder alarm and temperature indicators are provided 


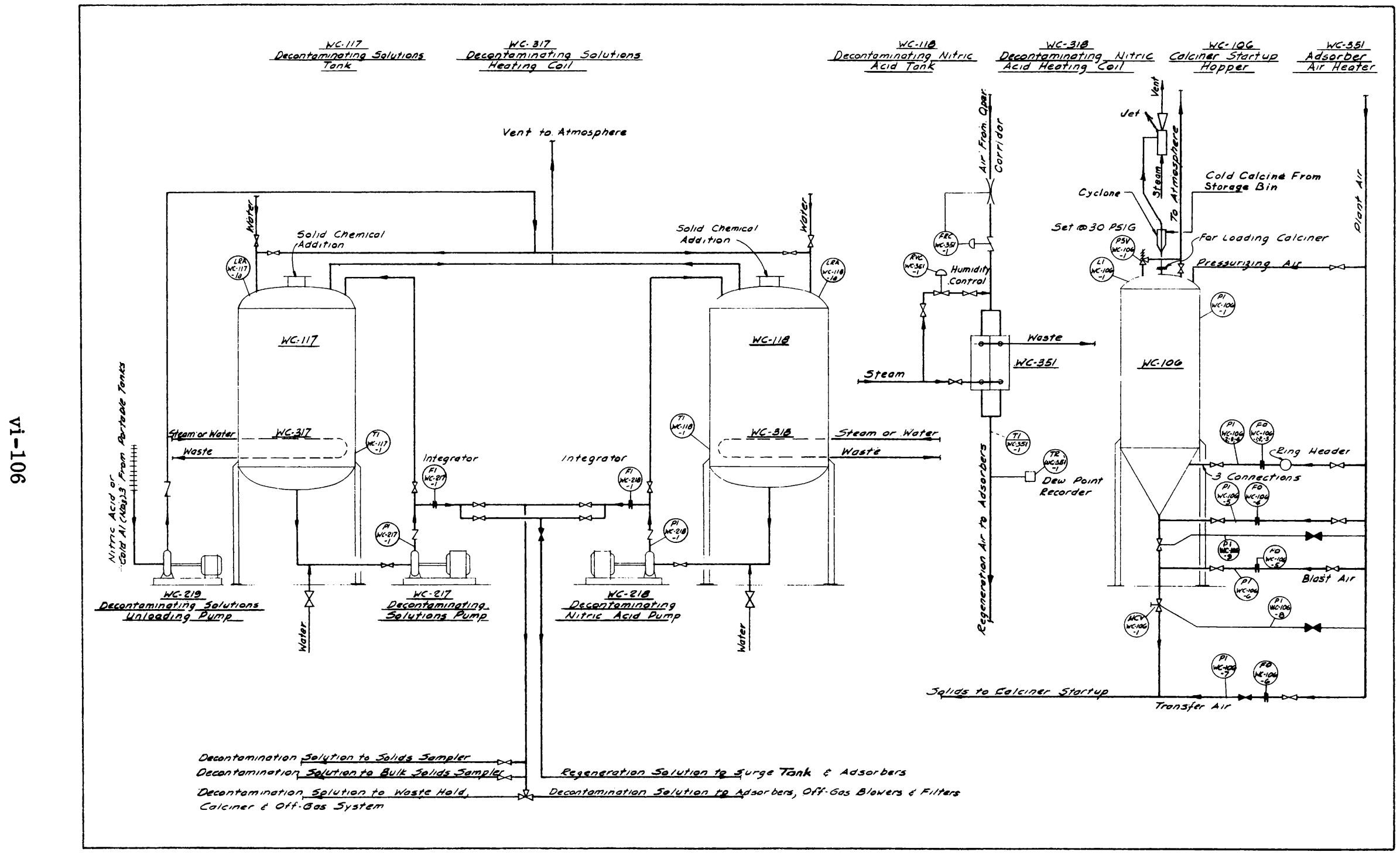

FIG. VI-5O DECONTAMINATION SYSTEM FLOW DIAGRAM 


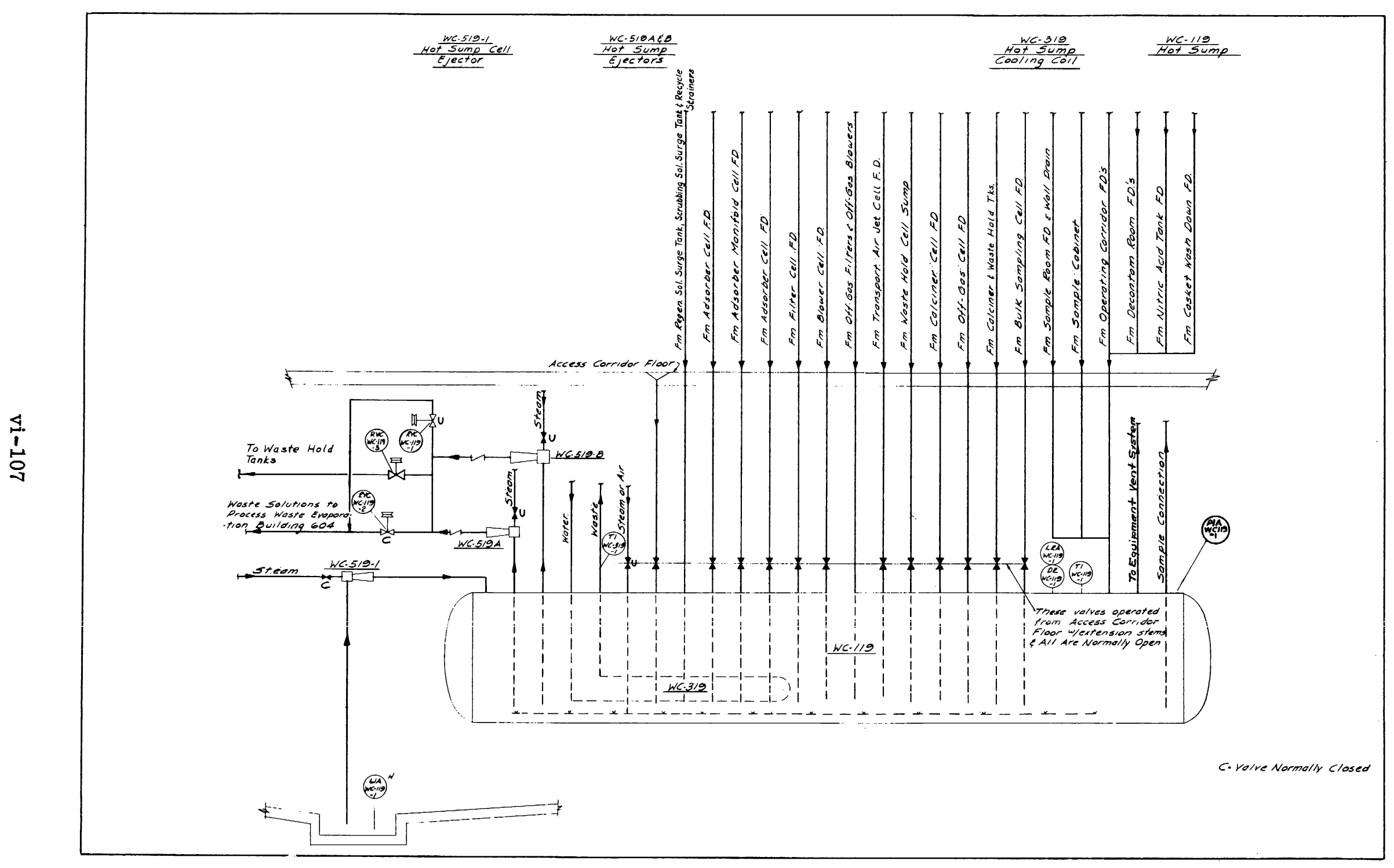

FIG. VI-5I HOT SUMP SYSTEM FLOW DIAGRAM. 
on the tanks. The two vessels are manifolded together, but can be isolated from each other by block valves.

10.22 Decontaminating Solution Pumps WC-217, WC-218, and WC-219. The decontaminating solution pumps, WC-217 and WC-218, transfer solutions from the tanks to the manifold headers that supply the individual or multiple process units. The pumps are single suction, centrifugal type with a closed impeller and are driven by $7.5 \mathrm{hp}$ electric motors. They are constructed of 18-8 and 19-9 stainless steel and will deliver $100 \mathrm{gpm}$ at a pressure of $50 \mathrm{psi}$. Pressure indicators and integrating flowmeters are provided on the pump discharge piping.

The decontaminating solution unloading pump (WC-219) is used for unloading chemicals from portable tanks or dumpsters into the decontaminating storage tanks. This unit is a $3.5 \mathrm{hp}$ centrifugal pump capable of delivering $40 \mathrm{gpm}$ at 11 psig. The casing, impeller, and all wetted surface parts on the pump are constructed of stainless steel. (A transfer line also has been installed from the main ICPP process building makeup area to the WCF storage tanks.)

10.23 Decontamination Manifolds. The distribution of decontaminating solutions to all process equipment and piping is accomplished through use of piping manifolds in the south room of WCF building. Solutions from storage tanks WC-117 or WC-118 are delivered by pump to a three-inch manifold header fitted with three-way plug valves that lead to individual piping or equipment in the radioactive area. Plant water and/or steam are supplied to a parallel manifold header which joins to the other side of the three-way plug valves. Normally, these valves are closed and the downstream side is flanged with a blind to insure that there is no backflow from process during operations. The blinds are removed from the flanges to put the decontamination system into service. Purge air is supplied to the spargers and decontamination lines downstream of the blinded flanges. These purge connections are all provided with pressure regulators, rotameters, pressure gauges, check valves, and block valves to insure against backflow.

\subsection{Decontamination Solutions}

Decontamination solutions used in the WCF will be the same solutions currently in use at ICPP. These include, in addition to water and steam, the following:

(1) 10 percent nitric acid

(2) 10 percent citric acid

(3) 10 percent oxalic acid 
(4) 10 percent $\mathrm{NaOH}$ and 2.5 percent tartaric acid

(5) $0.003 \underline{M}$ periodic acid

(6) 20 percent $\mathrm{HNO}_{3}$ and 3 percent $\mathrm{NaF}$

\subsection{Hot Sump WC-119 and Waste Transfer Lines}

All the radioactive waste solutions from the WCF equipment and cells can be drained by gravity to the hot sump WC-119. This vessel serves as a temporary storage for all wastes from the process or from decontamination. In addition, this vessel receives and stores the waste solutions from the ruthenium adsorber regeneration process. The final disposal of these wastes is made through waste transfer lines to the processes in ICPP or WCF. The hot sump WC-119 (Figure VI-52) is constructed of type 304L stainless steel and is designed for pressures from -1.5 to +5.0 psi at $90^{\circ} \mathrm{C}$. The normal operating conditions are $-0.4 \mathrm{psi}(11.9 \mathrm{psia})$ and $60^{\circ} \mathrm{C}$. The welds on this vessel were 100 percent radiographed and the vessel was hydrostatically tested at 174 psi. A cooling coil and sparger (air or steam) are provided in the bottom of the vessel; a decontamination sparger also is provided near the top of the vessel. Liquid level, density recorders, pressure, and temperature indicators are provided for the vessel and are located on the instrument panel of the operating corridor. A remote sampling system also is provided. The vessel is connected to the equipment vent system. All lines entering the tank from open drains (floor and sample gallery) are provided with 40-inch water seal legs to prevent air from entering the tank and to prevent escape of airborne activity. All other lines draining from the process are provided with valves that can be operated remotely from the instrument panel or operated manually from the access corridor above the hot sump.

The transfer of waste from the hot sump is made by steam jets through two 1-1/2-inch unloading lines. These lines contain check valves and are joined together for separate or common services. Waste to be reprocessed in the calciner is transferred through a 1-1/2-inch line and remote control valve to the scrubbing solution recycle line to the waste hold tanks. Waste to be processed in the ICPP is transferred through a 1-1/2-inch unloading line to a header that enters the waste evaporator feed tank.

\subsection{Equipment Vent System}

The equipment vent system maintains a vacuum on all sampling stations and the process vessels that are not directly connected to the off-gas system. In addition, the system contains equipment for removal of entrained radioactive 
WC 119
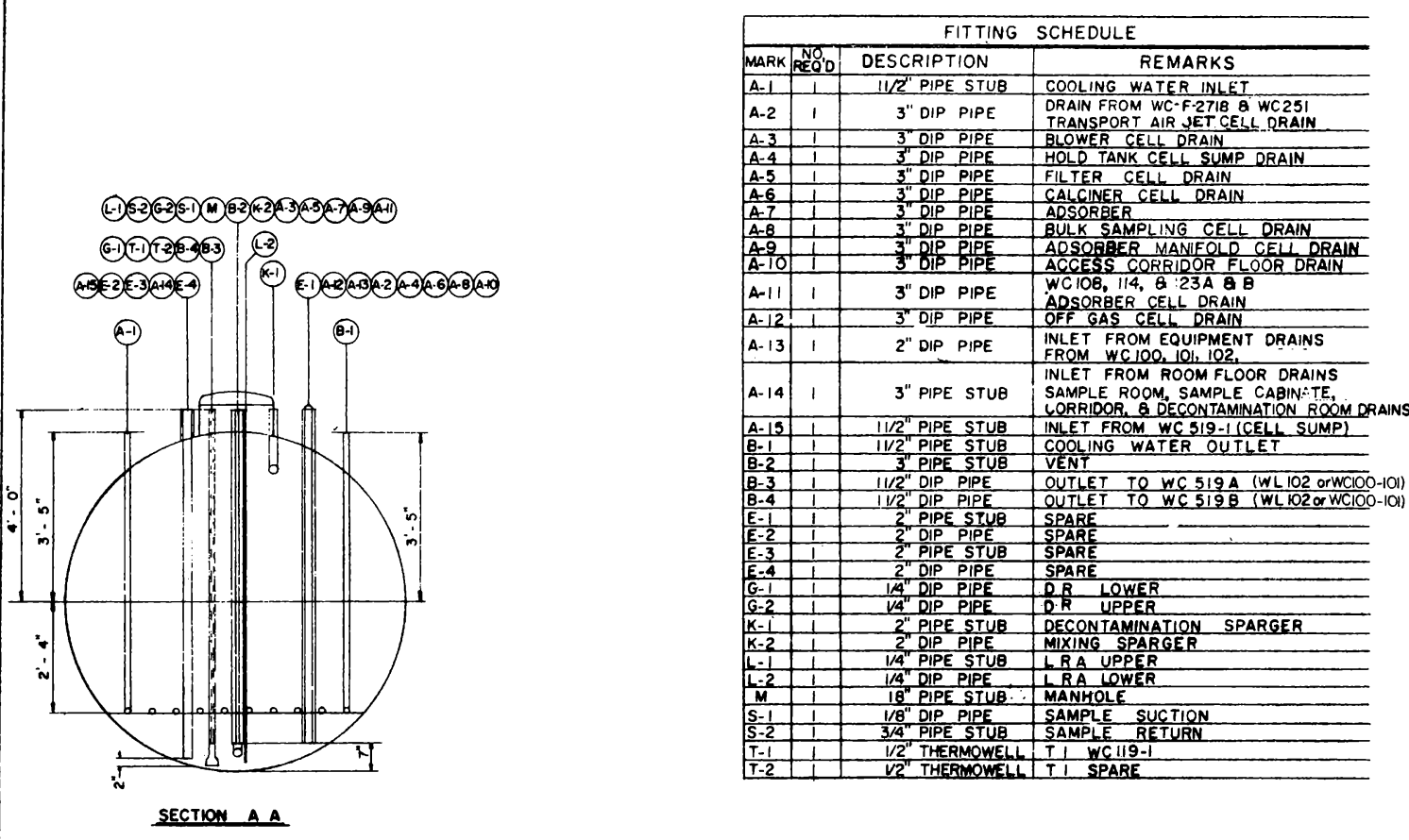

'21'- I" O.A.L. (APPROX.)
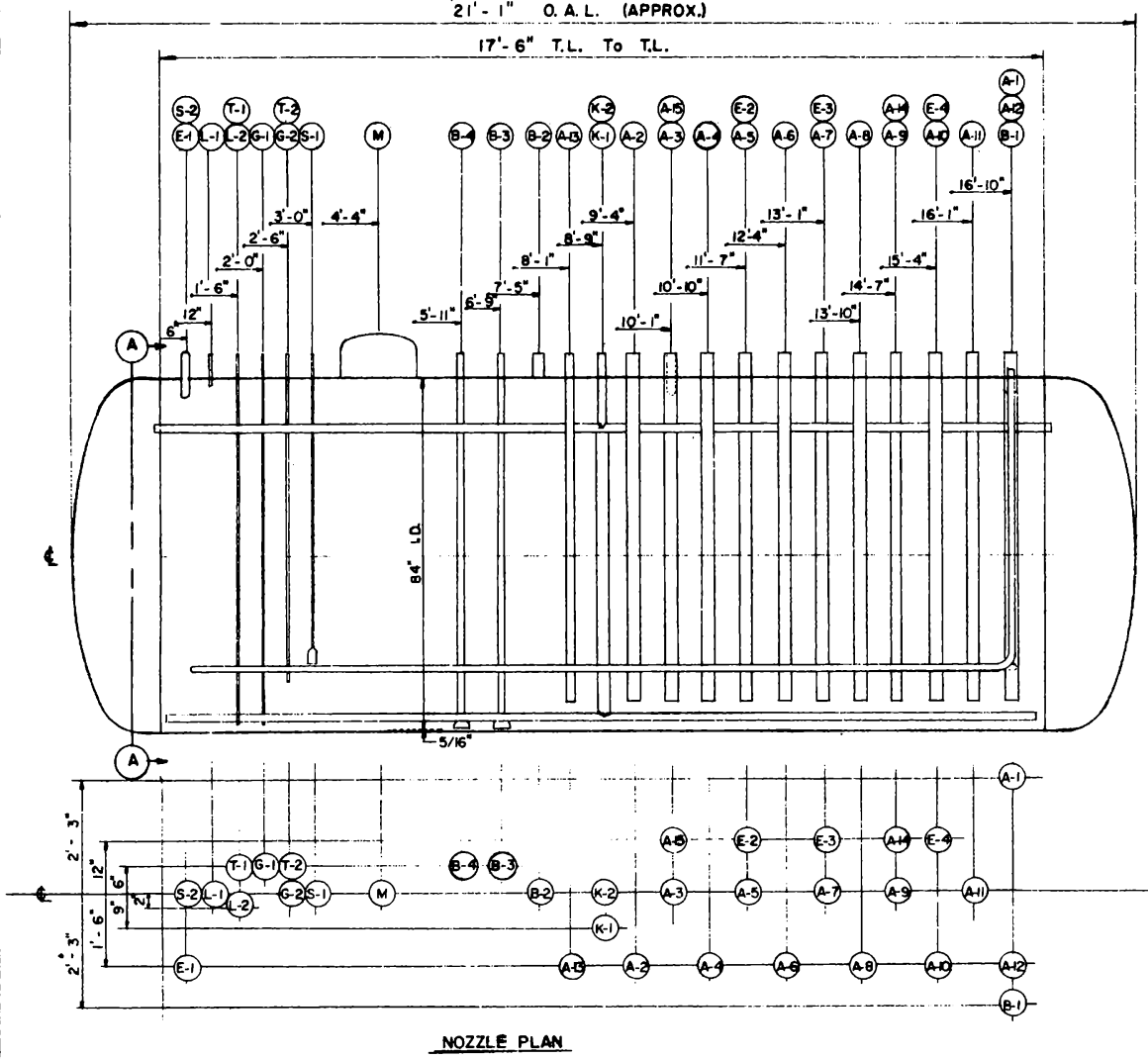

FIG, VI-52 HOT SUMP TANK 
particulate matter and moisture from the vent gases before they are discharged to the stack. Vacuum for this system is adjusted from the pressure indicator on the hot sump WC-119. The arrangement of the equipment vent system is show on Figure VI-53.

10.51 Equipment Vent Condenser WC-130. The equipment vent condenser (Figure VI-54) consists of a shell-and-tube type condenser mounted on a knockout pot and followed by a wire mesh demister. Steam may be injected into the gases entering the condenser; this increases the condensation rate and subsequently the cleanup of fine particles in the gases. Liquid collected in the knockout pot is drained continuously, by gravity, to the scrubbing solution surge tank WC-108.

The equipment vent condenser is constructed of type 347 stainless steel and is designed for pressures of $70 \mathrm{psi}$ at $150^{\circ} \mathrm{F}$. The normal operating pressure is $11.5 \mathrm{psia}$ at $125^{\circ} \mathrm{F}$. The unit was hydrostatically tested at $100 \mathrm{psi}$ and the welds on the structure were 100 percent radiographed. The cooling water rate to the condenser is controlled by manual block valves on water inlet and outlet lines. Temperature indicators are provided on the inlet and outlet lines for the vent gas and cooling water. A liquid level indicator is provided on the de-entrainment section and a pressure differential indicator is provided for the condenser and demister section. A decontamination spray is located above the condenser tubes.

10.52 Equipment Vent Heater WC-356. The equipment vent heater, WC356 , superheats the saturated gases from the demister to insure that no condensate will collect on the equipment vent filter.

The heater is a 10-inch OD tube-shell type heat exchanger containing fifty-five 3/4-inch tubes through which the vent gas flows. Steam is circulated through the shell. The unit is rated for heater duty of $21,000 \mathrm{Btu} / \mathrm{hr}$. The tubes and shell are constructed of type 347 stainless steel for pressures of 150 psi at $150^{\circ} \mathrm{F}$. The operating pressure is $11.5 \mathrm{psia}$ at $125^{\circ} \mathrm{F}$. The unit was hydrostatically tested at $100 \mathrm{psi}$. The temperature of the vent gas is automatically maintained by a temperature controller on the steam supply to the heater. Temperature indicators are provided on the vent gas inlet and outlet lines. A decontamination spray is located on the top of the heater.

10.53 Equipment Vent Filter F-2722. The equipment vent filter is an AEC high-efficiency type that removes the particulate matter from the gases before they are discharged from the system. The filter is contained in a detachable stainless steel housing that can be removed from the piping system through a 


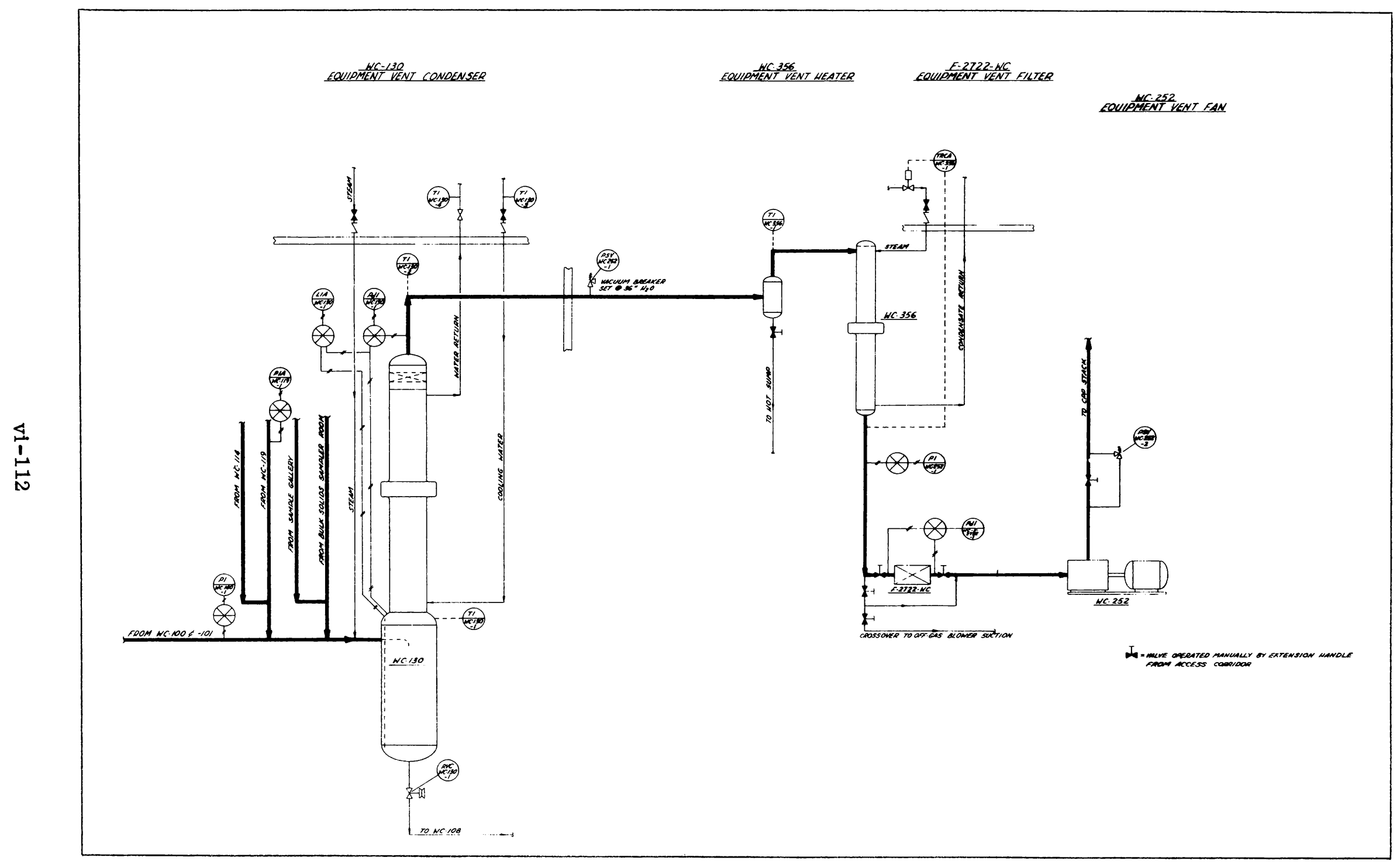

FIG. VI-53 EQUIPMENT VENT SYSTEM. 


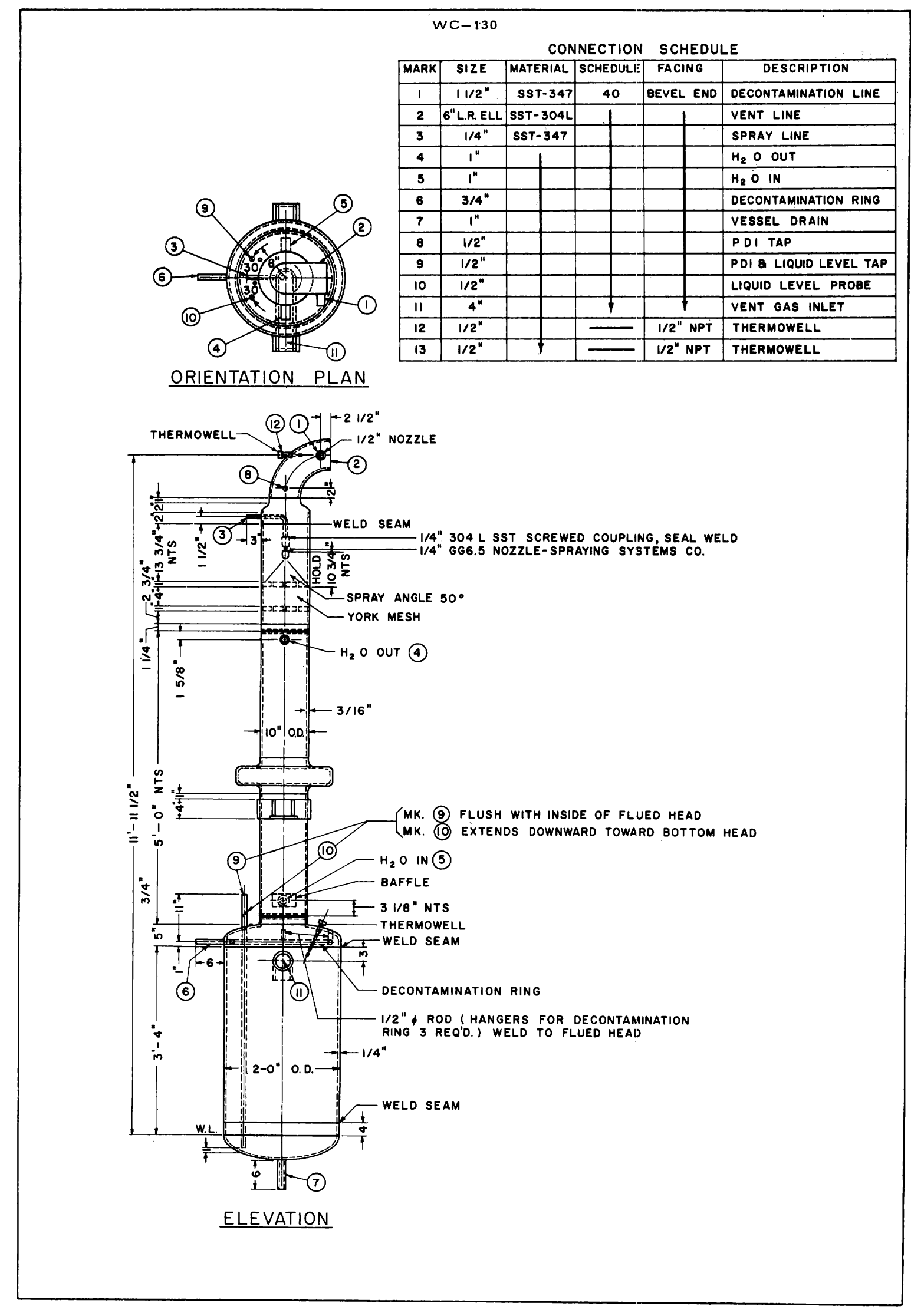

FIG. VI-54 EQUIPMENT VENT CONDENSER, 
cell hatch. A pressure differential indicator is provided for determining filter loading.

10.54 Equipment Vent Fan, WC-252. The vacuum in the equipment vent system is maintained by the equipment vent fan, and is manually controlled by throttling a valve in the blower suction line. The throttling valve is provided with an extension handle passing through the roof of the off-gas cell. The blower discharges to the off-gas header leading to the stack.

The equipment vent fan is a four-stage turbine-blower constructed of type 304 stainless steel. The fan can pull a vacuum of 11.1 psia when delivering $950 \mathrm{scfm}$. Normal operating pressure is 10.0 psia for $120 \mathrm{scfm}$. The fan is driven by a $30 \mathrm{hp}$ squirrel-cage induction motor. A vacuum breaker that opens at a 36 -inch water vacuum is provided upstream of the throttling valve. An ammeter on the power to the fan motor and a temperature recorder on the fan bearings are provided on the instrument panel. The off-gas blowers may be used as spares for the equipment vent fan through use of a bypass controlled by a manual valve and connecting the suction lines of the blowers.

\section{RADIATION MONITORING EQUIPMENT}

\subsection{General Description}

Personnel working at the WCF will be protected by an extensive system of radiation monitoring equipment and procedures. Included in this system are remote radiation monitors, constant air monitors, portal monitors, a hand and foot counter and instrumentation for monitoring off-gas activity. To supplement these permanently located instruments, mobile and portable instruments will be available at all times in the calciner health physics office. Health physics coverage also will be provided 24 hours a day.

\subsection{Remote Area Monitoring System}

Calciner personnel are made aware of direct radiation hazards by a monitoring system consisting of 10 remotely mounted detectors located throughout the plant. See Table VI-7 for detector location. Some of these, in addition to providing warning to personnel, also furnish information to operations personnel on the movement of radioactive materials from one locality to another. Each remote detector is connected to a central station unit mounted on the control panel in the operating corridor which indicates milliroentgens, roentgens, or 
TABLE VI-7

RADIATION DETECTOR STATIONS IN THE REMOTE AREA MONITORING SYSTEM

LOCATION
Operating corridor (east wall at north end)
Operating corridor (west wall at south end)
Sample gallery (center of south wall)
Filter cell corridor ( south wall at east end)
Filter cell corridor (south wall at midpoint)
Filter cell corridor (south wall at west end)
Access corridor (center of west wall)
Solids storage air blower building (air duct to the stack)
Solids storage air blower building (line to service waste trap)
Service waste from solids storage ( 1 l/2 in. line west of storage vault)

multiples thereof in a range from $1 \mathrm{mr} / \mathrm{hr}$ to $1000 \mathrm{r} / \mathrm{hr}$. The alarm system includes both visual and audio alarms.

\subsection{Constant Air Monitors}

Airborne radioactive contamination will be detected by four constant air monitors (CAMs). Two additional CAMs will be available for short periods of time such as during spike runs or start-ups. The four regular CAMs will be distributed throughout areas of the building frequented by personnel so that representative samples of air may be continuously collected from any of these areas. Sniffer hoses may be attached to the CAMs so that air samples can be drawn from cells and other remote areas.

\subsection{Portal Monitors}

In order to detect contamination on personnel and to minimize its being carried from the building, a monitor (frisker) is installed in the main corridor on the top floor just outside of the HP office. This unit is used to monitor personnel or material leaving through the main entrance to the building. This is a standard unit used throughout ICPP. 


\subsection{Hand and Foot Counter}

A hand and foot counter is located in the hallway just outside the HP office. This unit consists of a platform and housing which contains detector tubes for monitoring the hands and feet which are the most common parts of the person to become contaminated. This unit will detect contamination over a range of 0 to $20,000 \mathrm{c} / \mathrm{m}$ and display the findings on meters located on the front of the unit. 11.6 Portable and Mobile Instrumentation and Equipment

Portable and mobile instruments will be available at all times to supplement the stationary instruments described previously. These will include radiation detection instruments capable of detecting various levels from background to $500 \mathrm{r} / \mathrm{hr}$. There also will be high volume air samplers, mobile radiation monitors, and a floor scanner.

Respiratory equipment for emergency use is kept at the calciner building at all times and consists of two self-contained air units as well as air purifying respirators.

Items of protective clothing such as gloves and shoe covers will be available in the Health Physics office in the calciner building at all times. 11.7 Routine Area Survey Equipment

Routine area surveys will be made for radiation and radioactive contamination throughout the WCF at frequent intervals. Radiation surveys will be made by means of an appropriate instrument, usually a GM with headset, while contamination will be checked by rubbing a small piece of filter paper (smear) over a surface and then counting it in a lead pig which is connected to a scaler located in the HP office. A smear with a more adhesive type surface may be more feasible for use in the WCF than a dry smear because of the dryness of the calcine product. Any radiation source which will produce exposures at a rate of $7.5 \mathrm{mrem} / \mathrm{hr}$ or greater will be tagged and/or roped off. Floor contamination levels of $>500 \mathrm{~d} / \mathrm{m} \beta$ will require that the area be roped off or immediately decontaminated.

Routine surveys of the calciner will be made at least once each eighthour shift.

\subsection{WCF Off-Gas Sampler}

An off-gas sampling station is provided at the WCF for monitoring the level of radioactivity of off-gas discharged to the ICPP stack. The sampler is contained in a steel cabinet located at the east wall of the HP office. A schematic of the sampler piping is shown in Figure V-55. 


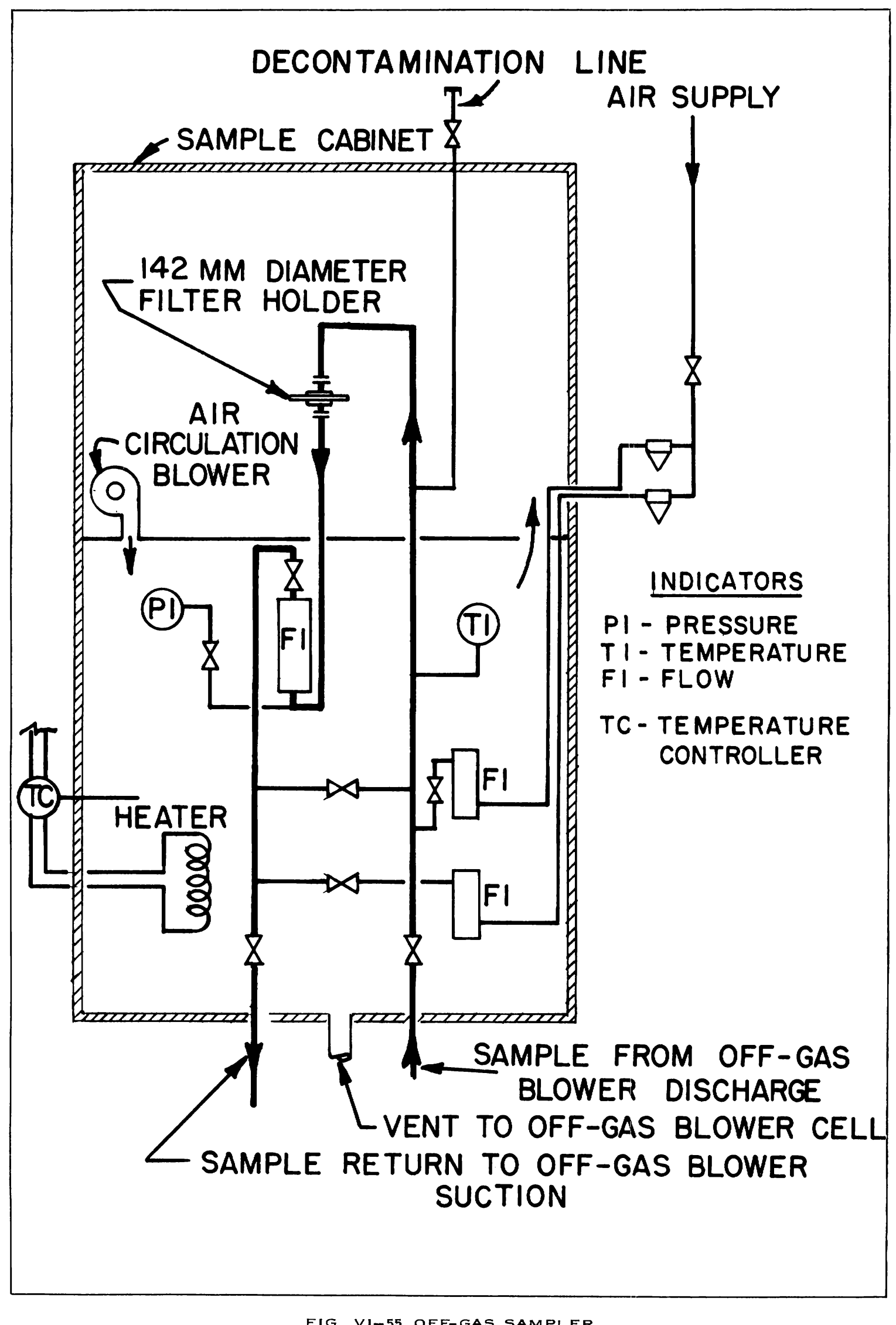

FIG. VI-55 OFF-GAS SAMPLER. 
A 2 to $5 \mathrm{scfm}$ sample stream, taken from the discharge side of the off-gas blowers, is passed through a $142 \mathrm{~mm}$ membrane filter (Type HA) in the cabinet and then returned to the suction side of the off-gas blowers. The amount of radioactive particulate matter collected on the filter is determined by counting the cesium-137 on the filter. The quantity of strontium-90 and other major fission products on the filter can be estimated from the concentrations relative to that of cesium-137 in the WCF feed. Provisions have been made to pass a portion of the sample stream through a caustic bubbler which adsorbs both the volatile and particulate ruthenium. An activity count of the caustic solution provides an estimate of the total ruthenium-106 in the sample stream. Flowrate instrumentation provided with the sampler enables the total activity passing to the ICPP stack to be computed from the measured activity of the sample stream.

To prevent condensation in the sampler piping, the sample cabinet is insulated and heated. A vent is provided between the cabinet and the off-gas blower cell so that any activity released inside the cabinet is swept toward the lower pressure blower cell with the circulating air.

\subsection{ICPP Stack Sampler and Monitor}

The radioactivity carried by the WCF off-gas also can be monitored at a sampling station provided at the 90 foot level in the ICPP stack. The WCF off-gases are diluted considerably by the other gases in the stack ( $\approx 10$ to 1 ) so that measurements at this station will not be as accurate as those made at the WCF sample station (Section 11.8).

The configuration and operation of the ICPP stacksampler and monitor are similar to that of the WCF off-gas samplers. A positive displacement blower pulls an off-gas sample $(\approx 10 \mathrm{CFM})$, taken isokinetically, from the stack, through a sampling manifold, and then returns it to the stack. The gross activity of the sample stream is measured with scintillation detectors connected to an integrating recorder. A filter assembly is provided for collecting particulate solids in the sample stream; an activity count of the filter paper provides a measure of the collected solids in the same manner applied at the WCF off-gas sampler. Also included in the stack sampler system is a caustic scrubber for collecting volatile fission products, ie, ruthenium and iodine. Flowrate instrumentation provided with the sampler enables the total activity omission from the stack to be estimated from that determined for the sample stream. A schematic of the ICPP stack sampler and monitor is shown in Figure VI-56. 


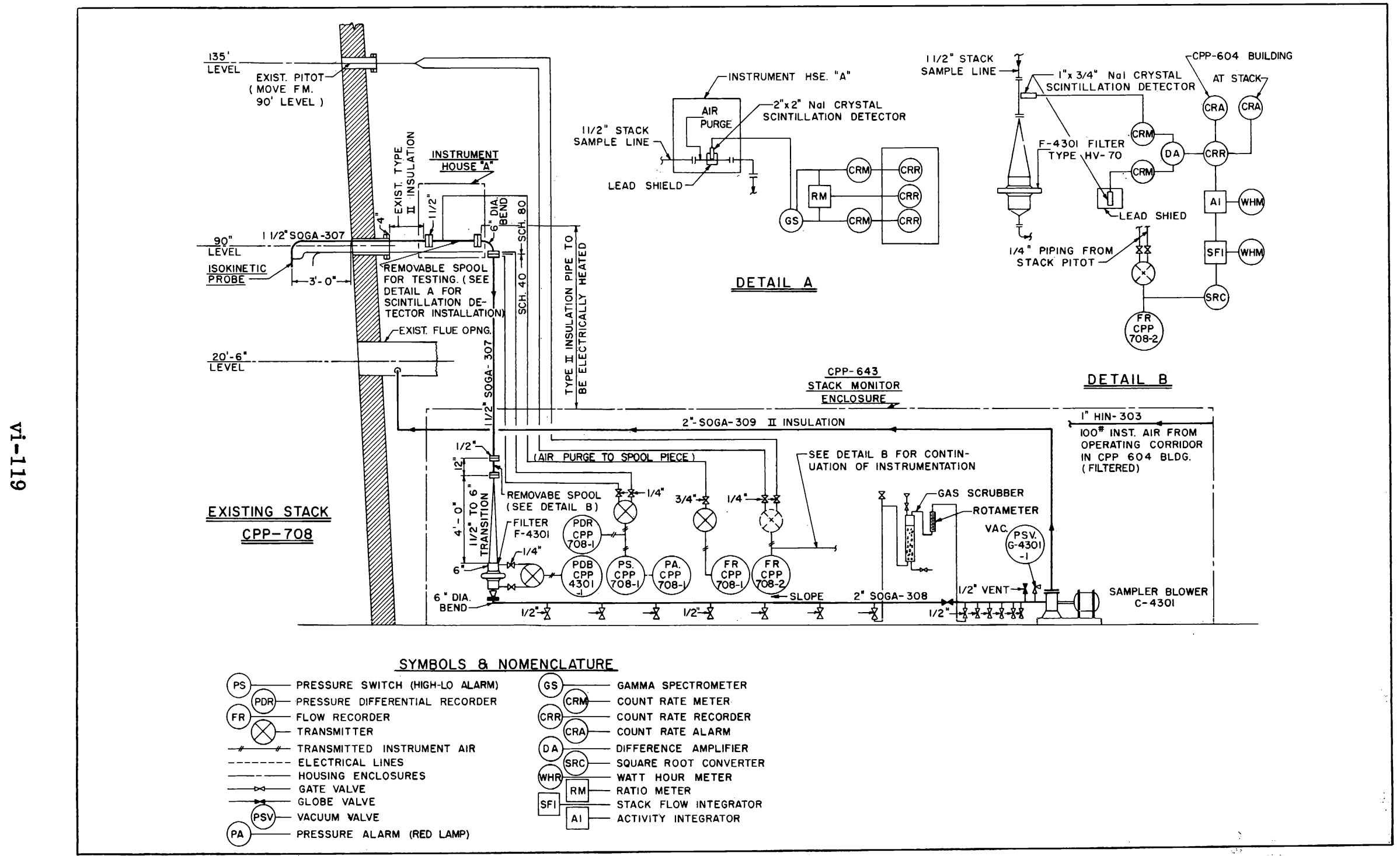

FIG. VI-56 ICPP STACK MONITORING SYSTEM, 


\subsection{Service Waste Monitoring System}

The service waste leaving the calciner building, ICPP-633, flows to a manhole, ICPP-309, where it joins the service waste from the ICPP service building, ICPP-606, and then to the service waste monitoring station, ICPP-709, where it is combined with the service waste from the remaining ICPP areas. The total plant service waste is then monitored for activity. If activity is detected in the total waste stream, it is possible to segregate the stream from manhole ICPP-309 and sample it independently. Further definition of the source of activity requires a survey by Health Physics personnel. An activity detector, connected to the remote area monitoring system (paragraph 11.2) is provided on the service waste line from the solids storage vault.

\section{REFERENCES}

1. Chemical Processing and Equipment; Selected Reference Material, United States Atomic Energy Program, compiled and edited by American Society of Mechanical Engineers, Washington D. C., U. S. Government Printing Office, 1955.

2. B. P. Brown, et al, Development of a Fluidized Bed Calcination Process for Aluminurn Nitrate Wastes in a Two-Foot-Square Pilot Plant Calciner. Part 1. Equipment Development and Initial Process Studies, IDO-14586 (June 20, 1962).

3. Chemical Processing Technology Quarterly Progress Report, 4th Qtr 1962, IDO-14611 (June 7, 1963).

4. Chemical Processing Technology Quarterly Progress Report, 3rd Qtr 1962, IDO-14599 (December 28, 1962).

5. W. L. Fleischmann, R. F. Koenig, "Liquid Metals Handbook", Sodium-NaK Supplement, TID-5277 (July 1, 1955).

6. M. J. Painter, G. A. Huff, Analytical Control Laboratory Operating Manual, IDO-14396 (March 21, 1957). 


\section{PROCESS ENGINEERING AND DEVELOPMENT}

\section{THE EFFECTS OF OPERATING}

\section{VARIABLES ON THE CALCINATION PROCESS}

\subsection{Introduction}

Effects of operating variables on the calcination process and on calciner product properties have been identified and related to the extent that positive control of the WCF is assured. The independent variables over which control may be, or is, exercised during operation of the WCF, include the superficial fluidizing velocity, bed temperature, feed atomizing air rate, waste feed rate and composition, bed pressure, and rate of scrubbing solution recycle to the feed. The important dependent variables that are monitored during operation include the product properties (discussed in Section V-4), calciner feed capacity and heat transfer rates, particle attrition and growth, and the rate of elutriation of solids from the bed. Ranges of operating conditions over which simulated waste solutions were satisfactorily processed in pilot plant calciners and in the WCF are shown in Table VII-1. The general effects of operating variables on the calcination process are summarized in Table VII-2. Most of the independent operating variables have interrelated effects on the process and on the properties of the calciner product; the independent variables and dependent variables are discussed separately in the following subsections.

\subsection{Independent Operating Variables}

1.21 Superficial Fluidizing Velocity. Superficial fluidizing velocity, defined as the velocity of the fluidizing gas on the basis of the empty cross section of the calciner at the bed temperature and vessel pressure, affects the degree of mixing in the bed, the tube-to-bed rate of heat transfer, and the rate of elutriation of material by the off-gas. In the ICPP pilot plant and WCF calcination programs, the fluidizing gas is arbitrarily considered to include the total gas introduced to the bottom of the bed but not the nozzle air, water vapor, and decomposition products of the feed. In the WCF, a fluidizing velocity of one foot per second has been selected as a compromise between good mixing and excessive solids elutriation. Lower velocities reduce solids elutriation but may result in bed caking due to inadequate fluidization. Higher velocities increase the solids elutriation rate which must be kept below the production rate or bed depletion will result. 
RANGE OF OPERATING VARIABLE VALUES EMPLOYED NIIH THE WCF AND ICPP PILOT PIAINT CALCINERS[a]

\begin{tabular}{|c|c|c|}
\hline Variable & \multirow{2}{*}{$\frac{\begin{array}{c}\text { Pilot Plant } \\
\text { Range }[4,10]\end{array}}{0.3-1.2}$} & \multirow{2}{*}{$\frac{\text { WCF Range }[3]}{0.5-2.2}$} \\
\hline Superficial Fluidizing Velocity, ft/sec $[b]$ & & \\
\hline Bed Temperature, ${ }^{\circ} \mathrm{C}$ & $250-550$ & 400 \\
\hline Bed Pressure, psia & $10 \cdot 7-18$ & 10.7 \\
\hline Nozzle Air-To-Liquid Volume Ratio ${ }^{[\mathrm{c}]}$ & $150-900$ & 150 to 650 \\
\hline \multicolumn{3}{|l|}{ Feed Composition: } \\
\hline Aluminum Nitrate, $\mathrm{M}$ & $0.8-2.0$ & $1.29-1.72$ \\
\hline Nitric Acid, & $1.2-3 \cdot 0$ & $0.59-2.34$ \\
\hline Sodium Nitrate, $\quad$ M & $0-0.25$ & $0.04-0.104$ \\
\hline Mercuric Nitrate, $\underline{M}$ & $0 \quad-0.016$ & 0 \\
\hline Boric Acid, & $0-0.2$ & -0.2 \\
\hline \multirow{2}{*}{\multicolumn{3}{|c|}{$\begin{array}{l}\text { [a] Two-foot-square and 12-inch diameter calciners used in pilot plant. } \\
\text { [b] The superficial fluidizing velocity is determined on the basis of } \\
\text { the empty cross section of the calciner at the calciner bed tem- } \\
\text { perature and vessel pressure, and includes the total gas introduced } \\
\text { at the botton of the bed but excludes nozzle air, water vapor, and } \\
\text { decomposition products of the feed. }\end{array}$}} \\
\hline & & \\
\hline \multicolumn{3}{|c|}{$\begin{array}{l}\text { [c] The air volume in the nozzle-air-to-liquid volume ratio is deter- } \\
\text { mined at the metered temperature and calciner vessel pressure. }\end{array}$} \\
\hline
\end{tabular}

The fluidizing velocity also affects product attrition but to a lesser extent than does the higher velocity feed-atomizing air. Heattransfer rates increase as a bed becomes fluidized, reach a maximum at some velocity above the incipient fluidizing velocity, and then decrease as the bed expands further. Absolute values for the effects of fluidizing velocity on heat transfer rates, solids elutriation rates, and the limit of adequate fluidization have not been established due to the difficulty in isolating the effect of this single variable.

1.22 Bed Temperature. Bed temperature significantly affects both calciner feed capacity and the product properties. During the development work, calciners were operated satisfactorily at bed temperatures between 250 and $550^{\circ} \mathrm{C}$. The upper limit on feed capacity is dependent on the maximum obtainable rate of heat transfer into the bed. This rate, in turn, is dependent largely on the bed 


\section{TABIE VII-2}

GENERAI EFFECT OF OPERATING VARIABIES ON CAICINATION PROCESS

\begin{tabular}{|c|c|c|}
\hline \multirow{2}{*}{$\begin{array}{l}\text { Operating Variable } \\
\text { Fluidizing Velocity }\end{array}$} & \multicolumn{2}{|c|}{ Effect of Increasing the Operating Variable } \\
\hline & \multirow[b]{2}{*}{$\begin{array}{l}\text { May decrease heat transfer rate } \\
\text { Slight increase in bed attrition } \\
\text { Increased product elutriation }\end{array}$} & \multirow[t]{2}{*}{ Secondary Effect } \\
\hline Fluidizing Velocity & & \\
\hline \multirow[t]{5}{*}{ Bed Temperature } & Reduced feed capacity & $\begin{array}{l}\text { Longer residence time of product in bed, } \\
\text { favorable to formation of alpha alumina }\end{array}$ \\
\hline & Favors alpha alumina formation & $\begin{array}{l}\text { Increased bed attrition, smaller bed } \\
\text { particle size, higher elutriation }\end{array}$ \\
\hline & Increased product porosity & Reduced product bulk density \\
\hline & $\begin{array}{l}\text { Reduced nitrate, mercury, and water } \\
\text { contents of product }\end{array}$ & \\
\hline & $\begin{array}{l}\text { Up to } 550^{\circ} \mathrm{C} \text { favors higher retention of } \\
\text { muthenium in product }\end{array}$ & \\
\hline Nozzle Air-To-Liquid & Increased bed attrition & Smaller particle size, higher elutriation \\
\hline $\begin{array}{l}\text { Volume Ratio (Feed } \\
\text { rate held constant) }\end{array}$ & Smaller feeä äroplets & Smaller particle size, higher elutriation \\
\hline Feed Rate & Decreased residence time of product in bed & Favorable to production of amorphous alumina \\
\hline \multicolumn{2}{|l|}{ Feed Composition: } & Reduced product bulk density \\
\hline Sodium & Favors alpha alumina formation & $\begin{array}{l}\text { Increased bed attrition, smaller particle } \\
\text { size, increased elutriation }\end{array}$ \\
\hline Boric Acid & Suppresses alpha alumina formation & \\
\hline Bed Pressure & Increased gas density & Decreased fluidizing velocity \\
\hline
\end{tabular}


temperature, as the maximum temperature of the heating system is set by material limits of both the exchanger tubes and the NaK. This is discussed in more detail in Section VII-1.3. Various product properties can be tailored to desired values by operating at a particular level of bed temperature, but often at the expense of feed capacity or another product property. The effect of temperature on product properties is discussed in Section V-4.

During development work, bed temperatures in a well fluidized bed have been uniform within the $5^{\circ} \mathrm{C}$ accuracy of measurement except in the narrow zone in which atomized feed is entering. Within the $20^{\circ}$ angle spray cone formed by the atomized feed, temperatures down to $100^{\circ} \mathrm{C}$ have been measured; this temperature depression disappears 12 to 15 inches from the nozzle [2]. Wide temperature gradients in a bed, other than in the nozzle zone, indicate a state of inadequate fluidization and, hence, poor heat transfer. This can be caused by excessive growth of the bed particles or by low fluidizing velocities.

Nominal temperature of operation planned for the WCF is $400^{\circ} \mathrm{C}$; lower bed temperatures are feasible, and operating temperatures down to $200^{\circ} \mathrm{C}$ or under are possible, but will create increased risk of bed caking. Operation at higher temperature levels will force a reduction in the feed rate and will alter various product properties.

1.23 Feed Atomizing Air Rate. The rate at which atomizing air is supplied to the pneumatic feed nozzles of a calciner governs the degree of feed atomization and significantly affects the attrition rate of particles in a fluidized bed. These factors, in turn, influence the bed particle size. By adjusting the volume of feed atomizing air during operation of the WCF and pilot plant calciners, the particle size of bed material has been stabilized in a range favorable both to heat transfer and to satisfactory rates of bed elutriation $[3,4,5]$. The degree of feed atomization is generally characterized by the feed nozzle air-to-liquid volume ratio (NAR). Operation at a high NAR value results in a finely atomized feed spray, and an accelerated attrition rate, both of which tend to decrease the size of bed particles. Decreasing the NAR value results in larger feed droplets, less bed particle attrition, and a corresponding growth of bed particles.

The relative rates of particle growth or reduction, or the stabilization of the size of a particle at a particular value of NAR, depend primarily on the frangibility of the bed material. A lower value of NAR usually must be used in conjunction with an alpha alumina bed than with an amorphous bed to obtain the desired degree of particle breakup to maintain stability of the bed particle 
size. (Bed attrition is discussed further in Section VII-1.32.) The proper value of NAR for particle size stabilization also is dependent on the nozzle design and size of calciner employed. Nevertheless, the overall effect of varying the NAR has been similar for all calciners.

The sensitivity of response in the WCF of bed particle size to variation in NAR is good. During a continuous period of operation lasting 38 days, particle growth of a bed was arrested by increasing the NAR from a value of 300 to $500^{[6]}$. Later when alpha alumina appeared in the bed material, particle size was stabilized by operating at a NAR value of 400 . The slow changes in particle size resulting from NAR variance indicate that the NAR can be used as an effective method for process control with minimum probability of completely upsetting the process.

1.24 Feed Rate, Composition, Activity. Feed rates ranging from 5 to 150 liters per hour per nozzle have been employed in properly fluidized beds without any tendency to cake a bed due to the density of feed introduction [7]. Higher feed rates per nozzle probably could be employed since heat transfer into the bed, rather than feed density in the reaction zone, has been the limiting factor on capacity in all tests to date. The minimum practical feed rate to the calciner is that rate at which the salts in the feed will replace that bed material lost through elutriation with no other product removal. At lower feed rates, gradual bed depletion would lead eventually to nozzle exposure, spray drying, and the formation of large quantities of submicron fines that are particularly difficult to remove from the off-gas. Low feed rates also result in high product residence times in the bed, a factor believed to be related to the formation of alpha alumina and perhaps to the volatile material content of the product.

Feed constituents affect the structure of the alumina phase of calciner product as demonstrated in experimental work at the Stanford Research Institute [8]. Satisfactory promotion or inhibition of the formation of alpha alumina are possible, respectively, by addition of nominal quantities of sodium on one hand, or boric acid or phosphate ion on the other, to the feed. Concentrations of boric acid as low as $0.01 \mathrm{M}$ in feed solutions have effectively inhibited formation of alpha alumina, while addition of sodium nitrate to feed in excess of the 0.04 to $0.08 \mathrm{M}$ level (in the absence of boric acid) have promoted the alpha alumina phase [7,9].

Various additives employed in feed solutions for particle growth studies in pilot plant calciners have had no noticeable effect on operation or on product 
properties. These additives include nitrates of chromium, copper, iron, and nickel. Operation of a pilot plant calciner with and without mercuric nitrate in the feed was not noticeably different [15].

The aluminum concentration affects the solids output rate of the calciner for any particular feed rate and significantly affects the intra-particle porosity and hence bulk density of calciner product. An extensive study has shown that the intra-particle porosity of alumina product ranges from 5 to 60 percent depending on feed aluminum concentration and bed temperature [10]. Low porosity product results with use of a combination of low bed temperature and dilute feed aluminum concentration.

Fission products and minor components present in waste solutions, but not added to feed solutions for pilot plant or WCF tests, are not expected to affect process control. This was substantiated by early tests at Argonne National Laboratory in $1957^{[1]}$. The operating variable relationships observed during calcination of feed solutions containing one part in eight of radioactive ICPP waste solution, did not noticeably differ from those observed when calcining non-radioactive feed solutions. Theoretical and laboratory studies at the Stanford Research Institute [8] substantiated the ANL work; numerous additives in the feed had no drastic effect upon the product characteristics, although some either promoted or inhibited formation of alpha alumina.

1.25 Bed Pressure. No significant effect on the process or on product properties has been related to bed pressure. Variations in bed pressure affect gas density and could change the superficial fluidizing velocity and the terminal settling velocities of bed particles; however, a compensation in the volume of fluidizing gas employed in the WCF can be made to override variations in bed pressure.

1.26 Rate of Recycle of Scrubbing Solution to the Feed. Limited additional control over the calcination process is afforded by adjusting the rate at which scrubbing solution is recycled to the waste hold tanks. It is desirable to minimize this rate as much as possible - low recycle rates allow more fresh waste to be processed through the calciner. Lowering the rate, however, increases the aluminum nitrate and undissolved solids concentrations in the scrubbing solution.

At the flowsheet conditions shown in Figure $\mathrm{V}-3$, a recycle rate of $20 \mathrm{gph}$ results in an aluminum concentration of 0.86 molar and an undissolved solids concentration of under $1.4 \mathrm{~g} / 1 \quad(\approx 0.01$ weight percent) [13]. Experience gained in the WCF testing indicates that aluminum concentrations up to 2 molar 
and undissolved solids concentrations up to 2 to 3 weight percent create no problems. When operating with an amorphous product, which dissolves in the scrubbing solution, the concentration of dissolved aluminum limits the recycle rate; at concentrations above 2 molar, aluminum nitrate begins to salt out and form plugs in the lines. The undissolved solids concentration limits the recycle rate when producing insoluble alpha alumina. Concentrations of undissolved alpha alumina above 2 to 3 weight percent bring about high rates of erosion on the valves and pumps.

\subsection{Dependent Operating Variables}

1.31 Capacity and Heat Transfer. The feed capacity of a fluidized bed calciner at any given feed composition is dependent upon the heat transfer area, the bed temperature, the temperature of the heating medium, the size of particles in the bed, and the fluidized bed density; the last two terms influence the heat transfer coefficient. Figure VII-1 shows the capacity per unit heat transfer area as a function of the mean temperature of the heating surface for several values of bed temperature assuming a heat transfer coefficient of $50 \mathrm{Btu} / \mathrm{hr}-\mathrm{ft}^{2}-{ }^{\circ} \mathrm{F}$ selected from the range of experimentally observed values of 40 to $100 \mathrm{Btu} / \mathrm{hr}-\mathrm{ft}^{2}{ }^{\circ} \mathrm{F}$. When the mass median particle diameter of product in a bed becomes significantly greater than 0.8 to 1.0 millimeters, the resulting decrease in the overall heat transfer coefficient causes a reduction in the calciner throughput capacity below curves given in Figure VII-1 [4]. Values of the heat transfer coefficient as low as $40 \mathrm{Btu} / \mathrm{hr}-\mathrm{ft}^{2}-^{\circ} \mathrm{F}$ have been observed in pilot plant calciners only when the mass median particle diameter of the bed exceeded one millimeter. During normal operation in the WCF, the heat transfer coefficient has easily been maintained above $75 \mathrm{Btu} / \mathrm{hr}-\mathrm{ft}^{2}{ }^{\circ}{ }^{\circ} \mathrm{F}$ by keeping the average size of bed particles below $0.6 \mathrm{~mm}$ and employing fluidizing rates of about one foot per second. The data used for Figure VII-1 were obtained with a typical synthetic (1.72M aluminum nitrate) waste solution. Unit heat transfer area was selected as the basis for the correlation, rather than calciner diameter or volume, because heat transfer to the fluidized bed has been found limiting, and because no test unit to date has employed as large a heat transfer area as its volume would permit [7]. The high rates of heat transfer and the factors affecting heat transfer observed with the fluidized bed calciner are similar to those reported by other investigators $[11,12]$.

1.32 Attrition and Particle Growth of Bed Material. Constant generation or addition of seed-size material is necessary in the fluidized bed calcination 


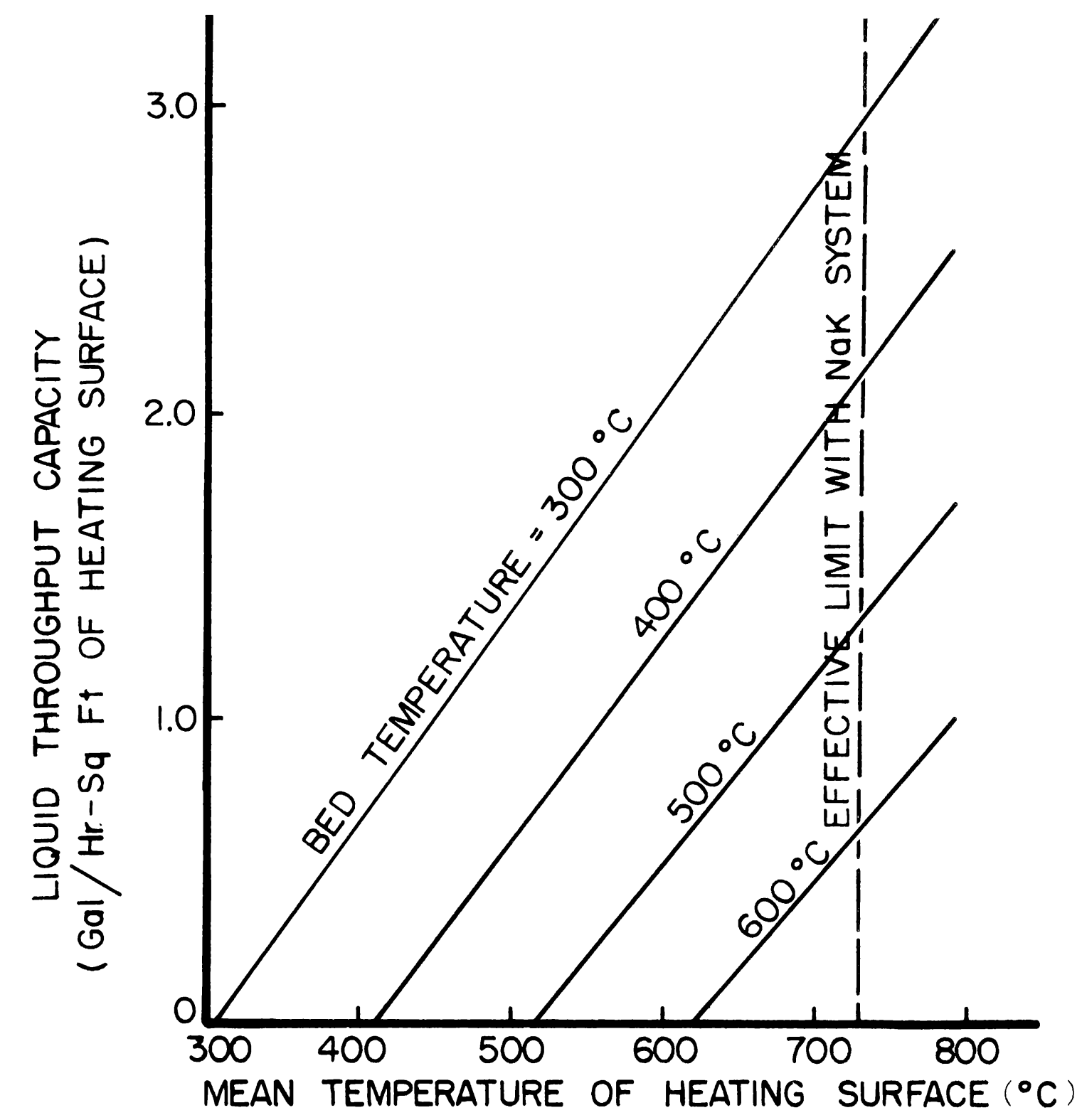

FIG. VII-1 CAPACITY (THROUGHPUT) OF A FLUIDIZED BED CALCINER AS A FUNCTION OF

process to maintain a stable average bed-particle size. In the WCF, these seeds are generated by attrition of the bed by the feed atomizing air and the fluidizing gas. Seeds automatically provided by bed attrition can be supplemented by introducing a suitably sized inert material to the bed [13], or alternatively, seeds could be generated artificially with an air jet grinder in the bed [7]; both methods have been tested in the ICPP pilot plant. Attrition of bed material is undesirable to the extent that it results in formation of material too small to function as seeds and which is rapidly elutriated from a bed. Attrition is 
significantly influenced by the physical nature of the bed material as well as by the rate of introduction of nozzle atomizing air and of fluidizing air.

In pilot plant calciners, attrition rates of bed material have been measured indirectly by determining the rate of elutriation of fine solids under varying conditions of operation. All such tests clearly indicate that the majority of attrition is related to the introduction of the feed spray. When neither aqueous feed solution nor nozzle air are being injected into a bed, the resulting attrition of old material by the fluidizing action is only 10 to 20 percent of that incurred during normal operation. With nozzle atomizing air, but without feed solution, the bed attrition rate is generally 30 to 80 percent of that found in normal operation [7]. An indeterminate factor which may affect attrition is the thermal shock a particle experiences when contacted by cold spray in the nozzle zone of the bed. Quantitative separation of this effect from that of direct particle breakup due to the high energy of the atomizing air has not been accomplished. Because there are many interwoven factors influencing bed attrition, a common denominator using pilot plant results as a basis has not been found for estimating attrition occurring in the WCF. It is believed, however, that the mechanism of attrition for beds in the WCF is similar to that of the pilot units.

1.33 Elutriation of Bed Particles. Elutriation of fines material from a fluidized bed calciner is affected by all of the independent operating variables to varying degrees, making quantitative evaluation of the individual effects difficult. Elutriation of material is undesirable because essentially all particulate matter must be separated from the off-gas. In extreme cases, elutriation can lead to bed depletion, and spray drying can result if the nozzles are exposed. This would be undesirable due to the small size of the spray-dried particles and the resulting increased load on the off-gas decontamination system.

The rate of elutriation of fines from a calcination vessel has been found to increase sharply with an increase in the superficial fluidizing gas velocity and with a decrease in the size of the bed particles, both effects being substantiated by results reported by Leva [11]. Leva also reports qualitatively that elutriation rates will increase with decreases in vessel freeboard, in fines density, and in fluid (air) viscosity. Vessel geometry also has an effect on elutriation rates. The quantitative effect of most of these variables, however, has not been determined during development of the fluidized bed calciner. An increase in the elutriation rate, sometimes as high as sevenfold, has been observed whenever the structure of bed material shifted from the amorphous 
to the alpha alumina form $[2,14]$. The greater frangibility of the alpha form results in more particle breakup and a reduced average bed particle size. The rate of elutriation of the smaller particles is much higher than that of the larger amorphous bed, even though the density of the alpha form is higher than that of the amorphous form.

The effect of fluidizing velocity on elutriation is apparent from pilot plant work where as much as an 80 percent reduction in the fines elutriation rate was obtained by lowering the fluidizing velocity from 1.0 to 0.5 feet per second ${ }^{[9]}$. However, these relative pilot plant values cannot be arbitrarily extrapolated to the WCF since other factors are involved.

Adequate vessel freeboard also will reduce elutriation. In accordance with a mechanism postulated by Zenz and Othmer [12], gas bubbles bursting through the bed, analogous to intermittent jets, impose a highly irregular velocity profile across the containing vessel and carry large particles high above the bed. If vessel freeboard is inadequate, large particles may be carried into the off-gas system before having a chance to settle out. A louvered baffle, installed in the vapor space of the WCF calciner ahead of the gas outlet, reduced carryover of bed material by as much as a factor of six [6].

\section{REMOVAL OF PARTICULATE SOLIDS FROM OFF-GAS}

The amount of suspended and entrained contamination present in the off-gas as it leaves the calciner is reduced in the WCF off-gas system well below the level required to permit discharge to the atmosphere (Section IX-1). It was determined during cold testing of the WCF that the overall reduction factor (decontamination factor or DF) for the off-gas system was about $3.6 \times 10^{5}$. This corresponds to an overall efficiency of approximately 99.9997 percent in reducing the particulate flow in the off-gas from approximately 29 pounds per hour at the outlet of the calciner to about $8 \times 10^{-5}$ pounds per hour downstream of the AEC filters. The purpose of this section is (a) to describe the techniques and procedures used in determining the efficiencies, and (b) to present data on the efficiency of individual element of the system.

In the conversion of aluminum nitrate waste solutions to granular alumina in the WCF fluidized bed process, quantities of decomposition gases and vapors, plus the fluidizing air, must be cleaned up before they can be released to the atmosphere. This off-gas carries with it, as it leaves the calciner, sizeable 
amounts of bed material and fineparticulate matter. The major cleanup elements in the off-gas system include, in order, a calciner cyclone, a quench tower and venturi scrubber, four ruthenium adsorbers in parallel, and three AEC-type filters in parallel.

The performance data reported for these elements were obtained largely during the tenth WCF test run in which radioactive sodium-24 was added to the calciner feed to aid in evaluating the degree of particulate removal of each element in the off-gas system, especially of the AEC-type filters. A complete re-

port of the removal of particulate matter from WCF off-gas is being prepared ${ }^{[16]}$.

\subsection{Determination of Off-Gas System Performance}

The efficiency of the individual elements in the off-gas system and the overall efficiency of the system were obtained from determinations of the mass rate of flow of particulate matter into and out of each element. 'The flow of bed material and fine particulate entering the calciner cyclone was determined by adding the weights of solids removed by the calciner cyclone and by the scrubbing system. Estimates of the solids removed by the cyclone were obtained by intermittently measuring the solids transferred to storage while the calciner product takeoff line was closed. Analyses of the scrubbing solution surge tank contents provided data on the amount of solids removed by the scrubbing system.

The rates of passage of fine solids between the succeeding cleaning elements were determined from the weight and/or activity of the solids collected by isokinetic samplers installed downstream from each element. The location of these samplers in relation to the various off-gas cleaning elements is shown in Figure VII-2. While the sampling was generally isokinetic, it developed that this was not necessary because the maximum particle diameter observed downstream of the scrubbing system was only 0.3 micron. According to Green and Lane [17], particles with densities of $1.0 \mathrm{~g} / \mathrm{cc}$ and having diameters less than five microns will follow the detailed flow patterns in the pipe, making isokinetic sampling unnecessary. The solids were generally collected on $142 \mathrm{~mm}$ diameter Type HA membrane filters through which a 2-10 cfm side stream of the off-gas was continuously aspirated. Sampling lines were kept short as possible and were heated along with the filter assembly to prevent condensation of the humid off-gas.

The procedure followed in sampling consisted of passing the side-stream of the off-gas through the filter for a specified time interval, removing the filter, obtaining a radioactive count of the filter, determining the residue weight on the filter either by ignition or activity ratio, and then converting 


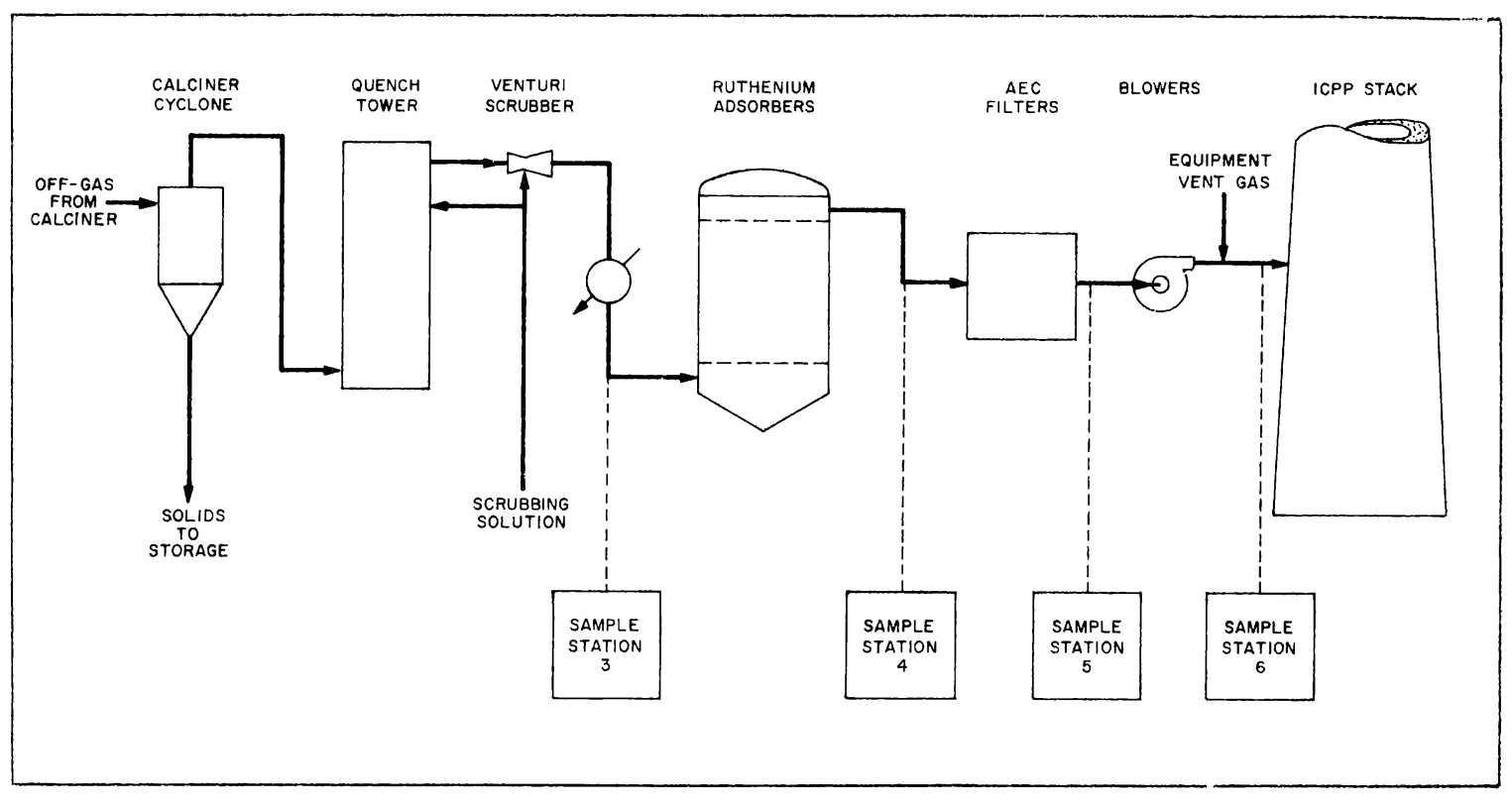

FIG. VII-2 LOCATION OF SAMPLE STATIONS FOR WCF OFF-GAS SYSTEM

the residue weight to an indicated solids rate in pounds per hour. Sampling intervals of 4,8 , or 24 hours were used, depending on the particulate matter concentration in the off-gas stream. Upon removal from the filter assembly, the filters were placed in plastic bags, counted for activity, ignited at $1000^{\circ} \mathrm{C}$, and weighed for residue. The membrane filters used have negligible ash when ignited at temperatures greater than $750^{\circ} \mathrm{C}$. Samples collected downstream of the scrubbing system (Station 3) were the only ones where sufficient solids for accurate weighing were consistently collected. For the other stations, the amount of particulate matter was determined by comparing the activity at the station being considered to the activity of Station 3 where the amounts of particulate matter as well as activity were accurately known. The amount of particulate matter can easily be calculated from the sample weight, sampling interval, sample flow, and the process off-gas flow rate. For a particular off-gas cleaning element, the decontamination factor can then be calculated by comparing the inlet to the outlet particulate matter flow rate.

\subsection{Off-Gas System Performance}

The overall decontamination factor for the off-gas cleaning system which includes the calciner cyclone, quench tower, venturi scrubber, ruthenium adsorbers, and AEC filters was $3.6 \times 10^{5}$. This corresponds to an efficiency of 99.9997 percent in removing particulate matter from the off-gas stream. 
Decontamination factors for individual elements and particulate matter flow rates between off-gas cleaning elements are given in Figure VII-3.

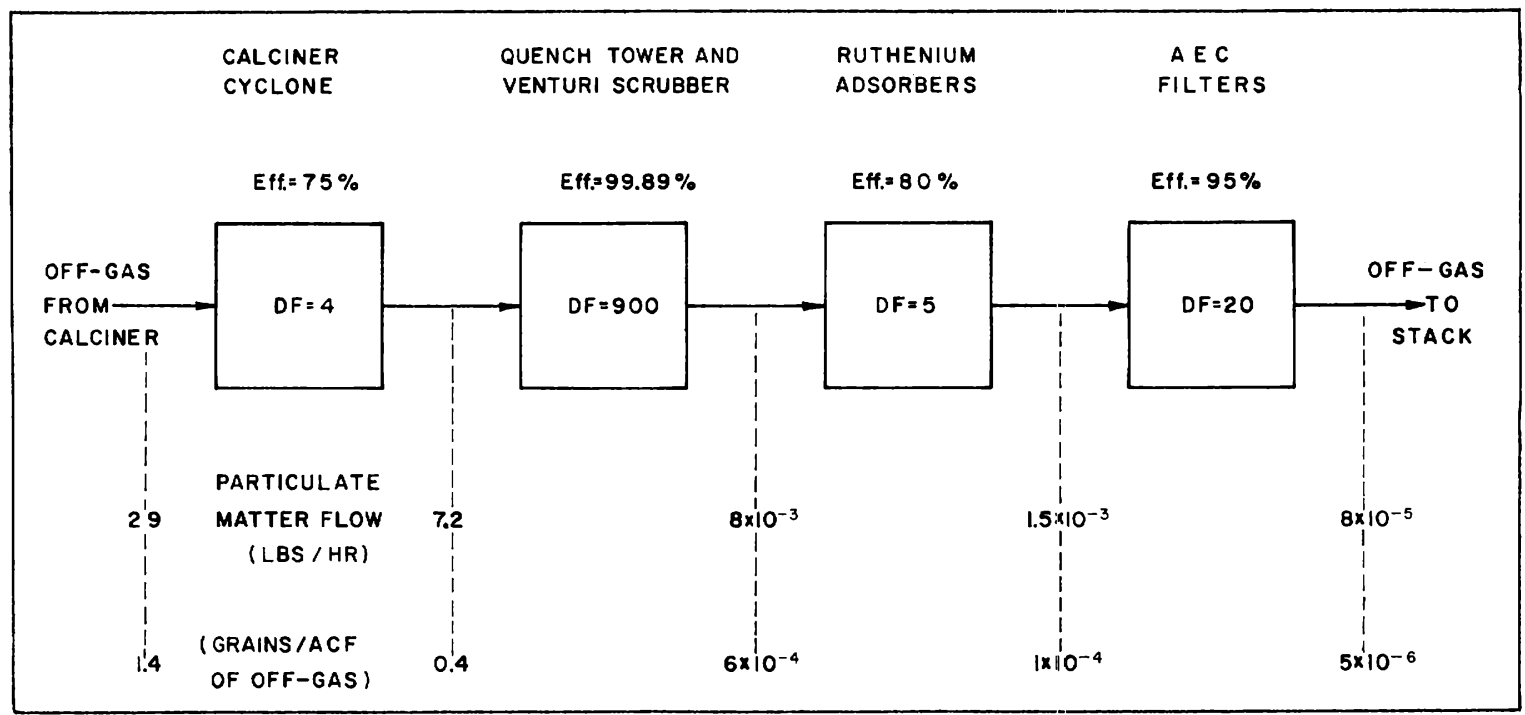

FIG. VII-3 PARTICULATE MATTER FLOW RATES AND DECONTAMINATION FACTORS FOR THE
WCF OFF-GAS SYSTEM.

An average of 7.2 pounds per hour of particulate matter was found remaining in the off-gas leaving the calciner cyclone. This was reduced to an average of $8 \times 10^{-3}$ pounds per hour by the quench tower and venturi scrubber. Electron microscope examination of the solids in the off-gas leaving the scrubbing system indicate that all of the particles are smaller than 0.3 micron in size. The quench tower and venturi scrubber combined had a decontamination factor of 900 which corresponds to an efficiency of 99.89 percent. The average off-gas loading downstream of the venturi scrubber was about $6 \times 10^{-4}$ grains/acf $\left(\approx 4 \times 10^{-5}\right.$ grams/acf). This agrees well with Wheeler's ${ }^{[18]}$ correlation of off-gas loading downstream of a venturi scrubber as a function of scrubbing solution, off-gas volume, and off-gas velocity in the venturi throat.

The ruthenium adsorbers had a decontamination factor of five (an efficiency of 80 percent) in removing particulate matter from the off-gas. There was no significiant holdup time of particulate matter in the adsorbers.

The AEC-type filters had a steady-state decontamination factor of 20 (95 percent efficient in removing particulate matter). The inlet flow of particulate matter to the filters, about $1.5 \times 10^{-3} \mathrm{lbs} / \mathrm{hr}$, was reduced to approximately $8 \times 10^{-5} \mathrm{lbs} / \mathrm{hr}$. Prior to adding the sodium-24 tracers, the AEC-type filters 
and assembly were tested with dioctylphthalate mist and found to be better than 99.99 percent efficient for 0.9 micron particles.

From activity measurements made on the membrane filters, it appeared that the solids loading downstream of the AEC-type filters increased steadily during the sodium-24 addition period of Run 10. Unfortunately, the sodium-24 decayed beyond the detection limits before an equilibrium solids loading was established. An indication of equilibrium solid loading was obtained by irradiating (at the MTR) filters from Station 5, downstream of the AEC filters. This produced sodium-24 in the solids on the filter (the calciner feed normally contained non-radioactive sodium nitrate). A comparison of the sodium-24 activity with that produced in a standard sample of known weight gave the weight of solids collected on the membrane filter. From this analysis, it was found that the AEC-type filters apparently had a holdup period of approximately 10 days before an equilibrium. amount of particulate matter penetrated the filter. Further evidence of this holdup was obtained from post-run samples when the particulate content of the off-gas downstream of the AEC filters remained high for several days with air being blown through the ruthenium adsorbers and AEC filters only. During the same period, the inlet gas loading dropped rapidly.

\section{REMOVAL OF RUTHENIUM FROM WCF OFF-GAS}

Ruthenium activity in the wastes comes from two isotopes, ruthenium-103 and ruthenium-106. In fresh wastes, ruthenium-103 (half life $=41$ days) contributes a major portion of the activity. In wastes more than one year out of the reactor, however, ruthenium-106 (half life $=1$ year) is the principal source of the ruthenium activity (Figure V-2).

Radioactive ruthenium presents a special problem during calcination, as it is the only fission product in the liquid wastes which can form a compound $\left(\mathrm{RuO}_{4}\right)$ volatile at the calcining temperature. The volatility problem with ruthenium is widely recognized and is treated as a special problem by all workers investigating high-temperature waste-volume-reduction techniques $[27,28,30,31$, $34,35,36,37,38,40]$.

Using data from experimental work at the Idaho Chemical Processing Plant $[5,20,22,23]$, the decontamination factor for ruthenium in the present WCF process is conservatively estimated at $3 \times 10^{3}$ (3 across the calciner and scrubbing system and $10^{3}$ across the silica gel beds). Experimental work 
at Argonne National Laboratory [1] indicates that this factor is low; decontamination factors up to $2 \times 10^{4}$ were obtained in their testing on a similar system. The numerous factors affecting ruthenium volatility cast some doubt on direct extrapolation of laboratory and pilot plant data to plant-scale processing so the conservative ICPP data are used throughout this study as a basis for analyzing the WCF activity release problem. Temperature and gas composition in the calciner affect the amount of ruthenium in the product; temperature and retention time affect the extent of ruthenium condensation in the off-gas system. Also, considerable evidence has been compiled to show that ruthenium deposits on stainless steel piping in the temperature range between 100 and $150^{\circ} \mathrm{C}[1,21,27]$. The fact that the "plating out" effect occurs until a saturation level is reached casts doubt on the validity of ruthenium removal data taken in short tests. If desired or necessary, ruthenium decontamination factors in the WCF can be improved by raising the temperature of calcination or employing a reducing gas, eg, carbon monoxide and nitric oxide, for fluidizing the bed. The experimental data on ruthenium volatility and removal from the calciner off-gas are discussed in more detail in the following paragraphs.

\subsection{Ruthenium Volatility}

Ruthenium in acidic waste solution exists as nitrato complexes of nitrosyl ruthenium [29] and is converted during calcination to an oxide, either $\mathrm{RuO}_{2}$ or $\mathrm{RuO}_{4}$ depending on the conditions of operation. Ruthenium dioxide is a dark blue solid which is insoluble in water. It is stable up to a red heat and decomposes into its elements at temperatures above $1025^{\circ} \mathrm{C}^{[41]}$. Neither the dioxide nor the metal (melting point $2250^{\circ} \mathrm{C}$ ) is volatile at temperatures employed in the WCF. Ruthenium tetroxide $\left(\mathrm{RuO}_{4}\right)$ is a yellow or brown compound which dissolves and decomposes in water, melts at $25^{\circ} \mathrm{C}$, and boils at $135^{\circ} \mathrm{C}$ at $760 \mathrm{~mm}$; at the WCF pressure, the boiling point is about $120^{\circ} \mathrm{C}[21]$.

To determine the extent of ruthenium volatility under calcination temperatures, work was performed at Argonne National Laboratory [1] in which diluted actual ICPP wastes were calcined in a six-inch diameter, air-fluidized bed at temperatures ranging from 350 to $550^{\circ} \mathrm{C}$. The volatility was determined from the concentrations of ruthenium appearing in the product and in the condensate collected in a condenser in the off-gas system. The suppression of ruthenium

volatility at higher temperatures is evident from the test results shown in Table VII-3. No other fission products volatilized at the temperatures employed. 
Temp

$\left({ }^{\circ} \mathrm{C}\right)$

350

400

450

500

500

550

\begin{tabular}{ll} 
& $\begin{array}{c}\text { Ruthenium Sontent } \\
(\% \text { of input })[\mathrm{a}]\end{array}$ \\
\hline Condensate & Calcined Solids
\end{tabular}

94

65

35

3

1

0.7
11

15

12

78

73

104

[a] Both inaccurate ruthenium analyses on the solids and plating of ruthenium on the piping are believed to have contributed to the poor material balances.

In additional ANL experiments, most of the ruthenium remained in the bed when a mixture of carbon monoxide and nitrogen (simulated producer gas) was used for the fluidizing gas. Table VII-4 shows a large difference between

TABIE VII-4

EFFECT OF CARBON MONOXIDE GAS ON RUTHENIUM VOLATILIZAIION

\begin{tabular}{ccc}
\hline $\begin{array}{c}\text { Bed Temperature } \\
\left({ }^{\circ} \mathrm{C}\right)\end{array}$ & Fluidizing Gas & $\begin{array}{c}\text { Ruthenium in Condensate } \\
(\% \text { of Input })\end{array}$ \\
\cline { 2 - 3 } 400 & $\mathrm{Air}$ & 65 \\
400 & $\mathrm{CO}-\mathrm{N}_{2}$ & 1.0 \\
550 & $\mathrm{Air}$ & 0.7 \\
550 & $\mathrm{CO}-\mathrm{N}_{2}$ & 0.3
\end{tabular}

air and carbon monoxide influence or ruthenium volatility at $400^{\circ} \mathrm{C}$ but virtually no difference at $550^{\circ} \mathrm{C}$. Suppression of ruthenium volatility by addition of sodium nitrite to the feed solution was not successful. This is contrary to the findings of Wilson [25, 32] for the same concentration of sodium nitrite - probably because of the higher temperatures used in the ANL tests.

Several laboratory experiments were conducted at ICPP $[21,24]$ to study ruthenium behavior at high temperatures, and it was determined that a number of factors, including the method of calcination, temperature, rate of decomposition, and the oxidizing power of the atmosphere, influenced the volatility of 
ruthenium. Ruthenium compounds decomposed at temperatures above $100^{\circ} \mathrm{C}$ to ruthenium tetroxide, which was thermally unstable at higher temperatures and decomposed to the non-volatile dioxide. While the data from these experiments do not agree quantitatively with those from the ANL studies, the observed effects of calcination temperature and atmosphere composition on the ruthenium volatility are qualitatively the same (Table VII-5); higher temperatures and

TABIE VII-5

RUTHENIUM VOLATILITY FROM ICPP LABORATORY STUDIES

\begin{tabular}{|c|c|c|c|c|}
\hline $\begin{array}{l}\text { Fluidizing } \\
\text { Medium }\end{array}$ & $\begin{array}{c}\text { Calcination } \\
\text { Temperature } \\
\left({ }^{\circ} \mathrm{C}\right)\end{array}$ & $\begin{array}{l}\text { Off-Gas } \\
\text { Oxygen Content } \\
\text { (Mole Fraction) }\end{array}$ & $\begin{array}{l}\text { Ruthenium } \\
\text { Volatility } \\
\text { (\% of Feed) }\end{array}$ & $\begin{array}{l}\text { Ruthenium } \\
\text { Retained On } \\
\text { Solids } \\
\text { ( } \% \text { of Feed) }\end{array}$ \\
\hline Air & 400 & 0.17 & 87 & - \\
\hline Air & 550 & 0.17 & 29 & 31 \\
\hline NO & 400 & $6 \times 10^{-4}$ & 34 & - \\
\hline NO & 400 & $1.4 \times 10^{-4}$ & 1.4 & 90 \\
\hline
\end{tabular}

reducing atmospheres again decreased the ruthenium volatility. It also was determined from the ICPP experiments that ruthenium volatility was unaffected by the nitrite content of the feed or by the amount of alumina present, and the use of steam rather than air as a fluidizing gas at $400^{\circ} \mathrm{C}$ had little or no effect. 3.2 Removal of Ruthenium from Off-Gas

3.21 Studies at Argonne National Laboratory. In pilot plant testing of a six-inch-diameter fluidized bed calciner at ANL [1], runs were made with synthetic feed solutions containing up to 12 percent of high-level activity waste from the ICPP. Ruthenium decontamination factors in excess of $10^{3}$ were achieved in the off-gas system with sintered stainless steel filters, a venturi scrubber, and a silica gel bed. Since the filters were operating at temperatures near those of calcination, it is doubtful they contributed to the decontamination factor. Up to 40 percent of the ruthenium was removed by the venturi scrubber. In these tests, scrubbing solution was not recycled to the feed solution as it will be during WCF operation; it is probable that more of the ruthenium would have been contained in the product had the scrubbing solution been recycled, resulting in still higher overall decontamination factors (ICPP studies Section VII-3.22).

The decontamination factors achieved in the ANL tests are summarized in Table VII-6. 
TABIE VII-6

DECONTAMTNATION FACTORS OBTAINED IN WASTE CALCINAIION TESTS WITI DILUTED ICPP WASTE SOLUTION

\begin{tabular}{|c|c|c|c|c|}
\hline $\begin{array}{l}\text { Percent } \\
\text { ICPP Waste } \\
\text { in Feed }\end{array}$ & $\begin{array}{l}\text { Bed } \\
\text { Temp } \\
\left({ }^{\circ} \mathrm{C}\right)\end{array}$ & $\begin{array}{l}\text { Run } \\
\text { Duration } \\
\text { (hrs) }\end{array}$ & $\begin{array}{l}\text { Ruthenium } \\
\text { Activity Removed } \\
\text { By Scrub Solution } \\
\text { (\% Feed) }\end{array}$ & $\begin{array}{l}\text { Overall Ruthenium } \\
\text { Decontamination Factor } \\
\text { (Feed thru Adsorber) }\end{array}$ \\
\hline $\begin{array}{r}0.4 \\
0.4 \\
1.0 \\
1.0 \\
1.0 \\
1.0 \\
12.0\end{array}$ & $\begin{array}{l}400 \\
500 \\
400 \\
500 \\
400 \\
500 \\
400\end{array}$ & $\begin{array}{r}6 \\
6 \\
6 \\
6 \\
85 \\
21 \\
6\end{array}$ & $\begin{array}{r}39 \\
<2 \\
32 \\
<2 \\
23 \\
<2 \\
15\end{array}$ & $\begin{array}{r}3.9 \times 10^{3} \\
1.7 \times 10^{4} \\
6.7 \times 10^{3} \\
1.6 \times 10^{3} \\
2.8 \times 10^{3} \\
8.3 \times 10^{3} \\
2 \times 10^{4}\end{array}$ \\
\hline
\end{tabular}

The temperature of the silica gel bed was maintained between 90 and $100^{\circ} \mathrm{C}$ during the ANL tests and no attempt was made to determine the effect of silica gel temperature on ruthenium adsorption. The silica gel beds in the WCF will be maintained between 60 and $65^{\circ} \mathrm{C}$ because of the improvement in ruthenium adsorption at lower temperatures found in ICPP tests (see following section). In regeneration tests of the silica gel at ANL, approximately 92 percent of the adsorbed ruthenium was removed from the silica gel with 1.75 bed volumes of warm water. Dilute nitric acid removed some ruthenium that was not extracted by water, but in all cases, a residual amount of about two percent of the total ruthenium collected remained with the silica gel. In spite of having employed a variety of ruthenium removal methods, little decrepitation of the silica gel was experienced in these tests.

3.22 Studies at the ICPP. During part of the pilot plant testing of a sixinch fluidized-bed calciner at the ICPP [5], ruthenium, including some radioactive ruthenium, was added to the feed at a concentration close to that in the ICPP high-level activity wastes. At $400^{\circ} \mathrm{C}$, most of the ruthenium was volatilized from the calciner and was recovered in the liquid effluent from the de-entrainment separator placed downstream of a venturi scrubber. When the effluent (or scrubbing solution) was recycled to the calciner feed, 67 percent of the ruthenium appeared in the product under steady state operation; the other 33 percent passed through the venturi scrubber with the off-gas. 
Hanson, et al [20], investigated many materials, ie, calcined alumina, activated alumina, polyethylene, molecular sieves, stainless steel, and silica gel for possible use as an adsorbent for ruthenium in the WCF off-gas. Silica gel was selected not only for its high capacity for adsorbing ruthenium but also for its ease of regeneration by water. Further laboratory testing at the ICPP $[20,23]$ developed the information in the following paragraphs regarding factors affecting the performance of silica gel.

The adsorption of ruthenium on silica gel is highly dependent on the temperature of adsorption, lower temperatures favoring greater adsorption. Although it would be preferable to operate an adsorber at very low temperatures, the off-gas at the WCF must be maintained above its dew point of 55 to $60^{\circ} \mathrm{C}$ to carry off the water contained in the feed; in addition to other problems, condensation can result in decrepitation of silica gel which is not fully saturated. In laboratory tests using silica gel to adsorb ruthenium vapors, a decontamination factor of 1000 was obtained at $60^{\circ} \mathrm{C}$; at $100^{\circ} \mathrm{C}$, the decontamination factor dropped to approximately 50 .

Silica gel continues to adsorb ruthenium even after it is saturated with water. Adsorption of other condensables from the calciner off-gas does not appear to affect ruthenium adsorption, nor does air, nitric acid vapor, or radiation have any apparent effect on the ability of silica gel to adsorb ruthenium [20]. Generally, regenerated silica gel gave higher decontamination factors than fresh silica gel, probably as a result of catalytic reduction of the ruthenium tetroxide by the species of ruthenium oxide already present on the adsorbent. Vitro Laboratories observed the same behavior (Section VII-3.23).

Early capacity tests $[20]$ of short duration $(\approx 1$ hour) indicated a ruthenium loading of 10 grams of ruthenium per cubic foot of silica gel could be realized and that capacity is dependent upon bed depth. Decontamination factors of 10 to 20 were obtained in a 13-inch-deep bed, and 200 to 1300 in a 26 -inch bed. The WCF adsorbers contain 36-inch-deep silica gel beds. Subsequent capacity tests [23] of longer duration (up to 77 days) indicated the early capacity figures were probably low; in a 40-inch-deep bed, a decontamination factor of 1013 was measured and a capacity of 97 grams of ruthenium per cubic foot of silica gel was obtained with no breakthrough of the ruthenium. In the early tests, approximately 90 percent of the ruthenium could be removed by water washing while in the latter tests, only 50 to 75 percent of the ruthenium was removed by water washing. 
3.23 Other Studies. Elliot, et al [27], passed the off-gas from a simulated waste solution decomposed at $600^{\circ} \mathrm{C}$ through a bed of ferric oxide and reported that the species of ruthenium collected on the ferric oxide was identified as ruthenium dioxide $\left(\mathrm{RuO}_{2}\right)$ by $\mathrm{X}$-ray examination. They also noted that the efficiency of the ferric oxide for removing ruthenium increased when ruthenium dioxide was present.

In a single test at Hanford, Gill and Wisehart [19] found that silica gel removed over 99.9 percent of the ruthenium in the off-gas produced in a ruthenium oxidation step utilized in the Redox process.

Basic studies on fission product properties by Vitro Laboratories indicated that gaseous ruthenium tetroxide $\left(\mathrm{RuO}_{4}\right)$ decomposed to the black, solid dioxide form $\left(\mathrm{RuO}_{2}\right)$ at temperatures between 98 and $155^{\circ} \mathrm{C}$ and that the decomposition rate was affected by temperature and the presence of water vapor. The decomposition reaction appeared to be autocatalytic; ie, the presence of the dioxide promoted the decomposition rate[41].

\subsection{Anticipated Adsorber Regeneration Frequency}

The frequency of adsorber regeneration must be such that safe limits are not exceeded by the pressure drop across the silica gel beds, the quantity of ruthenium adsorbed by the silica gel, or by the amount of radiation passing from the adsorber cells to areas occupied by personnel. Estimates based upon experimental data from laboratory, pilot plant, and WCF testing show regeneration frequencies varying from 150 days to several years depending upon the factor limiting the service cycle. In operation of the WCF, a regeneration cycle period of 120 days will be adhered to until the propriety of a longer period can be established through close monitoring of the adsorber pressure drop, activity buildup in the building corridors, and extensive sampling and analysis of the process off-gas for ruthenium.

3.31 Estimate of Adsorber Regeneration Period as Limited by Pressure Drop. In order to hold an adequate vacuum in the calciner, the pressure drop through the adsorber should not exceed 14 inches of water, five inches of which are attributable to the vessel piping and a clean bed. Data on the relationship between dust collection and bed pressure drop were obtained in both pilot plant and WCF tests. In the pilot plant tests, air containing 1-10 micron alumina dust was passed through a six-inch diameter by 23 -inch-long silica gel bed at a velocity of 0.30 feet per second [33]. The effect of dust buildup in the bed on the bed pressure drop in these tests is shown in Figure VII-4. Based upon these 


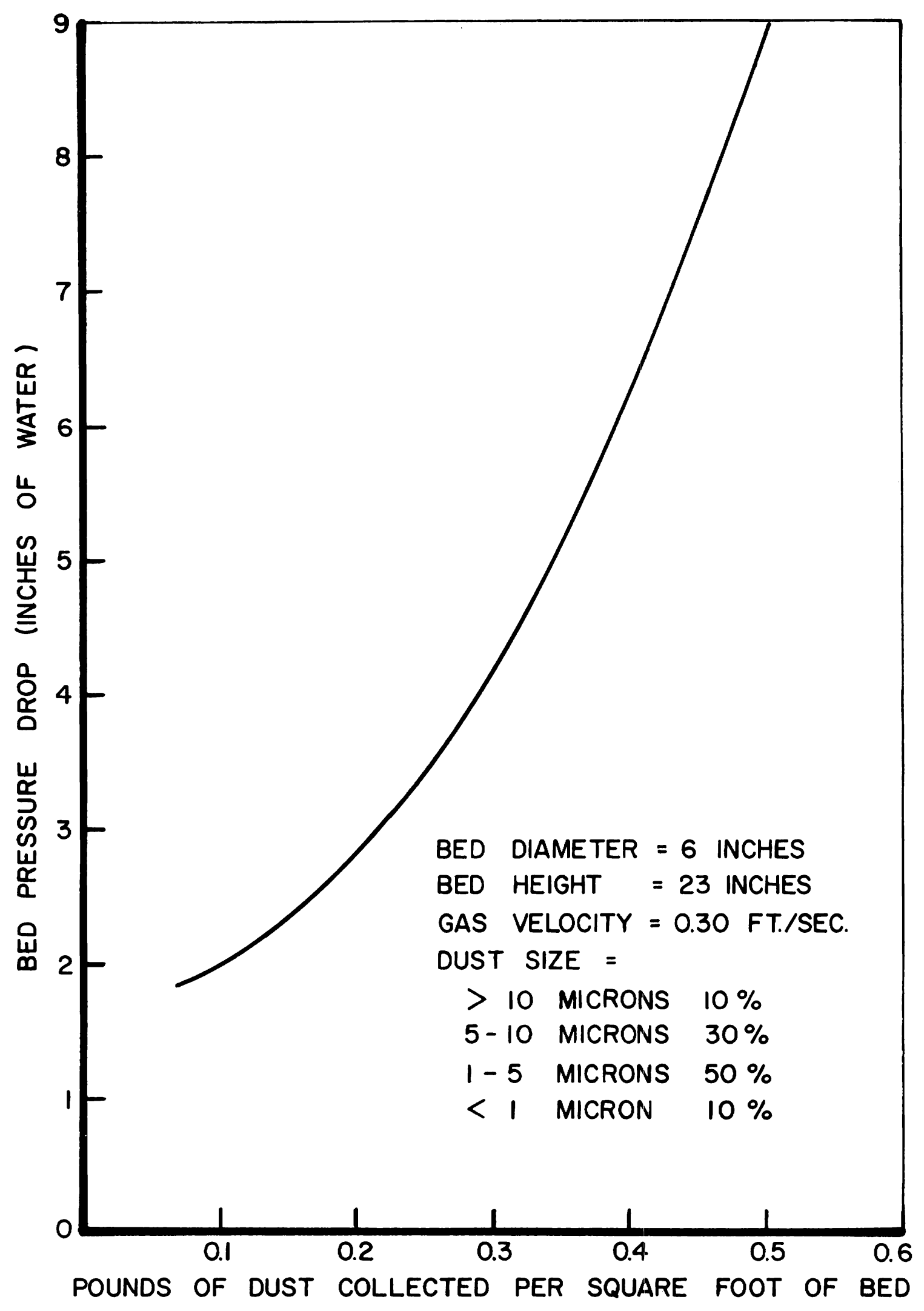

FIG. VII-4 EFFECT OF DUST ACCUMULATION ON PRESSURE DROP THROUGH A SILICA GEL
BED. 
data and the adsorber dust accumulation observed in WCF testing $(0.156 \mathrm{lb} /$ day), it is estimated that an adsorber should be regenerated every 350 days. On the other hand, the rate of pressure drop increase measured during the WCF testing indicates that a 150-day interval would be required to limit the adsorber pressure drop to 14 inches of water. The latter figure, while obtained in actual WCF operation, is an extrapolation from short running periods and very small changes in pressure drop, and is therefore probably less reliable than the former estimate.

3.32 Estimate of Adsorber Regeneration Period as Limited by Capacity of Silica Gel for Ruthenium. ICPP laboratory tests have shown that silica gel has the capacity to adsorb up to 97 grams of ruthenium per cubic foot of gel and that 38 grams cannot be removed by the regeneration [23]. For a ruthenium content of $0.04 \mathrm{~g} / 1$ in the waste solution being processed, and decontamination factors of 3 and 1000 across the scrubbing system and silica gel beds, respectively (Section VII-2, VII-3), the adsorber beds would have to be regenerated every 329 days to avoid exceeding a ruthenium content of 97 grams/ $\mathrm{ft}^{3}$. This limit is relatively unaffected by waste age, as the amount of inert ruthenium is considerably larger than the amount of active ruthenium in the waste solution $(0.04 \mathrm{~g} / 1$ inert vs $0.001 \mathrm{~g} / 1$ active in 200-day cooled waste).

3.33 Estimate of Adsorber Regeneration Period as Limited by Radioactivity Levels in Nearby Corridors. The maximum amount of radioactivity that each adsorber cell may contain so that the activity level in the adjacent corridor will be below $7.5 \mathrm{mr} / \mathrm{hr}$ is approximately $3 \times 10^{7}$ curies. At the estimated rates of ruthenium and particulate accumulation in the adsorbers (Sections VII-2 and VII-3), the cell activity, when processing 200-day cooled waste, would not building up to this level in several years of continuous processing.

\section{NaK TUBE VIBRATION STUDY}

At the time the WCF was being designed, considerable uncertainty existed regarding the dangers of a NaK leak into the fluidized bed. Primarily because of the added safety they afforded, special double-wall helium-filled bayonet tubes (see Section VI for detailed description) were selected for use in the fluidized-bed heat exchanger. Similar tube configurations had been developed and designed for use in the SIR [42] and Hallam [43] reactors; however, they are still considered a novel design. 
After 772 hours of test operation in the WCF, a helium leak occurred in one of the tubes. Prior to the leak, the NaK system had been started up 13 times and had been operated for 460 hours with the furnace outlet temperature below $1100^{\circ} \mathrm{F}$ and for 312 hours above $1100^{\circ} \mathrm{F}$. The leak was due to a circumferential crack around the bottom half of the outer tube, approximately $3 / 4$ inch from the tube-sheet weld. The tube was repaired by welding a 1-7/8 inch long sleeve of $1-1 / 2$ inch diameter, Schedule 40, Type 316 SS pipe over the break. One weld was made to the tube sheet and the other to the tube. Five days after the system was brought to operating temperature again, another leak developed in the same tube. This leak was due to circumferential cracking around the top half of the tube adjacent to the sleeve weld. The faulty tube was then completely encased in another tube which was welded to the tube-sheet and secured at the free end to permit only horizontal expansion and contraction.

The system was again brought to operating temperature and operated for another 17 days. An internal inspection at the end of this time revealed that the welded support for the free end had been torn from the shell of the calciner. Although all failures were on the same tube, the sheared support rod indicated the probability of external force rather than a faulty tube as the cause of failure. A fatigue stress analysis was then performed to determine the probable cause of failure.

Strain measurements were made on the tubes under a number of operating conditions at various temperatures [44]. The tests show that tube stresses above allowable design limits were induced by tube vibration when the NaK temperature was above $510^{\circ} \mathrm{C}$ and the fluidizing air rate exceeded $12,000 \mathrm{scfh}$. Since the calciner had been operated for more than 300 hours above these conditions, tube vibration appeared to be the logical reason for the tube failures.

As a consequence of the stress measurements, a tube support was installed in the calciner vessel to dampen the vibration (see Section VI for detailed description of tube support). Subsequent stress measurements [44] made with the support in place showed the vibration-induced stresses had been reduced to a very low level. Since the installation of the tube support, the calciner has been operated over 2500 hours with $\mathrm{NaK}$ temperatures above $510^{\circ} \mathrm{C}$ and the fluidizing air rate above $12,000 \mathrm{scfh}$. No leakage has occurred in that time and, at the conclusion of the last test run, a dye penetrant check revealed no evidence of stress cracking in or around the tube sheet welds. 


\section{REFERENCES}

1. J. W. Loeding, et al, The Fluid-Bed Calcination of Radioactive Waste, ANL-6322 (May 1961).

2. J. R. Bower, Ed, Chemical Processing Technology Quarterly Progress Report, 3rd Qtr 1960, IDO-14540 (February 15, 1961).

3. W. P. Palica, L. T. Lakey, Development of Fluidized Bed Calcination of Aluminum Nitrate Wastes in the Waste Calcining Facility, IDO-14608 (to be published).

4. B. P. Brown, et al, Development of a Fluidized Bed Calcination Process for Aluminum Nitrate Wastes in a Two-Foot-Square Pilot Plant Calciner. Part I. Equipment Development and Initial Process Studies, IDO-14586 (June 20, 1962).

5. D. R. Evans, Pilot Plant Studies with a Six-Inch Diameter Fluidized Bed Calciner, IDO-14539 (April 20, 1961).

6. J. R. Bower, Ed, Chemical Processing Technology Quarterly Progress Report, 3rd Qtr 1962, IDO-14599 (December 28, 1962).

7. J. A. Buckham, et al, Development of the Fluidized Bed Waste Calcination Process, Paper presented at the Fiftieth National Meeting American Institute of Chemical Engineers, Buffalo, New York, May 5-8, 1963.

8. H. J. Eding, et al, Phase Transformations in Alumina, IDO-14580 (December $5,1961)$.

9. J. R. Bower, Ed, Chemical Processing Technology Quarterly Progress Report, 2nd Qtr 1962, IDO-14593 (September 24, 1962).

10. B. R. Wheeler, et al, Development of a Fluidized Bed Calcination Process for Aluminum Nitrate Wastes in a Two-Foot-Square Pilot Plant Calciner. Part II. Factors Affecting the Intra-Particle Porosity of Alumina, IDO14587 (July 25, 1962).

11. Max Leva, Fluidization, McGraw Hill Book Co., New York, 1959.

12. F. A. Zenz, D. F. Othmer, Fluidization and Fluid-Particle Systems, Reinhold Publishing Corp., New York, 1960.

13. J. R. Bower, Ed, Chemical Processing Technology Quarterly Progress Report, 4th Qtr 1962, IDO-14611 (June 7, 1963).

14. J. R. Bower, Ed, Chemical Processing Technology Quarterly Progress Report, 1st Qtr 1962, IDO-14589 (June 1962).

15. J. R. Bower, Ed, Chemical Processing Technology Quarterly Progress Report, 3rd Qtr 1961, IDO-14574, p 31 (December 19, 1961). 
16. R. D. Modrow, L. T. Lakey, Removal of Particulate Matter from Off-Gas in the Waste Calcining Facility, IDO-14607 (to be published).

17. H. L. Green, W. R. Lane, Particulate Clouds: Dusts, Smokes, and Mists, D. Van Nostrand Co., Princeton, N. J., 1957.

18. B. R. Wheeler, Venturi Scrubber Evaluation for Waste Calcination Off-Gas Facilities, IDO-14484 (December 18, 1959).

19. W. E. Gill, D. E. Wisehart, A Study of Certain Properties of Ruthenium Compounds found in the Redox Process, HW-32175 (June 23, 1954).

20. D. A. Hanson, et al, The Adsorption of Ruthenium from Nitric Acid-Air Mixtures, IDO-14458 (June 8, 1959).

21. C. E. May, et al, Fission Product Ruthenium Volatility in a High Temperature Process, IDO-14439 (July 1, 1958).

22. C. E. May, et al, Ruthenium Behavior in a Nitric Acid Scrubber, IDO-14448 (September 29, 1958).

23. D. R. Anderson, D. W. Rhodes, Capacity Test Data for the Adsorption of Volatile Ruthenium on Silica Gel, IDO-14510 (June 17, 1960).

24. K. L.Rohde, et al, "Fission-Product Ruthenium Volatility at High Temperatures", Ind. Engr. Chem., 51, pp 68-70 (January 1959).

25. A. S. Wilson, Ruthenium Behavior in Nitric Acid, HW-45620 (September 1, 1956).

26. D. K. MacQueen, J. I. Stevens, Design Bases for ICPP Waste Calcination Facility, IDO-14462 (April 22, 1959).

27. M. N. Elliot, et al, Fixation of Radioactive Waste in Glass. Part III. The Removal of Ruthenium and Dust from Nitric Acid Vapours, AERE-R-4098 (1962).

28. M. N. Elliot, et al, The Disposal of Fission Product Wastes by Incorporation into Glass, AERE-R-3610 (1960).

29. J. C. Collings, Radioactive Wastes, Their Treatment and Disposal, E。 \& F. N. Spon., London (1960).

30. H. W. Godbee, W. E. Clark, The Use of Phosphite and Hypophosphite to Fix Ruthenium from High-Activity Wastes in Solid Media, ORNL-TM-125 (January 1962)。

31. W. E. Erlbach, R. W. Durham, The Behavior of Ruthenium in the Fixation of Fission Products, Paper presented at Nuclear Engineering and Science Conference, held at Chicago, March 17-21, 1958. Preprint 67, Session 16. 
32. Archie S. Wilson, "Ruthenium Volatilization in the Distillation of Nitric Acid", J. Chem. Engr. Data 5, pp 521-524 (October 1960).

33. The Fluor Corporation, Ltd., private communication.

34. E. R. Irish, Ed, Research and Development Activities Fixation of Radioactive Residues Quarterly Progress Report, 2nd Qtr 1961 (July 15, 1961).

35. E。 R. Irish, Ed, Research and Development Activities Fixation of Radioactive Residues Quarterly Progress Report, 3rd Qtr 1961 (October 13, 1961).

36. E. R. Irish, Ed, Research and Development Activities Fixation of Radioactive Residues Quarterly Progress Report, 4th Qtr 1961 (January 15, 1962).

37. E. R. Irish, Ed, Research and Development Activities Fixation of Radioactive Residues Quarterly Progress Report, 3rd Qtr 1962 (October 1962).

38. E. R. Irish, Ed, Research and Development Activities Fixation of Radioactive Residues Quarterly Progress Report, 4th Qtr 1962 (January 1963).

39. W. H. Reas, Chemical Laboratory Monthly Report, March 1963, HW77046C (April 15, 1963).

40. A. R. Bancroft, et al, The Volatilization and Collection of Ruthenium and Cesium in a System for Incorporating Fission Products into Glass, CRCE1004 (January 20, 1961).

41. Private Communication from Vitro Laboratories Under Research Subcontract to Phillips Petroleum Co.; M. H. Ortner, et al, Research and Development Studies on Waste Storage Process, Final Report (August 1959).

42. R. W. Lockhart, et al, Review of SIR Project Model Steam Generator Integrity, KAPL-1450, p 39 (November 1, 1955).

43. F. Boni, P. S. Otten, "Fermi and Hallam Steam Generators", Nucleonics, Vol. 19 , No. $\underline{6}$, pp 58-61 (June 1961).

44. S. D. Anderson, G. W. Hirschi, Vibrational Analysis of Unfired Horizontal Bayonet Tubes in a Fluidized Bed Calciner, IDO-16794 (October 19, 1962). 


\section{OPERATING ORGANIZATION AND PROCEDURES}

\section{ATOMIC ENERGY DIVISION OPERATING ORGANIZATION}

The Idaho Chemical Processing Plant (ICPP), operated for the USAEC by Phillips Petroleum Co., was selected as the site for construction of the Waste Calcining Facility (WCF). The responsibility for operation of the ICPP is vested in the Atomic Energy Division (AED), a division of Phillips' Research and Development Department, located in Idaho Falls, Idaho. In addition to operating the ICPP, the AED has operational responsibility for the Materials Testing Reactor, the Engineering Test Reactor, the Special Power Excursion Reactor Test (Spert), and Safety Test Engineering Program (STEP) activities. Research studies are being carried out in several related scientific fields. Successful operation of these facilities without serious incident or overexposure to personnel has been accomplished for many years.

The safe and efficient operation of the WCF requires a high degree of technical understanding of calcination and fluidized-bed behavior. Careful attention to operator training and supervision, operating procedures (and strict limitations on departure from these procedures), together with continuous functioning of a safeguards review committee, are considered essential and constitute the basic operating philosophy of the AED. Strong emphasis is placed on these factors. Although every reasonable effort will be made to attain objectives set forth for the WCF, these objectives will not be allowed to override fundamental considerations of safety.

Management of the AED is under the overall direction of a Division Manager, responsible to the Manager, Research and Development Department, for prosecution of Phillips' contractual obligations to the Atomic Energy Commission. The AED is divided into four major subdivisions: Operations, Technical, Engineering, and Administration. Each subdivision is headed by an Assistant Manager accountable to the Division Manager for all activities under his direction.

The functions or activities of the various subdivisions and the general organizational framework of the AED are illustrated in Figure VIII-1. The following paragraphs summarize the functions of the various subdivisions. 


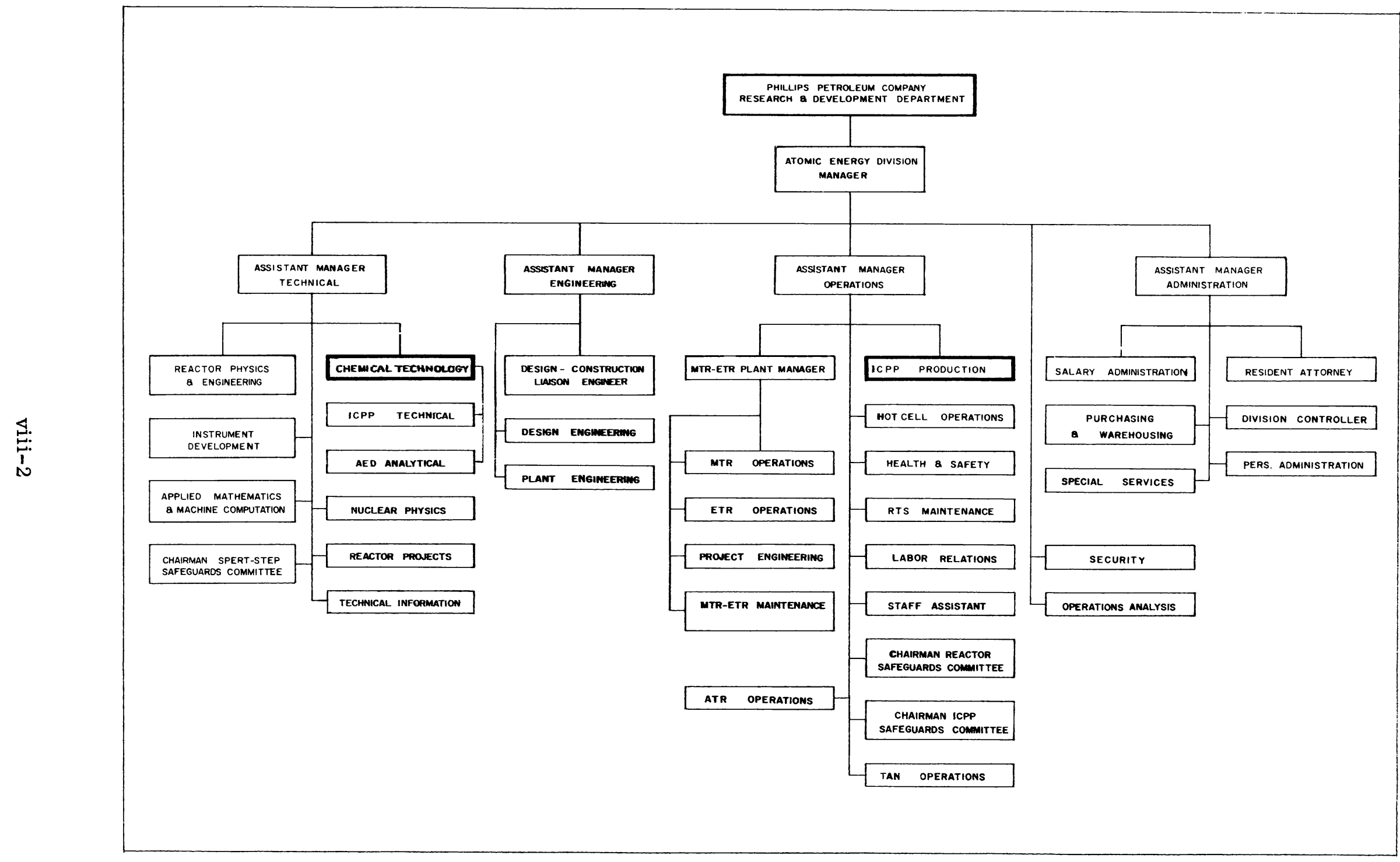

FIG. VIII-1 ORGANIZATIONAL FRAMEWORK OF THE AED. 
The primary functions of the Technical organization are: (a) to provide technical assistance to the operation of the various facilities and reactors; (b) to carry out research, development, and design for proposed new processes, reactors, or special projects requested by the USAEC; (c) to conduct research and development as authorized or requested by the AED in nuclear physics, reactor physics and engineering, and radiochemistry; and (d) to provide library and technical information services to the NRTS.

The primary functions of the Operations organization are: (a) to operate the ICPP (including the WCF), the MTR-ETR, and other reactors; (b) to provide the various types of maintenance services required to install, maintain, and repair experimental equipment, and maintain and repair plant equipment including all general maintenance of the NRTS; (c) to provide radiation-protection service and industrial-safety service to all personnel; and (d) to provide hot cell services for examination of irradiated materials.

The primary functions of the Engineering organization are: (a) to provide design and construction liaison with USAEC on projects falling within Phillips' contractual responsibilities; (b) to provide drafting and engineering forces and facilities required to furnish complete or conceptual designs for various AED projects; and (c) provide engineering assistance to the operating branches on non-nuclear plant and reactor problems.

The Administrative organization is responsible for all AED activities of an administrative nature, such as personnel administration, finance, internal control, purchasing and warehousing, and special services.

Each of the four AED subdivisions is divided into branches whose function is to carry out assigned activities or specialized services as required for accomplishing division programs. Each branch is under the direction of a Branch Manager who is responsible to the appropriate Assistant Manager for prosecution of approved programs and objectives.

The ICPP Production Branch, as part of the AED Operations organization, is responsible for the operation of all ICPP processes (including the WCF) and the associated supporting facilities. The ICPP Technical Branch, as part of the AED T€chnical organization, is responsible for planning, conducting, and evaluating certain phases of the calcination research and development program, and providing technical assistance to the Operations Branch. Figure VIII-1 illustrates the relationship of the ICPP Production Branch and the ICPP Technical Branch with other branches of the AED. 


\section{ICPP OPERA TING ORGANIZA TION}

A primary objective of the ICPP Production Branch is to operate the WCF and supporting facilities consistent with the objectives set forth for the calciner and consistent with safe operating practices. The organization, shown in Figure VIII-2, is available to fulfill these requirements.

Direct supervision is vested with the Operations Superintendent. A straightline organization exists, with lines of authority and communication running from the Division Manager, through the Assistant Manager of Operations, to the Superintendent of Operations.

The Operations Superintendent administers company policy as delegated to him and enforces at the branch level the operating policies and procedures established by management. The Superintendent consults, when necessary, with other units such as the ICPP Technical Branch, the ICPP Engineering Safeguards Committee, Design Engineering, etc, on problems which require more than Operations Branch review. The Assistant Superintendent must be sufficiently familiar with the Superintendent's duties that he can act for the Superintendent in his absence. The Assistant Superintendent primarily performs the following functions: (a) follows all operations to assure that the prescribed operating conditions are maintained; (b) trouble-shoots special problems; (c) maintains liaison with the ICPP Technical and Maintenance Service Branches; and (d) reviews and evaluates operating records and log books.

The Assistant to the Operations Superintendent assists with those responsibilities assigned to the Superintendent, handles arrangements for receipt and storage of reactor fuel, and is given special assignments.

Plant Engineering is responsible for initiating and reviewing proposed equipment design changes; maintaining liaison between ICPP Design Engineering, Operations, and ICPP Special Maintenance; and for general plant upkeep and repair.

Production Engineering evaluates process data; writes reports on plant operation; prepares operating instructions, data sheets, and operating manuals; and makes recommendations for process improvements.

The Shift Superintendent and Day Superintendent report to the Assistant Superintendent and direct the efforts of approximately 20 men per shift engaged in around-the-clock operation of the WCF, ICPP, and supporting facilities. In this capacity, they are responsible for the entire plant on off-shifts, weekends, and holidays. The Day Superintendent, in addition to being a relief Shift 


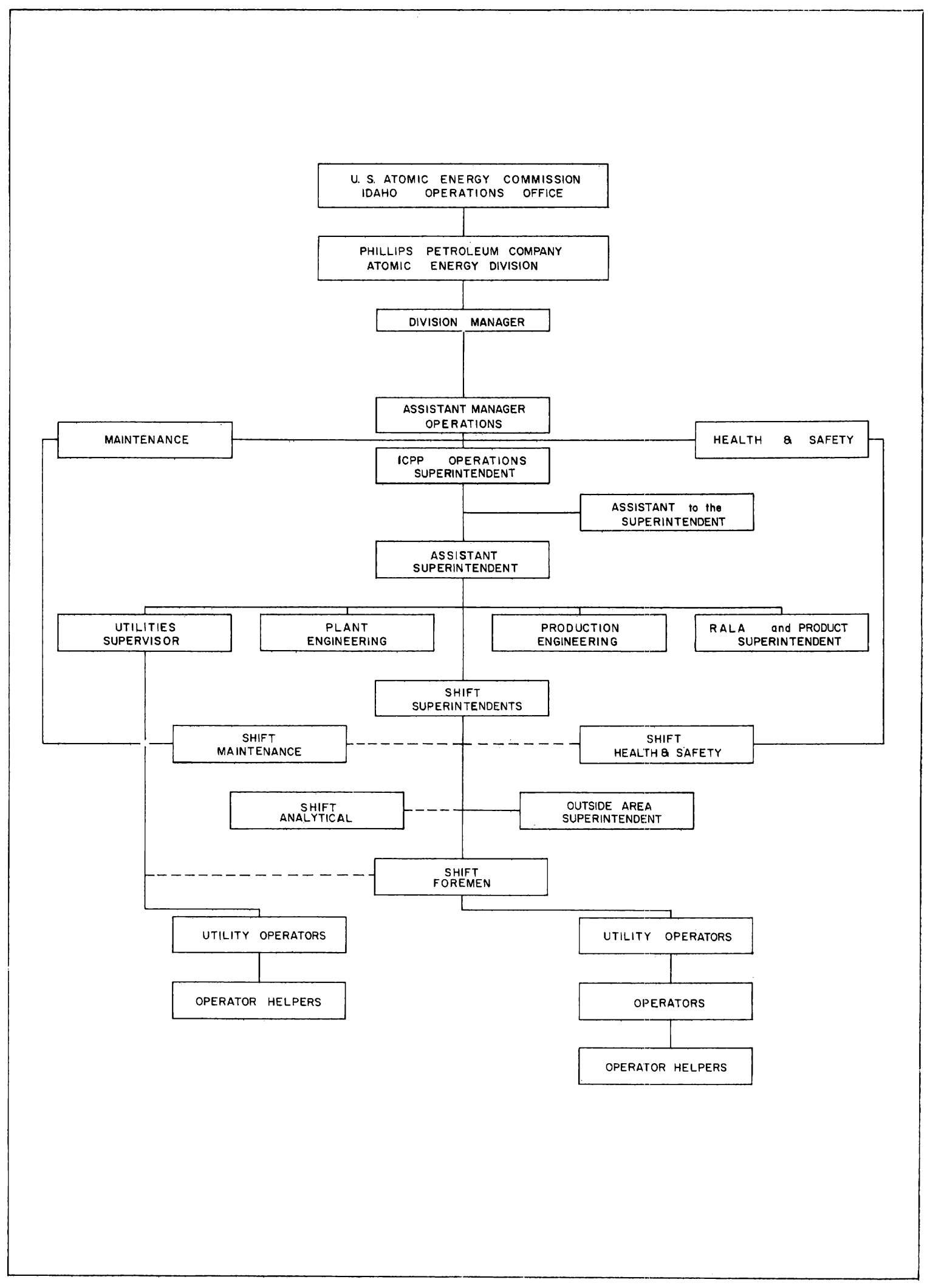
FIG. VIII- 2 RELATIONSHIP OF THE ICPP PRODUCTION BRANCH WITH OTHER BRANCHES OF
THE ATOMIC ENERGY DIVISION (AED). 
Superintendent, assists with the preparation and updating of operating manuals and training of personnel.

Each shift is staffed with a foreman, utility operator, two operators, and four operator helpers who are assigned, as needed, to the WCF supporting facilities. Two utility operators also are assigned as shift breakers for day shifts.

In addition, each shift is staffed with a utility operator and an operator helper to operate steam boilers, demineralizers, water systems, air compressors, diesel generators, and other service equipment.

The utility operator on each shift is familiar with all job functions and is responsible for work direction and overall job performance. He is assisted by two operators who are assigned, as needed, to the WCF or other facilities. The four operator helpers are under the direction of the utility operator or operators and are assigned to jobs of less responsibility. Maintenance, Analytical, and Security Personnel also are assigned to each shift.

\subsection{Training and Qualification of Personnel}

Recognizing that the safe operation of the WCF depends to a large degree on well-trained and experienced operators, the calciner is staffed with personnel who have undergone formal training in calcination and fluidized-bed theory and on-the-job training in calciner operation during extensive cold runs. Operating personnel are not assigned to the WCF exclusively, but rotate between job assignments at uranium-processing facilities, supporting facilities, and the WCF。 All operators are well trained for their duties at the WCF. Nearly all ICPP operators and helpers have worked at the WCF on various assignments from the early equipment-testing periods, through trial and cold runs (including radioactive spike operation), and are familiar with WCF equipment and procedures.

The Shift Superintendents and Foremen also have received similar training and operating experience for varying lengths of time.

Several formal training classes have been held for WCF personnel to provide basic information essential to an understanding of calciner operation. The following sources of information are readily available regarding calciner operation and procedures:

WCF Equipment Manual

WCF Operating Manual

ICPP Standard Practices Manual (This contains detailed operating procedures) 


\section{WCF Flowsheets}

WCF Equipment and Piping Drawings

It is mandatory for all Operations personnel to be thoroughly familiar with the sections appropriate to their individual jobs.

About eight persons, with the Operations' foreman as captain, make up a fire brigade on each shift. The brigade members have received instruction and training for various types of emergencies, including NaK fires, and are familiar with fire fighting and emergency equipment at the WCF. In case of a WCF emergency, when personnel evacuation is not necessary, the brigade members will immediately respond and take corrective action, where possible, until the fire department or other assistance arrives.

All operators assigned to the WCF also have completed at least one certified first aid course.

\subsection{Service Assistance}

Several branches of the AED Technical, Engineering, and Operations organizations will provide service in support of operation of the WCF. These branches are the ICPP Technical, ICPP Analytical, ICPP Design Engineering, ICPP Health and Safety, and ICPP Special Maintenance.

\subsection{ICPP Technical. The ICPP Technical Branch has the following} responsibilities: (a) to review and evaluate operating data in furtherance of the WCF program objectives; (b) to provide overall technical support for the WCF and perform specific surveillance functions during the early operation of the facility; (c) to advise the ICPP Production Branch regarding developments in calcination technology aimed at optimizing operating conditions; (d) to prepare comprehensive technical reports covering significant phases of plant experience; and (e) to promote research and development work to provide adequate solutions to current and future problems. In addition, the group will review WCF Standard Practices prior to initial hot operation and will work closely with the ICPP Production Branch in all phases of planning.

2.22 Health and Safety. As indicated in the AED organization chart (Figure VIII-1), the Health and Safety Branch is part of the Operations organization. The responsibility for operational safety resides in the line organization, with Health and Safety personnel in an assisting role. However, the Health and Safety organization also performs an inspection role independently of the 
operating organization and is vested by the Division Manager with the authority and responsibility to close down any operation which it considers unsafe. Health Physics personnel will be provided at the WCF around the clock on a shift basis. These personnel are under the direction of a Health Physics Supervisor. The group has the responsibility for providing the following service: (a) radioactivity surveys, (b) routine area monitoring, (c) routine first aid, and (d) assistance in training personnel. Work performed in any area which is potentially a radiation hazard must receive prior survey and appropriate approval of the Health Physics group, as specified by safe work permit procedures.

One individual specifically trained in industrial safety and under the direction of the AED Safety Engineer also is assigned to ICPP. It is the responsibility of the individual to provide industrial safety service by reviewing all safe work permits, by providing special safety equipment, and by instructing personnel in fire prevention and use of safety equipment.

2.23 AED Analytical. The responsibilities of the AED Analytical Branch pertinent to the WCF operation are as follows: (a) provide around-the-clock service to rapidly and accurately analyze routine samples needed for efficient WCF operation and report these results to Operations Shift Superintendent; (b) analyze non-routine samples as needed to provide additional information regarding calciner operation; and (c) develop additional analytical methods and procedures that may be required in future operation of the WCF.

2.24 ICPP Special Maintenance. ICPP Special Maintenance is part of the Operations organization. The responsibilities of the section are as follows: (a) to routinely inspect, maintain, and repair, when necessary, the mechanical and electrical equipment and process instrumentation at the WCF on an around-the-clock basis; (b) to modify or make major repairs on existing equipment; and (c) to provide engineering studies for improved mechanical equipment or operation.

2.25 ICPP Design Engineering. Design Engineering is responsible for the following services: (a) provide up-to-date drawings of calciner equipment and process; and (b) furnish engineering and drafting service for proposed changes in WCF process or equipment.

\subsection{ICPP Engineering - Safeguard Committee}

This committee is responsible for the following actions: (a) review procedures relating to all phases of operational methods; (b) review WCF flowsheets and specifications; (c) inspect equipment for compliance with safeguard criteria; 
(d) recommend methods of correcting existing hazards; and (e) approve all proposals for changes in process equipment or flowsheets.

\section{OPERATING POLICIES AND PROCEDURES}

The Atomic Energy Division of Phillips Petroleum Co., as a result of many years of experience, has adopted various practices to be followed by operating personnel. These practices establish uniform rules that must be complied with in the interest of good operation and safety. These, plus detailed WCF operating instructions, are contained in a "Standard Practices Manual". In addition, an operating manual and an equipment manual for the WCF are available for reference purposes.

\subsection{Standard Practices Manual}

The Standard Practices Manual includes specific instructions and operational criteria which are mandatory. For example, complete details are included covering calciner start-up, including the instruments to be checked, air and water purges to be started, and the proper sequence for placing equipment in operation. The manual is available to all operating personnel, and every man in the Operations Branch is responsible for becoming thoroughly familiar with the instructions contained therein pertaining to his job. The manual and procedures are subject to review every year by the Safeguards Review Committee.

\subsection{Safe Work Permits}

A safe work permit is required on any work performed at the WCF, or other ICPP installations, that presents the slightest possibility of being hazardous. The safe work permit serves the following purposes: (a) insures that all employees working on a particular job are fully aware of all safety or health physics hazards involved and know how to perform the work in a safe manner, and (b) provides a method whereby those responsible for the equipment, instruments, etc, or the area where the work is to be undertaken, are informed as to the nature of the work and that proper safety and health physics clearances have been obtained.

The person initiating a work request indicates in the proper space whether he believes a safe work permit should be required. The work supervisor has the final responsibility for insuring that no possible hazardous job is started before a permit is prepared. 
A safe work permit is not required if: (a) the nature of the work is suck that neither a health physics nor a safety hazard exists and the proper area supervisor has been notified of the work to be done; or (b) a Standard Practice, which has been approved by the same agencies which would approve a safe work permit, is in existence and pertains directly to the job involved.

The person initiating the safe work permit describes the job to be done, the location of the work, and the approvals to be obtained before starting the job. The job supervisor enters the names and maximum allowable exposures, obtains approvals, as indicated, and signs the safe work permit for work to start. A copy of the permit is left with the area supervisor after he has approved it. Restrictions regarding radiation or specific procedures must be followed exactly. Following completion of the work, the area supervisor signs the safe work permit. A copy is retained by health physics and the job supervisor.

\subsection{WCF Emergency Evacuation Procedure}

The emergency evacuation plans of the ICPP area, including the WCF, are integrated into the existing Phillips Petroleum Co. Emergency Action Plans. These plans provide emergency action procedures for dealing with emergencies arising within or affecting Phillips-operated areas, provide procedures for assistance to other NRTS plants in emergencies, and provide procedures for dealing with national emergencies. These plans include the procurement of emergency equipment, the organization and training of emergency teams, and education of individual employees.

emergency evacuations is given below.

3.31 Authority to Declare an Emergency. The following persons are authorized to declare an emergency and operate the evacuation alarm: the Operations Superintendent, the Assistant Operations Superintendent, the Operations Shift Superintendent, the Operations Shift Foreman, the Analytical Shift Foreman, and the responsible Health Physicist (radiation emergency only).

In the event any employee believes an emergency condition has occurred, he shall immediately notify one of the aforementioned persons delegated to declare an emergency.

\subsection{Warning System}

Evacuation - The signal for "evacuation" of the WCF area will be an oscillating siren at five seconds on and five seconds off, repeated for five minutes. 
(1) Upon receipt of an evacuation signal, all personnel will normally proceed to the ICPP Parking lot to await buses to remove them to a safe place.

(2) In cases where the above evacuation route and area will be unsafe, other escape routes will be indicated by Health Physics, Operation personnel, or evacuation Wardens.

Alert - The signal for an alert will be an approximate three-minute continuous sound of the sirens with nonvarying intensity. In the event of an alert signal, employees are to take cover inside buildings and await further instructions from their supervisors or evacuation wardens.

All Clear - The all-clear notification is given verbally.

3.33 Responsibility for Action and Notification. Upon determining that an emergency condition exists in a plant area requiring evacuation, the Supervisorin-Charge, or his designated alternate, will:

(1) Operate, or give instructions to operate, siren warning equipment.

(2) Order emergency shutdown of equipment, if deemed necessary.

(3) Notify NRTS Radio Communications Control Center and furnish all details as to the scope and location of the known situation. (4) Notify the Transportation Dispatcher, if deemed necessary. (5) In emergencies requiring partial or total evacuation and/or an emergency shutdown of equipment, he shall notify his immediate supervisor of the next higher supervisor. The AED Manager will always be called.

\subsection{Organized Groups}

Evacuation Wardens - Evacuation Wardens will be responsible for knowing all details of the emergency plans and possible hazards to be avoided in the evacuation of their area. During an evacuation, wardens are responsible for determining to the greatest extent possible that all personnel have left their respective areas. If possible, without jeopardizing personal safety, they should assure that appropriate operating equipment is shut down and classified documents and safes are secured. During off-shift hours, the warden's responsibility will be assumed by the shift supervisor or his designated alternate.

Emergency Reentry Teams - There are two reentry teams at ICPP as follows: 
(1) Personnel Rescue Team. The organized fire brigade will have the main responsibility for rescue and personnel search.

(2) Plant Inspection Team. This team shall consist of qualified persons who will be designated at the time of the emergency and will be accompanied by at least one health physicist.

\subsection{Emergency Equipment}

(1) The Health and Safety Section will at all times maintain, for emergency use, portable survey equipment, respiratory equipment, rescue equipment, and first aid equipment at the main guard gate. (2) Drawings showing area layout, floor plans, and major equipment locations will be kept in an emergency cabinet at the ICPP gate house and at the Security Building at Central Facilities.

3.36 Training of Employees. All working groups will instruct their employees in the requirements of the operating policies and procedures at approximately six-month intervals. 


\section{HAZARD AND ACCIDENT ANAL,YSIS}

\section{ACTIVITY RELEASE DURING NORMAL OPERATION}

During normal operation, there are three general ways in which radioactivity could be expected to be released to the atmosphere. These a re through: (a) release of process off-gas via the ICPP stack, (b) release of off-gas from the solids storage bins, and (c) release through sample handling operations. Activity carried by the process off-gas contributes the bulk of the radioactivity release during normal operation; activity release from the storage bins is expected to be insignificant while that from spillage of samples should be negligible. The activity expected in the released WCF process off-gas is 97-99 percent due to tritium and ruthenium and totals $\approx 56$ curies per day when calcining 200 -day cooled waste or $\approx 15$ curies per day when calcining five-year cooled waste (WM-185 tank on 9/63). The other important fission products found in the off-gas when calcining five-year cooled waste are, in order of decreasing activity: promethium-147, cesium-137, strontium-90, and cerium-144. The release rates of fission products, other than ruthenium and tritium, have been established in particulate cleanup studies during actual WCF tests; the release rate of ruthenium has been estimated from available pilot plant data and is therefore less accurate. Because of this, it is desirable that the actual ruthenium release rate be confirmed in initial operation with five-year cooled wastes (WM-185 tank wastes) prior to calcining fresher wastes. Most of the tritium in the feed is expected to be released to the atmosphere with the process off-gas.

Diffusion of the fission products into the atmosphere at the estimated WCF release rates results in ground level concentrations well below the limits prescribed in NBS HANDBOOK 69 [1] for all weather conditions when processing five-year cooled waste and over 80 percent of the time when processing 200-day cooled waste. For the latter type wastes, under looping and fumigation weather conditions, the ruthenium-103 and -106 concentrations may momentarily exceed the limits at some points, but then only by factors less than one order of magnitude.

The activity emission rates, estimated fission product concentrations in the atmosphere, sampling spills, and release of off-gas from the storage bins are discussed in more detail in the following sections. 


\subsection{Release of Process Off-Gas to the ICPP Stack}

1.11 Amount and Nature of Activity in Process Off-Gas. The important fission products found in the WCF process system are strontium-90, ruthenium103 and -106, cesium-137, cerium-144, tritium, and promethium-147. All of these, except ruthenium-103 and -106 and tritium, are expected to appear in the alumina product at essentially the same fission product-to-aluminum ratio as that appearing in the ICPP waste solutions (Table V-1). Ruthenium is an exception because it is partially volatilized as the tetroxide in the calciner. The volatilized portion is expected to condense only partially in the scrubbing system, thus possibly allowing some ruthenium to be released as a vapor. Essentially all of the tritium will probably be carried to the stack with the process off-gas.

The amount of fine solids, and subsequently the amount of fission products other than ruthenium and tritium, that would be released with the process off-gas has been fairly well established during prior testing of the WCF (Section VII-2). Based on these tests, it is estimated that approximateiy $8 \times 10^{-5}$ pounds of particulate solids would be released every hour; these solids would carry approximately 0.06 curie per day of fission products, other than ruthenium and tritium, when calcining wastes containing fission products aged five-years (WM-185 tank waste). A fission product age of 200-days raises this calculated activity release rate to 1.6 curies per day.

No assessment of the ruthenium release rate was attempted during the WCF testing; however, much pilot plant data are available on ruthenium behavior in calcination and off-gas cleanup equipment. These data are somewhat conflicting because of the different pilot plant configurations employed and the numerous factors (temperature, atmosphere composition, residence time) known to affect ruthenium volatility and removal. Ruthenium behavior is discussed in detail in Section VII-3. From the existing data, it is estimated that a ruthenium DF of at least 3000 (3 across the calciner and scrubbing system and 1000 across the silica gel beds and filters) would be achieved in the WCF. Two aspects of the WCF design make it likely that DF's higher than those reported in the pilot plant testing would be realized. These are (a) the condensation occurring in the scrubbing system, and (b) high residence time in the off-gas system. Both of these factors would promote the condensation of ruthenium in the scrubbing system and thus increase the quantity of ruthenium returned to the feed and eventually removed with the product to the storage bins over that anticipated from the pilot plant tests. 
Applying a ruthenium DF of 3000 to the WCF, results in an estimated ruthenium release rate of 0.12 curie per day when calcining wastes containing fission products aged five years (WM-185 tank waste). A fission product age of 200-day raises the calculated ruthenium release rate to 34.6 curies per day. In the former case, the ruthenium activity originates almost entirely with the 106 isotope; in the latter case, ruthenium-103 contributes 90 percent of the ruthenium activity.

A tabulation of the estimated rates of release of fission products when calcining either 200-day or five-year cooled wastes is presented in Table IX-1.

1.12 Atmospheric Contamination Through Release from ICPP Stack. The off-gas from the WCF is discharged to the atmosphere through the 250-foot-high ICPP stack. The resulting concentrations of fission products in the atmosphere surrounding the stack can be estimated through the use of Sutton's continuous point source diffusion equation [2], which defines the diffusion parameter $\left(\frac{X}{Q}=\frac{\text { curies per cubic meter at grade level }}{\text { curies released per second }}\right)$ as a function of weather conditions. Typical values of this parameter and a discussion of weather conditions at the NRTS are given in Section III.

Lapse and inversion weather conditions (other than fumigation and looping) occur about 80 percent of the tims at the NRTS. Either strong lapse or strong inversion conditions are in existence for about sixty percent of the time at the NRTS, and these may thus be considered typical of the prevailing weather. A looping or fumigation condition is possible the remaining 20 percent of the time. Atmospheric diffusion under these conditions is poorer, ie, the diffusion parameter $\left(\frac{X}{Q}\right)$ is high.

The diffusion parameters at the ICPP stack required to meet the maximum permissible concentrations in the atmosphere $\left(\mathrm{RCG}_{\mathrm{a}}\right)$ for fission products found in the WCF off-gas have been calculated for the emission rates established in the previous section; these also are presented in Table IX-1. A comparison of the required parameters with the estimated actual parameters given in Section III shows that, for five-year cooled waste and all weather conditions including looping and fumigation (diffusion parameters equal to $1.6 \times 10^{-3}$ and $2.5 \times 10^{-4} \mathrm{sec} /$ cubic meter, respectively), the fission product concentrations at ground level will be reduced below the limits given in NBS HANDBOOK 69 [1]. 
Waste solutions cooled only 200-days could be safely processed about 80 percent of the time without exceeding, even momentarily, the $\mathrm{RCG}_{\mathrm{a}}$ for ruthenium106 and -103 , which are the only nuclides in 200-day waste expected ever to exceed the concentration limits. For the balance of the time, however, when looping and fumigation weather conditions exist, the $\mathrm{RCG}_{\mathrm{a}}$ of these two isotopes could be exceeded at specific locations for brief periods. During fumigation

\section{TABLE IX-1}

ESTIMATED RADIOACIIVITY RELEASE RATE

FROM ICPP STACK AND DIFFUSION PARAMETERS REQUIRED TO MEET THE RCG OF RADIOACTIVE NUCLIDES IN THE ATMOSPHERE

\begin{tabular}{|c|c|c|c|c|c|c|c|}
\hline \multirow[b]{3}{*}{ Nuclide } & \multirow{3}{*}{$\begin{array}{c}\text { Maximum } \\
\text { Permissible } \\
\text { Concentration } \\
\text { in Air ( } \text { RCG }_{a} \text { ) } \\
\text { HB } 69 \text { (for } 40 \\
\text { hr week) } \\
\text { Curies/meter } 3\end{array}$} & \multirow{2}{*}{\multicolumn{3}{|c|}{ WASTE POST-REACTOR }} & \multirow{2}{*}{\multicolumn{3}{|c|}{$\begin{array}{l}\text { COOLING TIME } \\
\approx 5 \text { years (tank } 185 \text { on } 9.1 / 63)\end{array}$}} \\
\hline & & & & & & & \\
\hline & & $\begin{array}{l}\text { Curies per } \\
\text { day from } \\
\text { stack }\end{array}$ & $\begin{array}{l}\text { Curies per } \\
\text { second from } \\
\text { stack }\end{array}$ & $\begin{array}{c}\text { Diffusion } \\
\text { parameter } \\
\text { required } \\
\text { sec/meter3 }\end{array}$ & $\begin{array}{l}\text { Curies per } \\
\text { day from } \\
\text { stack }\end{array}$ & $\begin{array}{l}\text { Curies per } \\
\text { second from } \\
\text { stack }\end{array}$ & $\begin{array}{c}\text { Diffusion } \\
\text { parameter } \\
\text { required } \\
\text { sec/meter } 3\end{array}$ \\
\hline $\mathrm{Sr}-90$ & $3 \times 10^{-10}$ & $1.6 \times 10^{-2}$ & $1.8 \times 10^{-7}$ & $1.7 \times 10^{-3}$ & $1.4 \times 10^{-2}$ & $1.6 \times 10^{-7}$ & $1.9 \times 10^{-3}$ \\
\hline $\mathrm{Ru}-106$ & $6 \times 10-9$ & 3.5 & $4.1 \times 10^{-5}$ & $1.5 \times 10^{-4}$ & $1.2 \times 10^{-1}$ & $1.4 \times 10^{-6}$ & $4.3 \times 10^{-3}$ \\
\hline Cs-137 & $1 \times 10^{-8}$ & $1.6 \times 10^{-2}$ & $1.8 \times 10^{-7}$ & $5.6 \times 10-2$ & $1.6 \times 10^{-2}$ & $1.8 \times 10^{-7}$ & $5.6 \times 10^{-2}$ \\
\hline $\mathrm{Ce}-144$ & $6 \times 10-9$ & $3.5 \times 10^{-1}$ & $4.0 \times 10^{-6}$ & $1.5 \times 10-3$ & $5.8 \times 10^{-3}$ & $6.7 \times 10^{-8}$ & $9.0 \times 10^{-2}$ \\
\hline $\mathrm{H}-3$ & $2 \times 10-5$ & 19.3 & $2.2 \times 10^{-4}$ & $\times 10^{-2}$ & 14.4 & $1.7 \times 10^{-4}$ & $1.2 \times 10^{-1}$ \\
\hline $\operatorname{Pm}-147$ & $6 \times 10-8$ & $6.6 \times 10^{-2}$ & $7.6 \times 10^{-7}$ & $7.9 \times 10-2$ & $2.5 \times 10^{-2}$ & $2.9 \times 10^{-7}$ & $2.1 \times 10^{-1}$ \\
\hline Pu-239 & $2 \times 10^{-12}$ & $2.2 \times 10^{-7}$ & $2.6 \times 10^{-12}$ & $7.8 \times 10^{-1}$ & $2.2 \times 10^{-7}$ & $2.6 \times 10^{-12}$ & $7.8 \times 10-1$ \\
\hline Np-237 & $4 \times 10^{-12}$ & $3.8 \times 10^{-9}$ & $4.4 \times 10^{-14}$ & $9.1 \times 10^{1}$ & $3.8 \times 10-9$ & $4.4 \times 10^{-14}$ & $9.1 \times 10^{1}$ \\
\hline Co- 60 & $9 \times 10-9$ & $7.5 \times 10^{-6}$ & $8.7 \times 10^{-11}$ & $1.0 \times 10^{2}$ & $3.8 \times 10^{-6}$ & $4.4 \times 10-11$ & $2.0 \times 10^{2}$ \\
\hline Zr-95 & $3 \times 10^{-8}$ & $2.8 \times 10^{-1}$ & $3.2 \times 10^{-6}$ & $9.4 \times 10^{-3}$ & $3.8 \times 10-10$ & $4.4 \times 10^{-15}$ & $6.8 \times 10^{6}$ \\
\hline Sr-89 & $3 \times 10^{-8}$ & $1.6 \times 10^{-2}$ & $1.9 \times 10^{-7}$ & $1.6 \times 10^{-1}$ & $1.0 \times 10^{-10}$ & $1.1 \times 10^{-15}$ & $2.7 \times 10^{7}$ \\
\hline Y-91 & $3 \times 10^{-8}$ & $2.2 \times 10^{-1}$ & $2.6 \times 10^{-6}$ & $1.2 \times 10^{-2}$ & $1.9 \times 10-10$ & $2.2 \times 10^{-15}$ & $1.4 \times 10^{7}$ \\
\hline $\mathrm{Nb}-95$ & $1 \times 10^{-7}$ & $6.0 \times 10^{-1}$ & $6.9 \times 10^{-6}$ & $1.4 \times 10-2$ & $3.8 \times 10-10$ & $4.4 \times 10^{-1.5}$ & $3.3 \times 107$ \\
\hline Ru-103 & $8 \times 10^{-8}$ & 31.1 & $3.6 \times 10^{-4}$ & $2.2 \times 10^{-4}$ & $1.0 \times 10^{-12}$ & $1.2 \times 10^{-17}$ & $6.7 \times 10^{9}$ \\
\hline $\mathrm{Ce}-141$ & $2 \times 10-7$ & $5.4 \times 10^{-2}$ & $6.3 \times 10^{-7}$ & $3.2 \times 10^{-1}$ & $7.1 \times 10-20$ & $8.2 \times 10^{-25}$ & $2.4 \times 10^{17}$ \\
\hline TOTAL & & 55.5 curles $/ \mathrm{c}$ & & & uries/d & & \\
\hline
\end{tabular}

[a] Bases:

(1) Pm-147 for 5.75 years cooled waste is based on theoretical amount in 200 day waste

(2) Emission from ICPP stack due only to WCF particulates $=8 \times 10^{-5} \mathrm{lb} / \mathrm{hr}$

(3) Amount of rutbenium in feed that is vaporized and escapes collection in the venturi scrubber $\approx 30 \%$

(4) Efficiency of ruthenium adsorbers plus AEC filters for ruthenium $=99.9 \%$

(5) Radioactivity other than ruthenium is evenly distributed in granular solids and the particulate

(6) All H3 in feed released to stack with off-gas

(7) Concentration of Pu-239 and Np-237 assumed same in 200-day cooled waste as in WM-185 waste. Concentration of $\mathrm{H}^{3}$ in 200-day cooled waste also estimated from measured concentration in WM-185 tank 
conditions, the $\mathrm{RCG}_{\mathrm{a}}$ for ruthenium-106 and -103 at some point could momentarily be exceeded by factors of 1.7 and 1.1 , respectively $\left(2.5 \times 10^{-4} / 1.5 \times\right.$ $10^{-4}=1.7$ and $2.5 \times 10^{-4} / 2.2 \times 10^{-4}=1.1$ ). During looping conditions, the $\mathrm{RCG}_{\mathrm{a}}$ for Ru-106 and -103 could be exceeded momentarily at some point by factors of 11 and 7.2 , respectively $\left(1.6 \times 10^{-3} / 1.5 \times 10^{-4}=11\right.$ and $\left.1.6 \times 10^{-3} / 2.2 \times 10^{-4}=7.2\right)$.

The actual diffusion of fission products from the ICPP stack would be greater than indicated above, because the Sutton equation is based on a point source and a constant wind direction and, hence, tends to overestimate contaminant concentrations in the atmosphere [3]; no allowances are made for the effect of vertical gas velocity in the stack or for the effect of wind diversity. To determine an average concentration over a long period of time (days) from a continuous elevated source, the wind direction frequency toward the location being considered should be applied to the values given. Since the wind direction frequency to any one octant at ICPP (250-foot level) varies from 2 to 30 percent (Table IX-2), the average concentration at nearby points would include an additional safety factor varying from 3 to 50 ; at longer distances, the safety factor would be greater yet. The other factor which would make the actual isotope concentration less than that calculated from these diffusion parameters is the effect of stack velocity; in determining the diffusion values given in Table III-5, the actual stack height was used. No credit was taken for extra plume rise caused by the velocity of the stack gases as they issue from the stack. In summary, it can be said that the diffusion parameters given in Table III-5 are maximum values and, therefore, represent the maximum expected instantaneous concentration for a 30 minute average.

The increase in soil activity around the WCF from fallout and washout from the stack plume is expected to be negligible as shown in Appendix G. Final verification of this will be obtained through the site survey program continuously underway at the NRTS [36].

TABIE IX-2

WIND DISTRIBUTION FREQUENCY

NRTS Weather Bureau Office CFA 250 Ft Level (1951-1963)

\begin{tabular}{|c|c|c|}
\hline Wind & Direction & Percent/Octant \\
\hline & $\mathrm{N}$ & 11 \\
\hline & $\mathrm{NE}$ & 24 \\
\hline & $\mathrm{E}$ & 2.5 \\
\hline & $\mathrm{SE}$ & 4 \\
\hline & $S$ & 8 \\
\hline & SW & 30 \\
\hline & $\mathrm{W}$ & 12 \\
\hline & NW & 4 \\
\hline & CaIm & 4.5 \\
\hline
\end{tabular}




\subsection{Release of Off-Gas from Stored Solids to the ICPP Stack}

During normal operation, the solids storage bins are vented to the solids transport air return line. While the WCF process equipment is shut down for maintenance, or after the present bins have been filled, the storage bins will be isolated from the process building by closing block valves in the solids transport lines. The bins will then be vented directly to the ICPP stack through a condenser and filter located in the solids storage vault (Section VI-6). Since the WCF bins represent the first attempt at storing radioactive solids in bulk quantities, no directly applicable data are available on the activity which may be released through the bin vent system. Little activity release is anticipated, however, as the maximum temperature expected in the bins when storing solids from the aged ICPP wastes will be below $200^{\circ} \mathrm{C}$ (Section V-8). Since the product was retained for an average of 100 hours in the calciner at $400^{\circ} \mathrm{C}$, little, if any, evolution of residual volatile material is expected during longterm storage at $200^{\circ} \mathrm{C}$. However, a small amount of gas evolution is expected as a result of radiolytic decay of nitrate in the calcine product. While no direct data are available to positively substantiate it, ruthenium in the product is believed to be present as the non-volatile dioxide form. Ignition tests made on calcined ICPP waste at Argonne support this conclusion; no gamma activity loss, whatsoever, resulted from heating the product up to $700^{\circ} \mathrm{C}$ [4]. It is planned to substantiate this finding with similar tests of the radioactive solids produced in the initial operation of the WCF. Raising the temperature limitation on the solids would allow the use of thicker, and thus less expensive, storage bins.

\subsection{Release During Sample Handling Operations}

The sampling equipment in the WCF permits all sampling operations to be carried out remotely from behind shielding. The use of remote handling for the five liquid and two solids samplers (Section VI-9) reduces the potential for exposure in the event of spillage. The five liquid samplers are identical to those already in use at the Idaho Chemical Processing Plant; the use of these samplers, then, introduces no hazards greater than those already successfully overcome in the Idaho Chemical Processing Plant.

The two samplers for obtaining samples of the calciner solids have not been proven in radioactive service and, thus, will require more careful attention until operating experience is gained. Of these two, only the small solids sampler (Section VI-9) will be used with any degree of regularity. This sampler is housed in the sample gallery along with the liquid samplers, and the $15 \mathrm{cc}$ solids 
samples are handled in a manner identical to that employed with the liquid samples. Any spillage of these samples would be contained in the sampler gallery, in the transfer cask, or in the remote boxes where the analytical work is done. The total activity contained in one of these samples is approximately one curie when processing five-year cooled waste from tank WM-185. In terms of dosage, a sample is roughly equivalent to a one $\mathrm{r} / \mathrm{hr}$ source at one foot.

As of the date of this report, no definite need for the one-quart samples taken by the bulk solids sampler has appeared. It is expected, therefore, that this sampler will be used only infrequently. As with the small solids sampler, care must be observed with this operation until operating confidence is gained. No trouble is anticipated, however, as the sampling cubicle is vented to the equipment vent system and the sampling operation has been accomplished successfully during non-radioactive testing of the facility. No assessment of the hazards accompanying handling and use of the one-quart samples can be meaningful until the ultimate use of the sample is ascertained. The one-quart sample represents a source strength of approximately 60 curies when calcining five-year cooled waste from tank WM-185.

The only sampling that is not entirely carried out remotely is that of the process off-gas downstream of the AEC filters. The off-gas will be sampled by means of a Millipore filter for particulate matter. The amount of radioactive particulate matter collected can be controlled by the duration of the sampling period to minimize personnel exposure. A 24-hour sample of process off-gas generated from WM-185 waste, where all of the Ru-106 and particulate matter from the sample stream are collected on the sample filter, would have a dose rate of only nine $\mathrm{mr} / \mathrm{hr}$ (at three inches). This amount of activity would be sufficient to analyze for $\mathrm{Sr}-90, \mathrm{Ru}-106, \mathrm{Cs}-137$, and $\mathrm{Ce}-144$, but would not constitute a health hazard.

\section{ACTIVITY RELEASE FROM BYPASS OF OFF-GAS CLEANING ELEMENTS}

Decontamination of the process off-gas is effected by means of several cleaning elements placed in series - calciner cyclone, spray tower, venturi scrubber, silica gel beds, and AEC-type high-efficiency filters. Vent gases from the hot sump, waste hold tanks, regeneration solution tank, feed tank, and sample cubicles are cleaned by two elements - a condenser and an AECtype high-efficiency filter - before they are combined with the process off-gas 
to be discharged to the ICPP stack. The combined performance of the elements for removing activity from the off-gas has been fairly well established through the WCF and pilot plant testing (Section IX-1). The activity release to the stack would probably increase if any individual cleaning element was bypassed; however, the net increase cannot be readily deduced from known performance data, since bypassing an element increases the average particle size at the inlet of the succeeding element, and consequently increases the efficiency of that element. Estimates of the activity released with the WCF off-gas under several situations where elements are bypassed are given in Table IX-3. These estimates are necessarily conservative, as the effect of changing particle size generally has had to be ignored in making the estimate, and higher efficiencies would be expected with larger size particles.

\section{TABLE IX-3}

ACTIVITY RELEASE TO ATMOSPHERE WITH PORTIONS OF OFF-GAS SYSTEM BYPASSED

\begin{tabular}{|c|c|c|c|c|c|}
\hline \multirow[b]{3}{*}{ Normal Operation } & \multicolumn{3}{|c|}{ Perticulate } & \multicolumn{2}{|c|}{ Ruthenium } \\
\hline & $\begin{array}{l}\text { Solids Emission } \\
\text { From WCF } \\
(1 \mathrm{~b} / \mathrm{hr})\end{array}$ & \multirow{2}{*}{$\begin{array}{l}\begin{array}{l}200-\text { Day Waste } \\
(\text { curles/sec) }\end{array} \\
2.16 \times 10-5\end{array}$} & $\begin{array}{l}W M-185(9 / 63) \\
(\text { curles } / \mathrm{sec})\end{array}$ & $\begin{array}{l}\text { 200-Day Waste } \\
\text { (curles/sec) }\end{array}$ & \multirow{2}{*}{$\frac{\begin{array}{l}\text { WM-185 }(9 / 63) \\
(\text { curles } / \mathrm{sec})\end{array}}{1.4 \times 10^{-6}}$} \\
\hline & $8 \times 10^{-5}$ & & $6.0 \times 10-7$ & $4.0 \times 10^{-4}$ & \\
\hline Cyclone bypassed & $8 \times 10-5$ & $2.16 \times 10^{-5}$ & $6.0 \times 10^{-7}$ & $4.0 \times 10^{-4}$ & $1.4 \times 10^{-6}$ \\
\hline Scrubbing system bypassed $[a, b]$ & $<1.8 \times 10-2$ & $<4.86 \times 10^{-3}$ & $<1.35 \times 10^{-4}$ & $1.02 \times 10-3$ & $3.5 \times 10-6$ \\
\hline Adsorbers bypessed & $<4 \times 10^{-4}$ & $<1.08 \times 10^{-4}$ & $<3.0 \times 10^{-6}$ & 0.4 & $1.4 \times 10^{-3}$ \\
\hline Off-gas f1lters bypassed & $1.5 \times 10-3$ & $4.04 \times 10-4$ & $1.12 \times 10-5$ & $4.0 \times 10^{-4}$ & $1.4 \times 10-6$ \\
\hline Adsorbers and filters bypassed & $8 \times 10-3$ & $2.16 \times 10-3$ & $6.0 \times 10-5$ & 0.6 & $1.4 \times 10^{-3}$ \\
\hline Equipment vent fllter bypassed & $8 \times 10^{-5}$ & $2.16 \times 10-5$ & $6.0 \times 10^{-7}$ & $4.0 \times 10^{-4}$ & $1.4 \times 10^{-6}$ \\
\hline
\end{tabular}

An examination of the table shows that the adsorbers are the most critical elements, primarily because of the large ruthenium decontamination factor (103) attributed to the adsorbers. The worst case considered is the simultaneous bypassing of the adsorbers and off-gas filters; such an event would allow the total activity release rate to rise by a factor of $10^{3}$ to $1.46 \times 10^{-3}$ curies per second (based on WM-185 tank activity in September, 1963). The circumstances under which bypassing could occur and the consequences of bypassing are discussed in more detail in the following subsections. 


\subsection{Bypass of Calciner Cyclone}

The rate of input of solids to the calciner cyclone is approximately 28 pounds per hour. Normally, the cyclone removes 75 percent of the incoming solids, permitting an average of 7 pounds per hour to pass on to the scrubbing system. Three possibilities exist whereby the incoming solids could bypass the cyclone cleaning action. These are, erosion of the cyclone element walls or plenum separators (Figure VI-12), failure of the air supply to the cyclone fines jet, and plugging of the cyclone outlet or transport system.

Experience gained during test operation of the WCF indicates the erosion of the cyclone wearing surfaces occurs at a very slow rate (Appendix $\mathrm{H}$ ). A hole worn in an element wall or plenum separator would allow solids to pass directly from the inlet plenum to the outlet plenum. The resulting increase in the solids rate leaving the cyclone would be reflected in an increase of the aluminum concentration of the scrubbing solution. The composition of the scrubbing solution is routinely determined for the purpose of detecting troubles of this type.

Failure of the motive air to the cyclone fines jet would allow the transport air to flow into the cyclone hopper. The air flowing into the hopper would reentrain the solids accumulated in the hopper and carry them into the outlet gas stream. This type of failure could conceivably result from maloperation (inadvertent closing of supply air valve), a line break, or loss of the main air supply. In the two former cases, immediate indications of trouble would be evident in the form of a 10 to 20 percent increase in the transport air flow rate and a drop in the cyclone hopper temperature. Both are indicated on the control panel in the operating corridor. If undetected from these changes, the failure would result in a slow increase in the aluminum content of the scrubbing solution. Failure of the main air supply would be noted immediately through an alarm and the general disruption of controls.

A plug in either the cyclone hopper outlet or in the transport system downstream of the jet connection also would increase the solids rate passing the cyclone. In the first case, solids would build up in the hopper until the solids re-entrainment rate became equal to the rate of solids input. In the second case, the jet would backflow as the transport system pressure rises above the jet cutoff pressure (12.2 psia) and the backflowing motive gas would re-entrain solids into the cyclone outlet. The first indication of a plug in the cyclone hopper would be a drop in the transport air temperature downstream from the 
cyclone fines jet discharge. A second, but slower, indication would be the accompanying slow buildup of aluminum in the scrubbing solution. A plugged transfer line would be noted immediately through a steady drop in the transport air flow.

Little increase in activity of the off-gas released to the stack is expected from cyclone bypassing. Pilot plant calcination tests at Argonne [4] and venturi scrubber tests at the ICPP [6] indicate that the off-gas solids loading downstream of the venturi scrubber would be affected little, if any, by wide variations in the upstream loading. Cyclone bypassing also would have a negligible effect on ruthenium emission as little or none is ordinarily removed by the calciner cyclone.

\subsection{Failure of Scrubbing Solution Recirculation System}

A sudden failure of the scrubbing solution recirculation system, permitting hot calciner off-gas to pass uncleaned into the adsorbers, could occur by three means: (a) failure of the scrubbing solution pumps, (b) plugging or valve failure in the lines supplying scrubbing solution to the quench tower and venturi scrubber, and (c) sudden loss of the scrubbing solution. The possibility of any of these occurring is very remote. Duplicate pumps and valves are provided, and in the event of a primary power failure, the scrubbing solution pumps would be transferred to an emergency power circuit. If the instrument air supply is cut off, the valves to the quench tower open wide, providing an uninterrupted cooling flow. Line velocities in the piping are 2 to $5 \mathrm{ft} / \mathrm{sec}$, making plugging an unlikely event. A sudden loss of the contents of the scrubbing solution tank could come about only by a major rupture of the scrubbing solution tank or a line.

Should circulation of the scrubbing solution stop, two alarms, one indicating low pump outlet pressure and the other a high de-entrainment separator outlet temperature, would be energized immediately. In an emergency, cooling could be accomplished by adding fresh water to the decontamination sprays in the quench tower or by recirculating the scrubbing solution with the transfer jet, WC-508. While not equipped with automatic controls, these systems could be put into operation within minutes.

The passage of hot gases from the calciner to the adsorbers does not represent an instantaneous hazard as the silica gel beds constitute a large heat sink and evaporative cooler, preventing the gas temperatures at the filters from reaching their limit of $180^{\circ} \mathrm{C}$ for at least one hour after failure of the scrubbing system. Each adsorber bed holds approximately one ton of water after 
equilibrium is established between the silica gel and the off-gas stream. Bypassing the scrubbing system would raise the ruthenium level in the off-gas to the adsorbers by a factor of about 2.5 (Section VII-3).

The effect of a failure of this type on the activity release with the process off-gas being exhausted to the stack is difficult to estimate. The limited data available on particle size of the solids indicate that at least 99.8 percent of the particles entering the scrubbing system are larger than 0.3 micron in diameter. If the filter specification efficiency (99.95 percent on particles larger than 0.3 micron in diameter) is applied to this, the resultant solids release to the stack would be $1.8 \times 10^{-2} \mathrm{lbs} / \mathrm{hr}$. This is probably a high figure as a great number of particles smaller than 0.3 micron also would be removed by the silica gel beds and the filters.

\subsection{Bypass of Adsorbers}

The silica gel beds may be bypassed only by opening the adsorber bypass valve, PRC-WC-102-1. Normally, this valve opens automatically when the pressure upstream of the silica gel beds rises 3.65 psi (100 inches of water) above the normal pressure of 7.65 psia. It is hardly conceivable that flooding or plugging could result in a bed pressure drop this high; the most likely cause of an unexpected opening of the bypass valve is an inadvertent closing of all four of the adsorber inlet valves. Locks have been provided on the main control panel to prevent this; furthermore, the valves would remain in the open position should a failure occur in the instrument air supply.

Early in the WCF test program, it was found that bypassing the adsorbers endangered the filters because of the large amount of entrained water in the inlet gas to the beds. Liquids matted the filter media, leading to a high filter pressure drop and subsequent filter failure. An off-gas knockout pot and off-gas reheater, located downstream of the adsorbers, were installed as added protection against liquids reaching the filters. Bypassing the adsorbers would increase the solids loading in the off-gas to the filters by a factor of five; thus, the off-gas loading downstream of the filters, considering the probably increase in filter efficiency on the larger particles bypassing the adsorbers, would be increased by a factor of less than five. The ruthenium emission rate could rise by a factor as large as $10^{3}$, if the ruthenium passing the adsorbers is largely in the form of a gas. Tests at Hanford and Argonne [5,7], however, indicate that at least some of the ruthenium passing the scrubbing system and adsorbers would be in the form of particulate matter and would, therefore, be collected on the off-gas filters. 


\subsection{Filter Failure}

Off-gas could bypass a filter element either through holes in the element itself or through an improperly installed seal around the elements. Because of the low pressure drop, however, openings of several square inches are required to allow a substantial portion of the flow ( $>10$ percent) to bypass the filter elements. Prior to installation, all filter units (stainless steel housing with prefilter and AEC-type filter in place) are given a 0.9 micron DOP leak test to check the integrity of the filter and the seal. Following installation of the filter units, the only means of detecting bypassing would be by noting the increase in the measured activity level at the off-gas sampling stations. Complete bypassing of the filters would increase the solids activity release by a factor of 20 .

The greatest hazard associated with the filter operation is possible damage, or rupture, from contact with liquids. The filter media consists of many long fibers which mat when contacted with a liquid; the matting increases the pressure drop and filter failure usually occurs at pressure drops above 10 inches of water. Perforated screens placed in the filter units are designed to retain most of the media ( $>99$ percent) if a rupture should occur. In the two cases of filter rupture due to water damage experienced during the WCF test program, essentially all the filter material and its trapped dust were found in either the filter case or on perforated screens located in the blower suction lines. At the anticipated maximum dust loading on the filters between changes, each filter unit will contain approximately one pound of dust containing about 22 curies of fission product activity when processing WM-185 (5-year cooled) wastes. Although no mechanism has been postulated by which a filter unit could fail completely and release its entire dust load into the stack gas, the exposure of personnel after such an accident has been examined in Section IX-8.

\subsection{Bypass or Failure of Equipment Vent Filters}

Experience gained during the WCF test program indicates that the activity released through the equipment vent system would be negligible when operating normally. Entrainment could be a problem, however, at high sparging rates in the feed tank and hot sump tank. For this reason, the equipment vent condenser was added during the final modifications. 
3. ACTIVITY RELEASE FROM SYSTEM RUPTURE BY CHEMICAL REACTION OR FISSION PRODUCT DECAY HEAT

The possible release of radioactive matter from a system rupture, either as a result of chemical reaction or from heat generation due to fission product decay, is considered in this section of the report. Accidents of this type, while less likely to occur than activity releases from temporary overpressure of equipment or minor equipment failures, can potentially result in greater activity releases. The chemical reactions considered as possible hazards are combustion of $\mathrm{NaK}$ in the calciner vessel, explosion or burning of organic material in the process system, and decomposition of ammonium nitrate in the feed. Other chemicals in the process system are known to be inert or to exhibit slow reaction rates. Two situations are considered wherein fission product decay heat may present a hazard. One occurs if the calciner is shutdown with the bed in place and no means of cooling is available; the other situation develops upon loss of cooling air at the solids storage bins. The conditions under which these "accidents" may occur and the consequences are discussed in detail in the following paragraphs.

\subsection{Release of NaK Into the Calciner Vessel}

The use of NaK as a heat transfer medium for the WCF process introduces a potential hazard because of the high reactivity of this alkali metal alloy. Generally, this alloy will react with most compounds containing oxygen or halogens, and the rate and extent of reaction will depend upon the temperature, the amount of surface exposed, the manner of liquid metal dispersion, and the degree of containment of the reactants. In order to minimize the possibility of a NaK leak into the calciner, a special heat exchanger design employing duplex, bayonet-type tubes, and a helium-monitoring system was selected for the fluidized bed heater (Section VI-7). If a leak occurs in the outside tube, helium in the annulus between the inner and outer duplex tubes escapes and a drop in pressure is observed. If a leak occurs in the inner tube, NaK enters the helium chamber and a rapid pressure rise is observed. Appropriate high or low alarms indicate the location of the leak. Remedial action (it takes 30 seconds to stop the feed and 90 seconds to dump the NaK) is then taken before serious consequences can result. Obviously, a simultaneous rupture of both tubes is necessary before $\mathrm{NaK}$ can leak into the bed. Although the possibility of the occurrence is remote, the hazards of NaK leakage are examined in this section for the situation where no remedial action is taken. Three separate problems 
can arise under such conditions; these are (a) the possibility of an explosive hydrogen-oxygen reaction in the calciner, (b) the possibility of overheating the calciner, and (c) the possibility of an explosion downstream from the calciner.

3.11 Explosion in Calciner Vessel. It has been shown [8] that an explosion hazard will not exist if the ignition delay of $\mathrm{NaK}$ in air is very short, ie, of the order of milliseconds. The time for ignition to occur can be calculated on the basis that a critical source energy per unit area of flame wave must be exceeded. Based on the work of previous investigators $[9,10,11]$, the ignition delay has been estimated from the following equation for typical calciner conditions:

$$
\theta=\frac{\mathrm{kV}\left(\mathrm{T}_{\mathrm{a}}-\mathrm{T}_{\mathrm{n}}\right)}{\triangle \mathrm{H} \mathrm{U}^{2}}
$$

where:

$\theta=$ Ignition delay, seconds

$\mathrm{k}=$ Thermal conductivity of $\mathrm{NaK}$ at $700^{\circ} \mathrm{C}, 0.061 \mathrm{cal} /(\mathrm{cm})(\mathrm{sec})\left({ }^{\circ} \mathrm{C}\right)[12]$

$\mathrm{V}=$ Specific volume of $\mathrm{NaK}$ at $700^{\circ} \mathrm{C}, 1.4 \mathrm{cc} / \mathrm{g}$ [12]

$\mathrm{T}_{\mathrm{a}}=$ Adiabatic flame temperature, $2900^{\circ} \mathrm{C}$ [8]

$\mathrm{T}_{\mathrm{n}}=\mathrm{NaK}$ stream temperature, $700^{\circ} \mathrm{C}$

$\triangle \mathrm{H}=$ Heat of reaction of $\mathrm{NaK}, 50 \mathrm{cal} / \mathrm{g}$ [12]

$\mathrm{U}=$ Velocity of NaK through leak, estimated at $300 \mathrm{~cm} / \mathrm{sec}$ with $\mathrm{NaK}$ pressure in fluidized bed heater of 15 psig

$$
\theta=\frac{(0.061)(2900-700)}{(50)(300)^{2}}=4.2 \times 10^{-5} \text { seconds }
$$

Results of tests at Pratt and Whitney [8], in which hot NaK was atomized in air at room temperatures, indicate that the ignition delays were of the same order of magnitude as calculated by the above method. Therefore, it is apparent that a flame will appear virtually instantaneously if a leak occurs under the outlined conditions.

NaK leaking from the uppermost tube would enter the bed approximately one foot below the entrance of the atomizing spray. Assuming that the NaK would be transported upward at a velocity equal to the fluidizing air velocity, $1.0 \mathrm{ft} / \mathrm{second}$, it would take one second to reach the entrance level of the feed where the greatest possibility exists for copious quantities of water vapor to be present and where hydrogen may be formed. Probably of more importance in determining the time that might elapse before the NaK contacts constituents in the feed, however, is the size of the envelope created by the spray nozzles, ie, where liquid feed might exist. Because of the variety of factors involved, 
it is virtually impossible to estimate the time after NaK leakage begins at which the ratio of hydrogen to oxygen might exceed the lower explosive ratio of 0.19. If no NaK reacted with oxygen, ie, if it reacted only with water vapor and liquid nitric acid, it is theoretically possible to reach a hydrogen-to-oxygen ratio of 1.4; but, it is apparent from the competing reactions (Appendix $F$ ) that the actual ratio would be less. The auto-ignition temperature of hydrogen and oxygen $\left(609^{\circ} \mathrm{C}\right)$ will be exceeded virtually instantaneously by the temperature of the NaK-oxidizer flame front. For this and other reasons previously cited, it is believed that the possibility of a secondary hydrogen-oxygen reaction of explosive violence in the calciner is negligible.

3.12 Overheating of Calciner Vessel. The major result of a NaK leak into the calciner vessel will be the occurrence of rapid reactions between the NaK and oxidizing agents in the vessel. These reactions will release considerable amounts of energy (Appendix F) which will be dissipated as thermal energy absorbed by the solids and the reaction products, as sensible heat in the off-gas, and in heat losses from the calciner vessel by conduction, convection, and radiation. The interplay of these mechanisms along with the kinetics and completeness of the various reactions makes the derivation of the mathematical model very complex. However, with certain simplifying premises and assumptions, mathematical relationships between the NaK leak rate, time, and temperature have been developed. These premises, assumptions, and calculations are given in detail in Appendix F.

The equations for temperature as a function of burning time were developed by equating the heat input rates, ie, the sensible heat from the NaK, the sensible heat from the air, and the heat of reaction between the NaK and oxidants, to the heat absorption rates in the calciner environment, ie, the heat absorbed by the bed, the heat absorbed by the vessel wall, the heat absorbed by the NaK oxides, and the heat carried out by the off-gas. The development of these equations is covered in detail in Appendix F. For a leak rate of one gallon per minute, the following differential equation was obtained (Case I of Appendix F).

$$
\int_{t=400}^{t} \frac{d t}{48,590-114.3 t}=\int_{\theta=0}^{\theta} \frac{d \theta}{10.04 \theta+7.21 \times 10^{5}}
$$

where $\mathrm{t}$ is temperature, $\left({ }^{\circ} \mathrm{C}\right)$ and $\theta$ is time, seconds.

Upon integration and solving for $t$, the equation becomes:

$$
t=425-(24.9)\left(\frac{7.21 \times}{7.21 \times 10} 5 \frac{10^{5}}{+10.04 \theta}\right)^{11.4}
$$


Equations were developed in a similar manner to obtain temperature transients for the stoichiometric leak rate of $14.8 \mathrm{gpm}$ (Case II) and for a NaK leak rate of $205 \mathrm{gpm}$ (Case III). The calculated temperature transients for the three leak rates are shown graphically on Figure IX-1.

Of the three NaK leak rates considered, only the stoichiometric reaction rate of $14.8 \mathrm{gpm}$ would produce temperatures exceeding the maximum design operating temperature of $926^{\circ} \mathrm{C}$. This leak rate, however, would not raise the temperature high enough to melt the vessel walls. A discussion of the probable course of events at the three leak rates is presented below.

(1) NaK Leak of One Gallon Per Minute

For reasons cited earlier, the helium monitor for the heat exchanger would sound instantaneously. It is doubtful that a NaK leak of one gpm will be detected from an alarm of the calciner temperature recorder, TRA-WC-102-1, or the temperature controller TRCA-WC-102-1. With the controller set on automatic operation, the firing rate in the furnace will be reduced automatically to compensate for the heat input from NaK reactions. However, the level of NaK in the expansion tanks will decrease slowly as will the pressures in the NaK loop indicated by PI-WC-104-1 and PI-WC-104-2. The NaK level alarm in the expansion tanks would sound in 48 minutes.

(2) NaK Leak of 14.8 Gallons Per Minute

As was mentioned above, the highest instantaneous temperature would occur at a NaK rate of $14.8 \mathrm{gpm}$. The following sequence of events would occur.

(a) The helium monitor for the heat exchanger would sound almost instantaneously.

(b) The calciner high temperature alarm would sound in 8 seconds.

(c) The level alarm in the $\mathrm{NaK}$ expansion tanks would sound in 200 seconds.

(d) The maximum operating temperature, $926^{\circ} \mathrm{C}$, at normal operating pressure would be reached in 800 seconds, if remedial action were not taken to prevent the reactants from entering the calciner. (e) The maximum temperature attainable, $1375^{\circ} \mathrm{C}$, would be reached in 1820 seconds, by which time all of the available NaK would have been reacted. Thereafter, the calciner would cool.

(3) NaK Leak of 205 Gallons Per Minute

Initially, a NaK leak rate greater than the stoichiometric rate would cause a transient which would exceed that for the stoichiometric rate because 


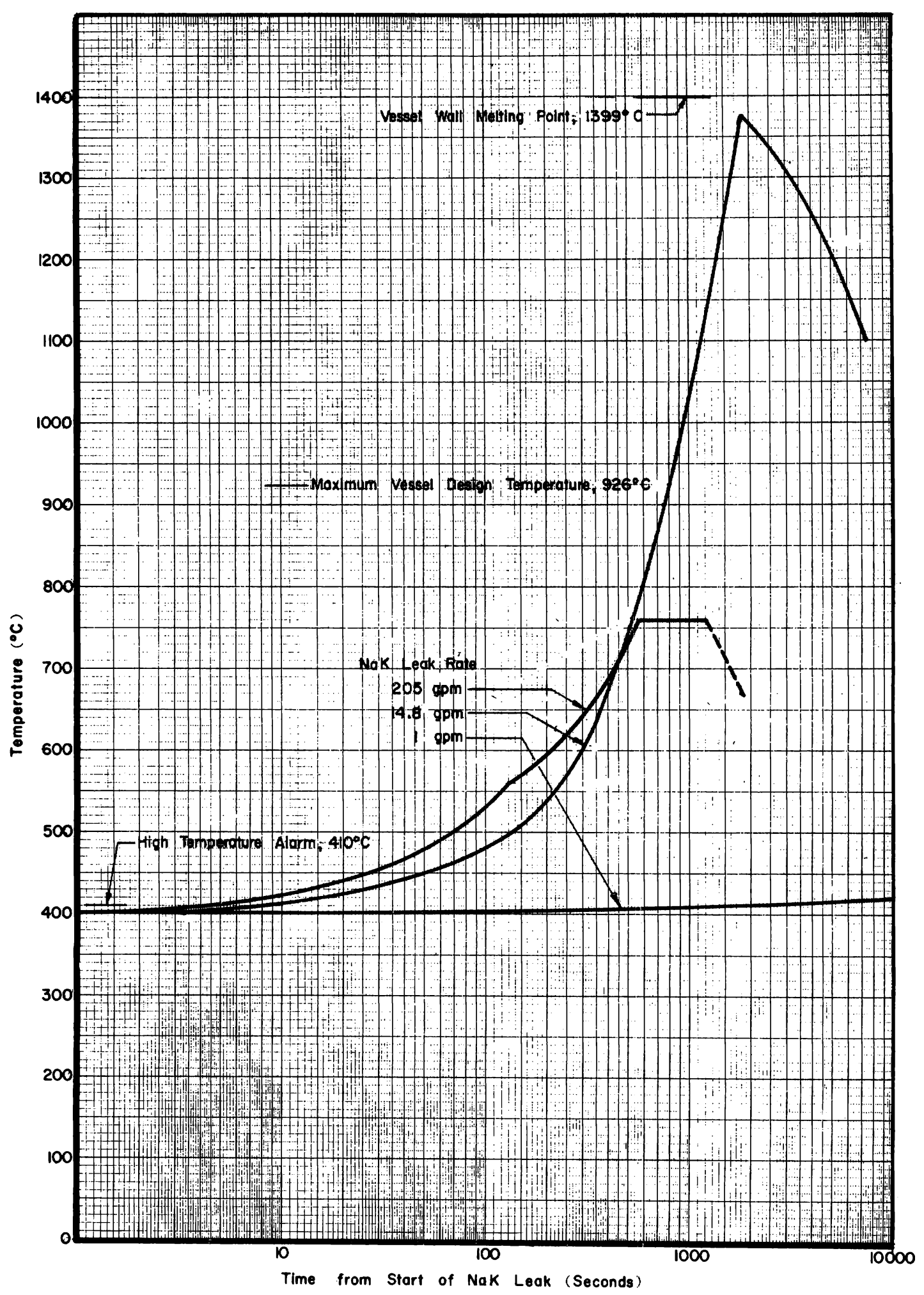

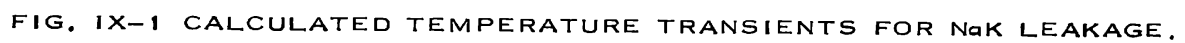


of the added heat input of the excess NaK introduced. After all of the NaK is introduced, the rate of temperature rise would be below that of the stoichiometric case because the excess $\mathrm{NaK}$ adsorbs heat and because the input of sensible heat from the $\mathrm{NaK}$ is stopped. If a leak rate of $205 \mathrm{gpm}$ were to occur, the following sequence of events would occur.

(a) The helium monitor on the heat exchanger would sound almost instantaneously.

(b) The calciner high temperature alarms would sound in five seconds.

(c) The expansion tank level alarm would sound in 14 seconds.

(d) All of the available NaK would have leaked into the calciner in 130 seconds, if no remedial action were taken.

(e) The bed temperature would continue to rise for 560 seconds until the boiling temperature of the $\mathrm{NaK}$ was reached. Thereafter the temperature would remain stable as the NaK vaporized.

(f) Vaporization would continue for an additional 635 seconds until the NaK was consumed. Thereafter the calciner would cool.

3.13 Explosion Downstream from Calcinex Vessel. Perhaps the most serious potential result of a NaK leak in the calciner, one which could happen only in the case of leaks faster than the stoichiometric rate $(14.8 \mathrm{gpm})$, is the carry-over of vaporized $\mathrm{NaK}$ from the calciner and the subsequent reaction of this NaK with the scrubbing solution. NaK, leaking at rates greater than the stoichiometric rate required to combine with all the oxidizers entering the calciner, would begin vaporizing as the temperature neared $760^{\circ} \mathrm{C}$. Absorption of heat by the vaporizing NaK accounts for the plateau in the temperature transient shown in Figure IX-1 for a leak of $205 \mathrm{gpm}$. The rate of NaK carry-over under such conditions is estimated at roughly $14 \mathrm{gpm}$. The reaction between $\mathrm{NaK}$, vaporized at this rate, and the scrubbing solution would evolve about $400 \mathrm{scfm}$ of hydrogen and release an estimated $75,000 \mathrm{kcal} / \mathrm{min}$ in the quench tower, sufficient to vaporize about $37 \mathrm{gpm}$ of water.

The likelihood of an explosive hydrogen-oxygen combination is difficult to assess, as the relative amounts of all gases present are dependent upon numerous factors, eg, NaK carry-over rate, air-sparging rate in the scrubbing solution tank, heat absorbed by the scrubbing solution, and the amount of steam formed. If such a mixture was formed, only the quench tower would be at a 
temperature high enough to ignite the mixture, and the most serious consequence of an explosion in the quench tower would be a rupture of the 10-inch off-gas line from the calciner cyclone. This would release radioactive solids into the off-gas cell at a rate equivalent to the normal cyclone carry-over rate of 7 to 8 pounds per hour. It is doubtful that all of these solids would be carried from the cell by the ventilation air; limited size distribution data [37] indicate that approximately 30 percent of the solids passing the cyclone are small enough $(<30$ microns) to be carried into the ventilation system. Furthermore, after the explosion pressure had subsided, the off-gas blowers would pull some of the released dust into the off-gas system, where it would be retained. The hazards of a dust release to the stack are discussed in Section IX-8.

Some pressure rise will occur whether or not an explosion takes place. Because of the complexity of the off-gas system, a rigorous quantitative description of the pressure rise is not feasible. However, there are several qualitative considerations that point to the self-limiting nature of such a pressure rise. Each off-gas blower is rated at 3230 inlet $\mathrm{cfm}$ with a pressure differential of 6.9 psi across the blowers. When there is a pressure increase in the system, the second blower will start up in parallel. It appears that this will carry away approximately two-thirds of the total volume. The solids storage bins, having a capacity of 8000 cubic feet, also will tend to slow the rise in pressure. A relief valve at solids storage will relieve to the ICPP stack through a high-efficiency filter at 2 psig. Also, a rise in pressure in the calciner to 2.3 psig will reduce the fluidizing air flow and stop the feed; both effects reduce the amount of oxidizing agents available and the rate of heat release.

\subsection{Organic-Air or Organic-Nitric Acid Reactions}

Oxidation and nitration of organic compounds are generally exothermic reactions which may be explosive or may result in the formation of explosive compounds. Therefore, the presence of organic materials in the process system might provide a possible mechanism for overheating or overpressuring equipment. The possibility of such reactions occurring in the WCF is quite remote, however, as organic compounds are not normally used or found in the WCF process systems. To get there, the organic material would have to be inadvertently introduced by one of the following means:

(1) Transfer of waste solution containing organic material into the waste hold tanks, 
(2) Overflow of lubricating oil from scrubbing solution pump bearings onto shaft seals and thence into the scrubbing solution surge tank,

(3) Inadvertent addition from decontamination system, or

(4) Inadvertent addition to the hot sump through cell and corridor building drains.

The possibility of a hazard being created by one of these means is minimized further by safety measures taken to preclude such "accidents" and the absence of conditions in the process system that would promote explosive reactions even if organic materials were present.

A surface sample (depth of nine inches) was taken from WM-185 tank and no organic interface or extraneous material of any kind was found. Inlet valves to this tank, which will provide the first feed to the WCF, are locked to prevent interim introduction of organic material into that tank. Previous samples taken from the bottom, middle, and top of all the first-cycle waste tanks also had shown no evidence of organic material (Section V-1). Blinds installed in all decontamination lines leading to process equipment prevent the accidental introduction of organic material through the decontamination system. Cleaning solvents such as trichlorethylene are used only sparingly in the WCF area. These solvents are normally collected and disposed of outside the ICPP area.

The nitration of paraffins, eg, lubricating oil, kerosene, solvents, is generally slight at the conditions found in the WCF [13]; nitrated paraffins generally cannot be detonated under heat, confinement, or impact [14]. In USAEC installations, two accidents involving liquid-phase nitric acid-organic systems have been reported $[15,16]$. These involved reactions at or above the boiling points of the mixtures $\left(130^{\circ} \mathrm{C}\right)$ and in concentrated aqueous solutions of metal nitrates. Temperatures in the WCF process tanks are normally below $50^{\circ} \mathrm{C}$ and steam coils in the tanks are not in use during normal operation. Air sparging of the tanks would tend to dilute vapors below combustible concentrations and to carry away volatile organic vapors. Sparking in the vapor space of process tanks is unlikely as all tanks are well grounded through floor mountings and connecting lines.

The spontaneous ignition temperatures of organic materials generally fall between 250 and $550^{\circ} \mathrm{C}$, and are heavily dependent upon environmental conditions, ie, pressure, atmosphere, presence of catalysts. For these reasons, the probability of ignition of organic compounds upon introduction in the calciner 
vessel cannot be definitely established without extensive investigation. In ANL tests, both sugar and kerosene were introduced with the feed to a pilot plant calciner with no unusual results [4]. Should ignition occur, prolonged operation with a high rate of input ( $>25 \mathrm{gph}$ ) of organic material might eventually overheat the calciner. The entry of the organic material can be stopped swiftly, however, by shutting off the feed, one of the first steps in all shutdown procedures.

\subsection{Decomposition of Ammonium Nitrate Present in the Feed}

The waste solutions proposed for initial processing in the WCF (Section V-1) contain only small quantities of ammonium nitrate - amounting to less than 2.5 pounds per hour in the 60 gallons per hour of feed solution from WM-182 or WM-185 waste tanks. A larger quantity appears in waste tank WM-180 amounting to a potential calciner input rate of 55 pounds per hour. Ammonium nitrate does not appear to present a hazard to the calciner operation because of the low concentrations in the feed to the calciner and the probable rapid decomposition of the ammonium nitrate in the calciner.

While the literature reflects some divergence of opinion on the degree of hazard involved in handling ammonium nitrate [17-21, 26-29], most investigators agree that when heat is applied to ammonium nitrate, the reactions shown in Table IX-4 are possible. Every reaction that forms ammonia requires energy while reactions consuming ammonia are spontaneous. Thermodynamically, ammonia should be consumed in the atmosphere of the calciner since reactions consuming ammonia proceed much more easily than reactions producing ammonia. It is conceivable that steam might shift the equilibrium of reactions consuming ammonia to form ammonia; experiments by Delsemme [22] seem to

\section{TABIE IX-4}

PROBABIE AMMONIUM NITRATE DECOMPOSITION REACTIONS

\begin{tabular}{|c|c|c|}
\hline Temperature ${ }^{\circ} \mathrm{C}$ & Reaction & Heat Produced Per Mole $\mathrm{NH}_{4} \mathrm{NO}_{3}$, $\mathrm{K}$ Cal \\
\hline 180 & $\mathrm{NH}_{4} \mathrm{NO}_{3} \rightarrow \mathrm{NH}_{3}+\mathrm{HNO}_{3}$ & -40 \\
\hline $180-200$ & $\mathrm{NH}_{4} \mathrm{NO}_{3} \rightarrow \mathrm{N}_{2} \mathrm{O}+2 \mathrm{H}_{2} \mathrm{O}$ & +13 \\
\hline 230 & $3 \mathrm{NH}_{4} \mathrm{NO}_{3} \rightarrow \mathrm{N}_{2} \mathrm{O}_{3}+6 \mathrm{H}_{2} \mathrm{O}+2 \mathrm{~N}_{2}$ & +21 \\
\hline $260-270$ & $4 \mathrm{NH}_{4} \mathrm{NO}_{3} \rightarrow 2 \mathrm{NH}_{3}+3 \mathrm{NO}_{2}+\mathrm{NO}+\mathrm{N}_{2}+5 \mathrm{H}_{2} \mathrm{O}$ & $-19 \cdot 5$ \\
\hline $260-270$ & $2 \mathrm{NH}_{4} \mathrm{NO}_{3} \rightarrow 2 \mathrm{~N}_{2}+\mathrm{O}_{2}+4 \mathrm{H}_{2} \mathrm{O}$ & +30 \\
\hline $260-300$ & $8 \mathrm{NH}_{4} \mathrm{NO}_{3} \rightarrow 2 \mathrm{NO}_{2}+4 \mathrm{NO}+5 \mathrm{~N}_{2}+16 \mathrm{H}_{2} \mathrm{O}$ & +19 \\
\hline$>300$ & $4 \mathrm{NH}_{4} \mathrm{NO}_{3} \rightarrow 2 \mathrm{NO}_{2}+3 \mathrm{~N}_{2}+8 \mathrm{H}_{2} \mathrm{O}$ & +30 \\
\hline$>300$ & $2 \mathrm{NH}_{4} \mathrm{NO}_{3} \rightarrow 2 \mathrm{NO}+\mathrm{N}_{2}+4 \mathrm{H}_{2} \mathrm{O}$ & +9 \\
\hline
\end{tabular}


indicate this would happen. However, there also will be large quantities of nitrogen dioxide present in the calciner atmosphere to counteract any such shift of equilibrium.

Since there is little possibility of ammonia being formed in the calciner, reformation of ammonium nitrate in the cooler parts of the process system also is improbable. Overtemperature then, rather than explosion, would be the most likely hazard, and, since the energy released from ammonium nitrate decomposition (up to 5 molar) would be less than the energy required for evaporation and calcination of the rest of the feed, a sudden release of energy is not probable. When calcining the waste from tank WM-180, which has the highest ammonium nitrate content, and assuming the reaction which would give the largest volume of gas per mole of reactant (reaction 5, Table IX -4 ), the gaseous product volume would amount to only about two percent of the total gas flow. These gases would be removed as soon as they were formed and could not be considered as "confined".

The physical factors which generally influence the sensitivity of solid ammonium nitrate toward explosion are temperature, confinement, impurities, initiation source strength, moisture content, density, packing, and particle size. The sensitivity of ammonium nitrate toward explosion may be increased by a number of materials [18, 23, 25, 30], but the only ones of concern in the ICPP wastes are carbonaceous material, chromates, and chlorides; these are present in such low quantity, however, that their effect should be negligible in the event of the extremely improbable formation of solid ammonium nitrate anywhere in the process system. Further, the alumina present in the calcination process should be an excellent diluent to minimize the danger of explosion.

Calcination studies have been performed in a six-inch diameter pilot plant calciner [24] using feed solutions containing 0.078 and 0.18 molar ammonium nitrate. No operational difficulty occurred.

\subsection{Overheating of the Calciner Vessel by Fission Product Heat}

The possible overheating of the calciner vessel by fission product heat dissipation during a shutdown in which the bed cannot be unloaded has been investigated. The calciner bed, weighing approximately 4500 pounds, will generate $1800 \mathrm{Btu} / \mathrm{hr}$ if produced from WM-185 waste or $67,000 \mathrm{Btu} / \mathrm{hr}$ if produced from 200-day cooled MTR-type waste. To assess consequences of such an occurrence, the calciner bed temperatures were estimated and temperature profiles plotted for a hypothetical situation in which the calciner was considered as an infinite cylinder, and the only heat losses were those occurring 
by convection and radiation from the cylinder wall to the cell atmosphere. Under these conditions, a 200-day cooled MTR- waste would reach the maximum calciner design temperature $\left(926^{\circ} \mathrm{C}\right.$ at normal operating pressure) at the vessel centerline in approximately 35 hours and would approach a maximum steady-state temperature (also at the vessel centerline) of $1630^{\circ} \mathrm{C}$. The calciner wall temperature, however, would never exceed an estimated $425^{\circ} \mathrm{C}$. A bed containing calcined WM-185 waste would actually decrease in temperature under the assumed conditions until it reached an equilibrium wall temperature of $60^{\circ} \mathrm{C}$ and an equilibrium centerline temperature of about $175^{\circ} \mathrm{C}$. The calculations supporting these estimates are given in Appendix D, as are detailed temperature profiles for the assumed cases.

The assumptions used to estimate these temperatures result in calculated temperatures in excess of those which would be encountered during an actual "accident". During a bed shutdown, the following two additional methods are available for dissipating the fission product heat generated within the calciner bed: (a) air flow through the bed (fluidizing air, nozzle air, purge air, or any combination of the three), and (b) forced circulation of unheated NaK through the calciner tube bundle. Details of these methods are summarized in Table IX-5.

\section{TABLE IX-5}

HEAT DISSIPATION SYSTEMS NORMALLY AVAILABLE

FOR CALCINER COOLING DURING SHUIDOWN

\begin{tabular}{|c|c|c|c|c|}
\hline \multirow{2}{*}{$\begin{array}{l}\text { Cooling } \\
\text { Medium }\end{array}$} & \multirow{2}{*}{$\begin{array}{l}\text { Coolant } \\
\text { Flow } \\
\text { Rate }\end{array}$} & \multicolumn{2}{|c|}{ Coolant Temperatures } & \multirow{2}{*}{$\begin{array}{c}\text { Heat Removal } \\
\text { Rate } \\
(\text { Btu/hr })\end{array}$} \\
\hline & & $\begin{array}{c}\text { Inlet } \\
\left({ }^{\circ} \mathrm{C}\right)\end{array}$ & $\begin{array}{r}\text { ortiet } \\
\left({ }^{\circ} \mathrm{C}\right)\end{array}$ & \\
\hline $\begin{array}{c}\text { Forced Circulation } \\
\text { of Nak }\end{array}$ & $39,000 \mathrm{ib} / \mathrm{hr}$ & 238 & 242 & $67,100^{[a]}$ \\
\hline $\begin{array}{c}\text { Fluidizing Air, } \\
\text { Nozzle Air, } \\
\text { Purge Air, }\end{array}$ & $394 \mathrm{scfm}$ & 100 & 4.00 & 268,000 \\
\hline Purge Air & 100 scfm & 100 & 400 & 68,100 \\
\hline
\end{tabular}


Forced circulation of $\mathrm{NaK}$ appears to be the most convenient method of cooling the bed because no off-gas cleanup is necessary; air flow through the bed would be a satisfactory second choice method. The only time air cooling through the bed could not be used would be in the event of a plug in the 10-inch off-gas line - a highly unlikely situation.

The presence of fission products in the calciner creates no hazard upon shutdown, therefore, except for fresh wastes and in the extremely improbably simultaneous loss of: (a) NaK pump, (b) fluidizing air blowers, (c) heating and ventilation system, (d) air sources to calciner, and (e) ability to procure additional equipment to circulate air through the calciner cell.

\subsection{Loss of Cooling Air at Solids Storage Bins}

The cooling air flowing through the solids storage vault is motivated by either the cooling air blower or natural circulation. As the existing bins will probably be filled with solids produced from the existing wastes in storage $(>5$ years old), natural circulation will provide adequate cooling and little use will probably be made of the cooling air blower with the present bins. The only means by which natural circulation can be cut off is through obstructions in the ducting and cooling air passages. Above grade, any obstruction (plugged filter, covered inlet) may be easily removed. No mechanical equipment or filters are located in the ducting below grade, so the only conceivable manner in which the air flow could be permanently stopped there would be through a major catastrophe which would completely rupture the bins or vault walls. Major catastrophes are discussed in Section IX -7 .

Should a bin leak and spill radioactive solids into the cooling air stream, it will be necessary to shut off the cooling air temporarily whenever changing outlet filters. This temporary loss of cooling air presents no problem, however, as explained in Section IX-4.4.

4. ACTIVITY RELEASE FROM SYSTEM FAILURE BY CORROSION, ABRASION, OR VIBRA TION

Operating conditions of the waste calcination process are such that all process vessels, equipment, and piping are stressed to a very low level, far below their ultimate strength. Consequently, corrosion, abrasion, or vibration would not be expected to result in a major failure, eg, vessel rupture, in which gross amounts of activity would be released into the operating cells. Rather, 
failures of this type, if they occur at all, should be progressive, appearing first as small openings. This should allow time for detection of the activity release and for the necessary process changes before the failure assumed major proportions. There also is a strong likelihood that impending failures of this type would be detected and corrected during periodic plant shutdowns. It is difficult to predict where failures of this type would occur, as long term experience is often the only accurate gauge of material performance. Material selection for the WCF was based largely upon previous experiences in the fuel processing facility, upon pilot plant calciner testing, and upon the experience obtained during the 3700 operating hour WCF test program (Sections VI-1 and Appendices $\mathrm{H}$ and $\mathrm{J}$ ). At all locations where necessary, questionable materials have been replaced with superior materials. There are numerous locations throughout the WCF where failure from corrosion, abrasion, or vibration can conceivably occur, and it is impractical to discuss each case separately. To assess the hazards resulting from failures of this type, the equipment has been divided into four general categories for discussion,ie, off-gas piping, vessels or piping containing solids, vessels or piping containing liquids, and solids storage bins.

\subsection{Off-Gas Piping or Vessels}

Any break in the integrity of the off-gas piping, adsorbers, or filter cases should not result in release of appreciable activity because the system operates under subatmospheric pressures ranging from 5.91 to 10.75 psia. The first indication of a leak in this equipment would be a loss of ability to maintain the system vacuum. By analysis of available pressure data, a break in this system could be located and measures could be undertaken to correct the trouble or initiate a shutdown. No serious release of activity should occur.

\subsection{Vessels or Piping Containing Dry Solids}

The principal equipment items containing dry solids are the calciner, calciner cyclone, solids transport piping, and the solids storage bins. All of these items are normally under a vacuum, except for approximately a one-foot section of the calciner vessel immediately above the air distributor plate and the solids storage bins when they are not being filled. The solids storage bins are considered separately in Section IX-4.4. Progressive failures in equipment under vacuum, such as any in the off-gas system, should not release appreciable activity and should be detected from the accompanying change in the system pressures. A leak in or near the lowest one-foot section of the calciner, where pressures are above atmospheric, would allow radioactive solids to be discharged 
into the cell. The most likely type of failure in that section is the abrasion of the $1 / 2$-inch product takeoff line. Based upon experience with the product takeoff line, solids would be ejected to the cell at a rate of approximately $100 \mathrm{lbs} / \mathrm{hr}$ if the line was to break near the calciner vessel wall. Of the solids dumped to the cell, at most 0.1 percent (Figure V-4) are small enough (30 microns or less) to be carried from the cell by the ventilation air (velocity in cell is approximately 0.13 foot/second). This release is equivalent to 0.2 curie/ $\mathrm{hr}$ if the solids are produced from wastes now in WM-185 tank; or 9.6 curies/hr for a 200-day cooled waste. The first indication of a release would be the alarm on the stack gas monitor; this would be followed by a dropping bed level if the release into the cell was above 25 to 30 pounds per hour. During the shutdown operation, this release rate could be reduced by lowering the calciner pressure.

\subsection{Vessels or Piping Containing Liquids}

A number of equipment items throughout the feed, scrubbing solution, regeneration solution, and waste handling systems contain radioactive liquids under sufficient pressure to leak into the cells should the equipment item fail from corrosion, erosion, or vibration. Liquid leaks should not be as serious as solids releases because liquids ordinarily do not create fine aerosols as a dry product would. Just as in the case of a release of solids, a leak in the liquid-containing equipment should be detected through either the ICPP stack monitor or from the liquid level instrumentation provided. In only one cell, the off-gas cell, would the liquids in the cell overflow the floor basin into the inhabited corridors. To do this, both the regeneration solutions drum $(5500$ gallons) and the scrubbing solution tank (2000 gallons) would have to rupture simultaneously. Liquids leaking into the cells drain to the hot sump tank, and decontamination sprays are provided in the cells to wash any residual liquids into the drains.

\subsection{Solids Storage Bins}

Failure of the solids storage bins would release solids onto the vault floor or into the cooling air stream. Small amounts of solids collected on the floor of the vault create no problem except, possibly, if water were to seep through minor cracks in the vault walls. A sump is provided to collect such seepage, and an alarm and jet are furnished to indicate the liquid level and to remove the liquid.

Solids elutriated by the cooling air stream present a more difficult problem. While up to five weight percent of the material lost from the bins could be 
elutriated from the cooling air channels (where the air velocities vary from 3 to 5 feet per second for natural and forced convection, respectively) into the vault, only 1.5 to 2.0 weight percent would reach the cooling air outlet duct (the air velocity in the vault above the bins is roughly 0.1 to 0.3 feet per second). The bulk of these solids would be trapped on the high efficiency filter in the outlet duct. A radiation alarm is provided in the cooling air stack to alert operating personnel of the activity release. To change outlet filters, the cooling air flow must be stopped or workers would be subjected to release of the uncleaned cooling air while the filters were removed (Section VI-6). This flow can be stopped by covering the inlet filters. Temperature rise in the bins is slow without the cooling air flow $\approx 2^{\circ} \mathrm{C}$ per hour for two-year cooled waste and $\approx 0.5^{\circ} \mathrm{C}$ per hour for WM-185 tank waste, ignoring heat losses) so that considerable time is available for changing the outlet filter before temperatures anywhere in the bins reach design limits. Numerous thermocouples are provided in the bins for monitoring those temperatures (Section VI-6.2).

The continued use of filters in the cooling air system is undesirable from the expense standpoint. For that reason, valves have been installed in the cooling air ducts which will close automatically at the first sign of activity in the cooling air. This permits normal operation without the filters in place; following such an event, the filters would be installed and replaced thereafter as necessary.

As an alternative measure, consideration is being given to installing a closed-loop cooling system in which the heat would be transferred from the cooling loop through a new finned heat exchanger to the atmospheric air. With such a system, no contaminated cooling air would be released to the surroundings in the event of a bin rupture. Figure IX-2 shows this possible cooling system along with the present system. Unless, or until, such an alternate measure is adopted, it will be necessary to maintain at least two sets of absolute filters on hand at all times for possible installation in the present cooling air outline line.

Corrosion is not a problem if the stored solids are dry. Moisture could conceivably be introduced into the bins if wet silica gel were transported there. The silica gel, however, would normally be dried prior to transporting to the bins in order to prevent plugging in the transport lines. The only other conceivable means by which liquids could reach the storage bins is through the decontamination of the solids transport lines or a break in the cooling coils of the off-gas trap, WC-116. Two decontamination lines are located in the vicinity 


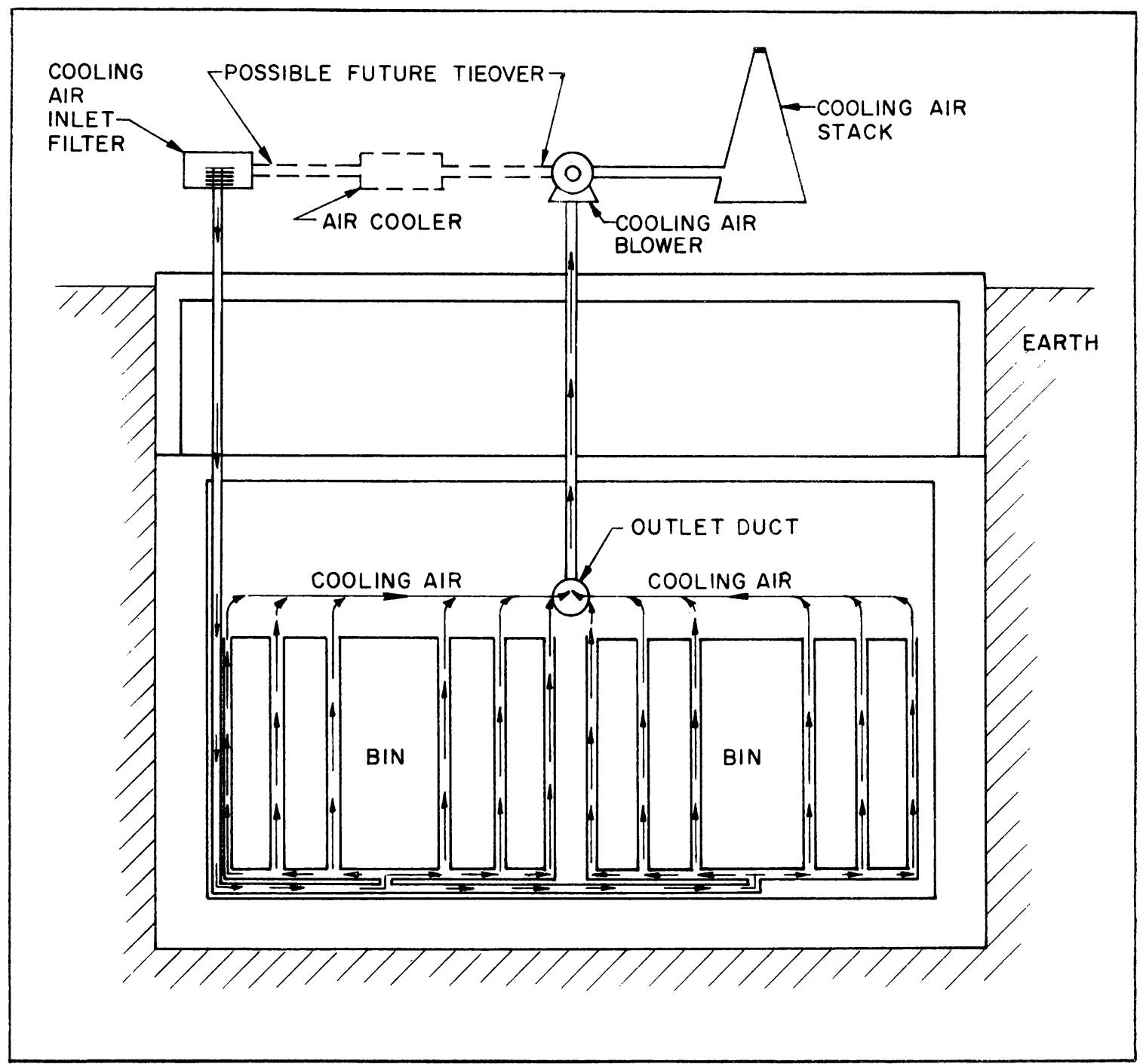

FIG. IX-2 COOLING AIR SYSTEM AND PROPOSED CLOSED-LOOP COOLING SYSTEM.

of the solids storage area; block valves, on each side of the solids storage cyclone, isolate the solids transport line from the solids storage bins. Thus, in order to get liquid into the bins, the decontamination lines would have to be in use, and the block valves would have to be either leaking or inadvertently left open. Liquids collected in the off-gas trap, whether condensed from the bin off-gas or leaking from a broken coil, drain into a receiver equipped with a level alarm (Section VI-6). The heat generated by the fission products would vaporize any liquid reaching the bins.

Abrasion presents no problem. The solids flow into the bins by gravity, and once in the bins, there is no further particle movement to cause abrasion. 
Vibration is expected to have a negligible effect on solids storage bin failure, as there is no moving machinery present in the storage cell. The only movement present would be cooling air in the annuli; this would be expected to have no effect on the bins, since the velocity is low (around $5 \mathrm{ft} / \mathrm{sec}$ ).

\section{ACTIVITY RELEASE IN THE WCF FROM OVERPRESSURE OF EQUIPMENT}

The sources from which process equipment can potentially be subjected to pressures higher than normal and thereby endanger equipment or personnel include: (a) steam supply (120 psig), (b) compressed air supply (100 psig), (c) water supply (80 psig), (d) scrubbing solution pumps (40 psig), (e) decontamination solution pumps (50 psig), and (f) the fluidizing air blowers (8 psig limited by slipping drive belts). Piping in the facility can generally withstand the maximum pressures exerted by each of these means; vessels, on the other hand, are designed for lower pressures ranging from 3.75 psig (solids storage bins and vessels) to $30 \mathrm{psig}$ (waste hold tanks, scrubbing solution surge tank, quench tower, etc). Other pressure-sensitive points in the process system include bellows in the off-gas piping ( $30 \mathrm{psig} \max$ ), bellows in instruments (vary from 5 to 150 psig), scrubbing solution pump and off-gas blower shaft seals (will allow backflow to environment at any pressure above atmospheric on process side), and the operating corridor and sample room floor drains (protected by 40 -inch liquid seal loops in the drain lines to the hot sump tank). Relief valves provided on the gas systems include a two-psig valve at the solids storage bins and a fivepsig valve on the primary off-gas system upstream of the adsorbers. The relief valve at solids storage discharges directly to the ICPP stack; the relief valve on the off-gas system discharges into the north adsorber cell. Gas released into the adsorber cells is carried to the ICPP stack if the cell ventilation system is operating.

The amount of activity that could be released should the pressure in the gas systems rise above ambient is difficult to assess as the extent of release depends primarily upon the speed with which the overpressure situation is corrected. Activity release through the off-gas blower and scrubbing solution pump seals would be slight because of the normal tightness of the seals. Such activity released through the seals would be carried to the ICPP stack by the cell ventilation air. Gases released through the relief valve in the off-gas system are relatively clean, having passed through the scrubbing system. 
The greatest hazard represented by a release through this valve is equivalent to the situation of bypassing the adsorbers and filters as previously discussed in Section IX-2. Gases released by opening the relief valve at the solids storage bins pass through an AEC high efficiency filter before being discharged to the atmosphere through the ICPP stack and are therefore relatively clean. The floor drains in the sample room and operating corridor floors likewise present no great hazard if vessel sparge rates and liquid levels in the vessels are maintained at or below normal operating levels. Activity released through these drains can result only from entrainment in the sparging air used in tanks connected to the equipment system. An estimate [31] of the entrainment from the hot sump when containing 4-1/2 feet of liquid (30-inch freeboard) and when being sparged at $100 \mathrm{scfm}\left(\approx 1 \mathrm{scfm}\right.$ air $/ \mathrm{ft}^{2}$ liquid surface $)$ is approximately $6 \times 10^{-12} \mathrm{lbs}$ liquid/lb air. The activity of a mist of this type would still be below the MPC of radionuclides [1] in air even if the liquid entrained were 200-day cooled waste. All process vessels and equipment containing radioactive material are connected to the primary off-gas or equipment vent systems which are maintained under a vacuum during operation. To pressurize any of the vessels or equipment to higher-than-normal pressures, one of the following accidents or failures must occur: (a) a blower failure, (b) an accidental closing of a valve, or (c) the plugging of a line. The effects of such accidents are discussed in detail in the following paragraphs.

\subsection{Loss of Off-Gas Blower or Equipment Vent Fan}

The effects of a total electrical outage in which the off-gas blowers and equipment vent fan are rendered inoperable are discussed in detail in the section on utility failures (Section IX-6.1). In the event of a loss of only the off-gas blowers, the fluidizing air blowers and air purges would continue to pour considerable air into the calciner and off-gas system. If corrective action were not taken soon, the system pressure might build up to 2.5 to 3 psig and open the relief valve on the solids storage bins. The large volume of the bins, however, slows the pressure buildup allowing operating personnel three to five minutes in which to shut off the fluidizing air blowers and reduce the purge air input into the system. A bypass line between the off-gas system and the equipment vent system also could be opened to hold the off-gas system pressure down.

If the equipment vent fan failed, the equipment vent system pressure would rise because of the air used on sparging and air-lifting, but should not rise high enough to blow the 40 -inch water seals in the operating and sample room drains. 
Again the bypass between the off-gas and equipment vent systems could be opened, and the off-gas blowers could be used to hold down the equipment vent system pressure.

\subsection{Accidenta1 Valve Closure}

Valves which may be accidentally closed to overpressure the calciner and off-gas systems include the adsorber isolation valves, the butterfly control valve at the blower suction, and the off-gas blower discharge valves. In the event the system is blocked in this manner,fluidizing and purge air will raise the system pressure rapidly to two psig when the relief valve at the solids storage bins will open. A further increase in pressure to five psig will open the relief valve on the primary off-gas line. To prevent blocking the off-gas system during a utility failure, all valves are designed to open on loss of instrument air.

The only valves in the equipment vent system are those isolating the equipment vent blower and filter. These valves will be locked and kept under administrative control to minimize operator errors which mayclose this system. If one of these valves is closed, gas pressure built up by air sparges and purges would be relieved into the operating corridor and sample room through 40 -inch water seals provided in the drain lines from these areas.

The solids storage bins and vessels, equipment vent fan, the adsorber vessels, and all filter cases (ie, off-gas filters, equipment vent filter, solids storage off-gas filter) are the only individual equipment items that can be isolated from the process gas systems by closing valves. The solids storage bins and vessels are protected against overpressure by a relief valve (two psig) and the absence of any high pressure steam or air connections leading into the bins. Relief valves also are provided on the equipment vent fan (five psig) and the adsorbers (five psig). The primary off-gas filters are protected against overpressure by a relief valve (five psig) on an air purge line which is the only manner in which the cases can be pressurized. There are no means by which either the equipment vent filter case or the solids storage off-gas filter case can be pressurized if isolated by closed valves.

\subsection{Line Plugging}

During the WCF test program, it was found that line plugging resulted from one of two causes - either an excessive concentration of solids in the scrubbing system or the drying of aluminum nitrate or a slurry on hot surfaces. These problems are illustrated by the following cases of plugging experienced, the causes of which have been removed in each case. 
(1) Steam leaking through a decontamination spray is believed to have plugged the calciner cyclone on one occasion.

(2) Scrubbing solution carried past the primary de-entrainment separator (prior to installation of secondary separator) dried on and partially plugged the tubes in the off-gas heater, WC-305. (3) The drain lines from both the quench tower and primary de-entrainment separator plugged at high undissolved solids concentrations in the scrubbing solution (5 to 10 percent).

(4) Feed solution splashed into, dried, and plugged the equipment vent line in the calciner cell.

The conditions which foster plugging have been largely eliminated by improved operating procedures and equipment modifications. No plugging occurred in the scrubbing system for the final 2000 hours of test operation in which the solids carry-over from the calciner cyclone was reduced to the 7 to $12 \mathrm{lb} / \mathrm{hr}$ range. Leakage of steam into the dry solids systems was traced to leaking three-way plug valves in the decontamination piping. These valves are isolated by line blinds while the plant is in operation. A secondary de-entrainment cyclone was installed downstream of the primary de-entrainment cyclone to minimize liquid carry-over into the off-gas heater. A condenser was installed and the piping rearranged in the equipment vent system to eliminate liquid carry-over in that system. Level instruments were installed on the quench tower and de-entrainment cyclones to give indications of plugged outlet lines.

In the event lines do become plugged, the pressure buildup would be relieved through the same routes and in the same manner as discussed in the previous section (5.1) - pump and blower seals, operating corridor and sample room floor drains, and system relief valves.

\section{EFFECT OF UTILITY FAILURE}

Failure of the electrical, water, steam, or air supply to the WCF is greatly minimized by the use of an emergency power generator and spare steam boilers, spare air compressors, and spare water pumps in the ICPP utility system (Section IV-4). Loss of these services could occur, however, if the supply lines into the facility are cut, or through other unlikely events. No release of activity would result, though it would be necessary to shut the facility down if any of 
these utility systems failed. The consequences of utility failures are discussed in detail in the following subsections.

\subsection{Simultaneous Failure of Both Normal and Emergency Electrical Systems}

Loss of electrical power to the WCF would shut down all electrical equipment and only those critical equipment items connected to the emergency power circuit (Section VI-8.2) would return to service automatically when the power is resumed. Other equipment items must be restarted by operating personnel. Included with the electrical equipment shutdown by loss of electrical power is the radiation monitoring equipment (excluding portable units usually carried by Health Physics personnel). For this reason, operating personnel would clear the building soon after becoming aware of the failure. The outlet valve from the feed tank (WC-105) closes on electrical failure. Failure to close this valve would not result in a release of activity, but the continued flow of feed into the calciner would create cakes difficult to remove. Battery powered lights, automatically energized by the power loss, would provide lighting for operating personnel leaving the lower building levels. Access can be regained as soon as Health Physics personnel establish that no activity has been released in the building.

Although all alarms would be de-energized during a power loss, the situation would be immediately apparent. The NaK pump, the NaK furnace, the fluidizing air blower, the scrubbing solution pump, the off-gas blower, the equipment vent fan, and the cell ventilation blower would stop immediately. If the compressed air supply was uninterrupted, a large amount of purge and sparge air would continue to flow into the calciner and other process equipment, placing the process system, storage bins, and equipment vent system under a slight positive pressure. All valves in the off-gas system and equipment vent system would remain open, permitting this air to flow to the ICPP stack. The positive pressure created in the process equipment by this air flow is approximately one psig - well below the relieving pressure of the relief valves in the off-gas system (five psig) and at solids storage (two psig) and the 40-inch liquid seals in the operating corridor and sample room floor drains. Some activity might be released into the process cells through the shaft seals on the off-gas blowers and scrubbing solution pumps. This release would probably be slight as the seals are normally tight fitting and the gas escaping has passed through a filter or consists mainly of tank sparging air. Check valves in the fluidizing air and transport air lines insure that activity would not back up into the building through the fluidizing air blower suction. All other lines extending from the process equipment to 
personnel areas, except the sample gallery vent, contain normally closed valves and generally also a check valve. The vent line from the sample gallery to the equipment vent system contains an air-operated valve that closes on failure of either the air or electrical supply. The adsorber bypass valve, which was installed to prevent system overpressure if all adsorber valves were inadvertently closed, would open as the off-gas system pressure rose. This valve would have to be closed from the operating panel prior to vacating the building or the hot purge gas emanating from the calciner might damage the off-gas filters. The effect of bypassing the adsorbers, other than overheating, is discussed in Section IX-2. Small amounts of contaminated gas might back up into the facility through the cell ventilation system from the ICPP stack as the pressure at the base of the stack is occasionally above atmospheric pressure. The cell ventilation line could be blocked outside the process building by inserting a blind between flanges at one end of the cell ventilation blower.

\subsection{Failure of Compressed Air System}

Loss of the main compressed air supply at the WCF would not result in an immediate shutdown as a failure of the electrical service would. All air for tank sparging, atomization of feed, motivation of the cyclone fines jet, lifting the feed solution, calciner pressure-control bleed, and product takeoff dilution would be expended almost immediately, but the $600 \mathrm{scf}$ held in the Instrument Air Receiver would provide air to control valves and minor purges for 5 to 10 minutes after loss of the 100 psig air supply occurred. A vacuum would continue to be maintained on the calciner, off-gas system, solids storage bins, and equipment vent system by the off-gas blowers and equipment vent fan. All pneumatic valves in these gas systems would open upon loss of instrument air and the off-gas blower and equipment vent fan would continue running so that fluidizing, transport, and purge air would continue to flow to the ICPP stack and no overpressuring of the gas handling systems would occur. Since there is little chance of activity release into inhabited areas in view of the vacuum in the process equipment, personnel would be able to remain in the facility and undertake an orderly shutdown; feed to the calciner is shut off automatically as the feed flow control valves would close upon loss of instrument air. Operators would be warned promptly of the air loss through low pressure alarms provided

on the 20 psig and 50 psig instrument air headers as well as on the 100 psig air supply. 


\subsection{Failure of Steam System}

Loss of the steam supply to the WCF affects the process only in that all heaters using steam would go out of service. The heaters (off-gas heater, offgas reheater, transport air heater, and equipment vent heater) are used only to superheat the humid process gases to eliminate condensation in the piping system and prevent plugging of the filters by the moisture. Immediately upon becoming aware of the loss through an alarm actuated by low steam pressure, operating personnel could take steps to reduce the humidity of the gas in the product transport system, gas leaving the venturi scrubber, and the equipment vent gas. These include stopping the feed, shutting down the NaK furnace, lowering the temperature of the off-gas leaving the scrubbing system (by increasing the water flow to the scrubbing solution cooler, WC-307), shutting off all tank sparges, placing a regenerated adsorber on stream(if available) and lowering the system vacuum. Further possible steps to prevent condensation in the process off-gas piping include closing the ventilation dampers to the adsorber manifold cell, filter pipe tunnel, and filter cells, thus preventing cold air being drawn into these areas. After these steps are taken, an orderly shutdown could be undertaken with little or no chance of plugging the filters with condensed moisture. The large amount of heat retained in the equipment and process cell walls (heating of these up to operating temperatures takes a week) would hold the piping temperatures above the reduced gas dew point for several days. The consequences of filter failures are examined in Section IX-2.4.

\subsection{Failure of the Water System}

Uses for water in the WCF process system include cooling of the scrubbing solution (in WC-307), cooling of the equipment vent gas (in WC-130), cooling of the gas released from the solids storage bins (in WC-116), cooling of the off-gas blower shaft seals, cooling of the oil in the off-gas blower lubrication system, and purging of instrument lines in the scrubbing system. While the loss of water for these uses would not result in any immediate activity release, continued operation of the facility would possibly result in blower and filter failures. Loss of scrubbing solution cooling would allow the saturation temperature (and water content) of the gas leaving the venturi scrubber to rise, which eventually could lead to condensation in the off-gas system and possible filter plugging. This can be prevented by shutting off the calciner feed and the NaK furnace as soon as the loss of water is established (a low water pressure alarm is 
provided on the main operating panel). The scrubbing system would than act as an evaporative cooler, resulting in a reduced saturation temperature (and water content) of the off-gas leaving the venturi scrubber.

The equipment vent condenser was installed to reduce the amount of liquid entrained in the equipment vent gas. Loss of cooling water to the equipment vent condenser would allow any liquid in this stream to pass on to the equipment vent heater and equipment vent filter. The amount of entrained liquid normally found in the equipment vent gas is very low, however, and could be reduced still further by lowering the air sparging rates on the waste hold tanks and hot sump. During the WCF test program, before the equipment vent condenser was installed, filter life varied from one hour to several days, depending on the air sparging rates used. Under the highest sparging rates, there is still adequate time to shut the facility down in an orderly manner.

Likewise, loss of the supply of cooling water to the off-gas blower shaft seals and oil cooler would not create an immediate crisis as the heat quantities in question are low, allowing the blower to be run for 10 minutes or longer after the water supply fails. Additional running time could be gained by switching to the spare blower. This is adequate time to shut the process system down; after the shutdown, vacuum may be maintained on both the equipment vent system and process off-gas system by the equipment vent fan, the operation of which is not dependent upon cooling water.

The cooling coils in the solids storage off-gas trap, WC-116 (Section VI-6) were installed primarily to remove the heat generated by fission products trapped in the wire mesh contained in the trap. It is anticipated that this heat load would be extremely low or non-existent. Radiative and convective heat losses would prevent the vessel from reaching temperatures endangering the vessel integrity should the water supply fail.

Loss of water for purges constitutes more of a nuisance than a hazard; the only foreseeable problem resulting from loss of purge water is possible plugging of some of the instrument probes.

\section{ACTIVITY RELEASE FROM MAJOR CATASTROPHES}

Unlike most other industrial facilities, nuclear facilities can add considerably to the damage resulting from the catastrophe if a criticality accident were to occur, or if large amounts of radioactivity were to be released. For this reason, 
the likelihood of radioactivity release accompanying a catastrophe and the extent to which the release adds to the hazardor damage accompanying the catastrophe are examined in this section. The only catastrophes that conceivably could inflict major damage upon the WCF (and the ICPP) are floods, earthquakes, and nuclear attacks. Fire does not present a major hazard because of the fire resistant nature of the steel and concrete structures, and the limited use of inflammable materials in the process.

\subsection{Floods}

The desert-like area in which the NRTS is located has a less than remote chance of ever being flooded. The nearest major river, the Snake, lies 50 miles east. Smaller streams, eg, Big Lost River, Little Lost River, and Birch Creek, disappear into the porous lava formations underlying the site (Section III). Even disregarding water seepage into the porous ground, filling the NRTS basin with water would require the full flow of the Snake River for several years, and the resulting reservoir would be larger than that backed up by Grand Coulee Dam. Such an event could not take place without a major change in the area topography.

Localized flooding conditions have occurred at the NRTS during spring runoff periods, but none have affected the ICPP area in the ten-year period the ICPP has been in existence. Should floods reach the WCF area, entry into the solids storage vault could be made only through minor cracks in the vault walls or through the overhead hatch. A sump is provided to collect seepage into the vault; the level in the sump is monitored and the seepage can be jetted outside for disposal. To flow into the vault hatch, the flood water would have to rise nine feet above the surrounding area, essentially a flat desert plain. When fully loaded, the bins will not float.

The solids storage bins, therefore, present a hazard no greater than does the present tank storage during flooding conditions; in fact, they are much safer than the tanks as the rate of diffusion of activity from a ruptured solids storage vessel during a flood would be considerably less than that from liquid tank storage in a similar situation. Activities in the calciner building, ICPP-633, present no hazard, as the process would be shut down if flood water endangered the building.

\subsection{Earthquake}

Unlike a flood situation, an earthquake gives no advance warning and thus poses the additional hazard of upsetting the process while it is in operation. The NRTS area is classed as a moderate (Class II) earthquake zone, and at 
movements of this intensity, no damage to the facility or storage bins is anticipated. The most likely cause of trouble would be the disruption of utility lines to the facility. The consequences of such losses have already been discussed in Section IX-6.

Earth movements sufficient to rupture process vessels, including the calciner and solids storage bins, would have to be of sufficient magnitude to break cell walls and probably destroy other facilities at the NRTS. In this event, the only way the WCF could add significantly to the overall release would be through atmospheric contamination by radioactive dust from the calciner vessel or solids storage vessels. Most of the solids in the calciner and storage bins would be confined to the immediate area; an estimated three percent of the solids are small enough ( $<10$ micron) to be carried as dust in the atmosphere but it is difficult to imagine a circumstance that could result in separation and dispersal of more than a small fraction of this material. In the case of WM-185 tank waste and the present solids storage bins, the total material smaller than 10 microns contains roughly 300,000 curies. The strontium in these solids amounts to 120,000 curies or approximately what is produced by a one-megaton fission bomb [34]. Loss of cooling air flow (either total or partial) would probably accompany any major rupture of the bin and vault walls. A detailed analysis of the temperature transients that would result if cooling air flow ceased is an extremely complex mathematical problem and was not undertaken in this study because of the marginal benefits of results. However, a few runs were conducted on IBM 650 and 7040 computers for simplified models of this situation when storing solids produced from WM-185 tank (aged five years). The results of these indicated that the bin wall temperatures would rise well above $343^{\circ} \mathrm{C}$ (maximum design temperature) and that centerline temperatures would rise well above the temperatures at which fission products may begin to volatilize $\left(700^{\circ} \mathrm{C}\right)$. No gross evolution of activity should occur even then, as any volatilized material would condense and solidify as it migrated away from the hot bin centerline towards the colder peripheral regions.

\subsection{Nuclear Bomb Hit}

Both the calciner building and the solids storage vault, being largely underground, are well protected from nuclear bomb damage, except in the case of a near hit (within $\approx 1$ to 2 miles for a 10 to 40 megaton bomb). A 20-megaton surface blast will form a crater 3400 feet in diameter by 800 feet deep [32]. Damage to heavy underground structures near such a blast varies from severe 
at 2100 feet from impact center to light at 4250 feet from the impact center [33]. The solids storage vault, being more compact, probably would withstand a heavier blast than would the present liquid storage tanks. Thus, operation of the WCF should decrease the hazard presented by such a catastrophe.

A rough assessment of the hazard the WCF represents under a nuclear attack can be made by comparing the activity release of a bomb, the activity in solids storage, and that presently already released to the environment by nuclear bomb testing. The present solids storage bins, when full of solids produced from existing liquid wastes, will contain approximately $3 \times 106$ curies of strontium-90 - roughly equivalent to that produced from a 30-megaton fission bomb [34]. The stratospheric and ground burdens of unconfined strontium-90 have been estimated as $0.2 \times 10^{6}$ and $5 \times 10^{6}$ curies, respectively, in 1961 [35] and are probably several times higher at present. It is apparent that release of the total radioactivity to be contained in the WCF and first storage bins would not add grossly to the activity release of a direct bomb hit. When contemplating the storage of the large amounts of radioactive wastes that will result from the expanding nuclear energy program, however, these factors become more important and may provide a justification for limiting the amount of waste stored in a single location. Such a study is beyond the scope of this report.

\section{RADIOLOGICAL HAZARDSOF ACTIVITY RELEASES FROM WCF ACCIDENTS}

As shown in the proceeding sections, radioactive material released in all the postulated accidents, except the major catastrophes, will pass through the 250-foot high ICPP stack. The release of activity to the atmosphere through the stack poses three types of radiation hazards: (a) direct radiation from the plume, (b) radiation from particulate solids deposited on the ground from the plume, and (c) ingestion or inhalation of the activity in the atmosphere or on the ground. An exact assessment of the radiological ha zards resulting accompanying WCF accidents is difficult to make because of the many factors involved, such as the amount of release, weather conditions, and particle size. However, an attempt has been made to provide a general picture of the potential radiological hazard by calculating the radiation levels or exposures for several postulated extreme situations following an accidental release. 
Ingestion or inhalation of particulate solids and contamination of large areas are the greatest hazards of an activity release. Direct radiation is a lesser problem. Of the fission products, strontium-90 presents the greatest hazard because of its solubility and long retention in the body skeleton. Cerium144 is also sometimes a heavy contributor to bone dose, but it is probably in an insoluble form (cerium oxide) in the plume and would not be retained long in the body.

Following the worst accident hypothesized in the preceeding sections -a hydrogen-oxygen explosion in the scrubbing system -- personnel working downwind of the stack under fumigation conditions for 15 minutes following the accident could inhale sufficient strontium-90 that the maximum weekly dose from the material retained by the bone would be 10 percent of the $R_{A-}$ diation Concentration Guide limit of $0.56 \mathrm{rem} /$ week [1]. Persons in surrounding communities would receive smaller doses. Ground contamination also could be a problem near the stack if the particles are large and fall out rapidly, or outside the NRTS boundary if the particles are "washed out" of the plume by rain or snow.

The radiation levels and exposures indicated by the calculations are undoubtedly high because the worst conditions were postulated for an accident. However, these point out the need for rapid detection of an accidental release and rapid emergency action following the release. Present procedures dictate (a) that the NRTS Warning Communication Center be notified within 15 minutes after the stack release reaches three $\mu \mathrm{c}$ strontium-90 per second or about $1 / 10$ the RCG at grade level based on an average atmospheric diffusion factor $(X / Q)$ of $10^{-5} \mathrm{sec} / \mathrm{m}^{3}$, and (b) that the process be shut down whenever the stack release reaches $300 \mu \mathrm{c}$ per second, corresponding to about 10 times the RCG at grade level for the same diffusion factor.

The hazards of an accidental release are discussed in more detail in the following paragraphs.

\subsection{Direct Radiation From the Stack Plume}

The external radiation hazard to personnel standing near the stack plume appears to be relatively low. In the case of the hydrogen-oxygen explosion in the scrubbing system (Section IV-3.3), the radiation dosage of a man at ground level under poor weather conditions for diffusion $\left(X / Q=2.5 \times 10^{-4} \mathrm{sec} / \mathrm{m}^{3}\right)$ would be $0.01 \mathrm{rem} / \mathrm{hr}$ when processing WM-185 waste and $1 \mathrm{rem} / \mathrm{hr}$ for 200-day 
cooled waste. If this accident occurred, an evacuation would take place immediately and exposure would be only a fraction of the above dosage. For comparison, external occupational limits for continuous exposure are $5 \mathrm{rem} / \mathrm{year}$ or approximately $0.1 \mathrm{rem} /$ week $^{[1]}$.

\subsection{Radiation from Ground Contamination}

The normal gas velocities in the cell ventilation piping and the ICPP stack are sufficient $(\approx 20 \mathrm{fps})$ for carrying particles as large as 800 microns, approximately the largest size found in the alumina product. To reach the cell ventilation piping, however, dust particles must be carried by the cell air into the ventilation piping. At the estimated air velocities in the cells $(\approx 0.1 \mathrm{fps})$, only particles less than 30 microns diameter would be carried into the ventilation piping. Particles this size and smaller constitute less than 0.1 percent of the solids in the bed (page ix-26) and less than 30 percent of the solids leaving the cyclone (page ix-19). Unless agglomeration has taken place, all alumina particles downstream from the scrubbing system will be smaller than three microns in diameter.

Since particles larger than 1-3 microns fall out primarily by gravitational settling, some activity deposition downwind of the stack could be expected after an explosion in the scrubbing system. "Dumping" of an off-gas filter could also result in a similar deposition if the normally small solids $(<0.3 \mu)$ on the filters agglomerate and act as larger particles. A crude idea of the extent of the deposition is furnished by the following example.

If two-thirds of the particles released from the ICPP stack are larger than 10 micron (settling velocity $\approx 0.006 \mathrm{~m} / \mathrm{sec}$ ), then these particles would be deposited on the ground in 12,500 seconds. Even at a relatively slow wind velocity of one meter per second, the gravitational fallout pattern would extend 12,500 meters downwind from the stack. The plume width at 12,500 meters can be estimated from the following relationship [38]

$$
2 \mathrm{y}_{\mathrm{o}}=2\left(\ln \frac{100}{\mathrm{p}}\right)^{1 / 2} \mathrm{C}_{\mathrm{y}} \times \frac{2-\mathrm{n}}{2}
$$

where

$$
\begin{aligned}
2 \mathrm{y} & =\text { plume width at } \mathrm{x}, \text { meters } \\
\mathrm{p} & =\text { conc. at } \mathrm{y} \text { as percent of axial conc. }=95 \text { (assumed) } \\
\mathrm{C}_{\mathrm{y}} & =\text { lateral diffusion coefficient } \\
\mathrm{n} & =\text { stability index } \\
\mathrm{x} & =\text { distance downwind, meters }
\end{aligned}
$$


Under strong inversion weather conditions (see page iii-12 for values of constants), the plume width is approximately 1000 meters at 12,500 meters from the stack. For a solids release of eight $\mathrm{lbs} / \mathrm{hr}$ over a 15 minute period when processing 200-day cooled waste, the activity deposition would be roughly: $\left(\frac{8 \mathrm{lb}}{\mathrm{hr}}\right)\left(\frac{1}{4} \mathrm{hr}\right)\left(\frac{2}{3}\right)\left(\frac{972 \text { curies }}{\mathrm{lb}}\right)\left[\frac{1}{(1 / 2)(1000)(12,500) \mathrm{m}^{2}}\right]=2 \times 10^{-4}$ curies $/ \mathrm{m}^{2}$ Such an activity deposition would create a field of two $\mathrm{mr} / \mathrm{hr}$ at one meter above grade based on a dose rate of $10 \mathrm{r} / \mathrm{hr}$ per curie $/ \mathrm{m}^{2}$ of deposited fission products [39]. Radiation levels this high are not particularly excessive; however, the contaminated area may present a formidable cleanup project if it is impractical to isolate or police it.

\subsection{Ingestion or Inhalation of Activity}

Ingestion or inhalation of radioactive material poses the greatest hazard accompanying a gross accidental release of solids from the stack because of the long retention period of fission products in the body even though the intake period may have been short. An analysis of the dosage received upon inhaling a mixture of fission products (Appendix K) shows that the dosage from strontium90 far exceeds that of the other fission products present. Cerium-144 also at times can be a heavy contributor to the dosage, but the cerium is probably in an insoluble form (cerium oxide) in the plume and would not be retained long. in the body. The maximum bone doses that would be received by personnel standing downwind of the stack for 15 minutes under adverse weather conditions are estimated in Table IX -6 for each of the postulated accidents, except major catastrophes, mentioned in the previous sections. In the worst case, the hydrogenoxygen explosion, the strontium-90 intake woud be $1.4 \mu \mathrm{c}$ and the retention by the bone would be $0.17 \mu \mathrm{c}$, resulting in a cumulative bone dose over a 50 year life of 54 rem. This dose would be accumulated over the assumed 50 year lifetime at a steadily decreasing rate with the highest rate (occurringshortly after exposure) being $0.05 \mathrm{rem} /$ week or approximately 10 percent of the recommended limit of $0.56 \mathrm{rem} /$ week [1].

If the particulate solids were extremely fine and weather conditions were favorable, the activity spread after an accident would carry well beyond the NRTS limits. The worst weather condition for carrying activity beyond the NRTS boundary is the strong inversion, and the maximum activity concentrations would occur at about 22 miles from ICPP (page G-3). Considering the release of 
eight $\mathrm{lb} / \mathrm{hr}$ for 15 minutes (two lbs total) as an instantaneous release, the total integrated dosage (TID) from strontium-90 at that distance can be estimated from the following relationship [40]:

$$
\operatorname{TID}_{\mathrm{Sr}-90}=\frac{2 \mathrm{Q}}{\pi \mathrm{C}^{2} \overline{\mathrm{u}}(\overline{\mathrm{u}} \mathrm{t})^{2-\mathrm{n}}} \exp \left[\frac{-\mathrm{h}^{2}}{\mathrm{C}^{2}(\overline{\mathrm{u} t})^{2-n}}\right]
$$

where:

$$
\begin{aligned}
\mathrm{Q} & =\text { activity released }=16 \text { curies }(8 \text { curies } \mathrm{Sr}-90 / \mathrm{lb} \text { solids) } \\
\mathrm{C} & =\text { diffusion coefficient }=0.031 \text { (page iii-12) } \\
\overline{\mathrm{u}} & =\text { wind velocity }=2 \text { meters per second }(\text { page } \mathrm{G}-3) \\
\overline{\mathrm{u}} & =\text { distance }, \approx 35,100 \text { meters } \\
\mathrm{n} & =\text { stability index }=0.50 \text { (page G-3) } \\
\mathrm{h} & =\text { effective stack height }=75 \text { meters } \\
\text { TID } & =3.3 \times 10^{-4} \text { curie-sec } / \text { meter }^{3}
\end{aligned}
$$

Using an average breathing rate of 10 meters $3 / 8 \mathrm{hrs}$, the intake of a human exposed to the cloud is approximately $0.12 \mu \mathrm{c}$. This intake would result in a lifetime bone dose of about 4 rem (Appendix $\mathrm{K}$ ) with a maximum dose rate less than one percent of the recommended $0.56 \mathrm{rem} /$ week [1].

Fallout or washout from the plume after an accident also could create a contamination problem outside the NRTS boundary. Assuming a particle deposition velocity of $10^{-3} \mathrm{~m} / \mathrm{sec}$ (page G-2), the activity deposited in the example of the preceeding paragraph would be $\left(4.4 \times 10^{-4}\right.$ curie-sec $\left./ \mathrm{m}^{3}\right)\left(10^{-3} \mathrm{~m} / \mathrm{sec}\right)$ or $0.44 \mu \mathrm{c} / \mathrm{m}^{2}$. Milk from cows grazing for 20 days on land contaminated to this extent could reach a strontium-90 concentration of $0.013 \mu \mathrm{c} / 1^{[\mathrm{a}]}$. A human drinking this milk for 30 days would ingest sufficient strontium-90 to result in a lifetime bone dose of 15 rem with a maximum dose rate less than three percent of the recommended limit of $0.56 \mathrm{rem} /$ week [1].

[a] Based upon a British study [41] indicating that a one $\mu \mathrm{c} / \mathrm{m}^{2}$ contamination level on grazing land results in milk contamination of $0.03 \mu \mathrm{c} /$ liter in 20 days. As shown in Appendix $\mathrm{K}$, an intake of one $\mu \mathrm{c}$ strontium -90 results in a lifetime bone dose of approximately $38 \mathrm{rem}$. 
Extensive surveys are conducted by the AEC Health and Safety Division after all unexpected activity releases at the NRTS. Any large amount of contamination at the NRTS or outside the site limits would be detected and isolated.

Table IX -6 gives the estimated lifetime bone dose from strontium-90 inhaled after WCF accidents.

TABLE IX-6

ESTIMATED LIFETIME BONE DOSE FROM STRONTIUM-90 INHALED
AFTER WCF ACCIDENTS [a]

\begin{tabular}{|c|c|}
\hline Accident & $\operatorname{Rem}[\mathrm{b}]$ \\
\hline Cyclone bypassing & $5 \times 10-4$ \\
\hline Scrub system bypassed & $<0.12$ \\
\hline Adsorbers bypassed & $<2.7 \times 10-3$ \\
\hline Off-gas filters bypassed & 0.01 \\
\hline Adsorbers and filters bypassed & 0.05 \\
\hline Equipment vent filter bypassed & $5 \times 10^{-4}$ \\
\hline "Dumping" of one off-gas filter [c] & 27 \\
\hline Hydrogen-oxygen explosion & 54 \\
\hline Broken product takeoff line & 0.7 \\
\hline $\begin{array}{l}\text { Lifetime dose from continuous expo } \\
\text { at limiting weekly rate of } 0.56 \text { re }\end{array}$ & 1456 \\
\hline \multicolumn{2}{|c|}{$\begin{array}{l}\text { [a] Assuming fumigation conditions }\left(X / Q=2.5 \times 10^{-4} \mathrm{sec} / \mathrm{m} 3\right) \text { and } 15 \\
\text { minutes exposure to cloud. } \\
\text { [b] Bone dosage from strontium-90 inhaled. } \\
\text { [c] Assuming filter "dumps" one pound of dust uniformly over a } 15 \text {-minute } \\
\text { period. }\end{array}$} \\
\hline
\end{tabular}




\section{NON-RADIOLOGICAL SAFETY PROBLEMS}

The WCF, like any industrial facility, has many potential safety problems created by operating equipment and the use of toxic chemicals. Of these, only three -- the safe handling of NaK, the emission of nitrogen oxides, and the emission of mercury -- are new problems introduced by operation of the WCF.

\subsection{Handling of $\mathrm{NaK}$}

Operation of the WCF marks the first time a liquid metal has been used in a process at the ICPP. While NaK is a highly reactive metal, operating and maintenance personnel have become accustomed to its handling during over 4000 hours of test operation of the WCF and over 13,000 hours of pilot plant testing at the ICPP chemical engineering laboratory. During the test period, $\mathrm{NaK}$ has been loaded into and unloaded from the system several times, and the NaK system has been opened for repairs four times. Two leaks have occurred and have been detected and contained without difficulty. This experience is backed up by routine safety lectures and handling demonstrations which are part of the continuing safety program at the ICPP. The NaK system is designed to prevent the spread of metal should a major vessel break (page iv-4 and page vi-78) and protective clothing is provided at the facility for emergencies involving NaK.

\subsection{Emission of Nitrogen Oxides}

As brought out in the process description (page $v-6$ ), nitrogen oxides, primarily nitrogen dioxide or tetroxide, are produced by the decomposition of the nitrates in the waste solution. The nitrogen oxides constitute approximately 2-1/2 percent of the process off-gas sent to the ICPIP stack. Operation of the process equipment and the processing cells under lower--than-ambient pressures reduces the possibility of nitrogen oxides being found in the operating areas of the WCF. Also, operating personnel have been trained in detecting the oxides and in the safety precautions necessary where there is a chance of it being released. At the top of the ICPP stack, the concentration of nitrogen oxides is approximately $210 \mathrm{ppm}$. At grade level, the concentration may momentarily get as high as $18 \mathrm{ppm}$ (under looping weather conditions) but generally is less than one ppm. The generally accepted maximum concentration for continuous exposure is five ppm. Irritation is pronounced at concentrations above about $60 \mathrm{ppm}$ and exposures to concentrations over $200 \mathrm{ppm}$ may be fatal [42]. 


\subsection{Emission of Mercury}

It is estimated that 20 percent of the mercury introduced into the WCF system with the feed may be vaporized and be released to the atmosphere with the process off-gas (page $\mathrm{v}-6$ ). This emission rate is equivalent to 97 grams per hour when processing WM-185 waste. Under fumigation weather conditions $\left(X / Q=2.5 \times 10^{-4} \mathrm{sec} / \mathrm{m}^{3}\right)$ this release would result in a maximum instantaneous grade level concentration of $0.007 \mathrm{mg} / \mathrm{m}^{3}$, well below the accepted maximum mercury concentration for continuous exposure of $0.1 \mathrm{mg} / \mathrm{m}^{3}[43]$.

\section{REFERENCES}

1. "Maximum Permissible Body Burdens and Maximum Permissible Concentrations of Radionuclides in Air and in Water for Occupational Exposure", National Bureau of Standards Handbook 69, June 5, 1959.

2. U. S. Department of Commerce Weather Bureau, Washington, D. C., Meteorology and Atomic Energy, AECU-3066, p. 44 (July 1955).

3. P. L. Magill, et al, Air Pollution Handbook, McGraw-Hill Co., N. Y., pp 5-19 (1956).

4. J. W. Loeding, et al, The Fluid-Bed Calcination of Radioactive Waste, ANL-6322, p 38 (May 1961).

5. Ibid, p 20 .

6. B. R. Wheeler, Venturi Scrubber Evaluation for Waste Calcination OffGas Facility, IDO-14484, p 7 (December 18, 1959).

7. E. R. Irish, Ed, Research and Development Activities - Fixation of Radioactive Residues, HW-76262, 4th Qtr, 1962 (January 1963).

8. J. W. Ahern, J. Doyle, Analytical and Experimental Studies of the Combustion of a NaK Stream in Air, PWAC-185 (1957).

9. O. A. Hougen, K. M. Watson, Chemical Process Principles, Part One, Material and Energy Balances, (New York: John Wiley and Sons, Inc., 1949) 312-13.

10. G. Von Elbe, The Problem of Ignition, Fourth Symposium on Combustion, MIT, September 1-5, pp 13-20 (1952).

11. D. B。 Spalding, The Combustion of Liquid Fuels, pp 853-856, Fourth Symposium on Combustion, MIT, September 1-5, pp 853-856 (1952).

12. C. B. Jackson, Ed, Liquid Metal Handbook. Sodium-NaK Supplement, TID-5277 (July 1, 1955). 
13. R. C. Fuson, Reactions of Organic Compounds, (New York: John Wiley and Sons, Inc., 1962).

14. R. E. Kirk, D. F. Othmer, Eds, Encyclopedia of Chemical Technology, (lst ed; New York: The Interscience Encyclopedia, Inc., 1952).

15. T. J. Colven Jr., et al, TNX Evaporator Incident January 12, 1953,DP-25 (May 1953).

16. L. J. King, W. T. McCarley, Plutonium Release Incident of November 20, 1959, ORNL-2989 (February 1961).

17. R. Anfschlager, "Is Ammonium Nitrate an Explosive", Chem. and Met. Eng., Volume 30, pp 619-621 (1924).

18. F. F. Braconier, A. H. Delseme, "Explosive Properties of Ammonium Nitrate”, Explosifs (Liege), Vol 5, No. 1, pp 34-36, (1952); Chimie and Industrie, Vol 68, p 382, (1952).

19. R. M. Cook, "Ammonium Nitrate as an Explosive", Chem. and Met. Eng. Vol 31, pp 231-233 (1924).

20. R. O. E. Davis, “Ammonium Nitrate: Hazards in Handling as a Fertilizer," Chem. and Met. Eng., Vol 51, p 101 (1944).

21. R. O. E. Davis, "Explosibility and Fire Hazard of Ammonium Nitrate Fertilizer", Amer. Fertilizer, 106, pp 1-6 (1947).

22. A. H. Delsemme, "The Mechanism of the Explosion of Ammonium Nitrate", Compt. Rend., 230, pp 1858-60 (1950).

23. M. H. Elliott, “Exothermal Decomposition of Mixtures Containing Ammonium Nitrate", Bureau of Mines Report of Investigation 3244 (March 1948).

24. D. R. Evans, Pilot Plant Studies with a Six-Inch Diameter Fluidized Bed Calciner, IDO-14539 (April 20, 1961).

25. C. Field, "The Product that Couldn't Explode", Chem. Eng., 54, p 146 (May 1947).

26. C. E. Munroe, "The Explosibility of Ammonium Nitrate," Chem. Met. Eng., 26, pp 535-542 (1922).

27. G. N. Norman "Ammonium Nitrate by Itself Is Not an Explosive", Chem. and Met. Eng., Vol 30, p 622 (1924).

28. A. H. Nuckolls, "The Comparative Explosion Hazard of Ammonium Nitrate Containing Organic Matter", Underwriter's Laboratory Research Bull. 39 August 1947).

29. A. Parisot, "Experimental Studies on the Velocity of Detonation of Explosive Substances", Mem. Artillerie Franc. 18 pp 499-598 (1939). 
30. J. Whetstone, A. W. Holmes, "Explosion and Fire Hazards of Ammonium Nitrate", Ind. Chem., 23, pp 717-723 (1947).

31. American Institute of Chemical Engineers, Bubble-Tray Design Manual, A report by the Distillation Subcommittee, New York, 1958.

32. Samuel Glasstone, Ed, The Effects of Nuclear Weapons, (rev. ed; Washington, D. C.: U. S. Atomic Energy Commission, 1962) p 293.

33. Ibid p 300 .

34. Ibid, footnote, p 484 .

35. Ibid, p 486.

36. J. R. Horan, Health and Safety Division Annual Report, 1961, USAEC Idaho Operations Office, IDO-12021 (May 21, 1962).

37. W. P. Palica, L. T. Lakey, Development of Fluidized Bed Calcination of Aluminum Nitrate Wastes in the Waste Calcining Facility, IDO-14608 (to be published).

38. U. S. Department of Commerce, Weather Bureau, Washington, D.C., Meterology and Atomic Energy, AECU-3066, p 155, (July 1955).

39. Ibid, $\mathrm{p} 110$.

40. Ibid, p 50 .

41. R. J. Garner, "An Assessment of the Quantities of Fission Products Likely to be Found in Milk in the Event of Aerial Contamination of Agricultural Land", Nature, Vol. 186, June 25, 1960, pp 1063-64.

42. N. Irving Sax, Dangerous Properties of Industrial Materials, Reinhold, New York, 1957, pp 950-1.

43. Ibid, p 868 . 


\section{APPENDIX A}

\section{DETERMINATION OF FISSION PRODUCT DISTRIBUTION IN AND TOTAL ACTIVITY OF WASTE

RESUL TING FROM REPROCESSING MTR-TYPE FUEL ELEMENTS

The compositions and activities of wastes presently in storage at the ICPP, as determined by chemical and radiochemical analyses, are tabulated in Section $\mathrm{V}-1$. These wastes vary in age from three to eight years. While the WCF will begin radioactive operation using these wastes as feed, it is desirable that the facility be capable of processing any wastes that become available which have been "cooled" for shorter periods of time. The activities of new wastes cannot be determined readily from the analytical data on the existing wastes as small errors in the analytical data become gross errors if the measured activity is extrapolated through several half-lives. To provide a more accurate activity estimate for analyzing the hazards involved in processing newer wastes, fission product distribution and activity data have been calculated in this section for a theoretical waste typifying that produced in the reprocessing of MTR-type fuel elements. The nuclides assumed to be in the theoretical waste were determined from examination of available literature [1, 2, 3] on fission product yields from fission of U-235, and include only those which contribute significant amounts of activity to the waste 200 days after discharge of the fuel from the reactor. The simplifying curves of Blomeke and Todd [1] were utilized to determine the fission product quantities per weight of U-235 charged to the reactor as a function of irradiation period, neutron flux, and cooling period. This yield was then converted to activity per gallon of waste using known data for the U-235/aluminum ratio in the fuel element, the aluminum dilution during reprocessing, and the aluminum concentration in the ICPP wastes.

The procedure followed is outlined in detail below. Results of the calculations are presented in Table A-3 as activity (in curies) per gallon of waste aged for periods of 0 days, 120 days, 200 days, 1 year, 2 years, 5 years, 10 years, and 20 years. 


\section{REACTOR DATA AND ASSUMPTIONS}

(1) Average neutron flux $=2.56 \times 10^{14} \mathrm{n} / \mathrm{cm}^{2}-\mathrm{sec}$

(2) Irradiation time $=20$ days $=1.728 \times 10^{6}$ seconds

(3) Element composition $=\frac{0.200 \mathrm{~kg} \quad U-235}{4.200 \mathrm{~kg}}$

(4) 95 percent of aluminum in waste orginates from the dissolution of fuelelements - the remaining five percent has been added as aluminum nitrate in reprocessing.

(5) Aluminum concentration in the waste tank is 1.74 molar.

\section{PROCEDURE}

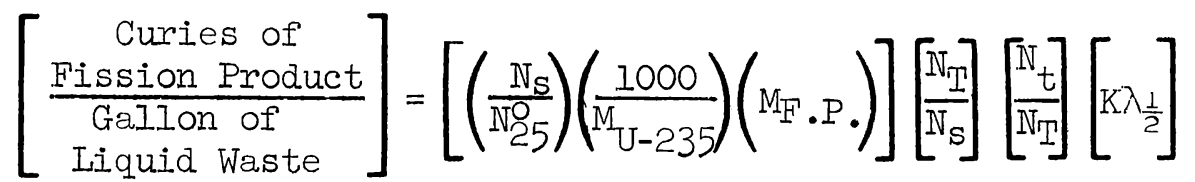

where:

$\left[\frac{N_{S}}{N_{25}^{0}}\right]$

Atoms of fission product at saturation per atoms of U-235 charged to reactor. Obtained from plots of Blomeke and Todd [1], page 57-78.

$\mathrm{M}_{U-235}=$ Molecular weight of uranium-235 in grams.

$\mathrm{M}_{\mathrm{F} . \mathrm{P}}=$ Molecular weight of fission product in grams.

$\left[\frac{N_{T}}{N_{S}}\right]=$ Atoms of fission product at the end of irradiation time $T$, per atoms of fission products at saturation. Obtained from plots of Blomeke and Todd [1], page 79-126.

$\left[\frac{N_{t}}{N_{T}}\right]=\begin{aligned} & \text { Atoms of fission product at the end of cooling time } t \text {, per atoms } \\ & \text { of fission product at the end of irradiation time } T \text {. Obtained from }\end{aligned}$ plots of Blomeke and Todd [1], page 127-211.

$\left[K \lambda_{\frac{1}{2}}\right]=A$ conversion factor relating uranium in feed to volume of waste 1 and weight of fission product to activity.

$=\left(\frac{0.2 \mathrm{~kg} \mathrm{U}-235}{4.2 \mathrm{~kg} \mathrm{AI}}\right)\left(\frac{1.74}{\text { liter }} \frac{\mathrm{mols} \mathrm{AI}}{\text { of waste }}\right)\left(\frac{0.02698 \mathrm{~kg} \mathrm{AII}}{\text { mols AI }}\right)\left(\frac{1 \text { liter }}{0.26418 \text { gaI }}\right)$ $\left(\frac{\text { mols }}{\text { grams }} \frac{\text { fission product }}{\text { of fission product }}\right)\left(\frac{6.023 \times 10^{23}}{\text { mol of fission product }}\right)$ $\left(\frac{(\text { curies })(\text { second })}{3.7 \times 10^{10} \text { atoms }}\right)\left(\frac{0.95 \mathrm{~g} \text { of } \mathrm{Al} \text { from reactor }}{\mathrm{g} \text { of } \mathrm{Al} \text { in waste }}\right)\left(\lambda_{\frac{1}{2}}\right)$

$\left[\mathrm{K} \lambda_{\frac{1}{2}}\right]=\frac{1.308 \times 10^{11}(\mathrm{~kg} \text { of } \mathrm{U}-235)(\text { curies } \cdot \mathrm{sec})\left(\lambda \frac{1}{2}\right)}{(\mathrm{gal})(\mathrm{g} \text { of fission product) }}$ 
where:

$\lambda_{\frac{1}{2}}=$ Fission product decay constant, $\sec ^{-1}$

A summary of the values defined above are shown in Tables A-1, A-2, and A-3. Table A-1 presents the relative quantities of fission product nuclides present at saturation $\left[\mathrm{N}_{\mathrm{S}}\right]$ and at reactor shutdown $\left[\mathrm{N}_{\mathrm{T}}\right]$. The fission product nuclide quantities for various cooling times, $t,\left[\mathrm{~N}_{\mathrm{t}}\right]$ are shown in Table A-2, and the final fission product activities of the theoretical waste (in curies per gallon of waste) are tabulated in Table A-3.

\section{TABLE A-I}

$\left(N_{S}\right.$ AND NT = GRAMS OF FISSION PRODUCT/kg U235

AT SATURATION AND AT IRRADIATION TIME T, RESPECTIVELY)

\begin{tabular}{|c|c|c|c|c|}
\hline Nuclide & $\mathbb{N}_{\mathrm{S}} / \mathrm{N}_{25}^{\mathrm{O}}[\mathrm{a}]$ & $N_{S}=\left(\frac{N_{S}}{N_{25}^{O}}\right)\left(\frac{1000}{M_{U-235}}\right) M_{F} \cdot P$ & $\mathrm{~N}_{\mathrm{T}} / \mathrm{N}_{\mathrm{S}}[\mathrm{b}]$ & $\mathrm{N}_{\mathrm{T}}=\mathrm{N}_{\mathrm{S}}\left(\frac{\mathrm{N}_{\mathrm{T}}}{\mathrm{N}_{\mathrm{S}}}\right)$ \\
\hline $\mathrm{Sr}^{89}$ & 0.040 & 15.15 & 0.2660 & 4.030 \\
\hline $\operatorname{sr} 90$ & 9.500 & $3,638 \cdot 30$ & 0.0016 & 5.821 \\
\hline y91 & 0.063 & 24.40 & 0.2100 & 5.124 \\
\hline Zr95 & 0.075 & 30.32 & 0.1950 & 5.912 \\
\hline $\mathrm{Nb}^{95}$ & 0.042 & 16.98 & 0.0350 & 0.594 \\
\hline Rul03 & 0.022 & 9.64 & 0.2850 & 2.747 \\
\hline $\mathrm{Ru}^{106}$ & 0.026 & 11.73 & 0.0370 & 0.434 \\
\hline $\mathrm{Cs}^{137}$ & 6.500 & $3,789 \cdot 36$ & 0.00225 & 8.526 \\
\hline $\mathrm{Ba}^{140}$ & 0.015 & 8.94 & 0.6500 & 5.811 \\
\hline $\mathrm{Ce}^{141}$ & 0.035 & 21.00 & 0.3500 & $7 \cdot 350$ \\
\hline $\operatorname{Pr} 143$ & 0.015 & 9.13 & 0.5800 & 5.295 \\
\hline $\mathrm{Ce}^{144}$ & 0.330 & 202.21 & 0.0460 & 9.302 \\
\hline $\mathrm{Nd} 147$ & 0.0054 & $3 \cdot 38$ & 0.7000 & 2.366 \\
\hline \multirow[t]{2}{*}{$\operatorname{Pm} 147$} & 0.160 & 100.09 & 0.0170 & 1.702 \\
\hline & & & & \multirow[t]{2}{*}{$\Sigma=65.014$} \\
\hline $\begin{array}{l}\text { [a] Blom } \\
\text { [b] Ibid }\end{array}$ & $\begin{array}{l}\text { and Todd }[1] \\
79-126\end{array}$ & p $57-78$ & & \\
\hline
\end{tabular}


TABIE A-2

$\left(N_{T}\right.$ AND $N_{t}=$ GRAMS OF FISSION PRODUCT/kg U-235 AT IRRADIATION TIME T AND AFTER DECAY TIME t, RESPECTIVELY)

\begin{tabular}{|c|c|c|c|c|c|c|c|c|c|c|c|c|c|c|c|}
\hline \multicolumn{2}{|c|}{$\begin{array}{l}\text { Time After } \\
\text { Irradiation }\end{array}$} & \multicolumn{2}{|c|}{$\begin{array}{l}120 \text { Days } \\
\left(1.037 \times 10^{2} \mathrm{sec}\right)\end{array}$} & \multicolumn{2}{|c|}{$\begin{array}{c}200 \text { Days } \\
(1.728 \times 107 \mathrm{sec}) \\
\end{array}$} & \multicolumn{2}{|c|}{$\begin{array}{r}1 \text { Year } \\
\left(3.154 \times 10^{7} \mathrm{sec}\right) \\
\end{array}$} & \multicolumn{2}{|c|}{$\begin{array}{l}2 \text { Years } \\
\left(6.307 \times 10^{7} \mathrm{sec}\right) \\
\end{array}$} & \multicolumn{2}{|c|}{$\begin{array}{r}5 \text { Years } \\
\left(1.577 \times 10^{8} \mathrm{sec}\right) \\
\end{array}$} & \multicolumn{2}{|c|}{$\begin{array}{c}10 \text { Years } \\
\left(3.1536 \times 6^{8} \mathrm{sec}\right) \\
\end{array}$} & \multicolumn{2}{|c|}{$\begin{array}{r}20 \text { Years } \\
\left(6.307 \times 10^{8} \mathrm{sec}\right) \\
\end{array}$} \\
\hline Nuclide & $\mathbb{N}_{\mathrm{T}}[\mathrm{b}]$ & $\mathbb{N}_{t} / \mathbb{N}_{T}[c]$ & $N_{t}$ & $\mathbb{N}_{t} / \mathbb{N}_{T}[c]$ & $N_{t}$ & $N_{t} / N_{T}[c]$ & $N_{t}$ & $N_{t} / N_{T}[c]$ & $N_{t}$ & $\mathrm{~N}_{\mathrm{t}} / \mathrm{N}_{\mathrm{T}}[\mathrm{c}]$ & ${ }^{1 i}{ }_{t}$ & $\mathbb{N}_{t} / \mathbb{N}_{T}[c]$ & $\mathrm{N}_{t}$ & $N_{t} / N_{T T}[c]$ & $\mathrm{N}_{\mathrm{t}}$ \\
\hline $\mathrm{sr}^{89}$ & 4.030 & 0.22 & 0.887 & 0.08 & 0.322 & 0.0098 & 0.0395 & 0.000098 & 0.000395 & $<10^{-5}$ & - & $<10^{-5}$ & - & $<10^{-5}$ & - \\
\hline $\mathrm{Sr}^{90}$ & 5.821 & $1.0^{[\mathrm{a}]}$ & 5.821 & $0.987^{[a]}$ & 5.745 & $0.976^{[a]}$ & 5.681 & $0.954^{[a]}$ & 5.555 & $0.884^{[a]}$ & 5.145 & $0.781^{[a]}$ & 4.546 & $0.609^{[a]}$ & 3.545 \\
\hline $\mathrm{r}^{91}$ & 5.124 & 0.25 & 1.281 & 0.093 & 0.477 & 0.013 & 0.067 & 0.00017 & 0.00087 & $<10^{-4}$ & - & $<10^{-4}$ & - & $<10^{-4}$ & - \\
\hline $\mathrm{zr}^{95}$ & 5.912 & 0.28 & 1.655 & 0.115 & 0.680 & 0.018 & 0.1064 & 0.00032 & 0.0019 & $<10^{-5}$ & - & $<10^{-5}$ & - & $<10^{-5}$ & - \\
\hline $\mathrm{Nb}^{95}$ & 0.594 & 2.65 & 1.574 & 1.35 & 0.802 & 0.26 & 0.1545 & 0.0044 & 0.002615 & $<10^{-5}$ & - & $<10^{-5}$ & - & $<10^{-5}$ & - \\
\hline $\mathrm{Ru}^{103}$ & 2.747 & 0.13 & 0.357 & 0.034 & 0.0933 & 0.0021 & 0.00576 & $<10^{-5}$ & $<0,00002$ & $<10^{-5}$ & - & $<10^{-5}$ & - & $<10^{-5}$ & - \\
\hline $\mathrm{Ru}^{106}$ & 0.434 & $0.797^{[\mathrm{a}]}$ & 0.346 & $0.684^{[a]}$ & 0.297 & $0.508^{[\mathrm{a}]}$ & 0.2205 & $0.251^{\lfloor a\rfloor}$ & 0.1088 & $0.031^{[a]}$ & 0.01345 & $0.00098^{[a]}$ & 0.000425 & $<10^{-5}$ & - \\
\hline $\mathrm{Cs}^{137}$ & 8.526 & $1.0^{[\mathrm{a}]}$ & 8.526 & $0.985^{[a]}$ & 8.398 & $0.974^{[\mathrm{a}]}$ & 8.305 & $0.948^{[a]}$ & 8.082 & $0.875^{[a]}$ & 7.460 & $0.765^{-a-}$ & 6.525 & $0.592^{[a]}$ & 5.050 \\
\hline $\mathrm{Ba}^{140}$ & 5.811 & 0.00155 & 0.009005 & 0.000019 & 0.0001094 & $<10^{-5}$ & $<0.00006$ & $<10^{-5}$ & $<0.00006$ & $<10^{-5}$ & - & $<10^{-5}$ & - & $<10^{-5}$ & - \\
\hline $\mathrm{Ce}^{141}$ & 7.350 & 0.074 & 0.544 & 0.0135 & 0.099 & 0.00038 & $<0.002788$ & $<10^{-4}$ & $<0.0007$ & $<10^{-4}$ & - & $<10^{-4}$ & - & $<10^{-4}$ & - \\
\hline $\mathrm{Pr}^{143}$ & 5.295 & 0.00265 & 0.01403 & $<10^{-4}$ & $<0.0005$ & $<10^{-4}$ & $<0.0005$ & $<10^{-4}$ & $<0.0005$ & $<10^{-4}$ & - & $<10^{-4}$ & - & $<10^{-4}$ & - \\
\hline $\mathrm{Ce}^{144}$ & $9 \cdot 302$ & $0.751^{[a]}$ & 6.936 & $0.621^{[a]}$ & 5.777 & $0.419^{[a]}$ & 3.897 & $0.175^{[a]}$ & 1.6275 & 0.0129 & 0.1180 & 0.000165 & - & $<10^{-5}$ & - \\
\hline $\mathrm{Na}^{147}$ & 2.366 & 0.00063 & 0.001491 & $<10^{-5}$ & $<0.00002$ & $<10^{-5}$ & $<0.00002$ & $<10^{-5}$ & $<0.00002$ & $<10^{-5}$ & - & $<10^{-5}$ & - & $<10^{-5}$ & - \\
\hline $\mathrm{Pm}^{147}$ & 1.702 & 2.20 & 3.744 & 2.1 & 3.574 & 1.8 & 3.064 & 1.4 & 2.383 & 0.68 & 1.157 & 0.17 & 0.289 & 0.0095 & .016 \\
\hline $\begin{array}{ll}{[a]} & N_{t} / \\
{[b]} & \text { See } \\
{[c]} & B 10\end{array}$ & $\begin{array}{l}\text { Calcul } \\
\text { st col } \\
e \text { and }\end{array}$ & $\begin{array}{l}\text { using: } \\
\text { Table A } \\
[1], \mathrm{pp}]\end{array}$ & $\begin{array}{l}\mathrm{N}_{\mathrm{t}}=\mathrm{N}_{\mathrm{T}} \mathrm{e}^{-} \\
27-2 \mathrm{II}\end{array}$ & & & & & & & & & & & & \\
\hline
\end{tabular}


TABLE A-3

ACTIVITY IN CURIES/GALLON OF WASTE $\left[=\mathrm{N}_{t}\left(K \lambda_{\frac{1}{2}}\right)\right]$

\begin{tabular}{|c|c|c|c|c|c|c|c|c|c|c|c|c|c|c|c|c|c|}
\hline \multicolumn{2}{|c|}{$\begin{array}{l}\text { Time After } \\
\text { Irradiation }\end{array}$} & \multicolumn{2}{|c|}{ O Days } & \multicolumn{2}{|c|}{120 Days } & \multicolumn{2}{|c|}{200 Days } & \multicolumn{2}{|c|}{1 Year } & \multicolumn{2}{|c|}{2 Years } & \multicolumn{2}{|c|}{5 Years } & \multicolumn{2}{|c|}{10 Years } & \multicolumn{2}{|c|}{20 Years } \\
\hline Nuclide & $\lambda_{\frac{1}{2}}\left(\mathrm{sec}^{-1}\right)^{[\mathrm{a}]}$ & $\mathrm{N}_{\mathrm{T}}[\mathrm{b}]$ & Activity & $\mathrm{N}_{t}^{[\mathrm{b}]}$ & Activity & $\mathrm{N}_{\mathrm{t}}{ }^{[\mathrm{b}]}$ & Activity & $\mathrm{N}_{\mathrm{t}}[\mathrm{b}]$ & Activity & $\mathrm{N}_{\mathrm{t}}^{[\mathrm{b}]}$ & Activity & $\mathrm{N}_{\mathrm{t}}{ }^{[\mathrm{b}]}$ & Activity & $\mathrm{N}_{\mathrm{t}}{ }^{[\mathrm{b}]}$ & Activity & $\mathrm{N}_{\mathrm{t}}[\mathrm{b}]$ & Activity \\
\hline $\mathrm{Sr}^{89}$ & $1.48 \times 10^{-7}$ & 4.030 & 875.80 & 0.887 & 192.80 & 0.322 & 72.60 & 0.0395 & 8.58 & 0.000395 & 0.09 & - & - & - & - & - & - \\
\hline $\mathrm{sr}^{90}$ & $7.85 \times 10^{-10}$ & 5.821 & 6.64 & 5.821 & 6.64 & 5.745 & 6.55 & 5.681 & 6.48 & 5.555 & 6.33 & 5.145 & 5.87 & 4.546 & 5.18 & 3.545 & 4.04 \\
\hline $\mathrm{y}^{91}$ & $1.38 \times 10^{-7}$ & 5.124 & 1016.82 & 1.281 & 254.20 & 0.477 & 94.70 & 0.067 & 13.30 & 0.00087 & 0.17 & - & - & - & - & - & - \\
\hline $\mathrm{zr}^{95}$ & $1.27 \times 10^{-7}$ & 5.912 & 1033.89 & 1.655 & 289.30 & 0.680 & 121.98 & 0.1064 & 18.60 & 0.0019 & 0.33 & - & - & - & - & - & - \\
\hline $\mathrm{Nb}^{95}$ & $2.29 \times 10^{-7}$ & 0.594 & 187.26 & 1.574 & 496.27 & 0.802 & 252.85 & 0.1545 & 48.74 & 0.002615 & 0.82 & - & - & - & - & - & - \\
\hline $\mathrm{Ru}^{103}$ & $1.96 \times 10^{-7}$ & 2.747 & 683.77 & 0.357 & 88.87 & 0.093 & 23.15 & 0.00576 & 1.43 & $<0.00002$ & 0.00 & - & - & - & - & - & - \\
\hline $\mathrm{Ru}^{106}$ & $2.20 \times 10^{-8}$ & 0.434 & 11.78 & 0.346 & 9.39 & 0.297 & 8.06 & 0.2205 & 5.99 & 0.1088 & 2.95 & 0.01345 & 0.37 & 0.000425 & 50.01 & - & - \\
\hline $\mathrm{Cs}^{137}$ & $8.27 \times 10^{-10}$ & 8.526 & 8.14 & 8.526 & 8.14 & 8.398 & 8.02 & 8.305 & 7.93 & 8.082 & $7 \cdot 72$ & 7.460 & 7.13 & 6.525 & 6.23 & 5.050 & 4.82 \\
\hline $\mathrm{Ba}^{140}$ & $6.27 \times 10^{-7}$ & 5.811 & 3404.60 & 0.009 & 52.70 & 0.0001 & 8.21 & $<0.00006$ & $<4.92$ & $<0.00006$ & - & - & - & - & - & - & - \\
\hline $\mathrm{Ce}^{141}$ & $2.51 \times 10^{-7}$ & $7 \cdot 350$ & 1711.48 & 0.544 & 126.66 & 0.099 & 23.05 & 0.002788 & 30.65 & $<0.0007$ & $<0.16$ & - & - & - & - & - & - \\
\hline $\operatorname{Pr}^{143}$ & $5.85 \times 10^{-7}$ & 5.295 & 2814.53 & 0.014 & 7.45 & $<0.0005$ & $<0.25$ & $<0.0005$ & - & $<0.0005$ & - & - & - & - & - & - & - \\
\hline $\mathrm{Ce}^{144}$ & $2.76 \times 10^{-8}$ & $9 \cdot 302$ & 233.12 & 6.986 & 175.18 & 5.777 & 144.71 & 3.897 & 97.66 & 1.6275 & 40.75 & 0.1180 & 2.80 & - & - & - & - \\
\hline $\mathrm{Na}^{147}$ & $7.10 \times 10^{-7}$ & 2.366 & 1681.15 & 0.0015 & 0.95 & $<0.00002$ & $<0.01$ & $<0.00002$ & - & $<0.00002$ & - & - & - & - & - & - & - \\
\hline \multirow[t]{2}{*}{$\mathrm{Pm}^{247}$} & $8.4 \times 10^{-9}$ & 1.702 & 12.81 & 3.744 & 28.18 & 3.574 & 26.90 & $<3.064$ & 23.07 & 2.383 & 17.94 & 1.157 & 8.70 & 0.289 & 2.18 & 0.160 & 1.20 \\
\hline & & \multicolumn{2}{|c|}{$\Sigma=1 \overline{3,681.79}$} & \multicolumn{2}{|c|}{$\Sigma=\overline{1736.73}$} & \multicolumn{2}{|c|}{$\Sigma=791.04$} & \multicolumn{2}{|c|}{$\Sigma=\overline{237.35}$} & & $\Sigma=77.26$ & \multicolumn{2}{|c|}{$\Sigma=24.87$} & \multicolumn{2}{|c|}{$\Sigma=13.60$} & \multicolumn{2}{|r|}{$\Sigma=10.06$} \\
\hline la & $\overline{\text { nd } T}$ & 1], pr & $5-39$ & & & & & & & & & & & & & & \\
\hline b] & $A-$ & iis 5 & ion & & & & & & & & & & & & & & \\
\hline
\end{tabular}




\section{REFERENCES}

1. J. O. Blomeke, Mary F。 Todd, Uranium-235 Fission Product Production as a Function of Thermal Neutron Flux, Irradiation Time, and Decay Time, 1. Atomic Concentrations and Gross Totals, ORNL-2127, Part I, Vol I and II.

2. R. C. Bolles, N. E. Ballou, Calculated Activities and Abundances of U-235 Fission Products, U. S. Naval Radiological Defense Laboratory Research and Development Report USNRDL-456-NS 081-001 (August 30, 1956).

3. Seymour Katcoff, "Fission-Product Yields from Neutron-Induced Fission", Nucleonics 18, pp 201-208 (November 1960). 


\section{APPENDIX B}

\section{ESTIMATION OF RATE OF HEAT GENERATION \\ RESULTING FROM FISSION PRODUCT DECAY IN SOLIDS FROM THE CALCINATION OF MT R-TYPE FUEL ELEMENT REPROCESSING WASTES}

The rate of heat generation resulting from the decay of fission products is an important factor in determining the design of the product storage bins and also is of interest in analyzing the hazards involved in a calciner shutdown without unloading the bed. To estimate the rate of heat generation, it is necessary first to ascertain the fission product distribution in the waste and then to determine the resulting amount of activity released by the decay of each of the constituents. The determination of the fission product distribution in and activities of the present ICPP first cycle wastess and a theoretical fresh waste solution are described in Section V-1 and Appendix A. The estimation of the heat generation rates in the solids resulting from the calcination of these waste solutions is described in this section. The procedure consists of (a) conversion of the waste activity to an activity per pound of solids, and (b) conversion of the activity per pound of solids into a heat generation rate using decay energies taken from available literature. The decay patterns and decay energies are summarized in Table B-1. The heat generation rates per pound of solids (Btu/hr-lb) are given in Tables B-2, B-3, B-4, B-5, and B-6 for the theoretical waste of Appendix $\mathrm{A}$ and the wastes presently contained in tanks WM-180, 182, 183, and 185.

\section{BASES AND ASSUMPTIONS}

(1) 91 percent of calcined solid is $\mathrm{Al}_{2} \mathrm{O}_{3}$ (Section $\mathrm{V}-4.1$ ).

(2) All radiation energy is dissipated as heat within the solids (This assumption is valid only for an infinitely large volume of solids, thus the calculated heat generation rate will be higher than the actual). 


\section{PROCEDURE}

$\left[\frac{\text { Btu }}{\text { (Hour)Ib of Solids }}\right]=\frac{\text { STEP I }}{\left[\frac{\text { Curies }}{\text { Gallon of Waste }}\right][\mathrm{C}]} \frac{\text { STEP II }}{\left[\frac{\text { Mev }}{\text { Disintegratioul }}\right][\mathrm{K}]}$

STFP I: Conversion of the waste activity to activity per pound of solids.

$$
\begin{aligned}
& {\left[\frac{\text { Curies }}{\text { Gallon of Waste }}\right]=\text { From Appendix A (for two-year cooled MTR-type }} \\
& \text { waste) or from radiochemical analysis of wastes } \\
& \text { presently in storage (Section V-1). } \\
& {[C]=\text { Conversion factor for gallons of waste per pound }} \\
& \text { of solids. } \\
& =\left[\frac{0.91 \mathrm{~g} \mathrm{Al}_{2} \mathrm{O}_{3}}{\mathrm{~g} \text { of }}\right]\left[\frac{54 \mathrm{~g} \text { of } \mathrm{Al}}{102 \mathrm{~g} \text { of } \mathrm{Al}_{2} \mathrm{O}_{3}}\right]\left[\frac{454 \mathrm{~g}}{1 \mathrm{~b}}\right] \\
& {\left[\frac{1 \mathrm{Mol} \text { of } \mathrm{Al}}{27 \mathrm{~g} \text { of } \mathrm{AI}}\right]\left[\frac{1 \text { Gallon }}{3.785 \text { Liters }}\right]\left[\frac{1}{\mathrm{~A} I \text { Molarity }}\right]} \\
& {[\mathrm{C}]=\left[\begin{array}{ll}
\frac{2 \cdot 140}{\text { Al Molarity }} & \frac{\text { Gallions of Waste }}{\text { Pound of Solids }}
\end{array}\right]}
\end{aligned}
$$

STEP II: Conversion of activity per pound of solids into heat generation rate per pound of solids.

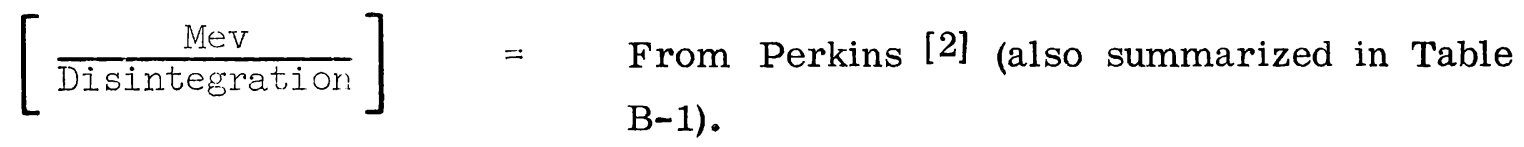

$$
\begin{aligned}
& {[\mathrm{K}] \quad=\quad \text { Factor relating activity to heat generation rate. }} \\
& {[K]=\left[\frac{3.7 \times 10^{10} \text { Disintegrations }}{(\text { Curie })(\text { Second })}\right]\left[\frac{1.52 \times 10^{-16} \mathrm{Btu}}{\text { Mev }}\right]\left[\frac{3600 \mathrm{Sec}}{\text { Hour }}\right]} \\
& {[\mathrm{K}]=0.02025\left[\frac{(\text { Disintegrations })(\mathrm{Btu})}{(\text { Curies })(\text { Mev })(\text { Hour })}\right]}
\end{aligned}
$$


TABLE B-1:

ESTIMATION OF ENERGY RESULTING FROM DECAY OF FISSION PRODUCTS

\begin{tabular}{|c|c|c|c|c|c|}
\hline & Decay Chain ${ }^{[1]}$ & $\begin{array}{l}\text { Average } \beta[2] \\
\text { Energy (Mev) }\end{array}$ & $\begin{array}{l}\text { Total y [2] } \\
\text { Energy (Mev) }\end{array}$ & $\begin{array}{lr}\text { Total } & {[2]} \\
\text { Energy } & \text { (Mev) }\end{array}$ & $\begin{array}{l}\text { Total Energy } \\
\text { Per Decay } \\
\text { Chain (Mev/dis.) }\end{array}$ \\
\hline \multirow{3}{*}{$\mathrm{Sr}^{89}$} & $\rightarrow$ Stable Y & 0.556 & 0.000 & 0.556 & 0.556 \\
\hline & $\rightarrow Y^{90}$ & 0.169 & 0.000 & 0.169 & -- \\
\hline & 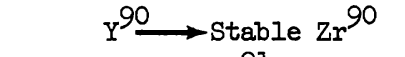 & 0.912 & 0.000 & 0.912 & 1.081 \\
\hline \multirow{3}{*}{$\begin{array}{l}\mathrm{Y}^{91} \\
\mathrm{Zr}\end{array}$} & $\longrightarrow$ Stable $\mathrm{Zr}^{91}$ & 0.593 & 0.000 & 0.593 & 0.593 \\
\hline & $-\mathrm{Nb}^{95}$ & 0.111 & 0.739 & 0.850 & $0.850^{[a]}$ \\
\hline & $\mathrm{Nb} \stackrel{95}{\longrightarrow}$ Stable $\mathrm{Mo}^{95}$ & 0.045 & 0.760 & 0.805 & $0.805^{[\mathrm{a}]}$ \\
\hline \multirow[t]{2}{*}{$\mathrm{Ru}^{1.03}$} & $\mathrm{Rh}^{103}$ & 0.065 & 0.498 & 0.563 & -- \\
\hline & 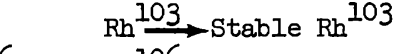 & 0.039 & 0.001 & 0.040 & 0.603 \\
\hline \multirow[t]{2}{*}{$\mathrm{Ru}^{10}$} & $\mathrm{Rh}^{106}$ & 0.010 & 0.000 & 0.010 & -- \\
\hline & 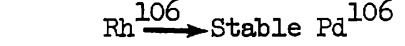 & 1.358 & 0.328 & 1.686 & 1.696 \\
\hline \multirow[t]{2}{*}{$\mathrm{Cs}^{137}$} & $\mathrm{Ba}^{137}$ & 0.173 & 0.000 & 0.173 & -- \\
\hline & $\mathrm{Ba}^{137} \longrightarrow$ Stable $\mathrm{Ba}^{137}$ & 0.066 & 0.595 & 0.661 & 0.834 \\
\hline \multirow[t]{2}{*}{$\mathrm{Ba}^{140}$} & $\mathrm{Ia}^{140}$ & 0.274 & 0.212 & 0.486 & -- \\
\hline & $\mathrm{Ia} \stackrel{140}{\longrightarrow} \mathrm{Ce}^{140}$ & 0.439 & 2.305 & 2.744 & 3.230 \\
\hline \multirow{4}{*}{$\begin{array}{l}\mathrm{Ce}^{14} \\
\mathrm{Pr}^{14} \\
\mathrm{Ce}^{14}\end{array}$} & - Stable $\mathrm{Pr}^{141}$ & 0.146 & 0.097 & 0.243 & 0.243 \\
\hline & Stable $\mathrm{Nd}^{143}$ & 0.315 & 0.000 & 0.315 & 0.315 \\
\hline & $-\operatorname{Pr}^{144}$ & 0.093 & 0.016 & 0.109 & -- \\
\hline & $\operatorname{Pr} \stackrel{144}{\longrightarrow}$ Stable $\mathrm{Nd}^{144}$ & 1.195 & 0.064 & 1.259 & 1.368 \\
\hline \multirow[t]{2}{*}{$\mathrm{Na}^{14}$} & $\mathrm{Pm}^{147}$ & 0.271 & 0.137 & 0.408 & $0.408^{[b]}$ \\
\hline & $\mathrm{Pm}^{147} \longrightarrow$ Stable $\mathrm{Sm}^{147}$ & 0.062 & 0.000 & 0.062 & $0.062^{[b]}$ \\
\hline$[a]$ & \multicolumn{5}{|c|}{$\begin{array}{l}\text { The last step of the two step decay of } \mathrm{Zr}^{95} \longrightarrow \mathrm{Nb} \stackrel{95}{\longrightarrow} \text { Mo } 95 \text { has been accounted for in the } \\
\text { determination of the distribution of } \mathrm{Nb} 95 \text {. }\end{array}$} \\
\hline$[\mathrm{b}]$ & \multicolumn{5}{|c|}{$\begin{array}{l}\text { The last step of the two step decay of } \mathrm{Nd}^{147} \stackrel{14}{\rightarrow} \mathrm{Pm}^{147} \rightarrow \mathrm{Sm}^{147} \text { has been accounted for in } \\
\text { the determination of the distribution of } \operatorname{Pm}{ }^{147} \text {. }\end{array}$} \\
\hline
\end{tabular}


TABLE B-2

HEAT GENERATION FROM THEORETICAL MTR-TYPE WASTE

\begin{tabular}{|c|c|c|c|c|c|c|c|c|c|}
\hline \multicolumn{2}{|c|}{$\begin{array}{l}\text { Time After } \\
\text { Irradiation }\end{array}$} & \multicolumn{2}{|c|}{ O Days } & \multicolumn{2}{|c|}{120 Days } & \multicolumn{2}{|c|}{200 Days } & \multicolumn{2}{|c|}{1 Year } \\
\hline Nuclide & $\mathrm{Mev} / \mathrm{dis} \mathrm{s}^{[\mathrm{a}]}$ & $\frac{\text { Curies }}{\text { Ib solid }}$ & $\frac{\text { Btu }}{\mathrm{hr-1b \text {solld }}}$ & $\frac{\text { Curles }}{\text { Ib solid }}$ & $\frac{\text { Btu }}{\mathrm{br}-1 \mathrm{~b} \text { sol1d }}$ & $\frac{\text { Curres }}{\frac{1 b \text { solid }}{4}}$ & $\frac{\text { Btu }}{\mathrm{hr-1b \text {sol1a }}}$ & $\frac{\text { Curres }}{1 \mathrm{lb} \mathrm{sol1d}}$ & $\frac{\text { Btu }}{\overline{h r-1 b \text { sol1d }}}$ \\
\hline Sr-89 & 0.556 & $1,077.23$ & 12.13 & 237.80 & 2.67 & 89.30 & $1 . \infty$ & 10.55 & 0.11 \\
\hline Sr-90 & 1.081 & 8.17 & 0.17 & 8.17 & 0.17 & 8.06 & 0.17 & 7.97 & 0.17 \\
\hline$Y-91$ & 0.593 & $1,250.69$ & 15.02 & 254.20 & 3.06 & 116.48 & 1.40 & 16.36 & 0.20 \\
\hline $2 \mathrm{r}-95$ & 0.850 & $1,271.68$ & 21.88 & 289.30 & 4.98 & 150.04 & 2.58 & 22.88 & 0.40 \\
\hline$\sqrt{ } b-95$ & 0.805 & 230.33 & 3.75 & 496.27 & 8.09 & 311.00 & 5.07 & 59.95 & 0.98 \\
\hline $\mathrm{Ru}-103$ & 0.603 & 841.04 & 10.27 & 88.87 & 1.08 & 28.47 & 0.35 & 1.76 & 0.02 \\
\hline Ru-106 & 1.696 & 14.49 & 0.49 & 21.55 & 0.40 & 9.91 & 0.34 & $7 \cdot 37$ & 0.26 \\
\hline Cs-137 & 0.834 & 10.01 & 0.17 & 10.01 & 0.17 & 9.86 & 0.17 & 9.75 & 0.17 \\
\hline$B a-140$ & 3.230 & $4,187.66$ & 273.93 & 64.80 & 4.24 & 10.10 & 0.66 & 6.05 & 0.39 \\
\hline Ce-141 & 0.243 & $2,105.12$ & 10.36 & 126.66 & 0.63 & 28.35 & 0.14 & 0.80 & -- \\
\hline $\operatorname{Pr}=143$ & 0.315 & $3,461.87$ & 22.08 & 7.45 & 0.05 & 0.31 & -- & -- & -- \\
\hline $\mathrm{Ce}-144$ & 1.368 & 286.74 & 7.94 & 215.47 & 5.97 & 177.99 & 4.93 & 120.12 & 3.33 \\
\hline Na- -147 & 0.408 & $2,067.81$ & 17.08 & 0.95 & 0.01 & 0.01 & -- & - & -- \\
\hline $\mathrm{Pm}=147$ & 0.062 & 15.76 & 0.02 & 34.66 & 0.04 & 33.09 & 0.04 & $\underline{28.38}$ & 0.03 \\
\hline$\Sigma=$ & & $16,828.60$ & 395.29 & $2,136.15$ & 31.56 & 972.29 & 16.85 & 291.94 & 6.06 \\
\hline \multicolumn{2}{|c|}{$\begin{array}{l}\text { Time After } \\
\text { Irradiation }\end{array}$} & \multicolumn{2}{|c|}{2 Years } & \multicolumn{2}{|c|}{5 Years } & \multicolumn{2}{|c|}{10 Years } & \multicolumn{2}{|c|}{20 Years } \\
\hline Nuclide & $\mathrm{Mev} / \mathrm{d}_{1 \mathrm{~s}}[\mathrm{a}]$ & $\frac{\text { Curies }}{1 \mathrm{lb} \text { solida }}$ & $\frac{\text { Btu }}{\mathrm{hr}-1 \mathrm{~b} \text { sol1d }}$ & $\frac{\text { Curfes }}{1 \mathrm{~b} \text { sol1d }}$ & $\frac{\text { Btu }}{\overline{\text { hr-1b solid }}}$ & $\frac{\text { Curies }}{1 \mathrm{~b} \text { solid }}$ & 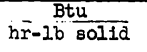 & $\frac{\text { Curles }}{1 \mathrm{~b} \mathrm{sol1d}}$ & $\frac{\text { Btu }}{\overline{h r-1 b \text { sol1a }}}$ \\
\hline Sr-89 & 0.556 & 0.11 & -- & $-\cdot$ & -- & -. & -. & -- & -- \\
\hline Sr-90 & 1.081 & 7.78 & 0.17 & 7.22 & 0.16 & 6.37 & 0.14 & 4.96 & 0.10 \\
\hline Y-91 & 0.593 & 0.21 & -- & -- & -- & -- & -- & -. & -- \\
\hline $\mathrm{zr}-95$ & 0.850 & 0.40 & 0.01 & -- & -- & -- & -- & -. & -- \\
\hline $\mathrm{Nb}-95$ & 0.805 & 1.01 & 0.02 & -- & -- & -- & -- & $-\cdots$ & -- \\
\hline $\mathrm{Ru}-103$ & 0.603 & -- & -- & -- & -- & -- & -- & -- & -- \\
\hline$R u-106$ & 1.696 & 3.63 & 0.13 & 0.46 & 0.01 & 0.01 & -. & -- & -- \\
\hline $\mathrm{Cs}-137$ & 0.834 & 9.50 & 0.16 & 8.77 & 0.15 & 7.66 & 0.13 & 5.93 & 0.10 \\
\hline $\mathrm{Ba}-140$ & 3.230 & -- & -- & -- & -- & -- & -- & -- & -. \\
\hline Ce-141 & 0.243 & 0.20 & -- & -- & -- & -- & -- & -- & -- \\
\hline Pr-143 & 0.315 & -- & -- & -- & -- & -- & -- & -- & -- \\
\hline $\mathrm{Ce}-144$ & 1.368 & 50.12 & 1.39 & 3.44 & 0.09 & -- & -- & -- & -. \\
\hline Nd-147 & 0.408 & -- & -- & -- & -. & -- & -- & -. & -- \\
\hline $\mathrm{Pm}-147$ & 0.062 & 22.07 & $\underline{0.03}$ & 10.70 & 0.02 & $\underline{2.68}$ & $\cdots$ & 1.48 & $\cdots$ \\
\hline$\Sigma=$ & & 95.03 & 1.91 & 30.59 & 0.43 & 16.72 & 0.27 & 12.37 & 0.20 \\
\hline
\end{tabular}

[a] From Table B-I, last column. 
TABLE B-3

HEAT GENERATION FROM ICPP WM-180 WASTE

\begin{tabular}{|c|c|c|c|c|c|c|c|c|c|}
\hline \multirow{2}{*}{$\frac{\text { Yeare After }}{\text { Nuclide }}$} & \multirow{2}{*}{$\frac{160 \longrightarrow}{\text { Act1v1ty }^{[\mathrm{g}]}}$} & \multicolumn{2}{|l|}{0 Years } & \multicolumn{3}{|c|}{1 Year } & \multicolumn{3}{|c|}{2 Yeara } \\
\hline & & Curles/1b & Btu/hr-lb & $\begin{array}{c}\text { Activity } \\
\left(d_{1} / \mathrm{m} / \mathrm{n}-\mathrm{ml}\right)\end{array}$ & Curles/1b & Btu/hr-lb & $\begin{array}{c}\text { Activity } \\
\text { (d1s/min-ml) }\end{array}$ & Curtes/1b & Btu/hr-1b \\
\hline Sr-89 & -- & -- & -- & -- & -- & -- & -- & -- & -- \\
\hline Sr-90 & $1.469 \times 10^{(0]}$ & 3.245 & 0.071 & $1.433 \times 10^{9}$ & 3.17 & 0.069 & $1.398 \times 109$ & 3.09 & 0.068 \\
\hline Y-91 & -- & -- & -- & -- & -- & -- & -- & -- & -- \\
\hline $2 r-95$ & -- & -- & -- & -- & -- & -- & -- & -- & -- \\
\hline Ru-103 & -- & -- & -- & -- & -- & -- & -- & -- & -- \\
\hline Ru-106 & $0.068 \times 109$ & 0.15 & 0.005 & $0.034 \times 109$ & 0.08 & 0.003 & $0.017 \times 109$ & 0.04 & 0.001 \\
\hline C8-137 & $1.702 \times 109^{[b]}$ & 3.76 & 0.063 & $1.658 \times 109$ & 3.69 & 0.062 & $1.615 \times 109$ & 3.57 & 0.060 \\
\hline $\mathrm{Ba}-140$ & -- & -- & -- & -- & -- & -- & -- & -- & -- \\
\hline $\mathrm{Ce}-141$ & -- & -- & -- & -- & -- & -- & -- & -- & -- \\
\hline $\operatorname{Pr}=143$ & -- & -- & -- & -- & -- & -- & -- & -- & -- \\
\hline $\mathrm{Ce}-144$ & $0.643 \times 10^{9}$ & 1.42 & 0.039 & $0.269 \times 109$ & 0.60 & 0.007 & $0.113 \times 109$ & 0.25 & 0.003 \\
\hline Nd-147 & -- & -- & -- & -- & -- & -- & -- & -- & -- \\
\hline$P_{m}-147$ & -- & -- & -- & -- & -- & -- & -- & -- & -- \\
\hline$\Sigma=$ & $3.882 \times 109$ & 8.58 & 0.178 & $3.394 \times 109$ & 7.54 & 0.141 & $3.142 \times 109$ & 6.95 & 0.132 \\
\hline
\end{tabular}

\begin{tabular}{|c|c|c|c|c|c|c|}
\hline \multirow{2}{*}{$\frac{\text { Years After }}{\text { Nuclide }}$} & \multirow{2}{*}{ 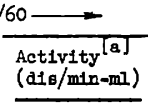 } & \multicolumn{2}{|c|}{ Years } & \multicolumn{3}{|c|}{10 Years } \\
\hline & & Curles/Ib & $\mathrm{Btu} / \mathrm{hr}-\mathrm{lb}$ & $\begin{array}{c}\text { Activity } \\
(\mathrm{dis} / \mathrm{m}+\mathrm{n}-\mathrm{ml})\end{array}$ & Curles/Ib & Btu/hr-J.b \\
\hline $5 r-89$ & -- & -- & -- & -- & -- & -- \\
\hline Sr-90 & $1.298 \times 109$ & 2.87 & 0.063 & $1.146 \times 109$ & 2.53 & 0.055 \\
\hline Y-91 & -- & -- & -- & -- & -- & -- \\
\hline $\mathrm{Zr}-95$ & -- & -- & -- & -- & -- & -- \\
\hline Ru-103 & -- & -- & - & -. & -- & -- \\
\hline Ru-106 & $0.002 \times 109$ & -- & -- & $0.0007 \times 109$ & -- & -- \\
\hline Cs-137 & $1.504 \times 109$ & 3.32 & 0.055 & $1.311 \times 109$ & 2.90 & 0.049 \\
\hline $\mathrm{Be}-140$ & -- & -- & -- & -- & -- & -- \\
\hline $\mathrm{Ce}-141$ & -- & -- & -- & -- & -- & -- \\
\hline $\operatorname{Pr}-143$ & -- & -- & -- & -- & -- & -- \\
\hline Ce-144 & $0.009 \times 109$ & 0.02 & -- & $0.0002 \times 109$ & -- & -- \\
\hline Na-147 & -- & -- & -- & -- & -- & -- \\
\hline $\operatorname{Pm}-147$ & -- & - & -- & -- & -- & -- \\
\hline$\Sigma=$ & $2.812 \times 109$ & $\overline{6.21}$ & $\overline{0.118}$ & $2.458 \times 109$ & $\overline{5.43}$ & $\overline{0.104}$ \\
\hline
\end{tabular}

[a] From waste tank analysis

[b] Back calculated to $3 / 60$ 
TABLE B-4

HEAT GENERATION FROM ICPP WM-182 WASTE

\begin{tabular}{|c|c|c|c|c|c|c|c|c|c|}
\hline \multirow{2}{*}{$\frac{\text { Yrs After } 3 / 60-}{\text { Nuclide[a] }}$} & \multicolumn{3}{|c|}{0 Years } & \multicolumn{3}{|c|}{1 Year } & \multicolumn{3}{|c|}{2 Years } \\
\hline & $\begin{array}{l}\text { Activity }[a] \\
(\text { dis/min-ml) }\end{array}$ & Curles/Ib & Btu/hr-Ib & $\begin{array}{c}\text { Activity } \\
\text { (dis/min-ml) }\end{array}$ & Curtes/lb & Btu/hr-Ib & $\begin{array}{c}\text { Activity } \\
(\mathrm{d} 1 \mathrm{~g} / \mathrm{min}-\mathrm{ml})\end{array}$ & Curles/Ib & $\mathrm{Btu} / \mathrm{hr}-\mathrm{Ib}$ \\
\hline $\mathrm{Sr}-89$ & $0.10 \times 10^{9}$ & 0.230 & 0.002 & --- & -- & $\cdots$ & $\cdots$ & $\ldots$ & -- \\
\hline Sr-90 & $2.49 \times 10^{9[\mathrm{~b}]}$ & 5.72 & 0.130 & $2.43 \times 10^{9}$ & 5.59 & 0.122 & $2.37 \times 10^{9}$ & 5.46 & 0.120 \\
\hline Y-91 & -- & -- & $\cdots$ & --- & --- & $\cdots$ & --- & $\cdots$ & $\cdots$ \\
\hline $\mathrm{Zr}-95$ & $0.274 \times 10^{9}$ & 0.631 & 0.010 & $\cdots$ & $\cdots$ & $\cdots$ & $\cdots$ & $\cdots$ & -- \\
\hline $\mathrm{Nb}-95$ & $\cdots$ & -- & -- & $\cdots$ & -- & $\cdots$ & $\cdots$ & $\cdots$ & $\cdots$ \\
\hline $\mathrm{Ru}-103$ & $\cdots$ & --- & --- &.-- & -- & $\cdots$ & -- & ... & $\cdots$ \\
\hline $\mathrm{Ru}-106$ & $0.64 \times 10^{9}$ & 1.485 & 0.051 & $0.32 \times 10^{9}$ & 1.150 & 0.040 & $0.16 \times 10^{9}$ & 0.364 & 0.012 \\
\hline Cs-137 & $2.67 \times 10^{9^{[b]}}$ & 6.14 & 0.104 & $2.60 \times 10^{9}$ & 5.99 & 0.100 & $2.53 \times 10^{9}$ & 5.81 & 0.098 \\
\hline $\mathrm{Ba}-140$ & $\cdots$ & -- & -- & -- & -- & -- & $\cdots$ & $\cdots$ & $\cdots$ \\
\hline $\mathrm{Ce}-141$ & -- & -- & --- & $\cdots$ & -- & $\cdots$ & $\cdots$ & $\cdots$ & $\cdots$ \\
\hline $\operatorname{Pr}-143$ & -- & $\cdots$ & -- & -- & -- & $-\ldots$ & --- & $\cdots$ & $\cdots$ \\
\hline $\mathrm{Ce}-144$ & $6.83 \times 10^{9}$ & $15 \cdot 72$ & 0.435 & $2.86 \times 10^{9}$ & 6.58 & 0.182 & $1.2 \times 10^{9}$ & 2.76 & 0.077 \\
\hline Na-147 & $\cdots$ & -- & -- & --- & -- & $\cdots$ & -- & $\cdots$ & $\cdots$ \\
\hline $\mathrm{Pm}-147$ & $\cdots$ & $\cdots$ & $\cdots$ & $-\cdots$ & $\cdots$ & $-\cdots$ & $\cdots$ & -- & -- \\
\hline$\Sigma=$ & $13.00 \times 10^{9}$ & 29.93 & 0.732 & $8.21 \times 10^{9}$ & 19.31 & 0.444 & $6.26 \times 10^{9}$ & 14.39 & 0.307 \\
\hline
\end{tabular}

\begin{tabular}{|c|c|c|c|c|c|c|}
\hline \multicolumn{2}{|l|}{ Yrs After $3 / 60 \longrightarrow$} & \multicolumn{2}{|l|}{5 Years } & \multicolumn{3}{|c|}{10 Years } \\
\hline Nuclide $[a]$ & $\begin{array}{c}\text { Activity } \\
\text { (dis/min-ml) }\end{array}$ & Curies/1b & $\mathrm{Btu} / \mathrm{hr}-\mathrm{Ib}$ & $\begin{array}{c}\text { Activity } \\
\text { (dis/min-mI) }\end{array}$ & Curles/1b & $\mathrm{Btu} / \mathrm{hr}-\mathrm{Ib}$ \\
\hline Sr-89 & --- & --- & --- & --- & --- & -- \\
\hline $\mathrm{Sr}-90$ & $2.20 \times 10^{9}$ & 5.06 & 0.111 & $1.95 \times 10^{9}$ & 4.49 & 0.098 \\
\hline$Y-91$ & -- & --- & $\cdots$ & -- & --- & -- \\
\hline $\mathrm{Zr}-95$ & -- & -- & -- & -- & $\cdots$ & -- \\
\hline $\mathrm{Nb}-95$ & $\cdots$ & --- & --- & --- & -- & $\cdots$ \\
\hline Ru-103 & $-\cdots$ & -- & --- & --- & --- & --- \\
\hline Ru-106 & $0.02 \times 10^{9}$ & 0.044 & $\ldots$ & -- & 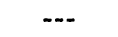 & --- \\
\hline Св-137 & $2.34 \times 10^{9}$ & 5.38 & 0.091 & $2.06 \times 10^{9}$ & 4.74 & 0.080 \\
\hline $\mathrm{Ba}-140$ & -- & -- & --- & $\cdots$ & --- & -- \\
\hline Ce-141 & --- & -- & --- & --- & -- & --- \\
\hline $\operatorname{Pr}-143$ & --- & --- & $\cdots$ & -- & $\cdots$ & $\cdots$ \\
\hline $\mathrm{Ce}-144$ & $0.09 \times 10^{9}$ & 0.21 & 0.006 & --- & $\cdots$ & $\cdots$ \\
\hline Nd-147 & --- & -- & -- & -- & --- & $\cdots$ \\
\hline$P m-147$ & --- & $\cdots$ & -- & -- & -- & -- \\
\hline$\Sigma=$ & $4.65 \times 10^{9}$ & 10.69 & 0.208 & $4.01 \times 10^{9}$ & 9.23 & 0.178 \\
\hline
\end{tabular}

[a] From waste tank analysis

[b] Back calculated to 3/60 
TABLE B-5

HEAT GENERATION FROM ICPP WM-183 WASTE

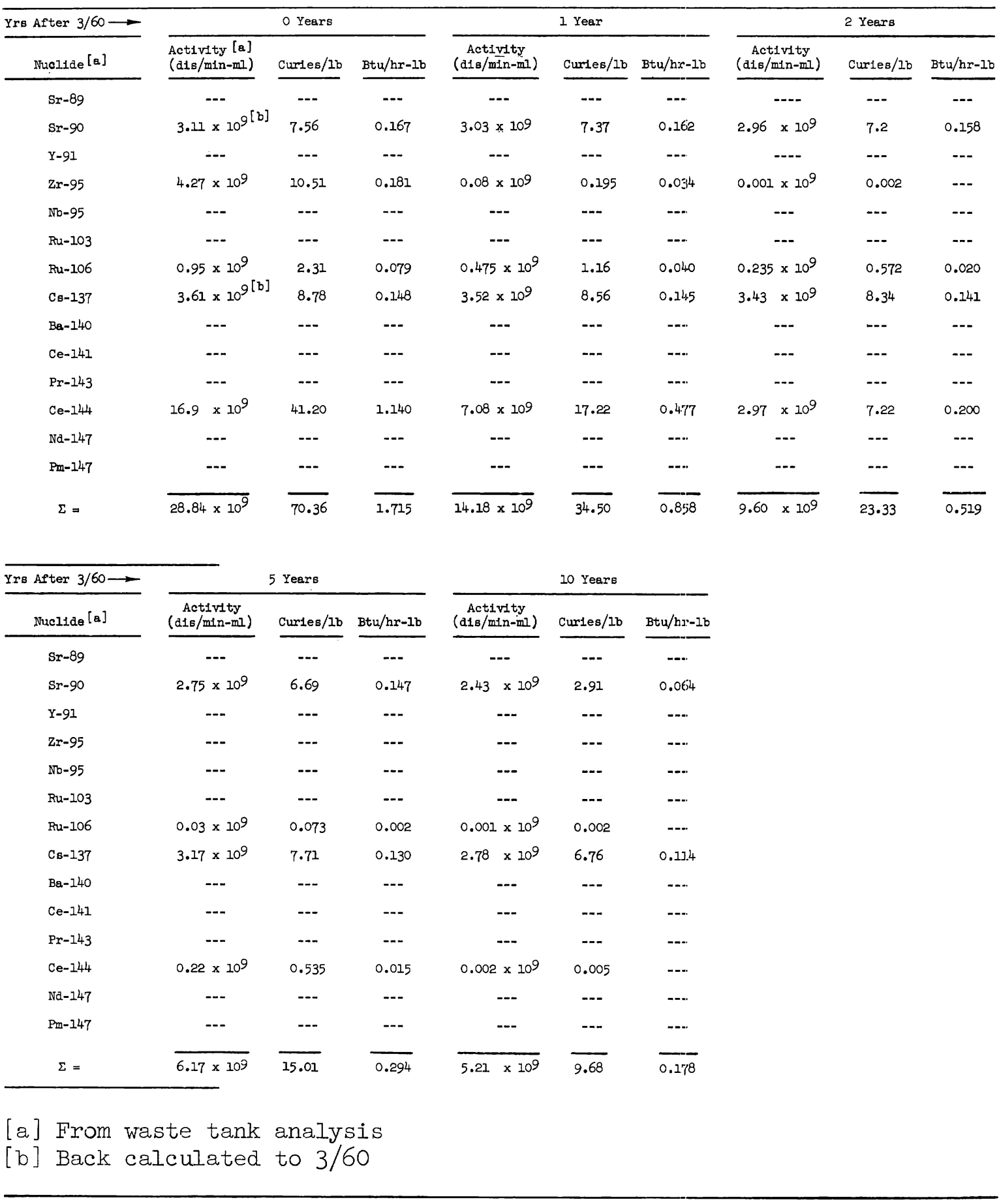


TABLE B-6

HEAT GENERATION FROM WM-185 WASTE

\begin{tabular}{|c|c|c|c|c|c|c|c|c|c|}
\hline \multirow{2}{*}{$\frac{\text { Yrs After } 3 / 60 \longrightarrow}{\text { Nuclide }}$} & \multicolumn{3}{|c|}{ O Year } & \multicolumn{3}{|c|}{1 Year } & \multicolumn{3}{|c|}{2 Years } \\
\hline & $\begin{array}{l}\text { Activity [a] } \\
\text { (dis/min-m]) }\end{array}$ & Curies/lb & $\mathrm{Btu} / \mathrm{hr}-\mathrm{Ib}$ & $\begin{array}{c}\text { Activity } \\
(\mathrm{d} 1 \mathrm{~s} / \mathrm{min}-\mathrm{ml})\end{array}$ & Curies/Ib & $\mathrm{Btu} / \mathrm{hr}-\mathrm{lb}$ & $\begin{array}{c}\text { Act1vity } \\
(d 1 s / m 1 n-m])\end{array}$ & Curles/1b & $\mathrm{Btu} / \mathrm{hr}-\mathrm{lb}$ \\
\hline Sr-89 & $0.96 \times 109$ & 2.011 & 0.023 & $0.009 \times 10^{9}$ & 0.019 & $\cdots$ & $0.001 \times 10^{9}$ & 0.002 &.-- \\
\hline $\mathrm{Sr}-90$ & $3.50 \times 10^{9[\mathrm{~b}]}$ & $7 \cdot 330$ & 0.160 & $3.42 \times 10^{9}$ & 7.160 & 0.157 & $3.33 \times 10^{9}$ & 6.990 & 0.153 \\
\hline Y-91 & $0.16 \times 10^{9}$ & 0.336 & 0.004 & $0.002 \times 10^{9}$ & 0.027 & $\cdots$ & -.. & -.. & -.- \\
\hline $2 r-95$ & $0.08 \times 10^{9}$ & 0.168 & 0.003 & $\cdots$ & $\cdots$ & -- & -- &.-- & $\ldots$ \\
\hline $\mathrm{Nb}-95$ & $0.14 \times 10^{9}$ & 0.294 & 0.005 & $0.006 \times 10^{9}$ & 0.013 & $\cdots$ & $-\cdots$ & --- & -- \\
\hline$R u-103$ & $\cdots$ &.- &.-- & $\ldots$ & -- &.-- & $-\cdots$ & $\ldots$ & $\ldots$ \\
\hline Ru-106 & $1.62 \times 10^{9}$ & 3.405 & 0.117 & $0.81 \times 10^{9}$ & 1.700 & 0.058 & $0.402 \times 10^{9}$ & 0.844 & 0.029 \\
\hline Cs-137 & $3.93 \times 10^{9^{[b]}}$ & 8.260 & 0.139 & $3.82 \times 10^{9}$ & 8.040 & 0.136 & $3.73 \times 10^{9}$ & $7 \cdot 740$ & 0.131 \\
\hline$B a-140$ & --- & --- & --- & -.. & -.- & $\cdots$ & $\cdots$ & $\ldots$ & $\cdots$ \\
\hline $\mathrm{Ce}-141$ & $\cdots$ & -- & --- & $-\cdots$ & --- & -.. & -.. &.- & $\cdots$ \\
\hline Pr-143 & $\ldots$ & $\cdots$ & -.. & $\ldots$ & -- & $\ldots$ & $\ldots$ & $\cdots$ & -.. \\
\hline $\mathrm{Ce}-144$ & $29.1 \times 10^{9}$ & 61.10 & 1.692 & $12.19 \times 10^{9}$ & 25.60 & 0.709 & $5.11 \times 10^{9}$ & 10.73 & 0.297 \\
\hline Nd-147 & -- & -- & -- & $\cdots$ & $\ldots$ & $\cdots$ & $\ldots$ & -- & --- \\
\hline $\mathrm{Pm}-147$ & $\cdots$ & $\cdots$ & -- & -- & --- & $\cdots$ & $-\cdots$ & -- & --- \\
\hline$\Sigma=$ & $39.50 \times 10^{9}$ & $\overline{82.90}$ & 2.143 & $20.26 \times 10^{9}$ & $\overline{42.56}$ & 1.060 & $12.57 \times 10^{9}$ & 26.31 & 0.610 \\
\hline
\end{tabular}

\begin{tabular}{|c|c|c|c|c|c|c|}
\hline \multirow{2}{*}{$\frac{\text { Yrs After } 3 / 60 \rightarrow}{\text { Nuclide }[a]}$} & \multicolumn{3}{|c|}{5 Years } & \multicolumn{3}{|c|}{10 Years } \\
\hline & $\begin{array}{c}\text { Act1vity } \\
\left(d_{1} / \mathrm{min}-\mathrm{ml}\right)\end{array}$ & Curies/1b & $B t u / h r-I b$ & $\begin{array}{c}\text { Activity } \\
\left(d_{1} / m-m-m I\right)\end{array}$ & Curles/Ib & Btu/hr-Ib \\
\hline $5 r-89$ & -.. &.-- & --- & -.. & --- & -.. \\
\hline $\mathrm{Sr}-90$ & $3.09 \times 10^{9}$ & 6.480 & 0.142 & $2.74 \times 10^{9}$ & 5.740 & 0.126 \\
\hline$Y-91$ & -- & $\cdots$ &.- & -.. & $\cdots$ & $\cdots$ \\
\hline $2 r-95$ & $\cdots$ & $\cdots$ & --- & $\cdots$ & $\cdots$ & $\cdots$ \\
\hline $\mathrm{Nb}-95$ & $\ldots$ & $\ldots$ &.- & $\ldots$ & -- & $\cdots$ \\
\hline Ru-103 & -- & -- & $\cdots$ & -- & $\cdots$ & $\cdots$ \\
\hline$R u-106$ & $0.050 \times 10^{9}$ & 0.105 & 0.004 & $0.01 \times 10^{9}$ & 0.002 & $\cdots$ \\
\hline Cs-137 & $3.45 \times 10^{9}$ & 7.250 & 0.122 & $3.06 \times 10^{9}$ & 6.360 & 0.107 \\
\hline$B Q-140$ & $\ldots$ & $\cdots$ & $\cdots$ & $\cdots$ & $=-$ & $\cdots$ \\
\hline Ce-141 & $\cdots$ &.-- & -- & $\cdots$ & $\cdots$ & $\cdots$ \\
\hline Pr -143 & $m$ & $\ldots$ & $\cdots$ &.-- & $\cdots$ & $\cdots$ \\
\hline Ce-144 & 0.378 & 0.784 & 0.022 & 0.048 & 0.101 & 0.003 \\
\hline NQ-147 & $\cdots$ & $m$ & $\cdots$ & $m$ & $\ldots$ & $\cdots$ \\
\hline$P \pi x=147$ & $\cdots$ & -- & $\cdots$ & $\cdots$ & $\cdots$ & $\cdots$ \\
\hline$\Sigma$ & $6.97 \times 10^{9}$ & 14.62 & 0.290 & $5.85 \times 10^{9}$ & 12.20 & 0.236 \\
\hline
\end{tabular}

[a] From waste tank analysis

[b] Back calculated to $3 / 60$ 


\section{REFERENCES}

1. J. O. Blomeke; M. F. Todd, Uranium-235 Fission-Production as a Function of Thermal Neutron Flux, Irradiation Time, and Decay Time. 1. Atomic Concentrations and Gross Totals, ORNL-2127, Part I, Vol. 1, pp 13-25 (August 19, 1957).

2. J. F. Perkins, R. W. King, "Energy Release from the Decay of Fission Products," Nuclear Science and Engineering, Vol. 3, No. 6, pp 726-46 (June 1958). 



\section{APPENDIX C}

\section{ESTIMATION OF TEMPERATURE PROFILES IN THE WCF SOLIDS STORAGE BINS}

During normal operation, the heat generated by the decay of fission products within the solids will be removed from the bins by thermal radiation to the walls of the solids storage vault and by circulation (natural or forced) of cooling air through the bin air channels. The principalfactors affecting the solids storage bin temperature profiles are the cooling air inlet temperature, cooling air flow rate, type of flow, the bin dimensions, thermal conductivity of the calcined solids, and the heat generation rate.

Due to the interrelationship of the variables, an exact determination of the solids storage temperature profiles would be a complicated and time consuming process. To reduce the complexity of the calculations, several simplifying assumptions were made. The errors introduced by these assumptions are either negligible or result in a calculated temperature higher than that expected in operation of the facility. The simplifying assumptions used for the temperature profile calculations are shown below:

(1) Instantaneous bin filling operation. The assumption of an instantaneous filling operation does not take into account the decay of the heat generation rates which will accompany the normal bin filling.

(2) Neglect the thermal radiation losses from the bin surfaces to the storage vault walls and the inter-radiation between the cooling air channel walls. Neglecting the bin thermal radiation losses results in higher temperature profiles.

(3) Fission product heat is generated and distributed evenly throughout the bed. Neglects the non-linear heat distribution of the gamma radiation. If considered, this would tend to decrease the wall temperatures and the centerline temperatures shown in Figures $\mathrm{C}-3$ and $\mathrm{C}-4$.

(4) All Ru-103 and Ru-106 remain in the calcined solids. During normal operation a portion of $\mathrm{Ru}$ would be removed by the 
adsorbers and final filters.

(5) Physical properties ( $0, k)$ of air and calcine determined at arithmetic mean temperatures. Results in negligible error.

(6) Neglect thermal radiation and convection losses from the top and bottom of the bins; the hottest temperatures will then be at the top portion of the bins (20-foot level) where the cooling air temperature is the highest. Neglecting these losses raises the calculated temperature levels.

(7) Neglect the temperature difference between the two walls of each bin. Neglecting this temperature difference increases the maximum centerline temperature. Actually the no-flux radius will shift until no temperature difference exists. This will decrease the centerline temperature by spreading out the heat load.

(8) Neglect the inlet and outlet cooling air channel pressure drops, assume inlet air temperature is $105^{\circ} \mathrm{F}$, and neglect the differences in pressure drop between the three cooling air channels. Results in negligible error.

(9) Neglect temperature difference across the bin wall thicknesses. Negligible error.

(10) Calcine density $=59.3 \mathrm{lb} / \mathrm{ft}^{3}$ 。 Based on WCF cold testing runs.

(11) Heat generation rates are $0.38 \mathrm{Btu} / \mathrm{hr}-1 \mathrm{~b}$ for the WM-185 waste and $1.90 \mathrm{Btu} / \mathrm{hr}-\mathrm{lb}$ for the two-year cooled waste. Estimated in Appendix B.

(12) Configuration. See Figure C-1.

The first step in determining the various heat loads into the cooling air channels was the estimation of the radii at which there exists no heat flux (intermediate between the walls of the middle and outer bins). The point of no heat flux is that point at which the temperature is a maximum, $q / A=0$, and $d T / d r=$ 0 . The derivation of this relationship is presented below.

1.

$$
q=\frac{Q r}{2}-{\frac{C_{1} k^{[1]}}{r}}^{[1]}
$$

2. Boundary condition:

$$
\text { at } r_{m}, T=T_{m} \text {, and } q=0
$$

3. Solving for the integration constant and substituting into Equation 1 above. 


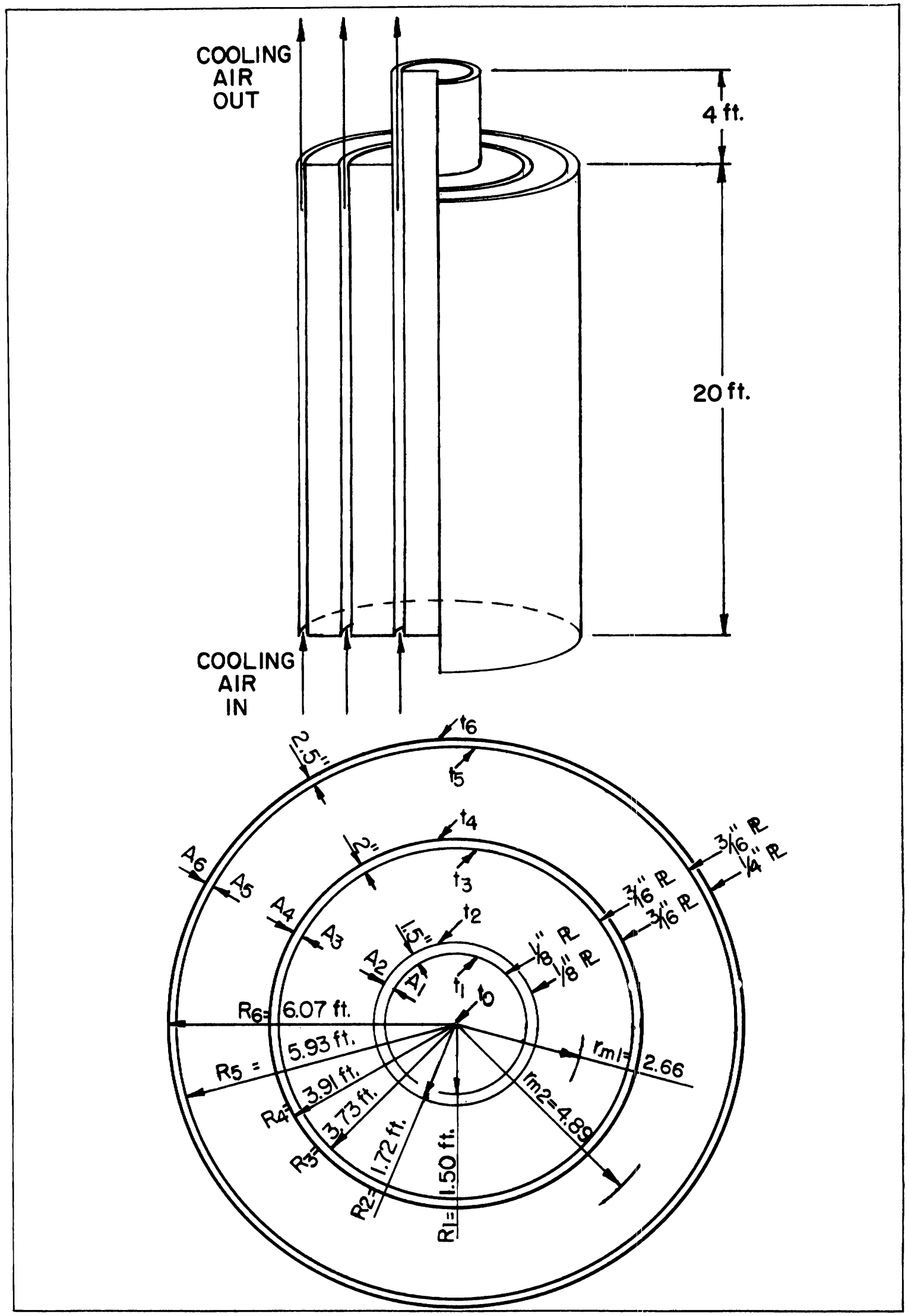

FIG, C-1 WCF SOLIDS STORAGE BIN. 


$$
r_{m}^{2}=\frac{2 k}{Q}\left[\frac{\left(t_{0}-t_{i}\right)+\frac{Q}{4 k}\left(R_{0}^{2}-R_{i}^{2}\right)}{\ln \left(R_{0} / R_{i}\right)}\right]
$$

4. But, assuming $t_{o}=t_{i}$ (Assumption 7, page C-2)

$$
r_{m}^{2}=\frac{R_{0}^{2}-R_{i}^{2}}{2 \ln \left(R_{0} / \bar{R}_{i}\right)}
$$

where:

$$
\begin{aligned}
\mathrm{r}_{\mathrm{m}} & =\text { no-heat-flux radius }(\mathrm{ft}) \\
\mathrm{k} & =\text { thermal conductivity at average temperature }\left(\mathrm{Btu} / \mathrm{hr}-\mathrm{ft}-{ }^{\circ} \mathrm{F}\right) \\
\mathrm{Q} & =\text { internal heat generation rate }\left(\mathrm{Btu} / \mathrm{hr}-\mathrm{ft}^{3}\right) \\
\mathrm{t}_{\mathrm{O}} & =\text { outside cooling air channel wall temperature }\left({ }^{\circ} \mathrm{F}\right) \\
\mathrm{t}_{\mathrm{i}} & =\text { inside cooling air channel wall temperature }\left({ }^{\circ} \mathrm{F}\right) \\
\mathrm{R}_{\mathrm{O}} & =\text { outside cooling air channel wall radius }(\mathrm{ft}) \\
\mathrm{R}_{\mathrm{i}} & =\text { inside cooling air channel wall radius }(\mathrm{ft})
\end{aligned}
$$

\begin{tabular}{|c|c|c|c|c|c|c|c|c|c|}
\hline \multicolumn{2}{|c|}{$\begin{array}{l}\text { Wall } \\
\text { Radius } \\
\text { (ft) }\end{array}$} & $\begin{array}{l}\text { Wall } \\
\text { Thickness } \\
\text { (in.) }\end{array}$ & \multirow{3}{*}{$\begin{array}{c}\begin{array}{c}\text { Bin } \\
\text { Volume }\end{array} \\
(f+3)\end{array}$} & \multirow{2}{*}{$\begin{array}{l}\begin{array}{l}\text { Distance } \\
\text { Between } \\
\text { Walls }\end{array} \\
\text { In }\end{array}$} & \multirow{2}{*}{$\begin{array}{c}\begin{array}{c}\text { Channel } \\
\text { Cross } \\
\text { Sectional } \\
\text { Area }\end{array} \\
\text { Bin }\end{array}$} & \multirow{3}{*}{$\begin{array}{l}\text { Channel } \\
\text { Volume } \\
(1+3)\end{array}$} & \multicolumn{2}{|c|}{$\begin{array}{c}\text { Heat Transfer } \\
\text { Area } \\
\left(f t^{2}\right)\end{array}$} & \multirow[t]{2}{*}{$\begin{array}{l}\text { No-Heat- } \\
\text { Flux } \\
\text { Radius } \\
\text { (ft) }\end{array}$} \\
\hline & & & & & & & & & \\
\hline$R_{1}$ & $\mathrm{R}_{2}$ & 2 & & (in.) & $\left(f t^{2}\right)$ & & $A_{1}$ & $A_{2}$ & \\
\hline 1.50 & 1.72 & $1 / 8 \quad 1 / 8$ & 141.5 & 1.5 & 2.22 & 44.4 & 188.6 & 216.1 & -- \\
\hline \multicolumn{10}{|c|}{ Middle Bin } \\
\hline $\mathrm{R}_{3}$ & $R_{4}$ & 3 & $\left(\mathrm{ft} \mathrm{t}^{3}\right)$ & (in.) & $\left(f t^{2}\right)$ & $(\mathrm{ft} 3)$ & $\mathrm{A}_{3}$ & $\mathrm{~A}_{4}$ & $r_{m I}$ \\
\hline 3.73 & 3.91 & $3 / 163 / 16$ & 689 & 2 & 4.32 & 86.4 & 468.6 & 491.2 & 2.66 \\
\hline \multicolumn{10}{|c|}{ Outer Bin } \\
\hline$R_{5}$ & $\mathrm{R}_{6}$ & 6 & $(\mathrm{ft} 3)$ & (in.) & $\left(f t^{2}\right)$ & $(f+3)$ & $A_{5}$ & $\mathrm{~A}_{6}$ & $r_{m 2}$ \\
\hline 5.93 & 6.07 & $3 / 161 / 4$ & 1250 & 2.5 & 5.28 & 105.5 & 745.5 & 762.6 & 4.89 \\
\hline
\end{tabular}

A summary of the bin dimensions, areas, and volumes is shown below. Figure $\mathrm{C}-1$ gives the locations of the various dimensions.

\section{TABULATION C-I}

The procedures used to estimate the temperature profiles for the solids storage bins, containing calcined WM-185 and two-year cooled MTR-type wastes, are described in the following paragraphs: 
(1) Calculating the bulk cooling air outlet temperatures by estimating the cooling air flow rate (from the blower curves and the pressure drop through each cooling air channel for forced convection, and from design calculations for natural convection), and the heat load into each of the cooling air channels.

(2) Estimating the cooling air channel wall temperatures by the trial and error solution of an equation relating cooling air inlet temperature, cooling air channel wall temperature and heat transfer coefficient, and heat load through the cooling air channel wall. (3) Estimating the temperature profile across the calcined solids contained in the bin by the solution of an equation derived from the basic equation presented in Glasstone [1] relating the temperature at any point $(t)$, the wall temperature $\left(t_{i}\right)$, the heat generation rate, the thermal conductivity, and the radii.

The temperature profiles for both forced (using the cooling air blower) and natural convection were estimated. For clarity, the forced and natural convection methods and results have been separated, with the forced convection section being presented first.

The forced and natural convection sections are divided into three subsections consisting of estimation of cooling air outlet temperature, cooling air channel wall temperature, and solids temperature profiles. Figure C-2 shows the various heat fluxes and bin dimensions.

\section{FORCED CONVECTION}

\subsection{Cooling Air Outlet Temperature}

The cooling air outlet temperatures are estimated from the cooling air flow rate (from the blower curves) and the heat loads into the individual cooling air channels using the following equations:

$$
q=v p S
$$

where:

$\mathrm{q}=$ Heat load to cooling air channel $(\mathrm{Btu} / \mathrm{hr})$

$\mathrm{v}=$ Volume of calcine in bin $\left(\mathrm{ft}^{3}\right)$ (Tabulation C-1)

$\rho=$ Calcined solids density $\left(59.3 \mathrm{lb} / \mathrm{ft}^{3}\right)$

$\mathrm{S}=$ Heat generation rate $(\mathrm{Btu} / \mathrm{hr}-1 \mathrm{~b})$, (from Figures $\mathrm{V}-11, \mathrm{~V}-12)$. 


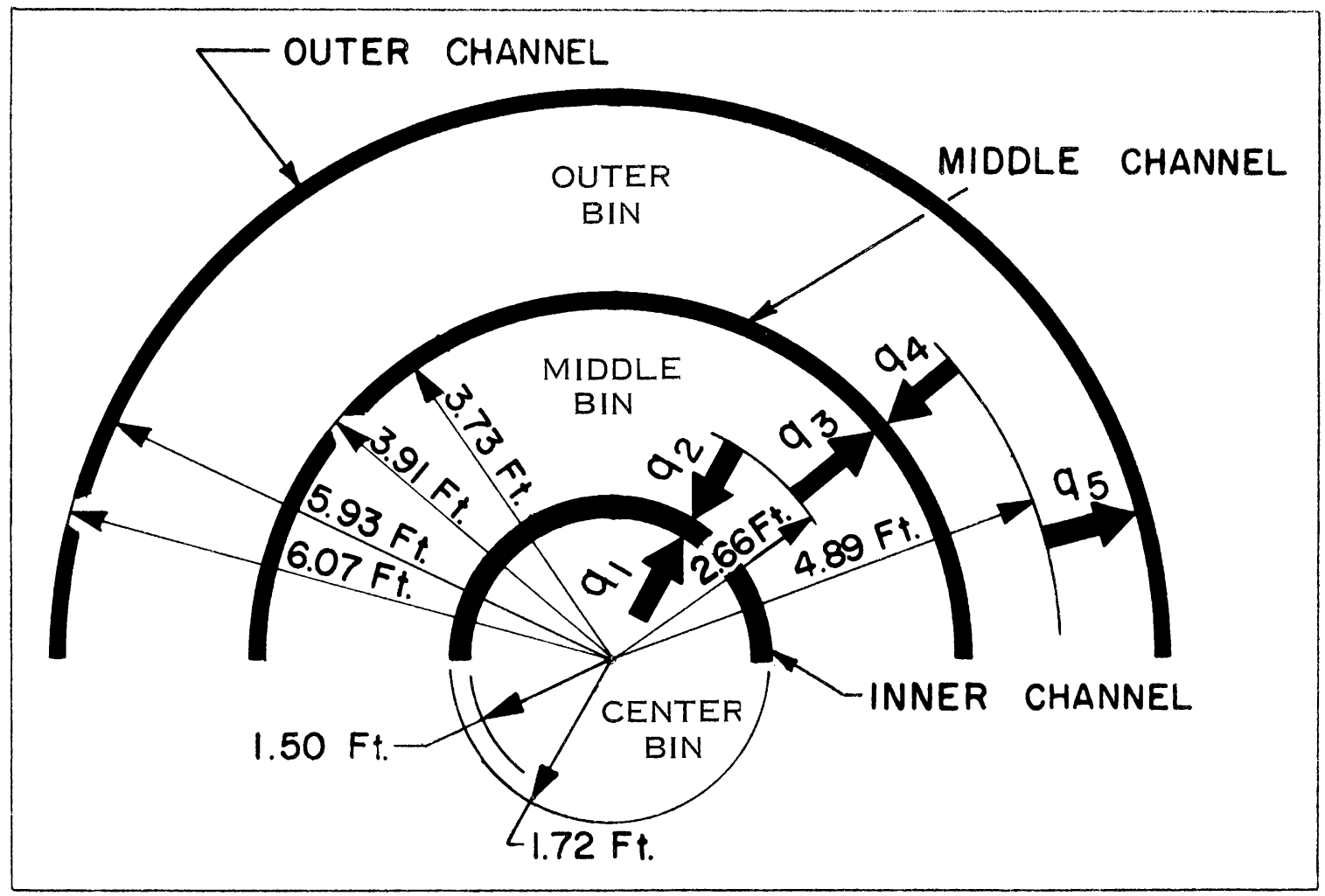

FIG. C-2 STORAGE BIN DIMENSIONS AND HEAT FLUUES.

The heat loads to the individual channels are: ${ }^{[a]}$

$$
\begin{aligned}
& q_{\text {inner channel }}=q_{1}+q_{2} \\
& q_{\text {middle channel }}=q_{3}+q_{4} \\
& q_{\text {outer channel }}=q_{5}
\end{aligned}
$$

A summary of the cooling air channel heat loads is given in Tabulation C-2.

The total design cooling air flow rate is 11,000 actual cubic feet per minute (for all four bins) or 2750 acfm per bin.

The flow rates for forced convection per channel are:

(1) inner channel $=600 \mathrm{acfm}$

(2) middle channel $=1040$ acfm

(3) outer channel $=1105 \mathrm{acfm}$

with a cooling air inlet temperature of $105^{\circ} \mathrm{F}[\mathrm{b}]$.

[a] For location of heat fluxes see Figure C-2.

[b] Estimated maximum ambient temperature for the next 75 years; from NRTS Weather Bureau.

$$
C-6
$$


TABULATION $\mathrm{C}-2^{[\mathrm{a}]}$

Inner Cooling Air Channel

\begin{tabular}{|c|c|c|c|c|c|c|}
\hline $\begin{array}{l}\text { Type of } \\
\text { Waste }\end{array}$ & $\begin{array}{c}\text { Heat } \\
\text { Generation } \\
\text { (Btu/hr-lb) } \\
(\mathrm{S})\end{array}$ & $\begin{array}{l}\text { Bin Heat } \\
\text { Generation } \\
\text { Volume } 1\end{array}$ & $\begin{array}{l}\text { Heat Flow } \\
\left(q_{1}\right)\end{array}$ & $\begin{array}{l}\text { Bin Heat } \\
\text { Generation } \\
\text { Volume } 2\end{array}$ & $\begin{array}{l}\text { Heat Flow } \\
\left(q_{2}\right)\end{array}$ & $\begin{array}{l}\text { Total Heat } \\
\text { Flow to } \\
\text { Inner } \\
\text { Channel }\end{array}$ \\
\hline Wm-185 & 0.38 & $141.5 \mathrm{ft}^{3}$ & $3,190 \mathrm{Btu} / \mathrm{hr}$ & $259 \mathrm{ft}^{3}$ & $5,840 \mathrm{Btu} / \mathrm{hr}$ & $\overline{9,030 \mathrm{Btu} / \mathrm{hr}}$ \\
\hline $2-\mathrm{yr}-\mathrm{MITR}$ & 1.90 & $141.5 \mathrm{ft}^{3}$ & $15,950 \mathrm{Btu} / \mathrm{hr}$ & $259 \mathrm{ft}^{3}$ & $29,180 \mathrm{Btu} / \mathrm{hr}$ & $45,130 \mathrm{Btu} / \mathrm{hr}$ \\
\hline \multicolumn{7}{|c|}{ Middle Cooling Air Channel } \\
\hline $\begin{array}{l}\text { Type of } \\
\text { Waste }\end{array}$ & $\begin{array}{c}\begin{array}{c}\text { Heat } \\
\text { Generation } \\
(B t u / h r-1 b) \\
(S)\end{array} \\
\end{array}$ & $\begin{array}{c}\text { Bin Heat } \\
\text { Generation } \\
\text { Volume } 3 \\
\end{array}$ & $\begin{array}{l}\text { Heat Flow } \\
\left(q_{3}\right)\end{array}$ & $\begin{array}{c}\text { Bin Heat } \\
\text { Generation } \\
\text { Volume } 4\end{array}$ & $\begin{array}{l}\text { Heat Flow } \\
\left(\mathrm{g}_{4}\right)^{-}\end{array}$ & $\begin{array}{l}\text { Total Heat } \\
\text { Flow to } \\
\text { Middle } \\
\text { Channel }\end{array}$ \\
\hline WM-185 & 0.38 & $429 \mathrm{ft}^{3}$ & $9,590 \mathrm{Btu} / \mathrm{hr}$ & $541 \mathrm{ft} 3$ & $12,190 \mathrm{Btu} / \mathrm{hr}$ & $\overline{21,760 \mathrm{Btu} / \mathrm{hr}}$ \\
\hline $2-y r-M I R$ & 1.90 & $429 \mathrm{ft}^{3}$ & 48,350 Btu/hr & $541 \mathrm{ft}^{3}$ & $60,950 \mathrm{Btu} / \mathrm{hr}$ & $109,300 \mathrm{Btu} / \mathrm{hr}$ \\
\hline \multicolumn{7}{|c|}{ Outer Cooling Air Channel } \\
\hline $\begin{array}{l}\text { Type of } \\
\text { Waste }\end{array}$ & $\begin{array}{c}\text { Heat } \\
\text { Generation } \\
(\mathrm{Btu} / \mathrm{hr}-1 \mathrm{~b}) \\
(\mathrm{S})\end{array}$ & $\begin{array}{l}\text { Bin Heat } \\
\text { Generation } \\
\text { Volume } 5\end{array}$ & $\begin{array}{l}\text { Heat Flow } \\
\left(\mathrm{a}_{5}\right)\end{array}$ & & & $\begin{array}{l}\text { Total Heat } \\
\text { Flow to } \\
\text { Outer } \\
\text { Channel }\end{array}$ \\
\hline$\overline{W M-185}$ & 0.38 & $708 \mathrm{ft}^{3}$ & $15, \overline{960 \mathrm{Btu} / \mathrm{hr}}$ & -- & --- & $15 \overline{, 960 \mathrm{Btu} / \mathrm{hr}}$ \\
\hline $2-y r-M T R$ & 1.90 & $708 \mathrm{ft}^{3}$ & $79,800 \mathrm{Btu} / \mathrm{hr}$ & --- & --- & $79,800 \mathrm{Btu} / \mathrm{hr}$ \\
\hline
\end{tabular}

[a] Refer to Figures $C-1$ and -2 for locations of volumes and fluxes.

The mass flow rate of cooling air to each channel was calculated using the following formulae:

$$
W=V \times \frac{P}{P_{O}} \times \frac{T_{0}}{T} \times \rho_{O}
$$

where:

$$
\begin{aligned}
& \mathrm{W}=\text { flow rate }(\mathrm{lb} / \mathrm{hr}) \\
& \mathrm{V}=\text { cooling air flow rate }(\text { acfh, from blower curves }) \\
& \mathrm{P}=\text { operating pressure }(12.30 \mathrm{psia}) \\
& \mathrm{P}_{\mathrm{O}}=\text { standard pressure }(14.70 \mathrm{psia}) \\
& \mathrm{T}_{\mathrm{O}}=\text { standard temperature }\left(60^{\circ} \mathrm{F}\right) \\
& \mathrm{T}=\text { operating temperature }\left({ }^{\circ} \mathrm{F}\right) \\
& \rho_{\mathrm{O}}=\text { standard air density }\left(0.0808 \mathrm{lb} / \mathrm{ft}^{3}\right) \\
& \qquad \mathrm{De}=\mathrm{D}_{0}-\mathrm{D}_{i}
\end{aligned}
$$

where:

$$
\begin{aligned}
& \mathrm{De}=\text { equivalent diameter for pressure drop (ft) } \\
& D_{\mathrm{O}}=\text { outside cooling air channel wall diameter (ft) } \\
& D_{\mathrm{i}}=\text { inside cooling air channel wall diameter }(\mathrm{ft})
\end{aligned}
$$

$$
G=\frac{W}{A}
$$


where:

$\mathrm{G}=$ cooling air mass flow rate $\left(\mathrm{lb} / \mathrm{hr}-\mathrm{ft}^{2}\right)$

$\mathrm{W}=$ cooling air flow rate $(\mathrm{lb} / \mathrm{hr})$

$A=$ cooling air channel cross sectional flow area $\left(\mathrm{ft}^{2}\right)$

$$
\mathrm{IN}_{\mathrm{Re}}=\frac{\mathrm{DeG}}{\mu}
$$

where:

$$
\begin{aligned}
& \mathrm{N}_{\mathrm{Re}}=\text { Reynolds number } \\
& \text { De }=\text { equivalent flow diameter }(\mathrm{ft}) \\
& \mathrm{G}=\text { cooling air mass flow rate }\left(\mathrm{lb} / \mathrm{hr}-\mathrm{ft}^{2}\right) \\
& \mu=\text { cooling air viscosity }(\mathrm{lb} / \mathrm{hr}-\mathrm{ft}) \\
& {[2]} \\
& \qquad F=\frac{4 \mathrm{fG}^{2 L}}{2 \mathrm{~g} \rho \mathrm{L}^{2 \mathrm{De}}}
\end{aligned}
$$

where:

$$
\begin{aligned}
\Delta \mathrm{F} & =\text { pressure drop }(\mathrm{ft} \text { of air) } \\
\mathrm{f} & =\text { friction factor } \\
\mathrm{G} & =\text { mass flow rate }\left(\mathrm{lb} / \mathrm{hr}-\mathrm{ft}^{2}\right) \\
\mathrm{L} & =\text { height of bins }(20 \mathrm{ft}) \\
\mathrm{g} & =\text { acceleration due to gravity }\left(4.18 \times 10^{8} \mathrm{ft} / \mathrm{hr}^{2}\right) \\
\rho & =\text { cooling air density }\left(1 \mathrm{~b} / \mathrm{ft}^{3}\right) \\
\text { De } & =\text { equivalent diameter for pressure drop }(\mathrm{ft})
\end{aligned}
$$

The cooling air outlet temperatures were then estimated using:

$$
t_{\text {outlet }}=t_{\text {inlet }}+\frac{q}{W c_{p}}
$$

where:

$$
\begin{aligned}
\mathrm{q} & =\text { heat load to cooling air channel }(\mathrm{Btu} / \mathrm{hr}) \\
\mathrm{W} & =\text { cooling air flow rate }(\mathrm{lb} / \mathrm{hr}) \\
\mathrm{c}_{\mathrm{p}} & =\text { cooling air specific heat at average temperature }\left(\mathrm{Btu} / \mathrm{lb}-{ }^{\circ} \mathrm{F}\right){ }^{[4]} \\
\mathrm{t}_{\text {outlet }} & =\text { cooling air outlet temperature }\left({ }^{\circ} \mathrm{F}\right) \\
\mathrm{t}_{\text {inlet }} & =\text { cooling air inlet temperature }\left(105^{\circ} \mathrm{F}\right)
\end{aligned}
$$

A summary of the preceeding calculations is presented in Tabulation C-3.

\subsection{Cooling Air Channel Wall Temperatures}

The procedure used for estimating the cooling air channel wall temperatures follows. The equations, as shown in the derivation, were solved for the heat 
TABUTAATION. C-3

\begin{tabular}{|c|c|c|c|c|c|c|c|c|}
\hline \multirow{2}{*}{$\begin{array}{c}\begin{array}{c}\text { Waste } \\
\text { and } \\
\text { Cooling } \\
\text { Channel }\end{array} \\
\text { WM-185 }\end{array}$} & $\begin{array}{c}\text { Flow } \\
\text { Rate } \\
\text { (acfm) }\end{array}$ & $\begin{array}{c}W \\
(\mathrm{Ib} / \mathrm{hr} r)\end{array}$ & $\begin{array}{c}\text { Heat } \\
\text { Load } \\
q \\
\text { (Btu/hr) }\end{array}$ & $\left({ }^{\circ} \mathrm{F}\right)$ & $\begin{array}{l}\text { Outlet } \\
\text { Temp } \\
\left({ }^{\circ} \mathrm{F}\right)\end{array}$ & $\begin{array}{c}\text { Avereage } \\
\text { Termp } \\
\left({ }^{\circ} \mathrm{p}\right)\end{array}$ & $\begin{array}{c}\text { Equivalent } \\
\text { Diameter } \\
\text { De } \\
\text { (ft) }\end{array}$ & $\begin{array}{c}\text { Channel } \\
\text { Area } \\
\text { A } \\
\left(f t^{2}\right)\end{array}$ \\
\hline & & & & & & & & \\
\hline Inner & 600 & 1860 & 9,030 & 19.4 & 124.4 & 114.7 & 0.22 & 2.22 \\
\hline Middle & 1040 & 3225 & 21,760 & 27.0 & 132.0 & 118.5 & 0.18 & 4.32 \\
\hline Outer & 1105 & 3430 & 15,960 & 18.6 & 123.6 & 114.3 & 0.14 & 5.28 \\
\hline \multicolumn{9}{|l|}{ 2-yr-MITR } \\
\hline Inner & 600 & 1860 & 45,130 & 97.0 & 202.0 & 153.5 & 0.22 & 2.22 \\
\hline Middle & 1040 & 3225 & 109,300 & 135.5 & 240.5 & 172.8 & 0.18 & 4.32 \\
\hline Outer & 1105 & 3430 & 79,800 & 93.1 & 198.1 & 15.1 .5 & 0.14 & 5.28 \\
\hline $\begin{array}{l}\text { Waste } \\
\text { and } \\
\text { Cooling }\end{array}$ & $\begin{array}{c}\text { Mass } \\
\text { Flow Rate } \\
\text { G }\end{array}$ & & & $\begin{array}{l}\text { Reynolds } \\
\text { No. } \\
N_{R e}\end{array}$ & $\begin{array}{r}\text { Frac } \\
\text { Fac } \\
f\end{array}$ & & $\Delta P$ & \\
\hline Channel & $\left(1 b / h r-f t^{2}\right)$ & & $\mathrm{Ib} / \mathrm{ft}-\mathrm{hr})$ & & & & ft $a i r)$ & . of $\mathrm{H}_{2} \mathrm{O}$ \\
\hline \multicolumn{9}{|l|}{ WM-185 } \\
\hline Inner & 838 & & 0.0460 & 4010 & 0.0 & & 0.860 & 0.0100 \\
\hline Middle & 746 & & 0.0460 & 2920 & 0.0 & & 0.872 & 0.0100 \\
\hline Outer & 650 & & 0.0460 & 1980 & 0.0 & & 0.887 & 0.0100 \\
\hline \multicolumn{9}{|l|}{ 2-yr-MTR } \\
\hline Inner & 838 & & 0.0472 & 3910 & 0.0 & & 0.994 & 0.0110 \\
\hline Middle & 746 & & 0.0475 & 2830 & 0.0 & & 1.006 & 0.0112 \\
\hline Outer & 650 & & 0.0472 & 1930 & 0.0 & & 1.027 & 0.0114 \\
\hline
\end{tabular}

transfer coefficient $\left(h_{\mathbf{i}}\right)$ and combined, thus reducing the procedure to a single equation. A "film temperature" was assumed ( the arithmetic mean of the bulk gas and the wall temperatures), the $\Delta t$ and wall temperature were calculated, and the original assumed "film temperature" was checked. The equations used are shown below:

$$
j_{H}=\frac{h_{i} \operatorname{De}}{k}\left(\frac{{ }^{C} p^{\mu}}{k}\right)_{f}^{-I / 3}
$$

and

$$
h_{i}=\frac{q}{(A)(\Delta t)}
$$

setting the $\left(h_{i}\right.$ 's) equal and solving for $\Delta t$

$$
\Delta t=\frac{(q)(D e)}{(A)\left(j_{H}\right)(k)\left(C_{p} p^{\mu / k}\right)_{f}^{I / 3}}
$$


where:

$\Delta \mathrm{t}=$ difference between bulk cooling air and wall temperatures

$\mathrm{q}=$ heat load through channel walls (Btu/hr)

$\mathrm{De}=$ equivalent diameter for heat transfer in annuli

$A=$ heat transfer surface $\left(\mathrm{ft}^{2}\right)$

$\mathrm{j}_{\mathrm{H}}=$ heat transfer factor, dimensionless [6]

$\mathrm{k}=$ thermal conductivity of air $\left(\mathrm{Btu} / \mathrm{hr}-\mathrm{ft}-{ }^{\circ} \mathrm{F}\right)^{[7]}$

$\left(\frac{{ }^{C}{ }^{\mu}}{k}\right)_{f}=$ Prandtl number, dimensionless, evaluated at "film temperature" [8] $\mathrm{h}_{\mathrm{i}}=$ heat-transfer coefficient $\left(\mathrm{Btu} / \mathrm{hr}-\mathrm{ft}^{2}-{ }^{\circ} \mathrm{F}\right)$

A summary of the values calculated in this section is presented in Tabulation $\mathrm{C}-4$.

TABULATION C-L

\begin{tabular}{|c|c|c|c|c|c|}
\hline $\begin{array}{c}\text { Waste and } \\
\text { Surface }\end{array}$ & $(\mathrm{Btu} / \mathrm{h} r)$ & $\begin{array}{c}A \\
\left(t^{2} t^{2}\right)\end{array}$ & $\begin{array}{l}\Delta t \\
\left({ }^{\circ} \mathrm{F}\right)\end{array}$ & $\begin{array}{c}\text { toutlet } \\
\left({ }^{\circ} \mathrm{F}\right)\end{array}$ & $\begin{array}{l}t_{\text {WaII }} \\
\left({ }^{\circ}{ }^{\prime}\right)\end{array}$ \\
\hline \multicolumn{6}{|l|}{ WM-185 } \\
\hline$I$ & $q_{1}=3190$ & $A_{I}=188.6$ & 3.8 & 124.4 & $t_{1}=128$ \\
\hline 2 & $q_{2}=5840$ & $A_{2}=216.1$ & 6.0 & 124.4 & $t_{2}=130$ \\
\hline 3 & $q_{3}=9570$ & $A_{3}=468.6$ & $5 \cdot 9$ & 132.0 & $t_{3}=138$ \\
\hline 4 & $q_{4}=12,190$ & $A_{4}=491.2$ & 7.2 & 132.0 & $t_{4}=139$ \\
\hline 5 & $q_{5}=15,960$ & $A_{5}=745.0$ & 9.2 & 123.6 & $t_{5}=133$ \\
\hline
\end{tabular}

$\underline{2-\mathrm{yr}-\mathrm{M} T R}$

$\begin{array}{llllll}1 & q_{1}=15,950 & A_{1}=188.6 & 15.0 & 202.0 & t_{1}=217 \\ 2 & q_{2}=29,180 & A_{2}=216.1 & 25.5 & 202.0 & t_{2}=228 \\ 3 & q_{3}=48,350 & A_{3}=468.6 & 24.8 & 240.5 & t_{3}=265 \\ 4 & q_{4}=60,950 & A_{4}=491.2 & 29.4 & 240.5 & t_{4}=270 \\ 5 & q_{5}=79,800 & A_{5}=745.0 & 39.0 & 198.1 & t_{5}=237\end{array}$

\subsection{Solids Temperature Profile}

The equations for the temperature profiles within the solids storage bins were obtained by deriving the relationships required from the basic equations presented in Glasstone [1]. Due to the differences in geometry between the center, outer, and middle bins, it was necessary to derive two sets of equations, each for a specific geometry, ie, one for the center bin (a cylinder) and a different one for the middle and outer bins (annuli). The equations a re presented on the following page. 
Inner bin temperature profile equation

$$
\left(t-t_{i}\right)=\frac{Q}{4 k}\left(R_{1}^{2}-r^{2}\right)^{[1]}
$$

Middle bin temperature profile equation

(1)

$$
t=-\frac{Q r^{2}}{4 k}+\left(C_{1}\right) \ln (r)+C_{2}^{[1]}
$$

(2) Boundary conditions:

(a)

$$
\begin{aligned}
& t=t_{2} \text { at } r=R_{2} \\
& t=t_{3} \text { at } r=R_{3}
\end{aligned}
$$

(b)

(3) Substituting the boundary conditions into equation 1 above

(a)

$$
\begin{aligned}
& t_{2}=-\frac{Q R_{2}^{2}}{4 k}+\left(C_{1}\right) \ln \left(R_{2}\right)+C_{2} \\
& t_{3}=-\frac{Q R_{3}^{2}}{4 k}+\left(C_{1}\right) \ln \left(R_{3}\right)+C_{2}
\end{aligned}
$$

(4) Solving for the integration constants $\mathrm{C}_{1}$ and $\mathrm{C}_{2}$, substituting into the original equation (1), and simplifying.

$$
t=t_{2}+\frac{Q}{4 k}\left(R_{2}^{2}-r^{2}\right)+\left[\ln \frac{r}{R_{2}}\right]\left[\frac{\left(t_{2}-t_{3}\right)-\frac{Q}{4 k}\left(R_{3}^{2}-R_{2}^{2}\right)}{\ln \left(R_{2} / R_{3}\right)}\right]
$$

\section{Outer bin temperature profile equation}

Following a procedure analogous to the previous one

$$
t=t_{4}+\frac{Q}{4 k}\left(R_{4}^{2}-r^{2}\right)+\left[\ln \frac{r}{R_{4}}\right]\left[\frac{\left(t_{4}-t_{5}\right)-\frac{Q}{4 k}\left(R_{5}^{2}-R_{4}^{2}\right)}{\ln \left(R_{4} / R_{5}\right)}\right]
$$


where:

$$
\begin{aligned}
\mathrm{t}= & \text { the temperature at radius } \mathrm{r}\left({ }^{\circ} \mathrm{F}\right) \\
\mathrm{Q}= & \text { rate of internal heat generation }\left(\mathrm{Btu} / \mathrm{hr}-\mathrm{ft}^{3}\right) \quad \text { (estimated from solids } \\
& \text { density and Figures } \mathrm{V}-11 \text { and } \mathrm{V}-12) \\
\mathrm{k}= & \text { thermal conductivity of the solids }\left(\mathrm{Btu} / \mathrm{hr}-\mathrm{ft}_{-}-{ }^{\circ} \mathrm{F}\right)[9] \\
\mathrm{R}_{\mathrm{n}}= & \text { radius at point " } \mathrm{n} \text { " }(\mathrm{ft}) \quad(\mathrm{Figure} \mathrm{C}-1) \\
\mathrm{r}= & \text { radius at temperature } \mathrm{t}(\mathrm{ft}) \\
\mathrm{C}= & \text { integration constant } \\
\mathrm{t}_{\mathrm{n}}= & \text { temperature at point " } \mathrm{n} \text { " }\left({ }^{\circ} \mathrm{F}\right) \quad(\text { Figure } \mathrm{C}-1)
\end{aligned}
$$

\begin{tabular}{|c|c|c|c|c|c|}
\hline $\begin{array}{l}\text { Temperature } \\
\text { Location }\end{array}$ & $\begin{array}{c}\text { Radius } \\
\text { (ft) }\end{array}$ & $\begin{array}{c}\text { WM-185 } \\
\text { Temperature } \\
\left({ }^{\circ} \mathrm{F}\right) \\
\end{array}$ & $\begin{array}{c}\text { WM-185 } \\
\text { Temperature } \\
\left({ }^{\circ} \mathrm{C}\right) \\
\end{array}$ & $\begin{array}{l}\text { 2-yr-MI'R } \\
\text { Temperature } \\
\left({ }^{\circ} \mathrm{F}\right) \\
\end{array}$ & $\begin{array}{c}\text { 2-yr-MTR } \\
\text { Temperature } \\
\left({ }^{\circ} \mathrm{C}\right) \\
\end{array}$ \\
\hline$t_{0}$ & 0 & 262 & 128 & 645 & 340 \\
\hline$t_{a}$ & 1.00 & 206 & 97 & 511 & 266 \\
\hline$t_{1}$ & 1.50 & 128 & 53 & 217 & 103 \\
\hline$t_{\text {outlet }}$ & 1.61 & 124 & 54 & 202 & 94 \\
\hline$t_{2}$ & 1.72 & 130 & 54 & 228 & 109 \\
\hline$t_{b}$ & 2.00 & 200 & 93 & 503 & 262 \\
\hline$t_{c}$ & 2.66 & 256 & 124 & 638 & 337 \\
\hline$t_{\alpha}$ & 3.25 & 215 & 102 & 580 & 304 \\
\hline$t_{3}$ & 3.73 & 138 & 59 & 265 & 129 \\
\hline$t_{\text {outlet }}$ & 3.82 & 132 & 56 & 240 & 116 \\
\hline$t_{4}$ & 3.91 & 139 & 59 & 270 & 132 \\
\hline$t_{e}$ & 4.25 & 213 & 100 & 537 & 281 \\
\hline$t_{f}$ & 4.89 & 252 & 122 & 654 & 345 \\
\hline$t_{g}$ & 5.60 & 187 & 86 & 449 & 231 \\
\hline$t_{5}$ & 5.93 & 133 & 56 & 237 & 114 \\
\hline$t_{\text {outlet }}$ & 6.00 & 124 & 51 & 198 & 92 \\
\hline
\end{tabular}

An average temperature of the solids was assumed, the temperature at point $r$ calculated and the assumed average temperature checked. The temperature profiles were calculated for a WM-185 and a 2-year cooled MTR-type waste. A summary of the calculations is presented in Tabulation C-5.

\section{TABULATION $\mathrm{C}-5$}

FORCED CONVECTION 
The complete calculated temperature profiles showing the location of the temperature points for forced convection with the bins containing calcined WM-185 and 2-year-MTR waste are shown in Figure C-3.

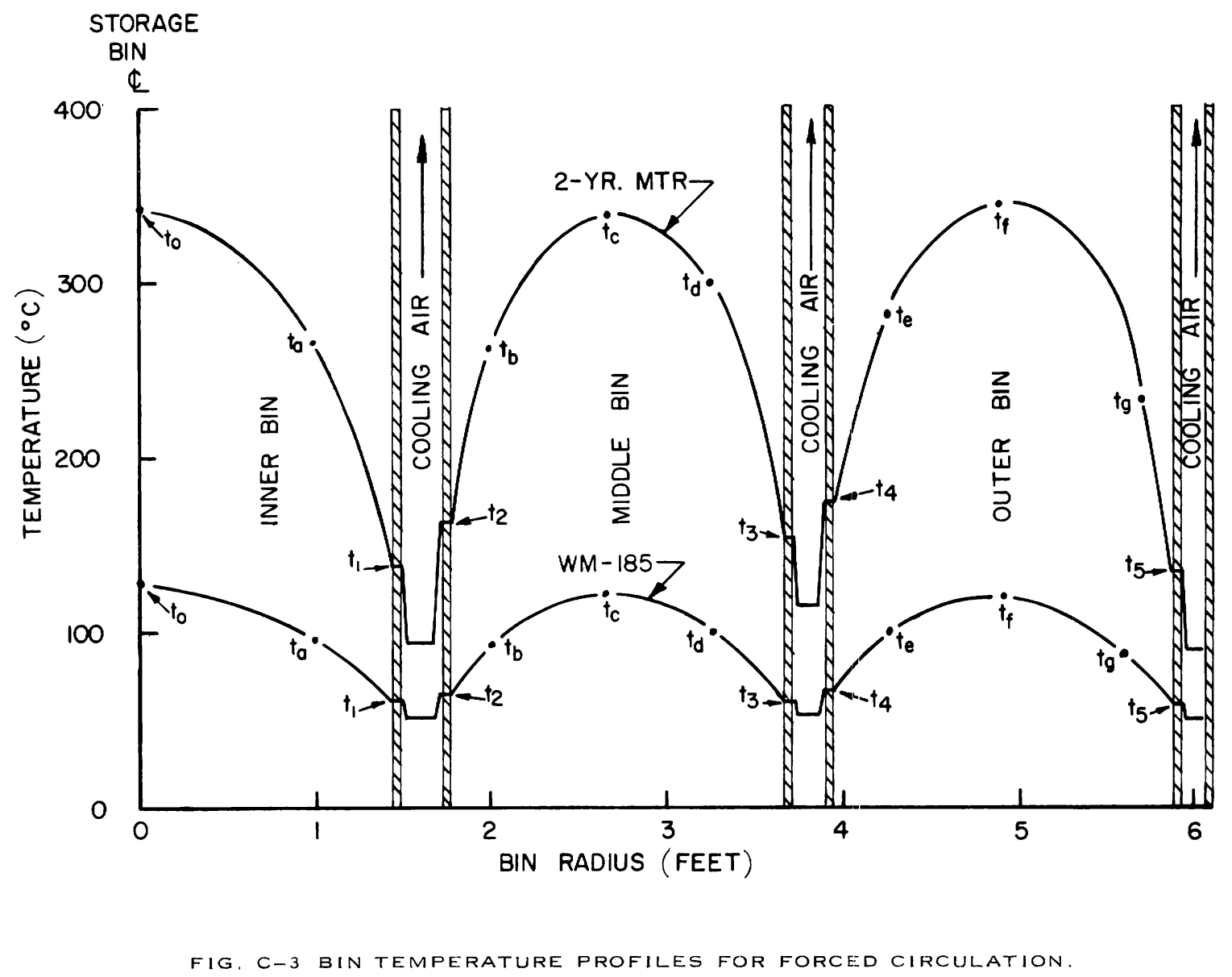

\section{NATURAL CONVECTION}

The procedures and assumptions used to determine the temperature profiles in the solid storage bins for natural convection are identical to those used for the forced convection section, with the exception of the correlations used to determine the cooling air wall temperatures.

\subsection{Cooling Air Outlet Temperatures}

The heat loads into the cooling air channels at steady state for natural convection are the same as those for forced convection and are shown in Tabulation C-2. 
The total design cooling air flow rate for a WM-185 or 2-year-MTR waste with natural convection and a fifty foot stack is 5000 acfm total or $1250 \mathrm{acfm}$ per bin (from Fluor design calculations). A summary of the calculated flow rates and outlet temperatures is shown in Tabulation C-6.

TABULATION C-6

\begin{tabular}{|c|c|c|c|c|c|}
\hline $\begin{array}{c}\text { Waste } \\
\text { and } \\
\text { Cooling Air } \\
\text { Channel }\end{array}$ & $\begin{array}{l}\text { Cooling Air } \\
\text { Flow Rate } \\
\text { (acfm) }\end{array}$ & $\begin{array}{c}W \\
(I b / h r)\end{array}$ & $\begin{array}{c}\text { Total } \\
\text { Heat Load } \\
(\text { Btu/hr) }\end{array}$ & $\left(\begin{array}{c}\Delta t \\
\left.{ }^{\circ} \mathrm{F}\right)\end{array}\right.$ & $\begin{array}{c}\text { Outlet } \\
\text { Temperature } \\
\left({ }^{\circ} \mathrm{F}\right)\end{array}$ \\
\hline \multicolumn{6}{|l|}{ WM-185 } \\
\hline Inner & 273 & $8 !+6$ & 9,030 & 43 & 148 \\
\hline Middle & 473 & 1,465 & 21,760 & 59 & 164 \\
\hline Outer & 502 & 1,558 & 15,960 & 41 & 156 \\
\hline \multicolumn{6}{|l|}{$2-\mathrm{yr}-\mathrm{MPR}$} \\
\hline Inner & 273 & 846 & 45,130 & 213 & 318 \\
\hline Middle & 473 & 1,465 & 109,300 & 293 & 398 \\
\hline Outer & 502 & 1,558 & 79,800 & 210 & 315 \\
\hline
\end{tabular}

\subsection{Cooling Air Channel Wall Temperatures}

As previously discussed, a correlation for natural convection differing from that for forced convection was used to determine the cooling air channel wall temperatures. The equations used are shown below.

and

$$
h_{c}=0.19(\Delta t)^{1 / 3^{[10]}}
$$

$$
h_{c}=\frac{q}{A(\Delta t)}
$$

Setting the $\left(\mathrm{h}_{\mathrm{C}}\right.$ 's) equal and solving for $\Delta t$

$$
\Delta t=\left[\frac{\mathrm{q}}{(0.19)(\mathrm{A})}\right]^{0.75}
$$


where:

$\Delta t=$ difference between bulk cooling air and cooling air channel wall temperatures $\left({ }^{\circ} \mathrm{F}\right)$

$\mathrm{q}=$ heat duty through cooling air channel wall (Btu/hr)

$\mathrm{A}=$ heat transfer surface $\left(\mathrm{ft}^{2}\right)$

A summary of the channel wall temperatures for natural convection is presented in Tabulation C-7. (For locations, see Figures C-1 and C-2).

\section{TABULATION $\mathrm{C}-7$}

\begin{tabular}{|c|c|c|c|c|c|}
\hline $\begin{array}{l}\text { Waste and } \\
\text { Surface }\end{array}$ & $\left(B+u^{q} / h r\right)$ & $\frac{A}{\left(f t^{2}\right)}$ & $\begin{array}{c}\Delta t \\
\left({ }^{\circ} F\right)\end{array}$ & $\begin{array}{l}t \text { outlet } \\
\left({ }^{\circ} \mathrm{F}\right)\end{array}$ & $\begin{array}{l}t \text { wa11 } \\
\left({ }^{\circ} \mathrm{F}\right)\end{array}$ \\
\hline \multicolumn{6}{|l|}{ WM-185 } \\
\hline 1 & $q_{1}=3190$ & $A_{1}=188.6$ & 29.0 & 148 & $t_{1}=177$ \\
\hline 2 & $q_{2}=5840$ & $A_{2}=216.1$ & 41.5 & 148 & $t_{2}=190$ \\
\hline 3 & $q_{3}=9570$ & $A_{3}=468.6$ & 35.2 & 164 & $t_{3}=199$ \\
\hline 4 & $q_{4}=12,190$ & $A_{4}=491.2$ & 36.6 & 164 & $t_{4}=201$ \\
\hline 5 & $q_{5}=15,960$ & $A_{5}=745.0$ & 35.0 & 156 & $t_{5}=191$ \\
\hline \multicolumn{6}{|l|}{ 2-yr-MIR } \\
\hline 1 & $q_{1}=15,950$ & $A_{1}=.188 .6$ & 98.0 & 318 & $t_{1}=416$ \\
\hline 2 & $q_{2}=29,180$ & $A_{2}=216.1$ & 140.0 & 318 & $t_{2}=458$ \\
\hline 3 & $q_{3}=48,350$ & $A_{3}=468.6$ & 114.0 & 398 & $t_{3}=512$ \\
\hline 4 & $q_{4}=60,950$ & $A_{4}=491.2$ & 131.0 & 398 & $t_{4}=529$ \\
\hline 5 & $q_{5}=79,800$ & $A_{5}=745.0$ & 117.0 & 315 & $t_{5}=432$ \\
\hline
\end{tabular}

\subsection{Solids Temperature Profile}

The temperature profiles within the solid storage bins for natural convection were calculated in exactly the same manner as those for forced convection, with bins containing WM-185 and two-year cooled MTR type wastes. The results of the calculations are tabulated in Tabulation $\mathrm{C}-8$ and plotted in Figure $\mathrm{C}-4$. 
TABUTATION C-8

NATURAL CONVECTION

\begin{tabular}{|c|c|c|c|c|c|}
\hline $\begin{array}{l}\text { Temperature } \\
\text { Location }\end{array}$ & $\begin{array}{l}\text { Radius } \\
(\mathrm{ft})\end{array}$ & $\begin{array}{c}\text { WM-185 } \\
\text { Temperature } \\
\left({ }^{\circ} \mathrm{F}\right)\end{array}$ & $\begin{array}{c}\text { WM-185 } \\
\text { Temperature } \\
\left({ }^{\circ} \mathrm{C}\right)\end{array}$ & $\begin{array}{c}\text { 2-yr-MTR } \\
\text { Temperature } \\
\left({ }^{\circ} \mathrm{F}\right)\end{array}$ & $\begin{array}{c}2-y r-M T R \\
\text { Temperature } \\
\left({ }^{\circ} \mathrm{C}\right)\end{array}$ \\
\hline$t_{0}$ & 0 & 304 & 151 & 833 & 445 \\
\hline$t_{a}$ & 1.00 & 253 & 122 & 668 & 353 \\
\hline$t_{1}$ & 1.50 & 177 & 80.5 & 416 & 213 \\
\hline$t_{\text {outlet }}$ & 1.61 & 148 & 64 & 318 & 159 \\
\hline$t_{2}$ & 1.72 & 190 & 88 & 458 & 237 \\
\hline$t_{b}$ & 2.00 & 258 & 126 & 679 & 359.5 \\
\hline$t_{c}$ & 2.66 & 310 & 154 & 858 & 459 \\
\hline$t_{a}$ & 3.25 & 280 & 138 & 787 & 419.5 \\
\hline$t_{3}$ & 3.73 & 199 & 93 & 512 & 267 \\
\hline$t_{\text {outlet }}$ & 3.82 & 164 & 73 & 398 & 203 \\
\hline$t_{4}$ & 3.91 & 201 & 94 & 529 & 276 \\
\hline$t_{e}$ & 4.25 & 288 & 142 & 749 & 398.5 \\
\hline$t_{f}$ & 4.89 & 348 & 176 & 833 & 445 \\
\hline$t_{g}$ & 5.60 & 327 & 164 & 789 & 420.5 \\
\hline$t_{5}$ & 5.93 & 191 & 88 & 432 & 222 \\
\hline$t_{\text {outlet }}$ & 6.00 & 156 & 69 & 315 & 157 \\
\hline
\end{tabular}




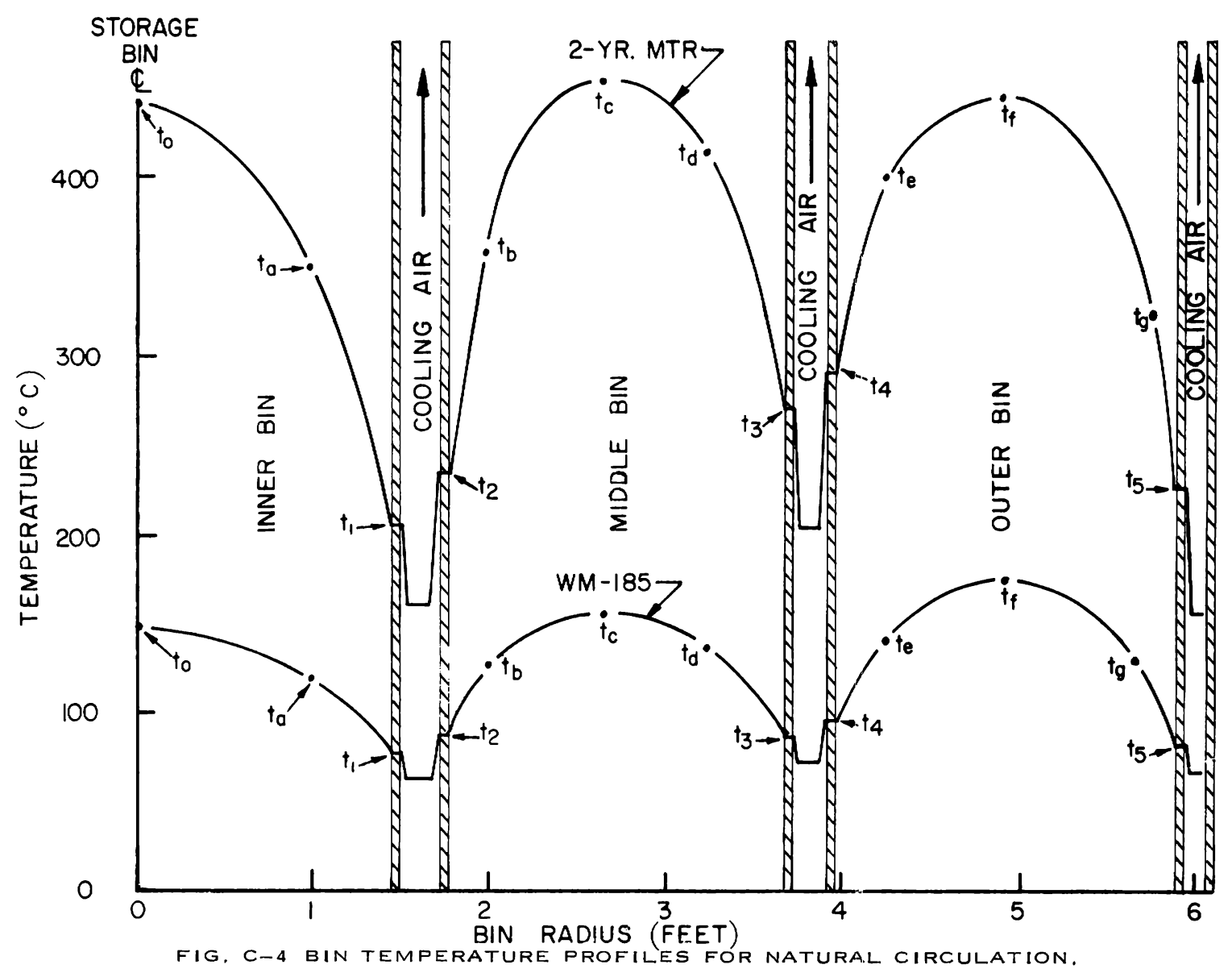

\section{REFERENCES}

1. S. Glasstone, Principles of Nuclear Reactor Engineering, D. Van Nostrand Co., New York, p 662 (1955).

2. W. H. McAdams, Heat Transmission, Third Ed. McGraw Hill Co., New York, p468 (1954).

3. D. Q. Kern, Process Heat Transfer, McGraw Hill Co., New York, p 109 (1950).

4. McAdams, op cit., p 464.

5. Kern, op cit., p 104.

6. Ibid, p 834 .

7. McAdams, op cit., p 457.

8. Ibid, $p 471$

9. P. N. Kelly, Thermal Conductivity of Alumina Produced by the Fluidized Bed Process, IDO-14592, p 21 (September 1962).

10. McAdams, op. cit., p 173. 



\section{APPENDIX D}

ESTIMATED EQUILIBRIUM TEMPERATURES IN CALCINER BED AFTER SHUTDOWN AND WTH NO INTERNAL COOLING

The primary factors determining the equilibrium calciner bed temperatures after a shutdown are: type of calcined waste present in the bed, velocity of ventilation air flowing past calciner, thermal conductivity of the solids, and of the vessel insulation, and the diameter of the calciner vessel. The methods used in these calculations to estimate the calciner bed temperature profiles are similar to those used for calculating temperature profiles in the storage bins (Appendix C). For clarity in presentation, the temperature calculations have been separated into three parts. These consist of estimation of (a) the ambient air and jacket temperatures, (b) the temperature drop across the insulation, and (c) the temperature profiles in the bed. The ambient air or bulk cell air temperature was estimated from the cell inlet air temperature, the flow rate of air in the cell, and the steady state heat transfer rate from the bed to the cell air. The outside insulation jacket temperature was then estimated using a calculated convective heat transfer coefficient. Next, the temperature drop across the insulation and the calciner bed was calculated from conventional heat transfer relationships for an annulus and a cylinder, respectively. To reduce the otherwise complicated heat transfer relationships, several simplifying assumptions have been made. The error introduced by each of these assumptions is either negligible or the calculated temperatures are higher than those that would actually be experienced.

Temperature profiles across the bed were determined for both WM-185 waste and 200-day cooled waste. The assumptions and bases used for the temperature calculations are tabulated below.

(1) Calciner bed consists of WM-185 waste $(Q=2865 \mathrm{Btu} / \mathrm{hr}$ ) or 200-day cooled $(Q=67,100 \mathrm{Btu} / \mathrm{hr})$ waste. Assumed that heat is generated uniformly through the bed and that all nuclear radiation is dissipated as heat in the bed.

(2) Neglect thermal radiation and convection losses from top and bottom of calciner vessel (infinite cylinder). Consideration of heat losses from the top and bottom of the vessel would result in lower calculated temperatures. 
(3) The calciner vessel is insulated over its entire length with a three-inch layer of Kaylo-Thermobestos. Actually, only that portion of the calciner vessel is insulated which contains bed material. The assumption of complete vessel insulation results in calculated temperatures higher than actual values.

(4) Neglect interface heat transfer resistance at the junctions of the calciner wall with the insulation and of the insulation and the jacket. Neglect temperature drop through the vessel and jacket walls. Both result in negligible error.

(5) Cell air (inlet) temperature $=100^{\circ} \mathrm{F}$. This temperature will normally be less than $100^{\circ} \mathrm{F}$, which would lower the temperature profiles.

(6) Ventilation air velocity past calciner. Normally, ventilation air flows through the cell parallel to the vertical axis of the calciner at a rate of $1595 \mathrm{acfm}$ (from ventilation measurements in cell). This rate is equivalent to a linear velocity of $0.133 \mathrm{ft} / \mathrm{sec}$ in the $15 \times 21$-foot cell. Natural convection will control the heat dissipation from the calciner walls because of the extremely low velocity of the "forced convection" air. Thus, the coefficients calculated are for natural rather than forced convection.

(7) Configuration shown in Figure D-1.

1. ESTIMATION OF BULK CELL AIR TEMPERATURE AND INSULATION OUTER SURFACE TEMPERATURE

The bulk cell air temperature was estimated from the following equation:

$$
\Delta t=\frac{Q}{W C_{p}}
$$

where:

$$
\begin{aligned}
\Delta \mathrm{t} & =\text { Difference between inlet and bulk cell air temperature, }\left({ }^{\circ} \mathrm{F}\right) \\
\mathrm{Q} & =\text { Heat load to cell air, }(\mathrm{Btu} / \mathrm{hr}) \\
\mathrm{W} & =\text { Cell air flow rate }=6060 \mathrm{lb} / \mathrm{hr} \\
\mathrm{C}_{\mathrm{p}} & =\text { Specific heat of air at constant pressure }=0.25 \mathrm{Btu} / \mathrm{lb}-{ }^{\circ} \mathrm{F}[1]
\end{aligned}
$$

A summary of this calculation is shown in Tabulation D-1. 


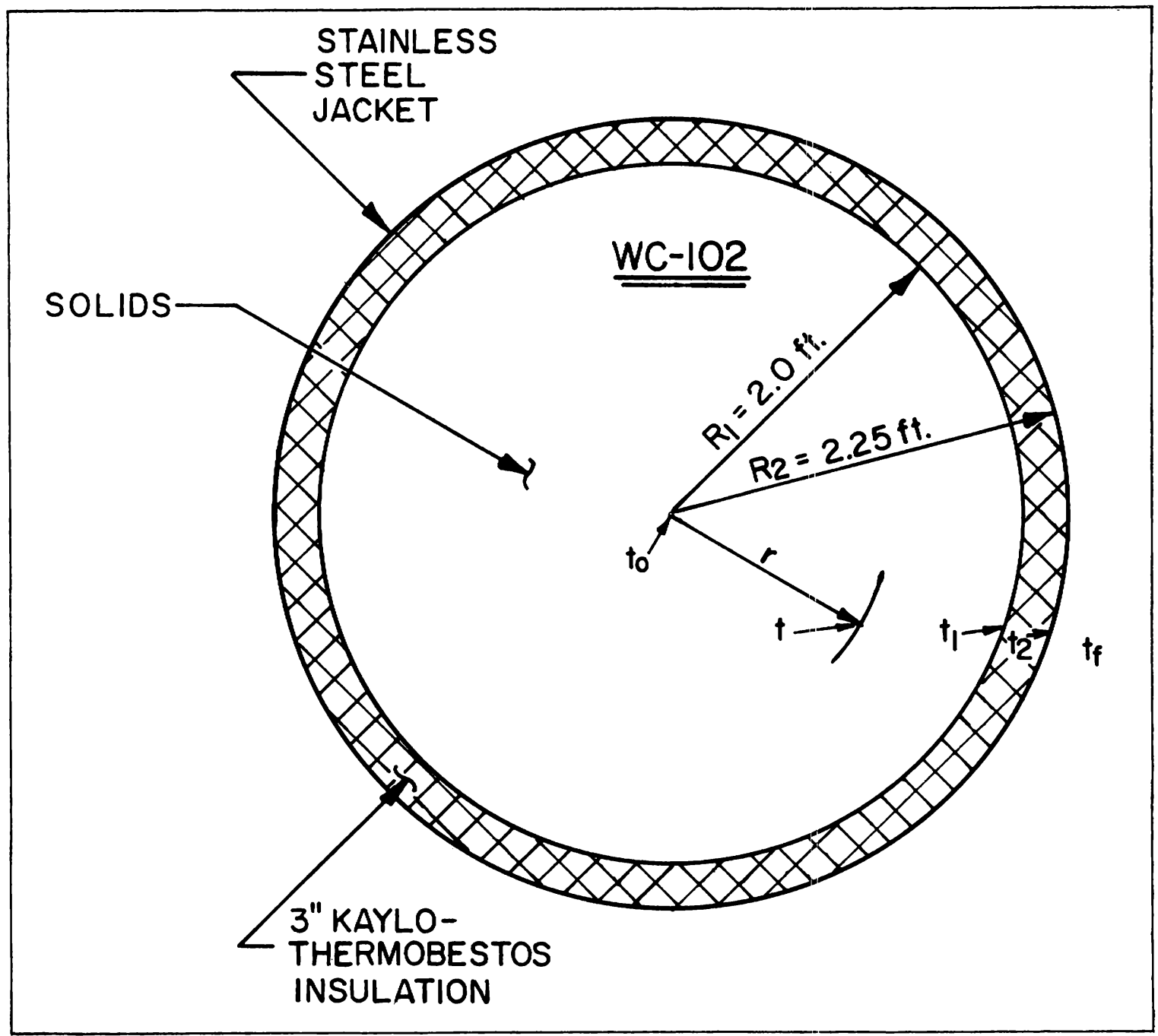

FIG. D-1 SECTIONAL VIEW OF CALCINER.

TABULATION D-I

\begin{tabular}{|c|c|c|c|c|c|}
\hline Waste & $(B t u / h r)$ & $\begin{array}{c}\mathrm{W} \\
(\mathrm{Ib} / \mathrm{hr})\end{array}$ & $\frac{\mathrm{C}_{\mathrm{p}}}{\left(\mathrm{Btu} / \mathrm{Ib}-{ }^{\circ} \mathrm{F}\right)}$ & $\begin{array}{c}\Delta t \\
\left({ }^{\circ} \mathrm{F}\right)\end{array}$ & $\left(\begin{array}{l}t_{f} \\
\left({ }^{\circ}\right)\end{array}\right.$ \\
\hline WM-185 & 2,865 & 6,060 & 0.25 & 2 & 102 \\
\hline 200-Day Cooled. & 67,100 & 6,060 & 0.25 & 44 & 144 \\
\hline
\end{tabular}

The jacket outer surface temperature was estimated by using

$$
t_{2}-t_{f}=\frac{Q R_{1}^{2}}{2 h R_{2}}
$$


where:

$$
\begin{aligned}
\mathrm{h} & =\text { sum of convection and radiation heat transfer coefficients } \\
& =\mathrm{h}_{\mathrm{c}}+\mathrm{h}_{\mathrm{r}}[3] \\
\mathrm{h}_{\mathrm{c}} & =0.19(\Delta t)^{1 / 3[4]} \\
\mathrm{h}_{\mathrm{r}} & =(4)(\sigma)\left(\epsilon_{\mathrm{avg}}\right)\left(\mathrm{T}_{\mathrm{avg}}\right)^{3[5]}
\end{aligned}
$$

where:

\begin{tabular}{|c|c|c|c|c|c|c|}
\hline Waste & $\begin{array}{l}\mathrm{T}_{\mathrm{avg}} \\
\left({ }^{\circ} \mathrm{F}\right)\end{array}$ & $\begin{array}{c}h_{C} \\
\left(B t u / f t^{2}-h r-F\right)\end{array}$ & $\begin{array}{c}h_{r} \\
\left(B t u / f t^{2}-h r-{ }^{\circ} F\right)\end{array}$ & $\begin{array}{c}h \\
\left(B t u / f t^{2}-h r-O^{\circ}\right)\end{array}$ & $\begin{array}{c}Q \\
\left(B t u / f t^{3}-h r\right)\end{array}$ & $\begin{array}{l}t_{2} \\
\left({ }^{\circ} \mathrm{F}\right)\end{array}$ \\
\hline WM-185 & 115 & 0.498 & 0.701 & 1.199 & 22.55 & 119 \\
\hline 200-Day & 284 & 1.245 & 1.555 & 2.800 & 889 & 426 \\
\hline
\end{tabular}

$$
\begin{aligned}
\mathrm{t}_{2}= & \text { Jacket outer surface temperature }\left({ }^{\circ} \mathrm{F}\right) \\
\mathrm{t}_{\mathrm{f}}= & \text { Bulk cell air temperature }\left({ }^{\circ} \mathrm{F}\right) \\
\mathrm{Q}= & \text { Heat load to cell air }(\mathrm{Btu} / \mathrm{hr}) \\
\mathrm{R}_{1}= & \text { Inside radius of calciner vessel }=2.0 \mathrm{ft} \\
\mathrm{R}_{2}= & \text { Outside radius of insulation }=2.25 \mathrm{ft} \\
\mathrm{h}= & \text { Heat transfer coefficient between cell air and jacket }\left(\mathrm{Btu} / \mathrm{ft}^{2}-\right. \\
& \left.\mathrm{hr}-{ }^{\circ} \mathrm{F}\right) \\
\mathrm{h}_{\mathrm{C}}= & \text { Heat transfer coefficient between cell air and jacket due to con- } \\
& \text { vection alone (Btu/ft } \left.{ }^{2}-\mathrm{hr}-{ }^{\circ} \mathrm{F}\right) \\
\mathrm{h}_{\mathrm{r}}= & \text { Heat transfer coefficient between cell air and jacket due to } \\
& \text { radiation alone }\left(\mathrm{Btu} / \mathrm{ft}{ }^{2}-\mathrm{hr}-{ }^{\circ} \mathrm{F}\right) \\
\Delta \mathrm{t}= & \text { Temperature difference between cell air and jacket }\left({ }^{\circ} \mathrm{F}\right) \\
\sigma= & \text { Stefan-Boltzman constant }\left(0.1713 \times 10^{-8} \text { Btu/ft }{ }^{2}-\mathrm{hr}^{\circ}{ }^{\circ} \mathrm{R}^{4}\right) \text { [6] } \\
\epsilon_{\text {avg }}= & \text { Emissivity of jacket at average temperature }(\text { dimensionless) [7] } \\
= & 0.45 \\
\mathrm{~T}_{\text {avg }=} & \text { Average absolute temperature }\left({ }^{\circ} \mathrm{R}\right)
\end{aligned}
$$

A summary of these calculations is shown in Tabulation D-2.

TABULATION D-2

\section{ESTIMATION OF TEMPERATURE DROP ACROSS INSULATION}

The temperature drop across the insulation was estimated using the following formula:

$$
t_{1}-t_{2}=\frac{Q_{1}^{2}}{2 k_{i}} \ln \frac{R_{2}}{R_{1}}
$$


where:

$\mathrm{t}_{1}=$ Inside insulation surface temperature $\left({ }^{\circ} \mathrm{F}\right)$

$\mathrm{t}_{2}=$ Jacket outer surface temperature $\left({ }^{\circ} \mathrm{F}\right)$

$\mathrm{Q}=$ Heat load through insulation and into ventilation air (Btu/hr.ft 3 )

$\mathbf{R}_{1}=$ Inside radius of calciner vessel $=2.0 \mathrm{ft}$

$\mathrm{k}_{\mathbf{i}}=$ Thermal conductivity of insulation $\left(\mathrm{Btu} / \mathrm{hr}-\mathrm{ft}-{ }^{\circ} \mathrm{F}\right){ }^{[8]}$

$R_{2}=$ Outside radius of insulation $=2.25 \mathrm{ft}$

A summary of the calculations is tabulated in Tabulation D-3.

TABULATION D-3

\begin{tabular}{|c|c|c|c|c|c|c|c|}
\hline Waste & $\begin{array}{l}t_{\text {avg }} \\
\left({ }^{\circ} \mathrm{F}\right)\end{array}$ & $\begin{array}{c}k_{i} \text { avg } \\
\left(B t u / h r-f t-{ }^{\circ} F\right)\end{array}$ & $\begin{array}{c}Q \\
\left(B t u / h r-f t^{3}\right)\end{array}$ & $\begin{array}{l}R_{I} \\
(f t)\end{array}$ & $\begin{array}{l}R_{2} \\
(f t)\end{array}$ & $\begin{array}{c}t_{2} \\
\left({ }^{\circ} \mathrm{F}\right)\end{array}$ & $\begin{array}{l}\mathrm{t}_{1} \\
\left({ }^{\circ} \mathrm{F}\right)\end{array}$ \\
\hline WM- 185 & 128 & 0.34 & 22.55 & 2.00 & 2.25 & 119 & 135 \\
\hline $\begin{array}{l}\text { 200-Day } \\
\text { Cooled }\end{array}$ & 615 & 0.56 & 889 & 2.00 & 2.25 & 426 & 801 \\
\hline
\end{tabular}

\section{ESTIMATION OF TEMPERATURE PROFILE IN BED}

The temperature profile across the calcined solids was estimated by means of the following formula.

$$
t-t_{1}=\frac{Q}{4 k_{b}}\left(R_{1}^{2}-r^{2}\right)^{[9]}
$$

where: $t_{0}=$ Temperature at centerline $\left({ }^{\circ} \mathrm{F}\right)$

$\mathrm{t}_{\mathrm{a}}=$ Temperature at $1 \mathrm{ft}$ radius $\left({ }^{\circ} \mathrm{F}\right)$

$\mathrm{t}=$ Temperature at radius $\mathrm{r} \quad\left({ }^{\circ} \mathrm{F}\right)$

$\mathrm{t}_{1}=$ Inside insulation surface temperature $\left({ }^{\circ} \mathrm{F}\right)$

$Q=$ Heat generation per unit volume of bed

$\mathrm{k}_{\mathrm{b}}=$ Thermal conductivity of bed (Btu/hr-ft- $\left.{ }^{\circ} \mathrm{F}\right)$ [10]

$\mathrm{R}_{1}=$ Inside radius of calciner vessel $=2.0 \mathrm{ft}$

$\mathbf{r}=$ Radius at which temperature equals $\mathbf{t}(\mathrm{ft})$

A summary of the calculations is presented in Tabulation D-4.

\section{TABULATION D-4}

\begin{tabular}{|c|c|c|c|c|c|c|c|c|c|}
\hline \multirow[b]{2}{*}{ Waste } & \multicolumn{2}{|c|}{$t_{\text {avg }}$} & \multicolumn{2}{|c|}{$\mathrm{k}_{\mathrm{b} \text { avg }}$} & \multirow{2}{*}{$\begin{array}{c}t_{1} \\
\left({ }^{\circ} \mathrm{F}\right)\end{array}$} & \multirow{2}{*}{$\begin{array}{c}\frac{Q}{(B t u / h r-f t 3)}\end{array}$} & \multirow{2}{*}{$\begin{array}{l}R_{I} \\
(f t)\end{array}$} & \multirow{2}{*}{$\begin{array}{l}t_{0} \\
\left({ }^{\circ} \mathrm{F}\right)\end{array}$} & \multirow{2}{*}{$\begin{array}{l}t^{a} \\
\left({ }^{\circ} F\right)\end{array}$} \\
\hline & $r=0$ & $r=1.0$ & $r=0$ & $r=1.0$ & & & & & \\
\hline WM-185 & 325 & 220 & 0.110 & 0.095 & 135 & 22.5 & 2.0 & 338 & 313 \\
\hline 200-Day & 2915 & 1830 & 0.410 & 0.319 & 801 & 889 & 2.0 & 2969 & 2856 \\
\hline
\end{tabular}


A summary of the calculated bed temperatures is presented in Tabulation D-5; the calculated temperatures also are plotted in Figure D-2.

TABULATIONI D-5

TEMPERATURE PROFIIES

\begin{tabular}{|c|c|c|c|c|c|}
\hline \multirow[b]{3}{*}{ Radius } & \multirow[b]{3}{*}{ Nomenclature } & \multicolumn{4}{|c|}{ Temperatures } \\
\hline & & \multicolumn{2}{|c|}{$\begin{array}{l}\text { WH-185 } \\
\text { Waste }\end{array}$} & \multicolumn{2}{|c|}{$\begin{array}{c}\text { 200-Day } \\
\text { Cooled Waste }\end{array}$} \\
\hline & & ${ }^{\circ} \mathrm{F}$ & ${ }^{\circ} \mathrm{C}$ & ${ }^{\circ} \mathrm{F}$ & ${ }^{\circ} \mathrm{C}$ \\
\hline 0 & $t_{0}$ & 338 & 170 & 2969 & 1631 \\
\hline 1 & $t_{a}$ & 3.13 & 156 & 2856 & 1568 \\
\hline 2 & $t_{1}$ & 135 & 57 & 801 & 427 \\
\hline 2.25 & $t_{2}$ & 119 & 48 & 426 & 219 \\
\hline Ambient & $t_{f}$ & 102 & 39 & 144 & 62 \\
\hline
\end{tabular}

\section{REFERENCES}

1. W. H. McAdams, Heat Transmission, 3rd Ed., McGraw Hill Book Co., New York, p 464 (1954).

2. S. Glasstone, Principles of Nuclear Reactor Engineering, D. Van Nostrand Co., New York, p 663 (1955).

3. McAdams, op. cit., p 179.

4. Ibid, p 173.

5. Ibid, p 78 .

6. Ibid, p 59 .

7. Ibid, p 475 .

8. Johns-Manville, "Insulation-Product Information", AIA File No. 37-D, p 21, (September 1962).

9. Glasstone, op. cit., p 662 .

10. P. N. Kelly, Thermal Conductivity of Alumina Produced by the Fluidized Bed Process, IDO-14592, p 21 (September 1962). 


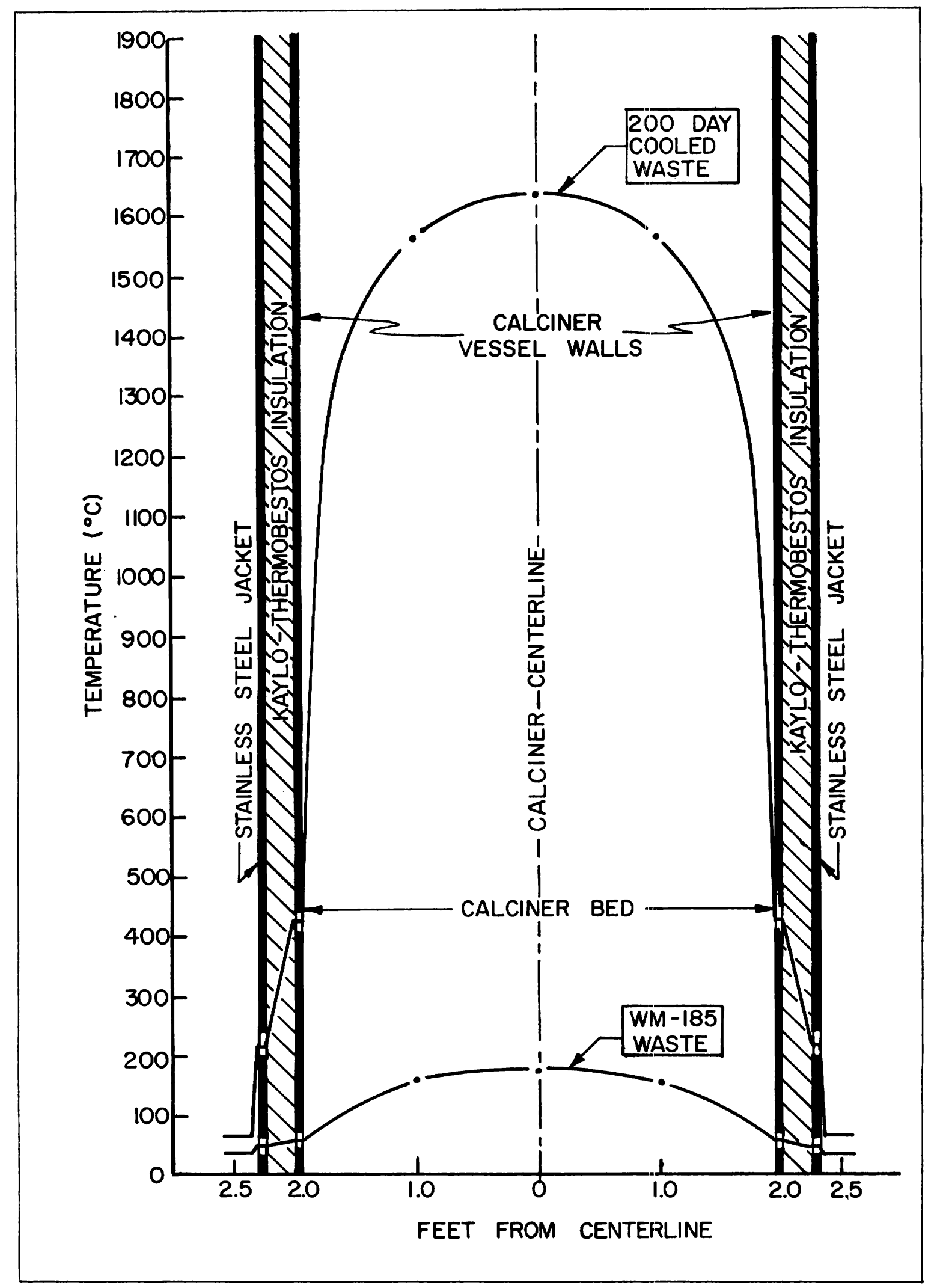
FIG. D-2 ESTIMATED EQUILIBRIUM TEMPERATURES IN CALCINER BED AFTER SHUTDOWN
WITH NO INTERNAL COOLING. 



\title{
APPENDIX E
}

\section{SUMMARY OF EXPERIENCE WITH MATERIALS OF CONSTRUCTION \\ USED IN NaK HEATING SYSTEMS}

\author{
THE FLUOR CORPORATION, LTD. \\ ENGINEERS AND CONSTRUCTORS \\ 2500 SOUTH ATLANTIC BOULEVARO \\ LOS ANGELES, CALIFORNIA
}

"C ADORESS

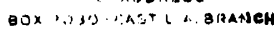

COS ANGELES 22. CALIF

May 21, 1958

Mr. H. M. Leppich, Director Engineering \& Construction Division

U. S. Atomic Energy Commission

P. 0. Box 1221

Idaho Falls, Idaho

Attention: Mr. A. L. Biladeau

Dear Sir:

USAEC CONTRACT AT(10-1)-883
FLUOR CONTRACT 5775
FILE NO. $5775-6-3$

This is a summary report describing the information obtained by Messrs. R. D. Walton, Jr. of the USABC (IDO) and J. A. Morrish of The Fluor Corporation, during the week of April 21 to 25, 1958, concerning the use of liquid metals as heat transfer media for the calciner. The following companies were visited:

Pratt-Whitney Aircraft, Middletown, Connecticut:

MSA Research Corporation, Callery, Pennsylvania.

Griscom-Russell Co., Massillon, Ohio

Oak Ridge National Laboratory, Oak Ridge, Tennessee

Argonne National Laboratory, Lemont, Illinois

Details of the discussions with the personnel at these locations are set forth in the appendix of this report. Summary of the important conclusions derived from these meetings follows:

1. Where conflicting statements existed between personnel at the various sites the majority or most logical conclusion is described in the summary.

2. All personnel contacted thought that the proposed NaK loop as shown on Fluor Drawings SK-38 and 39 was a workable system for heating the calciner.

3. All personnel recommended 316 S.S. as the most satisfactory material of construction.

4. There appears to be no significant difference in the corrosite properties of $\mathrm{NaK}$ and $\mathrm{Na}$ at the proposed operating temperature of $1,400^{\circ} \mathrm{F}$. 
5. Essentially no long term ( 6 months to 2 years) conclusive corrosion data is available for liquid metal systems operated at $1,400^{\circ} \mathrm{F}$. A number of tests have been performed for relatively short periods (132 to 2,000 hours). Results of these tests show a small initial corrosion rate. After this initial attack the container metal usualiy becomes passive and very little, if any, subsequent attack occurs. On the basis of these short duration tests, the corrosion rate should be less than 10 mils per year for a sodium or NaK loop constructed of 316 stainless steel in which the liquid metal oxide content is maintained below $50 \mathrm{ppm}$.

6. A diffusional type cold trap should be suitable for limiting the oxide content to below $50 \mathrm{ppm}$. The main advantage of a forced circulation cold trap is that the oxides content can be reduced faster during the startup (8 hours compared to 2 or 3 days). Either trap should maintain about the same oxide content.

7. A hot trap will probably maintain the oxide concentration below $10 \mathrm{ppm}$. The necessity for maintaining this low an oxide concentration is probably a borderline case since corrosion has been found to be within workable limits even at higher oxide concentration. However, with lower oxide concentrations the loop design can be simplified somewhat in that precautions against the accumulation of oxides in cold dead zones can be relaxed and cheaper pressure gauges such as ordinary bourdon tubes can be used. Since the cost of a hot trap is small, its installation might be considered a cheap insurance policy for the operation of a trouble-free system.

8. Plugging indicators are not absolutely necessary for the operation of a NaK loop but are desirable for a number of reasons. Their main use is to determine the oxide content of the system and therefore indicate whether the oxide removal equipment is functioning correctly. Direct sampling of the NaK for this purpose is difficult, expensive and of questionable reliability, even with experienced operators.

9. Nitrogen as a cover gas for the $\mathrm{NaK}$ system may cause nitriding of the 316 S.S. at the operating temperatures involved. As a result, helium or argon, although somewhat more expensive, should probably be used. NaK bubblers have been used by some installations for final clean up of the gas. Other installations consider the difficulty of removing the NaK entrained and vaporized in the cover gas during prepurification to outweigh the advantages of prepurification and have omitted this step from their plants.

10. Electromagnetic pumps of the $\mathrm{AC}$ conduction or Faraday type pump are available for circulating the $\mathrm{NaK}$ in the loop. Supposedly, new design features such as nicro brazing of armature leads to the pipe and nickel armature or bus bar leads now make these pumps completely reliable at temperatures as high as $1,500^{\circ} \mathrm{F}$. Capacities as high as $100 \mathrm{gpm}$ and 25 psi differential head with efficiencies in the range of 8 to $12 \%$ are available. Nickel bus bars reduce this efficiency some 25 to $30 \%$ but are required for high temperature operation. 
11. Magnetic flowmeters are accurate in the range of 2 to $10 \%$ if sufficient precaution is made for insulating or cooling the magnet to limit its temperature to between 200 and $300^{\circ} \mathrm{F}$.

12. Two main types of liquid level measuring devices are most commonly used. The simplest is the probe or spark plug type which is frequently applied to indicate high and low level. Some trouble may result at temperatures above $500 \mathrm{~F}$. due to condensation of $\mathrm{NaK}$ and shorting out of the probe. The $J$ tube which is somewhat more costly finds application for continuous level indication but needs calibration for change in temperature of the system.

13. Pressure measurements have been made successfully with either the Moore Nullmater or the Taylor bourdon type of instrument. If the oxide content is maintained at $10 \mathrm{ppm}$ or less, an ordinary bourdon gauge mounted on an 8 to 10 inch cold leg has operated satisfactorily.

14. Stainless steel mesh packed traps should be provided for removing NaK from any cover gas purge if the system is operated above about $500^{\circ} \mathrm{F}$.

15. Thermocouples are very commonly spot-welded on to the pipe and give nearly the same temperature reading as those placed in wells in the pipe.

16. A number of manufacturers have made bellows sealed valves suitable for the operation in liquid metal loops. A few of the most commonly used are listed as follows: Powell, Fulton Sylphon, Kiely-lueller, Hoke, Research Controls, Annin, P.K., Hammel Dahl, Black, Sivals and Bryson, and Westinghouse. Pneumatic seating is preferred so that the valve stem can expand or contract due to temperature differences. At operating temperatures above $1,200^{\circ} \mathrm{F}$. excellent scaling and fluxing possibilities are present and the valve can actually self-weld together and become inoperable. Special valves with seats of cermet (TiC-10\% Ni) are sometimes used to prevent self-welding.

17. An automatic technique has been developed for various types of Trepan welding. This method has been used successfully for the welding of tubes to tube sheets in liquid metal service. Coast Metals 52 brazing alloy is one of the recommended alloys which gives good resistance to liquid metals and also oxidation resistance to air.

18. For safe containment of the NaK in the calciner, double walled tubes of the duplex type should probably be used. Since these tubes are expanded very tightly together negligible loss in heat transfer coefficient results. Specifications for these tubes should be written stating that no scoring of the inner tube can be tolerated during the expansion procedure. Helium monitoring at a fixed pressure of gas between the tubes should be used to determine any leaks in the system.

19. No oxidation problems with 316 SS have been experienced by one installation using an oil fired heater to heat liquid metals up to 1,650 or $1,700^{\circ} \mathrm{F}$. 
20. Extreme care should be given to the design of liquid metal piping in regards to thermal stresses. To solve this problem some installations support the piping by means of ither counterbalanced weights or constant support hangers.

21. Initially the system should be thoroughly degreased and cleaned and a mass spectrometer helium test run to make sure the system is dry and that there are no leaks. The system is then filled with NaK brought up slowly to a temperature near normal operation and run isothermally for several hours. At this point the NaK is dumped to the sump tank, allowed to cool and then pressurized back into the system through S.S. mesh filters. This dumping and filling operation may be repeated profitably at least once more or until the majority of the oxides have been filtered out.

22. In areas which are readily accessible, liquid metal leak detecting devices are seldom used since even the smallest leak is immediately noticed by the liberation of voluminous amounts of opaque white oxide smoke. Normally the loop is not dumped immediately for small minor leaks as the empty furnace tubes may become overheated due to radiation from the hot firebrick. Liquid metal fires are normally easy to control as they do not flame up like hydrocarbon fires and can be easily extinguished with METI-I-X, sodium carbonate or graphite. They burn with intense heat and will, however, eventually melt any metal in contact with them. Spillage should be cleaned up immediately as superoxides of alkali metals may form later on the surface. These detonate weakly and can splash molten metals at personnel.

While at Argonne National Laboratory, a short visit was also made with Al Jonke and John Loeding to ascertain their progress on the calciner experimentation. They were shown preliminary flow sheets of the proposed calcination plant. They stated that due to clogging of the feed nozzles in the calciner they had found it wise to have a pump feeding the solution to the calciner. It was pointed out that the original design did have a pump for this purpose but, due to subsequent objections, it was replaced with a gravity head feed tank.

ANL has now finished installation of a venturi scrubber and silica gel adsorber following the calciner. One cold man has been made with a bypass around the venturl. Results of this test indicated a 2 to 3 " $\mathrm{Hg}$ pressure drop through 31 of silica gel in the adsorber. A superficial velocity of $0.4 \mathrm{ft} . / \mathrm{sec}$. was used and the bed was packed with 6-16 mesh silica gel. Several more cold runs and then a number of tracer Ru mus will be made before hot, roughly I per cent I CPP, wastes are fed to the calciner.

ANL was recently visited by J. E. Lloyd, Research Manager of Springfield Atomic Energy installation in England. Springfield has operated a $3^{\prime}$ I.D.-9' bed depth calciner for the production of $\mathrm{UO}_{3}$. This calciner is heated with resistance heaters mounted vertically inside the calciner. Feed is atomized in nozzles (2' below the top of the bed) similar to those proposed for the present calciner. Porous metal filters are used to remove entrained solids from the off gas. A 
superficial gas velocity of $0.5 \mathrm{ft.} / \mathrm{sec}$. (at atmospheric conditions) is used for fluidization. The unit has operated successfully for some 3,000 hours with a bed temperature of $300^{\circ} \mathrm{C}$ at about $15-20$ psig pressure. Mallinckrodt is also planning a similar calciner with either $\mathrm{NaK}$ or fused salts as the heat source (see MCW-1411).

Yours very truly,

THE FLUOR CgRPgRATION, LTD.

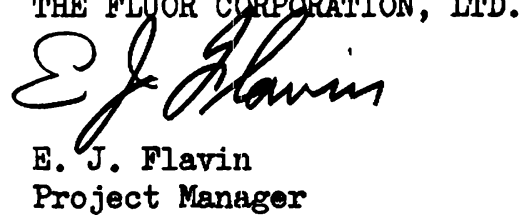

EJF :vd

cc: R. D. Walton, Jr., AEC (2)

A. L. Biladeau, AEC (23)

E. F. Edwards

L. Schuster

J. A. Morrish 


\subsection{DETAILS OF MEETING WITH PRATT-WHITNEY AIRCRAFT PERSONNEL} AT MIDDLETOWN, CONNECTICUT, APRIL 21, 1958

\subsection{PERSONNEL CONTACTED}

J. J. Wesbecher, Assistant Project Engineer

Ken Kelly, Liquid Metals Engineer

John Ahern, Engineer in Charge Radiator Tests

Bob Brown, Instrument Engineer

\subsection{GENERAL}

The Canel Operations Division of Pratt-Whitney has run a number of liquid metal loops using both $\mathrm{NaK}$ and $\mathrm{Li}$ as heat transfer media. Several of their NaK loops have been tested for 500 to 600 hours and as long as 1,200-1,300 hours.

A flow sheet of the calciner was shown to these people and their opinion was that $316 \mathrm{~S} . \mathrm{S}$. should be the most suitable alloy for construction of the liquid metals loop. They saw no reason to pick Na over NaK for the system.

\subsection{COLD TRAPPING}

Pratt-Whitney have never used a diffusional type of cold trap. They generally use the forced circulation type of their own modified design cooled to between 300 and $400^{\circ} \mathrm{F}$. The trap itself is a horizontal vessel packed with S.S. mesh and is designed for a $5 \%$ system hold-up time with a 5 minute delay time. Sufficient cooling of the liquid metal occurs in this drum due to atmospheric cooling and no precooling with coils is necessary.

\subsection{PLUGGING INDICATOR}

Pratt-Whitney recommended that a plugging indicator should be used in the liquid metals system to indicate the amount of oxides present.

\subsection{HOT TRAP}

No hot traps have been found necessary for operation of Pratt-Whitney's NaK loops.

\subsection{CORROSION}

There are two main types of corrosion attack occurring in liquid metal systems. The first is solution which is generally not mentioned but there is definite evidence that this kind of attack does occur. The second type which is most commonly known is penetration or intergranular attack. Solution differs from penetration in that the surfaces where solution occurs are evenly corroded away, whereas in penetration fissures result due to intergranular corrosion.

For a given loop there are at least five factors which affect the corrosion attack in the system. These are listed below but to date the interdependence of each related to others has not been definitely established: 
1.06 CORROSION (Continued)

1. Maximum to minimum temperature ratio.

2. Area ratio cooler to heater

3. Heat flux.

4. Heater and cooler velocities.

5. Heater to cooler volume relationships.

Some of the data available on the dynamic corrosion of 316 S.S. are presented here to show the order of magnitude of corrosion occurring in liquid metal operation:

\begin{tabular}{|c|c|c|c|c|c|c|c|}
\hline terial & Fluid & $\begin{array}{l}\text { Max. } \\
\text { Temp. } \\
\text { OF。 }\end{array}$ & $\begin{array}{l}\text { Min. } \\
\text { Temp. } \\
\text { F. }\end{array}$ & $\begin{array}{l}\text { Hours } \\
\text { Opera- } \\
\text { tion } \\
\end{array}$ & $\begin{array}{c}\text { Peno- } \\
\text { tration } \\
\text { Attack Mils }\end{array}$ & $\begin{array}{c}\text { Solution } \\
\text { Attack } \\
\text { Mils } \\
\end{array}$ & $\begin{array}{c}\text { Transfer } \\
\text { Deposition } \\
\text { Mils } \\
\end{array}$ \\
\hline $\begin{array}{c}316 \\
316 \\
316 \\
316 \\
\text { Inconel }\end{array}$ & $\begin{array}{l}\mathrm{Na} \\
\mathrm{Na} \\
\mathrm{Na} \\
\mathrm{Na} \\
\mathrm{NaK}\end{array}$ & $\begin{array}{l}1600 \\
1600 \\
1600 \\
1600 \\
1500\end{array}$ & $\begin{array}{l}1050 \\
1050 \\
1050 \\
1300 \\
1100\end{array}$ & $\begin{array}{r}132 \\
250 \\
250 \\
250 \\
1000\end{array}$ & $\begin{array}{c}2.5 \\
2.4 \\
2.0 \\
1.8 \\
4.5-5.5\end{array}$ & $\begin{array}{r}0 \\
0.5-1.5 \\
0.8-6.0 \\
- \\
-\end{array}$ & $\begin{array}{l}3.5 \\
5 \\
9 \\
4 \\
9.5\end{array}$ \\
\hline
\end{tabular}

The last column in the above table gives the amount of deposition by mass transfer occurring in the loop. This deposition usually occurs in the cold section of the loop whereas the attack of solution and penetration generally occurs in the hot section. It is difficult to draw conclusions from the above data because of the relatively short duration of the tests performed. It should be noted that there appears to be a certain passivity to penetration attack once the initial attack has occurred. Longer tests would have to be performed to ascertain if this passivity exists for solution attack. In view of these possibilities, it would therefore be misleading to extrapolate these corrosion results to a yearly basis. The last set of corrosion data shown above may indicate that inconel is infexior to 316. Data for Hastelloy $B$ indicates that its corrosion rate is similar to inconel.

\subsection{COVER GAS}

Mr. Kelly stated that P. \& W. uses argon as a covex gas for both NaK and Li operation. He stated that nitrogen was not a suitable cover gas for lithium loops because of the formation of nitrides with lithium. However, in his opinion he saw no reason for not using nitrogen in a NaK system as the nitride film formed on the tube wall in such a system is less than 0.0001 " thick.

\subsection{PUMPS}

Mr. Wesbecher stated that an E.M. pump should be bist for our purposes. P. \& W. have used successfully small GE and MSA pumps of the A. C. Faraday type at temperatures in excess of $1,400^{\circ} \mathrm{F}$. In the fabrication procedure of their loops they usually make their own bus bars and nicro braze them onto the loop. A standard GE or MSA pump has an efficiency of 6 or T\% with a capacity of 5 GPM and 100 psi head.

\subsection{FLOWMETERS}

Mr. Ahern says that magnetic flowmeters have been used with considerable success by $P_{0} \& W_{0}$. The magnets are kept cool (below $200^{\circ} \mathrm{F}$ ) by using metal 


\section{APPENDIX}

1.09 FLOWMETERS (Continued)

foil as an insulator or by air blowing if required. Flow rate measurements obtained by their use are usually accurate to within 8 or $10 \%$ of those obtained from heat balance calculations.

\subsection{PRESSURE}

Where pressure measurements are required in the loops P\&W use the Moore Nullmater pressure gauge.

\subsection{LIQUID LEVEL}

P\&W most commonly use the spark plug type of liquid level measuring device for high and low indications. For continuous level, the $\mathrm{J}$ probes seem most satisfactory, but should be calibrated for temperature range variations. Other types of devices investigated but not used to any great extent include impedance coils and hot cell level indicators.

\subsection{THERMOCOUPLES}

P\&W spot weld all their thermocouples to the pipe and obtain good results.

\subsection{VALVES}

Annin, Patterson-Kelly and Fulton Sylphon type valves have been used successfully by P\&W. Either Breeze or Solar make satisfactory bellows seals for these valves. It is important that provisions be made to take care of valve stem expansion during warm-up of the loop.

\subsection{WELDING}

All welds are heliarc. Welds should be X-rayed, or dye checked (if it is not possible to $X$-ray), then mass spectrographed with helium. Welds with oxide penetrations greater than 10 mills are thrown out.

\subsection{RESISTANCE HEATING}

For small test loops P\&W employ electrical resistance heating as the source of heat for their system. In this type of heating both the liquid metal and pipe wall act as resistances in parallel. They have designed units for as much as $60 \mathrm{KW}$ capacity.

\subsection{LOOP PREPARATION}

To start up a loop P\&W generally loosen all fittings and purge with argon. Fittings are then tightened and the loop is evacuated to at least 10 microns. This operation is repeated three times. Then the system is filled with NaK and operated for 4 hours isothermally at normal operating temperature. This $\mathrm{NaK}$ is then dumped, cooled, cleaned by S.S. mesh filtering and recharged for use to the system. 


\section{APPENDIX}

\subsection{LITERATURE}

As a background for further information on liquid metal systems $\mathrm{Mr}$. Wesbecher recommended the following list of references:

Oak Ridge Quarterly Progress Reports from 6/10/56 to 3/31/57 (Under Metallurgy and Dynamic Corrosion Section)

$\begin{array}{cc}\text { ORNI-1864 } & \text { NDA-10 } \\ -1947 & -15 \\ -2012 & -57 \\ -2061 & -38 \\ -2157 & -15 \mathrm{E}-65 \\ - \text { CF 55-1-169 } & -57-35 \\ & -577-28\end{array}$

Also the following P\&W reports which are available only from the Hartford area AEC office:

TIM-223
226
264
270
282
364
395

\subsection{OXIDATION}

To check further into the oxidation problems involved in the use of an oil fired NaK heater, Mr. Morrish placed a call on May 8, 1958, to Pratt-Whitney to learn their experience in this field. Mr. Herb Means said that P\&W had operated a heater of this type for a considerable length of time with no adverse results. He further stated that a Struthers-Wells type heater had been used. The coils were of 316 S.S. and ASTM No. 2 fuel oil had been used. The liquid metal had been heated to $1,650-1,700^{\circ} \mathrm{F}$. No noticeable oxidation or corrosion was experienced on either side of the tubes. However, precaum tions were made to operate the heater as close to a reducing atmosphere as possible by carefully controlling the amount of excess air used for combustion. (Note ORNL in paragraph 4.14 states that oxidation is more drastic when there is a lack of oxygen in the gas than when there is an excess present).

2.0 DETAILS OF MEETING WITH MSA RESEARCH CORPORATION PERSONNEL AT CALIERY, PENNSYLVANIA, APRIL 22, 1958

\subsection{PERSONNEL CONTACTED}

R. I. Campbell, Sales Engineer

R. E. Loe, Manager of Engineering Research

C. H. Staub, Director of Marketing

Walter Milich, Research Engineer 


\section{APPENDIX}

\subsection{GENERAL}

MSA manufactures and sells electromagnetic pumps, magnetic flowmeters, plugging indicators and cold traps as well as $\mathrm{K}$ and NaK. They have also performed considerable research work on the operation of liquid metal loops. Currently they are testing duplex tubes in a NaK to $\mathrm{Na}$ system for the production of $500 \mathrm{psia}, 600^{\circ} \mathrm{F}$ superheated steam.

The general scheme of our proposed loop was set forth to them. They thought that $316 \mathrm{~S}_{\circ} \mathrm{S}_{\text {。 }}$ was the best construction material available and saw no reason to use $\mathrm{Na}$ instead of $\mathrm{NaK}$ in the 100p.

\subsection{COLD TRAPPING}

Mr. Lee saw no reason why a diffusional type cold trap would not be sufficient for our system. This type of trap as compared to the forced circulation type merely requires a longer time during startup periods ( 2 or 3 days versus 8 - 10 hours) to reduce the oxide content to the operational level of $50 \mathrm{ppm}$. Once this level has been obtained either trap maintains about the same oxide content. For the design of the diffusional type $M$ r. Lee recommended that the line from the loop to the cold trap be short and contain no valve. This line should be designed so that its temperature is above $500-600^{\circ} \mathrm{F}$ while the bottom of the cold trap is maintained at $150-200^{\circ} \mathrm{F}\left(300^{\circ} \mathrm{F}\right.$ max. $)$.

\subsection{PLUGGING INDICATOR}

Mr. Lee stated that while a plugging indicator is not absolutely required for the normal operation of the loop, it would be advisable to include one for several reasons. With a plugging indicator it is possible to estimate the oxide content of the system accurately and simply. On the other hand, direct sampling and analyses of liquid metals is difficult, expensive and only about 50\% reliable. During startup of the system it is nice to know what the oxide content of the loop is. If too high the system can be dumped, cooled, filtered through S.S. mesh filters and rocharged to the system. Also an indication of the oxide content during normal operation is helpful to indicate whether the cold trap is performing adequately。

The plugging indicator for our system would be installed around the pump. It would consist of a throttle valve, air cooler, magnetic flowmeter, temperature indicator and perforated plugging disc. The perforations in the disc are normally 0.050 inch $i_{0} d$. An alternate arrangement would be to use a perforated globe valve in place of the perforated disc, with possible elimination of the throttle valve.

\subsection{HOT TRAP}

MSA are not convinced of the need for a hot trap. With a hot trap the oxide content could be reduced from 50 to $60 \mathrm{ppm}$ to less than $10 \mathrm{ppm}$. Whether this low oxide concentration is required is doubtful. MSA have not considered it important, and hence, do not use hot traps. 


\subsection{CORROSION}

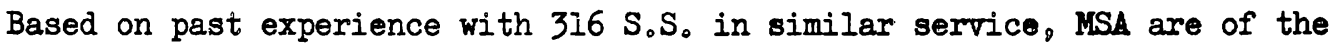
opinion we will not have any serious corrosion problems with the proposed loop.

\subsection{COVER GAS}

Mr. Lee says that MSA have had no trouble with nitriding due to the use of nitrogen as a cover gas. They, in fact, use nitrogen bubblers in their $316 \mathrm{~S} . \mathrm{S}$ 。 NaK still to determine the $\mathrm{Na}$ level of the kettlo, which operates at about $1,620^{\circ} \mathrm{F}$. On loop operation they normally use prepurified nitrogen passed through NaK bubblers for the cover gas. On some occasions helium and argon have also been used. Helium can easily be cleaned up by passing it through a bed of activated carbon maintained at liquid nitrogen temperatures.

\subsection{PUMPS}

MSA state that their 100-25 electromagnetic type pump should be ideal for circulating the NaK in the loop. This is an $\mathrm{A}_{0} \mathrm{C}$. Faraday type conduction pump modified with all nickel bus bars nicro brazed to the pipe. This modification will enable the pump to operate at temperatures as high as $1,400 \mathrm{~F}$. However, the expected efficiency of $8-12 \%$ will be lowered some $25-30 \%$ with the use of nickel bus bars. The possible use of a metal box to self contain the pump in case of piping failure is not recommended by MSA since the pump needs to run as cool as possible. The flow of each pump must be calibrated for temperature, $\mathrm{NaK}$ composition and the particular bus bar used. For $\mathrm{Na}$, below $500 \mathrm{~F}$ the viscosity becomes appreciable and the pump curves are not roliable.

\subsection{FLOWMETERS}

Magnetic flowmeters as produced by MSA are suitable for operation up to temperatures of $1,500^{\circ} \mathrm{F}$. If the magnet is maintajned below $300^{\circ} \mathrm{F}$, the flow measurements are reportedly good to within $2 \%$. Initially, MSA used orifices and venturis for flow measurements but once the magnetic flowmeters had been developed they found these much simpler and easier: to operate.

\subsection{LIQUID LEVEL}

MSA have found the spark plug type of probes cheap, easy to use and reliable for indicating the liquid metal level in a vessel. They have found that these probes will short out at temperatures above about $500^{\circ} \mathrm{F}$ due to condensation of the liquid metals. A simple homemade probe is used which is adjustable to various heights in the vessel.

For continuous level measurements $\mathrm{J}$ tubes have been used. However, at temperatures below $600^{\circ} \mathrm{F}$ the liquid metal does not always wet these tubes sufficiently to give accurate level measurements.

\subsection{VALVES}

The following valves were listed for possible use: Powell, Fulton Sylphon, Research Controls, Keiley-Mueller, Hoke, Annin, and Westinghouse. Some difficulty has been experienced with the failure of bellows due to chattering when the valves are used for throttling. Kieley-Mueller have produced valves 


\subsection{VALVES (Continued)}

completely reliable for temperatures up to $1,500^{\circ} \mathrm{F}$. Westinghouse produces a special high temperature throttle valve for liquid metals. For dump lines MSA have even used successfully ordinary carbon steel Chapman steam valves with dry asbestos packing. However, this practice is not recommended in the proposed calciner loop.

\subsection{DE-ENTRAINMENT TRAPS}

Above about $500^{\circ} \mathrm{F}$ MSA recommends de-entrainment traps on the cover gas lines to condense and remove $\mathrm{NaK}$ from the cover gas vented from vessels. Two types are commonly in use. One involves an S.S. mesh trap where liquid metal is disengaged due to cooling and surface contact with the mesh. The other type involves bubbling the gas through cold NaK. The first type is most commonly used for $\mathrm{NaK}$ while the second finds application for the higher melting point $\mathrm{Na}$ 。

\subsection{DUPLEX TUBES}

MSA is currently testing duplex tubes for the generation of 500 psia, $600^{\circ} \mathrm{F}$ superheated steam. The system involves a primary loop of NaK heated with a gas fired heater (essentially the same NaK system as reported in MSA Technical Report \#39). The $\mathrm{NaK}$ is then exchanged with $\mathrm{Na}$ and the $\mathrm{Na}$ is cooled in the bayonet duplex tubes of a steam boiler and superheater set up. For leak detection, helium is used as a monitor between the duplex tubes. The helium is maintained at a pressure intermediate between that of the steam and $\mathrm{Na}$. A change in pressure therefore indicates which side of the tube has failed. Tests indicate that there is negligible resistance to heat transfer between the tubes.

MSA recommend a similar use of duplex tubes in the calciner. They state that if $\mathrm{NaK}$ did leak into the calciner the hydroxides formed would immediately cause stress cracks in the calciner sholl.

\subsection{PIPING SUPPORTS}

To simplify thermal stress problems MSA usually support their loop piping by means of either counterbalanced weights or constant support hangers.

\subsection{DUMPING OF SYSTEM}

MSA do not normally dump the system for a small leak as the tubes in the fired heater may be ruined due to radiation from the hot firebrick. In the sump system they recommend the use of two valves in the line to prevent leakage. One of these valves serves as a block when the cooled NaK is recharged to the system through a bypass $S_{0} S_{\text {。 }}$ mesh oxide filter. Normally the valves are manually operated.

\subsection{LOOP PREPARATION}

In a new loop MSA normally clean everything first with detergent and water. The system is next evacuated, filled with helium and a mass spectrometer test run to make sure the system is dry and does not Jeak. Liquid metal 


\section{APPENDIX}

\subsection{LOOP PREPARATION (Continued)}

is then charged and the system mun isothermally at temperatures above $600^{\circ} \mathrm{F}$. Plugging tests are run and the $\mathrm{NaK}$ is dumped, cooled, and recharged. This filling and dumping procedure is repeated 2 or 3 times, or until the oxide content as indicated by the plugging tests is low enough to commence loop operation.

3.0 DETAILS OF MEETING WITH GRISCOM-RUSSELL COMPANY PERSONNEL AT MASSILLON, OHIO, APRIL 23,1958

\subsection{PERSONNEL CONTACTED}

Dewey Bosely, Sales Engineer

P. Otten, Special Projects Sales Engineer

R. Tidball, Development Engineer

Frank Boni, Supervisor, Special Projects Engineering

\subsection{GENERAL}

The purpose of this meeting with Griscom-Russell was to discuss and clarify the problems involved in the design and construction of the NaK fluidized bed heater in the calciner. In this field GR is one of the most experienced heat exchanger manufacturers. They also make a special type of doubled walled heat exchanger tubing called duplex tubing.

\subsection{PRELIMINARY DETAILS}

The general operation of the calciner and the fluidized bed were sot forth. GR personnel thought that the preliminary design as submitted by Fluor was feasible and practical for heating the calciner with NaK. This design involves the use of a vertical, bayonet type duplex tube exchanger which forms the bottom head of the calciner. Fluidizing air would be introduced through a perforated grid distribution plate located just above the top tube sheet of the exchanger. Each tube would pass through this grid and have sufficient clearance for expansion and contraction. A flange in the calciner shell just above the grid would be provided so that the exchanger could be lowered for inspection. Inert gas such as helium would be monitored for tube leakage by means of an upper tube sheet in the exchanger.

\subsection{MATERIALS OF CONSTRUCTION}

It was agreed that $316 \mathrm{~S}$.S. was probably the most suitable construction material for the entire exchanger. Due to the difficulty of fabrication of $347 \mathrm{~S} . \mathrm{S}_{\circ}, \mathrm{GR}$ recommended that the entire bottom section of the calciner up to the flange be constructed of $316 \mathrm{~S} . \mathrm{S}$.

\subsection{FLANGE}

If a calciner shell flange is provided, GR suggested that the "sargol" or "sarlun" type of flange would be most suitable for the calciner. This type of flange does not contain gaskets but depends on seal welding together the outer tip of the upper and lower lips of the flange. Support for the flange is obtained by bolting together rings above and below the flange. 


\section{APPENDIX}

\subsection{SOLIDS REMOVAL}

One of the main problems involved in the design of this exchanger is the necessity for removing solids as completely as possible from the bottom of the calciner during shut down periods. To aid in this, the possibility of sloping the top tube sheet was suggested. GR stated that this was very difficult and expensive to accomplish. Instead, they recommended one of two approaches: Tilt the tube bundle and make an elliptical flange where the bottom and top of the calciner join or simply tilt the whole calciner a small amount for easier removal of the solids. The latter approach would be the least costly and with minor piping changes could be altered to any desired degree of slope.

\subsection{DUPIEX TUBING}

For safe containment of the $\mathrm{NaK}$ it was agreed that duplex tubing should be used in the heat exchanger. Approximately 45 tubes, $1-1 / 2^{\prime \prime} 0 . D$. would be required for the specified duty. These tubes would protrude into the bed about $3-1 / 2$ to $4 \mathrm{ft}$. above the air distribution grid. GR personnel were queried about the amount of resistance to heat transfer these double tubes possessed. They stated that tests have shown only a very slight decrease in the heat transfer coefficient if the tubes are expanded properly. For our particular case where the transfer coefficient on the calciner side is low and controlling there should be negligible change in over-all transfer coefficient.

It is not possible to bend these tubes to less than about $20^{\prime}$ radius. Thus, it becomes apparent that if duplex tubes are to be used for the calciner, a bayonet type design with an inner core to bring in the $\mathrm{NaK}$ is the orily design possible.

\subsection{LITERATURE}

For further information on the operation of duplex tubes GR suggested the following reference: KAPL 1450, entitled "Review of the SIR Project ModelSteam Generation Integrity" by R.W. Lockhardt, November, 1955.

\subsection{WELDING}

Several different types of special trepan welding have been found necessary for the construction of liquid metal exchangers. GR is thoroughly familiar with these and will use them in the construction of the exchanger. Normally all welds are radiographed or dye checked to make sure they are satisfactory.

\subsection{STRESS PROBLEMS}

Three major stress problems must be solved in the design of the exchanger. These are listed as follows:

1. Shell to outer tube sheet stress.

2. Core tube sheet stress。

3. Radial growth of shell between tube sheets. 


\subsection{STRESS PROBLEMS (Continued)}

The magnitude of these stresses can be reduced in several ways. First, if it is possible to reduce the NaK temperature in and out of the heat exchanger this would materially help problems concerned with Items 2 and 3 , above. Second, if the fluidizing air is preheated hotter than $750^{\circ} \mathrm{F}$, stresses in Item 1 , above, will be greatly reduced.

\subsection{SURFACE FINISH REQUIRED}

Since this vessel, the tubes, and the outer tube sheet will be in contact with radioactive substances it must be possible to decontaminate these surfaces as completely as possible. To accomplish this, the relative roughness of the surfaces is important. GR indicated that the degree of finish required could greatly affect the price of the equipment. Mr. Walton was to determine AEC past practices in this field and notify Fluor as to their recommendations.

\subsection{PAID DESIGN CONTRACT}

In view of the complexity of this problem GR suggested a paid design contract to cover the high engineering cost involved in the final design of this exchanger. Rough guesses at present indicate that such design work would amount to about one-third of the total price of the complete exchanger and calciner.

\subsection{QUALITY SPECIFICATIONS}

A Number of quality specifications generally used in the construction of liquid metal heat exchangers were obtained from GR.

4.0 DETAIIS OF MEETING WITH OAK RIDGE NATIONAL LABORATORY PERSONIEL AT OAK RIDGE, TENNESSEE, APRIL 24, 1958

\subsection{PERSONNEL CONTACTED}

W. D. Manly, Associate Director of Metallurgy

J. H. DeVan, Dynamic Corrosion Group Leader

R. L. Heestand, Welding and Brazing Engineer

P. Patriarca, Welding and Brazing Engineer

E. E. Hoffman, General Corrosion Group Leader

R. E. MacPherson, Exp. Engineer, Reactor Projects Division

G. H. Burger, Instrument Engineer

\subsection{GENERAL}

Personnel at ORNL are probably some of the foremost authorities on the use of $\mathrm{NaK}$ as a high temperature heat transfer medium. Numerous testing programs have been performed at this site ranging in scope from the development of specialized welding techniques and high temperature valve construction materials to extensive corrosion survey work and the operation of actual plant scale equipment at temperatures of about $1,500 \%$. 


\section{APPENDIX}

\subsection{GENERAL (Continued)}

Flow sheets of our calcination process with the proposed use of $\mathrm{NaK}$ at $1,400^{\circ} \mathrm{F}$ were shown to these people. $\mathrm{Mr}$. Manly thought that, in general, we had a workable $\mathrm{NaK}$ system. He stated that corrosion would not be critical in 316 S.S. and said that there was essentially no difference in the corrosive properties of $\mathrm{NaK}$ and $\mathrm{Na}$. He noted, however, that the oxidation resistance of 316 S.S. is poor and advised us to check closely with people who have used oil fired NaK heaters. Evidently catastrophic oxidation can occur in the heater if excess impurities, such as sulfur and vanadium, are present in the fuel oil.

\subsection{COLD TRAPPING}

ORNL though the proposed use of a diffusional cold trap in our system would give adequate control of the oxide content in the loop. They have experienced no trouble in loop operation as long as the oxide content is maintained at less than $50 \mathrm{ppm}$. To accomplish this a cold trap temperature of about $200-300^{\circ} \mathrm{F}$ has been found satisfactory.

\subsection{PLUGGING INDICATORS}

Plugging indicators are used in the conventional manner by ORNL to check on the oxide content of their loops.

\subsection{CORROSION}

Mr. DeVan stated that flow rate is an important variable in liquid metals corrosion. This is why ORNL does most of their dynamic corrosion studies in large-scale loops. He stated that nearly all of the 18-8 stainless steels are potentially good for the construction of high temperature NaK loops. Stainless steels such as $304,347,316$, and 321 have nearly identical corrosion properties and hence other properties such as strength and workability play an important part in the final selection. of the nickel base alloys, inconel is best but it is inferior to the 18-8's. Inconel is, however, much superior to the 18-8's for the containment of fused salts. As a result most of the loops at ORNL are made of inconel. If loops are constructed of dissimilar alloys the mass transfer rate may be greater than that characteristic of the least resistant alloy. The inconel-3l6 S.S. combination is one of the exceptions in that the mass transfer rate for the system is no greater than would be expected for inconel alone. Like materials such as the 18-8's can also be used without harm. Transfer of carbon from a high carbon steel to a low carbon steel also occurs in NaK loops.

For a given hot $\mathrm{NaK}$ temperature ORNL has found that the amount of mass transfer deposition occurring in a loop is a linear function of the temperature range to which the $\mathrm{NaK}$ is cooled. The greater the temperature range, the greater the deposition. They have also found that this deposition in a system with small tubes may be critical due to the plugging of the tubes.

Mr. DeVan estimates the corrosion rate at the temperature of the proposed calciner loop should be about 1 to $1-1 / 2$ mils/year. He points out that this rate is difficult to predict due to several reasons. First, most

Page 11 of 18 


\subsection{CORROSION (Continued)}

of the data available are based on tests of short duration. Second, it has been found that the corrosion rate is faster at the beginning of a test and then tends to fall off very rapidly. Evidently the metal seems to build up a passivity to attack. Thus, extrapolation of these corrosion rates to longer periods of time may be quite erroneous.

In a phone conversation to $\mathrm{Mr}$. DeVan on May 9, 19.58, he indicated that he had obtained some additional corrosion data in liquid metals systems not mentioned previously during the visit to ORNL. While these data are not significantly different from those on which the conclusions cited above are based, they are summarized as follows for the purposes of background material. First, no long-term corrosion data are presently available in the range of 6 months to 2 years time. Second, at $1,500^{\circ} \mathrm{F}$ no difference in intergranular attack was experienced in loops operated for 500,750 , 1,000 , and 2,000 hours. All experienced about 1-.L/2 mils intergranular attack using 316 S.S. Third, difficulty in the operation of loops at ORNL has always been due to cold leg plugging (mass transfer deposition) and not to hot leg corrosion. Fourth, other alloys such as $430 \mathrm{~S} . \mathrm{S}$. have been tested but do not possess any better corrosion resistance than 316 S.S. Fifth, Dr. Holman of American Standard Atomic Research in Sunnyvale, California, reports that his company is currently conducting long-term corrosion tests in thermal convection loops using $316 \mathrm{~S} . \mathrm{S}_{\text {。 }}$ at $1,500^{\circ} \mathrm{F}$.

\subsection{COVER GAS}

ORNL prefer helium as a cover gas in their loops. They used to purify this gas in NaK bubblers, but have discontinued this practice because of the difficulty in removing the last traces of $\mathrm{NaK}$ frorn the gas. They do not recommend nitrogen as there is a possibility of nitriding at high temperatures. ORNL and the Naval Research Laboratory data indicate that nitriding definitely does occur at a temperature of $1,500^{\circ} \mathrm{F}$ and can amount to $5 \mathrm{mils}$ / year. The Creep testing laboratory at ORNL has also mun tests to determine the effect of nitriding. Some work on this subject has been reported in the Transactions of the American Metals Society as well as the following ORNL Metullurgical Division Semiannual Reports: ORNI-2080, 2422, and 2217.

\subsection{PUMPS}

ORNL generally use centrifugal pumps of the vertical, gas-sealed, sump type to circulate liquid metals through their loops. These pumps have been tested for many hours of operation and have been found to be very reliable and trouble-free.

The experience of this site in the use of electomagnetic pumps is rather limited. Mr. Grindell of ORNL reports as of a May 9, 1958, phone call that several small G.E. electromagnetic pumps of the A.C. Faraday type were tested a few years back in the temperature range of $1,400-1,500^{\circ} \mathrm{F}$. These pumps operated very successfully for the duration of tests (about 1,000 hours maximum), but were specially constructed with nickel lugs welded to the pipe to form the bus bars of the pump. However, no new type pumps with nickel bus bars nicro brazed to the pipe have been tested recently. 
4.07 PUMPS (Continued)

ORNL saw no reason why these $E_{0} M_{0}$ pumps should not be satisfactory for the calciner loop. Other pumps of interest mentioned were: Findly Engineering or Allis Chalmers rotating magnet, squirrel cage type of pump; and an electrical induction driven screw pump of British design (c.f. British Nuclear Eng. Jo. about 1955 or 1956).

Other literature on pumps includes: ORNL-CF Memo 54-8-234 (Early Work on Pumps) and ANP Progress Reports from 1954 to the present data.

\subsection{FLOWMETERS}

ORWL have used magnetic flowmeters with considerable success. They generally make their own and limit the magnet temperature to $300^{\circ} \mathrm{F}$ by insulating the pole faces with 3 or 4 alternate layers of shim stock and steel mesh.

\subsection{PRESSURE}

Either the Moore Nullmater or Taylor bourdon type of pressure gauges have been used successfully at ORNL.

\subsection{LIQUID IEVEL}

Spark plug leyel probes have been used extensively at this site. Above about $400-500 \mathrm{~F}$ shorting out may occur due to condensation of NaK on the probes. The condensed $\mathrm{NaK}$ can usually be removed by placing a 110 volt circuit across the probes. J tubes as manufactured by $G_{0} E_{0}$ (G. D. Collins, Atomic Power Equipment, San Jose) are used for continuous level measuring.

\subsection{THERMOCOUPLES}

Two methods of attaching thermocouples to the loops are generally employed. One method is to spot weld directly to the loop. The other involves melting a weld bead with a spot welder and sticking the thermocouple into the molten metal. Either method seems to give good results.

\subsection{VALVES}

Mr. MacPherson says that the Powell, cast 347SS, Y-type valves with stellite plugs have been used successfully as dump valves. These valves could also probably be made of $316 \mathrm{~S} . \mathrm{S}$. They are usually sealed with Breeze bellows. Because of the large thermal stresses possible, valves should not be screwed tight and for this reason pneumatic seating is best. If a little leakage can be tolerated in the dump line double valves are not required. For throttling ORNL has used Black, Sivals and Bryson as well as Hoke type valves.

When liquid metal systems are operated above $1,200^{\circ} \mathrm{F}$ oxide scales may form on the valves. According to $\mathrm{Mr}$. DeVan, these scales are perfect fluxing agents and may cause the valves to self-weld together and become inoperable. For this purpose ORNL has developed valves with bonded cermet seats ( $\mathrm{Ti}$ C-10\% Ni). These valves have been found to work best using a relatively hard plug material contacting the cermet seat。 


\subsection{WELDING}

Mr. Heestand described some of the specialized automatic welding techniques developed by ORNL and used by GR to construct heat exchangers. One of the techniques involves the use of trepan welding with back brazing of the tubes to the tube sheet. This technique is particularly useful for exchangers with the sheets greater than I/2" thick. It has been found to strengthen the structure and help eliminate stresses in the tube sheet. This technique is explained in ORNL-1955 and Metallurgy Division ANP Quarterly Progress Reports ORNI-1644 through 2340. Coast Metals 52 brazing alloy is one of materials which has been found to give good oxidation and corrosion resistance. A report on this subject is also available on a declassified basis: ORNL-CF-56-4.

\subsection{OXIDATION}

Oxidation of 316 S.S. is more drastic when there is a lack of oxygen in the gas than when there is an excess present. Mr. DeVan states this problem begins at $1,400^{\circ} \mathrm{F}$ and becomes acute at $1,600^{\circ} \mathrm{F}$. This oxidation is evident by inspection due to the sloughing off of the loosely attached oxide. If copper or copper oxide is present, this oxidation is usually accelerated and may become catastrophic. (Note P\&W in paragraph 1.18 recommend operation of the $\mathrm{NaK}$ heater in a reducing atmosphere).

\subsection{INSULATION}

ORNL generally uses a 1-1/2" thickness of Super-x with a 1-1/2" outside layer of $85 \%$ magnesia for insulation purposes.

\subsection{LEAK DETECTION AND FIRES}

Leak detectors are generally not employed in zones readily accessible. The voluminous amount of white, opaque, oxide smoke evolved is a rapid indication of even the smallest leak. However, precautions should be made to protect personnel against splattering. Liquid metals burn with intense heat and will eventually melt away the container material. Fires are usually extinguished quickly by applying a surface covering of graphite, Met-I-X or sodium carbonate. Alkali metals exposed to the atmosphere rapidly form a surface layer of superoxides. These superoxides detonate weakly upon contact and may splatter liquid metal.s randomly about the surroundings. For this reason it is wise to remove any spillage immediately once the fire has been extinguished. Fires are usually localized to only the immediate area where the liquid metal splashes. No flames occur, and as a result these fires are usually easier to extinguish than hydrocarbon fires.

\subsection{HOT TRAPS}

In a phone conversation with $M_{r}$. DeVan on May 9, 1958, hot traps were discussed further. In his opinion, a hot trap is definitely not warranted for the proposed calciner loop. He said, however, that the system should be kept reasonably clean of oxides by some means such as a cold trap. ORNL has performed tests with and without hot traps and even with controlled oxide addition to ascertain whether the maintenance of low oxide content is warranted. Briefly, their results have shown no difference in mass 


\subsection{HOT TRAPS (Continued)}

transfer deposition using a hot trapped system versus a system with controlled oxide content equivalent to as much as $0.05 \mathrm{wt} . \%$ oxide. The system was $\mathrm{NaK}$ in inconel at $1,500^{\circ} \mathrm{F}$. When, however, the oxide content was controlled at $0.15 \mathrm{wt} . \%$ a marked increase in mass transfer deposition did occur. In another system with similar operating conditions, the cold trap was run at $600^{\circ} \mathrm{F}$ with no increase in mass transfer deposits.

Their conclusions are that the maintenance of a low oxide content may be important for systems which operate at lower temperatures $\left(1,000^{\circ} \mathrm{F}\right.$ and below) or when $\mathrm{Zr}$ or $\mathrm{Ti}$ is used as a construction material. On the other hand, at higher temperatures it is only necessary to maintain a reasonable oxide content because the increased solubility of the construction material in the liquid metal over-shadows any corrosion due to high oxide content.

\subsection{SPECIFICATIONS}

A set of specifications covering welding techniques and general procedures in the fabrication of NaK loops was obtained from ORNL. While this information is largely for inconel, it may serve as a guide in the construction of the proposed 316 S.S. loop.

\subsection{DETAILS OF MEETING WITH ARGONNE NATIONAL LABORATORY} PERSONNEL AT LEMONT, ILLINOIS, APRIL 25, 1958

\subsection{PERSONNEL CONTACTED}

F. A. Smith, Group Leader, Experimental Liquid Metals Section of Reactor Engineering Group

R. L. Humphreys, Chemist

D. E。 Walker, Metallurgist

Dr.F.G. Foote, Chief Metallurgist

\subsection{GENERAL}

Argonne has done a considerable amount of work in the testing of sodium loops operating in the $1,000^{\circ} \mathrm{F}$ temperature range. Certain tests are also being conducted with loops operating with sodium at $800^{\circ} \mathrm{C}$.

The general scheme of our proposed NaK loop for the calciner was shown to $\mathrm{Mr}$. Smith and Mr. Humphreys. They agreed that $316 \mathrm{~S} . \mathrm{S}$. was probably the most suitable construction material and said NaK should be satisfactory. However, based on past experience, they prefer sodium since it is easier to handle, especially in the case of leakage and a fire. They state that Na will freeze after the fire is extinguished, and is therefore not as hard to handle as $\mathrm{NaK}$ which is usually liquid at room temperature.

\subsection{COLD TRAPPING}

Due to plugging of the line, ANL would prefer the use of a 2-inch connection to our diffusional cold trap. They estimate that we would maintain about $15 \mathrm{ppm}$ oxide content with this set-up. In addition to MSA, they suggest we contact G.E. who also make cold traps. 
5.04 HOT TRAPPING

In addition to a cold trap, ANL strongly recommend the use of a hot trap. In their opinion, a low oxide content in the 1 ppm range is necessary, particularly in the high temperature range of operation where there is a paucity of corrosion data. With this low an oxide content, the system may also be simplified somewhat in that precautions against the accumulation of oxides in cold dead zones can be relaxed and cheaper pressure gauges such as ordinary bourdon tubes can be used. For our particular installation, they suggest piping the main flow of $\mathrm{NaK}$ into the side of the expansion tank and out through the bottom with the hot trap suspended as a basket in the lower section of this vessel. Any one of a number of getters such as $\mathrm{Ti}, \mathrm{Zr}$, $\mathrm{U}$ or $\mathrm{Th}$ would be satisfactory in the form of chips in this basket. $U$ and Th are more efficient and since no neutron bombardment source is present they should be suitable for this use.

There appears to be no real data for the sizing of hot traps. They recommend a rule of thumb sizing whereby the amount of getter required is determined on the basis of retaining $1 \mathrm{mg}$ of oxygen per $\mathrm{cm}^{2}$ of getter surface.

\subsection{PLUGGING INDICATOR}

ANL states that a plugging indicator would be desirable to determine the oxide content of the liquid metal in the system. If a hot trap is used they recommend muning the plugging indicator continuously at a temperature below $100^{\circ} \mathrm{C}$ to determine if the system getters are functioning properly. A vacuum cup sampler may be used to determine very small amounts of oxide in the NaK but this determination is difficult and costly to perform.

\subsection{CORROSION}

As long as the temperature of liquid metals operation is limited to $I_{0} 000^{\circ} \mathrm{F}$ ANL reports that no major corrosion problems have been involved in their test loops. However, as a means of supporting their belief that hot traps are necessary for high temperature liquid metal systems, $\mathrm{Mr}$. Walker produced some photomicrographs of a pipe from an electromagnetic pump. This pump had failed due to random $50 \%$ intergranular corrosion on the down-stream pipe side. The system had been operated with sodium at $800^{\circ} \mathrm{C}$.

This information seemed inconclusive in that no means whatsoever had been employed for controlling the oxide content of the system during the test (no hot or cold trap used). Perhaps just a cold trap would have prevented the corrosion without the additional protection of a hot trap.

\subsection{COVER GAS}

ANL recommend either helium or argon as the cover gas. They say that there is some evidence that nitriding will occur at high temperatures.

\subsection{PUMPS}

Statistically, ANL has found more failures on the downstream pipe side of their electromagnetic pumps than any other place in the loops tested. For this reason, they recommend an adequate pipe wall thickness in our pump of not less than 0.100 inch. In their opinion it is better to sacrifice pumping efficiency for the additional wall thickness. They have had some trouble 
5.08 POMPS (Continued)

in nicro brazing the armature leads to the pipe and therefore advise careful checking of the pump in this respect. They also caution that for best operation of the pump the armature leads to the pump should be mounted in a horizontal position. In this position, any entrained gas in the NaK will rise to the top of the pipe and therefore tend to reduce the armature current conduction path less than gas passing through the center of the pipe.

\subsection{PRESSURE}

ANL is currently operating one test loop at $800^{\circ} \mathrm{C}$ with a carbon steel pressure gage mounted on an 8 to 10 inch cold leg above the loop. They say that the use of this cheap pressure gauge is possible only because a hot trap is included in the system. Without one, the oxides would tend to plug the bourdon tube and therefore require the use of a more expensive gauge such as the Moore or Taylor types.

\subsection{LIQUID LEVEL}

ANL uses spark plug type probes for liquid level determinations, but warn that precautions have to be taken against fouling due to liquid metal condensation at higher temperatures.

\subsection{VALVES}

Hammel Dahl valves have been found satisfactory for throttling purposes in large sodium systems at about $1,000^{\circ} \mathrm{F}$.

\subsection{DUPLEXX TUBING}

According to reports received by $\mathrm{ANL}$, the mechanical expansion of the inner tube into the outer tube in the duplex tube arrangement may be difficult to perform. Their information relates that the duplex tubes used by MSA in their steam generation loop were badly scored in this operation. During visits to both MSA and GR no mention was made by either company of this incident. However, these tubes seemed to be performing satisfactorily in service. Atomics International also use this type of tube but they did not mention this problem during a recent visit to their installation.

\subsection{LOOP PREPARATION}

ANL uses somewhat similar techniques to those previously described for loop preparation. They warn, however, that during the step of charging and heating the $\mathrm{NaK}$ in the loop the oxides will usually first exist in the form of solids floating on top of the NaK. These oxides require a relatively long time to dissolve. Thus, a large amount of oxide solids may remain in the loop when the $\mathrm{NaK}$ is dumped unless the system is maintained at a sufficiently high temperature for several hours or more. Most of these oxides can then be removed when the $\mathrm{NaK}$ is finally dumped to the sump tank, cooled and then repressurized back into the loop through bypass filters. Further oxide removal by repeating this charge and dump operation again is usually not practical as the cover gas required for this purpose generally contains sufficient impurities to again pollute the $\mathrm{NaK}_{\text {. }}$ 


\section{APPENDIX}

\subsection{LOOP HEATING}

Both resistance and alternating current induction heating have been used by ANL to maintain their system above the melting point of the sodium. In the induction heating, the nonmagnetic stainless steel is clad with 1/8" steel plate. The steel plate is heated by induction, the stainless steel by conduction. Insulation is applied and then the induction coils are wrapped around the insulation. 



\section{CALCULATION OF TEMPERATURE TRANSIENT FOR THE CALCINER IN EVENT OF A NaK LEAK}

Equations for estimating the temperature rise in the calciner during a NaK leak have been formulated by balancing the heat input rate to the heat output rate for the reactions likely to occur.

The heat balances equate the rate of sensible heat from incoming NaK and air, plus the energy liberated by the oxidizing reactions to the energy absorption rate by the vessel, the bed of solids, NaK oxides, and excess NaK, plus the sensible heat carried out of the vessel by the off-gas. The consequences of $\mathrm{NaK}$ leaking at three rates - $1.0 \mathrm{gpm}, 14.8 \mathrm{gpm}$, and $205 \mathrm{gpm}$ - were examined. Of the three rates, a leak of $1.0 \mathrm{gpm}$ is the most likely to occur as a tube would have to be completely broken off before the leak could reach the higher rates. The amount of $\mathrm{NaK}$ required to react with all of the oxidizer entering the calciner under normal operating conditions is $14.8 \mathrm{gpm}$ (the stoichiometric leak rate ). A leak rate of $205 \mathrm{gpm}$ is the maximum possible if one tube was completely broken off, the NaK system was completely full, and a gas pressure of 20 psig had been placed on the NaK system (emergency shutdown condition - Section VI-8.32).

Because of the complexity of calculations of this type, numerous simplifying assumptions were made. These assumptions resulted in negligible error or in calculated temperatures higher than actual. The assurnptions are listed below.

(1) It was assumed that no energy from the calciner is dissipated by radiation, conduction, or convection. Especially at the high temperatures that would be encountered in the more critical cases, these mechanisms would lower the temperature transients if appropriate allowances were made for heat losses to the surrounding cell.

(2) The assumption was made that excess NaK from a leak greater than the stoichiometric rate (the flow rate of $\mathrm{NaK}$ that will react with exactly all of the oxidizing material) will be distributed uniformly throughout the bed. The validity of this assumption depends upon the fluidizing velocity, the degree of fluidization, and the physical properties of the calcined solids and NaK. The density of NaK 
$(0.69 \mathrm{~g} / \mathrm{cc}$ at operating conditions) is slightly below that for the fluidized bed $(0.8 \mathrm{~g} / \mathrm{cc}$ at operating conditions). Thus, the NaK should have only a slight tendency to rise in the bed and would probably therefore have time to be distributed in a reasonably uniform manner by the fluidizing solids. Similarly, uniform temperature distribution throughout the bed was assumed, an assumption justified because of the random particle movement, frequent particle contacts, and the large surface area to volume ratio of the particles. The temperature of the off-gas leaving the vessel was assumed to be the same as that of the bed, an assumption consistent with the assumption of a well-mixed bed.

(3) The assumption was made that the NaK oxides would accumulate in the calciner bed. Assuming the oxides were to leave with the off-gas would have only a minor effect on the calciner heat balance. (4) It was assumed that there would be an instantaneous and complete reaction between the $\mathrm{NaK}$ and the available oxidizing materials. This implies that there would be excess $\mathrm{NaK}$ at a $\mathrm{NaK}$ flow rate greater than the stoichiometric rate. To arrive at an answer (on the safe side) for the case of a leak at a rate under the stoichiometric rate, the oxidizing reaction between $\mathrm{NaK}$ and the aluminum nitrate was considered to be the only reaction occurring because it produces the greatest amount of energy per pound of NaK reacted.

(5) All of the gas, exclusive of nitrogen, which enters the calciner was assumed to react with $\mathrm{NaK}$. Although about 45 percent of the oxygen enters near the top of the vessel, the degree of recirculation is unknown and the assumption of complete reaction is the more conservative approach.

(6) It was assumed the calciner would be operating at flowsheet conditions (Figure $\mathrm{V}-3$ ) at the time of an accident.

If the temperature of the calciner reaches the boiling point of $\mathrm{NaK}$ when there is excess $\mathrm{NaK}$ in the calciner, ie, if the leak rate exceeds the stoichiometric reaction rate, the heat required to vaporize the $\mathrm{NaK}$ will keep the bed temperature at the boiling point. The vaporized $\mathrm{NaK}$ could then be carried by the off-gas to the quench tower where there is a large supply of nitric acid and water available to oxidize it. Substantial amounts of hydrogen and steam would be generated by 
the resulting oxidation reactions. Calculations for the amount of hydrogen and steam generated are included in the discussion of the 205-gpm leak rate.

\section{OXIDIZER INPUT RATES AT NORMAL CALCINER OPERA TING CONDITIONS}

The rates at which oxidizing materials enter the calciner are shown in Table F-1. NaK normally enters the fluidizing bed heating bundle at a temperature of $680^{\circ} \mathrm{C}$ and at a rate of $39,000 \mathrm{lb} / \mathrm{hr}$. The approximate volume of $\mathrm{NaK}$ in the system is 442 gallons.

\section{TABLE F-1}

\section{INPUT RATES OF OXIDIZING MATERIALS INTO THE CAICINER}

\begin{tabular}{|c|c|c|c|c|c|c|}
\hline \multirow[b]{2}{*}{ Stream } & \multirow[b]{2}{*}{$\begin{array}{l}\text { Temperature } \\
\left({ }^{\circ} \mathrm{C}\right)\end{array}$} & \multicolumn{5}{|c|}{ Input Rates (Pounds per Hour) } \\
\hline & & $\mathrm{O}_{2}$ & $\mathrm{~N}_{2}$ & $\mathrm{H}_{2} \mathrm{O}$ & $\mathrm{HNO}_{3}$ & $\mathrm{Al}\left(\mathrm{NO}_{3}\right)_{3}$ \\
\hline Fluidizing Air & 410 & 254 & 846 & 0 & 0 & 0 \\
\hline Atomizing Air & 85 & 85 & 282 & 0 & 0 & 0 \\
\hline Transport Air & 107 & 107 & 360 & 7 & 0 & 0 \\
\hline Air Purges & 68 & 97 & 158 & 0 & 0 & 0 \\
\hline Waste Feed & 24 & 0 & 0 & 543 & 78 & 214 \\
\hline TOTAL & & 443 & 1646 & 550 & 78 & 214 \\
\hline
\end{tabular}

\section{REACTIONS OF NaK WITH OXIDIZER IN THE CALCINER VESSEL}

$\mathrm{NaK}$ will react with materials present in the calciner according to the following chemical equations. One mole of $\mathrm{NaK}$ as used in these equations has a "pseudo" molecular weight of 35.6 , and contains 0.676 mole percent potassium and 0.324 mole percent sodium. Only the primary reactions from $\mathrm{NaK}$ and oxidants to the end products are considered; dissociation reactions are neglected. Heats of reaction were determined from heats of formation obtained from the literature. [1] The heat of formation of liquid NaK is assumed to be zero at $18^{\circ} \mathrm{C}$, the base temperature used for all energy levels quoted in this appendix. 
To simplify the calculations, the reaction equations were written on the basis of the number of moles of NaK required to react with one mole of each oxidant as follows:

$$
\begin{aligned}
& 4 \mathrm{NaK}_{(1)}+\mathrm{O}_{2}(\mathrm{~g}) \longrightarrow 1.352 \mathrm{~K}_{2} \mathrm{O}(\mathrm{s})+0.648 \mathrm{Na}_{2} \mathrm{O}(\mathrm{s}) \\
& \Delta H_{\mathrm{R}}=-82,200 \mathrm{kcal} / \mathrm{Ib}-\mathrm{mole} \mathrm{O}_{2} \\
& 2 \mathrm{NaK}_{(1)}+\mathrm{H}_{2} \mathrm{O}(\text { I }) \rightarrow 0.676 \mathrm{~K}_{2} \mathrm{O}(\mathrm{s})+0.324 \mathrm{Na}_{2} \mathrm{O}(\mathrm{s})+\mathrm{H}_{2}(\mathrm{~g}) \\
& \Delta H_{\mathrm{R}}=-10,050 \mathrm{kcal} / \mathrm{lb}-\mathrm{mole} \mathrm{H}_{2} \mathrm{O} \\
& 6 \mathrm{NaK}_{(1)}+\mathrm{HNO}_{3} \rightarrow 2.028 \mathrm{~K}_{2} \mathrm{O}(\mathrm{s})+0.972 \mathrm{Na}_{2} \mathrm{O}_{(\mathrm{s})}+3 \mathrm{H}_{2}(\mathrm{~g})+0.5 \mathrm{~N}_{2}(\mathrm{~g}) \\
& \Delta \mathrm{H}_{\mathrm{R}}=-10,050 \mathrm{kcal} / \mathrm{Ib}-\mathrm{mole} \mathrm{HNO}_{3} \\
& 15 \mathrm{NaK}_{(1)}+\mathrm{Al}_{3}\left(\mathrm{NO}_{3}\right)_{3} \rightarrow 5.07 \mathrm{~K}_{2} \mathrm{O}(\mathrm{s})+2.43 \mathrm{Na}_{2} \mathrm{O}(\mathrm{s})+1.5 \mathrm{~N}_{2}(\mathrm{~g}) \\
& +0.5 \mathrm{Al}_{2} \mathrm{O}_{3}(\mathrm{~s}) \\
& \Delta H_{\mathrm{R}}=-364,000 \mathrm{kcal} / \mathrm{lb}-\mathrm{mole} \mathrm{Al}\left(\mathrm{NO}_{3}\right)_{3}
\end{aligned}
$$

Using the above reactions together with an energy balance, the stoichiometric leak rate of $\mathrm{NaK}$, ie, the leak rate required to react with all the oxidizer entering the calciner under normal conditions, was estimated at $14.8 \mathrm{gpm}$; the heat of reaction corresponding to this leak rate is approximately $540 \mathrm{kcal} / \mathrm{sec}$.

In the case of a NaK leak rate of one gpm, the assumption was made that the NaK reacts only with aluminum nitrate. This reaction was chosen because it yields the greatest amount of heat of the four reactions possible, 65.6 $\mathrm{kcal} / \mathrm{sec}$.

$$
\begin{aligned}
& {\left[\frac{1 \text { gal }}{\mathrm{min}}\right]\left[8.33 \times 0.69 \frac{1 \mathrm{~b}}{\mathrm{gaI}}\right]\left[\frac{1 \mathrm{~b}-\mathrm{mol} \mathrm{NaK}}{35.6 \mathrm{Ib} \mathrm{NaK}}\right]\left[\frac{1 b-\mathrm{mol} \mathrm{Al}\left(\mathrm{NO}_{3}\right)_{3}}{15 \mathrm{Ib}-\mathrm{mol} \mathrm{NaK}}\right]} \\
& {\left[\frac{364,000 \mathrm{kcal}}{1 \mathrm{~b}-\mathrm{mol} \mathrm{Al}\left(\mathrm{NO}_{3}\right.}\right]\left[\frac{1 \mathrm{~min}}{60 \mathrm{sec}}\right]=65.5 \mathrm{kcal} / \mathrm{sec}}
\end{aligned}
$$

\section{DETERMINATION OF MAXIMUM LEAK RATE}

The maximum leak rate possible was assumed to be that accompanying a complete break of one exchanger tube in the calciner with a pressure of 
20 psig placed on the NaK system. At this pressure in the expansion tank, the pressure at the exchanger tubes is approximately 33.3 psig or 110 feet of NaK. The maximum NaK discharge velocity through the leak can be estimated by assuming all the pressure energy is converted to kinetic energy:

$$
\text { Velocity }=\sqrt{2 g(\text { head })}=\sqrt{64.4(110)}=84 \mathrm{ft} / \mathrm{sec}
$$

The maximum NaK flow rate $(\mathrm{r})$ from the area of one severed tube $\left(0.005446 \mathrm{ft}^{2}\right)$ is calculated as follows:

$$
r=\left(\frac{84 \mathrm{ft}}{\mathrm{sec}}\right)\left(0.005446 \mathrm{ft}^{2}\right)\left(\frac{60 \mathrm{sec}}{\mathrm{min}}\right)\left(7.48 \frac{\mathrm{gal}}{\mathrm{ft}}\right)=205 \mathrm{gpm}
$$

\section{CONSTANTS USED IN THE CALCULATIONS}

These values were obtained from standard references, or are typical of process conditions:

Density of NaK

Density of fluidized bed

Specific heat of the NaK

$\mathrm{NaK}$ inlet temperature

Air inlet temperature

Specific heat of air

Specific heat of alumina

Weight of bed

Specific heat of steel

Weight of steel

Specific heat of $\mathrm{NaK}$ oxides

Specific heat of steam

Specific heat of nitrogen

Heat of vaporization of $\mathrm{H}_{2} \mathrm{O}$

Heat of vaporization of $\mathrm{NaK}$ (estimated)

$$
\begin{aligned}
& \rho_{\mathrm{NaK}}=0.69 \mathrm{~g} / \mathrm{cc} \\
& \rho_{\text {bed }}=0.8 \mathrm{~g} / \mathrm{cc} \\
& \mathrm{c}_{\mathrm{NaK}}=0.211 \mathrm{cal} / \mathrm{g}-{ }^{\circ} \mathrm{C} \\
& t_{\mathrm{NaK}}=680^{\circ} \mathrm{C} \\
& \mathrm{t}_{\text {air }}=242^{\circ} \mathrm{C} \\
& \mathrm{c}_{\text {air }}=0.255 \mathrm{cal} / \mathrm{g}-{ }^{\circ} \mathrm{C} @ 242^{\circ} \mathrm{C} \\
& { }^{\mathrm{c}} \mathrm{Al}_{2} \mathrm{O}_{3}=0.27 \mathrm{cal} / \mathrm{g}-{ }^{\circ} \mathrm{C} \\
& \mathrm{W}_{\text {bed }} \stackrel{3}{=} 1.71 \times 10^{6} \mathrm{~g} \\
& \mathrm{c}_{\text {steel }}=0.12 \mathrm{cal} / \mathrm{g}-{ }^{\circ} \mathrm{C} \\
& \mathrm{W}_{\text {steel }}=2.16 \times 10^{6} \mathrm{~g} \\
& \mathrm{c}_{\text {oxides }}=0.46 \mathrm{cal} / \mathrm{g}-{ }^{\circ} \mathrm{C} \\
& \mathrm{c}_{\text {steam }}=0.5 \mathrm{cal} / \mathrm{g}-{ }^{\circ} \mathrm{C} \\
& \mathrm{c}_{\mathrm{N}_{2}}=0.265 \mathrm{cal} / \mathrm{g}-{ }^{\circ} \mathrm{C}
\end{aligned}
$$

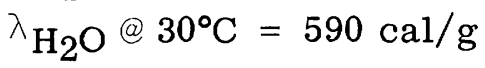

$$
\begin{aligned}
& \lambda_{\mathrm{NaK}} @ 760^{\circ} \mathrm{C}=625 \mathrm{cal} / \mathrm{g}
\end{aligned}
$$




\section{CALCULATIONS OF TEMPERATURE TRANSIENTS}

The derivations of the six equations needed to treat the three cases of $\mathrm{NaK}$ leak rates are tabulated in Table F-2. Heat inputs are listed along with the heat outputs. The basis for the enthalpy of all streams is zero at $18^{\circ} \mathrm{C}$. In each case, the heat input rate is equated to the heat removal rate, the variables are separated, and the resulting differential equation is integrated and evaluated between the appropriate time and temperature limits. The heat input and output rates for these terms in all six equations are summarized in Table F-2. Case I considers the transient resulting from a leak rate of one gpm. The rate equation is developed as follows:

Case I:

Sensible heat added by NaK

$$
+
$$

Sensible head added by air $+$

Heat of reaction

II

Heat absorbed by vessel

$+$

Heat absorbed by bed

$+$

Heat absorbed by $\mathrm{NaK}$ oxides $+$

Heat carried away by off-gas

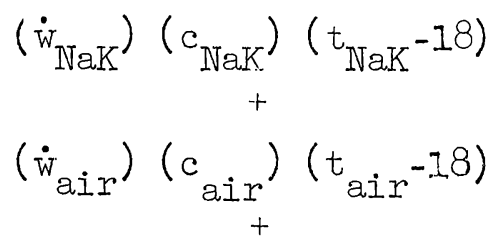

$\Delta \mathrm{H}_{r}$

if

$\left(w_{\text {steel }}\right)\left(c_{\text {steel }}\right)\left(\frac{d t}{d \theta}\right)$

$\left(w_{\text {bed }}\right)\left(c_{\mathrm{Al}_{2} \mathrm{O}_{3}}\right)\left(\frac{\mathrm{dt}}{\mathrm{d} \theta}\right)$

[a]

$\left(\dot{\mathrm{w}}_{\text {oxides }}\right)\left(c_{\text {oxides }}\right)\left[\theta \frac{\mathrm{d} t}{\mathrm{~d} \theta}+(t-18)\right]$ $+$

$\left(\dot{w}_{\text {off-gas }}\right)\left(c_{\text {off-gas }}\right)\left(t_{\text {off-gas }}-18\right)$

where:

$\vec{W}=$ flow or formation rate, $\mathrm{g} / \mathrm{sec}$

$\mathrm{c}=$ specific heat, $\mathrm{cal} /(\mathrm{g})\left({ }^{\circ} \mathrm{C}\right)$

$\mathrm{W}=$ weight, $\mathrm{g}$

$\Delta \mathrm{Hr}=$ heat of reaction, $\mathrm{kcal} / \mathrm{g}-$ mole

$\mathrm{t}=$ temperature, ${ }^{\circ} \mathrm{C}$

$\theta=$ time, sec

[a] Assuming oxides remain in bed 
TABIE F-2

ENERGY BAIANCE FOR THREE NaK IFAK RATES INTO THE CALCINER

\begin{tabular}{|c|c|c|c|c|c|c|c|}
\hline & \multicolumn{2}{|c|}{ HEAT IRPUI RATE $[\mathrm{a}]$} & \multirow[b]{2}{*}{$\begin{array}{l}\text { Heat of } \\
\text { Reaction } \\
\end{array}$} & \multicolumn{4}{|c|}{ HEAT REYOVAL RATE } \\
\hline & 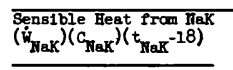 & 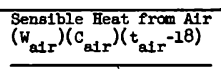 & & 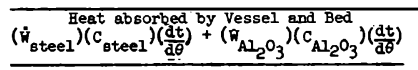 & 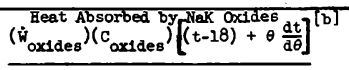 & 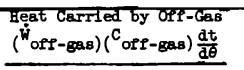 & $\begin{array}{l}\text { Heat Removed by Excess Nak } \\
\left(\hat{H}^{\text {excess })}\left({ }^{C} \text { Nak) }\left[(t-18)+\theta \frac{d t}{d \theta}\right]\right.\right.\end{array}$ \\
\hline Case I & & & & & & & \\
\hline $\begin{array}{l}\text { Mak Leak }=1.0 \text { g prem } \\
0<\theta<26,500 \text { seconds }\end{array}$ & $6 ; 810$ & 14,700 & 65,500 & $7.21 \times 105 \frac{\mathrm{dt}}{\mathrm{d} \theta}$ & $10.04\left[(t-18)+\theta \frac{d t}{d \theta}\right]$ & $38,600-104 \cdot 3(t)^{[c]}$ & 0 \\
\hline $\begin{array}{l}\text { Case II A } \\
\text { NaK Ieak }=14.8 \text { gpm } \\
\text { From start of leak to } \\
\text { compliete consumption of } \\
\text { NaK } 0<\theta<1,820 \text { seconds }\end{array}$ & 99,200 & 14,700 & 524,000 & $7.21 \times 105 \frac{\mathrm{dt}}{\mathrm{d} \theta}$ & $146.3\left[(t-18)+\theta \frac{d t}{d \theta}\right]$ & $55.0(t-18)$ & 0 \\
\hline $\begin{array}{l}\text { Case II B } \\
\text { Nak Leak }=14.8 \text { gpm } \\
\text { Cooling-oif period after } \\
\text { Jak } 18 \text { consumed } \\
\theta>1,820 \text { seconds }\end{array}$ & 0 & 14,700 & 0 & $7.21 \times 10^{5} \frac{\mathrm{dt}}{\mathrm{d \theta}}$ & $2.66 \times 105 \frac{\mathrm{dt}}{\mathrm{d} \theta}$ & $55.0(t-18)$ & 0 \\
\hline 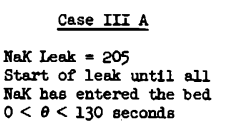 & $1,396,000$ & 14,700 & 524,000 & $7.21 \times 105 \frac{\mathrm{d} t}{\mathrm{~d} \theta}$ & $\left.146.3[\mathrm{t}-18)+\theta \frac{\mathrm{dt}}{\mathrm{d \theta}}\right]$ & $55.0(t-18)$ & $1746\left[(t-18)+\theta \frac{d t}{d \theta}\right]$ \\
\hline 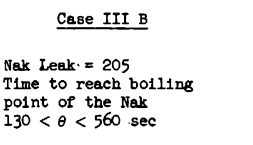 & 0 & 14,700 & 524,000 & $7.21 \times 10^{5 \frac{d t}{d \theta}}$ & $146.3\left[(t-18)+\theta \frac{d t}{d \theta}\right]$ & $55.0(t-18)$ & {$\left[2.27 \times 10^{5}-134(\theta-130)\right] \frac{\mathrm{d} t}{\mathrm{d \theta}}$} \\
\hline $\begin{array}{c}\text { Case III C } \\
\text { Nak Leak = } 205 \mathrm{gpm} \\
\text { T1me unt11 Nak 16 consumed } \\
560<\theta<1200 \text { seconds }\end{array}$ & 0 & 14,700 & 524,000 & 0 & 108,560 & 40,810 & $\begin{array}{c}624 W_{v}^{*} \\
*^{*} w_{v}-\text { rate of Nak Vaporization }\end{array}$ \\
\hline
\end{tabular}

[a] All units in table are calories per second.

[b] Derived by differentiating the equation $q=\dot{\text { H.c } \theta t}$ where:

iे 18 the rate 1 ncrease of mass per second
c 18 specific heat

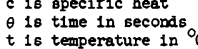

[c] Includes heat removed by non-condensed oxidants. 
Substituting appropriate values (see list of constants, paragraph 4) into this equation results in:

$$
\begin{aligned}
& 87,010 \mathrm{cal} / \mathrm{sec}= \\
& 7.21 \times 10^{5} \frac{d t}{d \theta}+10.04\left[(t-18)+\theta \frac{d t}{d \theta}\right]+38,600+104.3(t)
\end{aligned}
$$

Upon separation of variables and defining limits, the equation is:

$$
\int_{400}^{t} \frac{d t}{48,590-114.3(t)}=\int_{0}^{\theta} \frac{d \theta}{7.21 \times 10^{5}+10.04 \theta}
$$

Upon integration, the resulting equation is:

$$
t=(425)-(24.9)\left[\frac{7.21 \times 105}{7.21 \times 10^{5}+10.04 \theta}\right]^{11.4}
$$

Case II considers the transient resulting from a leak rate of $14.8 \mathrm{gpm}$, the rate at which all the available oxidants react with the NaK. Part A of Case II covers the period from the start of the leak until all the NaK (442 gallons) is consumed. Part B considers the cooling-off period following consumption of the NaK. The resulting equations for these two cases are:

Case II-A $\quad t=(3182)-(2783)\left[\frac{7.21 \times 10^{5}}{7.21 \times 10^{5}+146.3 \epsilon}\right]^{1.377}$

Case II-B $\quad \theta=(1820)-\left(1.79 \times 10^{4}\right) \ln \left[\frac{55.0(t)-15,690}{60,000}\right]$

Case III considers the temperature transient resulting from a leak rate of 205 gpm. Only 130 seconds would elapse before all of the NaK would be discharged into the bed.

Part A of Case III covers the period from the start of the leak until all the NaK has entered the bed. Part B covers the following burning period during which the $\mathrm{NaK}$ reacts at the stoichiometric rate $(14.8 \mathrm{gpm})$ with the entering oxidizer and up to the time NaK begins to vaporize. Part $\mathrm{C}$ covers the final period during which the $\mathrm{NaK}$ is vaporized. The resulting equations after separation of variables and integration are as follows: 
Case III-A $\quad t=(1012)-(612)\left[\frac{7.21 \times 10^{5}}{7.21 \times 10^{5}+1892 \theta}\right]^{1.03}$

Case III-B $\quad t=(2700)-(2140)\left[\frac{9.67 \times 10^{5}}{9.66 \times 10^{5}+12.4 \theta}\right]^{16.21}$

In Case III-C, after the bed temperature reaches the boiling point of NaK, the excess NaK will keep the bed temperature constant, or $\frac{d t}{d \theta}=0$. Another term is added to the equation to account for the latent heat of NaK that is vaporized. The resulting equation is as follows:

$$
538,700=149,370+624\left(w_{v}\right)
$$

where

$$
\begin{aligned}
W_{\mathrm{V}} & =\text { rate of vaporization of } \mathrm{NaK} \\
& =623 \mathrm{~g} / \mathrm{sec} \\
& =14.3 \mathrm{gpm}
\end{aligned}
$$

The amount vaporized, plus the amount oxidized, can be equated to the total amount of $\mathrm{NaK}$ in in the system and solved for the additional time required for NaK removal $\left(\theta^{\prime}\right)$.

$$
\begin{aligned}
{\left[\begin{array}{c}
\text { Tota. }] \\
\text { NaK }
\end{array}\right] } & =\left[\begin{array}{c}
\text { NaK } \\
\text { Consumed }
\end{array}\right]+\left[\begin{array}{c}
\text { NaK remaining } \\
\text { to be consumed }
\end{array}\right]+\left[\begin{array}{c}
\text { NaK remaining } \\
\text { to be vaporized }
\end{array}\right] \\
442 & =14.8\left(\frac{560}{60}\right)+14.8 \theta^{\prime} \\
\theta^{\prime} & =10.4 \text { minutes }
\end{aligned}
$$

The vaporized $\mathrm{NaK}$ will react with nitric acid and water in the quench tower according to the following equations:

$$
\begin{aligned}
\mathrm{NaK}+\mathrm{H}_{2} \mathrm{O} \longrightarrow 0.324 \mathrm{NaOH}+0.676 \mathrm{KOH}+0.5 \mathrm{H}_{2} \\
\Delta_{r}=-45.79 \mathrm{kcal} / \mathrm{g}-\mathrm{mole} \mathrm{NaK} \\
6 \mathrm{NaK}+\mathrm{HNO}_{3}+3 \mathrm{H}_{2} \mathrm{O} \longrightarrow-1.944 \mathrm{NaOH}+4.056 \mathrm{KOH}+0.5 \mathrm{H}_{2}+0.5 \mathrm{~N}_{2} \\
\Delta_{r}=-71.71 \mathrm{kcal} / \mathrm{g}-\mathrm{mole} \mathrm{NaK}
\end{aligned}
$$

[a] $\mathrm{NaK}$ will react at stoichiometric rate for 560 seconds before boiling. 
The hydrogen evolution rate for the first reaction, assuming the NaK is vaporized at a rate of $14.3 \mathrm{gpm}(623 \mathrm{~g} / \mathrm{sec})$, is:

$$
\begin{aligned}
& \left(\frac{623 \mathrm{~g} \mathrm{NaK}}{\mathrm{sec}}\right)\left(\frac{\mathrm{g}-\mathrm{mol} \mathrm{NaK}}{35.6 \mathrm{~g} \mathrm{NaK}}\right)\left(\frac{1 \mathrm{~g}-\mathrm{mol} \mathrm{H}}{2 \mathrm{~g}-\mathrm{mol} \mathrm{NaK}}\right)\left(\frac{1 \mathrm{lb}}{454 \mathrm{~g}}\right)\left(\frac{359 \mathrm{scf}}{1 \mathrm{~b}-\mathrm{mol}}\right)\left(\frac{60 \mathrm{sec}}{\mathrm{min}}\right) \\
& =416 \mathrm{scfm} \text { of } \mathrm{H}_{2}
\end{aligned}
$$

The reaction in the quench tower also will release considerable heat. If the second reaction were the only one to occur, the heat release would be sufficient to vaporize:

$$
\begin{aligned}
& \left(\frac{71.71 \mathrm{kcal}}{\mathrm{g}-\mathrm{mol} \mathrm{NaK}}\right)\left(\frac{1 \mathrm{~g}-\mathrm{mol} \mathrm{NaK}}{35.6 \mathrm{~g} \mathrm{NaK}}\right)\left(\frac{623 \mathrm{~g} \mathrm{NaK}}{\mathrm{sec}}\right)\left(\frac{60 \mathrm{sec}}{\mathrm{min}}\right)\left(\frac{\mathrm{g} \mathrm{H} \mathrm{H}_{2}}{0.540 \mathrm{kcaI}}\right)\left(\frac{1 \mathrm{~b}}{454 \mathrm{~g}}\right) \\
& \left(\frac{\mathrm{gal}}{8.33 \mathrm{Ib}}\right)=36.8 \mathrm{gpm} \text { of water }
\end{aligned}
$$

\section{REF ERENCE}

1. C. D. Hodgman, Ed. Handbook of Chemistry and Physics 36th Edition, Chemical Rubber Publishing Co., Cleveland, p 1682-1706 (1954). 


\section{APPENDIX G}

THE EFFECT OF NORMAL PARTICULATE DEPOSITION FROM WCF OFF-GAS ON SOIL ACTIVITY AT THE ICPP AND SURROUNDING AREAS

A slight increase in activity of the soil surrounding the WCF may result from the normal discharge to the atmosphere of radioactive particulate matter in the WCF process off-gas. This activity buildup proceeds through two mechanisms - transfer of radioactivity through contact between the plume and ground, and washout by rain or snow. If the WCF effluent rate is constant and continuous, the soil activity will reach an equilibrium level only after many years.

The rise in soil activity is expected to be slight because of the low stack effluent rate and small size of the particulate matter in the stack plume. To substantiate this expectation, an estimate was made of the buildup using process effluent activity data obtained from pilot plant and the WCF test programs, and mathematical relationships developed in studies on ground deposition rates. An accurate estimate of ground deposition rates requires extensive time-averaged data on weather conditions at the location being studied; data of this type, however, are not generally available.To circumvent this problem, a hypothetical situation was used wherein the locations of interest around the WCF lie in a straight line downwind of the stack in the direction of the maximum wind flow (see wind roses presented in Section III). The rates of particulate matter buildup on the ground were then calculated for various weather conditions (ie, lapse, inversion, fumigation, and rain) at these locations. An estimate of the equilibrium activity buildup in the soil was made from the calculated deposition rates and specific activity data for particulate matter formed when calcining WM-185 and 200-day cooled MTR-type wastes.

These data are summarized in Figures G-1 and -2 and show that the calculated dose rate from activity buildup in the soil is well below any hazardous level. Furthermore, the actual values obtained would be much lower than those calculated because: (a) the WCF is not scheduled to operate continuously, and (b) the actual wind diversity factor would be much lower than the 0.2 used in the calculations, especially at increasing distances from the ICPP stack.

The calculations are presented in detail in the following paragraphs. 
1. ESTIMATION OF PARTICULATE DEPOSITION

RATE FROM STACK PLUME BY GROUND CONTACT ONLY

The rate at which particulate matter is deposited from the stack plume by contact with soil can be calculated from the following relationships ${ }^{[1]}$ :

where:

$$
{ }^{\omega_{C G}}=(X)\left(V_{g}\right) \text { and } X=(K)(Q)
$$

$$
\begin{aligned}
{ }^{{ }^{\omega} \mathrm{CG}=} & \text { Weight deposition rate of particulates from plume, } \mathrm{g} / \mathrm{m}^{2}-\mathrm{sec} \\
\mathrm{V}_{\mathrm{g}}= & \text { Particle deposition velocity }=10^{-3} \mathrm{~m} / \mathrm{sec}[2] \\
\mathrm{X}= & \text { Air concentration of particulate at ground level, } \mathrm{g} / \mathrm{m}^{3} \\
\mathrm{~K}= & \text { Rate-concentration factor (equivalent to diffusion parameter dis- } \\
& \text { cussed in Sections III and IX-1), sec } / \mathrm{m}^{3} \\
\mathrm{Q}= & \text { Particulate effluent rate from ICPP stack, g/sec (estimated as } \\
& 10^{-5} \mathrm{~g} / \mathrm{sec} \text { from WCF test data) }
\end{aligned}
$$

The deposition rates were calculated for several distances out to fifty miles from the stack using stack diffusion parameters $\left(\frac{X}{Q}\right)$ obtained for each of the following weather conditions - fumigation, strong inversion, and strong lapse. These calculations are summarized in Table G-1. The predicted maximum mass deposition rate occurs at 75 meters from the stack under fumigation conditions, 35,100 meters under strong inversion conditions, and 540 meters under strong lapse conditions.

2. ADDITIONAL DEPOSITION ON SOIL DUE TO PLUME WASHOUT BY RAIN AND SNOW

Precipitation in the form of rain, snow, mist, etc, will result in additional deposition of particulate matter over and above that caused by plume contact with the ground. Precipitation may occur during any of the three types of plume conditions; during periods of precipitation at the NRTS, the average moisture deposition rate is approximately 0.05 inch of water per hour ${ }^{[3]}$. The washout factor may be estimated using the following formula ${ }^{[4]}$ :

$$
\omega_{\text {rain }}=\frac{{\Lambda Q_{o}} e^{-\Lambda x / u}}{u \pi^{1 / 2} C_{y}(x)^{1-0.5 n}}
$$


TABIE G-I

ESTIMATED PARTICULATE DEPOSITION RATE FROM CONTACT OF PLUME WITH GROUND

\begin{tabular}{|c|c|c|c|c|}
\hline \multirow[b]{3}{*}{ Location } & \multirow[b]{3}{*}{$\begin{array}{l}\text { Distance } \\
\text { (Meters) }\end{array}$} & \multicolumn{3}{|c|}{ Fumigation } \\
\hline & & \multicolumn{3}{|c|}{$\left(\vec{u}=2.24 \mathrm{mph}, \mathrm{n}=0.2, c_{\mathrm{y}}=0.33\right)$} \\
\hline & & $\begin{array}{r}(x / Q)=K \\
(\mathrm{sec} / \mathrm{m} 3)\end{array}$ & $\begin{array}{c}x \\
(\mathrm{~g} / \mathrm{m} 3)\end{array}$ & $\begin{array}{c}{ }_{\mathrm{\omega}} \mathrm{GC} \\
\left(\mathrm{g} / \mathrm{m}^{2}-\mathrm{sec}\right)\end{array}$ \\
\hline ICPP & 150 & $2.5 \times 10^{-4}$ & $2.5 \times 10^{-9}$ & $2.5 \times 10^{-12}$ \\
\hline MTR & 3050 & $1.6 \times 10^{-5}$ & $1.6 \times 10^{-10}$ & $1.6 \times 10^{-13}$ \\
\hline $\mathrm{CFA}$ & 4800 & $1.1 \times 10-5$ & $1.1 \times 10^{-10}$ & $1.1 \times 10^{-13}$ \\
\hline $\mathrm{EBR} I$ and $\mathrm{NRF}$ & 8800 & $6.3 \times 10^{-6}$ & $6.3 \times 10^{-11}$ & $6.3 \times 10^{-14}$ \\
\hline Atomic City & 17,300 & $3.7 \times 10^{-6}$ & $3.7 \times 10^{-11}$ & $3.7 \times 10^{-14}$ \\
\hline EBR II & 22,400 & $2.8 \times 10^{-6}$ & $2.8 \times 10^{-11}$ & $2.8 \times 10^{-14}$ \\
\hline Arco & 32,800 & $2.2 \times 10^{-6}$ & $2.2 \times 10^{-11}$ & $2.2 \times 10^{-14}$ \\
\hline TAN & 35,800 & $1.8 \times 10^{-6}$ & $1.8 \times 10^{-11}$ & $1.8 \times 10^{-14}$ \\
\hline Terreton & 45,600 & $1.4 \times 10^{-6}$ & $1.4 \times 10^{-11}$ & $1.4 \times 10^{-14}$ \\
\hline Idaho Falls & 68,500 & $9.9 \times 10-7$ & $9.9 \times 10^{-12}$ & $9.9 \times 10^{-15}$ \\
\hline \multirow[t]{3}{*}{ Predicted Max } & 75 & $4.7 \times 10^{-4}$ & $4.7 \times 10-9$ & $4.7 \times 10^{-12}$ \\
\hline & & \multicolumn{3}{|c|}{ Strong Inversion } \\
\hline & & \multicolumn{3}{|c|}{$\left(\bar{u}=4.5 \mathrm{mph}, \mathrm{n}=0.5, \mathrm{c}_{\mathrm{z}}=0.03, \mathrm{c}_{\mathrm{y}}=0.24\right)$} \\
\hline Location & $\begin{array}{l}\text { Distance } \\
\text { (Meters) }\end{array}$ & $\begin{array}{c}(x / Q)=K \\
\left(\mathrm{sec} / \mathrm{m}^{3}\right)\end{array}$ & $\begin{array}{c}x \\
\left(\mathrm{~g} / \mathrm{m}^{3}\right)\end{array}$ & $\begin{array}{c}{ }^{\omega_{\mathrm{GC}}} \\
\left(\mathrm{g} / \mathrm{m}^{2}-\mathrm{sec}\right)\end{array}$ \\
\hline ICPP & 150 & - & - & - \\
\hline MTR & 3050 & $3.4 \times 10-21$ & $3.4 \times 10-26$ & $3.4 \times 10^{-29}$ \\
\hline CFA & 4800 & $4.8 \times 10^{-13}$ & $4.8 \times 10^{-18}$ & $4.8 \times 10^{-21}$ \\
\hline EBR $I$ and $N R F$ & 8800 & $3.0 \times 10^{-8}$ & $3.0 \times 10^{-13}$ & $3.0 \times 10-16$ \\
\hline Atomic City & 17,300 & $1.3 \times 10^{-6}$ & $1.3 \times 10^{-11}$ & $1.3 \times 10^{-14}$ \\
\hline EBR II & 22,400 & $3.0 \times 10^{-6}$ & $3.0 \times 10^{-11}$ & $3.0 \times 10-14$ \\
\hline Arco & 32,800 & $2.6 \times 10^{-6}$ & $2.6 \times 10^{-11}$ & $2.6 \times 10-14$ \\
\hline TAN & 35,800 & $2.6 \times 10^{-6}$ & $2.6 \times 10^{-11}$ & $2.6 \times 10^{-14}$ \\
\hline Terreton & 45,600 & $2.4 \times 10^{-6}$ & $2.4 \times 10-11$ & $2.4 \times 10-14$ \\
\hline Idaho Falls & 68,500 & $1.8 \times 10^{-6}$ & $1.8 \times 10-11$ & $1.8 \times 10^{-14}$ \\
\hline Predicted Max & 35,100 & $2.6 \times 10-6$ & $2.6 \times 10-11$ & $2.6 \times 10^{-14}$ \\
\hline
\end{tabular}




\section{TABLE G-I (continued)}

ESTIMATED PARTICULATE DEPOSITION RATE FROM CONTACTE OF PLUME WITH GROUND

\begin{tabular}{|c|c|c|c|c|}
\hline \multirow[b]{2}{*}{ Location } & \multirow[b]{2}{*}{$\begin{array}{l}\text { Distance } \\
\text { (Meters) }\end{array}$} & \multicolumn{3}{|c|}{ Strong Lapse } \\
\hline & & $\begin{array}{c}(X / Q)=K \\
\left(\sec / \mathrm{m}^{3}\right)\end{array}$ & $\begin{array}{c}x \\
(\mathrm{~g} / \mathrm{m} 3)\end{array}$ & $\begin{array}{c}\omega^{\omega} \mathrm{GC} \\
\left(\mathrm{g} / \mathrm{m}^{2}-\mathrm{sec}\right)\end{array}$ \\
\hline ICPP & 150 & $9.3 \times 10^{-6}$ & $9.3 \times 10^{-11}$ & $9.3 \times 10^{-14}$ \\
\hline MTR & 3050 & $1.1 \times 10^{-6}$ & $1.1 \times 10^{-11}$ & $1.1 \times 10^{-14}$ \\
\hline $\mathrm{CFA}$ & 4800 & $4.9 \times 10^{-7}$ & $4.9 \times 10^{-12}$ & $4.9 \times 10^{-15}$ \\
\hline EBR I and NRF & 8800 & $1.6 \times 10^{-7}$ & $1.6 \times 10^{-12}$ & $1.6 \times 10^{-15}$ \\
\hline Atomic City & 17,300 & $5.1 \times 10^{-8}$ & $5.1 \times 10^{-13}$ & $5.1 \times 10^{-16}$ \\
\hline EBR II & 22,400 & $3.4 \times 10^{-8}$ & $3.4 \times 10^{-13}$ & $3.4 \times 10^{-16}$ \\
\hline Arco & 32,800 & $1.6 \times 10^{-8}$ & $1.6 \times 10-13$ & $1.6 \times 10^{-16}$ \\
\hline TAN & 35,800 & $1.3 \times 10^{-8}$ & $1.3 \times 10^{-13}$ & $1.3 \times 10-16$ \\
\hline Terreton & 45,600 & $8.8 \times 10-9$ & $8.8 \times 10-14$ & $8.8 \times 10^{-17}$ \\
\hline Idaho Falls & 68,500 & $4.2 \times 10^{-9}$ & $4.2 \times 10-14$ & $4.2 \times 10-17$ \\
\hline Predicted Max & 540 & $9.3 \times 10^{-6}$ & $9.3 \times 10^{-11}$ & $9.3 \times 10^{-14}$ \\
\hline
\end{tabular}

where:

$$
\begin{aligned}
\omega_{\text {rain }}= & \text { Deposition rate from center of plume due to rain, } \mathrm{g} / \mathrm{m}^{2}-\mathrm{sec} \\
\Lambda= & \text { Portion of particulate in cloud deposited per unit time }=9 \mathrm{x} \\
& 10^{-5} / \mathrm{sec}[5] \\
\mathrm{Q}_{\mathrm{o}}= & \text { Particulate effluent rate with WCF process off-gas }=10^{-5} \\
& \mathrm{~g} / \text { sec (see Section VII-2) } \\
\mathrm{u}= & \text { Wind speed }=7 \mathrm{~m} / \mathrm{sec}[6] \\
\mathrm{C}_{\mathrm{y}}= & \text { Diffusion coefficient in y direction (horizontal across plume) = } \\
& 0.25 \mathrm{~m} \text { [6] } \\
\mathrm{n}= & \text { Dimensionless parameter associated with stability }=0.2 \text { [6] } \\
\mathbf{x}= & \text { Distance measured from ICPP stack, meters. }
\end{aligned}
$$

Deposition rates from washout as calculated by this equation are summarized in Table G-2. 
3. NET DEPOSITION RATE FROM CONTACT OF PLUME WITH GROUND AND WASHOUT

A net total deposition rate at each location of interest may be obtained by: (a) correcting the individual deposition rates determined for each weather condition, ie, lapse, inversion, fumigation, and rain, by a time factor accounting for the fraction of time that particular weather condition exists, (b) summing the individual contributions to obtain a maximum deposition rate at the location of interest, and (c) correcting the maximum deposition rate for the fraction of time RATE FROM WASHOUT

\begin{tabular}{cc}
\hline $\begin{array}{c}x \\
\text { Meters })\end{array}$ & $\begin{array}{c}\omega \text { rain } \\
\left(\mathrm{g} / \mathrm{m}^{2}-\text { sec }\right)\end{array}$ \\
150 & $3.2 \times 10^{-12}$ \\
540 & $1.0 \times 10^{-12}$ \\
3,050 & $2.0 \times 10^{-12}$ \\
4,800 & $1.3 \times 10^{-13}$ \\
8,800 & $7.3 \times 10^{-14}$ \\
17,300 & $3.6 \times 10^{-14}$ \\
22,400 & $2.4 \times 10^{-14}$ \\
32,800 & $1.2 \times 10^{-14}$ \\
35,800 & $1.1 \times 10^{-14}$ \\
45,600 & $6.6 \times 10^{-15}$ \\
68,500 & $2.7 \times 10^{-15}$ \\
&
\end{tabular}

the plume blows toward the location of interest. The net deposition rates calculated in this manner are shown in Table G-3 and are graphically illustrated in Figure G-1. The time factors used for the different weather conditions were obtained from the NRTS Weather Bureau [6]. An assumed wind diversity factor of 20 percent, (the maximum time the wind blows over a $22-1 / 2^{\circ}$ arc - see Section III) was used to estimate the net deposition rate. This assumption is valid only if the stack plume has a uniform concentration over a $22-1 / 2^{\circ}$ arc at any distance from the stack, and the concentration is equal to the maximum concentration determined by the diffusion equations (Section III). Actually, the average plume concentration over the $22-1 / 2^{\circ}$ arc is much lower than the maximum, especially at long ranges, so the assumption of a 20 percent wind diversity factor results in a conservative or "safe" answer.

\section{ESTIMATION OF EQUILIBRIUM}

\section{RADIOACTIVITY BUILDUP IN SOIL FROM NET DEPOSITION RATE}

The type and level of radioactivity accompanying the particulate matter emitted to the atmosphere with the WCF process off-gas depends upon the type and age of the waste being processed. As in the other portions of this report, two aluminum nitrate wastes, cooled for 200 days and 5 years (WM-185 tank), respectively, have been used as examples of the wastes to be processed through 
TABLE $G-3$

ESTIMATED NET DEPOSITION RATES FROM ICPP STACK PLUME

\begin{tabular}{|c|c|c|c|c|c|c|}
\hline $\begin{array}{l}\text { D1stance From } \\
\text { ICPP Stack } \\
\text { (meters) } \\
\end{array}$ & $\begin{array}{l}\text { Meteorological } \\
\text { Cond1tion }\end{array}$ & $\begin{array}{l}\text { Maximum Rate of } \\
\text { Depost tion Dur1ng th1s } \\
\text { Cond1tion[a] } \\
\left(\mathrm{g} / \mathrm{m}^{2}-\mathrm{sec}\right) \\
\end{array}$ & $\begin{array}{l}\text { Percent of Time } \\
\text { Cond1t1on Ex1sts }[\mathrm{b}] \\
(\%) \\
\end{array}$ & $\begin{array}{c}\text { Deposition Rate Due to } \\
\text { Each Cond1 t1 ton } \\
\left(\mathrm{g} / \mathrm{m}^{2}-\mathrm{sec}\right) \\
\end{array}$ & $\begin{array}{c}\begin{array}{c}\text { Total Maximum } \\
\text { Deposition }\end{array} \\
\left(\mathrm{g} / \mathrm{m}^{2}-\mathrm{sec}\right) \\
\end{array}$ & $\begin{array}{l}\text { Net Deposition } \\
\text { Inclualng S1mplified } \\
\text { Wind Diversity } \\
\text { Factor } \\
\left(\mathrm{g} / \mathrm{m}^{2}-\mathrm{sec}\right) \\
\end{array}$ \\
\hline \multirow[t]{5}{*}{150} & Lapse & $9.3 \times 10^{-14}$ & 50 & $4.7 \times 10-14$ & & \\
\hline & Inversion & $\cdots$ & 48 & $\cdots$ & & \\
\hline & Fumigation & $2.5 \times 10-12$ & 2 & $5.0 \times 10^{-14}$ & & \\
\hline & Rein & $3.2 \times 10^{-12}$ & $13 / 4$ & $5.6 \times 10^{-14}$ & & \\
\hline & & & & & $1.5 \times 10^{-13}$ & $<3.0 \times 10-14$ \\
\hline \multirow[t]{5}{*}{540} & Lapse & $9.3 \times 10^{-14}$ & 50 & $4.7 \times 10^{-14}$ & & \\
\hline & Inversion & --- & 48 & ... & & \\
\hline & Fumigation & $7.7 \times 10^{-13}$ & 2 & $1.5 \times 10^{-14}$ & & \\
\hline & Ra1n & $1.0 \times 10^{-12}$ & $13 / 4$ & $1.8 \times 10^{-14}$ & & \\
\hline & & & & & $8.0 \times 10-14$ & $<1.6 \times 10-14$ \\
\hline \multirow[t]{5}{*}{3,050} & Lapse & $1.1 \times 10-14$ & 50 & $6.0 \times 10^{-.25}$ & & \\
\hline & Inversion & $3.4 \times 10-26$ & 48 & $1.6 \times 10^{-26}$ & & \\
\hline & Fumigation & $1.6 \times 10^{-13}$ & 2 & $3.2 \times 10^{-15}$ & & \\
\hline & Ro:in & $2.0 \times 20-13$ & $13 / 4$ & $3.5 \times 10^{-15}$ & & \\
\hline & & & & & $1.3 \times 10^{-14}$ & $<2.6 \times 10-15$ \\
\hline \multirow[t]{5}{*}{4,800} & Lapse & $4.9 \times 10^{-15}$ & 50 & $2.4 \times 10^{-15}$ & & \\
\hline & Inversion & $4.8 \times 10-21$ & 48 & $2.3 \times 10-21$ & & \\
\hline & Fumigation & $1.1 \times 10^{-13}$ & 2 & $2.2 \times 10^{-15}$ & & \\
\hline & Ra1n & $1.3 \times 10^{-13}$ & $13 / 4$ & $2.3 \times 10-15$ & & \\
\hline & & & & & $6.9 \times 10^{-15}$ & $<2.4 \times 10^{-25}$ \\
\hline \multirow[t]{5}{*}{8,800} & Lapse & $1.6 \times 10^{-15}$ & 50 & $8.0 \times 10-16$ & & \\
\hline & Inversion & $3.0 \times 10-16$ & 48 & $1.4 \times 10^{-16}$ & & \\
\hline & Pumlgation & $6.3 \times 10^{-14}$ & 2 & $1.3 \times 10^{-15}$ & & \\
\hline & Rain & $7.3 \times 10^{-14}$ & $23 / 4$ & $1.3 \times 10-15$ & & \\
\hline & & & & & $3.5 \times 10-15$ & $<7.0 \times 10-16$ \\
\hline \multirow[t]{5}{*}{17,300} & Lapse & $5.1 \times 10-16$ & 50 & $2.6 \times 10-16$ & & \\
\hline & Inversion & $1.3 \times 10^{-14}$ & 48 & $6.2 \times 10-15$ & & \\
\hline & Fumigation & $3.7 \times 10-14$ & 2 & $7.4 \times 10^{-16}$ & & \\
\hline & Rasn & $3.6 \times 10^{-14}$ & $13 / 4$ & $6.3 \times 10^{-16}$ & & \\
\hline & & & & & $7.8 \times \cdot 10^{-15}$ & $<1.6 \times 10^{-15}$ \\
\hline \multirow{5}{*}{22,400} & Lapee & $3.4 \times 10^{-16}$ & 50 & $1.7 \times 10^{-16}$ & & \\
\hline & Inversion & $3.0 \times 10^{-14}$ & 48 & $1.4 \times 10^{-14}$ & & \\
\hline & Fumigation & $2.8 \times 10-14$ & 2 & $5.6 \times 10-16$ & & \\
\hline & Rain & $2.4 \times 10.14$ & $13 / 4$ & $4.2 \times 10-16$ & & \\
\hline & & & & & $1.5 \times 10^{-14}$ & $<3.0 \times 10-15$ \\
\hline \multirow{5}{*}{32,800} & Lapse & $1.6 \times 10^{-16}$ & 50 & $8.0 \times 10-17$ & & \\
\hline & Inversion & $2.6 \times 10^{-14}$ & 48 & $1.2 \times 10^{-14}$ & & \\
\hline & Funigation & $2.2 \times 10^{-14}$ & 2 & $4.4 \times 10-16$ & & \\
\hline & Rain & $1.2 \times 10^{-14}$ & $13 / 4$ & $2.1 \times 10^{-16}$ & & \\
\hline & & & & & $1.3 \times 10^{-14}$ & $<2.6 \times 10^{-15}$ \\
\hline \multirow[t]{5}{*}{35,800} & Lapse & $2.3 \times 10-16$ & 50 & $7.0 \times 10-17$ & & \\
\hline & Inversion & $2.6 \times 10^{-14}$ & 48 & $1.2 \times 10^{-14}$ & & \\
\hline & Fumigation & $1.8 \times 10^{-14}$ & 2 & $3.6 \times 10^{-26}$ & & \\
\hline & Re1n & $1.1 \times 10^{-14}$ & $13 / 4$ & $1.9 \times 10^{-16}$ & & \\
\hline & & & & & $1.3 \times 10^{-14}$ & $<2.6 \times 10^{-15}$ \\
\hline \multirow{4}{*}{45,600} & Lapse & $8.8 \times 10-17$ & 50 & $4.4 \times 10^{-17}$ & & \\
\hline & Inverniton & $2.4 \times 10^{-14}$ & 48 & $1.1 \times 10.14$ & & \\
\hline & Fundgation & $1.4 \times 10-14$ & 2 & $2.8 \times 10^{-16}$ & & \\
\hline & Ra1n & $6.6 \times 10-15$ & $13 / 4$ & $1.2 \times 10-16$ & & \\
\hline \multirow[t]{5}{*}{68,500} & Lepse & $4.2 \times 10^{-17}$ & & $0,00-17$ & $2.1 \times 10^{-14}$ & $<2.2 \times 10^{-15}$ \\
\hline & Inversion & $\begin{array}{l}4.2 \times 10^{-17} \\
1.8 \times 10^{-14}\end{array}$ & 50 & $\begin{array}{l}2.1 \times 10^{-17} \\
8.6 \times 10^{-15}\end{array}$ & & \\
\hline & Fumlgat1on & & 48 & $\begin{array}{l}8.6 \times 10^{-15} \\
2.0 \times 10^{-16}\end{array}$ & & \\
\hline & Rain & $\begin{array}{l}9.9 \times 10^{-15} \\
2.7 \times 10^{-15}\end{array}$ & 2 & $\begin{array}{l}2.0 \times 10^{-10} \\
4.7 \times 10^{-17}\end{array}$ & & \\
\hline & & & $13 / 4$ & $401 \times 20$ & $8.9 \times 10-15$ & $<1.8 \times 10^{-15}$ \\
\hline
\end{tabular}




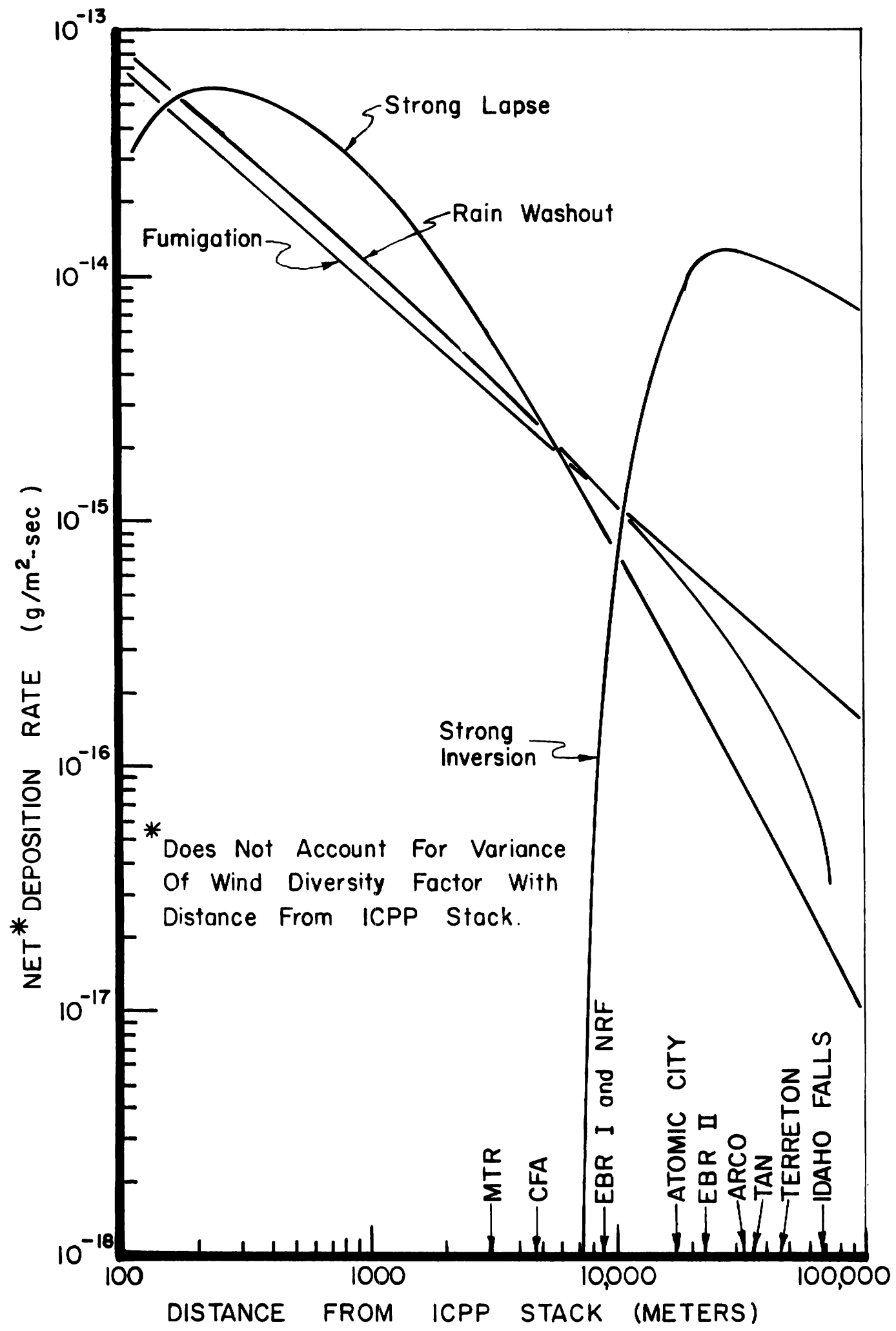

FIG. G-1 NET WEIGHT DEPOSITION RATES AT VARYING DISTANCES FROM THE ICPP STACK 
the WCF. The fission product spectrum and specific activity of the particulate solids (except for ruthenium) and the particulate emission rate have been discussed previously in other sections of the report - see Section V-1, Section VII-2, Section IX, and Appendix B. The emission rate of ruthenium, which poses a special problem because of its volatility, has been discussed and estimated in Sections VII-3 and IX-1.

The amount of each radioactive isotope deposited on the ground from the stack plume will eventually stabilize at an equilibrium value dependent on the effluent rate from the stack and the half-life of the isotope. This value may be determined by converting the net mass deposition rate to a net activity deposition rate and then equating the activity deposition rate to the decay rate.

Net activity deposition rate, $\omega \mathrm{A}=$ decay rate, $\lambda \mathrm{N}_{\mathrm{EQ}}$

Then $\quad \mathrm{N}_{\mathrm{EQ}}=(\omega)(\mathrm{A})\left(\frac{1}{\lambda}\right)$

where: $\mathrm{N}_{\mathrm{EQ}}=$ activity in soil after equilibrium is reached, curies $/ \mathrm{cm}^{2}$

$\omega=$ net mass deposition rate, $\mathrm{g} / \mathrm{cm}^{2}-\mathrm{sec}$

$\mathrm{A}=$ specific activity of particulate, curies $/ \mathrm{g}$

$\lambda=$ isotope decay constant, sec $^{-1}$.

These calculations and the estimated equilibrium activity levels are summarized in Table G-4 for an assumed "average" particulate deposition rate of $3 \times 10-18$ $\mathrm{g} / \mathrm{cm}^{2}-\mathrm{sec}\left(3 \times 10^{-14} \mathrm{~g} / \mathrm{m}^{2}-\mathrm{sec}\right)$.

\section{ESTIMATION OF THE DOSE RATE RESULTING FROM} THE EQUILIBRIUM ACTIVITY DEPOSITED ON THE SOIL

An estimate of the radiation dose rate from the activity buildup in the soil may be obtained by treating the activity deposit as a thin film on the surface of the ground. The dose rate from a thin film source is given in Rockwell [7] as:

$$
\begin{aligned}
\text { Dose } & =\frac{\mathrm{mr}}{\mathrm{hr}}=\frac{\phi}{\xi} \\
\text { but } \phi & =\frac{\mathrm{BS}_{\mathrm{A}}}{2}\left[\mathrm{E}_{1}(\mathrm{~b})\right] \\
\text { or Dose } & =\frac{\mathrm{mr}}{\mathrm{hr}}=\frac{\phi}{\xi}=\frac{\mathrm{BS}_{\mathrm{A}}}{2 \xi}\left[\mathrm{E}_{1}(\mathrm{~b})\right]
\end{aligned}
$$

where:

$$
\begin{aligned}
\mathrm{B} & =\text { Dimensionless symbolic buildup factor }=1.0 \text { for air } \\
\mathrm{S}_{\mathrm{A}} & =\text { Source strength of planar source, Mev } / \mathrm{cm}^{2}-\mathrm{sec} \\
& =\left(3.7 \times 10^{10}\right) \mathrm{N}_{\mathrm{EQ}} \mathrm{E}
\end{aligned}
$$


TABIE G-4

ESTIMATED EQUILIBRIUM SOIL RADIOACTIVITY

\begin{tabular}{|c|c|c|c|}
\hline Isotope [a] & $\begin{array}{l}\text { Specific Activity[b] } \\
\text { of Deposited } \\
\text { Particulates (A) } \\
\text { (curies/g) }\end{array}$ & $\begin{array}{c}I / \lambda=t_{\frac{1}{2}} / 0.693 \\
(\mathrm{sec})\end{array}$ & $\begin{array}{l}\text { Equilibrium }[\mathrm{c} \\
\text { Activity } \\
\mathrm{N}_{\mathrm{EQ}}=(\omega)(\mathrm{A})(\mathrm{\lambda}) \\
\left.\text { (curies } / \mathrm{cm}^{2}\right)\end{array}$ \\
\hline \multicolumn{4}{|c|}{ WM-185 Waste } \\
\hline $\operatorname{sr} 90$ & $1.56 \times 10-2$ & $1.27 \times 109$ & $<5.95 \times 10-11$ \\
\hline $\mathrm{Ru}^{106}$ & $0.07 \times 10-2$ & $4.55 \times 107$ & $<1.30 \times 10^{-14}$ \\
\hline $\mathrm{Cs}^{137}$ & $1.76 \times 10^{-2}$ & $1.36 \times 10^{9}$ & $<7.18 \times 10^{-11}$ \\
\hline $\mathrm{Ce}^{144}$ & $0.66 \times 10^{-2}$ & $3.54 \times 10^{7}$ & $<7.01 \times 10^{-13}$ \\
\hline
\end{tabular}

200-Day Cooled MTR Waste

$\begin{array}{llll}\mathrm{Kr}^{85} & 0.03 \times 10^{-1} & 4.69 \times 10^{8} & <4.22 \times 10^{-12} \\ \mathrm{Sr}^{90} & 0.18 \times 10^{-1} & 1.27 \times 10^{9} & <6.85 \times 10^{-11} \\ \mathrm{Y}^{91} & 1.52 \times 10^{-1} & 7.12 \times 10^{6} & <3.25 \times 10^{-12} \\ \mathrm{Zr}^{93} & 4.85 \times 10^{-7} & 5.00 \times 10^{13} & <7.27 \times 10^{-11} \\ \mathrm{Nb}^{95} & 4.62 \times 10^{-1} & 4.35 \times 10^{6} & <6.01 \times 10^{-12} \\ \mathrm{Zr}^{95} & 2.04 \times 10^{-1} & 7.84 \times 10^{6} & <4.79 \times 10^{-12} \\ \mathrm{Ru}^{103} & 0.30 \times 10^{-1} & 4.97 \times 10^{6} & <2.31 \times 10^{-12} \\ \mathrm{Ru}^{106} & 0.20 \times 10^{-1} & 4.55 \times 10^{7} & <1.23 \times 10^{-11} \\ \mathrm{Cs}^{137} & 0.21 \times 10^{-1} & 1.36 \times 10^{9} & <8.56 \times 10^{-11} \\ \mathrm{Ce}^{141} & 0.26 \times 10^{-1} & 3.98 \times 10^{6} & <3.10 \times 10^{-13} \\ \mathrm{Ce}^{144} & 3.40 \times 10^{-1} & 3.54 \times 10^{7} & <3.72 \times 10^{-11} \\ \mathrm{Sm}^{151} & 8.14 \times 10^{-5} & 4.24 \times 10^{9} & <1.03 \times 10^{-12}\end{array}$

[a] Significant isotopes determined in Appendices A \& B.

[b] Specific activities of all fission products but ruthenium are given in Appendix B. An "apparent" specific activity of ruthenium was determined from the specific activity of strontium-90 and the ratio of ruthenium to strontium appearing in the stack emission.

[c] $\omega=$ assumed "average" particulate emission rate of $3 \times 10^{-18} \mathrm{~g} / \mathrm{cm}^{2}-\mathrm{sec}$.

$\mathrm{N}_{\mathrm{EQ}}=$ Equilibrium activity deposition rate, curies $/ \mathrm{cm}^{2}$ (from Table G-4)

$f=$ Gamma photons per disintegration [8]

$E=$ Disintegration energy per photon, Mev/gamma photon [8]

$\phi=$ Scalar flux, $\mathrm{cm}^{-2}-\mathrm{sec}^{-1}$ 


$$
\begin{aligned}
\xi & =\text { Gamma flux }=500 \frac{\mathrm{Mev} / \mathrm{cm}^{2}-\mathrm{sec}}{\mathrm{mr} / \mathrm{hr}} \\
\mathrm{b} & =\Sigma(\mu \mathrm{t})=0.015[10] \\
\mathrm{E}_{1}(\mathrm{~b}) & =\int_{\mathrm{b}}^{\infty} \frac{\mathrm{e}^{-\mathrm{t}}}{\mathrm{t}_{\mathrm{n}}} \mathrm{dt}=3.5[11]
\end{aligned}
$$

Substituting and simplifying

$$
\text { Dose }=\frac{\mathrm{mr}}{\mathrm{hr}}=\mathrm{S}_{\mathrm{A}}\left(3.5 \times 10^{-3}\right)
$$

A summary of these calculations and the resulting radioactivity dose rates for the assumed activity weight deposition rate of $3 \times 10^{-18} \mathrm{~g} / \mathrm{cm}^{2}-\mathrm{sec}$ is presented in Table G-5. The dose rates at other weight deposition rates, ie, at other distances from the ICPP stack, are direct functions of the deposition rates, and are summarized in Table G-6 and Figure G-2.

\begin{tabular}{|c|c|c|c|c|c|c|c|}
\hline Nuclide & $\begin{array}{c}\mathrm{N}_{\mathrm{EQ}}[\mathrm{a}] \\
\left(\text { curies } / \mathrm{cm}^{2}\right) \\
\end{array}$ & $\begin{array}{c}\text { Conversion } \\
\text { Factor } \\
\text { (dis/sec-curie) } \\
\end{array}$ & $\begin{array}{c}f \\
(\gamma / \text { dis })^{[8]} \\
\end{array}$ & $\begin{array}{c}E \\
(\mathrm{Mev} / \gamma)^{[8]} \\
\end{array}$ & $\begin{array}{c}\mathrm{S}_{\mathrm{A}} \\
\left(\mathrm{Mev} / \mathrm{cm}^{2}-\mathrm{sec}\right) \\
\end{array}$ & $\begin{array}{c}\frac{B\left[E_{1}(b)\right]}{2 \xi} \\
\left(\mathrm{mr} / \mathrm{hr} / \mathrm{Mev} / \mathrm{cm}^{2}-\mathrm{sec}\right)\end{array}$ & $\begin{array}{c}\text { Dose } \\
(\mathrm{mr} / \mathrm{hr})\end{array}$ \\
\hline Ru-106 & $1.30 \times 10^{-14}$ & $3.7 \times 10^{10}$ & 0.20 & $\begin{array}{c}\text { WM-185 Waste } \\
0.51\end{array}$ & $4.90 \times 10^{-5}$ & $3.0 \times 10^{-3}$ & $1.47 \times 10^{-7}$ \\
\hline Cs-137 & $7.18 \times 10^{-11}$ & $3.7 \times 10^{10}$ & 0.92 & 0.66 & $1.62 \times 10^{0}$ & $3.0 \times 10^{-3}$ & $4.86 \times 10^{-3}$ \\
\hline \multirow[t]{2}{*}{$\mathrm{Ce}-144$} & $7.01 \times 10^{-13}$ & $3.7 \times 10^{10}$ & 1.00 & 0.13 & $3.37 \times 10^{-3}$ & $3.0 \times 10^{-3}$ & $1.01 \times 10^{-5}$ \\
\hline & & & & & & $\Sigma=$ & $4.87 \times 10^{-3}$ \\
\hline $\mathrm{Kr}-85$ & $4.22 \times 10^{-12}$ & $3.7 \times 10^{10}$ & $0.01^{200}$ & $\begin{array}{c}0 \text {-Day Cooled } \\
0.52\end{array}$ & $8.10 \times 10^{-4}$ & $3.0 \times 10^{-3}$ & $2.43 \times 10^{-6}$ \\
\hline$Y-91$ & $3.25 \times 10^{-12}$ & $3.7 \times 10^{10}$ & 0.03 & 1.20 & $4.33 \times 10^{-3}$ & $3.0 \times 10^{-3}$ & $1.30 \times 10^{-5}$ \\
\hline Zr-93 & $7.27 \times 10^{-11}$ & $3.7 \times 10^{10}$ & 0.25 & 0.03 & $2.01 \times 10^{-2}$ & $3.0 \times 10^{-3}$ & $6.02 \times 10^{-5}$ \\
\hline $\mathrm{No}-95$ & $6.01 \times 10^{-12}$ & $3.7 \times 10^{10}$ & 0.99 & 0.77 & $1.70 \times 10^{-1}$ & $3.0 \times 10^{-3}$ & $5.10 \times 10^{-4}$ \\
\hline$Z r-95$ & $4.79 \times 10^{-12}$ & $3.7 \times 10^{10}$ & 0.99 & 0.77 & $1.35 \times 10^{-1}$ & $3.0 \times 10^{-3}$ & $4.05 \times 10^{-4}$ \\
\hline Ru-103 & $2.31 \times 10^{-12}$ & $3.7 \times 10^{10}$ & 0.96 & 0.04 & $3.28 \times 10^{-3}$ & $3.0 \times 10^{-3}$ & $9.84 \times 19^{-6}$ \\
\hline Ru-106 & $1.23 \times 10^{-11}$ & $3.7 \times 10^{10}$ & 0.20 & 0.51 & $4.63 \times 10^{-2}$ & $3.0 \times 10^{-3}$ & $1.39 \times 10^{-4}$ \\
\hline Cs -137 & $8.56 \times 10^{-11}$ & $3.7 \times 10^{10}$ & 0.92 & 0.66 & $1.92 \times 10^{0}$ & $3.0 \times 10^{-3}$ & $5.76 \times 10^{-3}$ \\
\hline $\mathrm{Ce}-141$ & $3.10 \times 10^{-13}$ & $3.7 \times 10^{10}$ & 1.00 & 0.15 & $1.72 \times 10^{-3}$ & $3.0 \times 10^{-3}$ & $5.16 \times 10^{-6}$ \\
\hline $\mathrm{Ce}-144$ & $3.72 \times 10^{-11}$ & $3.7 \times 10^{10}$ & 1.00 & 0.13 & $1.79 \times 10^{-1}$ & $3.0 \times 10^{-3}$ & $5.37 \times 10^{-4}$ \\
\hline \multirow[t]{2}{*}{$\mathrm{Sm}-151$} & $1.03 \times 10^{-12}$ & $3.7 \times 10^{10}$ & 1.00 & 0.02 & $7.61 \times 10^{-4}$ & $3.0 \times 10^{-3}$ & $2.28 \times 10^{-7}$ \\
\hline & & & & & & $\Sigma=$ & 7.4 \\
\hline
\end{tabular}

\section{TABLE G-5}

CONVERSION FROM RADIOACTIVITY DEPOSITION

RATE TO RADIOACTIVITY DOSE RATE

[a] From Table G-4 
TABLE G-6

RADIOACTIVITY DOSE RATES AS A FUNCTION OF DISTANCE FROM ICPP STACK

\begin{tabular}{|c|c|c|c|}
\hline $\begin{array}{c}\text { Distance } \\
\text { From } \\
\text { Stack }\end{array}$ & $\begin{array}{c}\text { Rate of } \\
\text { Weight } \\
\text { Deposition }\end{array}$ & $\begin{array}{c}\text { Radioactive } \\
\text { Dose Rate } \\
\text { For WM-185 } \\
\text { Waste }\end{array}$ & $\begin{array}{l}\text { Radioactive } \\
\text { Dose Rate } \\
\text { For } 200-\text { day } \\
\text { Cooled MIR }\end{array}$ \\
\hline (m) & $\left(\mathrm{g} / \mathrm{m}^{2}-\mathrm{sec}\right)$ & $(\mathrm{mr} / \mathrm{hr})$ & $(\mathrm{mr} / \mathrm{hr})$ \\
\hline 150 & $3.0 \times 10^{-14}$ & $4.87 \times 10^{-3}$ & $7.44 \times 10^{-3}$ \\
\hline 540 & $1.6 \times 10^{-14}$ & $2.60 \times 10^{-3}$ & $3.97 \times 10^{-3}$ \\
\hline 3050 & $2.6 \times 10^{-15}$ & $4.22 \times 10^{-4}$ & $6.45 \times 10^{-4}$ \\
\hline 4800 & $1.4 \times 10^{-15}$ & $2.27 \times 10^{-4}$ & $3.47 \times 10^{-4}$ \\
\hline 8800 & $7.0 \times 10^{-16}$ & $1.13 \times 10^{-4}$ & $1.73 \times 10^{-4}$ \\
\hline 17,300 & $1.6 \times 10^{-15}$ & $2.59 \times 10^{-4}$ & $3.98 \times 10^{-4}$ \\
\hline 22,400 & $3.0 \times 10^{-15}$ & $4.87 \times 10^{-4}$ & $7.44 \times 10^{-4}$ \\
\hline 32,800 & $2.6 \times 10^{-15}$ & $4.22 \times 10^{-4}$ & $6.45 \times 10^{-4}$ \\
\hline 35,800 & $2.6 \times 10^{-15}$ & $4.22 \times 10^{-4}$ & $6.45 \times 10^{-4}$ \\
\hline 45,600 & $2.2 \times 10^{-15}$ & $3.56 \times 10^{-4}$ & $5.44 \times 10^{-4}$ \\
\hline 68,500 & $1.8 \times 10^{-15}$ & $2.92 \times 10^{-4}$ & $4.46 \times 10^{-4}$ \\
\hline
\end{tabular}

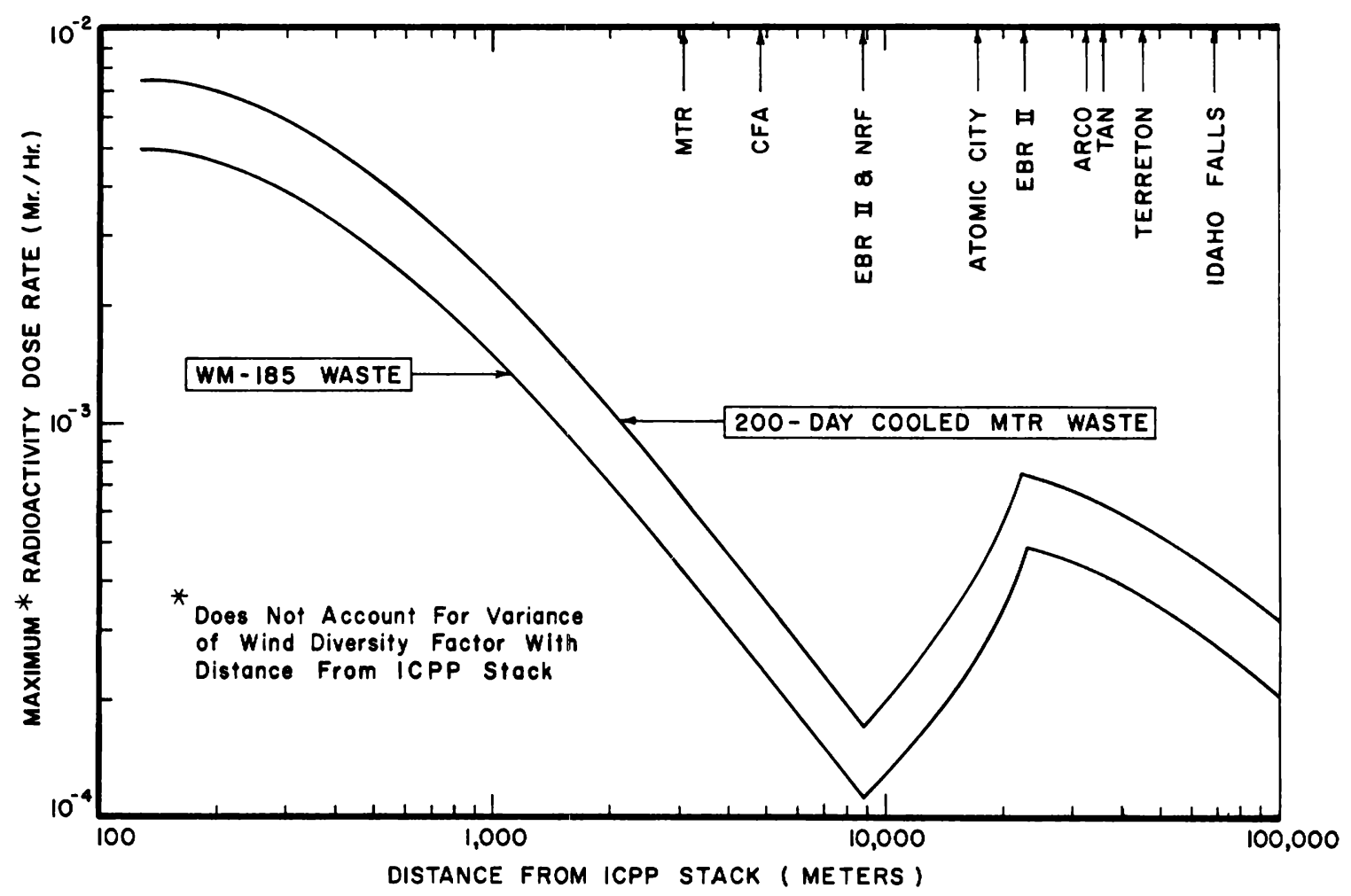

FIG. G-2 MAXIMUM RADIOACTIVITY DOSE RATES AS A FUNCTION OF DISTANCE FROM THE ICPP STACK 


\section{REFERENCES}

1. J. J. Fuquay, Meterology as Related to Waste Disposal and Weapons Tests, HW-47721A, p 12 (January 15, 1957).

2. Ibid, p 20 .

3. G. A. DeMarrais, The Engineering Climatology of the National Reactor Testing Station, IDO-12004, p 39 (November 1958).

4. U. S. Weather Bureau, Washington, D. C., Meterology and Atomic Energy, AECU-3066, p 96 (July 1955).

5. Ibid, p 95.

6. Personal communication with N. Islitzer, NRTS Weather Bureau.

7. T. Rockwell III, Ed, Reactor Shielding Design Manual, Mc Graw-Hill Book Co., New York, p 353 (1956).

8. Nucleonics, p 186-195, (November 1960).

9. Rockwell, op cit., p 20, Figure 2.2.

10. Ibid, p 448.

11. Ibid, p 372 . 

WTH WCF EQUIPMENT DURING TESTING PROGRAM

Because the selection of materials was based largely upon previous experience with corrosive chemicals in radioactive processing, corrosion presented few problems during the WCF test program. The handling of solids in the equipment was a new experience, however, and several abrasion problems were brought to light and had to be corrected. Since abrasion was obviously a potential problem, a program of measurement and inspection was instituted early in the test program to develop data on equipment wear. A portable ultrasonic thickness tester was purchased and used to determine equipment thicknesses at critical locations throughout the process system. These measurements were supported by micrometer measurements and visual inspection whenever equipment was opened for maintenance or modification. The inspection program will be continued during WCF operation, although limited to infrequent periods when the facility has been decontaminated to allow maintenance work. The results of the measurements and observations are summarized below.

\section{ULTRASONIC THICKNESS TESTER}

Thickness measurements were made four times throughout the 4000 thours of WCF testing at forty-eight locations where corrosion or abrasion appeared as possible problems. The location of these measurements is given in Table $\mathrm{H}-1$ and the measurements are given in Table H-2. Prior to taking each set of measurements, the instrument was checked by using a stainless steel plate of known thickness. All checks indicated the instrument was capable of determining thicknesses within \pm 3 percent. Micrometer measurements made at accessible locations after the test program was completed are shown on Table H-3. No gross corrosion or abrasion is indicated by the thickness measurements. 


\section{TABIE H-I}

\section{WCF PROCESS PIPING LOCATION FOR WAII THICKNESS MEASUREMENTS}

\begin{tabular}{|c|c|}
\hline $\begin{array}{l}\text { Location } \\
\text { Point No. }\end{array}$ & LOCATION \\
\hline 1 & 10-in. header between calciner and cyclone (west slde on lower end of line) \\
\hline 2 & 10-in. header between calciner and cyclone (north side on lower end of line) \\
\hline 3 & 10-in. header between calciner and cyclone (south side on lower end of line) \\
\hline 4 & 10-1n. header between calciner and cyclone (north side on upper end of line) \\
\hline 5 & 10-in. header between calciner and cyclone (west side on upper end of line) \\
\hline 6 & 10-in. ell from the quench tower (north slde on lower end of ell) \\
\hline 7 & 10-1n. ell from the quench tower (south slde on lower end of ell) \\
\hline 8 & 10-1n. ell from the quench tower (north side at midpoint of ell) \\
\hline 9 & 10-in. ell from the quench tower (south side at midpoint of ell) \\
\hline 10 & 10-in. ell from the quench tower (north slde at upper end of ell) \\
\hline 11 & 10-1n. ell from the quench tower (south s1de at upper end of el1) \\
\hline 12 & 3-1n. scrubbing solution line entering the quench tower (outside position of ell) \\
\hline 13 & 3-in. scrubbing solution line to the quench tower (top postion of ell) \\
\hline 14 & 10-in. ell to the quench tower (north side of ell) \\
\hline 15 & 10-1n. ell to the quench tower (south slde of ell) \\
\hline 16 & $\begin{array}{l}\text { 10-in. }-180^{\circ} \text { bend between de-entrainment separator and off-gas heater } \\
\text { (west side of bend) }\end{array}$ \\
\hline 17 & $\begin{array}{l}\text { 10-in. - } 180^{\circ} \text { bend between de-entrainment separator and off-gas heater } \\
\text { (east side of bend) }\end{array}$ \\
\hline 18 & 10-1n. ell to the venturl scrubber (east slde of ell) \\
\hline 19 & 0.84-in.-0.D. NaK furnace tube (west inspection port on furnace - left tube) \\
\hline 20 & 0.84-in.-0.D. NaK furnace tube (west inspection port, center tube) \\
\hline 21 & 0.84-in.-0.D. NaK furnace tube (west inspection port, right tube) \\
\hline 22 & 0.84-in.-0.D. NaK furnace tube (east inspection port, left tube) \\
\hline 23 & $0.84-1$ r O.D. NaK furmece tube (east inspection port, center tube) \\
\hline 24 & 0.84-in.-0.D. NaK furnace tube (east inspection port, right tube) \\
\hline 25 & Solid storage cyclone (inlet side at top of cyclone) \\
\hline 26 & Solid storage cyclone (top of cyclone; $60^{\circ}$ from tangent point) \\
\hline 27 & Solld storage cyclone (top of cyclone; $120^{\circ}$ from tangent point) \\
\hline 28 & Solld storage cyclone ( $4 \mathrm{in}$. below top of cyclone; $120^{\circ}$ from tangent point) \\
\hline 29 & Solld storage cyclone ( $6 \mathrm{in}$. below top of cyclone; $120^{\circ}$ from tangent point) \\
\hline 30 & Solld storage cyclone ( $8 \mathrm{in}$. below top of cyclone; $120^{\circ}$ from tangent point) \\
\hline 31 & Solid storage cyclone (conical section of cyclone; $110^{\circ}$ from tangent point) \\
\hline 32 & Solld storage cyclone (conical section of cyclone; $90^{\circ}$ from tangent point) \\
\hline 33 & 10-in. ell from calciner cyclone (north side of ell) \\
\hline 34 & 10-1n. ell from calciner cyclone (midpoint around ell) \\
\hline 35 & 10-1n. ell from calciner cyclone (east side of ell) \\
\hline 36 & $\begin{array}{l}\text { 3-in. adsorber unloading line in calciner cell (on ell upstream of } Y \text { to } \\
\text { transport air line) }\end{array}$ \\
\hline 37 & $\begin{array}{l}\text { 3-1n. adsorber unlooding line in calciner cell (on ell at junction of } Y \\
\text { to transport air line) }\end{array}$ \\
\hline 38 & 3-1n. transport air line (on 3-1n. line downstream of $Y$ from adsorber line) \\
\hline 39 & $\begin{array}{l}\text { 10-1n. off-gas header leaving calciner cell (west side of ell entering } \\
\text { sleeve in wall) }\end{array}$ \\
\hline 40 & 10-in. off-gas header leaving calciner cell (midpoint around ell) \\
\hline 41 & 10-in. off-gas header leaving calciner cell (south side of ell) \\
\hline 42 & 10-in. off-gas header leaving calciner cell (north side of ell) \\
\hline 43 & 10-1n. off-gas header leaving calciner cell (top side of ell) \\
\hline 44 & $\begin{array}{l}\text { 3-in. transport air line from the calciner (west side of bend ell at midpoint } \\
\text { of bend) }\end{array}$ \\
\hline 45 & 3-in. transport alr line from the calciner (east side of bend ell at bottom end) \\
\hline 46 & 3-In. transport air line from the calciner (east side of bend ell at top end) \\
\hline 47 & $\begin{array}{l}\text { 3-in. transport air line from the calciner (west side of line upstream of } \\
\text { bend ell) }\end{array}$ \\
\hline 48 & $\begin{array}{l}\text { 10-1n. off-gas header from the quench tower (south side of } 10-1 \text {. line upstream } \\
\text { of eli) }\end{array}$ \\
\hline
\end{tabular}


TABLE H-2

SONIZON THICKNESS MEASUREMENTS

OF WASTE CALCINATION FACILITY PROCESS PIPES

\begin{tabular}{|c|c|c|c|c|c|}
\hline \multirow{2}{*}{$\begin{array}{l}\text { Point } \\
\text { No. }\end{array}$} & \multirow{2}{*}{$\begin{array}{l}\text { Naminal } \\
\text { Well } \\
\text { Th1ckness } \\
\text { (1n.) }\end{array}$} & \multicolumn{4}{|c|}{$\begin{array}{l}\text { Measured Thickness } \\
\text { (1n.) }\end{array}$} \\
\hline & & October $4-5,1960$ & June 22,1961 & December $4-6,1961$ & April 9, 1963 \\
\hline 1 & 0.365 & -- & --- & 0.384 & 0.360 \\
\hline 2 & 0.365 & --- & --- & --. & 0.335 \\
\hline 3 & 0.365 & $\cdots$ & -- & 0.387 & 0.395 \\
\hline 4 & 0.365 & -- & -- & 0.365 & 0.340 \\
\hline 5 & 0.365 & $\cdots$ &.- & 0.398 & 0.373 \\
\hline 6 & 0.250 & 0.263 & 0.253 & 0.245 & 0.263 \\
\hline 7 & 0.250 & 0.263 & 0.256 & 0.250 & 0.263 \\
\hline 8 & 0.250 & 0.265 & 0.256 & 0.248 & 0.263 \\
\hline 9 & 0.250 & 0.263 & 0.256 & 0.247 & 0.263 \\
\hline 10 & 0.250 & 0.264 & 0.254 & 0.248 & 0.260 \\
\hline 11 & 0.250 & 0.263 & 0.252 & 0.247 & 0.260 \\
\hline 12 & 0.216 & 0.193 & 0.196 & 0.184 & 0.196 \\
\hline 13 & 0.216 & 0.209 & 0.212 & 0.200 & 0.225 \\
\hline 14 & 0.365 & --- & --- & 0.395 & 0.375 \\
\hline 15 & 0.365 & --- & $-\cdots$ & 0.381 & 0.385 \\
\hline 16 & 0.250 & -- & -- & 0.254 & 0.250 \\
\hline 17 & 0.250 & --- & -- & 0.260 & 0.260 \\
\hline 18 & 0.250 & -- & --- & --- & 0.250 \\
\hline 19 & 0.109 & 0.117 & 0.174 & 0.113 & 0.101 \\
\hline 20 & 0.109 & 0.116 & 0.114 & 0.1211 & 0.104 \\
\hline 21 & 0.109 & 0.123 & 0.121 & 0.119 & 0.118 \\
\hline 22 & 0.109 & $\ldots$ & 0.116 & 0.114 & 0.105 \\
\hline 23 & 0.109 & 0.122 & 0.119 & 0.117 & 0.103 \\
\hline 24 & 0.109 & 0.118 & 0.114 & 0.112 & 0.116 \\
\hline 25 & 0.188 & 0.213 & 0.207 & 0.204 & 0.204 \\
\hline 26 & 0.188 & 0.215 & 0.206 & 0.201 & 0.196 \\
\hline 27 & 0.188 & 0.218 & 0.209 & 0.205 & 0.206 \\
\hline 28 & 0.188 & 0.217 & 0.209 & 0.025 & 0.206 \\
\hline 29 & 0.188 & 0.217 & 0.209 & 0.206 & 0.207 \\
\hline 30 & 0.188 & 0.217 & 0.209 & 0.206 & 0.208 \\
\hline 31 & 0.188 & 0.209 & 0.202 & 0.195 & 0.201 \\
\hline 32 & 0.188 & 0.205 & 0.198 & 0.195 & 0.191 \\
\hline 33 & 0.365 & -- & 0.398 & 0.394 & 0.395 \\
\hline 34 & 0.365 & -.. & 0.402 & 0.399 & 0.400 \\
\hline 35 & 0.365 & --. & 0.400 & 0.390 & 0.392 \\
\hline 36 & 0.216 & 0.217 & 0.210 & 0.206 & 0.208 \\
\hline 37 & 0.216 & 0.216 & 0.206 & 0.204 & 0.204 \\
\hline 38 & 0.216 & -- & -.- & --- & 0.214 \\
\hline 39 & 0.365 &.- & 0.398 & 0.392 & 0.395 \\
\hline 40 & 0.365 & -- & 0.401 & 0.400 & 0.397 \\
\hline 41 & 0.365 & -- & 0.400 & 0.394 & 0.400 \\
\hline 42 & 0.365 & -.- & 0.397 & 0.391 & 0.396 \\
\hline 43 & 0.365 & $\cdots$ & 0.406 & 0.400 & 0.390 \\
\hline 44 & 0.216 & --- & 0.236 & 0.200 & 0.224 \\
\hline 45 & 0.216 & -.- & -.- & 0.194 & 0.194 \\
\hline 46 & 0.216 & 0.208 & --. & 0.192 & 0.198 \\
\hline 47 & 0.216 & --- & 0.210 & 0.202 & 0.222 \\
\hline 48 & 0.250 & --- & 0.264 & 0.218 & 0.260 \\
\hline
\end{tabular}


TABIE H-3

WAI工 THICKIVES MEASUREMENTS ON PROCESS PIPING ACCESSIBLE FOR INSPECTION

\begin{tabular}{|c|c|c|c|}
\hline Points & $\begin{array}{c}\text { Sonizon Measure } \\
(\text { in.) }\end{array}$ & $\begin{array}{l}\text { Micrometer Measure } \\
(\text { in.) }\end{array}$ & Remarks \\
\hline 1 & 0.360 & 0.387 [a] & \multirow{8}{*}{$\begin{array}{c}\text { No visual evidence } \\
\text { of wear }\end{array}$} \\
\hline 2 & 0.335 & 0.340 [a] & \\
\hline 3 & 0.395 & $0.387[a]$ & \\
\hline 4 & 0.340 & 0.338 [a] & \\
\hline 33 & 0.395 & 0.395 & \\
\hline 34 & 0.400 & 0.403 & \\
\hline 10 in & PSA 3011 from WC-908 & 0.261 & \\
\hline 10 in & PSA 3011 to $W C-305$ & 0.259 & \\
\hline
\end{tabular}

\section{VISUAL INSPECTION OF EQUIPMENT}

\subsection{Calciner Cyclone, WC-131, and Connecting Lines}

During the final WCF modifications made prior to radioactive operation, the calciner cyclone was removed and completely rebuilt at Phillips Petroleum Co. shops. Visual inspection of all the connecting lines, the cyclone shell, and cyclone internals showed no evidence of abrasion. The face of the cyclone inlet baffle, where abrasion was most expected, still showed the fabrication marks.

\subsection{Solids Storage Cyclone}

After approximately 3500 hours of service in the WCF testing, the solids storage cyclone (WC-915) was removed for inspection. No wear in the connecting lines or in the cyclone barrel was observed.

\subsection{Product Takeoff Line}

Product will be removed from the calciner vessel through approximately eight feet of $1 / 2$-inch schedule 40 line connecting the calciner vessel to the solids transport line. Transfer of product in this manner was done for the last two test runs only, exposing the transfer line to approximately 1600 hours of service. Gas velocities approach 100 feet per second in the line. 
Visual observation of the line as it was being dismantled after the test runs showed no evidence of abrasion. Less than 4 mils of wear was indicated by micrometer measurements of the 1/2-inch pipe outlet into the three-inch transport line. This location is believed to be most exposed to abrasion since the $1 / 2$-inch line is curved sharply within the three-inch line to eject solids parallel to the transport air flow. Nevertheless, these junctions will be fabricated of hardened stainless steel for "hot" operation.

\subsection{Feed and Scrubbing Solution Control Valves}

During the WCF test program, failures of the feed and scrubbing solution flow-control valves were experienced when the Stellite trim originally supplied with valves failed from corrosion or a combination of abrasion and corrosion. Subsequently, the three feed valves were rebuilt with various types of facing materials and one scrubbing solution valve was rebuilt with hardened 17-4PH stainless steel for testing. Inspection of the valves after 700 hours of additional service indicated that hardened $17-4 \mathrm{PH}$ stainless steel plugs and Type 347 stainless steel seats would perform satisfactorily in the feed control valves [1]. New feed valves using these trim materials are being installed for radioactive operation. Inspection of the rebuilt scrubbing solution valve showed no signs of trim deterioration and the remaining scrubbing solution valves have been rebuilt in Phillips Petroleum Co. shops with 17-4PH stainless steel trim.

\subsection{Slide Valves}

Slide valves are used at the WCF in the adsorber unloading lines (4), calciner drain lines (3), product takeoff lines (4), and as transport air jet block valves (2). The two latter installations are currently being made as part of the final WCF modifications. After the final WCF test run was completed, one of the adsorber unloading valves was found to have a fractured plug making the valve inoperable. These valves, as well as the calciner slide valves, utilized sleeves and plugs fabricated of a 94 percent tungsten carbide - 6 percent cobalt alloy, extremely hard (Rockwell $\mathrm{C} \approx 90$ ) but fragile. Following this discovery, all plugs in the adsorber slide valves and calcincer slide valves were replaced with plugs fabricated of $17-4 \mathrm{PH}$ stainless steel. The new slide valves being procured for the product takeoff and transport air lines will use plugs fabricated of $17-7 \mathrm{PH}$ stainless steel (Rockwell $\mathrm{C} \approx 45$ ) and sleeves fabricated of $17-4 \mathrm{PH}$ stainless steel (Rockwell $\mathrm{C} \approx 32$ ). The two types of stainless steels were specified to obtain the hardness difference believed necessary to prevent galling of the sliding surfaces. While there has been no experience at the WCF with 
hardened stainless parts in the slide valves, it is anticipated that the material change will improve the corrosion resistance and lower the abrasion resistance. Of the tungsten carbide plugs removed from the original slide valves, only one (in the calciner cone drain line) showed evidence of deterioration. A slight amount of grooving, either from abrasion or a combination of corrosion and abrasion, occurred on the plug surface where purge air issued from the interface between the plug and seat.

\subsection{Scrubbing Solution Pumps}

The vertical, suspended-shaft, centrifugal pumps used to circulate scrubbing solution have been in service for approximately 3000 hours of the WCF test program. The wearing parts (impellers and bowls) of these pumps are fabricated from Type 304 stainless steel. Moderate wear was observed on one pump after approximately 1400 hours of service. The solids content of the scrubbing system was unusually high during this period. Inspection after the last test run indicated that very little additional abrasion of the bowl or impeller had occurred [2].

\subsection{Calciner Interior}

Abrasion occurred at two locations in the calciner vessel during the WCF testing. Impingement of the starting bed material wore heavily on a tightening rod of the NaK bundle tube support during bed loading operations. This was corrected by the relocation of the tube support.

The Type 304 stainless steel caps installed over the orifices in the air distributor plate wore through during the test program from impingement of bed material circulating near the caps. Testing at the ICPP Chemical Engineering Laboratory showed that this could be overcome by reducing the gap between the cap and plate and by moving the cap support legs at least four inches from the cap [3]. These changes were made and the new caps were fabricated of 17-4PH stainless steel to improve wear resistance.

\section{REFERENCES}

1. J.R. Bower, Ed, Chemical Processing Technology Qua rterly Progress Report, 4th Qtr 1962, IDO-14611 (June 7, 1963).

2. E. J. Bailey, Testing of Pumps for Use in Nitric Acid-Alumina Slurry Service, IDO-14612 (May 20, 1963).

3. J.R. Bower, Ed, Chemical Processing Technology Qua rterly Progress Report, lst Qtr 1963, IDO-14616 (August 19, 1963). 
CALCULATED RADIATION LEVELS AT CRITICAL EXTERNAL WALL SURFACES IN THE WCF

\section{METHOD AND ASSUMPTIONS}

In calculating the radiation levels at the cell external surfaces facing areas normally inhabited by personnel (corridor walls and roof), only the primary vessels in a cell have been considered as sources. The generally high estimates made of the activity contained in a vessel more than correct for neglecting the activity contained in the piping. The equations and methods of Rockwell[1] were used for the calculations; these are exemplified in the examples 1 and 2 for the waste hold tanks, WC-100 and WC-101. In determining the radiation level at the operating corridor wall, the waste hold tank was treated as a finite cylinder lying parallel to the shielding wall. The radiation level on the cell roof (sample corridor floor) was estimated by treating the waste hold tanks as infinite cylinders lying perpendicular to the shielding wall. Similar treatments were made on the remaining process vessels; the calculated radiation levels for all critical locations are summarized in Table V-6

The radiation levels were calculated for wastes of three ages; 200-day cooled, two-year cooled, and WM-185 waste tank on 9/63. The activities corresponding to these cooling periods are (Section $\mathrm{V}$ ):

\begin{tabular}{lcc}
\multicolumn{1}{c}{ Waste } & $\begin{array}{c}\text { Curies/Gallon } \\
\text { of Feed }\end{array}$ & $\begin{array}{c}\text { Curies/Pound } \\
\text { of Alumina }\end{array}$ \\
\cline { 2 - 2 } 200 day & 791 & 972 \\
Wear & 77 & 95 \\
WM-185 Tank & 15 & 19
\end{tabular}

Vessel dimensions, the source strengths, and the estimated linear adsorption coefficients of the vessel contents are summarized in Table I-1. To simplify the calculations, it was assumed that the fission product disintegration releases one gamma photon at an energy level of $1.0 \mathrm{Mev}$. 
TABLE I-I

DIMENSIONS, ACTIVITY LEVELS, AND ESTIMATED LINEAR ABSORPTION COEFFICIENTS FOR WCF PROCESS VESSELS

\begin{tabular}{|c|c|c|c|c|c|c|c|}
\hline \multirow[t]{2}{*}{ Vessel } & \multirow[t]{2}{*}{ Contents } & \multicolumn{2}{|c|}{$\begin{array}{c}\text { Dimens1ons } \\
\text { (feet) }\end{array}$} & \multirow{2}{*}{$\begin{array}{l}\text { Linear Abs }[d] \\
\text { Coeff1c1ent } \\
\left(\mathrm{cm}^{-1}\right)\end{array}$} & \multicolumn{3}{|c|}{$\begin{array}{l}\text { Activity } \\
\text { (curles) }\end{array}$} \\
\hline & & Ro & $\mathrm{H}$ & & 200 day & 2 year & WM-185 \\
\hline WC-100/WC-101 & Feed & 3.0 & 8.5 & 0.091 & $1.42 \times 10^{6}$ & $1.39 \times 10^{5}$ & $2.78 \times 10^{4}$ \\
\hline wC-102 & Alumina & 2.0 & 6.0 & 0.057 & $4.14 \times 10^{6}$ & $4.05 \times 10^{5}$ & $8.09 \times 10^{4}$ \\
\hline WC-105 & Feed & $=0.88$ & $\approx 7$ & 0.091 & $2.71 \times 105$ & $2.65 \times 10^{4}$ & $5.30 \times 103$ \\
\hline WC-108 & Scrubbing Solution & 2.5 & 14 & 0.071 & $3.64 \times 105$ & $3.56 \times 10^{4}$ & $7.12 \times 10^{3}$ \\
\hline WC-908 & Alumina & 1.25 & 4 & 0.071 & $7.3 \times 10^{4}$ & $7.13 \times 10^{3}$ & $1.43 \times 10^{3}$ \\
\hline WC-119 & $\begin{array}{l}\text { Feed (25\%) } \\
\text { Scrubbing Solut1on (25\%) } \\
\text { Water }(50 \%)\end{array}$ & 3.75 & 18 & 0.065 & $1.26 \times 10^{6}$ & $1.23 \times 10^{5}$ & $2.46 \times 10^{4}$ \\
\hline WC- $-110 / 1211212 / 113$ & Alumina \& Ru-106 & 3.5 & 3.0 & 0.053 & $7.56 \times 10^{5[a]}$ & $7.15 \times 10^{4[a]}$ & $6.51 \times 10^{3^{[0]}}$ \\
\hline$F-2718 / 23 / 24$ & Alumine & $\approx 1.26$ & 1 & 0.009 & $569^{[b]}$ & $56^{[b]}$ & $11^{[\mathrm{b}]}$ \\
\hline$W C-251 A \& B$ & Alumina & 1.75 & 6 & 0.004 & $62^{[c]}$ & $6^{[c]}$ & $1^{[c]}$ \\
\hline WC-115 & Alumina & 6 & 20 & 0.057 & - & -- & $9.06 \times 10^{6}$ \\
\hline $\begin{array}{l}\text { [a] } 7.8 \text { pounds of } \\
\text { [b] } 0.6 \text { pounds of } \\
\text { [c] } 0.1 \text { pounds of } \\
\text { [d] From Rockwell }[1\end{array}$ & $\begin{array}{l}\text { In each adsorber. (Amoun } \\
\text { In each filter case. } \\
\text { in each blower. } \\
\text { pp } 447-448 \text { uoing } \mathrm{Al}, \mathrm{H}_{2} \mathrm{O} \text {, }\end{array}$ & collec & in 150 & Interval betwe & regeneration). & & \\
\hline
\end{tabular}

\section{Example 1:}

Determination of radiation level at operating corridor wall adjacent to waste hold cell.

\section{Configuration:}

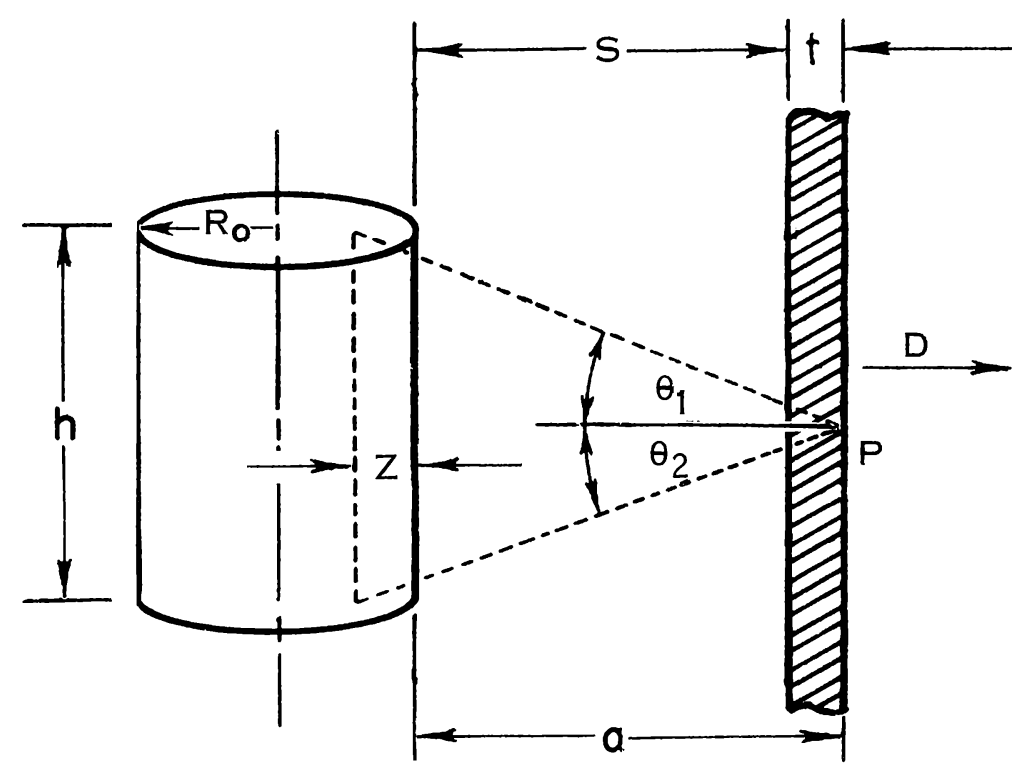

Equations:

$$
\text { Scalar Flux }(\phi)=\frac{B S_{V} R_{O}^{2}}{2(a+Z)} \quad F\left(\theta_{1} b_{2}\right)
$$

but Dose rate (D) $=\phi / \xi$

so $\quad$ Dose rate (D) $=\frac{B S_{V} R_{O}^{2}}{2(a+Z) \xi} \quad F\left(\theta_{1} b_{2}\right)$ 


\section{Calculations:}

Source activity $=\underline{1.42 \times 10^{6} \text { curies }}$

Energy per disintegration $=\underline{1.0 \mathrm{Mev}}$

Gamma photons per disintegration $=1$

Dose rate factor, $\xi=\underline{520} \frac{\mathrm{Mev} / \mathrm{cm}^{2}-\mathrm{sec}}{\mathrm{mr} / \mathrm{hr}}$

$\mathrm{R}_{\mathrm{O}}=\underline{3}$ feet

$=91.5 \mathrm{~cm}$

$\mathrm{Ro}^{2}=8350 \mathrm{~cm}^{2}$

$\mathrm{h}=\underline{8.5} \mathrm{ft}(260 \mathrm{~cm})$

$\mathrm{h} / 2=\underline{130} \mathrm{~cm}$

$\mathrm{V}=\underline{240 \mathrm{ft}^{3}}$

$$
=\underline{6.8 \times 10^{6}} \mathrm{~cm}^{3}
$$

Source Strength, $Q_{V}=0.21$ curies $/ \mathrm{cc}$

$\mathrm{S}_{\mathrm{V}}=7.73 \times 10^{9} \mathrm{Mev} / \mathrm{sec}-\mathrm{cm}^{3}$

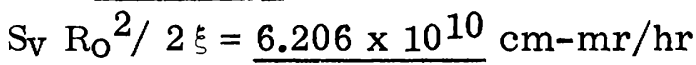

Source matrix material $=\mathrm{Al}-\mathrm{HNO}_{3}-\mathrm{H}_{2} \mathrm{O}$

Source density, $\rho_{\mathrm{S}}=\underline{1.3} \mathrm{~g} / \mathrm{cc}$

Source mass absorption coefficient $\left(\mu_{\mathrm{S}} / \rho\right)_{\mathrm{E}}=0.070 \mathrm{~cm}^{2} / \mathrm{g}$

Source linear absorption coefficient $\mu_{S}=\underline{0.091} \mathrm{~cm}^{-1}$

Shield material $=$ concrete $($ via lead)

Shield density, $\rho_{t}=2.3 \mathrm{~g} / \mathrm{cc}$ (concrete)

$$
=\underline{11.4} \mathrm{~g} / \mathrm{cc} \text { (lead) }
$$

Lead mass absorption coefficient $\mu_{t} / \rho=0.074 \frac{\mathrm{cm}^{2}}{\mathrm{~g}}$

Lead linear absorption coefficient, $\mu_{t}=\underline{0.84} \mathrm{~cm}^{-1}$

Concrete/lead thickness ratio, $\left(t_{c} / t_{p b}\right)_{t}=\underline{6.5}$

Vessel spacing, $s=\underline{4}$ feet

Actual shield thickness $=\underline{4.5}$ feet $=\underline{137} \mathrm{~cm}$

Equivalent lead thickness, t, $21.1 \mathrm{~cm}$

Relaxation length, $b=\mu_{t} t=17.7$ (checks relaxation length

used to obtain concrete/lead thickness ratio)

$\mathrm{a}=30.48(\mathrm{~s}+\mathrm{t})=\underline{259} \mathrm{~cm}$

$\mathrm{a} / \mathrm{R}_{\mathrm{O}}=\underline{2.83}$

$\mathrm{a}+\mathrm{R}_{\mathrm{O}}=\underline{351 \mathrm{~cm}}$

$\mu_{\mathrm{S}}\left(\mathrm{a}+\mathrm{R}_{\mathrm{o}}\right)=\underline{31.9}$

$\mathrm{M}=\underline{2.3}$

$\left(\frac{1}{M}\right)=\underline{0.43}$ 


$$
\begin{aligned}
& { }_{\mathrm{S}} \mathrm{z}=3.29 \\
& \mathrm{z}=36.2 \mathrm{~cm} \\
& \mathrm{a}+\mathrm{z}=\underline{295} \mathrm{~cm} \\
& \theta=\tan ^{-1}\left(\frac{\mathrm{h} / 2}{\mathrm{a}+\mathrm{z}}\right)=24^{\circ} \\
& \mathrm{b}_{2}=\mathrm{b}_{1}+\mu_{\mathrm{S}} \mathrm{z}=\underline{21.0} \\
& \mathrm{~F}\left(\theta_{1} \mathrm{~b}_{2}\right)=\underline{1.9 \times 10^{-9}} \\
& \text { Buildup factor, } \mathrm{B}_{1}=8.8 \\
& B \mathrm{~S}_{V} \mathrm{R}_{\mathrm{O}} 2 / 2(\mathrm{a}+\mathrm{z})=1.85 \times 10^{8} \\
& \mathrm{D}=0.35 \mathrm{mr} / \mathrm{hr}
\end{aligned}
$$

Example 2: Determination of radiation level at sample gallery floor above waste hold cell.

\section{Configuration:}

Equations:

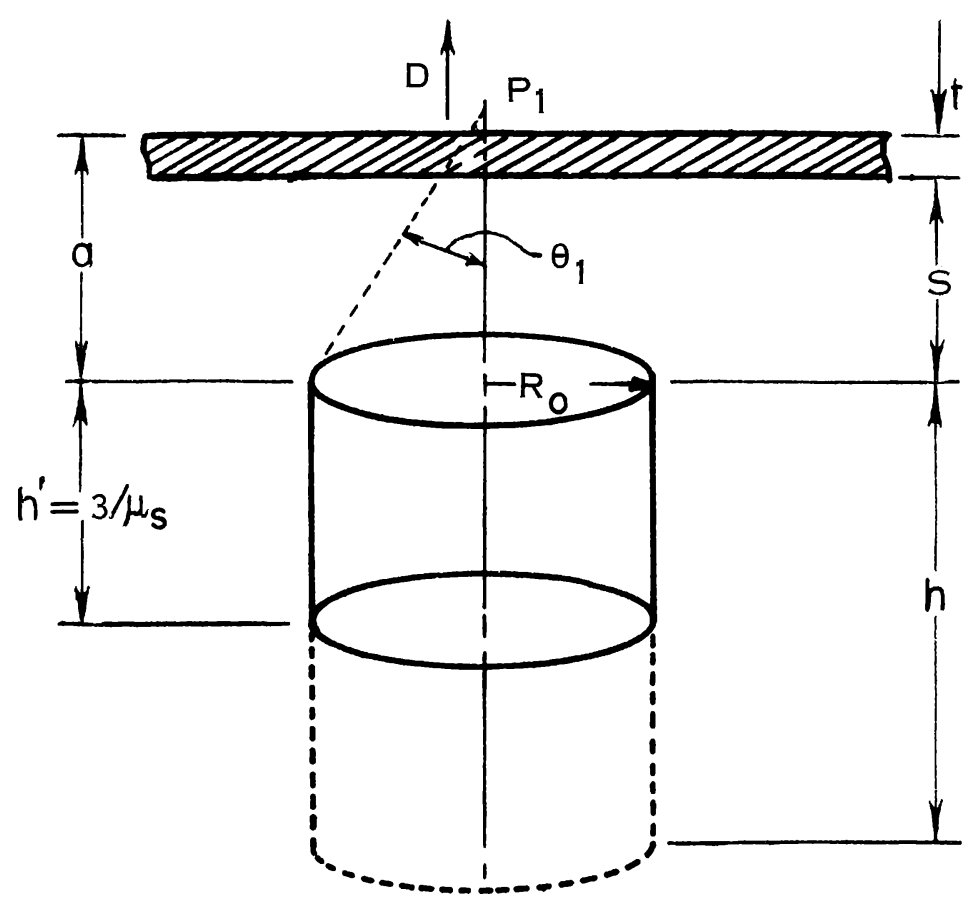

$$
\text { Scalar Flux }(\phi)=\frac{B S_{V}}{2 \mu_{S}} \quad\left[E_{2}\left(b_{1}\right)-\frac{E_{2}\left(b_{1} \sec \theta_{1}\right)}{\sec \theta_{1}}\right]
$$

but Dose rate $(\mathrm{D})=\phi / \xi$

so $\quad$ Dose rate $(D)=\frac{B S_{V}}{2 \mu_{S} \xi} . \quad\left[E_{2}\left(b_{1}\right)-\frac{E_{2}\left(b_{1} \sec \theta_{1}\right)}{\sec \theta_{1}}\right]$

\section{Calculations:}

Source activity $=\underline{1.42 \times 10^{6}}$ curies

Energy per disintegration $=\underline{1.0} \mathrm{Mev}$

Gamma Photons per disintegration $=1$

Dose rate factor, $\xi=\underline{520} \frac{\mathrm{Mev} / \mathrm{cm}^{2}-\overline{\mathrm{sec}}}{\mathrm{mr} / \mathrm{hr}}$ 


$$
\begin{aligned}
\mathrm{R}_{\mathrm{O}} & =\underline{91.5} \mathrm{~cm} \\
\mathrm{R}_{\mathrm{O}}^{2} & =\underline{8350} \mathrm{~cm}^{2} \\
\mathrm{~h} & =\underline{8.5} \mathrm{ft} \\
& =\underline{260} \mathrm{~cm} \\
\mathrm{~V} & =\underline{240} \mathrm{ft}^{3} \\
& =6.8 \times 10^{6} \mathrm{~cm}^{3}
\end{aligned}
$$

Source strength, $Q_{V}=0.21$ curies $/$ second

$\mathrm{S}_{\mathrm{V}}=7.73 \times 10^{9} \mathrm{Mev} / \mathrm{sec}-\mathrm{cm}^{3}$

Source matrix material $=\mathrm{Al}_{-}-\mathrm{HNO}_{3}-\mathrm{H}_{2} \mathrm{O}$

Source density, $\rho_{\mathrm{S}}=\underline{1.3} \mathrm{~g} / \mathrm{cc}$

Source mass absorption coefficient $\left(\mu_{S} / \rho_{E}=0.070 \mathrm{~cm}^{2} / \mathrm{g} \quad \mathrm{p} 447{ }^{[1]}\right.$ Source linear absorption coefficient, $\mu_{\mathrm{s}}=\underline{0.091 \mathrm{~cm}^{-1}}$

$\mathrm{h}^{\prime}=3 / \mu_{\mathrm{S}}=32.6 \mathrm{~cm}$

Shield material $=$ Concrete $($ via lead)

Shield density, $\rho_{t}=\underline{2.3} \mathrm{~g} / \mathrm{cc}$ (concrete)

$$
=\underline{11.4} \mathrm{~g} / \mathrm{cc} \text { (lead) }
$$

Lead mass absorption coefficient $\left(\mu_{\mathrm{t}} / \mathrm{c}\right)_{\mathrm{E}}=\underline{0.074} \mathrm{~cm}^{2} / \mathrm{g}$

Lead linear absorption coefficient $\left(\mu_{\mathrm{t}}\right)=\underline{0.84} \mathrm{~cm}^{-1}$

Concrete/lead thickness ratio, $\left(\mathrm{tc} / \mathrm{t}_{\mathrm{pb}}\right)_{\mathrm{E}}=\underline{6.5}$

Vessel spacing, $s=\underline{4} \mathrm{ft}$

Shield thickness $=\underline{4.5} \mathrm{ft}$

Equivalent lead thickness, $\mathrm{t},=21.1 \mathrm{~cm}$

Relaxation length, $b_{1}, \mu_{t} T=\underline{17.7}$ (checks length used for

$$
\left(t_{\mathrm{c}} / \mathrm{t}_{\mathrm{pb}}\right)_{\mathrm{E}}
$$

$\mathrm{a}=30.48(\mathrm{~s}+\mathrm{t})=\underline{259} \mathrm{~cm}$

Buildup factor $\mathrm{B}=8.8$

$\theta_{1}=\tan ^{-1} \mathrm{R}_{\mathrm{o}} / \mathrm{a}=19.5^{\circ}$

$\sec \theta_{1}=\underline{1.061}$

$b_{1} \sec \theta_{1}=\underline{18.8}$

$\mathrm{E}_{2}\left(\mathrm{~b}_{1} \sec \theta_{1}\right)=3.3 \times 10^{-10}$

$\mathrm{E}_{2}\left(\mathrm{~b}_{1} \sec \theta_{1}\right) / \sec \theta_{1_{-}}=\underline{3.11} \times 10^{-10}$

$\mathrm{E}_{2}\left(\mathrm{~b}_{1}\right)=1.05 \times 10^{-9}$

$\mathrm{E}_{2}\left(\mathrm{~b}_{1}\right)-\mathrm{E}_{2}\left(\mathrm{~b}_{1} \sec \theta_{1} / \sec \theta_{1}\right)$ upper limit $=\underline{6.39 \times 10^{-10}}$

$\mathrm{B} \mathrm{Sv} / 2 \mu_{\mathrm{S}} \xi=\underline{7.146 \times 10^{8}}$

D upper limit $=\frac{\mathrm{B} \mathrm{Sv}}{2+\mathrm{s} \xi}\left[\mathrm{E}_{2}\left(\mathrm{~b}_{1}\right)-\frac{\mathrm{E}_{2}\left(\mathrm{~b}_{1} \sec \theta_{1}\right)}{\sec \theta_{1}}\right]=0.45 \mathrm{mr} / \mathrm{hr}$ 


\section{REF ERENCE}

1. T. Rockwell III, Reactor Shielding Design Manual, McGraw - Hill, 1956. 
SUMMARY OF WCF NON-RADIOACTIVE TESTING OPERATIONS

\begin{tabular}{|c|c|c|c|c|}
\hline \multirow[b]{2}{*}{ Run No. } & \multicolumn{2}{|c|}{ Dates } & \multirow{2}{*}{$\begin{array}{c}\text { Duration } \\
\text { of Run } \\
(\mathrm{hr})\end{array}$} & \multirow{2}{*}{$\begin{array}{l}\text { Cumulative } \\
\text { Operating Time } \\
(\mathrm{a} r)\end{array}$} \\
\hline & From & To & & \\
\hline 1 & $2 / 5 / 61$ & $2 / 7 / 61$ & 2 & \\
\hline $2 \mathrm{~A}$ & $4 / 11 / 61$ & $4 / 11 / 61$ & 5 & \\
\hline B & $4 / 11 / 61$ & $4 / 12 / 61$ & 22 & \\
\hline $\mathrm{C}$ & $4 / 14 / 61$ & $4 / 15 / 61$ & 17 & \\
\hline 3 & $5 / 18 / 61$ & $6 / 2 / 61$ & 368 & 368 \\
\hline $4 \mathrm{~A}$ & $9 / 27 / 61$ & $10 / 5 / 61$ & 195 & 563 \\
\hline B & $10 / 12 / 61$ & $10 / 18 / 61$ & 120 & 683 \\
\hline 5 & $10 / 28 / 61$ & $11 / 17 / 61$ & 502 & 1185 \\
\hline 6 & $3 / 13 / 62$ & $3 / 24 / 62$ & 251 & 1436 \\
\hline 7 & $4 / 13 / 62$ & $4 / 26 / 62$ & 306 & 1742 \\
\hline 8 & $5 / 25 / 62$ & $6 / 10 / 62$ & 363 & 2105 \\
\hline 9 & $6 / 13 / 62$ & $7 / 20 / 62$ & 885 & 2990 \\
\hline $10 \mathrm{~A}$ & $10 / 11 / 62$ & $10 / 13 / 62$ & 41 & 3031 \\
\hline $\mathrm{B}$ & $10 / 22 / 62$ & $11 / 21 / 62$ & 700 & 3731 \\
\hline 11 & $10 / 16 / 63$ & $11 / 12 / 63$ & 660 & 4391 \\
\hline
\end{tabular}

[a] Does not include water feed of Run 1 or unsteady state conditions of Run 2. 



\section{APPENDIX $\mathrm{K}$}

\section{CALCULATED TOTAL PERSONAL LIFETIME RADIATION \\ DOSES FROM INHALATION OR INGESTION OF RADIOACTIVE} MATERIAL FOLLOWING ACCIDENTAL RELEASE FROM FACILITY

Bases and Assumptions:

(1) Assume man breathes contaminated air for fifteen minutes at ICPP following accidental release of activity from the facility to the stack.

(2) Assume fumigation weather conditions exist at time of accident. Diffusion factor $(X / Q)$ is equal to $2.5 \times 10^{-4} \mathrm{sec} / \mathrm{m}^{3}$ (page iii-13).

(3) Assume fallout of particulates is negligible over 15 minute period. This is valid for particles generally smaller than 10 to 20 microns as they probably would be in all postulated accidents.

(4) Normal breathing rate for man is $10 \mathrm{~m}^{3 / 8}$ hours ${ }^{[1]}$.

(5) Assume processing of 200-day cooled waste.

(6) Assume lifetime period of exposure to inhaled or ingested material of fifty years [1].

\section{Equation}

$$
\operatorname{Rem}=\frac{(74)\left(f_{a}\right)\left(I_{o}\right)(T)[\Sigma E(R B E) N]\left(1-e^{-\frac{0.693 t}{T}}\right)}{m}
$$

where:

$$
\begin{aligned}
\mathrm{f}_{\mathrm{a}} & =\text { fraction of inhaled activity going to organ } \\
\mathrm{I}_{\mathrm{O}} & =\text { amount of fission product inhaled, } \mu \mathrm{c} \\
\mathrm{T} & =\text { effective half life, days } \\
\Sigma \mathrm{E}(\mathrm{RBE}) \mathrm{N} & =\text { effective energy, Mev } \\
\mathrm{t} & =\text { period of exposure to inhaled material, days } \\
\mathrm{m} & =\text { organ mass, grams }
\end{aligned}
$$

Values for $\mathrm{f}_{\mathrm{a}}, \mathrm{T}, \Sigma, \mathrm{E}(\mathrm{RBE}) \mathrm{N}$, and $\mathrm{m}$ are given in Reference 1. Sample Calculation for $\mathrm{Sr}-90$ Dose Following $\mathrm{H}_{2} / \mathrm{O}_{2}$ Explosion

Normal solids release rate $=8 \times 10^{-5} \mathrm{lbs} / \mathrm{hr}$.

Solids release rate after explosion $=8 \mathrm{lbs} / \mathrm{hr}$.

Normal strontium-90 release rate $=1.8 \times 10^{-7} \mathrm{c} / \mathrm{sec}$

Strontium-90 release rate after explosion

$$
=\left(1.8 \times 10^{-7}\right)\left(\frac{8}{8 \times 10^{-5}}\right)
$$


$=1.8 \times 10^{-2}$ curies $/$ second

Concentration of strontium -90 at grade

$=\left(1.8 \times 10^{-2} \mathrm{c} / \mathrm{sec}\right)\left(2.5 \times 10^{-4} \mathrm{sec} / \mathrm{m}^{3}\right)$

$=4.5 \times 10^{-6} \mathrm{c} / \mathrm{m}^{3}$

$=4.5 \mu \mathrm{c} / \mathrm{m}^{3}$

Air inhalation rate $=10 \mathrm{~m}^{3} / 8 \mathrm{hrs}$.

Air inhaled in 15 minutes $=0.313 \mathrm{~m}^{3}$

Strontium-90 inhaled $=(4.5)(0.313)=1.4 \mu \mathrm{c}$

$$
\operatorname{Rem}=\frac{(74)\left(f_{a}\right)\left(I_{0}\right)(T)[\Sigma E(R B E) N]\left(1-e^{-\frac{0.693 t}{T}}\right)}{m}
$$

where:

$$
\begin{aligned}
\mathrm{f}_{\mathrm{a}} & =0.12 \\
\mathrm{I}_{\mathrm{O}} & =1.4 \mu \mathrm{c} \\
\text { Organ considered } & =\text { bone } \\
\mathrm{T} & =6400 \text { days } \\
\Sigma \mathrm{E}(\mathrm{RBE}) \mathrm{N} & =5.5 \mathrm{Mev} \\
\mathrm{m} & =7000 \text { grams } \\
\mathrm{t} & =18,250 \text { days }
\end{aligned}
$$

Rem $=54$

The dose calculations for the other isotopes and organs are summarized in Table K-1.

Strontium-90 Bone Dose for Similar Exposure Following Other Accidents

From the previous calculations, an intake of $1.4 \mu \mathrm{c}$ of strontium-90 produces a lifetime bone dose of $54 \mathrm{rem}$ or $1 \mu \mathrm{c}=38 \mathrm{rem}$. Applying this factor to the estimated strontium-90 inhaled under similar conditions, the strontium-90 doses have been estimated for the other accidents postulated at the WCF. The results are summarized in Table $\mathrm{K}-2$.

\section{References}

1. Recommendations of the International Commission on Radiological Protection, ICRP Publication 2. Report of Committee II on Permissible Dose for Internal Radiation, Pergamon Press, N. Y., 1959.

2. H. Etherington, Ed., Nuclear Engineering Handbook, McGraw-Hill, N.Y., 1958, p 7-44. 
TABLE K-1

LIFETIME DOSES FROM INHALATION OF STACK PLUME FOR FIFTEEN MINUTES AFTER $\mathrm{H}_{2}-\mathrm{O}_{2}$ EXPLOSION IN WCF

\begin{tabular}{|c|c|c|c|c|c|c|c|c|c|c|c|}
\hline Isotope & $\begin{array}{c}\text { Stack [8] } \\
\text { Release } \\
\text { (curles } / \mathrm{sec} \text { ) }\end{array}$ & $\frac{\text { Conc. at Grade }}{\left(\mu \mathrm{c} / \mathrm{m}^{3}\right)}$ & $\begin{array}{c}\text { Isotope [c] } \\
\text { Intake } \\
\left(\mathrm{m}^{3}\right) \\
\end{array}$ & $\begin{array}{c}\text { Solubility } \\
\text { 1n } \\
\text { Body } \\
\end{array}$ & $\begin{array}{c}\text { Organ } \\
\text { Expoosed }\end{array}$ & $\begin{array}{l}\text { Fraction Resching } \\
\text { Organ } \\
\text { (fa) } \\
\end{array}$ & $\begin{array}{c}\text { Erfective } \\
\text { Hafl-Life } \\
\text { Deys } \\
(t) \\
\end{array}$ & $\begin{array}{l}\text { Efrective } \\
\text { Energy, Mev } \\
\Sigma E(R B E) \mathbb{B}\end{array}$ & $\begin{array}{c}\text { Maas of } \\
\text { Organ, Grams } \\
(\mathrm{m}) \\
\end{array}$ & $1-e^{\frac{-0.693 t}{t}}$ & $\begin{array}{c}\text { Dose } \\
(\mathrm{rem})\end{array}$ \\
\hline $\mathrm{co}^{60}$ & $8.7 \times 10^{-6}$ & $2.2 \times 10^{-3}$ & $6.9 \times 10^{-4}$ & & $\overline{\substack{\text { Body } \\
\text { Liver }}}$ & $\begin{array}{l}0.4 \\
0.02\end{array}$ & $\begin{array}{l}9.5 \\
9.5\end{array}$ & $\begin{array}{l}1.5 \\
0.72\end{array}$ & $\begin{array}{r}70000 \\
1700\end{array}$ & $\begin{array}{l}1 \\
1\end{array}$ & $\begin{array}{l}4 \times 10^{-6}-6 \\
4 \times 10^{-6}\end{array}$ \\
\hline $\mathrm{sr}^{89}$ & $1.9 \times 10^{-2}$ & 4.74 & 1.5 & $\mathrm{~s}$ & $\begin{array}{l}\text { Body } \\
\text { Bone }\end{array}$ & $\begin{array}{l}0.4 \\
0.28\end{array}$ & $\begin{array}{l}50.3 \\
50.4\end{array}$ & $\begin{array}{l}0.55 \\
2.8\end{array}$ & $\begin{array}{l}70000 \\
7000\end{array}$ & $\frac{1}{1}$ & $\begin{array}{l}0.02 \\
0.63\end{array}$ \\
\hline $\mathrm{sr}^{90}$ & $1.8 \times 10^{-2}$ & 4.5 & 1.4 & s & $\begin{array}{l}\text { Body } \\
\text { Bone }\end{array}$ & $\begin{array}{l}0.4 \\
0.12\end{array}$ & $\begin{array}{l}5700 \\
6400\end{array}$ & $\begin{array}{l}1.1 \\
5.5\end{array}$ & $\begin{array}{r}70000 \\
7000\end{array}$ & $\begin{array}{l}0.89 \\
0.86\end{array}$ & $54^{3.3}$ \\
\hline$r^{91}$ & $2.6 \times 10^{-1}$ & 65 & 20 & & $\begin{array}{l}\text { Body } \\
\text { Bone }\end{array}$ & $\begin{array}{l}0.25 \\
0.17\end{array}$ & $\begin{array}{l}58 \\
{ }_{58}\end{array}$ & $\begin{array}{l}0.59 \\
2.9\end{array}$ & $\begin{array}{r}70000 \\
7000\end{array}$ & $\frac{1}{1}$ & 0.2 \\
\hline $2 x^{95}$ & $3.2 \times 10^{-1}$ & 80 & 25 & & $\begin{array}{l}\text { Body } \\
\text { Bone }\end{array}$ & $\begin{array}{l}0.25 \\
0.09\end{array}$ & $\begin{array}{l}55.5 \\
59.5\end{array}$ & $\begin{array}{l}1.1 \\
1.1\end{array}$ & $\begin{array}{r}70000 \\
7000\end{array}$ & $\frac{1}{1}$ & $\begin{array}{l}0.4 \\
1.6\end{array}$ \\
\hline $\mathrm{mb}^{95}$ & $6.9 \times 10^{-1}$ & 173 & 54 & & $\begin{array}{l}\text { Body } \\
\text { Bone }\end{array}$ & $\begin{array}{l}0.25 \\
0.10\end{array}$ & $\begin{array}{l}33.5 \\
33.8\end{array}$ & $\begin{array}{l}0.51 \\
0.37\end{array}$ & $\begin{array}{l}70000 \\
7000\end{array}$ & $\frac{1}{1}$ & $\begin{array}{l}0.2 \\
0.7\end{array}$ \\
\hline $\mathrm{Ru}^{103}$ & 1.08 & 270 & 85 & I & $\begin{array}{l}\text { Body } \\
\text { Bone } \\
\text { Koney }\end{array}$ & $\begin{array}{l}0.27 \\
0.02 \\
0.05\end{array}$ & $\begin{array}{l}6.2 \\
12 \\
2.4\end{array}$ & $\begin{array}{l}0.44 \\
0.62 \\
0.22\end{array}$ & $\begin{array}{r}70000 \\
7000 \\
300\end{array}$ & $\begin{array}{l}1 \\
1 \\
1\end{array}$ & $\begin{array}{l}0.07 \\
0.073 \\
0.55\end{array}$ \\
\hline $\mathrm{Ru}^{106}$ & $1.23 \times 10^{-1}$ & 38 & 11.9 & I & $\begin{array}{l}\text { Body } \\
\text { Bone } \\
\text { Bone } \\
\text { Xdaney }\end{array}$ & $\begin{array}{l}0.27 \\
0.02 \\
0.05\end{array}$ & $\begin{array}{c}7.2 \\
15.2 \\
2.48\end{array}$ & $\begin{array}{l}1.4 \\
6.5 \\
1.3\end{array}$ & $\begin{array}{r}70000 \\
7000 \\
300\end{array}$ & $\begin{array}{l}1 \\
1 \\
1\end{array}$ & $\begin{array}{l}0.03 \\
0.25 \\
0.47\end{array}$ \\
\hline $\mathrm{Cs}^{137}$ & $1.8 \times 10^{-2}$ & 4.5 & 1.4 & s & $\begin{array}{l}\text { Body } \\
\text { Bone } \\
\text { Muacle } \\
\text { Luver }\end{array}$ & $\begin{array}{l}0.75 \\
0.03 \\
0.30 \\
0.05\end{array}$ & $\begin{array}{r}70 \\
138 \\
138 \\
89\end{array}$ & $\begin{array}{l}0.59 \\
1.4 \\
0.59 \\
0.41\end{array}$ & $\begin{array}{l}70000 \\
7000 \\
3000 \\
1700\end{array}$ & $\begin{array}{l}1 \\
1 \\
1 \\
1\end{array}$ & $\begin{array}{l}0.05 \\
0.09 \\
0.08 \\
0.1\end{array}$ \\
\hline $\mathrm{Ce}^{142}$ & $6.3 \times 10^{-2}$ & 15.7 & 5 & I & $\begin{array}{l}\text { Body } \\
\text { Bone }\end{array}$ & $\begin{array}{l}0.25 \\
0.075\end{array}$ & $\begin{array}{l}30 \\
31\end{array}$ & $\begin{array}{l}0.21 \\
0.81\end{array}$ & $\begin{array}{r}70000 \\
7000\end{array}$ & 1 & $\begin{array}{l}0.008 \\
0.1\end{array}$ \\
\hline $\mathrm{Ce}^{144}$ & $4.0 \times 10^{-1}$ & 100 & 31 & I & $\begin{array}{l}\text { Body } \\
\text { Boden } \\
\text { Lilver }\end{array}$ & $\begin{array}{l}0.25 \\
0.075 \\
0.06\end{array}$ & $\begin{array}{l}191 \\
243 \\
146\end{array}$ & $\begin{array}{l}1.3 \\
6.3 \\
1.3\end{array}$ & $\begin{array}{r}70000 \\
7000 \\
1700\end{array}$ & $\begin{array}{l}1 \\
1 \\
1\end{array}$ & $\begin{array}{c}2 \\
38 \\
15\end{array}$ \\
\hline $\mathbf{p m}^{147}$ & $7.6 \times 10^{-2}$ & 19 & 6 & & $\begin{array}{l}\text { Body } \\
\text { Bone } \\
\text { Liver }\end{array}$ & $\begin{array}{l}0.25 \\
0.29 \\
0.02\end{array}$ & $\begin{array}{l}383 \\
570 \\
383\end{array}$ & $\begin{array}{l}0.069 \\
0.35 \\
0.069\end{array}$ & $\begin{array}{r}70000 \\
7000 \\
1700\end{array}$ & $\begin{array}{l}1 \\
1 \\
1\end{array}$ & $\begin{array}{l}0.04 \\
1.1 \\
0.14\end{array}$ \\
\hline $\mathrm{Pu}^{239}$ & $2.56 \times 10^{-7}$ & $6.4 \times 10^{-5}$ & $2 \times 10^{-5}$ & & $\begin{array}{l}\text { Body } \\
\text { Bone } \\
\text { Liver }\end{array}$ & $\begin{array}{l}0.25 \\
0.20 \\
0.20 \\
0.038\end{array}$ & $\begin{aligned} 6.4 \times 10^{4} \\
7.2 \times 10^{4} \\
3 \times 10^{4}\end{aligned}$ & $\begin{array}{r}53 \\
270 \\
53\end{array}$ & $\begin{array}{r}70000 \\
7000 \\
1700\end{array}$ & $\begin{array}{l}0.18 \\
0.16 \\
0.34\end{array}$ & $\begin{array}{l}0.003 \\
0.13 \\
0.048\end{array}$ \\
\hline $\mathrm{sp}^{237}$ & $4.0 \times 10^{-9}$ & $1.1 \times 10$ & $\approx$ & & -- & -- & .- & -- & -. & -. & -- \\
\hline
\end{tabular}

TABLE $K-2$

ESTIMATED LIFETIME BONE DOSES FROM STRONTIUM-90 INHAIED AFTER WCF ACCIDENTS

\begin{tabular}{|c|c|c|c|c|c|}
\hline Accldent & $\begin{array}{c}\text { Sollds Release Rate [a] } \\
(\mathrm{lb} / \mathrm{hr})\end{array}$ & $\begin{array}{c}\text { Strontium-90 [b] } \\
(\mathrm{c} / \mathrm{sec}) \\
\end{array}$ & $\begin{array}{c}\text { Conc. at Grade [c] } \\
\left(\mu \mathrm{c} / \mathrm{m}^{3}\right) \\
\end{array}$ & $\begin{array}{l}\text { Intake }{ }^{[\mathrm{d}]} \\
(\mu \mathrm{c})\end{array}$ & $\underline{\operatorname{Rem}[\mathrm{e}]}$ \\
\hline Cyclone bypassing & $8 \times 10^{-5}$ & $1.8 \times 10^{-7}$ & $4.5 \times 10^{-5}$ & $1.4 \times 10^{-5}$ & 0.0005 \\
\hline Scrub system bypassed & $<1.8 \times 10^{-2}$ & $<4 \times 10^{-5}$ & $<1 \times 10^{-2}$ & $3 \times 10^{-3}$ & $<0.11$ \\
\hline Adsorbers bypassed & $<4 \times 10^{-4}$ & $<9 \times 10^{-7}$ & $<2.25 \times 10^{-4}$ & $7.5 \times 10^{-5}$ & $<0.003$ \\
\hline Off-gas filters bypassed & $1.5 \times 10^{-3}$ & $3.4 \times 10^{-6}$ & $8.5 \times 10^{-4}$ & $2.7 \times 10^{-4}$ & 0.01 \\
\hline Adsorbers and filters bypassed & $8 \times 10-3$ & $1.8 \times 10-5$ & $4.5 \times 10-3$ & $1.4 \times 10^{-3}$ & 0.05 \\
\hline Equipment vent filter bypassed & $8 \times 10^{-5}$ & $1.8 \times 10-7$ & $4.5 \times 10^{-5}$ & $1.4 \times 10^{-5}$ & 0.0005 \\
\hline "Dumping" of one off-gas filter & 4 & $9.0 \times 10-3$ & 2.25 & 0.75 & 27 \\
\hline Hydrogen-oxygen explosion & 8 & $1.8 \times 10^{-2}$ & 4.5 & 1.4 & 54 \\
\hline Broken product takeoff line & 0.1 & $2.25 \times 10^{-4}$ & $5.6 \times 10^{-2}$ & 0.02 & 0.7 \\
\hline \multicolumn{6}{|c|}{$\begin{array}{l}\text { [a] From Section IX } \\
\text { [b] Specific activity of solids } \approx 8 \text { curies } \mathrm{Sr}^{90} \text { per pound. } \\
\text { [c] Under fumigation conditions }\left(X / Q=2.5 \times 10^{-4} \mathrm{sec} / \mathrm{m}^{3}\right) \\
\text { [d] Assumed intake of } 0.313 \mathrm{~m}^{3} \text { - equivalent to } 10 \mathrm{~m} / 8 \mathrm{hr} \\
\text { [e] One } \mu \mathrm{c}=38 \mathrm{rem} \text {. }\end{array}$} \\
\hline
\end{tabular}






\section{PHILLIPS \\ PETROLEUM COMPANY

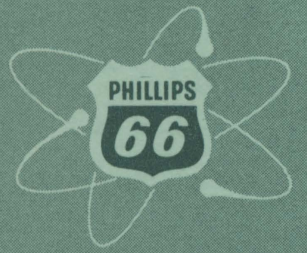

ATOMIC ENERGY DIVISION 